Modality in Kazakh as spoken in China 



\title{
Modality in Kazakh as spoken in China
}

\author{
Aynur Abish
}

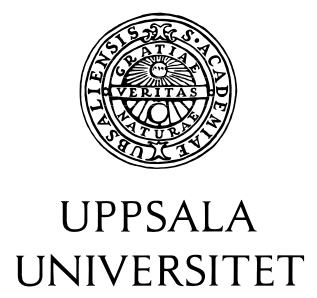


Dissertation presented at Uppsala University to be publicly examined in Ihresalen, Engelskaparken, Uppsala, Saturday, 24 May 2014 at 14:15 for the degree of Doctor of Philosophy. The examination will be conducted in English. Faculty examiner: Professor László Károly (Johannes Gutenberg University Mainz, Germany).

\begin{abstract}
Abish, A. 2014. Modality in Kazakh as spoken in China. $x x+259$ pp. Uppsala: Uppsala University, Department of Linguistics and Philology. ISBN 978-91-506-2392-5.
\end{abstract}

This is a comprehensive study on expressions of modality in one of the largest Turkic languages, Kazakh, as it is spoken in China. Kazakh is the official language of the Republic of Kazakhstan and is furthermore spoken by about one and a half million people in China in the Xinjiang Uyghur Autonomous Region and in Aksai Kazakh Autonomous County in Gansu Province.The method employed is empirical, i.e. data-oriented. The modal expressions in Kazakh are analyzed in a theoretical framework essentially based on the works of Lars Johanson. The framework defines semantic notions of modality from a functional and typological perspective. The modal volition, deontic evaluation, and epistemic evaluation express attitudes towards the propositional content and are conveyed in Kazakh by grammaticalized moods, particles and lexical devices. All these categories are treated in detail, and ample examples of their different usages are provided with interlinear annotation. The Kazakh expressions are compared with corresponding ones used in other Turkic languages. Contact influences of Uyghur and Chinese are also dealt with.The data used in this study include texts recorded by the author in 2010-2012, mostly in the northern regions of Xinjiang, as well as written texts published in Kazakhstan and China. The written texts represent different genres: fiction, non-fiction, poetry and texts published on the Internet. Moreover, examples have been elicited from native speakers of Kazakh and Uyghur.

The Appendix contains nine texts recorded by the author in the Kazakh-speaking regions of Xinjiang, China. These texts illustrate the use of many of the items treated in the study.

Keywords: Turkic languages, Kazakh, modality

Aynur Abish, Department of Linguistics and Philology, Box 635,

Uppsala University, SE-75126 Uppsala, Sweden.

(C) Aynur Abish 2014

ISBN 978-91-506-2392-5

urn:nbn:se:uu:diva-221400 (http://urn.kb.se/resolve?urn=urn:nbn:se:uu:diva-221400)

Printed by Elanders Sverige AB, 2014 


\section{Contents}

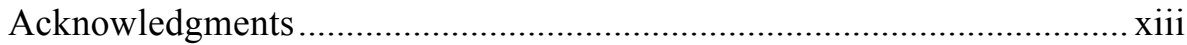

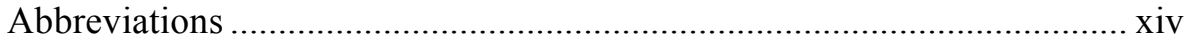

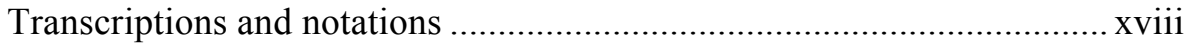

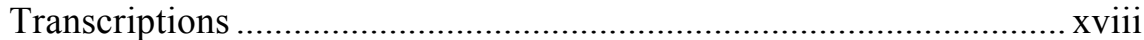

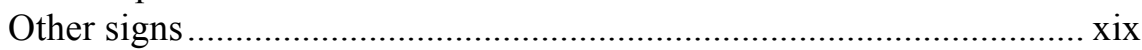

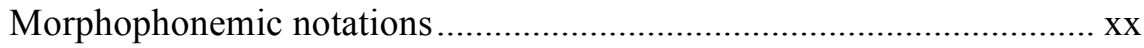

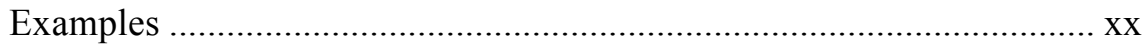

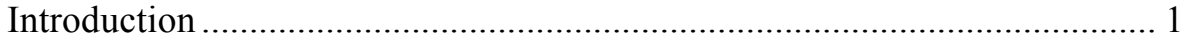

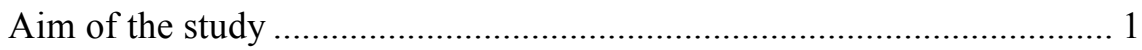

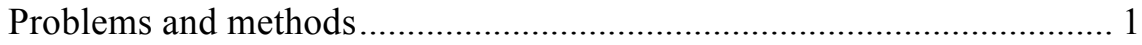

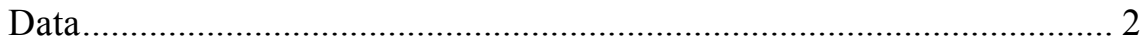

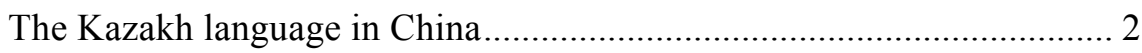

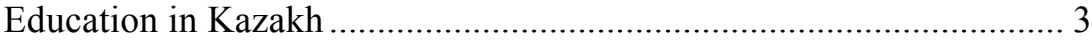

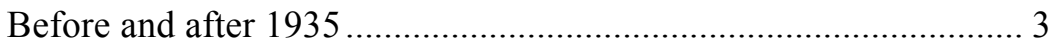

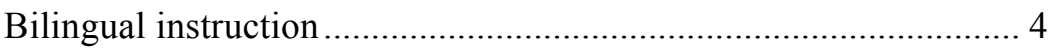

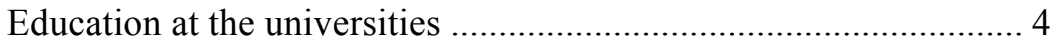

Code-copying varieties of Kazakh ..................................................... 4

Research on Kazakh in China ........................................................... 5

Xinjiang Academy of Social Sciences, Ürümqi ................................ 5

Minzu University of China, Beijing ................................................... 5

The Working Committees of Minorities' Language and Writing .... 6

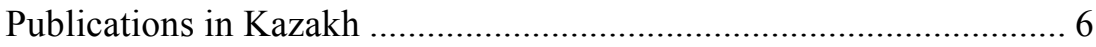

Broadcasting in Kazakh as spoken in China......................................... 7

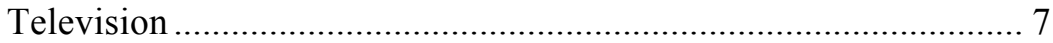

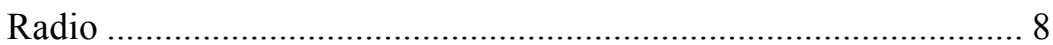

Previous studies on Kazakh as spoken in China .................................. 8

Doctoral theses about Kazakh in China ......................................... 9

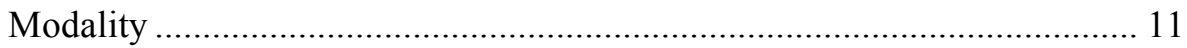

Types of modality markers ……………............................................ 12

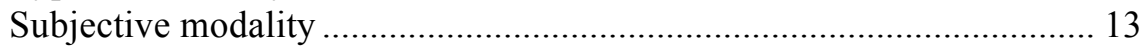

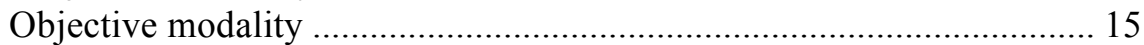

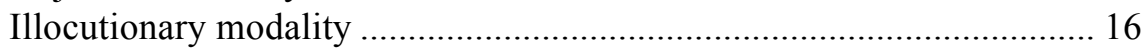

Personal and impersonal constructions..................................................... 17 
Non-modal notions: Inherent properties ......................................... 17

Moods............................................................................................. 19

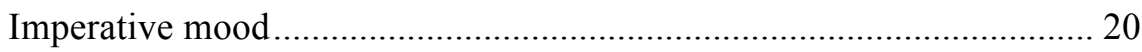

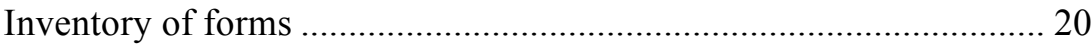

Affirmative ................................................................... 20

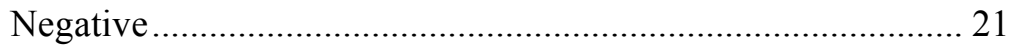

Basic semantic and syntactic properties .................................... 22

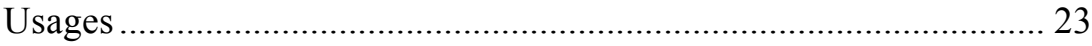

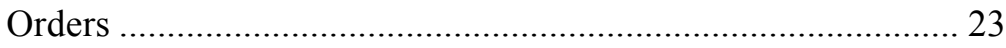

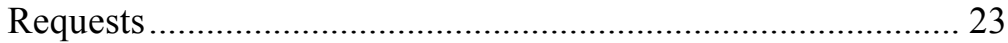

Permission ........................................................................... 24

Advice and suggestions ..................................................... 24

Prohibitive usages ........................................................ 25

Good wishes and curses...................................................... 25

Downtoning imperatives .......................................................... 26

Ways of replacing imperatives ................................................. 27

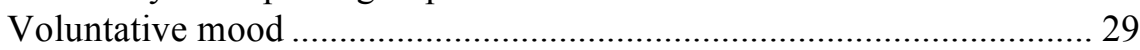

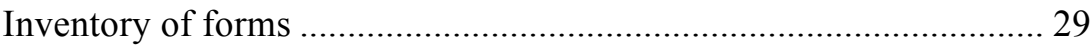

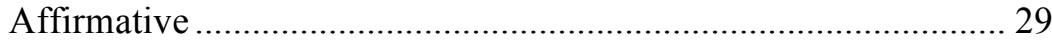

Negative ............................................................................ 30

Basic semantic and syntactic properties ................................... 30

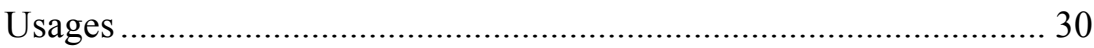

Usage of the first person forms of the voluntative ...................... 30

Usage of the third person forms of the voluntative ..................... 32

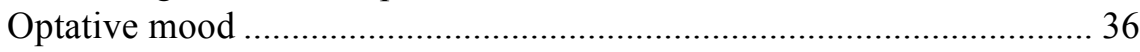

Inventory of forms .................................................................... 36

Affirmative ......................................................................... 36

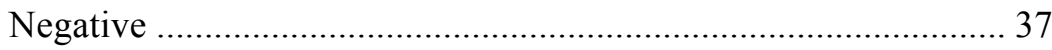

Basic semantic and syntactic properties ....................................... 38

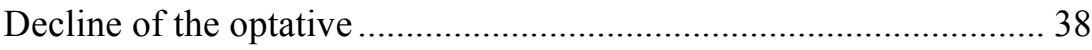

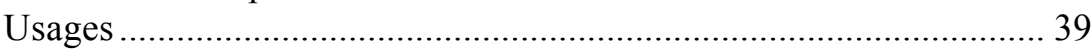

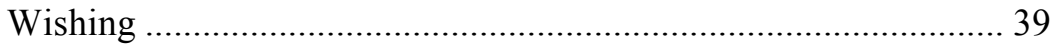

Polite request ............................................................................ 39

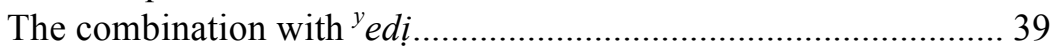

Hypothetical mood .......................................................................... 40

Inventory of forms ................................................................... 40

Affirmative ......................................................................... 40

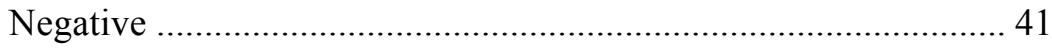

Basic semantic and syntactic properties ........................................ 41

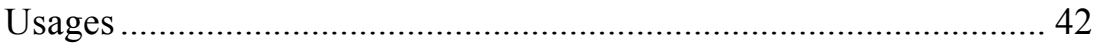

In main clauses ............................................................. 42

In subordinate clauses ........................................................ 44

Combination with ${ }^{y} e d i$ in main clauses ..................................... 46 
Combination with ${ }^{y} e d i$ in conditional clauses ................................... 47

Combination with ${ }^{y}$ eken in main clauses........................................ 48

Combination with ${ }^{y}$ eken in conditional clauses .............................. 50

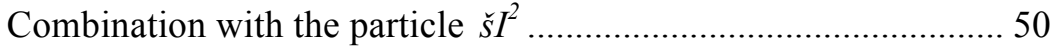

Combination with kaytedi / kałay .................................................... 51

Combination with the particle $d A^{2}$ in concessives ..........................51

Combination with $w h$-interrogatives ............................................. 52

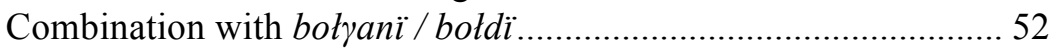

Combination with rana 'just, only' ................................................. 53

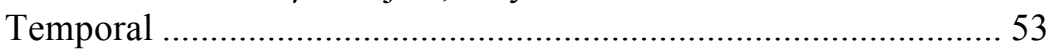

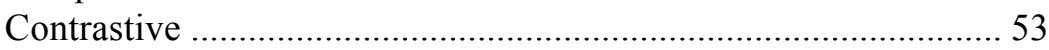

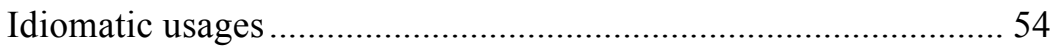

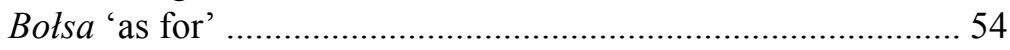

Tursa 'considering the fact that' ................................................. 55

Botmasa 'except for', 'apart from' ................................................ 55

Botmasa / ne botmasa / yá botmasa 'or, otherwise' .................. 56

Aytpese 'if not, otherwise' ..................................................... 57

Aytse de 'even so, nevertheless, however, but, though' ............. 57

Dese de 'even so, nevertheless, however, but, though' .............. 57

Süytse 'in fact, in reality, in truth' ............................................. 58

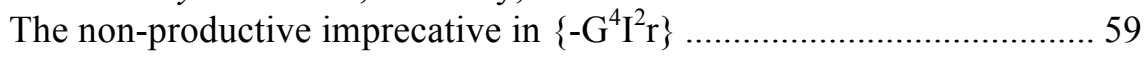

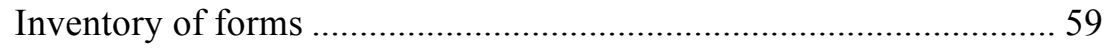

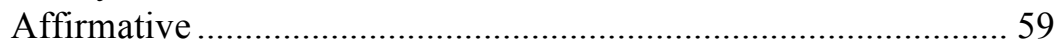

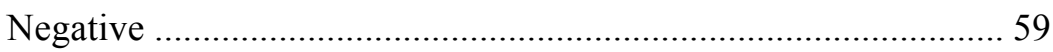

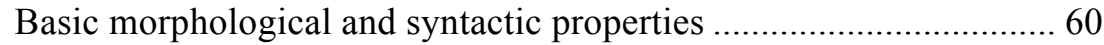

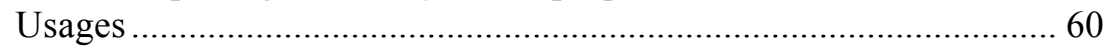

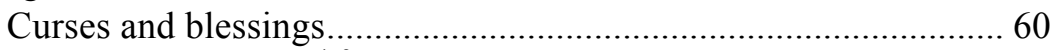

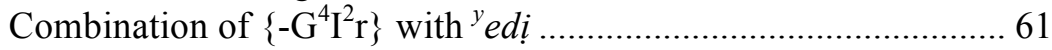

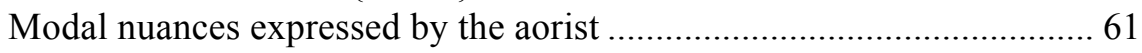

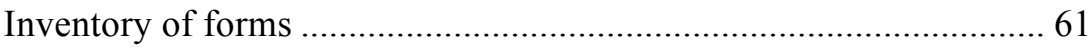

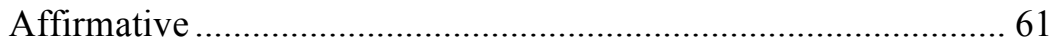

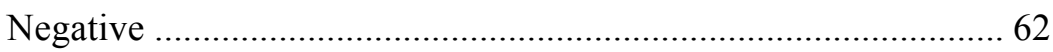

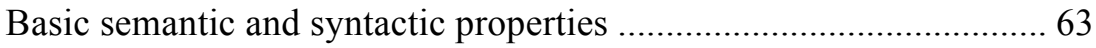

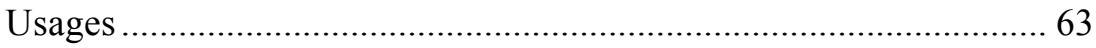

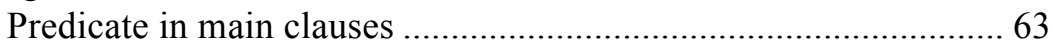

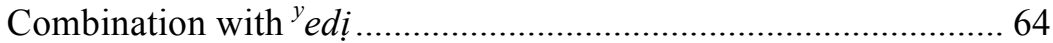

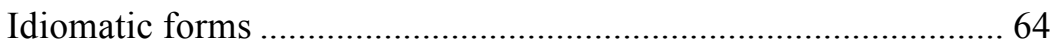

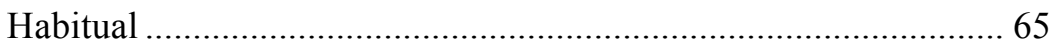

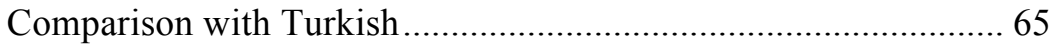

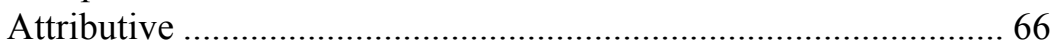

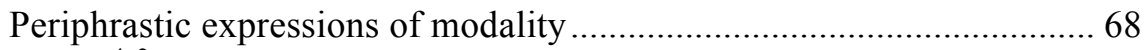

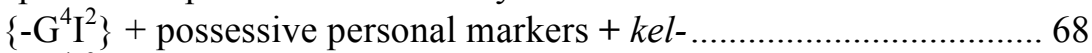

$\left\{-\mathrm{G}^{4} \mathrm{I}^{2}\right\}+$ possessive personal markers + bar ...................................... 70

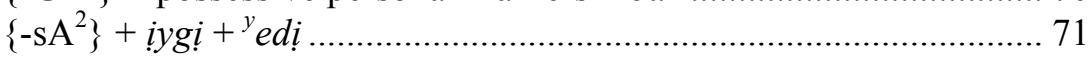




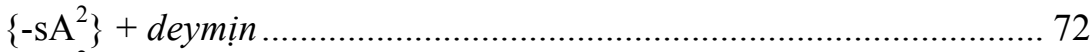

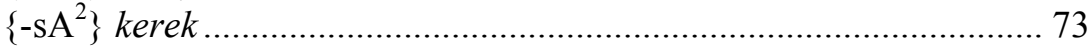

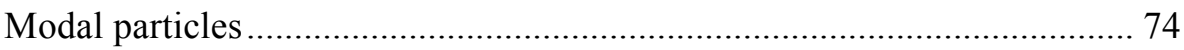

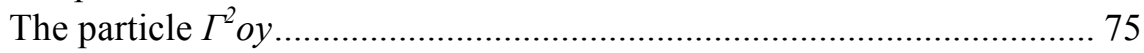

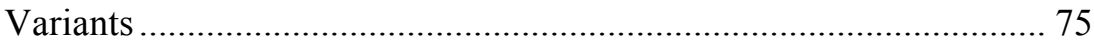

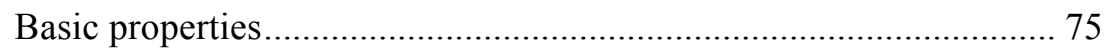

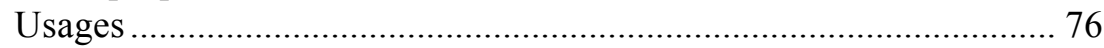

Reference to shared knowledge................................................... 76

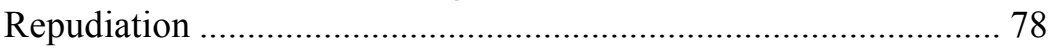

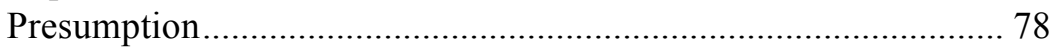

Non-modal usage: Tag-question .................................................... 79

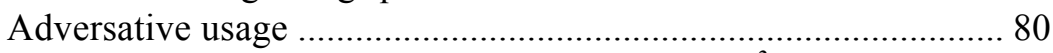

The combination of the hypothetical mood and $\Gamma^{2}$ oy................... 80

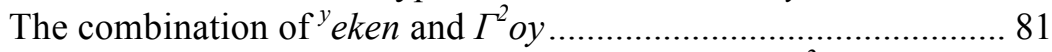

The combination of expressions of possibility and $\Gamma^{2} o y \ldots \ldots \ldots \ldots \ldots . . .81$

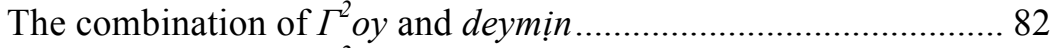

The combination of $\Gamma^{2}$ oy and deysin ............................................... 82

The complex particles bar yoy / bar yoy de / bar yoy ši ................. 83

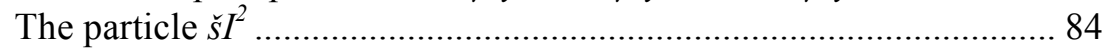

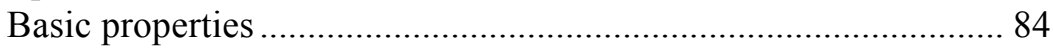

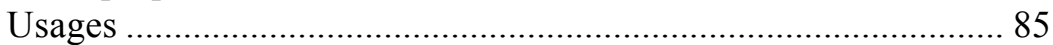

Combinations of $\breve{s} I^{2}$ with voluntatives and imperatives ............ 85

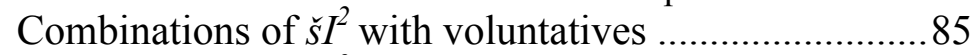

Combinations of $\breve{s} I^{2}$ with imperatives ............................ 85

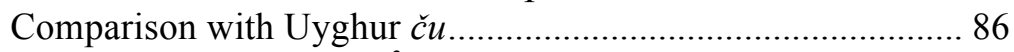

The use of the particle $\breve{s} I^{2}$ with hypothetical forms ................... 87

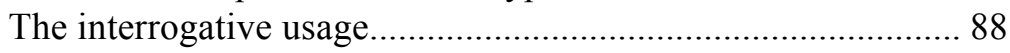

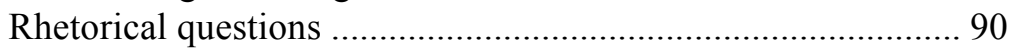

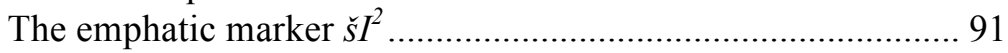

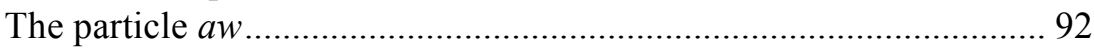

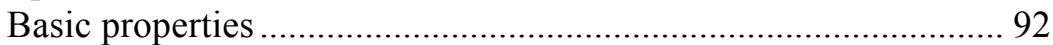

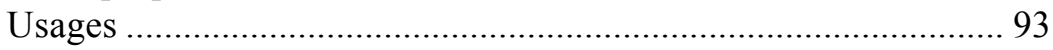

Emphasizing the truth of a statement.......................................... 93

Combination of $a w$ with the indirective particle ${ }^{y}$ eken .............. 93

Combination of $a w$ with hypothetical forms .............................. 94

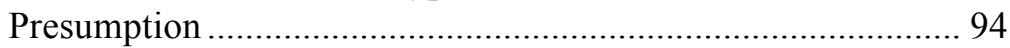

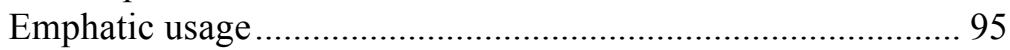

Combination of $a w$ with deymin ................................................. 95

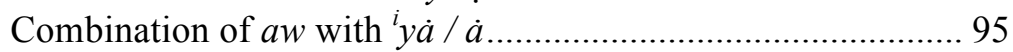

Combination of $a w$ with modal adverbs ................................... 96

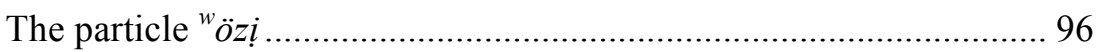

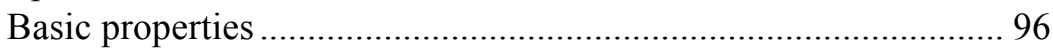

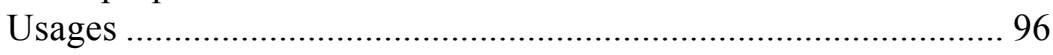




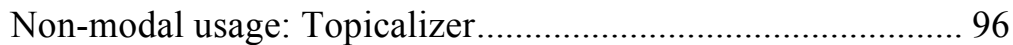

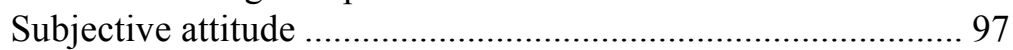

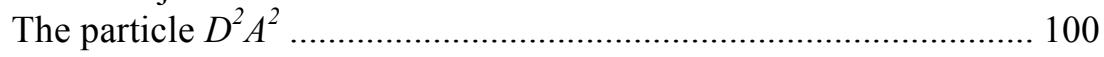

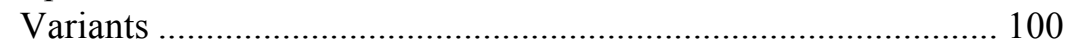

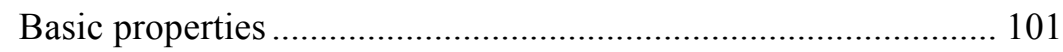

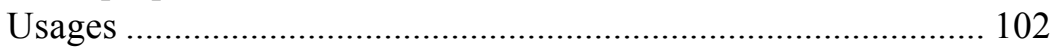

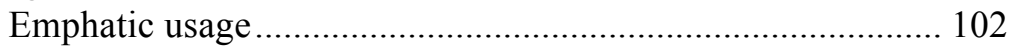

Combinations with indirective forms ……………................. 102

In juxtaposed clauses .......................................................... 103

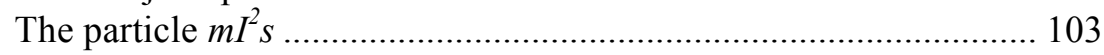

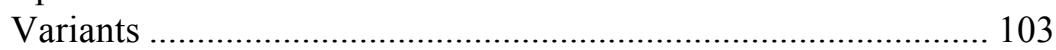

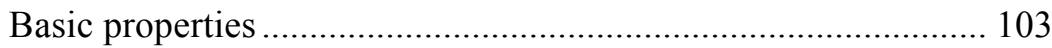

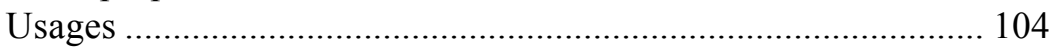

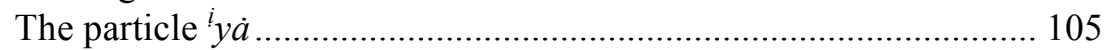

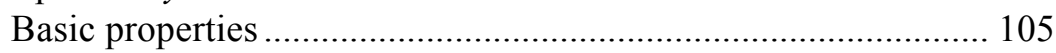

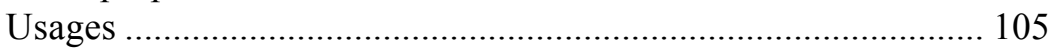

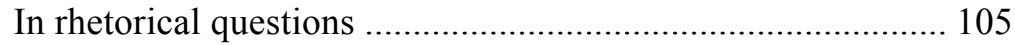

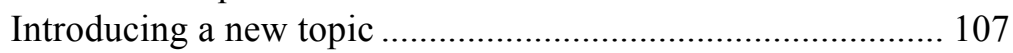

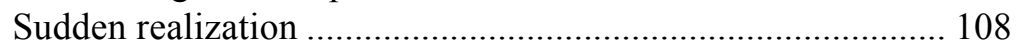

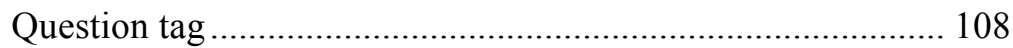

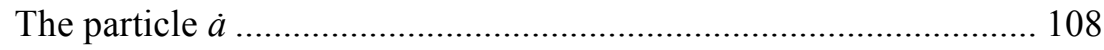

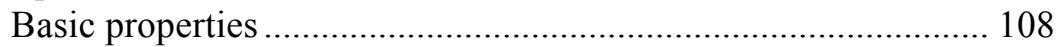

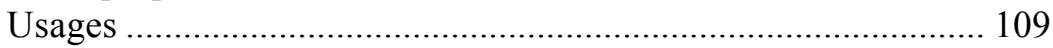

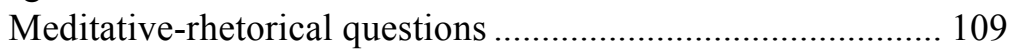

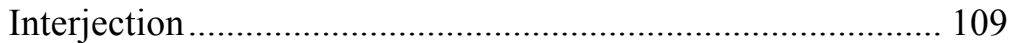

Set phrase $\dot{a}$ degennen .................................................111

Set phrases à degenše / a degenše botyan jok .............111

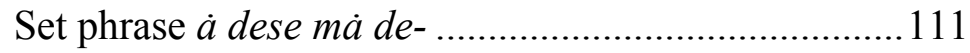

Comment on a piece of information ....................................... 111

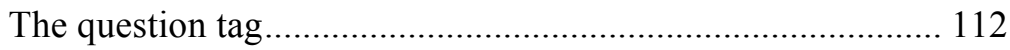

Combination with imperative and voluntative mood markers 113

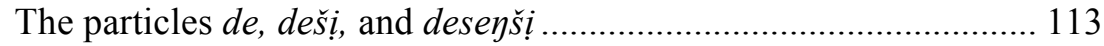

Basic properties ......................................................................... 113

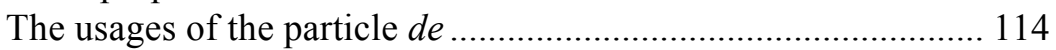

The usages of the particle deš .................................................... 115

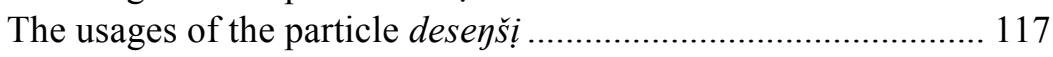

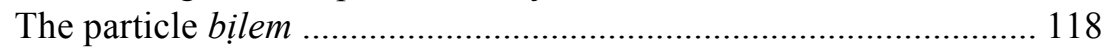

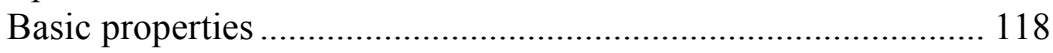

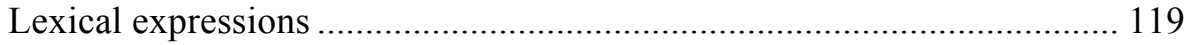

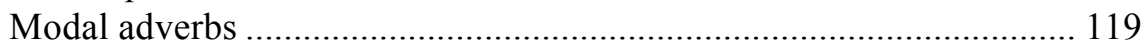

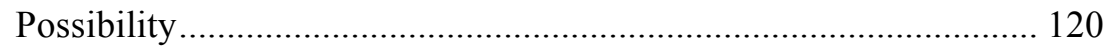

Bàlkịm 'maybe, perhaps', bàlki 'perhaps' ................................... 120

Mümkün 〈mümkịn〉 'possible' .................................................... 120 


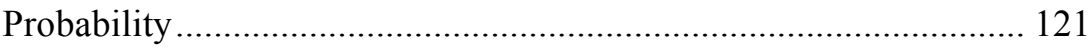

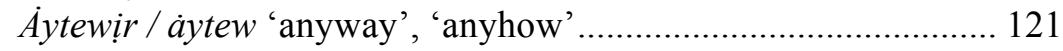

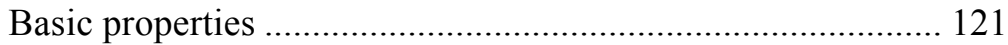

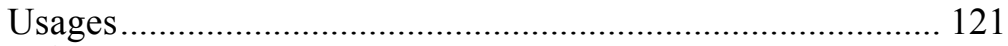

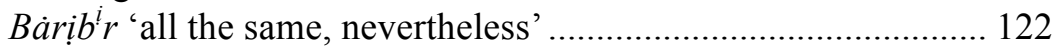

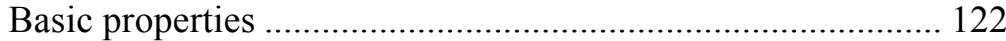

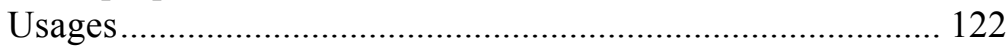

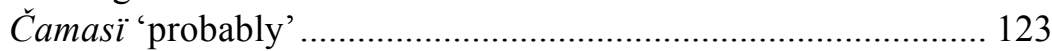

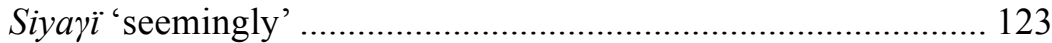

Asịli ‘most probably', 'actually'.................................................... 124

Sịà 'apparently, probably', zadï 'essentially', tegị 'obviously, apparently' ......................................................................... 124

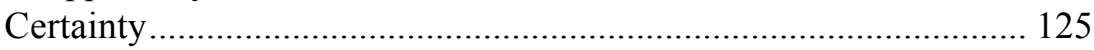

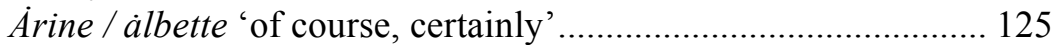

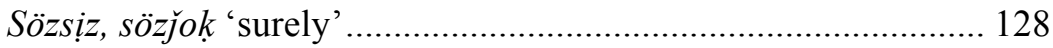

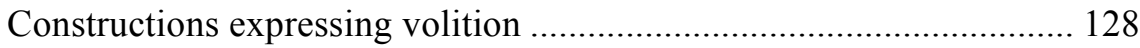

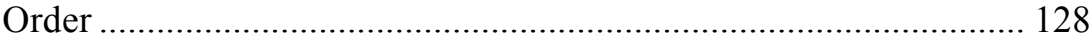

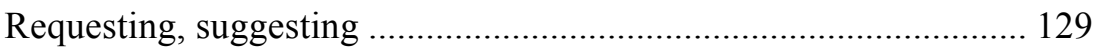

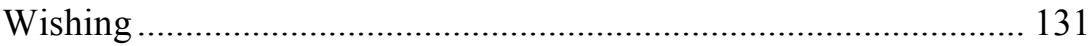

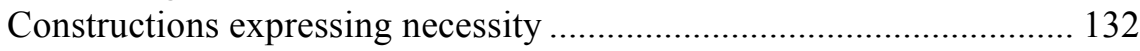

Comparison with Uyghur............................................................... 136

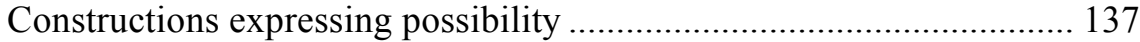

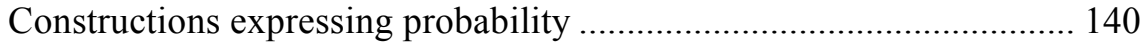

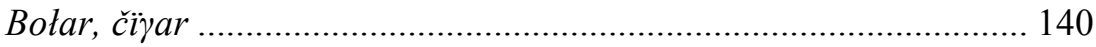

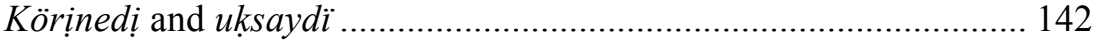

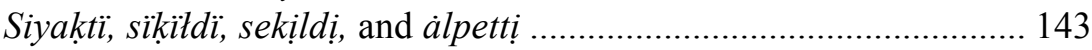

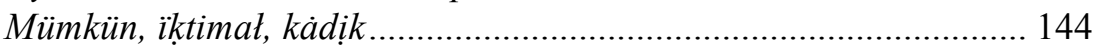

Botmasïn 'it is hopefully not...' ................................................... 145

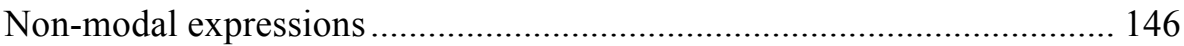

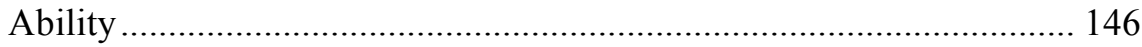

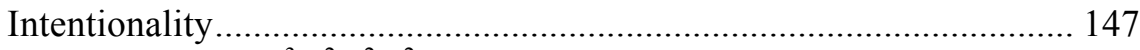

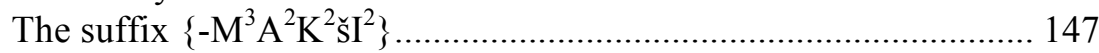

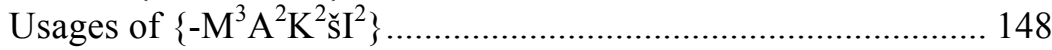

As predicate in main clauses.................................................. 148

$\left\{-\mathrm{M}^{3} \mathrm{~A}^{2} \mathrm{~K}^{2} \mathrm{~s}^{2}\right\}$ with inanimate subjects ................................. 150

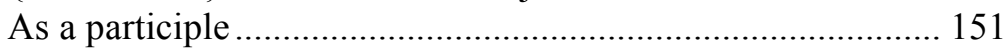

The sentential particle aytpakšĭ .............................................. 152

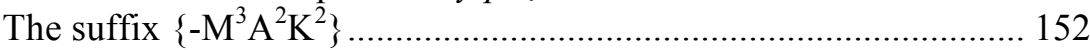

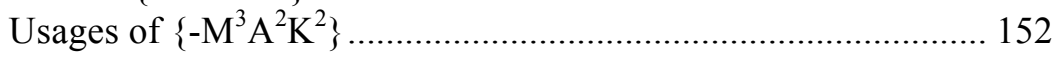

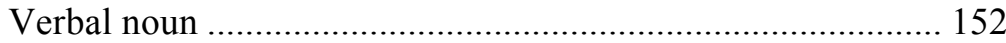

Predicate in main clauses...................................................... 153

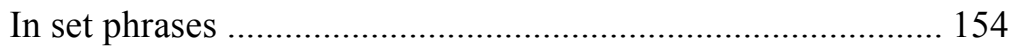

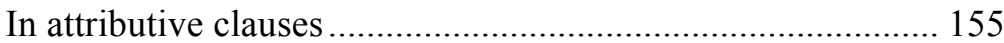




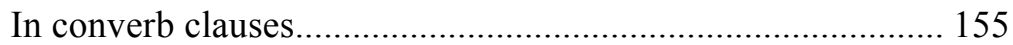

Small clause with nouns meaning intention ............................ 156

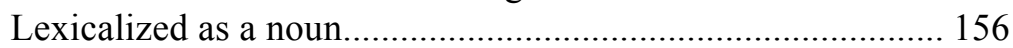

The sentential particle demek.................................................. 156

The conjunction turmak 'not to mention' ................................. 157

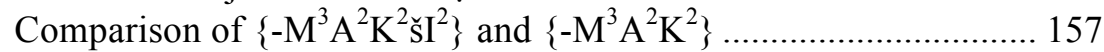

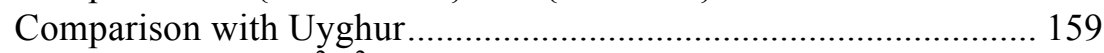

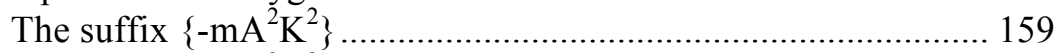

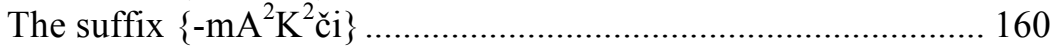

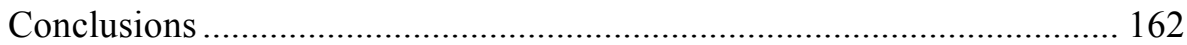

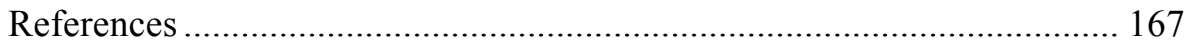

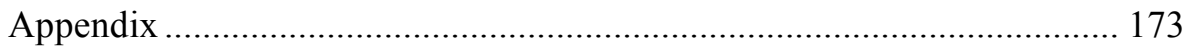

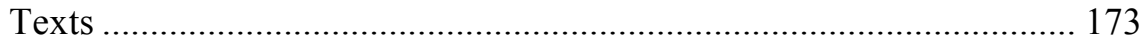

T1. Bałanïy dünyege keluwine bayłanistï salttar 'Customs concerning

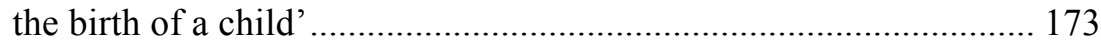

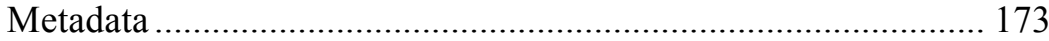

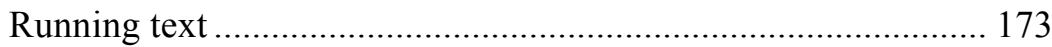

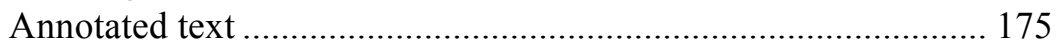

T2. Aygili adam: Musattar 'A famous person: Musattar' ................ 185

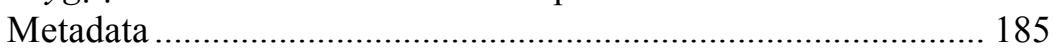

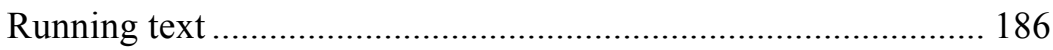

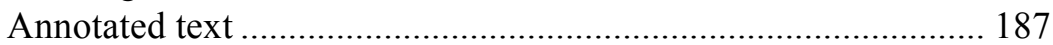

T3. Buwuršindayï xatïk ustazï 'A school teacher in Burqin' ............. 197

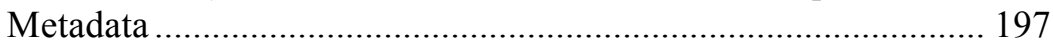

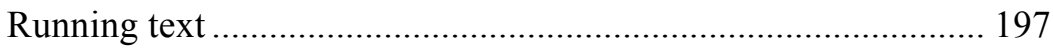

Annotated text ......................................................................... 199

T4. Aytakïnnïy äygimesị 'The story of Aytakïn' .............................. 209

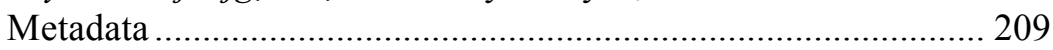

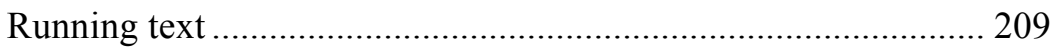

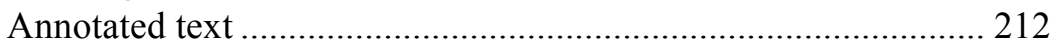

T5. J̌uggodayi kazak tịli 'The Kazakh language in China' ................ 228

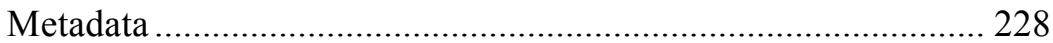

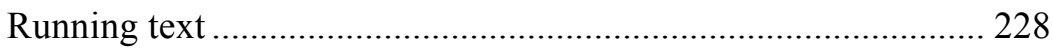

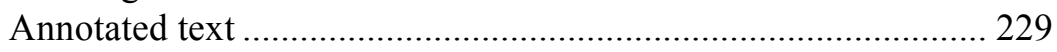

T6. Urpakka akiliya 'Advice to the descendants' ........................... 236

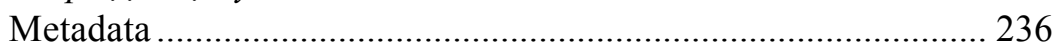

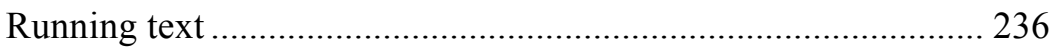

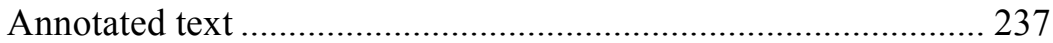

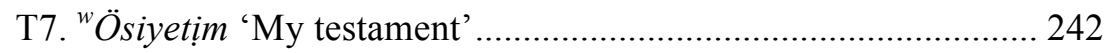

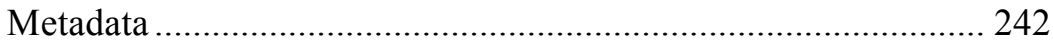

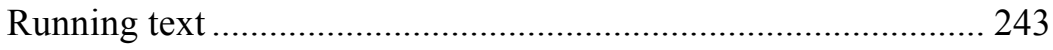

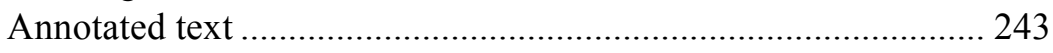




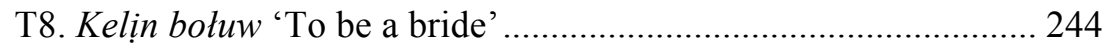

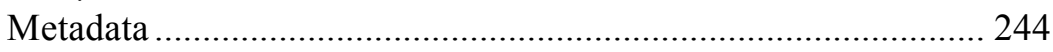

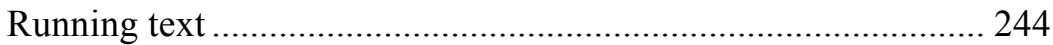

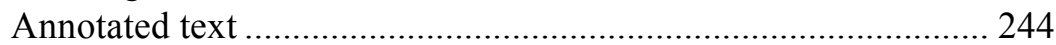

T9. J̌oyatyan kolfon 'The lost cell phone' ......................................... 246

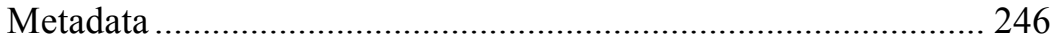

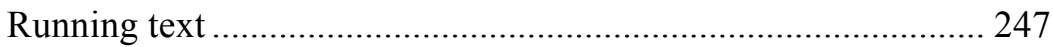

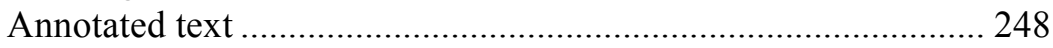




\section{Acknowledgments}

The experiences I gained by growing up in the multilingual landscape of Ürümqi have played a decisive role in my choice of academic career. I first of all thank my parents, sister and brother, and my wider family of Kazakhs in Xinjiang for making it possible for me to become a native speaker of the two large Turkic languages Kazakh and Uyghur. Later, I had the wonderful opportunity to study Kazakh at the Minzu University of China in Beijing, where I was a student of the prominent scholars in Kazakh studies Professor Zhang Dingjing and Professor Erkin Awgali. Their never-ceasing support has significantly contributed to my achievements.

In 2009, I was awarded a scholarship by the Chinese Research Council to study Turkic languages at the Department of Linguistics and Philology, Uppsala University. A year later the department accepted me as Ph.D. student and provided additional financial support for four years. I wish to express my thanks for this generous support which made this thesis possible and provided me with the chance to visit summer schools in Germany and Turkey, and to participate at conferences in Hungary, Kazakhstan, and Germany. For the last few years the department has been my academic home, a place where I could deepen my knowledge of Turkic and general linguistics. I thank all my teachers and fellow students for helpful discussions on various topics, including non-linguistic issues as well. Special thanks are due to Associate Professor Birsel Karakoç for her insightful comments on my thesis.

I am deeply indebted to my main supervisor, Professor Éva Ágnes Csató Johanson, for her scholarly guidance during my work on the dissertation. My other supervisor, Professor Lars Johanson, Johannes Gutenberg University, Mainz, opened new perspectives for me in comparative Turkic linguistics and typology. I am immensely grateful to him for our long and rewarding discussions during the last four years. I also wish to thank Professor Abdurishid Yakup, who was my supervisor for two years and contributed to the development of my work with valuable comments and advice.

Five years in Sweden does not make me a Swede, but the experience of participating in Swedish life and enjoying the comradeship of my friends in Uppsala has changed me in many respects. I will carry these values with me and take good care of them. Tack så mycket! 


\section{Abbreviations}

Table 1.

1

2

3

A.CONV

A.INTERJEC

A.PART

A.PART

A.PRES

ABIL

ABL

$\mathrm{ACC}$

ACCORDING TO.POSTP

ADV

AFORESAID.FILL

AFTER1.POSTP

AFTER2.POSTP

AGAINST.POSTP

AK.PART

ALONG.POSTP

AOR

AOR.LOC.CONV

AOR.PTCP

APPROX

ATIN.PAST.INTRAT

ATIN.PTCP

AW.INTERJEC

AW.PART

AY.INTERJEC

ȦY.INTERJEC

AYTPAKŠ̆II.PART

BEFORE.POSTP

BOL.COP

FORMER.FILL

CAUS

COME OUT.POSTV

COME.POSTV

COMP

COMPLETE.POSTV first person

second person

third person

converb in $\left\{-\mathrm{A}^{2} / /-\mathrm{y}\right\}$

interjection $a$

particle $a$

particle $\dot{a}$

present tense in $\left\{-\mathrm{A}^{2} / /-\mathrm{y}\right\}$

ability

ablative

accusative

postposition boÿ̈nča 'according to'

adverb

$\dot{a} \operatorname{lgi}$ / a agi 'aforesaid' used as a filler when one cannot find the right word or name

postposition keyịn 'after'

postposition soy 'after'

postposition karsï 'against, towards, in front of'

particle $a k$

postposition boyï 'along, since'

aorist $\left\{-\left(\mathrm{A}^{2}\right) \mathrm{r}\right\}$

converb based on the locative of the aorist

aorist participle

approximative

past intra-terminal in $\left\{-\mathrm{A}^{2} \ddot{\mathrm{t}}^{2} \mathrm{n} / /-\mathrm{yt} \mathrm{I}^{2} \mathrm{n}\right\}$

participle in $\left\{-\mathrm{A}^{2} \ddot{\mathrm{t}}^{2} \mathrm{n} / /-\mathrm{yt} \ddot{I}^{2} \mathrm{n}\right\}$

interjection $a w$

particle $a w$

interjection $a y$

interjection $\dot{a} y$

particle aytpakši

postposition burun 'before'

the copula bot- 'to become, be'

filler bayayi 'former, bygone, long-ago'; used when one cannot find the right word or name

causative

čik- 'to come out' used as a postverb

kel- 'to come' used as a postverb

comparative

worïnda- 'to complete' used as a postverb

xiv 


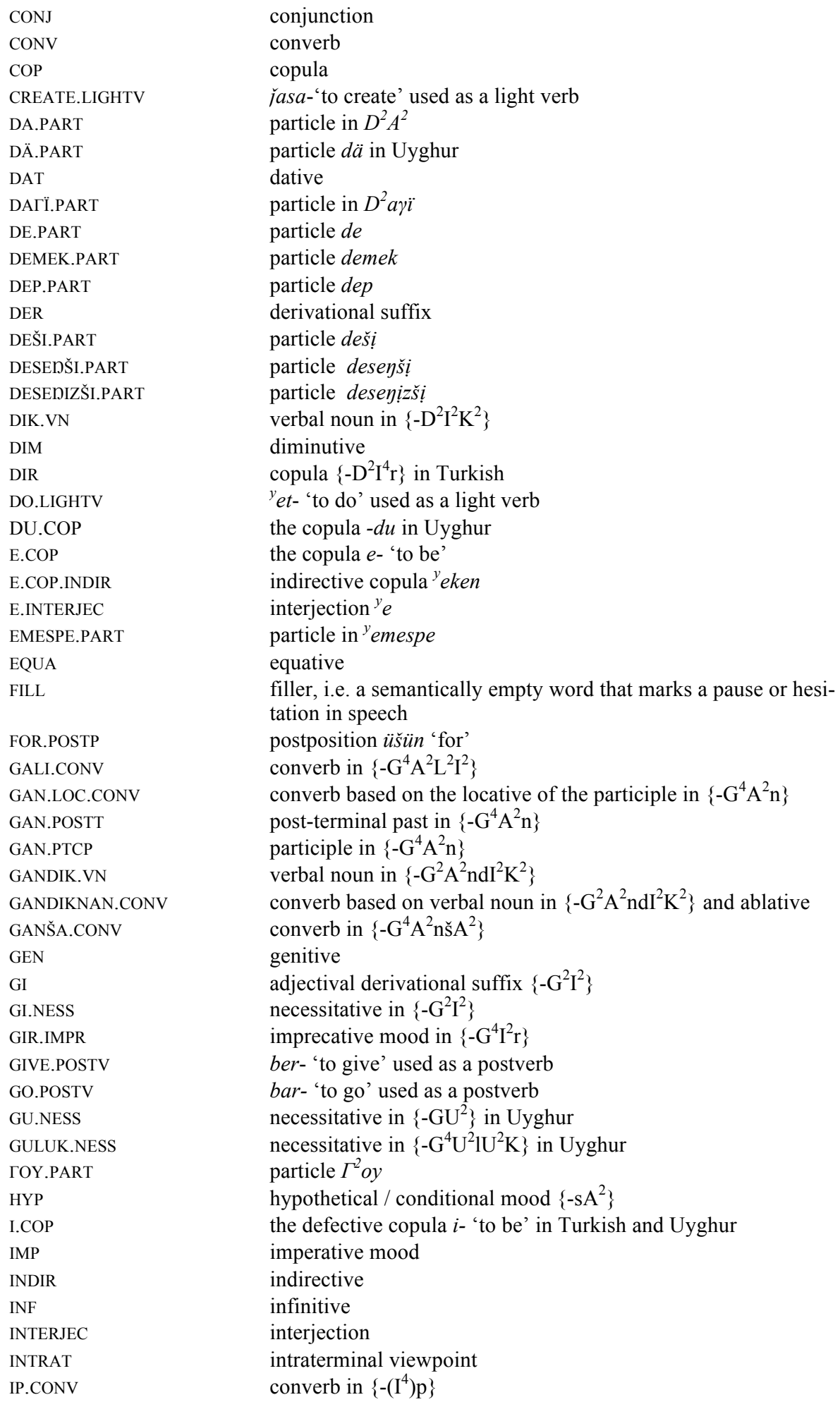




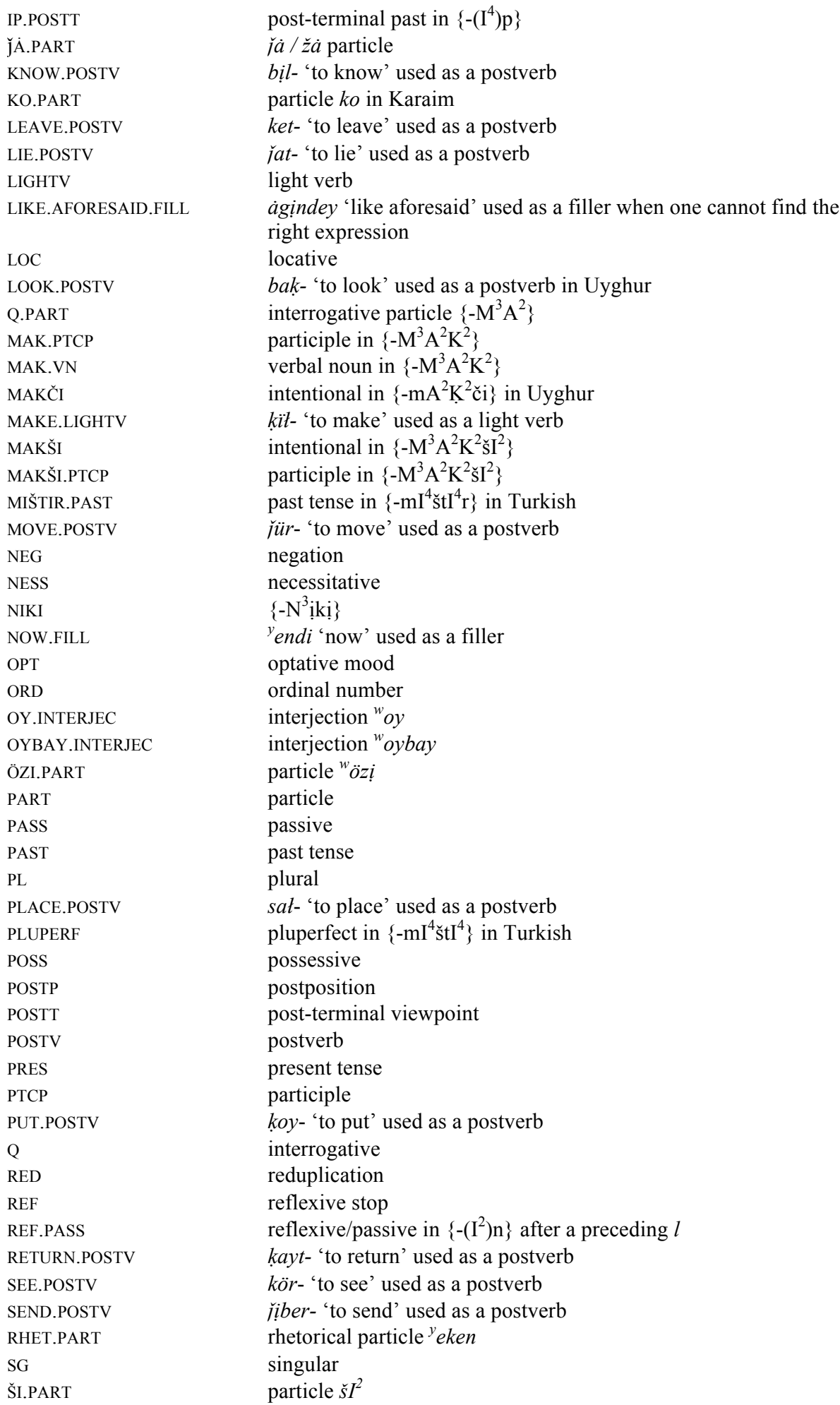


SIT.POSTV

STAND.POSTV

STAY.POSTV

SUPER

TAKE.POSTV

THAT.FILL

THIS.FILL

THROW.POSTV

TOWARD.POSTP

TUR.COP

TURMAK.CONJ

UNTIL.POSTP

UW.VN

UWDA.INTRAT

UWŠI.PTCP

$\mathrm{VN}$

VOL

WHAT.FILL

WITH.POSTP

YAं.INTERJEC

YȦ.PART
${ }^{w}$ otïr - 'to sit' used as a postverb tur- 'to stand' used as a postverb kat- 'to stay' used as a postverb superlative

at- 'to take' used as a postverb so / sot / ana 'that' used as a filler mïna 'this' used as a filler tasta- 'to throw' used as a postverb postposition karay 'toward, towards' copula tur 'to be' conjunction turmak 'not to mention' postposition deyịn 'until'

verbal noun in $\left\{-\mathrm{w} / /-(\varnothing) \mathrm{U}^{2} \mathrm{w}\right\}$ intraterminal in $\left\{-\mathrm{wdA}^{2} / /-(\varnothing) \mathrm{U}^{2} \mathrm{wdA}^{2}\right\}$ participle in $\left\{-w s ̌ I^{2} / /-(\varnothing) \mathrm{U}^{2}\right.$ wš $\left.\mathrm{I}^{2}\right\}$ verbal noun voluntative mood nemene 'what' used as a filler postposition $M^{3}$ en $/ M^{3}$ enen 'with' interjection ${ }^{i} y \dot{a}$ particle ${ }^{i} y \dot{a}$ 


\section{Transcriptions and notations}

\section{Transcriptions}

The following table presents the transcription system used in this study to render the Turkic (mostly Kazakh) data. This system is based on the one employed by Johanson (Johanson \& Csató eds $2006^{2}: 18-19$ ) and later modifications by the same author.

Table 2.

\begin{tabular}{|c|c|c|c|c|}
\hline Transcription & $I P A$ & Description & Cyrillic & Arabic \\
\hline $\mathrm{a}$ & {$[a]$} & low back unrounded vowel & A a & 1 \\
\hline$\dot{\mathrm{a}}$ & {$[\varepsilon]$} & lower-mid front unrounded vowel & Ә ә & $l_{\varepsilon}$ \\
\hline ə & [ə] & mid-central unrounded vowel & Ы ы & ى \\
\hline $\mathrm{b}$ & {$[\mathrm{b}]$} & bilabial weak stop & Б б & ب \\
\hline$\check{\mathrm{c}}$ & $[\mathrm{t}]]$ & palatal strong affricate & Ч ч & ₹ \\
\hline d & {$[\mathrm{d}]$} & prepalatal weak stop & Д д & د \\
\hline $\mathrm{e}$ & {$[\mathrm{e}]$} & upper-mid front unrounded vowel & $\mathrm{E} \mathrm{e}$ & 。 \\
\hline $\mathrm{f}$ & {$[\mathrm{f}]$} & labial strong fricative & $\Phi \phi$ & ف \\
\hline $\mathrm{g}$ & {$[\mathrm{g}]$} & postpalatal weak stop & $\Gamma \Gamma$ & 3 \\
\hline $\mathrm{h}$ & {$[\mathrm{h}]$} & glottal voiceless fricative & $\mathrm{h} \mathrm{h}$ & $ه$ \\
\hline $\mathrm{i}$ & {$[\mathrm{I}]$} & near high front unrounded lax vowel & I i & \& \\
\hline $\mathrm{i}$ & [i] & high front unrounded vowel & И и & ي \\
\hline$\ddot{i}$ & {$[\mathrm{w}]$} & high back unrounded vowel & Ы ы & ى \\
\hline j & {$[d]$} & palatal weak affricate & Ж ж & ج \\
\hline $\mathrm{k}$ & {$[\mathrm{k}]$} & postpalatal strong stop & К к & ك \\
\hline k & [q] & velar strong stop & Қ қ & ق \\
\hline 1 & [1] & voiced lateral approximant & Л л & J \\
\hline 1 & {$[\nmid]$} & voiced lateral velarized approximant & Л л & 」 \\
\hline $\mathrm{m}$ & {$[\mathrm{m}]$} & bilabial nasal & $\mathrm{M} \mathrm{м}$ & s \\
\hline $\mathrm{n}$ & {$[\mathrm{n}]$} & prepalatal nasal & $\mathrm{H} \mathrm{H}$ & ن \\
\hline $\mathrm{y}$ & {$[\mathrm{y}]$} & postvelar nasal & $\mathrm{H}$ & 可 \\
\hline $\mathrm{o}$ & [o] & upper-mid back rounded vowel & $\mathrm{O}$ o & 9 \\
\hline$\ddot{0}$ & {$[\varnothing]$} & upper-mid front rounded vowel & $\Theta \theta$ & عو \\
\hline $\mathrm{p}$ & {$[\mathrm{p}]$} & bilabial strong stop & $\Pi$ П & 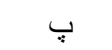 \\
\hline $\mathrm{r}$ & {$[\mathrm{r}]$} & prepalatal trill & $\mathrm{P} p$ & J \\
\hline s & {$[\mathrm{s}]$} & prepalatal strong fricative & $\mathrm{C} \mathrm{c}$ & 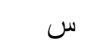 \\
\hline
\end{tabular}




\begin{tabular}{|c|c|c|c|}
\hline$\check{\mathrm{s}}$ & {$\left[\int\right]$} & postalveolar, strong fricative & Щ щ \\
\hline $\mathrm{t}$ & {$[\mathrm{t}]$} & prepalatal strong stop & $\mathrm{T} \mathrm{T}$ \\
\hline $\mathrm{u}$ & {$[\mathrm{u}]$} & high back rounded vowel & $¥ ¥$ \\
\hline$\ddot{\mathrm{u}}$ & {$[\mathrm{y}]$} & high front rounded vowel & $\mathrm{Y}_{\mathrm{Y}}$ \\
\hline$\dot{\mathrm{u}}$ & {$[\mathrm{H}]$} & high near-front rounded vowel & Уy \\
\hline $\mathrm{V}$ & {$[\mathrm{v}]$} & labial weak fricative & B в \\
\hline $\mathrm{w}$ & {$[\mathrm{w}]$} & bilabial glide & $\mathrm{y} y$ \\
\hline $\mathrm{x}$ & {$[x]$} & postvelar strong fricative & $\mathrm{Xx}$ \\
\hline $\mathrm{y}$ & {$[\mathrm{j}]$} & palatal glide & $\breve{И ̆ ~ и ̆ ~}$ \\
\hline $\mathrm{z}$ & {$[\mathrm{z}]$} & prepalatal weak fricative & 33 \\
\hline$\check{z}$ & [3] & palatal weak fricative & Ж ж \\
\hline$\gamma$ & {$[\gamma]$} & velar weak fricative & $\digamma_{\mp}$ \\
\hline
\end{tabular}

A raised character indicates an extra-short or evanescent segment. This can be a vowel, as in $b^{i} r$ 'one', or a consonant, as in ${ }^{y} e l$ 'country'.

\section{Other signs}

Brackets of the type \langle\rangle are used for glosses.

Hyphens are used to indicate morpheme boundaries.

A dash is placed to the right of verbal stems.

A dash is placed to the left of bound elements.

The sign < means 'has developed from', and > means 'has developed into'.

Simple arrows are used for morphological derivation. Thus $\leftarrow$ means 'is derived from'.

Curly brackets of the type \{\} are used for morphophonemic transcriptions.

A bracketed initial vowel sign indicates a consonant that occurs after stemfinal vowels and is absent after stem-final consonants.

A bracketed initial zero sign (Ø) indicates that the final vowel of the stem is dropped when the marker is added.

$\varnothing$ is the sign used for a zero element.

Double slashes // can be used to indicate postconsonantal and postvocalic alternants in one formula.

Language-specific morphemes are given in italics.

The asterisk * sign is used for an unacceptable form.

In the examples, an $\mathrm{X}$ indicates a pronoun that can be rendered as 'he/she/it' or 'that' or 'it/him/her/them' in the English translation.

Syllables bearing high pitch, i.e. accented syllables, are underlined. 


\section{Morphophonemic notations}

The following abbreviations are used in notations of morphophonemic suffix alternations:

$\begin{array}{lll}\left\{\mathrm{A}^{2}\right\} & = & a, e(\text { Uyghur } a, \ddot{a}) \\ \left\{\mathrm{A}^{2} / /-\mathrm{y}\right\} & =a, e, y \\ \left\{\mathrm{~A}^{3}\right\} & =a, e, \ddot{o} \\ \left\{\mathrm{D}^{2}\right\} & =\quad d, t \\ \left\{\mathrm{G}^{4}\right\} & =\quad g, \gamma, k, k \\ \left\{\mathrm{I}^{2}\right\} & =\quad i, \ddot{l} \\ \left\{\mathrm{I}^{3}\right\} & =\quad u, \ddot{u}, i \text { (Uyghur) } \\ \left\{\mathrm{I}^{4}\right\} & =\quad i, \ddot{u}, u, \ddot{u} \\ \left\{\mathrm{I}^{4}\right\} & =i, \ddot{i}, u, \ddot{u} \text { (Turkish) } \\ \left\{\mathrm{K}^{2}\right\} & =\quad k, k \\ \left\{\mathrm{~L}^{2}\right\} & =\quad l, t \\ \left\{\mathrm{~L}^{4}\right\} & =\quad l, t, d, t \\ \left\{\mathrm{M}^{3}\right\} & =\quad m, b, p \\ \left\{\mathrm{~N}^{3}\right\} & =\quad n, d, t \\ \left\{\mathrm{U}^{2}\right\} & =\quad u, \ddot{u} \\ \left\{\mathrm{U}^{4}\right\} & =\quad u, \ddot{u}, i, \ddot{i} \text { (Kirghiz) } \\ \left\{\Gamma^{2}\right\} & =\quad \gamma, k\end{array}$

\section{Examples}

Examples are presented in interlinear form consisting of the source text, a morphological annotation, and a free translation. For the morphological annotation see Abbreviations. The language is not specified when the example illustrates Kazakh as spoken or written in China. In other cases the language is specified. The source of the examples is not specified when the data is elicited from native speakers. In other cases, the source is given after the translation.

Examples taken from the recorded texts are numbered in accordance with the text in Appendix; thus T1 is Text 1 in Appendix. The number of the sentence in the text is given after a slash; thus T1/ 1 means Sentence 1 in Text 1 in Appendix. All Kazakh examples are given in a Turcological transcription; see Transcriptions above. Uyghur examples are given in standard Turcological transliteration. Examples taken from other languages than Kazakh are given in the standard orthography. Chinese examples are given in Pinyin script indicating the tone. 


\section{Introduction}

\section{Aim of the study}

The aim of this study is to investigate expressions of modality in Kazakh as spoken in China. Since Turkic modal categories are generally less studied than other grammatical issues, a comprehensive study of them seems well justified. No systematic comparison with the Kazakh varieties spoken in Kazakhstan will be made. The delimitation of the topic to Kazakh as spoken in China is motivated by the fact that the author is in a position to use linguistic data collected in the Kazakh-speaking regions of China. It is not assumed here that the Kazakh spoken in these regions today should be regarded as a specific dialect. However, the documentation to be presented illustrates that certain special innovative developments have taken place and can be explained by the sociolinguistic status of the speakers, many of whom are bi- or trilingual and are influenced by the two dominating contact languages, Chinese and Uyghur. It is hoped that the linguistic data presented here can serve as basis of comparison in forthcoming studies on the development of Kazakh as spoken in China.

Another specific aim of this work is to present some previous studies on Kazakh in China that have been published in Chinese or in Kazakh written in Arabic script, and which are not easily accessible for English-speaking readers. Due to the necessary delimitation of the scope of this investigation, less reference will be made to the important studies published in the former Soviet Union and Kazakhstan.

\section{Problems and methods}

The method employed here is empirical, i.e. data-oriented. The modal expressions in Kazakh are analyzed in a functional framework essentially based on the works of Lars Johanson. This author has developed an integrated model for describing modal expressions in Turkic languages; see, for instance Johanson 2009, 2012a, 2012b, 2013, and forthcoming. The framework defines semantic notions of modality in a functional and typological perspective. This approach has been applied in the present work by asking what devices Kazakh applies in order to express various semantic notions and structuring the presentation of these according to formal categories such as grammaticalized suffixes, particles, and lexical devices. The contribution 
of the present investigation is to apply this theoretical framework and methodological approach to an in-depth analysis of the Kazakh data.

\section{Data}

The data used in this study include texts recorded by the author in 2010 2012, mostly in the northern regions of Xinjiang (see Appendix), as well as written Kazakh texts published in Kazakhstan and China. The written texts represent different genres: fiction, non-fiction, poetry, and texts published on the internet. Moreover, examples have been elicited from native speakers of Kazakh and Uyghur.

\section{The Kazakh language in China}

According to the most recent annual statistics published in Xinjiang Yearbook (XJYB 2011), based on the census of 2009, the Kazakh population in the People's Republic of China amounted to 1,514,800, making it the second largest Kazakh population in the world.

Kazakhs in China mainly inhabit Ili Kazakh Autonomous Prefecture (Ille kazak aptonomiyati ${ }^{w}$ obitïis), Mori Kazakh Autonomous County (Mori kazak aptonomiyałi awdani) and Barkol Kazakh Autonomous County (Barköl kazak aptonomiyati awdani) (XJYB 2011: 352). The Kazakh language is spoken in the following areas of Xinjiang:

- The Ili, Altay, and Tarbagatay regions, all of which belong to Ili Kazakh Autonomous Prefecture.

- Ürümqi City, the Daban City region (in Ürümqi County), and the Tongsan region belonging to Ürümqi City.

- Mori Kazakh Autonomous County and the counties Qitai, Jimsar, Manas, and Hutubi, which belong to the Changji Hui Autonomous Prefecture (Sanji xuyzu aptonomiyati ${ }^{w}$ obitïisi).

- Barkol Kazakh Autonomous County of the Hami region (Kumit aymayïn̈̈ Barköl kazak aptonomiyatï awdani).

- Arasan and Jinghe Counties, which belong to the Bortala Mongol Au-

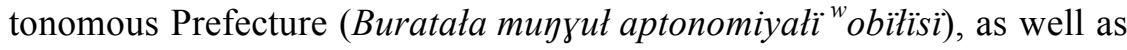
Bortala City.

Outside of Xinjiang in China, Kazakh is spoken in Aksai Kazakh Autonomous County (Aksay kazak aptonomiyati awdani) in Gansu Province and in some parts of Qinghai Province as well. 
Kazakh is one of the significant minority languages in China, ${ }^{1}$ playing an especially important role in the areas where Kazakhs dominate. In the different regions of Ili Kazakh Autonomous Prefecture, Kazakh serves as a lingua franca (Chinese tōngyòng yŭyán); i.e. it is used as a common language between speakers whose native languages are different, e.g. Uyghur, Chinese, and Xibe. Kazakh is a language of communication among Kazakhs in the other Kazakh autonomous counties. In Ili Kazakh Autonomous Prefecture the organs of the Communist Party and the government use both Kazakh and Chinese as official languages. However, the official documents issued by the authorities to the township level administrations are mostly written in Kazakh. The Congress of the Party in this prefecture employs a translation agency for Kazakh. Public signs including names of places, streets, etc., and official stamps, are both in Kazakh and Chinese. Kazakh is also used in the courts when they deal with a case concerning a Kazakh person (Li 2007: 1673-1674).

Kazakh is a language of education, is an object of research, and it has its own print and broadcast media in China. ${ }^{2}$

\section{Education in Kazakh}

\section{Before and after 1935}

Before 1935, there were no public schools in the Kazakh-speaking regions. Education outside the family was provided by Islamic religious institutions. The first Islamic school was established in Xinjiang in 1870, according to Ruoyu Fang (2009: 228). Kazakh boys went to the mosque to study religion and to learn Persian, Arabic, and Chaghatay, the written Turkic literary language of Central Asia.

After 1935, the religious institutions changed their function and became public schools. Especially after the foundation of the People's Republic of China in 1949, the Xinjiang Uyghur Autonomous Region implemented the Communist Party's ethnic policy and introduced education in the minority languages (XJUAR 2009: 432; see also Zhou 2003: 36-59). According to the statistical data provided in XJUAR (2009: 433-434), in 2004 there were 971 secondary and high schools and 3329 elementary schools, at which education was conducted in the six major minority languages: Uyghur, Kazakh, Mongol, Kirghiz, Xibe, and Russian. At 787 schools, including elementary, secondary, and high schools, education was bilingual (XJUAR 2009: 433-434). In 1991, there were 588 Kazakh elementary schools, with 138,973 students, 89 secondary schools, with 31,880 students, and 42 high schools, with 16,067 students, in total in Ili Kazakh Autonomous Prefecture.

\footnotetext{
${ }^{1}$ For more information about the status of Kazakh see Abish \& Csató (2011: 276).

${ }^{2}$ For more information on the history and culture of the Kazakhs in China see Benson \& Svanberg 1988, 1998, and Light 1993.
} 


\section{Bilingual instruction}

In 1964, several experimental classes (Chinese shíyàn bān) were strated at some secondary schools in Xinjiang (Xiaohua Fang 2009: 59). In these classes, all subjects were taught in Chinese, except for Kazakh literature. From 1966 to 1976, due to the turmoil of the Cultural Revolution, Kazakh schools were closed. Minority education in Xinjiang began to be restored and developed after 1976. At Kazakh schools, Chinese language acquisition started first from the third grade, later from the first grade in elementary schools. Until the end of 2004, at Kazakh elementary, secondary, and high schools the main subjects were taught in Kazakh. The teaching materials were translated from Chinese. In 2005, bilingual or alternatively monolingual Chinese instruction for Kazakh children started from the first grade (Abish \& Csató 2011: 277). Bilingual education was expanded to $100 \%$ of the preschools in the year 2011 throughout Xinjiang.

\section{Education at the universities}

Courses at Chinese universities are taught mainly in Chinese. Thus Kazakh students who are educated in Kazakh schools, must take one or two years of preparatory courses (Chinese yùkē) after enrollment at a university outside Xinjiang. The aim of these courses is to improve the students' competence in Chinese before they start to study their major subject. Certain subjects are given in Uyghur at the universities in Xinjiang.

\section{Code-copying varieties of Kazakh}

As a result of the bilingual and Chinese-monolingual education of Kazakh children, a high-copying variety of the language has developed among the young Kazakh generations. ${ }^{3}$ Although this is a natural process, it meets with many negative attitudes among the Kazakh people; see also Csató (1998) for similar negative attitudes in the Karaim community. ${ }^{4}$ These attitudes and the high-copying variety spoken in Ürümqi have been studied in a paper by Abish \& Csató (2011). The following conclusions were drawn:

Languages do not die of copying, as Johanson (2002a) has pointed out, but they might change significantly as a result of it. More important in language maintenance is the attitude towards language use. As in urban multicultural settings Kazakh is used in a restricted domain, the speakers can develop less favorable attitudes to the use of this language. This can in the future lead to more and more speakers shifting to the dominant languages. Sociolinguistic studies of language attitudes can shed more light on this issue. The documentation of the language use as it is today is an important and urgent task. Kazakh is not an endangered language at present (Bradley 2005), but increasing bilingualism will surely lead to many contact-induced changes. Moreover, as

\footnotetext{
${ }^{3}$ This variety of the language is illustrated in Text 9 of Appendix.

${ }^{4}$ This is illustrated by Text 5 in Appendix.
} 
the conditions for the development of Kazakh varieties are different in the various regions in Xinjiang, increasing divergence may be observed in the future. (p. 289)

\section{Research on Kazakh in China}

Academic research on Kazakh is carried out at several institutions in China:

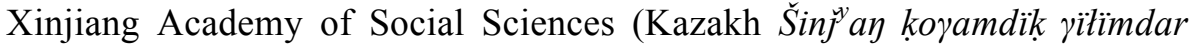
àkedemiyasï, Chinese Xīnjiāng shèhuì kēxuéyuàn), Minzu University of China (Kazakh ${ }^{w}$ Ortalïk utttar universiteti, Chinese Zhōngyāng mínzú dàxué), Xinjiang University (Kazakh Šinjyay universiteti, Chinese Xīnjiāng dàxué), The Working Committee of Minorities' Language and Writing of the Xinjiang Uyghur Autonomous Region (Kazakh Šinyay tịl jazuw komiteti, Chinese Xīnjiāng wéiwúěr zìhìū mínzú yǔyán wénzì gōngzuò wěiyuánhui), The Working Committee of Minorities' Language and Writing of Ili Kazakh Autonomous Prefecture (Kazakh Ille tịl jaazuw komitetị, Chinese Yīlí hāsàkè zìzhìhōu mínzú yǔyán wénzì gōngzuò wěiyuánhui), and Ili Normal University (Kazakh Ille pedagogika šöywànị, Chinese Yīlí shïfàn xuéyuàn). We here provide some information about these institutions.

\section{Xinjiang Academy of Social Sciences, Ürümqi}

Research on Kazakh is carried out at the Institute of Languages of the Xinjiang Academy of Social Sciences. The Institute of Languages was founded in 1978. Since then, the institute has published numerous linguistic and historical books, and a variety of dictionaries in Chinese, Uyghur, and Kazakh.

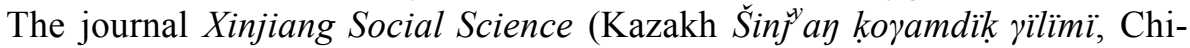
nese Xīnjiāng shèhui kèxué) is published quarterly by the Academy, which also organizes national and regional academic conferences and symposiums. Scholars from Kazakhstan regularly visit the Academy.

\section{Minzu University of China, Beijing}

The Department of Kazakh Language and Literature at Minzu University of China is a relatively young department. The study of Kazakh was introduced there by Professor Geng Shimin and some other scholars in 1953. In 1971, a Section of Kazakh Language and Literature was established. ${ }^{5}$ The section was headed by Professor Geng Shimin (1971-1989), Professor Li Zengxiang (1989-1995), and Professor Erkin Awgali (1995-2004). In April 15, 2004,

\footnotetext{
${ }^{5}$ From 1994 to 1996, it was called Department of Turkic Languages and Literatures (Kazakh Türịk tektes ulttar tịl-ädebiyeti fakuttetị, Chinese Tüjué yǔyán wénxué xì). From 1996 to 2000 its name was Department of Uyghur, Kazakh, Kirghiz Languages and Cultures (Kazakh

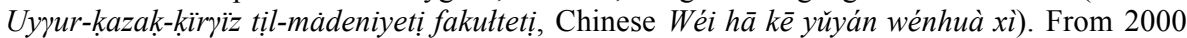
to 2001, the name was changed to Department of Turkic Languages and Cultures (Kazakh Türịk tektes utttar tịl-mádeniyeti fakultetị, Chinese Tüjué yǔyán wénhuà xi). From 2001 to 2004, it was renamed Department of Uyghur, Kazakh, Kirghiz Languages and Literatures

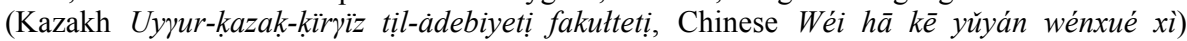
(DEKLL 2013).
} 
the Section of Kazakh Language and Literature was made into a separate department. From the beginning the head of the new department has been Professor Zhang Dingjing.

Over the past 60 years, 47 faculty members have worked in the fields of Kazakh language and literature at Minzu University of China. At present there are 11 faculty members with 189 undergraduates, 20 MA students and nine $\mathrm{PhD}$ students enrolled at the department. Moreover, the department has held workshops and international conferences, and published five volumes containing the proceedings of these academic meetings. Since 2006, the department has had close cooperation with academic institutions and universities in Kazakhstan, and with other foreign universities, for instance Uppsala University.

The Working Committees of Minorities' Language and Writing

The Working Committee of Minorities' Language and Writing of the Xinjiang Uyghur Autonomous Region was founded in 1960. This committee is responsible for the standardization of the minority languages of Xinjiang including Kazakh. The committee is also responsible for creating new Kazakh words. The Working Committee of Minorities' Language and Writing in Ili Kazakh Autonomous Prefecture was established earlier, already in 1950. The main task of this committee is to coordinate the language use between Uyghur and Kazakh in the prefecture.

\section{Publications in Kazakh}

There are three publishing houses which publish Kazakh books, CDs, and DVDs in China: The Ethnic Publishing House (Kazakh Utttar baspasï, Chinese Mínzú chūbăn shè) in Beijing, Xinjiang People's Publishing House (Kazakh Šinj゙ay xalik baspasï, Chinese Xīnjiāng rénmín chūbăn shè) in Ürümqi, and Ili People's Publishing House (Kazakh Ile xalik baspasï, Chinese Yìlí rénmín chübăn shè) in Kuytun.

According to statistics from 2010, Xinjiang has 12 publishing houses, including 10 book publishers, and two audio and video publishing houses. In Xinjiang 1153 persons work in the publishing sector, including 726 professional and technical workers. They publish 127 newspapers, including 52 in ethnic languages, and 207 journals, of which 113 are in ethnic languages (XJYB 2011: 335). 11 Kazakh newspapers are regularly published. The best known of these are: "Xinjiang Daily" (Kazakh Šinj"ay gázeti, Chinese Xìnjiāng rìbào), "Altay Daily" (Kazakh Altay gázetị, Chinese Ālètài ribào), "Tacheng News" (Kazakh Tarbayatay gàzetị, Chinese Tăchéng ribào). The number of Kazakh journals is 27. The best known are: "Ili River" (Kazakh Ille wözenị, Chinese Yīlí hé), "Tarbagatay" (Kazakh Tarbayatay, Chinese Tăchéng), "Heritage" (Kazakh Mura, Chinese Yíchăn), "Altay Spring Sce- 
nery" (Kazakh Altay ayasï, Chinese Ālètài chūnguāng), "Dawn" (Kazakh Šưuła, Chinese Shŭguāng).

The academic journals published in Kazakh include:

Tịl juane awdarma 'Language and Translation" ${ }^{96}$ (Chinese Yǔyán yŭ fānyi) ${ }^{7}$

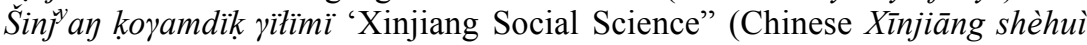
kèxué)

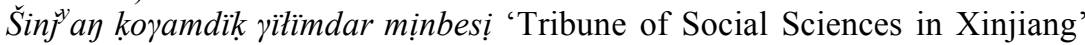
(Chinese xīnjiāng shèkē lùntán)

Šinj"ay universiteti yilïmi jurnati: filosofiya-koyamdik yilïmdar 'Journal of Xinjiang University. Philosophy, Humanities \& Social Science' (Chinese Xìnjiāng dàxué xuébào: shèhui kēxué)

Ile pedagogika šuxweyuwàni yïtïmi jurnatï 'Journal of Ili Normal University' (Chinese Yīlí shîfàn xuéyuàn xuébào)

Articles about the language, history, and culture of Kazakh written in Chinese appear in some Chinese academic journals, for instance:

Yīli shīfàn xuéyuàn xuébào 'Journal of Xinjiang Normal University'

Zhōngyāng mínzú dàxué xuébào: Zhéxué shèhui kēxué băn 'Journal of The Central University of Nationalities. ${ }^{8}$ Humane and Social Sciences Edition'

Shijiè mínzú 'World Ethno-National Studies'

Xīběi mínzú yánjiū 'N.W. Journal of Ethnology'

Zhōngguó mínzú jiàoyù 'Minority education'

Xīběi mínzú dàxué xuébào 'Journal of Northwest University for Nationalities'

Minzú yǔwén 'Minority Languages of China'

Scholarly publications about Kazakh written in Chinese are published by different Chinese publishers. The most important of these are Zhōngyāng mínzú dàxué chūbăn shè 'Chinese Minzu University Press', and Mínzú chūbăn shè 'The Ethnic Publishing House'.

\section{Broadcasting in Kazakh as spoken in China}

\section{Television}

The Xinjiang television station was founded in October 1970, in Ürümqi. Broadcasting in Kazakh was established in 1993 as a shared-time program together with the Chinese and Uyghur languages. At present, there are fifteen TV channels at the station, of which three TV channels (XJTV3 XJTV8 and XJTV12) broadcast in Kazakh. These cover the entire territory of Xin-

\footnotetext{
${ }^{6}$ The English translations of the journals' names are the ones printed on the journals.

${ }^{7}$ This is a high-quality periodical published in Xinjiang. It is sponsored by The Working Committee of Minority Language and Writing of the Xinjiang Uyghur Autonomous Region and the Xinjiang Translators' Association and is published in five ethnic languages, namely Chinese, Uyghur, Kazakh, Mongol, and Kirghiz.

${ }^{8}$ This is the former name of Minzu University of China.
} 
jiang. XJTV3 and XJTV8 transmit programs in Kazakh for about 16 hours a day. The children's TV channel, XJTV12, however, is a shared-time channel with Chinese and Uyghur. It transmits programs four hours a day. As a satellite channel, XJTV3 is also sent to some parts of Beijing and Gansu, where there are Kazakh communities, as well as to Kazakhstan. Apart from these, there is a Kazakh channel in the TV broadcasting service for local Kazakhs in Ili, Altay, and Tarbagatay. Every larger county with Kazakh inhabitants has its own shared-time TV channel, mostly broadcasting local, domestic, and international news in Kazakh for about two hours a day.

Radio

In Beijing, the radio programming in Kazakh at China national radio is allocated seven hours a day. In Ürümqi, at Xinjiang people's broadcasting, there are about 18 hours of programming a day except for Tuesdays and Thursdays. In Ili, the Ili Kazakh general broadcasting service sends programs for about 16 hours a day.

\section{Previous studies on Kazakh as spoken in China}

Several grammars and dictionaries written in both Kazakh and Chinese have been published in China. The most well-known grammars in Kazakh are:

Kazịrgi kazak tịli ['Modern Kazakh language'] 1983. Language and writing committee in Xinjiang (eds) Beijing: The Ethnic Publishing House

Kazirgi kazak tịli ['Modern Kazakh language'] 1985. Department of languages of Xinjiang University (eds). Ürümqi: Xinjiang Education Press

Kazịrgi kazak tịli ['Modern Kazakh language'] 1994. Beijing: The Ethnic Publishing House

Asïł, "Ömirḳan 1996. Kazịrgị kazak tịlị ['Modern Kazakh language']. Ürümqi: Xinjiang Teenagers Press

Geng, Shimin \& Kảken, Mảken \& " Orïnbay, Jumatay 1999. Kazịrgi kazak tịli ['Modern Kazakh language']. Beijing: The Ethnic Publishing House

Ramet, Mellat \& Ȧbịlyazï, Ałïmseyịt (eds) 2002. Kazịrgi kazak tịli ['Modern Kazakh language'] 2002. Ürümqi: Xinjiang People's Publishing House

Professors at Minzu University of China have published grammars written in Chinese:

Geng, Shimin \& Li, Zengxiang 1985. Hāsàkè yŭ jiăn zhì ['A brief introduction to Kazakh']. Beijing: Chinese Minzu University Press

Geng, Shimin 1989. Xiàndài hāsàkè yǔ yǔfă ['Modern Kazakh grammar']. Beijing: Chinese Minzu University Press

Zhang, Dingjing 2004. Xiàndài hāsàkè yŭ shřyòng yŭfă ['A practical grammar of Modern Kazakh']. Beijing: Chinese Minzu University Press

As the writing systems employed for writing Kazakh in Kazakhstan and China are different, some dictionaries edited in Kazakhstan have been repub- 
lished in China in the Arabic script. For instance, the monolingual Kazakh dictionary Kazak tịlịị tüsündịrme sözdigị, 1-10 tom ['Comprehensive Kazakh dictionary, 1-10'] (Chinese Hāsàkèyǔ xiángjiě cídiăn) published in Xinjiang People's Publishing House in 1992 is a republication in Arabic script of Kazak tilinịi tüsịndịrme sözdigi 1-10 tom ['The comprehensive Kazakh dictionary 1-10'] published in Almaty during 1974-1986.

Bilingual dictionaries published in China include: ${ }^{9}$

Kazakša-kanzuša sözdịk ['Kazakh-Chinese dictionary'] (Chinese Hā hàn cídiăn) 1977. Xinjiang People's Publishing House

Hàn hā cídiăn ['Chinese-Kazakh dictionary'] (Kazakh Kanzuša-ḳazaḳša sözdịk) 1979. Xinjiang People's Publishing House

Hàn hà chéngyǔ cídiăn ['Chinese-Kazakh proverbs'] (Kazakh Kanzušakazakšsa makał-mátelder sözdịgị) 1979. The Ethnic Publishing House

Daүorša-kazakša-kanzuša sözdịk ['Daghur-Kazakh-Chinese dictionary'] (Chinese Dáwò'ěr hāsàkè hànyǔ cídiăn) 1982. Xinjiang People's Publishing House

Hàn hā yùyán xué míngcí shùyŭ duizhào xiăo cídiăn ['Chinese-Kazakh linguistic terminology dictionary'] ('Kanzuša-kazakakša tịl bịlịm atawłarì sałïstïrmałï sözdigị’) 1985. Xinjiang People's Publishing House

Kazakša-kanzuša sözdịk ['Kazakh-Chinese dictionary'] (Chinese Hā hàn cídiăn) 1989. The Ethnic Publishing House

${ }^{w}$ Orïsša-kazaǩ́s-xanzuša kïskaša sözdịk ['Russian-Kazakh-Chinese dictionary’] (Chinese É hā hàn jiănmíng cídiăn) 1995. The Ethnic Publishing House

Kazakša-kanzuša sözdịk ['Kazakh-Chinese dictionary'] (Chinese Hā hàn cídiăn) 2005. The Ethnic Publishing House

Doctoral theses about Kazakh in China

Up to the present time three doctoral theses on Kazakh have been defended in China. All of them are written in Chinese. Two have already been published:

Huang, Zhongxiang 2005. Hāsàkè yǔ cíhuì yǔ wénhuà ['Kazakh vocabulary and culture']. [A Library of Doctoral Dissertations in Social Science in China]. Beijing: Chinese Social and Science Press.

Zhang, Dingjing 2003. Xiàndài hāsàkè yǔ xūcí ['Function words in Modern Kazakh']. Beijing: The Ethnic Publishing House.

Two other dissertations have recently been defended:

Wei, Wei Xiàndài Hāsàkè yǔ biăodá yŭqì yìỳ de jù diào shiyàn yánjiū ['An experimental study on intonations in modal sentences in Modern Kazakh']

\footnotetext{
${ }^{9}$ See for a list of dictionaries Yang (1999).
} 
2013. (Under the supervision of Zhang, Dingjing at Minzu University of China). ${ }^{10}$

Biduła, Patima Gǔdài tūjué yǔcí zài hāsàkè yǔ zhòng de yănbiàn ['A diachronic study of the changes of some Old Turkic lexical items in Modern Kazakh'] 2013. (Under the supervision of Erkin Awgali at Minzu University of China).

${ }^{10}$ This dissertation has not been accessible to us since it has not been published yet. 


\section{Modality}

The terms mood and modality have been applied in linguistics in many different ways; for a detailed account of the history of these terms see van der Auwera \& Zamorano Aguilar (forthcoming). In the present study, we will not discuss the history of these terms or their various definitions in current linguistic descriptions. The framework applied here is essentially based on several publications by Johanson (2009, 2012a, 2012b, 2013, forthcoming) and personal communication with him.

The conceptual domain of modality as defined here includes the expression of attitudes towards the proposition. Notions of volition, deontic evaluation, and epistemic evaluation are conveyed by modality markers.

Some of the types of grammaticalized modal notions dealt with in Johanson's studies are volition, deontic necessity and epistemic possibility. In the article Modals in Turkic (2009), the first two types of modal notions are briefly presented in the following way:

Volition:

'it is desidrable that', etc., suggesting that the action in question be carried out. The notions include demands, requests, directives, commands, impositions, entreaties, admonitions, warnings, exhortations, proposals, recommendations, advice, encouragement, incitement, etc. They also include desiderative, precative, permissive, promissive, intentional senses of wish, hope, desire and willingness. The volitional content may be realizable or unrealizable. (Johanson 2009: 489)

\section{Necessity:}

'it is necessary that'. The conditions motivating the necessity for the subject referent to carry out the action may be physical or social. The markers may be used to express directives that impose or propose that the action be carried out, to compel, incite or encourage to action. Expressions of necessity can develop into a sense of desire or intention. They normally also express deontic obligation in terms of moral, legal or social norms. The obligation may be strong, compulsive, in the sense of must, have to, need to, or weaker, obligative or advisory, in the sense of should, ought to. (Johanson 2009: 491)

The third modal notion, epistemic possibility, covers various types of assessments of the propositional content and can reflect a commitment to the 
truth of the proposition, i.e. to its certainty, probability, possibility, etc. The source of the evaluation can be the addresser's personal opinion or some other source.

\section{Types of modality markers}

Modal notions can be conveyed by different devices. In this study, we distinguish between moods, modal particles, and lexical expressions of modality.

Moods are highly grammaticalized inflectional forms of verbs. Turkic languages possess well-developed systems of distinctive grammatical moods that occur in main clauses, are expressed by verbal inflections and cover a wide range of notions within the conceptual domain of modality. The languages exhibit indicative, imperative, voluntative, optative, hypothetical, necessitative, potential, confirmative, presumptive, counterfactual, and other moods.

The indicative, which is morphologically unmarked, is the realis mood. It conveys factuality and is used for neutral, straightforward assertion. It indicates that the utterance is intended as a statement of fact, i.e. that something is actually the case; see Example 1.

Example 1

Aygül kel-e jatïr.

Aygul come-A.CONV LIE.POSTV.AOR3

'Aygul is coming.'

The other moods are irrealis moods indicating that a state of affairs is not actually the case, not factual, but rather imagined or hypothetical. They express wishes, desires, requirements, necessity, possibility, fear, counterfactual reasoning, etc. The conceptual and functional boundaries between them are not always clearly distinguished. The usages of different moods may even overlap in one and the same language. A mood is not always used for one single semantic domain, but can express several kinds of modal notions, for example both volitional and deontic notions (Johanson forthcoming). As far as Kazakh moods are concerned, see the chapter Moods.

Modal particles are grammaticalized free morphemes expressing modal notions. Kazakh has a rich inventory of modal particles; see the chapter $\mathrm{Mo}$ dal particles.

Slightly grammaticalized lexical expressions conveying modal notions will be studied in the chapter Lexical expressions.

An important distinction is made between synthetic and analytic devices. In Turkic, the synthetic devices are bound inflectional markers, suffixes. 
Most of these are attested in similar forms at the oldest known stage of the development of Turkic documented in the East Old Turkic inscriptions. These old markers already represent advanced stages of their respective grammaticalization processes. The expressions of volition and necessity are all of unknown origin, i.e. they cannot be traced back to independent lexical elements. Whatever the lexical sources may have been, they have already undergone the changes typical of grammaticalization: extension of occurrence, desemanticization, decategorialization and material erosion. There is no indication that these devices have been copied from other languages. (Johanson 2009: 488)

Turkic languages also employ analytic devices:

various analytic (periphrastic) devices for expressing volition, necessity and possibility: nominal or verbal predicates with nonfinite forms as complements. The synthetically expressed moods are, as mentioned, semantically vague, e.g. open to various interpretations. The analytic devices can be used to convey more specific information. The analytic constructions basically express 'objective' modalities, but they have also played an essential role in the renewal of the 'subjective' modalities expressing volition, necessity and possibility. Language contacts have played an essential role for this renewal. It is impossible to claim that all these analytic devices have emerged under foreign influence, but their use has undoubtedly been corroborated or expanded by foreign models. (Johanson 2009: 495)

The Kazakh mood categories imperative, voluntative, optative and hypothetical are synthetic devices. Another synthetic inflectional form, the aorist, can convey modal meanings; see the chapter Mood and Aibixi (2012: 39-42). The synthetic possibility/impossibility forms based on $\left\{-\mathrm{A}^{2} / /-\mathrm{y}\right\}+$ at- or + bịl- and $\left\{-\mathrm{A}^{2} / /-\mathrm{y}\right\}+a t-m a-$ or + bil $l-m e$ - are not modal forms according to the definition applied in this study because they convey inherent properties and not attitudes. See more about this distinction below.

Analytical devices employed in Kazakh are based on lexical verbs, e.g. kała- 'to want, to wish', nominal items, e.g. kajet, kerek, tiyị 'needed, necessary' or šart 'essential', adverbs, particles, etc. Analytical forms will be dealt with in connection with the synthetic forms and in the chapters Modal particles and Lexical expressions; see also Aibixi (2012: 42-44).

\section{Subjective modality}

A distinction can be made between subjective and objective modality. According to Johanson (2009: 489), subjective modality expresses the addresser's cognitive or affective attitude toward the event described in the proposition, which represents a possible fact. It can signal meanings of subjective reasoning, personal involvement, emotions, and personal judgments. The evaluation is restricted to the addresser's personal opinion, and the addresser takes personal responsibility for it. 
One kind of subjective modal meaning is concerned with volition, the addresser's wish with respect to the realization of the propositional content. It indicates desire, need, hope, fear, purpose, command, demand, request, intention, encouragement, incitement, permission, appeal, warning, advice, recommendation, promise, etc. In Example 2, the hypothetical mood in combination with the particle deymin 'lit. I say' expresses the addresser's subjective will.

Example 2

Kezdes-se-m deymin.
meet-HYP-1SG DEYMIN.PART
'I would like to meet.'

Lexical expressions such as atta katasa 'God willing' may also be used to express the addresser's wish; see Example 3.

Example 3

Alta kata-sa, tayi kezig-er-miz.

Allah will-HYP3 again meet-AOR-1PL

'If Allah wills, we might meet again.'

A second kind of subjective modal meanings is concerned with deontic modality, i.e. possibility and necessity in terms of freedom and duty to act, e.g. 'X may do' (permission), 'X should do' (advice), 'X must do' (compulsion).

Example 4

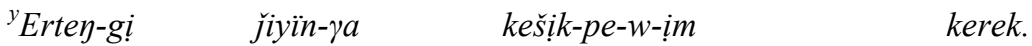

tomorrow-GI meeting-DAT late-NEG-UW.VN-POSS1SG necessary

'I should not be late for tomorrow's meeting.'

A third kind of subjective modal meaning is concerned with epistemic evaluation, based on the addresser's own assessment of the propositional content as being more or less certain or likely. Epistemic modality indicates certainty, confirmation, reliability, probability, likelihood, potentiality, presumption, uncertainty, doubt, counterfactuality, etc. It may mark the addresser's level of commitment to the truth of an utterance, e.g. it 'might be the case' (low probability), 'may be the case' (possibility), 'should be the case' (high probability), 'must be the case' (very high probability). The source of this evaluation is a personal opinion that the event is certain, probable, possible, unlikely, etc. Examples: 'I believe', 'I know', 'I think', etc. Lexical expressions such as in my opinion or in my experience may be used (mostly in the initial position of a clause). In Example 5, the Kazakh adverb menče 'as for me' conveys the subjective evaluation of the addresser. 
Example 5

Men-če, $\quad k e l-e-d i ̣$.

I-DER come-A.PRES-3

'As for me, X comes. / As for me, X will come.'

\section{Objective modality}

Modality is not exclusively addresser-oriented. Modal expressions can express desirability, necessity, potentiality, etc., in a more general sense of 'what should / may / would be', e.g. 'it is desirable, wanted, requested, conceivable, necessary, probable, possible, acceptable, permissible that'. Objective modality distinctions present evaluations of the believability, obligatoriness or desiderability of a propositional content as independent of the addresser's own stance. The evaluation may be made according to the standards of a higher will, laws, traditions, social conventions, etc. Voluntatives and optatives may be less dependent on the addresser's own will, necessitatives less dependent on the addresser's own assessment and hypothetical expressions less dependent on the addresser's own imagination, etc. In Example 6 , the voluntative expresses the meaning 'it is desirable'.

Example 6

Mektep-ke kešịk-pe-y kel-eyịk.

school-DAT be late-NEG-A.CONV COME.POSTV-VOL1PL

'It is desirable that we not come late to work'.

Objective deontic modal devices are used to evaluate events with respect to moral, legal or social norms, e.g. whether they are obligatory, necessary, acceptable, allowable, permissible, or unacceptable, prohibited, forbidden, etc. In Example 7, kajet renders an objective deontic meaning.

Example 7

Gül čöp-ter-dị ayała-uw kajet.

flower grass-PL-ACC protect-UW.VN necessity

'One must protect the flowers and the plants.'

Objective epistemic modalities evaluate the likelihood of an event occurring in terms of knowledge of events in general, e.g. whether they are certain, probable, possible, conceivable, improbable, doubtful, impossible, etc. The lexical item kerek 'necessary' can convey an objective epistemic meaning in Example 8. 
Example 8

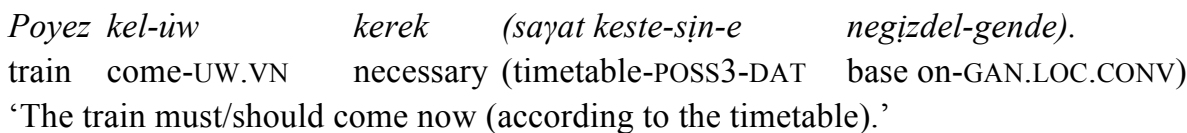

Subjective modality can be combined with objective modality, in which case subjective modality ('according to my knowledge') takes the objective modality ('is forbidden') within its scope. ${ }^{11}$

Example 9

Bịl-üw-ịm-de, but jer-de temeki čeg-üw-ge know-UW.VN-POSS1SG-LOC this place-LOC tobacco smoke-UW.VN-DAT tiyịm sat-ïn-a-dï. interdiction put-REF.PASS-A.PRES-3

'As I understand it, it is forbidden to smoke here.'

\section{Illocutionary modality}

Illocutionary modality concerns the addresser's comment on his or her own utterance. The illocutionary value of a sentence can be specified or modified by lexical means, "illocutionary satellites" (Dik 1989: 49) or "style disjuncts" (Greenbaum 1969: 92, Schreiber 1972: 321, Quirk et al. 1985: 615). In sentences such as Frankly, he is good and In brief, he is good, the satellites frankly and in brief are not manner adverbials that modify the event expressed in the predication. The sentences can be paraphrased as I am speaking frankly when I say that ..., If I may sum up, I would say that ..., etc. (Greenbaum 1969: 82).

In Example 10, the addresser comments on the proposition 'I do not want to go' by adding the expression ašïïn aytsam 'frankly speaking, to tell the truth'. In Example 11, the expression 'eskerte keteyin 'let me warn (you)' functions as an illocutionary operator.

11 In the grammar MKL, the chapter dealing with modality is called modat sözder ['modal words']. In this chapter, the modal words are described both from semantic and grammatical perspectives. A distinction is made between subjective and objective modal meanings. This distinction does not correspond to the one employed by us in this study. The authors of this grammar regard the moods and the aorist marker to be synthetic devices to express objective modal meanings, whereas the subjective modal meanings are claimed by them to be expressed by specific lexical items and some kömekši sözder ['functional words']. The functional words are those we call particles in this study. Evidentiality is also described in this grammar as a modal category expressed by the indirective copula ${ }^{y}$ eken and the verbal inflectional suffix $\left\{-\left(\mathrm{I}^{2}\right) \mathrm{pt \textrm {I } ^ { 2 }}\right.$. 
Example 10

$\begin{array}{lll}\text { A ̌̌ĭ-ï-n } & \text { ayt-sa-m, } & \text { bar- } y \ddot{i}-m \\ \text { clear-POSS3-ACC } & \text { tell-HYP-1SG } & \text { go-GI-POSS1SG } \\ \text { kel-me-y } & \text { tur. } & \\ \text { come-NEG-A.CONV } & \text { STAND.POSTV3 } & \end{array}$

'Frankly speaking, I do not want to go.'

Example 11

$\begin{array}{llll}{ }^{y} \text { Eskert-e } & \text { ket-eyịn, } & \text { kün } & \text { sözsịz jaw-a-dï. } \\ \text { warn-A.CONV } & \text { LEAVE.POSTV-VOL1SG } & \text { weather } & \text { definitely fall-A.PRES-3 }\end{array}$

'I warn you, it will definitely rain.'

\section{Personal and impersonal constructions}

Moods are often, particularly in older Turkic languages, open to different interpretations with respect to the subject of the construction, when it is not explicitly identified as a specific referent. A remnant of this vagueness is found in modern Turkish, where the third-person necessitative-debitive marker $\{-\mathrm{mAlI}\}$ shows both personal and impersonal uses, e.g. Gel-meli 〈come-NESS ' $\mathrm{X}$ ought to come' or 'It is necessary to come', 'One ought to come'. Identity of the addresser and the subject referent is possible in the first person, e.g. Turkish Gid-eyim 'I want to go' = 'I want myself to go'. A similar ambiguity may occur with respect to agents and patients. The East Old Turkic necessitative marker $\{-\mathrm{GU}\}$ is an example of this since it can refer to both agents and patients, e.g. ber-gü 〈give-NESS〉 'someone who shall give' or 'something that shall be given, something to give' (Johanson: forthcoming).

\section{Non-modal notions: Inherent properties}

Inherent distinctions, which define "the relations between a participant in a state of affairs and the realization of that state of affairs" (Hengeveld 1987: 56, cf. also Hengeveld 1988: 233), are not modal distinctions expressing any attitude towards the predication and will therefore not be treated here as genuinely modal expressions. They are based on actional phrases that belong to the internal structure of the predications, and express inherent properties of participants. If they express an attitude, it is the attitude of the addresser as a participant. Diachronically, they tend to develop into grammatical modal expressions. In this study, we will briefly deal with some types of inherent properties of participants, for example ability and intention, in the chapter Non-modal expressions. In Examples 12 and 13, the ability to swim and the intention to swim are inherent properties and thus are not covered by our definition of modality. 
Example 12

Matta-y at-a-mïn.

swim-A.CONV TAKE.POSTV-A.PRES-COP1SG

'I can swim.'

Example 13

Matta-makšï-mïn.

swim-MAKŠI-COP1SG

'I intend to swim.' 


\section{Moods}

Moods are synthetic devices consisting of bound inflectional suffixes and expressing different basic modal notions. Most markers used in modern Turkic languages

... represent advanced stages of their respective grammaticalization processes. The expressions of volition and necessity are all of unknown origin, i.e. they cannot be traced back to independent lexical elements. Whatever the lexical sources may have been, they have already undergone the changes typical of grammaticalization: extension of occurrence, desemanticization, decategorialization and material erosion. There is no indication that these devices have been copied from other languages. (Johanson 2009: 488) ${ }^{12}$

Turkic languages have grammaticalized modal categories in different ways. For instance, necessitative mood may be expressed by grammaticalized mood markers in some of them. Thus, the Turkish necessitative mood is expressed by $\{-\mathrm{mAlI}\}$, e.g. Gel-meli(dir) 'X must/ought to come'. It may also be used in an epistemic sense, expressing presumption, e.g. Zengin olmall 〈rich be-NESS.3SG〉 'X must be rich'. In Kazakh, however, necessity is expressed in an analytic way, i.e. by lexical items (see Lexical expressions).

Turkic languages possess different moods to express volition, primarily the imperative, voluntative, optative and hypothetical moods. The moods can be combined with other elements such as particles and lexical items to express different types of volition. The most important of these combinations will be presented in what follows. We will also include the non-productive imprecative forms and some modal usages of the aorist. Not all mood categories have complete paradigms for all persons. In the last part of the presentation of volitional expressions, some periphrastic constructions will be described.

Volition is expressed by voluntative, optative and hypothetical markers, meaning 'it is desirable that', etc., suggesting that the action in question be carried out. The notions include demands, requests, directives, commands, impositions, entreaties, admonitions, warnings, exhortations, proposals, recommendations, advice, encouragement, incitement, etc. They also include desiderative, precative, permissive, promissive, intentional senses of wish,

\footnotetext{
${ }^{12}$ See also Csato (2012b) on the sustainability of bound morphology in Karaim.
} 
hope, desire and willingness. The volitional content may be realizable or unrealizable.

The devices used are not imperatives in the sense of direct commands to second persons. They do not define relations between participants and the realization of the action. They are thus not agent-oriented, i.e. objective moods that denote the will of the subject referent, but rather subjective moods. This does not, however, mean that they are necessarily speakeroriented in the sense of expressing the speaker's own will. The desiderability may also be conceived of as impersonal, representing a general or higher will. (Johanson 2009: 489)

In some traditional Turkic grammars, the paradigms are merged into a so-called 'imperative' paradigm that includes the imperative and the third-person voluntative, or into a so-called 'optative' paradigm that also includes the first-person voluntative. Kazakh grammars (Geng et al. 1999: 234, KG 2002: 513, Zhang 2004: 412, Mamanov 2007: 101, MKL 2010: 468) describe the 'imperative' as a complete paradigm including voluntative. There are, however, considerable formal and functional differences between the volitional moods (Johanson in print).

Moods expressing volition are subtle categories, subject to strong vacillation. It is impossible to establish original, sharply defined spheres of use from which the various usages can be derived. All attempts to find 'fundamental' notions attached to the moods have failed (Johanson 2009: 489-491).

\section{Imperative mood}

\section{Inventory of forms}

\section{Affirmative}

As in many other languages, the singular form of the imperative in Kazakh is homonymous with the bare verbal stem, e.g. Bar! 〈go.IMP〉 'Go!', Kel! 〈come.IMP〉 'Come!' The polite form of the imperative, used to address one person, is built with the suffix $\left\{-\left(\mathrm{I}^{2}\right) \mathrm{yI}^{2} \mathrm{z}\right\}$, e.g. Bar-ïyïz! 〈go-IMP〉 'Go!', Kel-ịing! 〈come-IMP〉 'Come!'

The plural of the imperative is formed with the suffix $\left\{-\left(\mathrm{I}^{2}\right) \eta-\mathrm{dA}{ }^{2} \mathrm{r}\right\}$, e.g. Bar-ïy-dar! 〈go-IMP-PL〉 'Go!', Kel-ị-der! 〈come-IMP-PL〉 'Come!' The polite form of the imperative in the plural is formed with the suffix $\left\{-\left(\mathrm{I}^{2}\right) \eta \mathrm{I}^{2} \mathrm{z}-\mathrm{dA}^{2} \mathrm{r}\right\}$, e.g. Bar-ïyïz-dar! 〈go-IMP-PL〉 'Go!', Kel-ịiz-der! 〈come-IMP-PL〉 'Come!'

Corresponding forms are already found in East Old Turkic as represented by Old Uyghur and Karakhanid. Here the pronominal plural marker $\{-\mathrm{Iz}\}$ and the nominal plural marker $\{-1 \mathrm{Ar}\}$ combine pleonastically in forms such as $\{-(\mathrm{I}) \mathrm{y}-\mathrm{Iz}-\mathrm{lA} \mathrm{A}\}$. In Old Uyghur, the plural of the imperative in $\{-(\mathrm{I}) \eta\}$ can be used for polite address to a person of higher rank ("auch für die höfliche 
Einzahl" ['also for the polite singular'] von Gabain 1941: 110-111), whereas the plural form in $\{-(\mathrm{I}) \mathrm{y}-1 \mathrm{Ar}\}$ is not used as a polite form. In Karakhanid and Chaghatay, however, $\{-(\mathrm{I}) \mathrm{y}-\mathrm{lAr}\}$ and $\{-(\mathrm{I}) \mathrm{nIz}-\mathrm{lAr}\}$ form honorific imperatives for sets of individuals.

In Kazakh, both the singular form of the imperative, i.e. the bare verbal stem, e.g. Kel! 'Come!', and the plural form in \{-(I)ydAr\}, e.g. Kel-in-der!, are used with addressees who are closely related to the addresser, who are younger, or who have a lower position. Note, however, that the suffixless form may be used when praying to God. Although $\{-(\mathrm{I}) \mathrm{\eta} \mathrm{Iz}\}$ is formally a plural suffix (Kirchner 2006a: 326), it is only used in Kazakh for addressing a single individual in a polite way, e.g. Kel-iniz! Forms in \{-(I)yIz-dAr\} are used to give an order to several persons in a polite way, e.g. Kel-iniz-der! $\{-(\mathrm{I}) \mathrm{yIz}\}$ and $\{-(\mathrm{I}) \mathrm{yIz}-\mathrm{dAr}\}$ may be used to address persons who are older, in a higher position or strangers.

As for the possible development of the Kazakh system, it can be assumed that the plural in $\{-(\mathrm{I}) \mathrm{n}\}$ was first used as the polite form for addressing one person, with $\{-\mathrm{Iz}\}$ being added to address a set of individuals. This extended form $\{-(\mathrm{I}) \mathrm{y}-\mathrm{Iz}\}$ later came to be used for polite address to a single individual, e.g. Kel-iy-iz! 'Come!'. Subsequently the simple $\{-(\mathrm{I}) \mathrm{y}\}$ form lost its old function. Double-marked plurals such as $\{-(\mathrm{I}) \mathrm{y}-\mathrm{dAr}\}$, formed by adding $\{-\mathrm{LAr}\}$, were introduced to signal polite address to a set of individuals.

In Modern Uyghur, polite imperatives are formed with $\{-(\mathrm{I}) \mathrm{n}\}$ for a single addressee and \{-(I)y-1Ar\} for a set of addressees, e.g. Kir-in!, Kir-iy-lar! 'Please enter!' A respectful form used for a single individual and a set of individuals is $\left\{\right.$-silA ${ }^{2}$ \}, e.g. Käl-si-lä! 'Come!' (cf. De Jong 2007: 113, Hahn 2006: 393, Hahn \& Ibrahim 2006: 611, )

In Old Uyghur, Karakhanid, Chaghatay, Uyghur, Uzbek, Old Ottoman, etc., alternative forms of the singular imperative are formed with the suffix \{-GIl\} or \{-GIn\}, e.g. Old Uyghur Aya-yil! 'Venerate!' Uyghur Bar-yin! (goIMP〉 'Go!' (cf. Hahn \& Ibrahim 2006: 610), Uzbek Oki-gin! 〈read-IMP〉 'Read!', Čik-kin! (come out-IMP) 'Come out!', Karaim Išan-ÿ̈n T'en'ri-g'ä! 〈believe-IMP God-DAT〉 'Believe in God!' (Csató 2012a: 123-124). They express reinforcement, urgency, insistence, etc., and are probably based on the imperatives of kil- and kïn- 'to do', derivable from a root *kï- 'to do'. They were thus originally imperative verbs themselves rather than particles added to imperatives (Johanson forthcoming).

The corresponding Kazakh form, $\left\{-G^{2} I^{2} n\right\}$, is today only used in poetic styles. It can, however, be observed in the southern dialect spoken in the Ili region, perhaps under the influence of Uyghur. In oral texts, the old form $\left\{-G^{2} I^{2} 1\right\}$ may be observed (Geng 1989: 137).

\section{Negative}

Negative forms of the imperative are based on the verbal stem and the suffix of negation $\left\{-\mathrm{M}^{3} \mathrm{~A}^{2}\right.$ \}, e.g. Bar-ma! 〈go-NEG.IMP) 'Do not go!' The polite 
form of the negated singular imperative is built with the suffix $\left\{-\mathrm{M}^{3} \mathrm{~A}^{2}-\mathrm{nI} \mathrm{I}^{2} \mathrm{z}\right\}$, e.g. Kör-me-yiz! (watch-NEG-IMP〉 'Do not watch!'

The negated plural forms are built with the suffix $\left\{-\mathrm{M}^{3} \mathrm{~A}^{2}-\mathrm{y}-\mathrm{dA} \mathrm{A}^{2} \mathrm{r}\right\}$, e.g.

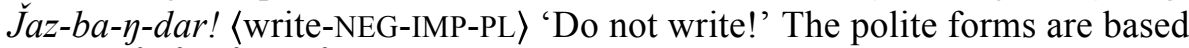
on $\left\{-\mathrm{M}^{3} \mathrm{~A}^{2}-\eta \mathrm{I}^{2} \mathrm{z}-\mathrm{dA}{ }^{2} \mathrm{r}\right\}$, e.g. Ket-pe-yiz-der! 〈leave-NEG-IMP-PL〉 'Do not leave!'

\section{Basic semantic and syntactic properties}

The imperative is a volitional mood expressing the addresser's wish for a future state of affairs. It gives direct, straightforward commands: requesting, wishing, instructing, inciting, urging, appealing, warning, cursing, advising, directing, or permitting. In all Turkic languages, it differs from the other volitional moods in its semantic, syntactic, and morphological properties and does not form genuine paradigms together with them (Johanson in print).

In imperative sentences, the wishing person is the addresser, which is not necessarily the case in sentences based on other volitional moods. The essential feature of imperatives is that they only refer to second persons. The addresser turns directly to one or more addressees with a request to perform or not to perform a given action. Imperatives can also be used as apostrophes, exclamatory passages in a speech addressing absent persons. The first actant of an imperative sentence is thus the addressee, who is expected to be in control of the desired state of affairs.

Null subjects are normal in imperative sentences. Explicit subjects are unusual, but possible, e.g. Sen kel! 〈you come.IMP〉 'You come!', or in the polite form Siz kel-ịiz (you come-IMP) 'You come!'. The pronoun used for plural subjects is rendered by Sen-der kel-in-der! 〈you-PL come-IMP-PL〉 'You come!' or by the polite form Siz-der kel-iniz-der! 〈you-PL come-IMP-PL) 'You come!'

It may sometimes be difficult to distinguish imperative subjects from vocatives, which are not morphologically marked in Turkic. They are, however, typically separated from the rest of the clause by an intonational break, which is not the case with imperative subjects.

Sentences based on imperatives are thus direct appeals to those expected to make the future state of affairs true. This is not the case with other volitional moods, e.g. Jasa-sïn! 〈live-VOL3〉 'May X live!'. Imperative sentences function as appeal function, i.e. are directly oriented toward the addressee, e.g. Aynur, kel! 〈Aynur come.IMP〉 'Aynur, come!'

Like sentences based on other volitional moods, imperative sentences cannot be tested for their truth value in the way that sentences such as Kel-di ' $\mathrm{X}$ came'. It is not possible to answer the question whether Kel! 'Come!' is true or not. Imperatives cannot combine with interrogative markers, whereas other volitional moods can. For instance, the voluntative can be combined 
with the question particle, e.g. Kayt-ayik pa? 〈return-VOL.2PL Q.PART〉 'Shall we return?'

Imperative forms in Kazakh do not carry other personal markers than plural and politeness markers. Imperatives cannot combine with copula particles. According to Johanson, they cannot occur with evidential markers as there is no possibility to indicate whether the request is based on some source or not. Imperatives do not occur with past tense markers, since the addressee is obviously not being requested to carry out an action in the past. Other moods can often combine with third-person past tense markers, especially in narrated monologues, techniques for direct representation of a character's thoughts or other contents of consciousness, e.g. Turkish «Git-sin-di〉〈goVOL-PAST) ' $\mathrm{X}$ should go' (in print).

Possible tense distinctions are those between an immediate and a more remote future. In Yakut, a present imperative requests immediate action ('act now'), whereas a remote (prospective, distant) imperative requests later fulfillment ('act later'). For Yakut, see Korkina et al. 1982: 320-324. This distinction is not made in Kazakh.

\section{Usages}

The following examples illustrate various usages of imperatives.

\section{Orders}

This usage of the imperative is the prototypical one. In Example 14, the imperative is based on the postverb constructions.

Example 14

$\begin{array}{lll}\text {...kimiyatik tïyaytk } \text {. }_{\text {š }} \text { - } t \ddot{i} & \text { at-ïp } & \text { kel! } \\ \text { fertilizer-ACC } & \text { take-IP.CONV } & \text { COME.POSTV.IMP }\end{array}$

'Bring the fertilizer!' (T5/ 30)

According to Zhang (1990a: 88), this plain imperative form can be used to address a person with whom the addresser is on intimate terms.

Requests

In the following example, the addresser asks the Creator to fulfill a wish (see Zhang 2004: 414). 
Example 15

Jarat-kan

iye- $m$

jar

bot- $a$

create-GAN.PTCP

possessor-POSS1SG helper

BOL.COP-A.CONV

kör!

SEE.POSTV.IMP

'My Creator, please be with me!'

\section{Permission}

The imperative may express permission given by an addresser to the addressee when the addresser is aware of the intention of the addressee.

Example 16

Context: You hear someone knock on the door and you permit the person to enter.

Kịr!

come in.IMP

'Come in!'

\section{Advice and suggestions}

The imperative can be used to indicate advice or suggestions as in Example 17, or in the proverb in Example 18.

Example 17

${ }^{y}$ Endị maransen ${ }^{y}$ endị mïna urpak jön-ịn-de

now I.DAT you NOW.FILL THIS.FILL descendant direction-POSS3-LOC

ne jaz-a-sïy, ne ayt-a-sïy menị

what write-A.PRES-COP2SG what tell-A.PRES-COP2SG say-HYP-2SG I.GEN

urpak jön-ịn-de ayt-ar-ïm $\quad b^{i} r$-ịnčị:

descendant direction-POSS3-LOC tell-AOR-POSS1SG one-ORD

"Urpak jaksï-dan üyren-ịy-der!"

descendant good-ABL learn-IMP-PL

'Now, If you ask me what I would write and what I would say concerning the descendants, what I would say concerning the descendants is first of all "Young ones, learn from what is good!".' (T6/2)

According to Zhang (2014: 414), the singular form of the imperative is used in proverbs to refer to general subjects, as in Example 18.

Example 18

Küš-ịy-e sen-be, iss-ịy-e sen.

strength-POSS2SG-DAT believe-NEG.IMP work-POSS2SG-DAT believe.IMP

'Bùyào píng lìqì shuōhuà, yào píng shìqíng shuōhuà.' (Zhang 2004: 414)

['Don't rely on your strength, but rely on your working capacity.'] 
Prohibitive usages

Negated imperative (prohibitive) sentences indicate that a certain action is not permitted and appeal to the addressee not to carry it out. They can be used for warnings, cautionary advice, etc.

Example 19

But jer-de temeki tart-pa-yïz.

this place-LOC tobacco smoke-NEG-IMP

'Do not smoke here.'

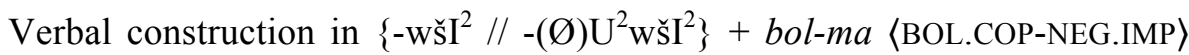
may express a strong warning or threat.

Example 20

${ }^{w}$ Ötịịik ayt-uwši bot-ma, bała-m!

lie tell-UWŠI.PTCP BOL.COP-NEG.IMP child-POSS1SG

'Never tell a lie, my child!'

Good wishes and curses

The imperative is used for good wishes (Examples 21 and 22) and curses (Examples 23 and 24), mostly in cases when the subject is not an agent who controls the event, but an experiencer. The use of the imperative is an alternative to the use of the optative.

Example 21

Gül-dey jä̀ná

flower-EQUA bloom.IMP

'May you bloom like a flower!'

Example 22

J̌ejis-ke jet-e ber-ịy-der!

success-DAT reach-A.CONV GIVE.POSTV-IMP-PL

'May you always be successful!'

Example 23

Ake-y-nen bata at-ma-y karyïs at!

father-POSS2SG-ABL blessing take-NEG-A.CONV curse take.IMP

'May your father not bless but curse you!'

Example 24

J̌etim kat!

orphan stay.IMP

'May you become an orphan!' 


\section{Downtoning imperatives}

There are several ways to downtone, i.e. to soften, imperatives, e.g. by adding the particle $\breve{s} I^{2}$ as in Examples 25 and 26. (See more about this particle in the chapter Modal particles.) The meaning of the particle can be rendered by 'please' in English.

Example 25

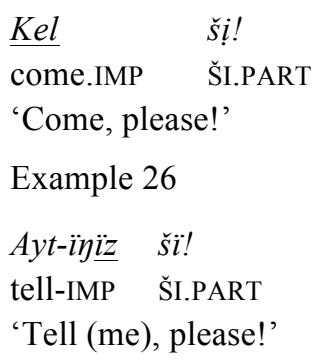

Another way of downtoning imperatives is to employ certain postverbs such as koy- 'to put' and jụber- 'to send'. In Example 27, the lexical verb söndir- 'to turn off' contains an $\left\{-\left(\mathrm{I}^{4}\right) \mathrm{p}\right\}$ converb. In the next example, however, the $\left\{-\mathrm{A}^{2} / / \mathrm{y}\right\}$ converb is used. The latter is used to signal intimacy between the addresser and addressee. Zhang (1990a: 88) suggests that, in this case, the addresser is an elder person, and the addressee a youth or a junior.

Example 27

Šam-dï söndịr-ịp koy.

light-ACC turn off-IP.CONV PUT.POSTV.IMP

'Please turn off the light.'

Example 28

Šam-dï söndịr-e $\quad$ oy.

light-ACC turn off-A.CONV PUT.POSTV.IMP

'Please turn off the light.'

When the postverb koy- 'to put' follows a converb in $\left\{-\mathrm{A}^{2} / / \mathrm{y}\right\}$, i.e. a vowel or a glide, it is pronounced as yoy. In this case, the imperative form of the postverb is homophonous with the particle $\Gamma^{2}$ oy (see Modal particles). The dictionary DKLL describes this form in terms of the particle $\Gamma^{2}$ oy having a special function, i.e. adding the meaning 'to entreat' or expressing fondness (“өтіну, еркелету мағынасын үстемелейді”) (2011: 410). In our opinion, the imperative form of the postverb and the particle must be distinguished. The construction in Example 27 consists of a converb of a lexical verb and the postverb koy- 'to put'. In Example 28, the expression söndịr-e yoy 'please turn off' is also a compound verb including the postverb koy. An 
argument for this analysis is that this postverb can be inflected, e.g. in the plural; see Example 29.

Example 29

$\begin{array}{lll}\check{S} \text { am-di } & \text { söndịr-e } & \text { yoy-ïy-dar! } \\ \text { light-ACC } \quad \text { turn off-A.CONV } & \text { PUT.POSTV-IMP-PL } \\ \text { 'Please turn off the light!' } & \end{array}$

The homonymous particle $\Gamma^{2}$ oy cannot be inflected and occurs mostly in postpredicate position. Using comparative forms of adjectives in $\left\{-\left(\mathrm{I}^{2}\right) \mathrm{rA}^{2} \mathrm{~K}^{2}\right\}$ can soften the tone of the imperative.

Example 30

Tez-ịrek bittir.

quick-COMP finish.IMP

'Please finish it a little faster.'

Ways of replacing imperatives

Some alternative constructions can be used instead of imperatives. For instance, verbal nouns (infinitives) in $\left\{-(\varnothing) \mathrm{U}^{2} \mathrm{w} / /-\left(\mathrm{U}^{2}\right) \mathrm{w}\right\}$, without any marker of person, can be used for short instructions or commands in recipes, prescriptions, etc. Infinitives are the least marked forms of the verb and have impersonal meanings, which makes them suitable as lexical entries in dictionaries. As alternatives to imperatives, infinitives are probably copies of corresponding Russian expressions, e.g. He кypumb! Ne kurit' 〈not smoke.INF〉 'No smoking!', cf. Kazakh Temeki ček-pe-w! 〈smoke.NEG-INF〉. Other examples: Russian Cudemb muxo! Sidet' tixo 〈sit. INF quietly〉 'Sit quietly!', cf. Kazakh Tinïs ${ }^{w}$ otïr-uw! 〈quiet sit-INF〉. The frequency of this usage is, however, limited at present.

The following examples are instructions given at schools.

Example 31

Mektep-ke way-ïn-da kel-uw.

school-DAT time-POSS3-LOC come-UW.VN

'(One should) come to school on time.'

Example 32

Tazatik-tï jakssï ịste-w.

cleaning-ACC good do-UW.VN

'(One should) do the cleaning well.'

It is also possible to use hypothetical forms with second-person endings, as in Example 33, or in combination with $\left\{-\mathrm{G}^{4} \mathrm{~A}^{2} \mathrm{n}\right\}$ bol-sa 〈GAN.PTCP BOL.COP-HYP $\rangle$ with second-person endings as in Example 34. 
Example 33

J̆az-ïp Jịber-se-niz.

write-IP.CONV SEND.POSTV -HYP-2SG

'Would you write it?'

Example 34

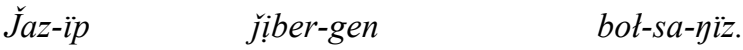

write-IP.CONV SEND.POSTV-GAN.PTCP BOL.COP-HYP-2SG

'Would you write it?'

In colloquial styles, another option is to add $\left\{-\mathrm{sA}^{2}-\mathrm{y}\right\}$ instead of $\{-\mathrm{sA}-\mathrm{n}\}$ to the verbal stem. This form probably comes from the possessive type of the second-person singular hypothetical mood. The personal ending $-\eta$ is changed to $-y$ to entreat or beg the interlocutor who is intimate with the addresser. According to my experience, this form is typically used in Tarbagatay.

Example 35

Kel-se-y.

come-HYP-2SG

'Please come / do come.'

The expressions $\left\{-\mathrm{sA}^{2}\right\}$ kayt-e-di? 〈HYP how.to.do-A.PRES-3〉 and $\left\{-\mathrm{sA}^{2}\right\}$ bot-ar-ma ${ }^{y}$ eken? 〈HYP BOL.COP-AOR-Q.PART RHET.PART〉, which contain hypothetical forms of the second person, can be used as alternatives to imperatives; see Examples 36 and 37.

Example 36

$\begin{array}{lll}\text { Bügün } & \text { kat-sa- } \eta & \text { kayt-e-dị? } \\ \text { today } & \text { stay-HYP-2SG } & \text { how.to.do-A.PRES-3 }\end{array}$

'How would it be if you were to stay today?'

Example 37

$\ddot{U} y$-di tazała-sa- $y$ bot-ar ma ${ }^{y}$ eken?

home-ACC clean-HYP-2SG BOL.COP-AOR Q.PART RHET.PART

'I wonder if it would be possible for you to clean the house?'

Without the use of rhetorical particle ${ }^{y}$ eken 'I wonder', this sentence would not be a polite request ${ }^{13}$ but a simple yes/no question.

The aorist form $\left\{-\left(\mathrm{A}^{2}\right) \mathrm{r}\right\}$ can also be used as an alternative to an imperative, which Zhang (1990a: 89) calls a 'paraphrastic expression'.

\footnotetext{
${ }^{13}$ Compare the use of the particle with wohl in German.
} 
Example 38

${ }^{w} \ddot{O} z$-ịnị $\quad$ jaksiłap $\quad{ }^{w}$ oyła-p kör-er-sị.

self-POSS2SG beneficially think-IP.CONV SEE.POSTV-AOR-COP2SG

'Try to think about it as beneficial for yourself (would you?)' (Zhang 1990a: 90)

Examples 31-38 can be interpreted as suggestions to the interlocutor to consider doing something, while actually implying a strong request or an appeal. These expressions can be used when it is necessary for the speaker to avoid a direct request.

Optatives of the second person can also be used as alternatives to imperatives.

Example 39

Konak-tar-dï jaksï küt-üp at-yay-sïy.

guest-PL-ACC good receive-IP.CONV TAKE.POSTV-OPT-COP2SG

'You should be attentive to the guests.'

\section{Voluntative mood}

\section{Inventory of forms}

Affirmative

The first person singular voluntative marker is $\left\{-\left(\mathrm{A}^{2}\right) \mathrm{yI}^{2} \mathrm{n}\right\}$, e.g. Bar-ayïn 〈go-VOL1SG〉 'I will go / Let me go', Kel-eyin 〈come-VOL1SG〉 'I will come / Let me come'.

The first person plural voluntative marker is normally $\left\{-\left(\mathrm{A}^{2}\right) \mathrm{yI}^{2} \mathrm{~K}^{2}\right\},{ }^{14}$ e.g. Bar-ayik 〈go-VOL1PL〉 'Let us go', Kel-eyik 〈come-VOL1PL〉 'Let us come'. The form $\left\{-\left(\mathrm{A}^{2}\right) \mathrm{L}^{2} \mathrm{I}^{2} \mathrm{~K}^{2}\right\}^{15}$ may be used in written registers, e.g. Kel bała-łar woki-lik 〈come-IMP child-PL study-VOL1PL〉 'Come (children), let us study'. The form $\left\{-\left(\mathrm{A}^{2}\right) \mathrm{L}^{2} \mathrm{I}^{2}\right\}^{16}$ may be applied in the Southern dialects, mainly in the Ili region, e.g. Bar-ati 〈go-VOL1PL〉 'Let us go' (Geng et al. 1999: 235).

The third person singular and plural form is $\left\{-\mathrm{sI}^{2} \mathrm{n}+\varnothing\right\},{ }^{17}$ e.g. Bar-sïn $\langle$ go-VOL3〉 'Let X go', Kel-sịn 〈come-VOL3〉 'Let X come'. The plural suffix $\left\{-\mathrm{L}^{4} \mathrm{~A}^{2} \mathrm{r}\right\}$ cannot be added.

\footnotetext{
${ }^{14}$ The type $\{-(\mathrm{A}) \mathrm{yIK}\}$ is found in almost all Kipchak languages, e.g. Karachay-Balkar Ač-ayïk 'Let us open', Crimean Tatar Al-ayïk 'Let us take', Karaim Bar-ayïx 'Let us go'.

${ }^{15}$ The standard Uzbek marker is $\{-(\dot{a}) y l i k\}$, e.g. Bår-ayylik 'Let us go'. Kirghiz has the variant $\{$-(A)lIK $\} / /$-ylIK\}, e.g. Ber-elik 'Let us give', Ber-be-ylik 'Let us not give'.

${ }^{16}$ The basic form is $\{-(\mathrm{A}) 1 \mathrm{I}\}$, found in East Old Turkic, Karakhanid, Middle Kipchak, Chaghatay, Kirghiz etc., e.g. East Old Turkic Kïl-ali 'Let us do'. Chaghatay Oku-lï 'Let us read'. This type also occurs in Uyghur $\{-(\mathrm{A}) y l i\}$, e.g. Oku-yli 'Let us read' (Hahn \& Ibrahim 2006: 610). Kirghiz $\{-\mathrm{AlI} / /$-ylI $\}$, e.g. Ber-eli 'Let us give'.

${ }^{17}$ The Orkhon Turkic voluntative marker of the third person singular is $\{-z U n\}$, e.g. Bar-zun 'Let X go'.
} 


\section{Negative}

Negated forms of the voluntative mood are built by adding the negation suffix $\left\{-\mathrm{M}^{3} \mathrm{~A}^{2}\right\}$ to the verbal stem followed by a voluntative marker. The function is to express a wish, request, command, advice or permission not to do.

The form of the singular first person negation is $\left\{-\mathrm{M}^{3} \mathrm{~A}^{2}-\mathrm{yI} \mathrm{I}^{2} \mathrm{n}\right\}$, e.g. Bar-ma-ÿ̈n 〈go-NEG-VOL1SG〉 'I will not go / Do not let me go', Küt-pe-yịn 〈wait-NEG-VOL1SG〉 'I will not wait / Do not let me wait'.

The form of the first person negated plural is $\left\{-\mathrm{M}^{3} \mathrm{~A}^{2}-\mathrm{yI} \mathrm{I}^{2} \mathrm{~K}^{2}\right\}$ e.g. Kara-ma-yïk 〈look-NEG-VOL1PL〉 'Let us not look', Söyle-me-yịk $\langle$ speak-NEG-VOL1PL〉 'Let us not speak'.

The third person negated singular and plural is $\left\{-\mathrm{M}^{3} \mathrm{~A}^{2}-\mathrm{sI}^{2} \mathrm{n}\right\}$, e.g.

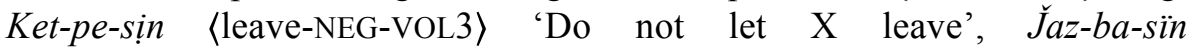
$\langle$ write-NEG-VOL3〉 'Do not let X write'.

Basic semantic and syntactic properties

Voluntatives like imperatives and optatives, are used in utterances indicating that an action is desirable. Voluntative markers express notions of will, desire, wishing, intention, request, command, demand, entreaty, advice, recommendation, exhortation, warning, hope, permission, or possibility with respect to the fulfillment of a given action. Voluntatives primarily express the addresser's subjective will. The wish expressed may be meant to be fulfilled by the addressee or to be transmitted by the addressee as a relayed message for a third person, e.g. Kel-sin 'May X come'. The desiderability may, however, also be conceived as objective: "it is desired that ...". The realization of the action is not necessarily conceived of as dependent on the participation and contribution of the subject referent. The voluntative is semantically close to the optative and the aorist (Johanson 2009: 489).

The markers combine the expression of the voluntative mood with indication of person and number. A common thematic base is lacking. The markers are of unknown origin and cannot reliably be traced back to lexical sources. As Menges remarks, in this category (which he calles "imperative"), "ancient suffixes of heterogeneous character have survived down into the historical period, having undergone, during the latter, some influences on the part of the existing suffixes denoting person" (1995: 140).

\section{Usages}

Usage of the first person forms of the voluntative

First-person voluntative markers express one's own or a group's wish, willingness, readiness, intention, decision or promise to perform a given action: 'I/we will do', 'Let me/us do', etc. They may convey a request for permission to carry out the action. They can in general be paraphrased by means of superordinate predicates meaning 'to allow', 'to permit', etc. 
The first person singular of the voluntative expresses one's wish, intention, self-encouragement or readiness to perform an action: 'I will act', 'I want myself to act', 'Let me act'. It can also represent a higher will: 'It is desirable that I act'. The addresser may be identical with the subject referent. The addresser may, though not necessarily, also ask the addressee for permission.

Example 40

J̌awab-ïn men ber-eyin.

answer-POSS3-ACC I give-VOL1SG

'Let me answer the question.'

Voluntatives of the first person plural express a group's wish, intention, desire, intent or readiness to perform an action together with the addressee(s) or/and possibly other persons, e.g. 'We will act', 'I want us to act', 'Let us act'. They often have adhortative function, expressing an appeal to carry out an action together: 'Let us act'. They can also represent a higher will: 'It is desirable that we act'. The addresser may also, though not necessarily, ask the addressee for permission. The markers often have an agent-oriented, cohortative function, signaling encouragement or discouragement, expressing a plea, an appeal, an invitation, an incitement to do something together with the addresser. Zhang regards the function as one of proposal or suggestion (1990a: 90).

Example 41

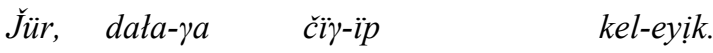

move outside-DAT come out-IP.CONV COME.POSTV-VOL1PL

'Come, let us go out.'

Example 42

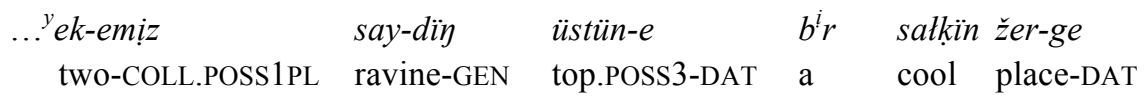

žat-ayïk...

lie-VOL.1PL

'...let's sleep in a cool place up in the ravine...' (T4/35)

An alternative way of expressing mutual encouragement or urging is to use the negated present tense in yes/no questions. The high pitch falls on the last syllable before the interrogative particle $\left\{-\mathrm{M}^{3} \mathrm{~A}^{2}\right\}$ (see Zhang 1990a: 90). Example 41 can alternatively be expressed as Example 43 . 
Example 43

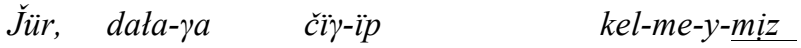

move outside-DAT come out-IP.CONV COME.POSTV-NEG-A.PRES-COP1PL

be?

Q.PART

'Come, why don't we go out?'

According to Zhang (2004: 413), the first person plural of the voluntative can be used to convene, convoke, gather, invoke, mobilize, or muster the addressee(s).

Example 44

Dušpan-dar-dï joyatt-ayik!

enemy-PL-ACC annihilate-VOL1PL

'Let us annihilate the enemies!'

Zhang (2004: 413) also claims that using the first person plural form of the voluntative can be used as a downtoned alternative to the imperative.

Example 45

Sabaktas-tar, köyill kloy-a tïyda-yïk.

classmate-PL attention put-A.CONV listen-VOL1PL

'Tóngxuémen, zánmen zhùyì tīngjiăngle.' (Zhang 2004: 413)

['Students, let's listen (to the lesson) attentively.']

Usage of the third person forms of the voluntative

Third person voluntatives signal a command, demand, instruction, appeal, invitation, request, etc., that an action be brought about by some entity (person or object) other than the addressee. Possible translations include ' $\mathrm{X}$ shall do', 'X should do', 'may X do', 'let X do', etc.

They do not directly address the entity that is requested to bring about the action, and the realization is mostly conceived of as less dependent on its participation (Johanson forthcoming).

Example 46

Sabak-tï ${ }^{w}$ osï kịlàs-tá tïyda-sïn

class-ACC this class-LOC listen-VOL3

'Let $\mathrm{X}$ attend a class in this classroom'. 
Example 47

Tüsür-ül-gen

let fall-PASS-GAN.PTCP

${ }^{w}$ orïnda-t-sïn.

complete-PASS-VOL3

'The order that is given should be completed no later than today.'

The third person of the voluntative may be used to indicate the addresser's wish to grant permission, or allow the object to continue to do something. In this case, the addresser does not necessarily want the interlocutor to transmit the information (Zhang 2004: 415).

Example 48

$\begin{array}{lllll}{ }^{w} \text { O-tar } & \text { kel-e } & \text { ber-sịn, } & \text { bịz } & \text { tamak-tï } \\ \text { X-PL } & \text { come-A.CONV } & \text { GIVE.POSTV-VOL3 } & \text { we } & \text { dish-ACC } \\ \text { tart-a } & \text { ber-eyịk. } & & \end{array}$

'Let them come, we will serve our dish.'

Example 49

Ne de-se de-y ber-sin.

what say-HYP3 say-A.CONV GIVE.POSTV-VOL3

'Whatever it is, let them speak (it doesn't bother me)'.

The voluntative of the third person is used to express the addresser's hope and wish that something will be realized or fulfilled (Zhang 2004: 415). Example 50 illustrates good wishes, whereas Example 51 is a curse.

Example 50

Ak jot bot-sïn!

white road BOL.COP-VOL3

'Have a good trip!', Lit. 'May the road be white!'.

Example 51

Köz-ị kör bot-sïn!

eye-POSS3 blind BOL.COP-VOL3

'May X's eye become blind.'

In rhetorical questions, the voluntative of the third person is used to express something that is difficult or impossible to change, to fulfill or to perform. According to Zhang (2004: 415), such sentences signal the speaker's sympathy. 
Example 52

Dünye-de munday ${ }^{18 w}$ oyay is kay-dan bot-sïn?

world-LOC this.EQUA easy affair which-ABL BOL.COP-VOL3

'Shìjiè shàng nă yǒu zhème róngyì de shì er.' (Zhang: 2004: 415)

['How could it be easy? Lit. 'From where should such easy things come to the world?']

The same also holds for the first person singular and plural of the voluntative mood.

Example 53

Bị kay-dan bịl-eyik?

we which-ABL know-VOL1PL

'How could we know?' ('We cannot know.')

The double form of the third person of the voluntative, an affirmative and a negative, can be used in the first clause of concessive sentences to express that the outcome will be the same, no matter whether the state of affairs is realized or not. The English translation can be 'no matter', 'even if', 'even though', 'whether ... or not'; see Example 54. This idiomatic usage seems to be restricted to the third person. In first persons, the analogous forms of the hypothetical mood followed by the particle $D^{2} A^{2}$ 'also' are preferred; see Example 55.

Example 54

Šakïrtuw kel-sịn kel-me-sịn, bar-yan-ïm

invitation come-VOL3 come-NEG-VOL3 go-GAN.PTCP-POSS1SG

bar-yan.

go-GAN.POSTT3

'No matter if an invitation comes or not, I will definitely go.'

Example 55

Šakïrtuw at-sa-m da at-ma-sa-m da,

invitation get-HYP-1SG DA.PART get-NEG-HYP-1SG DA.PART

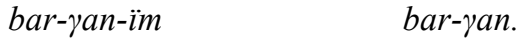

go-GAN.PTCP-POSS1SG go-GAN.POSTT3

'No matter if I get an invitation or not, I will definitely go.'

The third person forms of the voluntative can also be used impersonally, without reference to a specific entity requested to bring about the action. The Turkish third person form of the voluntative of the copula ol- 'to become,

\footnotetext{
${ }^{18}$ Munday is a contracted form of mïna-day 〈this-EQUA) 'like this' or mïnan-day 〈this-EQUA〉 'like this'.
} 
be', ol-sun 〈COP-VOL3SG can be used impersonally in the sense of 'So be it!', 'All right', 'I do not mind'.

Example 56 Turkish

\section{A: Bugün okul-a geç kal-acă̆-ım. \\ today school-DAT be late-FUT-1SG \\ 'I will be late for school today.}

B: Ol-sun!

COP-VOL3SG

'All right. I don't mind.'

The corresponding Kazakh form of the copula bot- 'to become, be', bot-sïn 〈BOL.COP-VOL3SG〉, does not seem to allow this impersonal usage. The answer in Examples 57 and 58 are not impersonal. Observe that the verb used in the answer has to be an echo-form of the verb in the statement it refers to.

Example 57

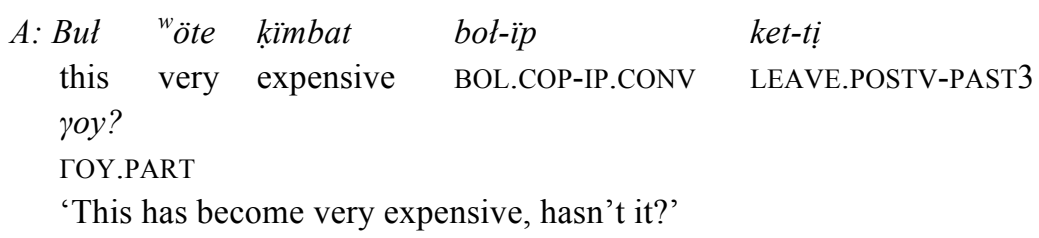
B: Kïmbat bot-sïn.
expensive BOL.COP-VOL3
'It's all right. I don't mind.'

Example 58

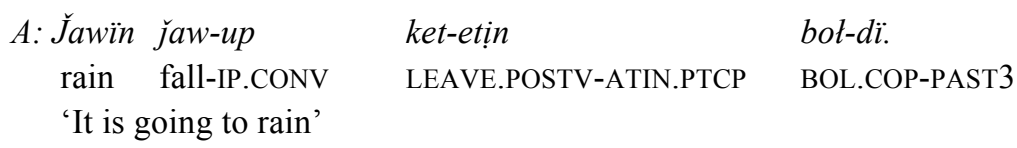

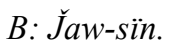

fall-vOL3

'Let it rain, I do not mind.'

The negated forms of the third person voluntative convey prohibitive meanings, Jaz-ba-sï 〈write-NEG-VOL3〉 'Do not let X write'.

Yes/no questions are formed with postposed question particles. The constructions solicit the opinion of the addressee(s). Third-person constructions are often used to ask for permission or advice. 
Example 59

Kel-sin be?

come-VOL3 Q.PART

'Shall X come?'

First-person constructions request permission to perform the action.

Example 60

Ket-eyin be?

leave-VOL1SG Q.PART

'Shall/may I leave?'

First-person plural constructions may also include the addressee as a potential co-performer.

Example 61

Kayt-ayïk pa?

return-VOL1PL Q.PART

'Shall we return?'

Questions may also be expressed by means of interrogative words ("whwords").

Example 62

$\mathrm{Ne}$ ayt-ayïn?

what tell-vOL1SG

'What shall I say?'

\section{Optative mood}

\section{Inventory of forms}

\section{Affirmative}

The grammatical markers of the optative mood are $\left\{-G^{4} A^{2} y\right\}$ and the pronominal type of the personal endings.

The marker of the first person singular is $\left\{-G^{4} A^{2} y-m I^{2} n\right\}$, e.g. Kat-yay-mïn 〈stay-OPT-COP1SG〉 'May I stay', Kör-gey-mịn 〈see-OPTCOP1SG〉 'May I see', Tap-kay-mïn 〈find-OPT-COP1SG〉 'May I find', Ket-key-min 〈leave-OPT-COP1SG〉 'May I leave'.

The marker of the first person plural is $\left\{-\mathrm{G}^{4} \mathrm{~A}^{2} \mathrm{y}-\mathrm{mI}^{2} \mathrm{z}\right\}$, e.g. Kat-yay-mïz 〈stay-OPT-COP1PL〉 'May we stay', Kör-gey-mị 〈see-OPT-COP1PL〉 'May we see', Tap-kay-mïz 〈find-OPT-COP1PL〉 'May we find', Ket-key-mị 〈leaveOPT-COP1PL > 'May we leave'. 
The marker of the second person singular is $\left\{-G^{4} A^{2} y-s I^{2} y\right\}$, e.g.

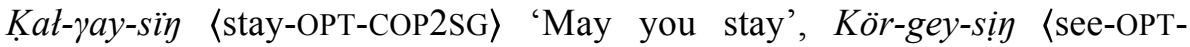
COP2SG) 'May you see', Tap-kay-sïy (find-OPT-COP2SG〉 'May you find', Ket-key-sin 〈leave-OPT-COP2SG〉 'May you leave'. The polite form is $\left\{-\mathrm{G}^{4} \mathrm{~A}^{2} \mathrm{y}\right.$-sI ${ }^{2} \mathrm{z}$, e.g. Kel-gey-siz $\langle$ come-OPT-COP2SG) 'May you come'.

The marker of the second person plural is $\left\{-G^{4} A^{2} y-s I^{2} y-d A^{2} r\right\}$, e.g. Kat-yay-sïy-dar 〈stay-OPT-COP2SG-PL〉 'May you stay', Kör-gey-sị-der 〈see-OPT-COP2SG-PL) 'May you see', Tap-kay-sïy-dar 〈find-OPT-COP2SG-PL) 'May you find', Ket-key-sin-der 〈leave-OPT-COP2SG-PL〉 'May you leave'. The polite form is $\left\{-\mathrm{G}^{4} \mathrm{~A}^{2} \mathrm{y}-\mathrm{sI}^{2} \mathrm{z}-\mathrm{dA}{ }^{2} \mathrm{r}\right\}$, e.g. Kel-gey-siz-der (come-OPTCOP2SG-PL) 'May you come'.

The third person singular and plural are formed with the suffix $\left\{-G^{4} A^{2} y-\varnothing\right\}$. The same form is used for both singular and plural. There is no

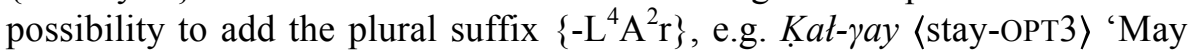
$\mathrm{X}$ stay', Kör-gey 〈see-OPT3〉 'May X see', Tap-kay 〈find-OPT3〉 'May X find', Ket-key 〈leave-OPT3〉 'May X leave'.

\section{Negative}

The negated first person singular form is $\left\{-\mathrm{M}^{3} \mathrm{~A}^{2}-\mathrm{G}^{2} \mathrm{~A}^{2} \mathrm{y}-\mathrm{mI} \mathrm{I}^{2} \mathrm{n}\right\}$, e.g. Bar-ma-yay-mï 〈go-NEG-OPT-COP1SG〉 'May I not go', Ket-pe-gey-min

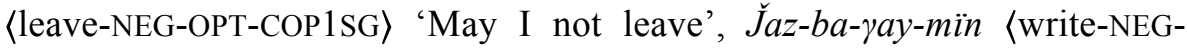
OPT-COP1SG 'May I not write'.

The negated first person plural form is $\left\{-\mathrm{M}^{3} \mathrm{~A}^{2}-\mathrm{G}^{2} \mathrm{~A}^{2} \mathrm{y}-\mathrm{mI} \mathrm{I}^{2} \mathrm{z}\right\}$, e.g. Bar-ma-yay-mïz 〈go-NEG-OPT-COP1PL〉 'May we not go', Ket-pe-gey-miz

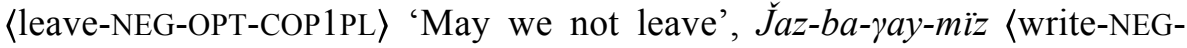
OPT-COP1PL ' 'May we not write'.

The negated second person singular form is $\left\{-\mathrm{M}^{3} \mathrm{~A}^{2}-\mathrm{G}^{2} \mathrm{~A}^{2} \mathrm{y}-\mathrm{sI} \mathrm{I}^{2} \mathrm{y}\right\}$, e.g. Bar-ma-yay-sïy 〈go-NEG-OPT-COP2SG〉 'May you not go'. Ket-pe-gey-sin 〈leave-NEG-OPT-COP2SG〉 'May you not leave'. Jaz-ba-yay-sï 〈write-NEGOPT-COP2SG 'May you not write'. The negated polite form is $\left\{-\mathrm{M}^{3} \mathrm{~A}^{2}-\mathrm{G}^{2} \mathrm{~A}^{2} \mathrm{y}-\mathrm{sI}^{2} \mathrm{z}\right\}$, e.g. Kör-me-gey-sịz (watch-NEG-OPT-COP2SG〉 'May you not watch'.

The negated second person plural form is $\left\{-\mathrm{M}^{3} \mathrm{~A}^{2}-\mathrm{G}^{2} \mathrm{~A}^{2} \mathrm{y}-\mathrm{sI}^{2} \mathrm{y}-\mathrm{d} \mathrm{A}^{2} \mathrm{r}\right\}$, e.g. Bar-ma-yay-sïy-dar 〈go-NEG-OPT-COP2SG-PL〉 'May you not go', Ket-pe-gey-sin-der 〈leave-NEG-OPT-COP2SG-PL〉 'May you not leave',

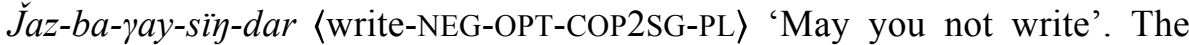
negated polite plural form is $\left\{-\mathrm{M}^{3} \mathrm{~A}^{2}-\mathrm{G}^{2} \mathrm{~A}^{2} \mathrm{y}-\mathrm{sI}^{2} \mathrm{z}-\mathrm{d} \mathrm{A}^{2} \mathrm{r}\right\}$, e.g. Ket-pe-geysiz-der 〈leave-NEG-OPT-COP2SG-PL〉 'May you not leave'.

The negated third person singular and plural form is $\left\{-\mathrm{M}^{3} \mathrm{~A}^{2}-\mathrm{G}^{2} \mathrm{~A}^{2} \mathrm{y}\right\}$, e.g. Bar-ma-yay 〈go-NEG-OPT3) 'May X not go', Ket-pe-gey 〈leave-NEG-OPT3〉 'May X not leave', J̆az-ba- $\gamma$ ay 〈write-NEG-OPT3) 'May X not write'. 


\section{Basic semantic and syntactic properties}

According to Johanson (in print) the optative mood displays a range of functions that have developed along various diachronic paths. It conveys meanings of willing, wishing, desire, intention, hope, aspiration, incitement, requesting, promising, advice, expectation, necessity, obligation, and prediction with respect to a non-factual situation. Like the old IndoEuropean optative, it covers various deontic and epistemic notions of necessity and potentiality. Compare the use of the English auxiliary may for both strong wishes, e.g. May X come, and epistemic or deontic possibility, e.g. $X$ may come.

The optative in Kazakh is used as a main clause predicate with different personal endings. As Johanson points out, it does not necessarily reflect the attitude of the addresser. Nor does it necessarily suggest that the realization of the event is dependent on the cooperation of the addressee or the subject referent (2009: 490, in print).

Johanson (in print) states that since the optative can refer to the future, it is sometimes called "optative-future". The nuances of prospectivity appear, however, by virtue of the modal meanings. Situations described as desired, expected, or possible must belong to a time later than the moment of speaking. The prospective optative can be compared to the Indo-European prospective subjunctive and, for instance, the use of the English will.

\section{Decline of the optative}

Outside the northeast branch of Turkic, the optative experienced a decline, lost ground, and fell into decay. Of its once complete paradigms, only parts were preserved. According to Johanson (in print), in Tatar, Uzbek, etc. the simple marker is today almost entirely missing. The reason is that its semantics largely overlapped with those of the voluntative. The moods conveyed similar meanings, both signaling 'it is desirable that...'. For the most part there were no clear-cut boundaries between the types. The functions of the optative were largely taken over by the voluntative, forms of the hypothetical mood in $\left\{-\mathrm{sA}^{2}\right\}$, and the old present tense ("aorist").

Kazakh presently uses optative only in archaizing styles and in formulaic

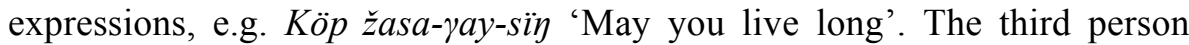
optative $\left\{-G^{4} A^{2} y\right\}$ at present has the tendency to be replaced by the voluntative third personal mood form $\left\{-\mathrm{sI}^{2} \mathrm{n}\right\}$. However, the combinations of the optative marker and the past tense form of the copula, ${ }^{y}$ edi, expressing an unfulfillable wish, are still being used. ${ }^{19}$

\footnotetext{
${ }^{19}$ In many languages such as Turkmen, Karachay-Balkar, Crimean Tatar, Kumyk, and Kirghiz, optatives only occur in combination with past copulas or auxiliaries (Johanson in print).
} 


\section{Usages}

Wishing

The simple form of the optative mood expresses wishing, desire or hope in the sense 'I wish ...', 'May I/we do', etc. In the first person singular, the addresser and the subject referents coincide. The optative expresses a wish, desire in Examples 63, 64, and 65.

Example 63

${ }^{w}$ Osï jarïs-ta

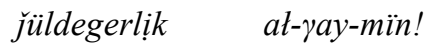

this competition-LOC championship take-OPT-COP1SG

'May I win the championship in this competition!'

Example 64

Bakïtii bot-ray-sïn!

happy BOL.COP-OPT-COP2SG

'May you be happy.'

Example 65

Kuday tịlgöz-den sakta- $\gamma a y$.

God curse-ABL prevent-OPT3

'May God prevent (us from experiencing) the curse.'

Polite request

Zhang (2004: 428) points out that the form of second persons may tone down the effect of an imperative in a polite way .

Example 66

Tịleg-ịm-di $\quad k$ kabitda- $\quad$ ay-siz.

request-POSS1SG-ACC accept-OPT-COP2SG

'May you accept my request!'

The combination with ${ }^{y} e d i$

Negative optatives $\left\{-\mathrm{M}^{3} \mathrm{~A}^{2}-\mathrm{G}^{2} \mathrm{~A}^{2} \mathrm{y}\right\}$ with past copula ${ }^{y}$ edi in personal endings express admonition, i.e. fear, worry and warnings against the possible occurrence of an undesired situation.

Example 67

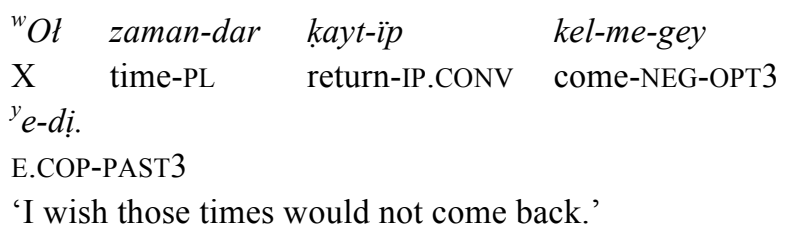


Example 68

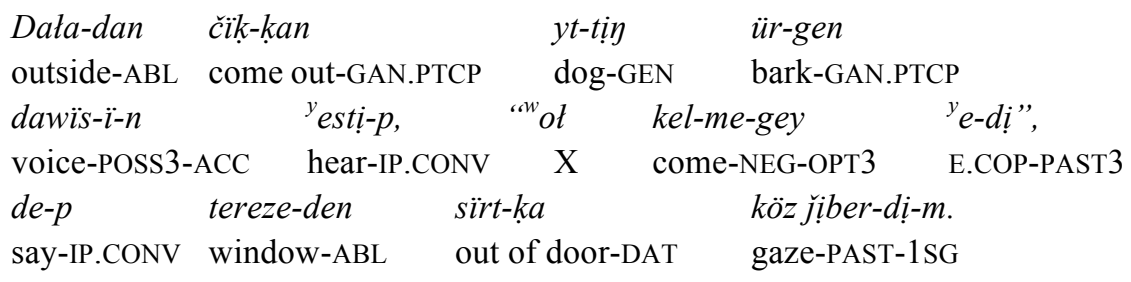

'I heard the barking of the dog from the outside, and I looked out of the window thinking: "I hope X does not come".'

Uyghur shares the same property when the negative optative marker $\left\{-\mathrm{mi}-\mathrm{G}^{2} \mathrm{~A}^{2} \mathrm{y}\right\}$ occurs with the past tense copula idi. The contracted form is $\left\{-\mathrm{mi}^{2} \mathrm{G}^{2} \mathrm{iydi}\right\}+$ personal endings as in Example 69 .

Example 69 Uyghur

Yaxši täkrar kil-al-mi-di-m, muällim män-din good repetition LIGHTV-ABIL-NEG-PAST-1SG teacher I-ABL sora-p yür-mi-giy-di.

ask-IP.CONV POSTV-NEG-OPT-PAST3

'I wasn't able to revise well, so I do hope the teacher does not ask me.' (Tömür 2003: 317, 2011 2 :284)

\section{Hypothetical mood}

\section{Inventory of forms}

\section{Affirmative}

The grammatical marker of hypothetical mood is $\left\{-\mathrm{sA}^{2}\right\}$ with possessive types of personal endings.

The hypothetical marker of the first person singular is $\left\{-\mathrm{sA}^{2}-\mathrm{m}\right\}$, e.g.

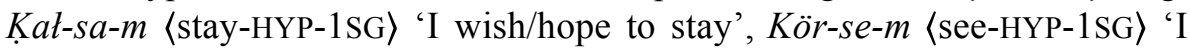
wish/hope to see'.

The first person plural hypothetical marker is $\left\{-\mathrm{sA}^{2}-\mathrm{K}^{2}\right\}$, e.g. Kat-sa-k 〈stay-HYP-1PL〉 'I wish/hope we stay', Kör-se-k $\langle$ see-HYP-1PL〉 'I wish/hope we see'.

The second person singular hypothetical marker is $\left\{-\mathrm{sA}^{2}-\mathrm{n}\right\}$, e.g. Kat-sa- $\eta$ $\langle$ stay-HYP-2SG〉 'I wish/hope you stay', Kör-se- $\eta\langle$ see-HYP-2SG〉 'I wish/hope

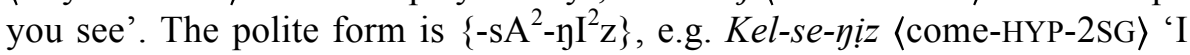
wish/hope you come'.

The second person plural hypothetical marker is $\left\{-\mathrm{sA}^{2}-\eta-\mathrm{dA}{ }^{2} \mathrm{r}\right\}$, e.g. Kat-sa-y-dar 〈stay-HYP-2SG-PL〉 'I wish/hope you stay', Kör-se- $\eta$-der 〈seeHYP-2SG-PL ' 'I wish/hope you see'. The polite form is $\left\{-\mathrm{sA}^{2}-\mathrm{nI}^{2} \mathrm{z}-\mathrm{dA}{ }^{2} \mathrm{r}\right\}$, e.g. Kel-se-yiz-der 〈come-HYP-2SG-PL〉 'I wish/hope you come'. 
The third person form $\left\{-\mathrm{sA}^{2}-\varnothing\right\}$ is the form for both the singular and plural of the hypothetical mood. There is no possibility to add the plural suffix $\left\{-L^{4} \mathrm{~A}^{2} \mathrm{r}\right\}$ after it, e.g. Kat-sa 〈stay-HYP3〉 'I wish/hope X stay(s)', Kör-se 〈see-HYP3〉 'I wish/hope X see(s)'.

\section{Negative}

The negative of the first person singular is $\left\{-\mathrm{M}^{3} \mathrm{~A}^{2}-\mathrm{sA} \mathrm{A}^{2}-\mathrm{m}\right\}$, e.g. Bar-ma-sa-m 〈go-NEG-HYP-1SG〉 'I wish/hope not to go', Ket-pe-se-m 〈leave-NEG-HYP-1SG〉 'I wish/hope not to leave'.

The first person plural negative form is $\left\{-\mathrm{M}^{3} \mathrm{~A}^{2}-\mathrm{sA}^{2}-\mathrm{K}^{2}\right\}$, e.g. Bar-ma-sa-k (go-NEG-HYP-1PL) 'I wish/hope we do not go', Ket-pe-se-k 〈leave-NEG-HYP-1PL〉 'I wish/hope we do not leave'.

The second person singular negative form is $\left\{-\mathrm{M}^{3} \mathrm{~A}^{2}-\mathrm{s} \mathrm{A}^{2}-\mathrm{n}\right\}$, e.g. Bar-ma-sa- $\eta$ 〈go-NEG-HYP-2SG〉 'I wish/hope you do not go', Ket-pe-se- $\eta$ 〈leave-NEG-HYP-2SG 'I hope you do not leave'. The polite singular negative

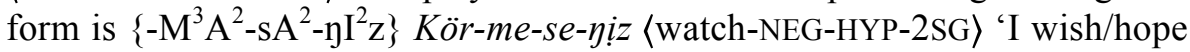
you do not watch'.

The second person plural negative form is $\left\{-\mathrm{M}^{3} \mathrm{~A}^{2}-\mathrm{sA}^{2}-\mathrm{n}-\mathrm{dA} \mathrm{A}^{2} \mathrm{r}\right\}$, e.g. Bar-ma-sa-y-dar (go-NEG-HYP-2SG-PL) 'I wish/hope you do not go', Ket-pe$s e-\eta$-der 〈leave-NEG-HYP-2SG-PL〉 'I wish/hope you do not leave'. The polite plural negative form is $\left\{-\mathrm{M}^{3} \mathrm{~A}^{2}-\mathrm{sA}^{2}-\mathrm{nI}^{2} \mathrm{z}-\mathrm{dA}{ }^{2} \mathrm{r}\right\}$, e.g. Ket-pe-se-piz-der 〈leave-NEG-HYP-2SG-PL〉 'I wish/hope you do not leave'.

The third person singular and plural form is $\left\{-\mathrm{M}^{3} \mathrm{~A}^{2}-\mathrm{sA}^{2}-\varnothing\right\}$, e.g. Bar-ma-sa 〈go-NEG-HYP3〉 'I wish/hope X do(es) not go', Ket-pe-se 〈leaveNEG-HYP3〉 'I wish/hope X do(es) not leave'.

\section{Basic semantic and syntactic properties}

Most Turkic languages possess a hypothetical mood that serves as a basis for independent sentences. The hypothetical mood is often called the conditional mood. Johanson uses the term hypothetical because it covers the basic meaning better: "Hypothetical markers express an imaginative mood in the sense of supposed events, and may, as such, convey desiderative meanings: desire, wish or hope in the sense of 'imagine it is the case', 'what if it were the case?"' (Johanson 2009: 491). Zhang (2004: 417) uses the term jiăshè shì 'hypothetical mood' instead of conditional mood.

Hypothetical markers are mostly used as converbs in dependent clauses expressing hypothetical conditions. This use in the protasis of conditional sentences will be dealt with in Usages. The conditional meaning can be highlighted by using some lexical items copied from Arabic/Persian: ${ }^{y}$ eger 'if', 'egerde 'if' or mübáda 'if', 'in case something undesired happens'. These are mostly but not exclusively used in written registers. Example 70 is taken from our recordings. 
Example 70

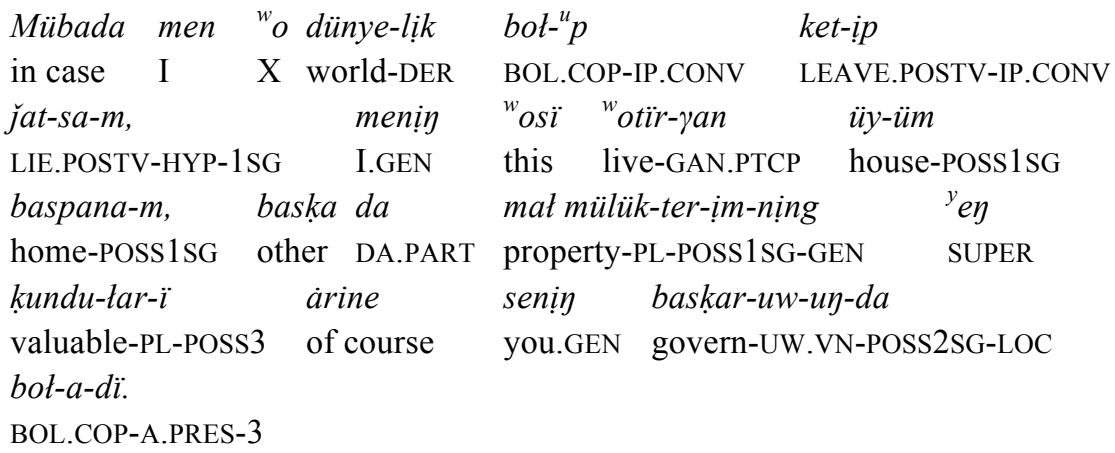

'In case I pass away, the house where I live, my home, and my most valuable other belongings, of course, will be in your hands.' (T7/ 2)

\section{Usages}

In main clauses

In main clauses, the hypothetical mood expresses volition, e.g. a wish, desire, will or hope. Three different forms of the hypothetical can be used: (i) $\left\{-\mathrm{sA}^{2}\right\}$, (ii) $\left\{-\mathrm{G}^{4} \mathrm{~A}^{2} \mathrm{n}\right\}$ + the hypothetical form of the copula bot- "to become, be', and (iii) $\left\{-\mathrm{A}^{2} \mathrm{tI}^{2} \mathrm{n} / /-\mathrm{ytI} I^{2} \mathrm{n}\right\}$ + the hypothetical form of the copula bot- 'to become, be'. The possessive personal endings are added to these forms. Examples 71 and 72 illustrate the use of the simple hypothetical form (i).

Example 71

Češe-m "wosin-da bot-sa!

mother-POSS1SG this-LOC BOL.COP-HYP3

'I wish my mother was here!'

Example 72

Atta kata-sa!

Allah bless-HYP3

'May Allah bless (you/us)!'

The examples express a strong wish, desire or hope for something that is not easily attainable, or something that cannot or probably will not happen.

According to Zhang (2004: 421), this usage also expresses the speaker's request for something that he/she hopes for. 
Example 73

Partiya, ükịmet ${ }^{w}$ orïn-dar-ï munday surkiyatik-ka

Party government place-PL-POSS3 this.EQUA wickedness-DAT

jot koy-ma-sa.

allow-NEG-HYP3

'Dàn yuàn dăng hé zhèngfǔ bùmén néng zhìzhǐ èliè xíngjìng' (Zhang 2004: 421)

['I hope that the offices of the party and the government will not allow such wickedness.']

In spoken registers, the form in $\left\{-s A^{2} y\right\}\left(-s A^{2} y>-s A^{2} \eta\right)$ is used to mark intimacy between the speaker and the interlocutor .

Example 74

Ayt-sa-y.

tell-HYP-2SG

'Do tell!'

The postterminal form in $\left\{-G^{4} A^{2} n\right\}+$ the hypothetical form of the copula bot- 'to become, be' can express an unreal wish or a wish that is difficult to fulfill. The participle form in $\left\{-G^{4} A^{2} n\right\}$ in itself expresses a postterminal meaning.

Example 75

Bay bot-yan bot-sa-m.

rich BOL.COP-GAN.PTCP BOL.COP-HYP-1SG

'I wish I was rich.'

Example 76 can be interpreted as a strong wish the fulfillment of which is important for the speaker.

Example 76

Aman esen bok-uw-ïm-dï bitir-gen bol-sa-m.

safely study-UW.VN-POSS1SG-ACC finish-GAN.PTCP BOL.COP-HYP-1SG

'I wish I will finish my education safely.'

Note that the hypothetical mood of the second person can signal a polite request as in Example 77.

Example 77

Jaz-ïp Jịber-gen bot-sa- $y$.

write-IP.CONV SEND.POSTV-GAN.PTCP BOL.COP-HYP-2SG

'Could you just write it?' 
The participle in $\left\{-\mathrm{A}^{2} \mathrm{tI}^{2} \mathrm{n} / /-\mathrm{ytI}^{2} \mathrm{n}\right\}$ combined with the hypothetical form of the copula bot- 'to become, be' expresses that something in the future will take place; see Example 78. This example can be interpreted in two ways: either as expressing the speaker's hope or as an impersonal hope in the sense 'it is to be hoped that'.

Example 78

Könsert-tị sonda bar-ïp $\quad{ }^{w} \ddot{o} z \quad k \ddot{o} z-i ̣ y-m e n$

concert-ACC there go-IP.CONV self eye-POSS2SG-WITH.POSTP

kör-etịn bot-sa- $y$.

watch-ATIN.PTCP BOL.COP-HYP-2SG

'Hopefully you will go to the concert and see it with your own eyes.'

The impersonal reading is also possible when the simple hypothetical or the combination of $\left\{-\mathrm{G}^{4} \mathrm{~A}^{2} \mathrm{n}\right\}$ and bol-sa- $\eta(i z)\langle$ BOL.COP- HYP-2SG), i.e. the second person hypothetical, are used.

The simple hypothetical or the combination in $\left\{-\mathrm{sA}^{2}\right\}$, and the combination of $\left\{-G^{4} A^{2} n\right\}$ and the hypothetical form of the copula bot- 'to become, be', can indicate an idea or plan put forward for consideration, or the act of asking politely or formally for something.

Example 79

But surak-ka men jawap ber-se-m.

this question-DAT I answer give-HYP-1SG

'What about my answering the question?'

Example 80

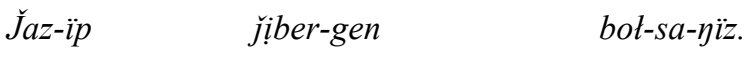

write-IP.CONV SEND.POSTV-GAN.PTCP BOL.COP-HYP-2SG

'What about your writing it?'

Example 81

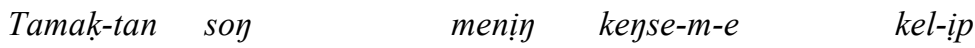

food-ABL AFTER2.POSTP I.GEN office-POSS1SG-DAT come-IP.CONV

ket-se.

LEAVE.POSTV-HYP3

'What about X coming to my office after the meal.'

In subordinate clauses

Full conditional sentences contain two clauses: the condition or protasis, and the consequence or apodosis. In Kazakh conditional sentences expressing a factual condition, the protasis is based on a hypothetical form in $\left\{-\mathrm{sA}^{2}\right\}$ as in Example 82. 
Example 82

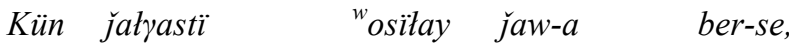

sky continuous this way fall-A.CONV GIVE.POSTV-HYP3

taw- $y$ a čik-pa-y-mïz.

mountain-DAT ascend-NEG-A.PRES-COP1PL

'If it rains continuously in this way, we won't climb up the mountain.'

When the event referred to will take place in the future, the prospective form $\left\{-\mathrm{A}^{2} \mathrm{tI}^{2} \mathrm{n} / /-\mathrm{ytI}^{2} \mathrm{n}\right\}$ can be used in combination with the hypothetical form of the copula bol-.

Example 83

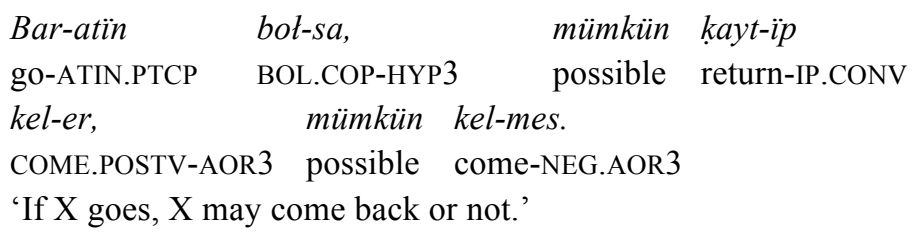

Example 84

$\ddot{U} y$-ge $\quad$ erte kel-etin bot-sa- $\eta$ tamak-ka

home-DAT early come-ATIN.PTCP BOL.COP-HYP-2SG food-DAT

dayïndat-a ber.

prepare-A.CONV GIVE.POSTV.IMP

'If you come home early, start to prepare food.'

The above examples imply that the actions in the two clauses have a potential relationship; i.e. the action expressed by the verb in the main clause doubtlessly can be carried out if the condition in the conditional clause is fulfilled.

When the postterminal form in $\left\{-\mathrm{G}^{4} \mathrm{~A}^{2} \mathrm{n}\right\}+$ the copula bol- in $\left\{-\mathrm{sA}^{2}\right\}$ is used in the protasis, the event referred to took place in the past. When the predicate of the apodosis is an aorist form in $\left\{-\left(\mathrm{A}^{2}\right) \mathrm{r}\right\}$, either affirmative or negative, the conditional sentence expresses a supposition of the speaker about the proposition in the main clause; see Example 85.

Example 85

But kabar-di 'yesti-gen bot-sa, üy-ge

this news-ACC hear-GAN.PTCP BOL.COP-HYP3 home-DAT

kel-ip kat-ar.

come-IP.CONV STAY.POSTV-AOR3

'If X has heard the news, s/he will possibly come.'

Using a combination of the aorist in $\left\{-\left(\mathrm{A}^{2}\right) \mathrm{r}\right\}$ and the hypothetical form of the copula bot-in the protasis also implies a prospective meaning. In this 
case the apodosis can be based on a predicate in the present tense $\left\{-\mathrm{A}^{2} / /-\mathrm{y}\right\}$, the aorist in $\left\{-\left(\mathrm{A}^{2}\right) \mathrm{r}\right\}$, the voluntative, the imperative; or the intentional form in $\left\{-\mathrm{M}^{3} \mathrm{~A}^{2} \mathrm{~K}\right\}$ (see Non-modal expressions).

Example 86

$\begin{array}{lclll}\text { But kasiporïn } & \text { kel-er } & \text { bot-sa, } & { }^{y} \text { el-ge } \\ \text { this enterprise } & \text { come-AOR.PTCP } & \text { BOL.COP-HYP3 } & \text { country-DAT } \\ \text { kompaniya-men } & \text { kos- } a & b^{i} \text { rneše } & \text { milliyon } & \text { dottar karji } \\ \text { company-WITH.POSTP } & \text { add-A.CONV } & \text { several } & \text { million } & \text { dollar fund } \\ \text { kel-mek. } & & & & \end{array}$

come-MAK3

'If this enterprise comes, it will bring together with the company several million dollars of funding to the country.'

A special usage can be observed in proverbs in which the speaker's attitude towards the proposition is expressed; see Example 87.

Example 87

Adillsiz bot-sa bi ${ }^{w}$ oy-bas, $\quad$ ayelsịz

injustice BOL.COP-HYP3 judge succeed-NEG.AOR3 without wife

bot-sa üy woy-bas.

BOL.COP-HYP3 home succeed-NEG.AOR3

'If the judge is unjust, he will not succeed. If the home is without a wife it will not be sweet.'

Combination with ${ }^{y} e d i$ in main clauses

In main clauses, the past tense copula ${ }^{y} e-d i$ (E.COP-PAST3〉 expresses counterfactual wishes. See the following examples, in which the hypothetical in $\left\{-\mathrm{sA}^{2}\right\}$ is combined with ${ }^{y} e d i$.

Example 88

Men de amerika-ya bar-sa-m ${ }^{y} e$-dị.

I DA.PART America-DAT go-HYP-1SG E.COP-PAST3

'If I too would go to America!' (But it is not the case.)

Example 89 illustrates the combination of the postterminal in $\left\{-G^{4} A^{2} n\right\}+$ the copula bol- in $\left\{-\mathrm{sA}^{2}\right\}$ and $+{ }^{y} e d i$. See also above.

Example 89

Men de sen-der-men bar-yan bot-sa-m

I DA.PART yOu-PL-WITH.POSTP go-GAN.PTCP BOL.COP-HYP-1SG

${ }^{y} e-d i$.

E.COP-PAST3

'If only I had also gone with you.' (But it is not the case.) 
In Example 90 the intraterminal form in $\left\{-\mathrm{A}^{2} \mathrm{tI}^{2} \mathrm{n} / /-\mathrm{ytI} \mathrm{I}^{2} \mathrm{n}\right\}+$ the copula bol- in $\left\{-\mathrm{sA}^{2}\right\}$ are combined with ${ }^{y} e d i$.

Example 90

\begin{tabular}{|c|c|c|c|c|}
\hline $\begin{array}{l}e t-k e \\
\text { road-DAT }\end{array}$ & 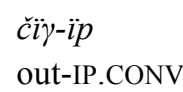 & $\begin{array}{l}{ }^{w} \text { ok-uw } \\
\text { study-Uw.VN }\end{array}$ & $\begin{array}{l}\text { woray-ïn- } a \\
\text { chance-POSS3-DAT }\end{array}$ & $\begin{array}{l}\text { iye } \\
\text { possessing }\end{array}$ \\
\hline bot-atïn & & $t-s a-m$ & ${ }^{y} e-d i$. & \\
\hline
\end{tabular}

'If only I would have the chance to go abroad and study.'

These examples exclude the possibility of the achieving what is desired, promised, or predicted. It indicates 'it is not the case now'.

The copula ${ }^{y} e d i$ can also be observed to be pronounced as ${ }^{y} e t t i$. This sounds as the past tense of the verb ${ }^{y}$ et- 'to do', i.e. ${ }^{y}$ et-ti $\langle$ do-PAST3〉 ' $\mathrm{X}$ made it', but it is probably a variant of ${ }^{y} e d i$.

Combination with ${ }^{y} e d i$ in conditional clauses

In counterfactual conditional clauses a hypothetical form is used in the protasis, and the predicate of the main clause is marked by the past copula ${ }^{y} e-d i$ 〈E.COP-PAST3〉; see Example 91.

Example 91

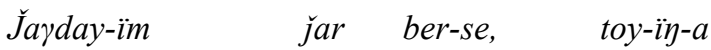

situation-POSS1SG order give-HYP3 wedding-POSS2SG-DAT

bar-ar $\quad{ }^{y} e-d i-m$

go-AOR.PTCP E.COP-PAST-1SG

'Had my situation allowed it, I would have gone to your wedding.' (But my situation did not allow it.)

In another type of counterfactual conditional expression, the postterminal form in $\left\{-G^{4} A^{2} n\right\}$ and the hypothetical form of the copula bot- are used in the protasis; see Example 92.

Example 92

\begin{tabular}{|c|c|c|}
\hline${ }^{w} \ddot{O m i r}-g e$ & aynat-ïp & kel-gen \\
\hline life-DAT & turn-IP.CONV & COME.POSTV-GAN.PTCP \\
\hline bot-sa-k, & bakït-tïy & 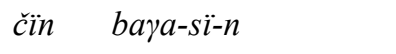 \\
\hline $\begin{array}{l}\text { L.COP-HYP-1PL } \\
\text {-er }\end{array}$ & happiness-GEN & worth-POSS3SG-ACC \\
\hline
\end{tabular}

'Had we been reborn, we would know the real worth of happiness.' (But we cannot be reborn.) 
The protasis, as in Example 93, can also be based on an intraterminal form in $\left\{-\mathrm{A}^{2} \mathrm{tI}^{2} \mathrm{n} / /-\mathrm{ytI} \mathrm{I}^{2} \mathrm{n}\right\}$ and the hypothetical form of the copula bot-.

Example 93

\begin{tabular}{|c|c|c|c|}
\hline $\begin{array}{l}\text { Munda } \\
\text { here }\end{array}$ & $\begin{array}{l}{ }^{y} e-k e n-i \eta \eta-d i \\
\text { E-GAN.PTCP-POSS2SG-ACC }\end{array}$ & $\begin{array}{l}\text { bịl-etịn } \\
\text { know-ATIN.PTCP }\end{array}$ & $\begin{array}{l}\text { bot-sa-m, } \\
\text { BOL.COP-HYP-1SG }\end{array}$ \\
\hline seni & čakïr-ar & ${ }^{y} e-d i-m$. & \\
\hline $\mathrm{ACC}$ & call-AOR.PTC & E.COP-PAST- $1 \mathrm{SG}$ & \\
\hline
\end{tabular}

Example 94 illustrates that the aorist marker $\left\{-\left(\mathrm{A}^{2}\right) \mathrm{r}\right\}$ and the hypothetical form of the copula bot-are in the protasis.

Example 94

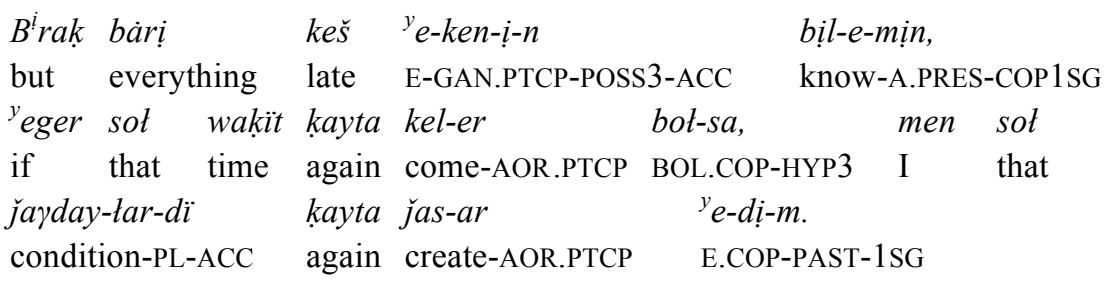

'But I know it is late now; had that time come back, I would have created that situation again.'

Note that conditional sentences construed with a hypothetical form in the protasis and the past copula ${ }^{y} e d i$ in the main clause can also be used in a rhetorical question.

Example 95

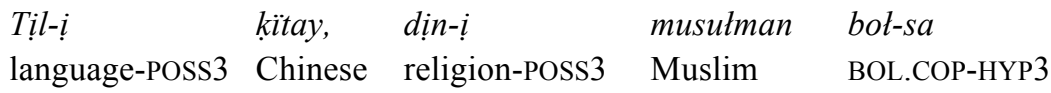

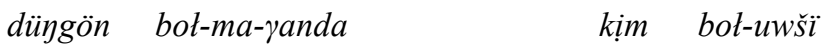

Dungan BOL.COP-NEG-GAN.LOC.CONV who BOL.COP-UWŠI.PTCP

${ }^{y} e-d i ?$

E.COP-PAST3

'If X speaks Chinese and is a Muslim, and X is not a Dungan, then what could X be?' (All Chinese Muslims are Dungan.)

Combination with ${ }^{y}$ eken in main clauses

The combination of the hypothetical form $\left\{-\mathrm{sA}^{2}\right\}$ with the rhetorical particle ${ }^{y}$ eken expresses a strong and passionate wish or hope in Kazakh. This rhetorical particle has the same form as the indirective copula particle ${ }^{y}$ eken. ${ }^{20}$ However, according to Johanson (2012a: 55-56, cf. Karakoç 2005: 22-32),

${ }^{20}$ For more information about the indirective particle ${ }^{y}$ eken see Johanson (2000a, 2012). 
functionally, the rhetorical particle displays its own distinct characteristics in relation to the indirective copula particle. Unlike the indirective copula, the rhetorical ${ }^{y}$ eken can co-occur with the simple preterite, does not convey any indirective meaning, and is not capable of carrying personal markers. In light of all these functional differences, Johanson (2012a: 56) points out that the etymologies of these two versions of the particle might be traced back to distinct markers. The indirective copula particle ${ }^{y}$ eken could be traced back to an old particle ärkän, whereas the rhetorical particle goes back to the old particle ärkin; see Example 96.

Example 96

$\begin{array}{lll}\text { Sinauw-dan } & \text { wöt-üp } \quad \text { ket-se-m } & { }^{y} \text { eken. } \\ \text { exam-ABL } & \text { pass-IP.CONV LEAVE.POSTV-HYP-1SG } & \text { RHET.PART } \\ \text { 'I wish indeed I could pass the exam.' } & \end{array}$

The hypothetical form in $\left\{-\mathrm{sA}^{2}\right\}$ combined with the interrogative particle $\left\{-\mathrm{M}^{3} \mathrm{~A}^{2}\right\}$, or an interrogative pronoun + the rhetorical particle ${ }^{y}$ eken, expresses "rhetorical questions, with readings of wondering and hesitation" (Johanson 2012a: 55). Example 97, the combination is used in order to encourage the interlocutor to consider a message or a point of view.

Example 97

$\begin{array}{llll}\ddot{U} y-d i & \text { tazała-sa-k } k & p a & { }^{y} \text { eken? } \\ \text { home-ACC } & \text { clean-HYP-1PL } & \text { Q.PART } & \text { RHET.PART } \\ \text { 'How about cleaning the house?' }\end{array}$

Zhang (2004: 421) remarks that the constructions with $\left\{-\mathrm{sA}^{2}\right\}+$ bot- $a+-m a$ 〈HYP-BOL.COP-A.PRES-Q.PART $\rangle+{ }^{y}$ eken and $\left\{-\mathrm{sA}^{2}\right\}+$ bot-ar $+-m a\langle$ HYPBOL.COP-AOR-Q.PART $\rangle+{ }^{y}$ eken can also indicate the speaker's request for something that is hoped for. These two construction express different meanings. The first one, as illustrated by Example 98, conveys the speaker's sincere attempt to ask for permission. The second one, illustrated by Example 99, expresses that the the statement implies a warning or even intimidation.

Example 98

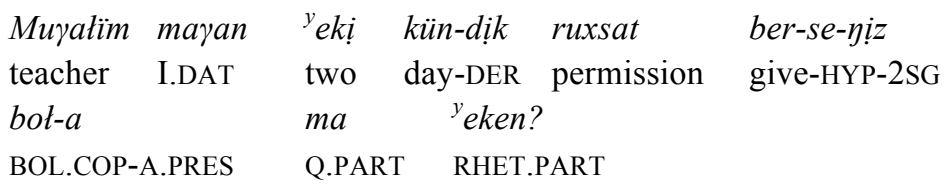

'Lăoshī, nín néng bùnéng gěi wǒ zhǔn wǒ liăng tiān jiă?' (Zhang 2004: 421)

['Teacher, is it possible for you to give me two days' leave?'] 
Example 99

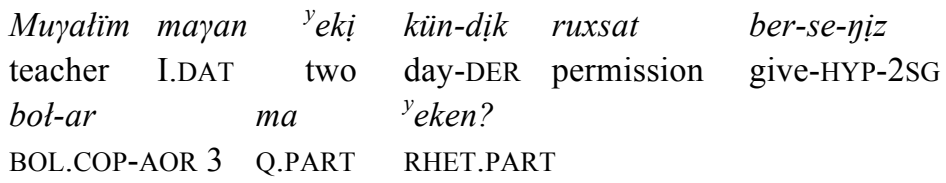

'Lăoshī, nín shìfǒu néng zhǔn wǒ liăng tiān jiă?' (Zhang 2004: 421)

['Teacher, why don't you give me two days leave?']

Combination with ${ }^{y}$ eken in conditional clauses

When the indirective copula ${ }^{y}$ eken occurs in the apodosis, as in Example 100 , it expresses that the speaker regrets, is repentant or is disappointed over having missed an opportunity. The hypothetical form in $\left\{-\mathrm{sA}^{2}\right\}$ is used in the protasis.

Example 100

\begin{tabular}{|c|c|c|c|}
\hline $\begin{array}{l}\text { Munda } \\
\text { here }\end{array}$ & $\begin{array}{l}{ }^{y} e-k e n-i \underline{y}-d \underline{i} \\
\text { E.COP-GAN.PTCP-POSS2SG-ACC }\end{array}$ & $\begin{array}{l}\text { bịl-etịn } \\
\text { know-ATIN.PTCP }\end{array}$ & $\begin{array}{l}\text { bot-sa-m, } \\
\text { BOL.COP-HYP-1SG }\end{array}$ \\
\hline seni & čakür-ar & ${ }^{y}$ eken-mịn. & \\
\hline $\mathrm{ACC}$ & call-AOR.PTCP & E.COP.INDIR-COP1SG & \\
\hline
\end{tabular}

When the verb form in the apodosis is an interrogative form of the aorist in $\left\{-\left(\mathrm{A}^{2}\right) \mathrm{r}\right\}$ followed by the indirective copula ${ }^{y}$ eken, the sentence indicates subjective evaluation of probability.

Example 101.

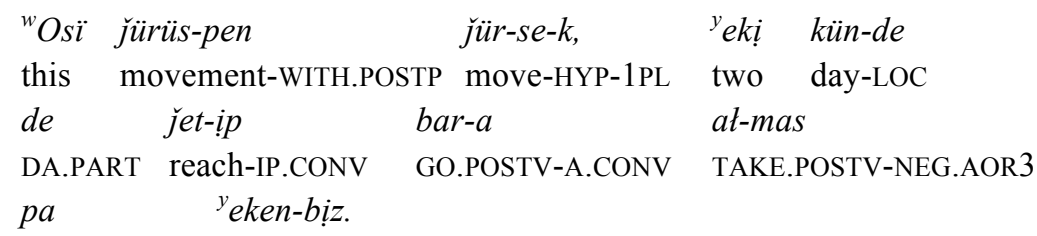

Q.PART E.COP.INDIR-COP1PL

'Walking so, we will not arrive there even in two days.'

Combination with the particle $\breve{s} I^{2}$

A particle $\breve{s} I^{2}$ (see Modal particles) can also be added to all the hypothetical forms we have mentioned so far, i.e. the forms that indicate a wish, desire, will or hope, and can be used in rhetorical question 'what if it were the case?', or in the sense of 'if only'. In combination with the particle $\breve{s} I^{2}$ these expressions indicate hopeless wishes and regrets. 
Example 102

\begin{tabular}{|c|c|c|}
\hline $\begin{array}{l}\text { Kel-se } \\
\text { come-HYP3 }\end{array}$ & $\begin{array}{l}\text { Šị? / } \\
\text { ŠI.PART }\end{array}$ & $\begin{array}{l}\text { Kel-se } \\
\text { come-HYP3 }\end{array}$ \\
\hline
\end{tabular}

'What if X comes? / If only X would come.'

Note that when the particle $\check{s} I^{2}$ is added to the hypothetical of the second person it can express a sort of volitional meaning, i.e. that the speaker reminds the interlocutor(s) to be cautious when performing the indicated action. This expression can convey an impatient attitude.

Example 103

$\begin{array}{llll}\text { J̆ot-dan } & \text { "öt-kende } & \text { bayka-sa- } y \text {-dar } & \check{s i ̈ !} \\ \text { street-ABL } & \text { pass-GAN.LOC.CONV } & \text { pay attention-HYP-2SG-PL } & \text { ŠI.PART } \\ \text { 'Be careful when you cross the street!' } & \end{array}$

Combination with kaytedi / kałay

The combination in main clauses of a hypothetical form in $\left\{-\mathrm{sA}^{2}\right\}$ with the interrogative pronominal verb kayted $i^{21}$ 'how to do' or the interrogative pronoun katay 'how' indicates an idea or a plan put forward for consideration, or a wish that is expressed by the speaker politely or formally and is expected to be fulfilled.

Example 104

Bügün kat-sa-y kayt-e-dị?

today stay-HYP-2SG how to do-A.PRES-3

'How about you staying today?'

Combination with the particle $d A^{2}$ in concessives

According to Zhang (1993: 24, 2004: 419), verb forms in $\left\{-\mathrm{sA}^{2}\right\}+$ the $d A^{2}$ particle in the subordinate clause indicate a concessive conditional meaning. The expression can correspond to 'although', 'no matter' or 'even if', etc. in English.

Example 105

$\begin{array}{lllll}{ }^{w} \mathrm{Ot} & \text { awur-up } & \text { jür-se } & \text { de } & \text { yejbek-ke } \\ \mathrm{X} & \text { get sick-IP.CONV } & \text { MOVE.POSTV-HYP3 } & \text { DA.PART } & \text { labor-DAT }\end{array}$

\footnotetext{
${ }^{21}$ Kaytedi is an interrogative pronominal verb which is probably contracted from the combination of katay 'y etedi 〈how do-A.PRES-3〉 'how to do'. There are other similar pronominal expressions, for example, kaytse de, which is also a shortened expression of katay 'etse de 〈how do-HYP3 DE.PART〉 'in any case', and kaytkende de from katay ${ }^{y}$ etkende de 〈how do-GAN.LOC.CONV- DE.PART) 'under any circumstances'.
} 
kat ${ }^{i}$ nas- $t i$.

attend-PAST3

'Tā sūi bìngzhe, dàn háishì cānjiāle láodòng.' (Zhang 2004: 419)

['Although he was sick, he still attended the work.']

Example 106

Kanča jaman bot-sa da, ${ }^{w}$ ot ${ }^{w} \ddot{o z}$ bała-m

how much bad BOL.COP-HYP3 DA.PART X self child-POSS1SG

roy.

TOY.PART

'No matter how bad $\mathrm{X}$ is, $\mathrm{X}$ still is my own child.'

Combination with $w h$-interrogatives

When the conditional clause contains a wh-interrogative, it can express meanings such as 'whatever', 'whoever' etc.

Example 107

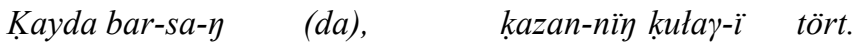

where go-HYP-2SG (DA.PART) pan-GEN ear-POSS3 four

'Wherever you go, a pan has four handles.'

Example 108

${ }^{w}$ Ot katay akša taw-up jan-ï-n

$\mathrm{X}$ how money find-IP.CONV life-POSS3-ACC

bak-kan bot-sa, men de $b^{i} r$

care-GAN.PTCP BOL.COP-HYP3 I DA.PART a

amat-ï-n karastïr-ar-mïn.

strategy-POSS3-ACC investigate-AOR-COP1SG

'Just as $\mathrm{X}$ earned his money and survived, so will I also try to find a way.'

Example 109

Tịl-dị sen kałay üyren-se- $\eta$, men de sołay

language-ACC you how learn-HYP-2SG I DA.PART that way

üyren-e-min.

learn-A.PRES-COP1SG

'Just as you learned the language, so will I also learn it.'

Combination with botyanï / bołd $і$

The hypothetical verb form in $\left\{-\mathrm{sA}^{2}\right\}$ combined with the copulas botyani 〈BOL.COP-GAN.PTCP-POSS3〉 or botdï 〈BOL.COP-PAST3〉 can mean 'as long as' and 'only if'. Zhang (2004: 418) explains the meaning of such constructions as "chōngzú tiáojiàn guānxi” ('sufficient conditional relation'); i.e. once the condition is fulfilled, the outcome is guaranteed. 
Example 110

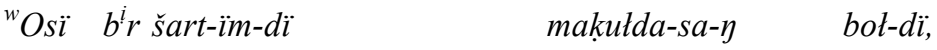

this a condition-POSS1SG-ACC approve-HYP-2SG BOL.COP-PAST3

bartik šart-ïy-dï makutda-y-mïn.

all condition-POSS2SG-ACC approve-A.PRES-COP1SG

'Zhǐyào nǐ dāyìng wǒ zhè yīgè tiáojiàn, wǒ jiù dāyìng nǐ suǒyǒu de tiáojiàn.' (Zhang 2004: 418)

['If you accept my only condition, I will accept all of your conditions.']

Example 111

J̌emis bot-sa bot-yan-ï, men jür-e

fruit BOL.COP-HYP3 BOL.COP-GAN.PTCP-POSS3 I move-A. CONV

ber-e-min.

GIVE.POSTV-A.PRES-COP1SG

'As long as fruit is available, I will survive.'

Combination with rana 'just, only'

The hypothetical forms in $\left\{-\mathrm{sA}^{2}\right\}$ with the particle yana can express 'only when', 'only if'. The restrictive meaning 'only' is supplied by the particle rana here.

Example 112

J̌atikpay üyren-se- $\eta \quad$ yana jeyis-ke jet-e

untiring learn-HYP-2SG only success-DAT reach-A.CONV

at-a-sïy.

TAKE.POSTV-A.PRES-COP2SG

'Only if you learn untiringly may you succeed.'

Temporal

The suffix $\left\{-\mathrm{sA}^{2}\right\}$ can be used to express the temporal meaning 'when'.

Example 113

Üsen kel-e jat-sa, atdïn-a $b^{i} r$

Usen come-A.CONV LIE.POSTV-HYP3 front.POSS3-DAT a

karya kel-ip kon-a kat-a-dï.

crow come-IP.CONV sit-A.CONV STAY.POSTV-A.PRES-3

'When Usen was on the way, a crow descended and suddenly sat down in front of him.'

\section{Contrastive}

Hypothetical forms can be used to link two clauses in a contrastive sense. i.e., to emphasize the differences between the information provided in the linked clauses. 
Example 114

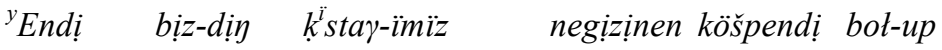

NOW.FILL we-GEN village-POSS1PL mainly nomadic BOL.COP-IP.CONV

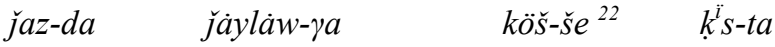

summer-LOC summer pasture-DAT move-HYP3 winter-LOC

$k^{i}$ stawtik-ka bar-i ${ }^{i} p$ mat bay-a-di.

winter residence-DAT go-IP.CONV livestock breed-A.PRES-3

'And our village is mainly nomadic, whereas (the people) in the summertime move to the summer pasture, in the winter (they) go to the winter residence and breed (their) livestock.' (T3/23)

Example 115

$\begin{array}{lllll}\text { Kïz-ï } & \text { "kiyịm } & \text { at-a-mïn" } & \text { de-se, } & u l-\ddot{i} \\ \text { daughter-POSS3 } & \text { clothes } & \text { buy-A.PRES-COP1SG } & \text { say-HYP3 } & \text { son-POSS3 }\end{array}$

"jeytịn at-a-mïn" de-y-dị.

food buy-A.PRES-COP1SG say-A.PRES-3

'While X's daughter says "I want to buy clothes", X's son says "I want to buy food".'

Idiomatic usages

Botsa 'as for'

The copula form of the hypothetical form of the copula, bot-sa 〈BOL.COP-HYP3〉 can function as a topic marker. It can be interpreted in English as 'as for', 'with regard to'.

Example 116

At menị bar arman-ïm bol-sa, tek seni

but I.GEN all wish-POSS1SG BOL.COP-HYP3 only you.ACC

rana bakïtti kït-uw.

just happy MAKE.LIGHTV-UW.VN

'But as for my wish, it is just to make you happy.'

Note that, according to Zhang (2004: 422), the Kazakh particle botsa can only mark the subject of the clause.

Other Turkic languages have similar topic markers based on hypothetical forms of the copula, e.g. Turkmen bol- $\theta a\langle$ BOL.COP-HYP3〉, and Turkish $i$-se 〈I.COP-HYP3〉 (Johanson 2006b: 59).

${ }^{22}$ The hypothetical form $\left\{-\mathrm{sA}^{2}\right\}$ is pronounced as $-\check{s} a$, because of assimilation with the stem-final $\check{s}$. 
Tursa 'considering the fact that'

Zhang (1993: 26, 2004: 420) points out that tur-sa 〈TUR.COP-HYP3〉 strengthens the truth of an assertion in the non-main clause. The expression is often use when the statement is contrary to what has been expected or what has been asserted. The meaning can be interpreted as 'in point of fact' in English.

Example 117

A: Aysuluw kel-e-dị.

Aysulu come-A.PRES-3

'Aysulu will come.'

$\begin{array}{lclll}\text { B: } A k \grave{s} a-s \ddot{i} & \text { jok } & \text { tur-sa, } & { }^{w} \text { ot } & k e l-e \\ \text { money-POSS3SG } & \text { no } & \text { TUR.COP-HYP3 } & \text { she } & \text { come-A.CONV } \\ & \begin{array}{l}\text { at-ma-y-dï. } \\ \text { TAKE.POSTV-NEG-A.PRES-3 }\end{array} & & & \end{array}$

'Considering the fact that she does not have money, she will not be able to come.'

\section{Botmasa 'except for', 'apart from'}

The negated hypothetical form of the copula bot-ma-sa 〈BOL.COP-NEGHYP3) when used in the idiomatic sense 'except for', 'apart from', expresses an eliminable condition, i.e. a circumstance which is not crucial to the truth of the statement presented in the main clause (Zhang 1993: 24, 2004: 418)

Example 118

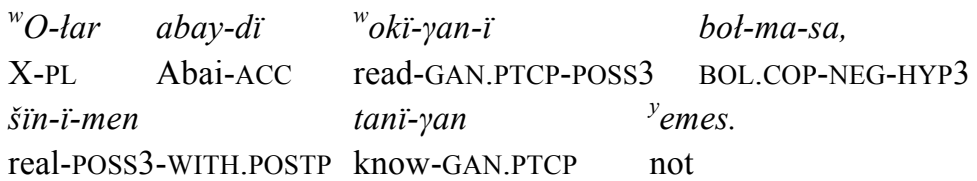

'Tāmen chú dúguò guānyú ā bài de shū yřwài, bìng bù zhēnzhèng rènshi ā bài.' (Zhang 2004: 418)

['Except for having read the book about Abai, they do not really know anything about him.']

Example 119

\begin{tabular}{|c|c|c|}
\hline 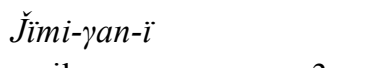 & bot-ma-sa, & pálendey $b^{i}$ \\
\hline smile-GAN.PTCP-POSS3 & BOL.COP-NEG-HYP3 & not such an \\
\hline bịldịr-gen- $i$ & jok. & \\
\hline express-GAN.PTCP-POSS3 & no & \\
\hline
\end{tabular}

Example 120 illustrates a special use of botmasa. Botmasa is the negated predicate of the protasis in a rhetorical question. Observe that the corre- 
sponding non-negated expression is built with tursa 'considering the fact that'; see Example 121.

Example 120.

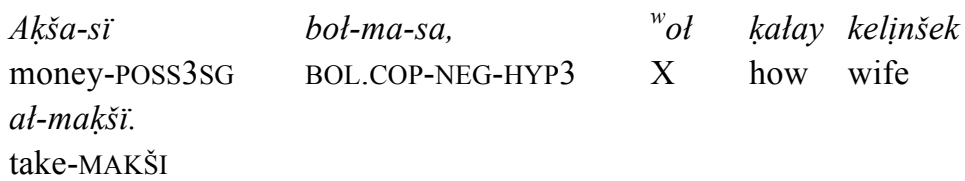

'Considering that $\mathrm{X}$ does not have money, how does $\mathrm{X}$ intend to marry?'

Example 121

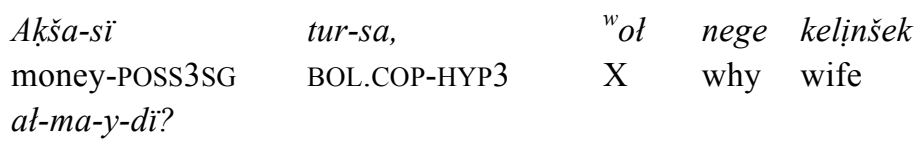

TAKE.POSTV-NEG-A.PRES-3

'Considering that $\mathrm{X}$ has money, why doesn't $\mathrm{X}$ intend to marry?'

Botmasa / ne botmasa / yá botmasa 'or, otherwise'

Certain items based on the hypothetical forms of the copula, bot-ma-sa 〈BOL.COP-NEG-HYP3〉, ne bot-ma-sa 〈or BOL.COP-NEG-HYP3〉, ya bot-ma-sa, 〈or BOL.COP-NEG-HYP3〉, are used to link alternative expressions-clauses or sentence constituents - in the sense of 'or, otherwise' in English. Corresponding items in other Turkic languages are Turkish yok-sa 〈non-existingHYP3SG〉 'or, otherwise', Uyghur bol-mi-sa 〈BOL.COP-NEG-HYP3〉, yaki bol$m i-s a\langle$ or BOL.COP-NEG-HYP3〉, ya bol-mi-sa 〈or BOL.COP-NEG-HYP3〉 all meaning 'or'.

Example 122

${ }^{w}$ Öley ayt, ne botmasa biy bile!

song sing.IMP or dance.IMP

'Sing or dance!'

Example 123

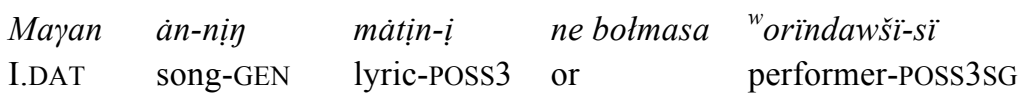

kajet.

necessary

'I either need the lyrics of the song or the name of the performer.'

Zhang (2003, 146, 2004: 536) is of the opinion that botmasa, ne botmasa, y $\dot{a}$ botmasa and yáki botmasa are used to signal that the speaker prefers the first of the alternatives. The second option is given for consideration only if the first one cannot be fulfilled. He also points out the differences between these conjunctions. Botmasa straightforwardly marks that the interlocutor prefers 
the first alternative. Ne botmasa is a more polite expression. Ya botmasa and yáki botmasa express the speaker's preference in an indirect way.

Aytpese 'if not, otherwise'

A necessary condition is expressed by the conjunction ayt-pe-se /do it like that-NEG-HYP3 > 'if not, otherwise'.

Example 124

Men misat-men tüsündir-eyin, aytpese woy-ïm-dï

I example-WITH.POSTP explain-VOL1SG otherwise thougt-POSS1SG-ACC

jetkiz-e at-ma-y-mïn.

deliver-A.CONV TAKE.POSTV-NEG-A.PRES-COP1SG

'I shall illustrate it with an example, otherwise I can't explain my thought.'

Example 125

"Aytpese üz-üp

ket-ip kat-atin

otherwise break-IP.CONV LEAVE.POSTV-IP.CONV STAY.POSTV-ATIN.PTCP

"e-di!" de-y-di.

E.COP-PAST3 SAY-A.PRES-3

'“'Otherwise, they would have broken (the hobbles) and left", he writes.' (T4/ 43)

Aytse de 'even so, nevertheless, however, but, though'

Aytse de (do it so-HYP3 DA.PART) 'even so, nevertheless' is a conjunction expressing adversative meaning (Geng et al. 1999: 282, Zhang 2003: 169, 2004: 556).

Example 126

Dawus-um jaksï yemes, àytse de but àn-dị ayt-ïp

voice-POSS1SG good not even so this song-ACC sing-IP.CONV

kör-eyịn.

SEE.POSTV-VOL1SG

'My voice is not good, even so I may try to sing this song.'

Some synonymous expressions mentioned in Kazakh grammars are süyt-se de 〈söytse de〉 〈do it so-HYP3 DA.PART〉 'even so, nonetheless' (Geng et al. 1999: 282), üyt-se de 〈öytse de〉 (do it so-HYP3 DA.PART〉 'even so, though, although' (Zhang 2003: 169, 2004: 556).

Dese de 'even so, nevertheless, however, but, though'

When de-se 〈say-HYP3) 'if X says / when X says' combines with the particle $D^{2} A^{2}$, i.e. dese de, it functions as an adversative conjunction and expresses the same meaning as aytse de as we just mentioned above. The conjunction aytse de in Example 127 can be substituted for dese de as the following example illustrates. 
Example 127

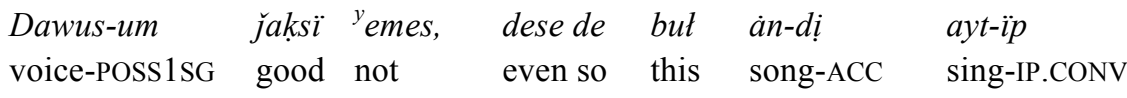

kör-eyịn.

SEE.POSTV-VOL1SG

'My voice is not good, even so I may try to sing this song.'

Note that when the verb in the protasis is in the voluntative mood combined with dese, the relation between two clauses is interpreted such that the action in the subordinate clause is the person's wish that could not be fulfilled because of the circumstance presented in the main clause.

Example 128

\begin{tabular}{|c|c|c|c|}
\hline$b$ & $\nu \eta-\gamma a$ & $\begin{array}{l}y i n \\
\text {-VOL1SG }\end{array}$ & $\begin{array}{l}d \\
\text { sc }\end{array}$ \\
\hline & $\begin{array}{ll}y & \end{array}$ & & \\
\hline & pass-Ur & difficult & BOL.COP-PAST \\
\hline
\end{tabular}

"When I have thought about going back to Xinjiang, but it has now become difficult to cross (the border)".' (T4/67)

Example 129

Näzän- $\gamma$ a telefon ber-eyịk de-se-k

Nazan-DAT telephone give-VOL.1PL say-HYP-1PL

kara, telefon jok, adaš.

look.IMP telephone non-existing friend

'When we wanted to call Nazan, look, there was no phone, (my) friend.' (T9/22)

Süytse 'in fact, in reality, in truth'

Süytse 〈söytse〉〈do it so-HYP3〉 'if $\mathrm{X}$ do(es) it so/when $\mathrm{X}$ do(es) it so' is a conjunction which introduces a clause that explains what actually is the case. The predicate in the clause introduced by this conjunction is always an indirective form, either with the indirective particle ${ }^{y}$ eken (mostly after nominals), or $\left\{-\left(\mathrm{I}^{2}\right) \mathrm{ptI}^{2}\right\}$ (after verbs) Zhang (2003: 152, 2004: 542).

Example 130

\begin{tabular}{|c|c|c|c|}
\hline $\begin{array}{l}\text { Keš-ke } \\
\text { evening-DAT }\end{array}$ & $\begin{array}{l}\text { mat- } \ddot{-}-n \\
\text { cattle-POSS3-ACC }\end{array}$ & $\begin{array}{l}\text { gende-gende, } \\
\text { unt-GAN.LOC.CONV }\end{array}$ & $\begin{array}{l}\check{s} a k t i ̈ \\
\text { approximately }\end{array}$ \\
\hline yerkek koy & $b o t-{ }^{u} p$ & $\check{c} \ddot{\gamma} \gamma-a-d \ddot{i}$, & \\
\hline male sheep & non-existing BOL.COP- & -IP.CONV & $S-3$ \\
\hline üytse & 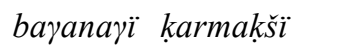 & koyšï-łar-dï & atda-p \\
\hline fact & that one fisherman & shepherd-PL-ACC & deceive \\
\hline$r$ - $\gamma a n d a$ & 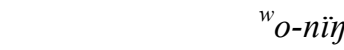 & serịk-ter-ị & koj \\
\hline AND.POST & -GAN.LOC.CONV X.GEN & companion-PL & p-ACC \\
\hline
\end{tabular}


$\begin{array}{lll}t i z-i p & \dot{a} k e t-e & \text { ber-ip-ti. } \\ \text { construct a raw-IP.CONV } & \text { take away-A.CONV } & \text { GIVE.POSTV-IP.POSTT-3 }\end{array}$

'Bàngwăn diănshù shí, fāxiàn shăole shí lái zhǐ yáng, yuánlái, dāng diàoyú rén zài hǒngpiàn yángguānmen shí, tā de tónghuǒ jiù bă yáng guăi păole.' (Zhang 2003: 153, 2004: 542)

['In the evening, when they counted them (the sheep), they found that ten (male) sheep were missing. Actually, while that fisherman deceived the shepherds, his companions apparently spirited away the sheep.']

\section{The non-productive imprecative in $\left\{-\mathrm{G}^{4} \mathrm{I}^{2} \mathrm{r}\right\}$}

The marker $\left\{-G^{4} I^{2} r\right\}$ is an old suffix that in modern Kazakh expresses maledictions, i.e. curses. It is no longer used any more to express good wishes. The suffix is not productive and is only used in set phrases wishing evil upon somebody. Earlier the suffix was productive and could express both benedictions and curses. In modern Kazakh, the voluntative of the third person in $\left\{-\mathrm{sI}^{2} \mathrm{n}\right\}$ has taken over these functions.

\section{Inventory of forms}

\section{Affirmative}

The marker of the imprecative is $\left\{-\mathrm{G}^{4} \mathrm{I}^{2} \mathrm{r}\right\}$. Personal endings or the plural suffix $\left\{-\mathrm{L}^{4} \mathrm{~A}^{2} \mathrm{r}\right\}$ cannot be attached to this suffix, e.g. ${ }^{w} \ddot{O} l$-gir ! 〈die-GIR.IMPR 'May X die!', Jan-ïy čik-kïr! 〈soul-POSS2SG come out- GIR.IMPR〉 'May you die!', Mïy bot-yïr! 〈thousand BOL.COP-GIR.IMPR〉 'May X have thousand (more descendents)!', Kurï-p ket-kị!! 〈vanish-IP.CONV LEAVE.POSTVGIR.IMPR) 'May X perish!'

However, plural forms can occur in the Kazakh of speakers influenced by Uyghur because in Uyghur the plural marker $\left\{-\mathrm{L}^{2} \mathrm{~A}^{2} \mathrm{r}\right\}$ can be applied after the marker $\left\{-\mathrm{G}^{4} \mathrm{U}^{2} \mathrm{r}\right\}$.

A deverbal derivational suffix $\left\{-\mathrm{G}^{4} \mathrm{I}^{2} \mathrm{r}\right\}$ occurs in some items, e.g. ${ }^{w} \ddot{o} t-k i r$ 'sharp', at-yïr 'clever'.

\section{Negative}

The negative of the imprecative is built by adding $\left\{-\mathrm{M}^{3} \mathrm{~A}^{2}-\mathrm{G}^{2} \mathrm{I}^{2} \mathrm{r}\right\}$ to the ver-

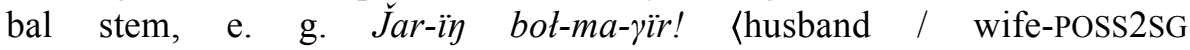
BOL.COP-NEG-GIR.IMPR〉 'May you be left lonely!', Köger-me-gịr! 〈grow blue-NEG-GIR.IMPR〉 'May X fall into decay!', Bak jaz-ba-yïr! 〈luck write-NEG-GIR.IMPR〉 'May X be unfortunate!', Jür-gịz-be-gịr! 〈move-CAUSNEG-GIR.IMPR > 'May X not be able to walk!', Batpak-tan čik-pa-yïr! 〈swamp-ABL come out-NEG-GIR.IMPR〉 'May X not come out from the swamp!', J̌et-pe-gị! 〈reach-NEG-GIR.IMPR〉 'May X not reach (it)!'. 


\section{Basic morphological and syntactic properties}

Imprecative forms can be used as a predicate or as an attribute to a nominal. In the first case, the logical subject can only be a third person, because the marker $\left\{-G^{4} I^{2} r\right\}$ cannot take any personal agreement.

Example 131

Köz-üm kör bot-yï!

eye-POSS1SG blind BOL.COP-GIR.IMPR

'May my eyes become blind!'

The imprecative expression can also be used attributively, as in the small clause wölgenị kurï̈̈̈r 'may your corpse dry up', below.

Example 132

${ }^{w}$ Öl-gen-ịn kurï-ÿ̈r češek.

die-GAN.PTCP-POSS2SG dry-GIR.IMPR smallpox

'You smallpox, your corpse may dry up.'

The imprecative can be inflected for case and possessive as Example 133 illustrates.

Example 133

$\begin{array}{llll}{ }^{w} \text { Öl-gịr-dịn } & y t-i-n & q u w-u p & \text { jịber-di-m. } \\ \text { die-GIR.IMPR-GEN } & \text { dog-POSS3-ACC } & \text { chase-IP.CONV } & \text { SEND.POST-PAST-1SG }\end{array}$

'I chased away the dog of X who should die.' / 'I chased away the dog who should die.'

The imprecative marker $\left\{-G^{4} U^{2} r\right\}$ in Uyghur possesses similar properties, but the plural marker can be attached when the logical subject is plural and is not expressed overtly, e.g. Öl-gür-lär! 'May they die!'.

Old Uyghur possesses the marker \{-GUr\}, e.g. Ol öl-gür! 'May X die!' Several modern Turkic languages use its equivalents in phrases expressing curses and good wishes, e.g. Uzbek Båy bol-gir! 'May X become rich!', Kör bol-gir! 'May X become blind!'. A close semantic counterpart is $\{-(\mathrm{y}) \mathrm{AsI}\}$ $\{-(\mathrm{y}) \mathrm{AsI}-\mathrm{j} \mathrm{A}\}$ in Turkish, e.g. Kör ol-ası! 'May X become blind!'.

\section{Usages}

Curses and blessings

In modern Kazakh, the imprecative is solely used in curses; see the following examples. 
Example 134

Jan-ïy čik-kïr!

soul-POSS2SG come out- GIR.IMPR

'May you die!' (lit. 'May your soul leave you!')

Example 135

Karyïs at-kïr!

curse shoot-GIR.IMPR

'May you be cursed!'

In earlier varieties of Kazakh, this form could also be used in blessings, as the following examples illustrate.

Example 136

Jännàt-tá jan-ïy bot-yïr!

heaven-LOC soul-POSS2SG BOL.COP-GIR.IMPR

'May your soul (rest) in heaven!'

Example 137

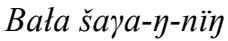

$k \ddot{z} z \ddot{\gamma} \gamma-\ddot{i}-n$

kör-gịr!

descendent-POSS2SG-GEN happiness-POSS3-ACC

see-GIR.IMPR

'May you see the happiness of your descendents!'

Combination of $\left\{-\mathrm{G}^{4} \mathrm{I}^{2} \mathrm{r}\right\}$ with ${ }^{y} e d \underline{i}$

The particle $\left\{-G^{4} I^{2} r\right\}$ in combination with the past tense form of the copula $e$ - 'to be' may be used to express the speaker's unfulfillable or unrealistic wish.

Example 138

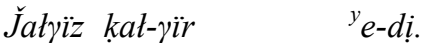

alone stay-GIR.IMPR E.COP-PAST3

'May that X might be left alone.'

\section{Modal nuances expressed by the aorist}

\section{Inventory of forms}

Affirmative

The aorist is formed with the suffix $\left\{-\left(\mathrm{A}^{2}\right) \mathrm{r}\right\}$ and pronominal type of personal endings.

The first person singular form for expressing possibility is $\left\{-\left(\mathrm{A}^{2}\right) \mathrm{r}-\mathrm{mI}^{2} \mathrm{n}\right\}$, e.g. Kat-ar-mïn〈stay-AOR-COP1SG〉 'I might stay', Kör-er-mịn〈see-AOR- 
COP1SG〉 'I might see', "'Okï-r-mïn 〈read-AOR-COP1SG〉 'I might read', Bịl-er-mịn 〈dance-AOR-COP1SG〉 'I might dance'.

The first person plural marker for expressing possibility is $\left\{-\left(\mathrm{A}^{2}\right) \mathrm{r}-\mathrm{mI}^{2} \mathrm{z}\right\}$, e.g. Kat-ar-mïz 〈stay-AOR-COP1PL〉 'We might stay', Kör-er-miz 〈see-AORCOP1PL 'We might see', 'Okï-r-mïz 〈read-AOR-COP1PL〉 'We might read', Bile-r-miz 〈dance-AOR-COP1PL〉 'We might dance'.

The second person singular marker for expressing possibility is

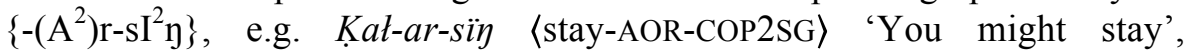
Kör-er-sị 〈see-AOR-COP2SG〉 'You might see', ${ }^{w} O k i ̈-r-s i ̈$ 〈read-AORCOP2SG) 'You might read', Bile-r-sị 〈dance-AOR-COP2SG) 'You might dance'. The polite form is $\left\{-\left(\mathrm{A}^{2}\right) \mathrm{r}-\mathrm{sI}^{2} \mathrm{z}\right\}$, e.g. Kel-er-sị $\langle$ come-AOR-COP2SG 'You might come'.

The second person plural marker for expressing possibility is $\left\{-\left(\mathrm{A}^{2}\right) \mathrm{r}-\mathrm{sI}^{2} \mathrm{y}-\mathrm{dA}{ }^{2} \mathrm{r}\right\}$, e.g. Kat-ar-sïy-dar 〈stay-AOR-COP2SG-PL〉'You might stay', Kör-er-sịy-der 〈see-AOR-COP2SG-PL) 'You might see', ${ }^{w} O k \ddot{i}-r-s \ddot{\eta}$-dar $\langle$ read-AOR-COP2SG-PL〉 'You might read', Bile-r-sin-der 〈dance-AORCOP2SG-PL) 'You might dance'. The polite form is $\left\{-\left(\mathrm{A}^{2}\right) \mathrm{r}-\mathrm{sI}^{2} \mathrm{z}-\mathrm{dA} \mathrm{A}^{2} \mathrm{r}\right\}$, e.g. Kel-er-siz-der 〈come-AOR-2SG-PL〉 'You might come'.

The third person marker $\left\{-\left(A^{2}\right) r-\varnothing\right\}$ is the marker for expressing possibility in both singular and plural. It is not possible to add the plural suffix $\left\{-\mathrm{L}^{4} \mathrm{~A}^{2} \mathrm{r}\right\}$ after it, e.g. Kat-ar 〈stay-AOR3〉 'X might stay', Kör-er 〈see-AOR3〉 'X might see', 'Okï-r $\langle$ read-AOR3 $\rangle$ 'X might read'.

\section{Negative}

The first person singular negative is $\left\{-\mathrm{M}^{3} \mathrm{~A}^{2} \mathrm{~s}-\mathrm{pI}^{2} \mathrm{n}\right\}$, e.g. Bar-mas-pïn 〈go-NEG.AOR-COP1SG〉 'I won't go', Kị-mes-pin 〈enter-NEG.AOR-COP1SG〉

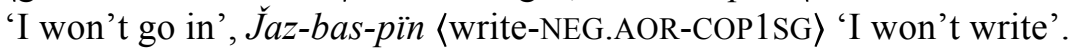

The first person plural negative form is $\left\{-\mathrm{M}^{3} \mathrm{~A}^{2} \mathrm{~s}-\mathrm{pI}^{2} \mathrm{z}\right\}$, e.g. Bar-mas-p̈̈z 〈go-NEG.AOR-COP1PL) 'We won't go', Kirr-mes-piz 〈enter-NEG.AOR-COP1PL〉 'We won't go in'.

The second person singular negative form is $\left\{-\mathrm{M}^{3} \mathrm{~A}^{2} \mathrm{~s}-\mathrm{sI}^{2} \mathrm{\eta}\right\}$, e.g. Bar-mas-sïy 〈go-NEG.AOR-COP2SG〉 'You won't go', Kịr-mes-sịn 〈enterNEG.AOR-COP2SG 'You won't go in'. The polite singular negative form is $\left\{-\mathrm{M}^{3} \mathrm{~A}^{2} \mathrm{~s}-\mathrm{sI}^{2} \mathrm{z}\right\}$, e.g. Ket-pes-siz 〈leave-NEG.AOR-COP2SG) 'You won't leave'.

The second person plural negative form is $\left\{-\mathrm{M}^{3} \mathrm{~A}^{2} \mathrm{~s}-\mathrm{SI}^{2} \mathrm{y}-\mathrm{dA}{ }^{2} \mathrm{r}\right\}$, e.g. Bar-mas-sïy-dar 〈go-NEG.AOR-COP2SG-PL) 'You won't go', Kịr-mes-sị-der 〈enter-NEG.AOR-COP2SG-PL) 'You won't go in'. The polite plural negative form is $\left\{-\mathrm{M}^{3} \mathrm{~A}^{2} \mathrm{~s}-\mathrm{sI}^{2} \mathrm{z}-\mathrm{dA}{ }^{2} \mathrm{r}\right\}$, e.g. Ket-pes-siz-der 〈leave-NEG.AOR-2SG-PL〉 'You might not leave / You won't leave'.

The third person singular and plural form is $\left\{-\mathrm{M}^{3} \mathrm{~A}^{2} \mathrm{~s}-\varnothing\right\}$, e.g. Bar-mas 〈go-NEG.AOR3〉 'X might not go / X won't go', Kịr-mes (enter-NEG.AOR3〉 'X won't go in'. 


\section{Basic semantic and syntactic properties}

The aorist marker $\left\{-\left(\mathrm{A}^{2}\right) \mathrm{r}\right\}$ functions as a mood marker in main clause predicates, indicating prospectivity with the meaning of epistemic possibility. Negated forms can also express volition, a firm decision.

Geng (1989: 128) describes the form as "jiānglái bu dingshi" ["future aorist'] and Geng et al. (1999: 228) calls the form "tïyanaksïz keler šak" ['aorist future tense']. Zhang labels the form as "huò rán jiānglái shi" ['future tense expressing probability']. In other grammars, the aorist is denoted as "bolžałdik / bolžałdï keler šak" ['asssumptive future tense'] (KG 2002: 519, Mamanov 2007: 116, MKL 2010: 466).

Also in Turkish, the aorist mainly has modal uses including tendency, inclination and possibility. In the Uyghur and Kazakh, its function has developed further and it now only expresses modal meanings. Traces of the use of the older present tense can be found in Kazakh antiquated written styles. The aorist may also occur as a predicate in non-main clauses. In this case, it does not function as a mood. See more about this in the description of the usages.

\section{Usages}

Predicate in main clauses

As mentioned, in main clause predicates the form $\left\{-\left(\mathrm{A}^{2}\right) \mathrm{r}\right\}$ expresses epistemic evaluation of the possibility that something may or may not happen.

Example 139

$\begin{array}{ll}\text { Kel-ip } & \text { kat-ar. } \\ \text { come-IP.CONV } & \text { STAY.POSTV-AOR3 } \\ \text { 'X might come.' } & \end{array}$

The negation of the possibility can signal the speaker's determination not to perform an action, as in Example 140, or denote the speaker's best estimation of the likelihood of an event as in Example 141. KG (2002: 519) also points out that instead of expressing possibility, the negation of the aorist tends to denote the strong will and firm attitude of the speaker.

Example 140

${ }^{w}$ Oran ${ }^{y}$ endi bar-mas-pün.

X.DAT now go-NEG.AOR-1SG

'I won't go there anymore.'

Example 141
Kir-e
ber,
woyan-ïp
ket-pes.
come in-A.CONV GIVE.POSTV.IMP wake up-IP.CONV
LEAVE.POSTV-NEG.AOR3
'Come in, $\mathrm{X}$ won't wake up.' 
Zhang (2004: 332-333) points out that forms of the second person can function as a polite and gentle command or a request.

Example 142

${ }^{y}$ Ertey tüs-ten keyịn ${ }^{w} \ddot{o z}$-ịn de

tomorrow noon-ABL AFTER1.POSTP self-POSS2SG DA.PART

kel-er-sị

come-AOR-COP2SG

'Míngtiān xiàwǔ nǐ yě lái yī tàng ba.' (Zhang 2004: 333)

['Tomorrow, in the afternoon, could you come as well please?']

Combination with ${ }^{y} e d i$

A past copula ${ }^{\mathrm{y}}$ edi 〈E.COP-PAST3〉 may be added to the aorist to express a counterfactual meaning. In spoken registers, as in Example 143, the contracted form ${ }^{y}$ em $\left\langle\right.$ E.COP-1SG is used instead of ${ }^{y}$ edịm.

Example 143

Bar-ar $\quad{ }^{y}$ em.

go-AOR.PTCP E.COP.1SG

'I would have gone.'

Note that in Turkish the aorist with the past copula $\{-(\mathrm{A} / \mathrm{I}) \mathrm{rdI}\}$ can denote past habitual meaning.

Example 144 Turkish

Ahmet sabah-lar-l bir elma ye-r-di.

Ahmet morning-PL-POSs3 an apple eat-AOR-3

'In the mornings Ahmet used to eat an apple.'

In Kazakh, this is not possible. This meaning is expressed with $\left\{-w \breve{s}^{2}\right.$ // -(Ø) $\left.\mathrm{U}^{2} \mathrm{ws} \check{I}^{2}\right\}+{ }^{y}$ edi with copula personal endings.

Example 145

Axmet täyertey-der- $i \quad b^{i} r \quad$ atma je-wši $\quad{ }^{y} e$-dị.

Ahmet morning-PL-POSS3 an apple eat-UWŠi.PTCP E.COP-PAST3

'In the mornings Ahmet used to eat an apple.'

Idiomatic forms

Two items, bot-ar 〈BOL.COP-AOR3〉 'it is possible' and cïy-ar 〈come outAOR3〉 'can turn out to be' $\leftarrow$ čik- 'to come out, result', denote presumption (see more in the chapter Lexical expressions). 
Habitual

In proverbs and sayings, the aorist denotes a habit, a characteristic of the person referred to.

Example 146

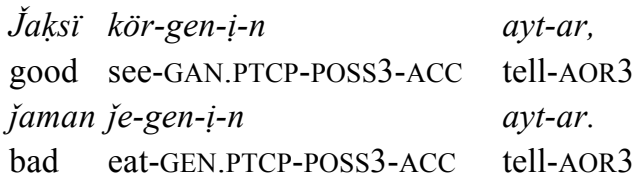

'A good (person) talks about what $\mathrm{s} /$ he has seen, and a bad (person) talks about what s/he has eaten.'

Comparison with Turkish

According to Göksel and Kerslake, the Turkish aorist can refer to a state of affairs that has been directly observed or experienced by the speaker, without implying that it has the status of a rule or principle (2005: 339). In Kazakh, the present tense $\left\{-\mathrm{A}^{2} / /-\mathrm{y}\right\}$ is used instead.

The Turkish aorist expresses scientific and moral axioms or normative or prescriptive statements.

Example 147 Turkish

Iki iki daha dört ed-er.

two two more four make-AOR3

'Two and two make four.' (Göksel and Kerslake 2005: 339, Example 56)

The corresponding expression in Kazakh is given in Example 148.

Example 148

${ }^{y}$ Eki jer-de ${ }^{y}$ eki tört (bot-a-di).

two place-LOC two four (BOL.COP-A.PRES-3)

'Two and two make four.'

The Turkish aorist can express generic statements about the characteristic qualities or behavior of a class or an individual. In Example 149 it describes a habit of an individual.

Example 149 Turkish

Ali sigara iç-mez.

Ali cigarette smoke-NEG.AOR

'Ali doesn't smoke.' (Göksel and Kerslake 2005: 340, Example 67)

The corresponding Kazakh expression would be as in Example 150. 
Example 150

Ali temeki tart-pa-y-di.

Äli cigarette smoke-NEG-A.PRES-3

'Ali does not smoke.'

The passive of the Turkish negative aorist is regularly used in public notices expressing prohibitions; see Example 151.

Example 151 Turkish

Gir-il-mez.

come in-PASS-NEG.AOR

'No entry.' (Göksel and Kerslake 2005: 340, Example 62)

A corresponding expression in Kazakh is illustrated in Example 152.

Example 152

Kịr-uw-ge bot-ma-y-dï.

come in-UW.VN-DAT BOL.COP-NEG-A.PRES-3

'It is not possible to go in.'

Attributive

The aorist can be used as an attribute modifying the meaning of a nominal. See Examples 153-156, in which the expressions barar jer 'place to go', umitiłmas bałatik kez 'unforgettable childhood time', and tamak botar $b^{i}$ rdeme 'something to eat' are used.

Example 153

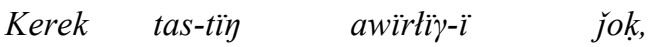

necessary stone-GEN weight-POSS3 non-existing

bar-ar jer-dịy atïstïy-ï jok.

go-AOR.PTCP place-GEN long distance-POSS3 non-existing

'A stone that you need has no weight, the place where you will go, is not far away.'

Example 154

${ }^{y} E \eta \quad$ bakïttï sät-ter-ịm, umït-ït-mas bałatik

SUPER happy moment-PL-POSS1SG forget-PASS-NEG.AOR.PTCP childhood kez-der-ịm.

time-PL-POSS1SG

'My happiest time was my unforgettable childhood.'

The aorist $\left\{-\left(\mathrm{A}^{2}\right) \mathrm{r}\right\}$ in such usage, can imply future time reference. 
Example 155

Tamak bot-ar birdeme-ler at-sa-y sï.

food BOL.COP-AOR.PTCP something-PL take-HYP-2SG ŠI.PART

'Buy something that can serve as a meal.'

Example 156

Bar-ar jer bas-ar taw-um kat-ma-y,

go-AOR.PTCP place step-AOR.PTCP mountain-POSS1SG stay-NEG-A.CONV

sịz-ge kel-ịp pana tịle-p ${ }^{\text {wotir-mïn. }}$

you-DAT come-IP.CONV shelter beg-IP.CONV SIT.POSTV-COP1SG

'I came to beg you for a shelter, because I did not have anywhere to go to (no mountain to climb),'

Nominalized forms of the aorist $\left\{-\left(\mathrm{A}^{2}\right) \mathrm{r}\right\}$ can be used as nouns and are inflected in possessive suffixs and case. See Examples 157-159 in which the aorist is assigned different cases.

Example 157

Baska ayt-ar-ïy bar ma?

other tell-AOR.PTCP-POSS2SG existing Q.PART

'Is there anything else you will say?'

Example 158

Context: A mother sees her daughter who is wearing a very short skirt to attend an important occasion.

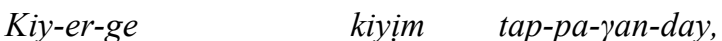

wear-AOR.PTCP-DAT clothes find-NEG-GAN.PTCP-EQUA

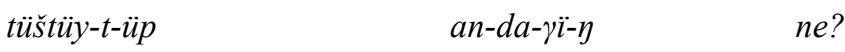

become short-CAUS-IP.CONV X-LOC-GI-POSS2SG what

'As if you could not find any clothes to wear, what is that short thing (that you are wearing)?'

Example 159

\begin{tabular}{|c|c|c|c|}
\hline uratïm & & burun & \\
\hline & ${ }^{w}$ ok $\ddot{i}-y$ & basta-dï. & \\
\hline & read-A.CON & START.POSTV- & \\
\hline
\end{tabular}

'Before the teacher arrived, the students had started to read their books.'

A negated aorist in $\left\{-\mathrm{M}^{3} \mathrm{~A}^{2} \mathrm{~s}\right\}$ in the ablative, without a postposition, may express that an action that was supposed to be carried out did not occur. In this case, the aorist functions as a converb. 
Example 160

\begin{tabular}{|c|c|c|c|}
\hline Muxtar & jarïk-tï & söndịr-mes-ten & $k \ddot{o z} z-\underline{i}$ \\
\hline Muhtar & light-ACC & turn off-NEG.AOR.PTCP-ABL & eye-POSs3 \\
\hline ill-ịn-ịp & & ket-ti. & \\
\hline attach-R & ASS-IP.CONV & LEAVE.POSTV-PAST3 & \\
\hline
\end{tabular}

The aorist in $\left\{-\left(\mathrm{A}^{2}\right) \mathrm{r}\right\}$ in the locative also functions as a converb.

Example 161

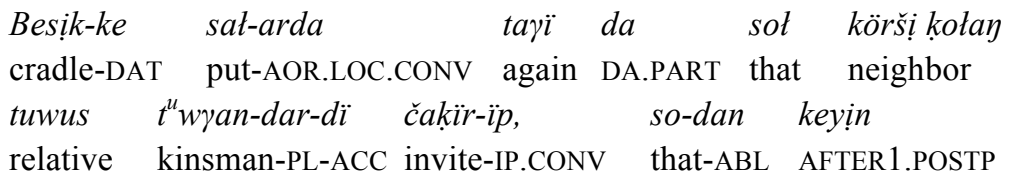

${ }^{w}$ o-łar ${ }^{w} \ddot{o} z$-ịn-e tuštuk, ágịndey a agi,

X-PL self-POSS3-DAT suitable LIKE.AFORESAID.FILL AFORESAID.FILL

nemene, bu bała- $\gamma a$ čàšúw at-a kel-e-dị.

WHAT.FILL this child-DAT present take-A.CONV COME.POSTV-A.PRES-3

'Moreover, when they put the baby into the cradle they invite the neighbors and relatives, and they bring suitable presents and they put them into the cradle.'

(T1/ 12)

\section{Periphrastic expressions of modality}

Modal notions can be expressed with periphrastic expressions that are combinations of a mood marker and a lexical item. Two periphrastic constructions express inclination, i.e. a person's natural tendency or urge to act or feel in a particular way, a disposition.

\section{$\left\{-\mathrm{G}^{4} \mathrm{I}^{2}\right\}+$ possessive personal markers + kel-}

The combination of the old necessitative marker $\left\{-\mathrm{G}^{4} \mathrm{I}^{2}\right\}^{23}$ with a personal marker of the possessive type followed by the verb kel- 'to come' expresses an inclination to do something. If the verb kel- is negated the construction expresses disinclination, i.e. unwillingness, aversion to do something. This construction is labeled as kaław ray 'optative mood' in some grammars written in Kazakh (Geng et al. 1999: 238, MKL 2002: 470, KG 2002: 514,

${ }^{23}$ The form $\left\{-G^{4} I^{2}\right\}$ probably is a preserved form of the Old Uyghur necessitative marker \{-GU\} which expresses meanings of purpose, necessity, potentiality, expectation, and intention. von Gabain (1959: 36) remarks that it had an abstract basic meaning from which expressions of necessity, potentiality, and purpose ("ein Müssen, Können und ein Zweck") developed. It can refer to subject and non-subject participants. Thus be:r-gü means someone or something that will/ought to give and something to be given. The meaning 'one must' is normally expressed by the composite suffix $\{-\mathrm{GUIUK}\}$, negated $\{-\mathrm{GUsUz}\}$, e.g. Bil-gülük 〈know-GULUK.NESS〉 'It is necessary to know', and Modern Uyghur has preserved this marker. 
Mamanov 2007: 96), and as yuànwàng shì 'optative mood' in grammars written in Chinese (Geng 1989: 140, Zhang 2004: 425). MKL and Mamanov subcategorize the construction as "erikti kataw ray, a 'voluntary optative mood' that signals the desire to do or not to do something. Zhang (2004: 425) subcategorizes the construction as zhi shù yuànwàng shi, a 'direct stated optative mood' that denotes that the speaker states the wish of the subject referent directly. We reserve the term "optative" for verb forms that constitute the optative paradigm; see Optative. Thus, items conveying meanings similar to those of optative verb forms will not be labeled optative in the present work. The following example illustrates inclination.

Example 162

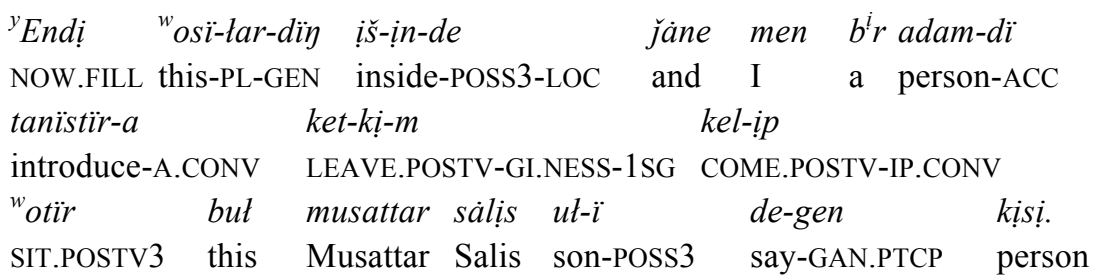

'Now, I would like to introduce to you one of them: Musattar Salis.' (T2/ 7)

See the following examples of expressions of inclination and disinclination based on $\left\{-\mathrm{G}^{4} \mathrm{I}^{2}\right\}+$ kel- 'to come' and kel-me- $\langle$ come-NEG $\rangle$ 'not to come'.

Example 163

Seni kör-gị-m kel-e-dị.

you.ACC see-GI.NESS-POSS1SG come-A.PRES-3

'I want to see you / I have got the urge to see you / I feel like seeing you / the desire to see you befallen me.'

Example 164

Seni kör-gị-m kel-me-y-dị.

you.ACC see-GI.NESS-POSS1SG come-NEG-A.PRES-3

'I don't have the desire to see you.'

See the following versions of Examples 163 and 164. In these versions, the past tense forms in $\left\{-D^{2} I^{2}\right\}$ are used.

Example 165

$\begin{array}{lll}\text { Seni } & \text { kör-gị-m } & \text { kel-dị. } \\ \text { you.ACC } & \text { see-GI.NESS-POSS1SG } & \text { come-PAST3 } \\ \text { 'I have got / got the desire to see you.' }\end{array}$ 
Example 166

Seni kör-gị-m kel-me-dị.

you.ACC see-GI.NESS-POSS1SG come-NEG-PAST3

'I have not got / did not get the desire to see you.'

The past tense forms, in Examples 166 and 167, describe an event that started in the past and is relevant to the present situation as well.

Uyghur employs the same construction to express inclination, i.e. $\left\{-G^{4} U^{2}\right\}$ + possessive personal markers $+k a ̈ l-$ 'to come, arrive, reach'. Examples 165 and 166 can be uttered in Uyghur as following.

Example 167 Uyghur

$\begin{array}{lll}\text { Sèni } & k \ddot{r} r-g \ddot{u}-m & k \dot{e} l-i-d u . \\ \text { you.ACC } & \text { see-GU.NESS-POSS1SG } & \text { come-PRES-3 }\end{array}$

'I want to see you.' (I am getting the desire to see you. ${ }^{24}$ )

Example 168 Uyghur

Sèni kör-gü-m käl-mä-y-du.

you.ACC see-GU.NESS-POSS1SG come-NEG-PRES-3

'I don't have the desire to see you.'

The suffix $\left\{-G^{4} U^{2}\right\}$ in Modern Uyghur is productive and functions as a participle, e.g. bar- $\gamma u$-däk yär 〈go-PTCP-EQUA place〉 'a place to go'. However, the form in $\left\{-\mathrm{G}^{4} \mathrm{I}^{2}\right\}$ in Kazakh is not productive and is restricted only to the periphrastic expressions discussed here.

\section{$\left\{-\mathrm{G}^{4} \mathrm{I}^{2}\right\}+$ possessive personal markers + bar}

Inclination can also be expressed with the periphrastic form $\left\{-\mathrm{G}^{4} \mathrm{I}^{2}\right\}$ in combination with a personal marker of the possessive type and the lexical item bar 'existing'. The construction can be interpreted in English as 'one has the desire to do something'. This expression is only mentioned in Zhang's grammar (2004: 425) as parallel to $\left\{-\mathrm{G}^{4} \mathrm{I}^{2}\right\}+$ possessive personal markers + kel-. Negation is expressed by substituting jok 'non-existing' for bar 'existing'. The construction is not mentioned in the other grammars, probably because this is not a genuine way of expressing inclination in Kazakh and its use is restricted to the spoken registers. We assume that this is a selective copy of the corresponding Uyghur expression which is frequently used. See the following Kazakh examples.

\footnotetext{
${ }^{24}$ The similar expression exists in Turkish with similar construction, e.g. Istanbul'u göresim geldi. (Lewis 1967: 165)
} 
Example 169

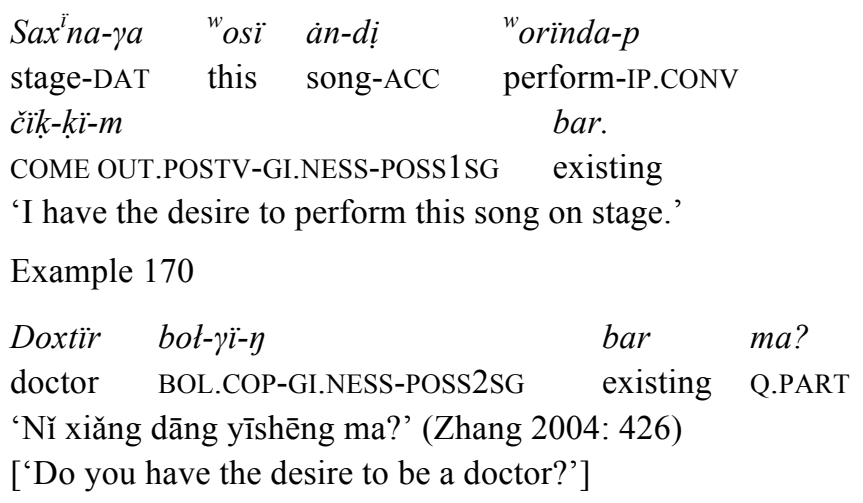

The corresponding Uyghur construction uses $\left\{-\mathrm{G}^{4} \mathrm{U}^{2}\right\}$ with a personal marker of the possessive type and bar 'existing'. The negated form is built with yok 'non-existing'. Example 170 can be translated into Uyghur in the following form.

Example 171 Uyghur

$\begin{array}{llll}\begin{array}{ll}\text { Doxtur } \\ \text { doctor }\end{array} \quad \text { BOL.COP-GU.NESS-POSS2SG } & \text { bar } & \text { mu? } \\ \text { 'Do you have the desire to be a doctor?' } & & \text { Q.PART }\end{array}$

$$
\left\{-\mathrm{sA}^{2}\right\}+i y g i+{ }^{y} e d i
$$

A wish can be expressed by the periphrastic expression based on a hypothetical form in $\left\{-\mathrm{sA}^{2}\right\}$ combined with $i y g i$ ' content' and the past tense form of the copula ${ }^{y} e d i$-. A personal ending of the possessive type is attached to the copula. This periphrastic expression is also labeled "optative mood" in some grammars (Geng 1989: 140, Geng et al. 1999: 238, MKL 2002: 470, Zhang 2004: 425, Mamanov 2007: 96). The form is not mentioned in KG 2002. MKL and Mamanov subcategorize the construction as tilekti kaław ray 'wishful optative mood'; i.e. the speaker wish for the state of affairs to happen or not to happen. Zhang subcategorizes the constructions as wăn shù yuànwàng shì 'indirectly stated optative mood'; i.e. the speaker states in a tactful or indirect way his/her hope to fulfill an action. The negative expression may be formed by adding a negation marker $\left\{-\mathrm{M}^{3} \mathrm{~A}^{2}\right\}$ to the verb stem.

Example 172

$\begin{array}{lll}\text { Bittir-se } \quad \text { iygi } & { }^{y} e-d i-m . \\ \text { finish-HYP3 } & \text { content } & \text { E.COP-PAST-1SG } \\ \text { 'I would be content if I finished it.' }\end{array}$


Example 173

Bịtịr-me-se iygi $\quad{ }^{y} e-d i-m$.

finish-NEG-HYP3 content E.COP-PAST-1SG

'I would be content if I did not finish it.'

Another slightly different construction is built with $\left\{-\mathrm{sA}^{2}\right\}$ with the possessive type of personal endings and iygi 'content' and 'edi. This is also described as "optative mood" in Zhang's grammar (2004: 426-427). KG (2002: 514) mentions this form but not the previous form.

Example 174

Bịtịr-se-m iygi $\quad{ }^{y} e-d i$.

finish-HYP-1SG good E.COP-PAST3

'It would be good if I could finish it.'

The difference between Examples 172 and 174 is that the endings representing the person of the subject are attached to the copula in the first one, and to the hypothetical verb form in the latter. Zhang states that logically, the subject marking should attach to the hypothetical form as in Example 174. The construction illustrated in Example 172, in which the past copula ${ }^{y}$ edi bears the subject marker, is secondary and is a result of the grammaticalization process (2004: 427). The construction represented by Example 172 is currently disappearing.

$\left\{-\mathrm{sA}^{2}\right\}+$ deymin

A wish can also be expressed by the frequently used periphrastic expression based on the hypothetical marker $\left\{-\mathrm{sA}^{2}\right\}$ combined with de-y-min 〈say-A.PRES-COP1SG〉 'I say'.

Example 175

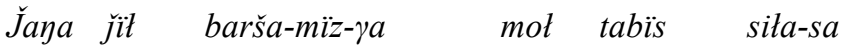

new year all-POSS1PL-DAT rich success present-HYP3

de-y-min.

say-A.PRES-COP1SG

'I wish that the new year will bring much success to all of us.'

The rhetorical particle ${ }^{y}$ eken can be added after the hypothetical form without any change of the meaning.

Example 176

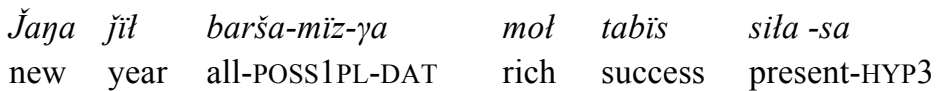


yeken de-y-min.

RHET.PART SAY-A.PRES-COP1SG

'I wish that the new year will bring much success to all of us.'

$\left\{-\mathrm{sA}^{2}\right\}$ kerek

Kerek 'necessary' occurs with hypothetical forms of the preceding non-main predicate and indicates the meaning 'it must be', i.e. expresses presumption. It expresses subjective epistemic evaluation of a particular fact on the basis of probability.

Example 177

Umït-ïp ket-ken bot-sa kerek.

forget-IP.CONV LEAVE.POSTV-GAN.PTCP BOL.COP-HYP3 necessary

'X must have forgotten.'

Example 178

\begin{tabular}{|c|c|c|c|c|}
\hline $\begin{array}{ll}\text { Jumïla } & i s \\
\text { unanimously a }\end{array}$ & $\begin{array}{l}i s-k e \\
\text { affair-DAT }\end{array}$ & $\begin{array}{l}\text { kirịs-se-k, } \\
\text { start-HYP-1PL }\end{array}$ & $\begin{array}{ll}\text { ǰirma } & { }^{w} \text { otïz } \\
\text { twenty } & \text { thirty }\end{array}$ & $\begin{array}{l}\text { jüt-da } \\
\text { year-LOC }\end{array}$ \\
\hline 'evropa-n̈̈y & bịl-gen & & bịl-ịp, & ropa \\
\hline Europe-GEN & know-c & AN.PTCP-POSS3-ACC & know-IP.CONV & Europe \\
\hline katar-ïn-a & kos & $t-\ddot{i p}$ & ket-e & \\
\hline row-POSS3-DAT & add & PASS-IP.CONV & LEAVE.POSTV-A.CON & \\
\hline$a t-u w-i ̈ m \ddot{z}-\gamma a$ & & tärix-tc & tan japon-dar & mïsat \\
\hline TAKE.POSTV-UV & JW.VN-POS & history & y-ABL Japan-PL & npl \\
\hline 1 & & & rek. & \\
\hline L.COP-A.CON & TAK & POSTV-HYP3 & cess & \\
\hline
\end{tabular}

'If we start to act unanimously, we could learn what the Europeans know; we could reach Europe's level in 20-30 years. Japan might be the example.' (J̌anbolatov 2008: 102) 


\section{Modal particles}

The modal particles described in this chapter express stance, i.e. some kind of cognitive or affective attitude towards the events described, and play an especially significant role in spoken communication. For a brief general presentation of Turkic stance particles see Johanson (2012). The functions of the Kazakh modal particles, i.e. whether they express volition, deontic evaluation or epistemic evaluation, vary according to specific usages in different communicative situations. It is often difficult to find adequate translational equivalents for them in other languages.

Free morphemes functioning as stance markers are either particles or adverbs. As defined here, particles are free elements that cannot be inflected by adding suffixes. Adverbs can be used alone as independent utterances, e.g. Arine! or Albette! 'Of course!'. Particles are dependent on a host and thus cannot be used as independent utterances.

The modal particles are typically enclitic; i.e. they constitute a prosodic unit with their hosts and are not accentable. There are also, however, accentable particles such as aw, ${ }^{i} y \dot{a}, \dot{a}, D^{2} A^{2}$, bịlem, deši and deseyši ticles such as $\Gamma^{2}$ oy and $\check{s} I^{2}$ belong to the enclitic type in some usages and to the accentable type in other usages.

We can distinguish among particles according to the syntactic positions in which they may occur. $D^{2} A^{2}, m I^{2} s$, de, dešị, and desenši can take only a postpredicate position. Of these, $D^{2} A^{2}$, de, deši by other elements, so they are not necessarily in sentence-final position. The particle $m I^{2} s$ is always in sentence-final position. Some others, e.g. $\dot{a},{ }^{i} y \dot{a}$, bilem, can occur both in sentence-final and sentence-initial positions. The particles $\Gamma^{2} o y, a w,{ }^{w} \ddot{o z} i$ can follow the first constituent of the clause and occur in postpredicate positions. Of those in postpredicate position, ${ }^{w} \ddot{o} z i$ cannot be followed by any other element and is thus sentence-final. One particle, $\check{s} I^{2}$, can be attached to any constituent. 
Table 3. The syntactic position of particles

\begin{tabular}{|c|c|c|c|c|c|}
\hline Particles & $\begin{array}{c}\text { S- } \\
\text { initial }\end{array}$ & $\begin{array}{c}\text { Following the first } \\
\text { constituent of the } \\
\text { clause }\end{array}$ & $\begin{array}{c}\text { Following any } \\
\text { constituent }\end{array}$ & Postpredicate & $\begin{array}{c}\text { S- } \\
\text { final }\end{array}$ \\
\hline$\dot{a}$ & + & & & & + \\
\hline$a w$ & & + & & + & \\
\hline bịlem & + & & & & + \\
\hline$D^{2} A^{2}$ & & & & + & \\
\hline$d e$ & & & & + & \\
\hline deseyšị & & & & + & \\
\hline deši & & & & + & \\
\hline$\Gamma^{2} o y$ & & + & & + & \\
\hline $\begin{array}{l}{ }^{i} y \dot{a} \\
m I^{2} s\end{array}$ & + & & & & $\begin{array}{l}+ \\
+\end{array}$ \\
\hline$\check{S} I^{2}$ & & + & + & + & \\
\hline${ }^{w} \ddot{o} z i$ & & + & & & + \\
\hline
\end{tabular}

In the following, the semantic, syntactic and prosodic properties of the modal particles will be presented. The description will start with $\Gamma^{2} o y$, the most frequently used modal particle.

\section{The particle $\Gamma^{2}$ oy}

\section{Variants}

The particle $\Gamma^{2}$ oy has two variants, yoy and koy. The form yoy is attached to stems that end in a vowel or a voiced consonant, e.g. ${ }^{w} O k i-y$-di yoy 〈study-A.PRES-3 TOY.PART〉 'X studies, you know'. The form koy follows

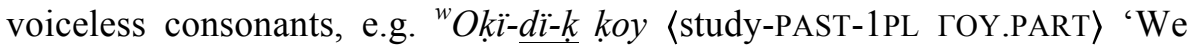
studied, you know', Kör-di-k koy 〈see-PAST-1PL ГOY.PART〉 'We saw it, you know'.

\section{Basic properties}

The particle $\Gamma^{2}$ oy does not have any lexical meaning. Its basic contribution is to mark some type of epistemic evaluation, an assessment of the propositional content. It can express a commitment to the truth of the proposition, i.e. to its certainty, probability, possibility, etc. The source of the epistemic evaluation can be the opinion of the addresser or some other person. The basic meaning varies according to the communicative functions of different types of usages, as will be described below. The particle is typically 
enclitic, i.e. unaccented. In such cases, the high pitch is on the last accentable syllable of the preceding word, as in Example 179.

Example 179

...kerịküšster yoy.

oppositional-PL TOY.PART

'...oppositionals, you know.' (T4/2)

In the following example, the high pitch is on the syllable preceding the negation.

Example 180

\begin{tabular}{|c|c|c|c|}
\hline$O y$ & àke-m & ay & \\
\hline $\begin{array}{l}\text { OY.INTERJEC } \\
u \gamma \text {-at-ma-di- }\end{array}$ & father-POSS1SG & $\begin{array}{l}\text { AY.INTERJEC } \\
\text { yoy.” }\end{array}$ & \\
\hline understand- $f$ & L-NEG-PAST-1SC & ГOY.PAR & \\
\hline
\end{tabular}

“'Oh my dear, oh, I have not been able to understand it".' (T5/ 9)

In some specific usages the particle is accentable; see below.

$\Gamma^{2}$ oy mostly occurs in postpredicate position. When used in adversative constructions, however, it is attached to the first word of a clause.

Particles with similar formal and semantic properties occur in other Turkic languages, for instance Karakalpak yoy (Baskakov 1958: 154) Uyghur $\Gamma^{2} u$ (Tömür 2003: 493, 2011²: 426), Kirghiz $\Gamma^{2} o$ (Hu 1986: 156), Uzbek $k \ddot{u}$ (Wurm 1959: 524). Karaim employs $k o$ in a similar function, e.g. Bil'ás' $k o$ 〈know-PRES-2SG KO.PART〉 'Well, you know'. ${ }^{25}$ The etymology of these Turkic particles is unknown. They are not likely to derive from the verb koy- 'to put, to place'; see Downtoning imperatives.

\section{Usages}

Reference to shared knowledge

$\Gamma^{2}$ oy may be used to refer to some knowledge shared by the addresser and the addressee(s). According to Zhang (2003: 228, 2004: 609), it may be used to remind the interlocutor that the addresser is referring to some shared knowledge. In this case, the particle can be translated into English as 'as you know'.

Example 181

\begin{tabular}{|c|c|c|c|}
\hline & & $\begin{array}{l}\text { körgensizz, } \\
\text { ill-mannere }\end{array}$ & nedegen \\
\hline
\end{tabular}

${ }^{25}$ Éva Á. Csató personal communication. 
de-p süyt-üp jat-a-dï joy.

say-IP.CONV do SO-IP.CONV LIE.POSTV-A.PRES-3 ГOY.PART

"What an ill-mannered, what a bad (child) this is"-(they) often say so, as you know.' (T6/ 16)

Example 182

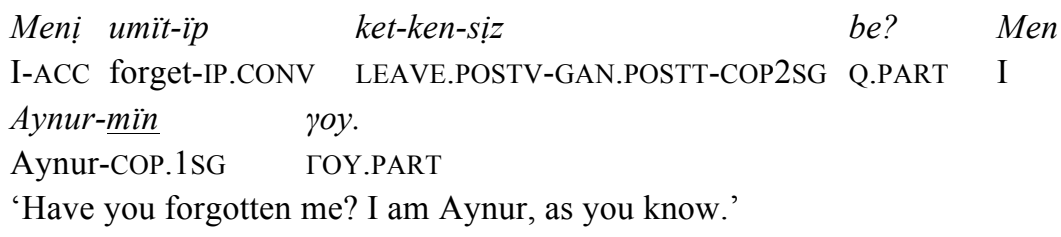

The particle $\Gamma^{2}$ oy is used similarly to the particle $y a$ in Turkish and certain southern dialects of Uyghur in Xinjiang.

Example 183 Turkish

Geçen yaz git-mişti-k ya.

last summer go-PLUPERF-1PL PART

'We went there last summer, as you know.'

Example 184 Uyghur

U ket- $t i \quad y a$.

$\mathrm{X}$ leave-PAST3 PART

'X has left, as you know.'

The particle $\Gamma^{2}$ oy sometimes occurs together with the filler ${ }^{y}$ endị; see Example 185. This combination is frequently used in Uyghur; see Example 186.

Example 185

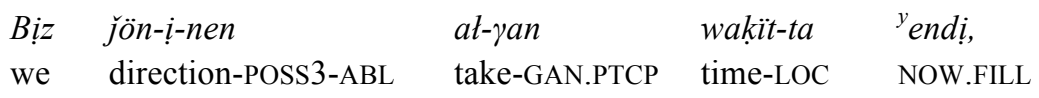

ádeptị tärtipti $\quad$ bot-uw-dï därịpte-y-miz

polite well-behaved BOL.COP-UW.VN-ACC advocate-A.PRES-COP1PL

yoy ${ }^{y}$ endị.

TOY.PART NOW.FILL

'As for us, (the bride) is expected to be polite and well behaved, you know.' (T8/ 1)

Example 186 Uyghur

Iš-lar tügi-di $\quad \underline{\text { an }} \quad \ddot{m}$ di.

work-PL finish-PAST3 PART NOW.FILL

'The work is done, as you know.'

The particle $\Gamma^{2}$ oy can be used to introduce a new topic with reference to shared knowledge. 
Example 187

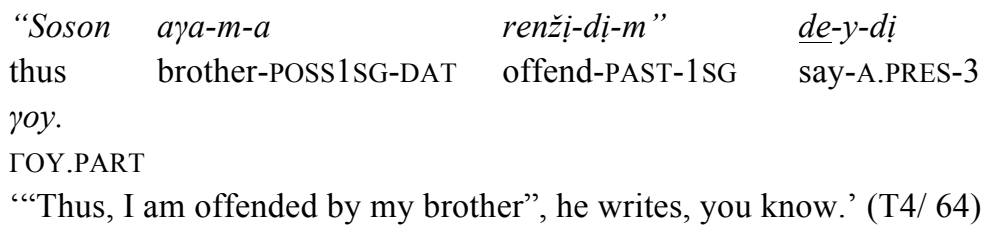

The Turkish particle $y a$ is also used in this way. In the following example, the addresser starts a conversation about a friend living in America whom the interlocutor also knows.

Example 188 Turkish

Amerika'da bir arkadaş-ım var ya.

America-LOC a friend-POSS1SG existing PART

'A friend of mine in America, you know.'

Repudiation

The particle can be used in a response to express repudiation; i.e. it may challenge the statement or presupposition of the interlocutor. Observe that the predicate is then accented in an emphatic way.

Example 189

$\begin{array}{lllll}\text { A: } \text { Sayan } & \text { "tapsïrma } & \text { iste" } & \text { de-p } & \text { ayt-pa-dï-m } \\ \text { you.DAT } & \text { homework } & \text { do } & \text { say-IP.CONV } & \text { say-NEG-PAST-1SG } \\ \text { ba? } & & & & \\ \text { Q.PART } & & & & \\ \text { 'Did } & & & \end{array}$

'Did I not tell you to do your homework?'
B: Iste-di-m $\quad$ ooy. ${ }^{26}$
do-PAST-1SG TOY.PART
'But I have done it.'

Presumption

Zhang (2003: 229, 2004: 610) points out that the particle can express that the addresser presumes the validity of the statement. In the next examples, the particle may be translated into English as 'I presume', 'it must be the case that'. In spoken Turkish, $\left\{-\mathrm{mI}^{4} \mathrm{sstI}^{4} \mathrm{r}\right\}$ can be used to express a similar meaning; see Example 191.

\footnotetext{
${ }^{26}$ The Turkish translation would be 'Yaptım ya', 'Yaptım ki', 'Yaptım ama', and 'Yaptım zaten'.
} 


\section{Example 190}

Context: The addresser sees a boy whose face is injured.

Mïna bala töbeles-ken yoy.

this child scuffle-GAN.POSTT3 TOY.PART

'I presume this child has scuffled.'

Example 191 Turkish

Bu çocuk kesinlikle kavga et-miştir.

this child definitely fight DO.LIGHTV-MIŠTIR.PAST.3SG

'I presume this child has definitely fought.'

In the following examples, the particle $\Gamma^{2}$ oy is used first to mark shared knowledge. The second occurrence of the particle marks presumption. In our recording, the addresser in this case pronounces the particle emphatically, i.e. with high pitch.

Example 192

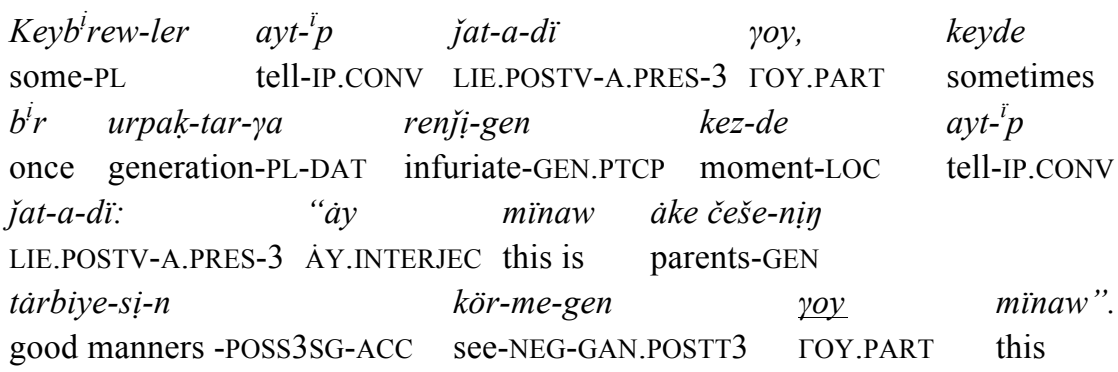

'As you know, some people often say, sometimes, when (they) get angry with the young ones, "Well, this (child) surely has not learned good manners from her/his parents".' (T6/ 15)

Non-modal usage: Tag-question

The particle $\Gamma^{2}$ oy can also be interpreted as a question in the sense of 'why?' or 'why not?' and be pronounced with rising interrogative intonation. In Example 193, the particle $\Gamma^{2}$ oy is accented in order to catch the interlocutor's attention.

Example 193

Keše üy-ge kel-me-di-n yoy?

yesterday home-DAT come-NEG-PAST-2SG ГOY.PART

'You did not come home yesterday, did you / why not?'

Zhang (2003: 228, 2004: 610) claims that in the interrogative usage, the particle is used to express that the addresser wishes to elicit an explanation from the interlocutor. The accent, as Example 194, can fall on the second syllable of the lexical word preceding the particle. 
Example 194

$\begin{array}{ll}\text { Kül-e-siz } & \text { yoy? } \\ \text { laugh-A.PRES-COP.2SG } & \text { ГOY.PART }\end{array}$

'Nǐ xiào shénme ya?' (Zhang 2003: 229, 2004: 610)

['Why are you laughing?']

Adversative usage

A specific usage of the particle $\Gamma^{2}$ oy can be observed in adversative sentences. In such constructions, the particle is always accented and follows the first, topicalized, constituent of the clause, e.g. kün 'sun' and ${ }^{w} o t$ ' $\mathrm{X}$ ' in the following examples.

Example 195

Kün yoy čïr-ïp tur, bírak kattï suwuk.

sun TOY.PART come out-IP.CONV STAND.POSTV3 but very cold.

'The sun is certainly shining but it is still rather cold.'

Example 196

${ }^{w} \mathrm{Ot}$ yoy ${ }^{w} \ddot{o z} \quad$ adam-ïmïz $\quad{ }^{y}$ endi, kiyanattik

$\mathrm{X}$ ГOY.PART self man-POSS1PL now betrayal

jasa-p ket-pe-se ${ }^{27}$.

CREATE.LIGHTV-IP.CONV LEAVE.POSTV-NEG-HYP3

' $\mathrm{X}$ is certainly our man but only if he does not betray us.'

According to Zhang (2003: 229-230, 2004: 611), the connection between the two parts of the clauses is such that in the first clause the particle $\Gamma^{2}$ oy emphasizes the addresser's belief that what is said is true, and the second clause expresses new information.

Example 197

Sịz yoy jeyill aptomobil-men jür-e-sị, $a t$

you TOY.PART light automobile-WITH.POSTP move-A.PRES-COP2SG but

bị $\quad$ šị?

we ŠI.PART

'Nín zìrán shì yǒu xiăochē zuò, kě wǒmen ne?' (Zhang 2003: 230, 2004: 611)

['You certainly take a car, but what about us?']

The combination of the hypothetical mood and $\Gamma^{2}$ oy

In spoken registers, the particle $\Gamma^{2}$ oy can often occur with the hypothetical $\operatorname{mood}\left\{-\mathrm{sA}^{2}\right\}$. In this case it can serve to mark that the condition is irreal, as in Example 198. In Example 199, it signals that the idea is a 'what-if', though worth thinking about. The particle is accented in both examples.

${ }^{27}$ The Turkish translation would be 'O bizim adamımı da hayınlı etmese'. 
Example 198

Akke-m bịz-dị saÿ̈n-sa yoy, jan-ïmïz-da

father-POSS1SG we-ACC miss-HYP3 ГOY.PART around-POSS1PL-LOC

bot-uw-di armanda-sa yoy.

BOL.COP-UW.VN-ACC hope-HYP3 ГOY.PART

'Had my father missed us, he would have wanted to be with us.' (But this is not the case.)

Example 199

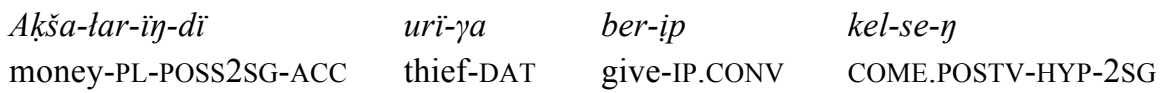

yoy.

TOY.PART

'What if you give your money to a thief.'

The combination of ${ }^{y}$ eken and $\Gamma^{2}$ oy

In combination with the indirective particle ${ }^{y}$ eken, $\Gamma^{2}$ oy gets a mirative meaning, expressing the addresser's surprise at new and unexpected information (cf. DeLancey 1997). Zhang (2003:228, 2004: 610) also claims that this combination signals surprise. The lexical element in the predicate is accented.

Example 200

Context: The addresser sees a boy whose face is injured.

Mïna bała töbeles-ken yoken yoy.

this child scuffle-GAN.PTCP E.COP.INDIR3 ГOY.PART

'This child has apparently scuffled, you know.'

Example 201

Context: The addresser understands that $\mathrm{X}$ has learnt about a secret.

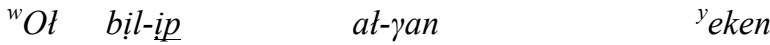

X know-IP.CONV TAKE.POSTV-GAN.PTCP E.COP.INDIR3

roy.

TOY.PART

'X has apparently figured it out, you know.'

The combination of expressions of possibility and $\Gamma^{2}$ oy

The unaccented particle $\Gamma^{2}$ oy may be added to expressions of possibility that consist of a hypothetical form of a lexical verb followed by bolad $\ddot{i}$ (BOL. COP-A.PRES-3〉 'is possible' (see Lexical expressions). In this case, it emphasizes the feasibility of a piece of advice. 
Example 202

\begin{tabular}{|c|c|c|}
\hline $\begin{array}{ll}\text { Tịpti } & \text { šama-sï } \\
\text { even } & \text { strength-POSs }\end{array}$ & $\begin{array}{l}\text { kel-me-ytin } \\
\text { come-NEG-ATIN.PTCP }\end{array}$ & $\begin{array}{l}\text { bot-sa, } \\
\text { BOL.COP-HYP3 }\end{array}$ \\
\hline 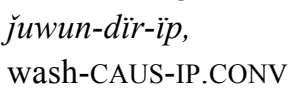 & $\begin{array}{ll}\text { kiyimm-i }-n & \check{j u w-u p,} \\
\text { clothes-POSS3-ACC } & \text { wash-IP.CONV }\end{array}$ & $\begin{array}{l}\text { bas- } \ddot{l} \\
\text { head-Poss } 3\end{array}$ \\
\hline$g \ddot{o} z-\ddot{u}-n$ & $\check{\jmath u w-u p, ~}$ & $k o y-s a$ \\
\hline OSS3-ACC & do it as this-IP.CONV & PUT.POSTV-HYP3 \\
\hline bot-a-dï & roy. & \\
\hline ART BOL.COP-A & ГOY.PART & \\
\hline
\end{tabular}

'When the (old) people are not able (to take care of themselves), then the bride should even be able to wash them, wash their clothes, and their hair and faces, shouldn't she?' (T8/ 6)

The combination of $\Gamma^{2}$ oy and deymin

The accented particle $\Gamma^{2} o y$ in combination with $d e-y$-min $\langle$ say-PRES-1SG〉 'I say' expresses the addresser's surmise or conjecture. According to Zhang (2003: 229, 2004: 611), it conveys the meaning that there is no evidence to confirm the statement.

Example 203

$\ddot{U} y$-ge urï kịr-gen yoy deymịn.

home-DAT thief enter-GAN.POSTT 3 TOY.PART DEYMIN.PART

'I think a thief has entered the house.'

Example 204

Bes-ịnši ay-łar-da yoy de-y-mịn taza kïzik

five-ORD month-PL-LOC ГOY.PART say-A.PRES-COP1SG very interesting bot-di.

BOL.COP-PAST3

'In May, I think, something very interesting happened.' (T9/ 1)

The combination of $\Gamma^{2}$ oy and deysin

The particle $\Gamma^{2}$ oy cannot be used in a question containing an interrogative pronoun, as in Example 205.

Example 205

$\begin{array}{lllll}* \ddot{U} y \text {-ge } & \text { kim } & \text { kị-ip } & \text { ket-e-di } & \text { yoy? } \\ \text { home-DAT } & \text { who } & \text { enter-IP.CONV } & \text { LEAVE.POSTV-A.PRES-3 } & \text { ГOY.PART }\end{array}$

On the other hand, a combination of $\Gamma^{2}$ oy with deysin 'you would say' can be added to such questions in order to mark that the question is not meaningful and therefore cannot be answered. Thus Example 205 should be expressed as Example 206 illustrates. 
Example 206

Context: The interlocutor locks the door of the house. The addresser wants to express that nobody would enter the house anyway so it does not make sense to lock the door.

Üyge kim kị-ip ket-e-dil

home-DAT who enter-IP.CONV LEAVE.POSTV-A.PRES-3

yoy deysin?

TOY.PART Say-A.PRES-COP2SG

'Who will enter the house, you think?'

The complex particles bar yoy / bar yoy de / bar yoy ši

The complex particles bar yoy, bar yoy de and bar yoy šï, in which yoy is accented, can follow any constituent of a sentence. In the following examples, bar yoy follows a topicalized constituent. Zhang (2003: 196, 2004: 583) claims that it is used only in spoken registers and has the function to draw the interlocutor's attention to the constituent marked by the particle. The rest of the sentence is a statement about this constituent.

Example 207

Universitet-ter bar yoy katïy kar sebeb-ị-nen university-PL existing ГOY.PART thick snow reason-POSS3-ABL dematïs-ka tara-t-ït-ïp-tï.

rest-DAT disperse-CAUSE-PASS-IP. POST-3

'The universities, you know, apparently had a day off because of the heavy snow.'

In Example 208, there are two topicalized constituents, universitetter and katï kar sebebinen, marked by bar yoy.

Example 208

Universitet-ter bar yoy katïy kar sebeb-ị-nen university-PL existing ГOY.PART thick snow reason-POSS3-ABL

bar yoy dematïs-ka tara-t-ït-ïp-tï.

existing ГOY.PART rest-DAT disperse-CAUSE-PASS-IP.POSTT-3

'Because of the heavy snow the universities apparently had a day off, you know.'

In Turkish, the corresponding complex particle consisting of a combination of var 'existing' and the particle ya can be used. See the Kazakh Example 209 and its Turkish translation in Example 210. 
Example 209

Ankara-da bar yoy katïy kar jaw-ïp-tï.

Ankara-LOC existing ГOY.PART thick snow fall-IP.POSTT-3

'In Ankara, you know, it apparently snowed heavily.'

Example 210 Turkish

Ankara-da var ya yoğun kar yağış-

Ankara-LOC existing YA.PART heavy snow fall-POSs3

ol-muş.

ol.COP-MIŠ.INDIR3

'In Ankara, you know, there was apparently heavy snow.'

The complex particle bar yoy gets the special interpretation of a threat when occurring in postpredicate position.

Example 211

\begin{tabular}{|c|c|c|c|c|c|}
\hline $\begin{array}{l}S \ddot{z} z-d i \underline{ } \\
\text { word-ACC }\end{array}$ & $\begin{array}{l}t \ddot{y} d a-m a-s a-\eta \\
\text { listen-NEG-HYP-2SG }\end{array}$ & $\begin{array}{l}\text { sayan } \\
\text { you.DAT }\end{array}$ & $\begin{array}{l}\text { kämpit } \\
\text { candy }\end{array}$ & \multicolumn{2}{|c|}{$\begin{array}{l}\text { at-ïp } \\
\text { buy-IP.CONV }\end{array}$} \\
\hline ber-me-y & \multicolumn{3}{|c|}{ koy-a-mün } & bar & yoy. \\
\hline GIVE.POST & EG-A.CONV & \multicolumn{2}{|c|}{ PUT.POSTV-A.PRES-COP1SG } & existing & ГOY.PART \\
\hline
\end{tabular}

Observe also that the corresponding Turkish expression var ya cannot occur in postpredicate position.

In the Kazakh examples the particles de or $\check{s} i$ can be added to the complex particle bar yoy without changing the meaning of the sentences.

\section{The particle $\check{s} I^{2}$}

Basic properties

The enclitic modal particle $\check{s} I^{2}$ has two harmonic variants, a front $\check{s} \grave{i}$ and a back šĭ, e.g. Kel šị! 〈come.IMP ŠI.PART〉 'Come, please', Ayt šĭ! 〈tell.IMP ŠI.PART ' Tell (it), please!'. In certain spoken varieties, the particle has four variants: $\check{c} \grave{i}, \check{c} \ddot{i}, \check{s} \underline{i}$ and $\check{s} \ddot{i}$. The variants $\check{c} \grave{i}$ and $\check{c} \ddot{l}$ occur after consonants, e.g. Kel $\check{c} i !$, Ayt $\check{c} i !$. The variants $\check{s} \grave{i}$ and $\check{s} i$ are employed after vowels, e.g. Ket-pe ši! 〈leave-NEG-IMP ŠI.PART〉 'Do not leave, please'. In most usages it is nonaccentable, and constitutes a prosodic unit with its host. For exceptions see below.

Particles with similar forms and functions also occur in some other Turkic languages, e.g. East Old Turkic $\breve{c} U$, Uyghur $\check{c} u$ (accented) (Tömür 2003: 488,

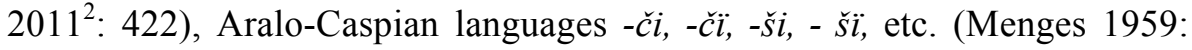
472-473), Kirghiz $\check{c} U$ (Hu 1986: 155), Noghay, Karakalpak šI (Doerfer 1959: 387, Baskakov 1958: 745), Tatar -čI (-чы, -че) (Thomsen 1959: 419: 
"-čci, $-\check{c} c$ "). The forms may go back to an interrogative particle * $\check{c} u$ (Doerfer 1959: 387).

The modal particle $\breve{s} I^{2}$ does not have any lexical meaning. Its basic semantic contribution is to express a notion of volition. Itcan only occur in postpredicate position except in its emphatic usage.

\section{Usages}

Combinations of $\breve{s} I^{2}$ with voluntatives and imperatives

The particle $\breve{s} I^{2}$ can follow voluntatives or imperatives. It is described as a particle that marks "renforcement de l'impératif" ['reinforcement of the imperative'] Deny et al. 1959: 807), an emphatic command (Doerfer 1959: 387), a polite imperative (Thomsen 1959: 419), etc. Zhang (2003: 194, 2004: 581) claims that the combinations in question have the meaning of qiqiú shi qi shi yŭqi 'request in an entreating manner'. In our view, in combination with these moods the particle is also used to ask for consent or to emphasize a wish. In this function, it is not accented.

\section{Combinations of $\breve{s} I^{2}$ with voluntatives}

In Example 212, the predicate verb carries a voluntative marker of the first person singular and is followed by the particle $\breve{s} I^{2}$. The function can be interpreted either as softening the tone, signaling that the addresser appeals to, begs, entreats, or requests something from the interlocutor, or as reinforcing the wish of the addresser. In this case, it can be translated with please, which can also indicate both politeness and reinforcement of a request. Example 212 and 213 are ambiguous between these readings.

Example 212

$\begin{array}{ll}\text { Bar-ayïn } & \check{s i} ! \\ \text { go-VOL1SG } & \text { SI.PART }\end{array}$

'Please let me go!'

Example 213

Dała-da jel azïna-p ket-ti, ${ }^{y}$ esik, outside-LOC wind howl IP.CONV LEAVE.POSTV-PAST3 door

tereze-ler-dị bekịt-ịp at-ayïn sï!

window-PL-ACC close-IP.CONV TAKE.POSTV-VOL1SG ŠI.PART

'The wind has started to howl around outside, please let me close the door and windows!'

Combinations of $\breve{s} I^{2}$ with imperatives

When combined with imperative forms the particle $\check{s} I^{2}$ functions either to soften or intensify the imperative. The latter meaning is marked by an emphatic stress on the verb. See also above in Downtoning imperatives. 
Example 214

Koy $\check{s} i$ !

stop ŠI.PART

'Stop it please!' or 'Do stop it!!!'

The combination of the particle $\check{c} U \sim \check{s} U$ with imperatives is documented in Karakhanid, where it is used in direct address, e.g. Käl-čü! Käl-š̈̈ 'Do come!', Bar-ma-ču! 'Don't go!', Bar-yïl šu! 'Go!' It is also found in several modern languages, e.g. Tatar Bir-čị (бир-че) 'Please give'.

Comparison with Uyghur $\check{c} u$

Though the functions of the Uyghur particle $\check{c} u$ are in most cases very similar to the those of Kazakh $\breve{s} I^{2}$, there are also some differences. Some differences, based on Tömür's description of the Uyghur particle (2003: 488-491, $2011^{2}$ : 422-425), will be mentioned here. According to Tömür, when attached to voluntatives and imperatives, the Uyghur particle expresses intimacy or fondness.

Example 215 Uyghur

Bikar oltur-yučä öy-gä xät yaz-ayli ču. in vain sit-CONV home-DAT letter write-VOL1PL PART

'Why don't we write a letter home instead of sitting doing nothing.' (Tömür 2003: 491, 2011 2 : 424)

Example 216 can be rendered in Kazakh with the voluntative and $\breve{s} I^{2}$, but the function of the Kazakh particle is to denote that the addresser entreats the interlocutor.

Example 216

Beker ${ }^{w}$ otïr-yanša üy-ge sat jaz-ayïk šĭ. in vain sit-GANŠA.CONV home-DAT letter write-VOL1PL ŠI.PART

'Instead of sitting (here) in vain, let us please write a letter home!'

Tömür points out that after voluntatives and imperatives, $\check{c} u$ may be used as an intensifier.

Example 217 Uyghur

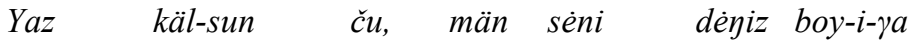

summer come-VOL3 PART I you.ACC sea length-POSS3-DAT

apir-i-män.

take-PRES-COP1SG

'Let summer come, then I will take you to the seaside.' (Tömür 2003: 491, 2011'2 425) 
The same meaning in Kazakh must be expressed as in Example 218, where atdïmen 'at first' is added to $\check{s} I^{2}$.

Example 218

\begin{tabular}{|c|c|c|c|c|c|}
\hline $\begin{array}{l}\breve{J a z} \\
\text { summer }\end{array}$ & $\begin{array}{l}\text { kel-sinn } \\
\text { come-VOL3 }\end{array}$ & $\begin{array}{l}\check{s} \underline{i} \\
\text { ŠI.PART }\end{array}$ & $\begin{array}{l}\text { atdïmen, } \\
\text { at first }\end{array}$ & $\begin{array}{l}\text { men } \\
\text { I }\end{array}$ & $\begin{array}{l}\text { seni } \\
\text { you.ACC }\end{array}$ \\
\hline & & ar-a-mïn. & & & \\
\hline
\end{tabular}

'Please (first) wait until the summer comes, (then) I will take you to the seaside.'

Combinations of imperatives and third-person voluntatives with $\breve{s} I^{2}$ often occur with lexical items such as käne 'where' / bàle- $m$ 〈misfortune-POSS1SG〉 'my misfortune', in which all elements are unaccented. The combinations indicate serious warnings. In Example 219, the postverb construction $t^{i} y s$-ip kör-〈тиіс-〉 expresses the meaning 'to try to provoke'.

Example 219

Kork-pa, zay bar, $\quad{ }^{y}$ endi sayan tiys-ip afraid-NEG law existing now you.DAT provoke-IP.CONV kör-sin ši kine / bälem.

SEE.POSTV-VOL3 ŠI.PART where / my misfortune

'Do not be afraid, there is the law, now just let $\mathrm{X}$ try to provoke you.'

In corresponding Uyghur expressions, kèni 'where' is used; see Example 220.

Example 220 Uyghur

Kork-may, ḳanun bar, ämdi siz-gä čèkil-ip afraid-NEG law existing now you-DAT provoke-IP.CONV bak-sun ču (kèni).

SEE.POSTV-VOL3 PART (where)

'Do not be afraid, there is the law; now just let $\mathrm{X}$ try to provoke you.' (Tömür 2003: 491, 20112: 425)

The use of the particle $\check{s} I^{2}$ with hypothetical forms

Combinations of unaccented $\check{s} I^{2}$ with hypothetical forms express unrealized past event, similar to Turkish expressions with keşke, keşki 'I wish' or Uyghur kaški 'if only'. Zhang (2003: 194, 2004: 581) points out that the function is to emphasize (reinforce) the desire, wish or hope expressed in the sentence. There is mostly a connotation of regret or repentance. 
Example 221

Bar-sa-m $\quad \check{s} i$.

go-HYP-1SG ŠI.PART

'I wish I had gone (but I did not)!'

Example 222

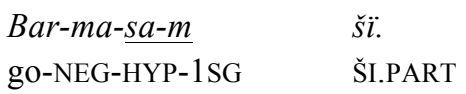

'I wish I had not gone (but I went)! / I regret that I went.'

When $\breve{s} I^{2}$ combines with a second-person hypothetical form it may express a strong recommendation. It can also convey a connotation of reproach, i.e. express disapproval or disappointment. The following example can be uttered when the addresser knows that the interlocutor has not been careful when crossing the street.

Example 223

\begin{tabular}{|c|c|c|c|}
\hline J̌ot-dan & ${ }^{w} \ddot{o t}$-kende & bayka-sa-y-dar & ši. \\
\hline
\end{tabular}

Like the Kazakh combination, the Uyghur one expresses entreaty and regret (Tömür 2003: 314-316, 20112: 281-282). Corresponding combinations in other languages may also express regret, e.g. Tatar Ukï-sa-m-čl 'If I only had studied' (Thomsen 1959: 419). Also in the Aralo-Caspian languages, hypothetical (or conditional) forms can function as optatives or polite circumlocutions of imperatives when $\check{s} i$ is attached (Menges 1959: 473). A Karakalpak example is given by Baskakov: Мен барсам-шы!! 'Аx, если бы я пошёл! ['I wish I went!'] (1958: 745).

The interrogative usage

The particle $\check{s} I^{2}$ may be used in the sense of 'what about?' when asking for information or opinions. When it follows a hypothetical form it means 'what if?' It is always unaccented, with the preceding word carrying the accent. A non-harmonic form $\check{s}$ e is used in Standard Kazakh (KG 2002: 562). According to Zhang (2003: 194, 2004: 581), the particle can occur after a nominal phrase or after the hypothetical marker to refer to a particular concern the addresser wants to ask about.

Example 224

\begin{tabular}{|c|c|c|c|}
\hline A: Bała-tar- $\ddot{\imath}$ & češe-sịn-e & kara-ma-y-di & ${ }^{y}$ eken. \\
\hline
\end{tabular}


B: Kïz-ï $\quad \check{s i} ?$

daughter-POSS3 ŠI.PART

'Her daughter, what about her?'

Example 225

A: ${ }^{y}$ Ertey $\quad \ddot{y}$-ge kel-ip kat-ar.

tomorrow home-DAT come-IP.CONV STAY.POSTV-AOR3

'X may come home tomorrow.'

B: Kel-me-se $\quad \check{s} \underline{i}$ ?

come-NEG-HYP3 ŠI.PART

'And what if $\mathrm{X}$ will not come?'

Uyghur $\check{c} u$ may also be used as an interrogative particle, as Example 226 illustrates.

Example 226 Uyghur

A: Tursun käl-di.

Tursun come-PAST3

'Tursun has arrived.'

B: ̈̈xmät ču?

Ahmet PART

'How about Ahmet?' (Tömür 2003: 488, 2011²: 422)

Uyghur $\check{c} u$ can follow a hypothetical clause as in Example 227.

Example 227 Uyghur

$\ddot{A} t \ddot{a} \quad k \dot{e} l-\ddot{a} l-m i-s \ddot{a}-m \quad \underline{c u}$ ? (Kandak bol-i-du?)

tomorrow come-ABIL-NEG-HYP-1SG PART (how BOL.COP-PRES-3)

'And if I can't come tomorrow?' (= What happens?) (Tömür 2003: 488, 2011²: 422).

Hu compares the use of the Kirghiz particle $\check{c} U^{4}$ to that of the Chinese question particle ne 'what about?', which occurs at the end of interrogative sentences (Hu 1986: 155-156).

Example 228 Kirghiz

Men bar-a-män, siz či?

I go-PRES-COP1SG you PART

'Wǒ yào qù, nín ne?' (Hu 1986: 155-156)

['I will go, and what about you?'] 
Karakalpak $\check{s} I^{2}$ is used in a similar way.

Example 229 Karakalpak

Sen-ši?

you-PART

'And you?' (Baskakov 1958: 745).

As Baskakov observes, the particle is used similarly to the Kazakh particle in other functions as well. For instance, with imperatives Aл-ubl! at-ši! 'Возьми-ка!' ['Take (it), please!'] (Baskakov 1958: 745).

Rhetorical questions

The negated converbs in $\left\{-\mathrm{M}^{3} \mathrm{~A}^{2}-\mathrm{y}\right\}$ and $\left\{-\mathrm{M}^{3} \mathrm{~A}^{2}-\mathrm{G}^{4} \mathrm{~A}^{2} \mathrm{n}-\mathrm{dA} \mathrm{A}^{2}\right\}$ can be used in rhetorical questions corresponding to English 'of course' or 'why not?' Zhang (2003: 195, 2004: 582) renders the meaning as 'of course, no need to ask'. The particle is unaccented in this usage.

Example 230

A: Čakïr-ma-sa da bar-a-mïz ba sonda? call-NEG-HYP3 DA.PART go-A.PRES-COP1PL Q.PART then 'Shall we go then, even if $\mathrm{X}$ has not invited (us)?'

B: Bar-ma-y / bar-ma-yanda

go-NEG-A.CONV/ go-NEG-GAN.LOC.CONV ŠI.PART

'Of course, why shouldn't we?'

Example 231

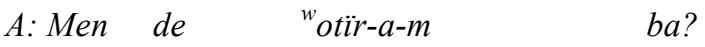

I DA.PART sit-A.PRES-COP1SG Q.PART

'Shall I also sit down?'

B: ${ }^{w}$ Oẗ̈r- $\underline{m a-y} /{ }^{w}$ oẗ̈r-ma- $\underline{\text { anda }} \quad \check{\text { sï? }}$

sit-NEG-A.CONV / sit-NEG-GAN.LOC.CONV ŠI.PART

'Of course, why shouldn't you?'

Uyghur employs a similar construction to express this meaning.

Example 232 Uyghur

A: Sän mu bar-a-m-sän?

you PART go-PRES-Q-COP2SG

'Are you going too?' 
B: Bar-ma-y $\quad \underline{c u}$ ?

go-NEG-A.CONV PART

'Of course, why shouldn’t I be going?' (Tömür 2003: 488, 2011²: 422)

The emphatic marker $\check{s} I^{2}$

In its emphatic usage, the particle $\breve{s} I^{2}$ can follow any constituent of a sentence that the addresser wants to mark as the focus. Zhang (2003: 195, 2004: 582) states that such usages occur mostly in spoken registers. The particle is harmonic and always accented in this usage.

Example 233 can be uttered in answer to the question "Who goes home?" Thus, sen 'you', the constituent answering the question, is the focus constituent.

Example 233

Sen $\underline{s i}, \quad$ üy-üy-e kayt.

you ŠI.PART home-POSS2SG-DAT return.IMP

'You go home!'

As Example 234 illustrates, more than one constituent can be marked with $\check{S} I^{2}$. The meaning of the particle can be rendered as 'just' or 'of all', denoting the least likely or expected person (cf. German ausgerechnet).

Example 234

Aset $\underline{s} \underline{i} \quad{ }^{w} \ddot{o z} \quad$ bała-sï-n $\underline{s i} \quad \ddot{u} y$-den

Aset ŠI.PART self child-POSS3SG-ACC ŠI.PART home-ABL

$k u w$-up-ti.

send away-IP.POSTT-3

'Aset (of all persons) drove his own son (of all persons) out of the house.'

Zhang (2003: 195, 2004: 582) also claims that the function of the particle is to draw the attention of the interlocutor to a certain constituent of the sentence. We describe this as emphasis. The Uyghur particle $\check{c} u$ has a similar usage. According to Tömür (2003: 489, 2011 2 : 422), it is added to emphasize a constituent. In his example, given here as Example 235, the emphasized constituent is the topic.

Example 235 Uyghur

Män $\check{c} u \quad b u \quad$ yékin-da u yär-gä bar-al-ma-y-män.

I PART this near-LOC that place-DAT go-ABIL-NEG-PRES-COP1SG

'As for me, I won't be able to go there in the near future.' (Tömür 2003: 489, $2011^{2}$ :

423)

The combinations bar šĭ and roy šĭ may follow any constituent of a sentence that the addresser wants to stress (cf. the usage of $\Gamma^{2} o y$ ). 
Example 236 illustrates a special Uyghur usage that has no equivalent in Kazakh. The particle $\check{c} u$, which is always accented, marks, together with texxi 'even', a further element that has the property expressed by the predicate of the first sentence.

Example 236 Uyghur

Bu yär bäk molčilik ikän, hawa-si ču téxi.

this place very rich I.COP.INDIR3 climate-POSS3SG PART even

'This land is very rich, and the climate (is good too)' (Tömür 2003: 490, 2011'2: 423).

\section{The particle $a w$}

Basic properties

The non-harmonic and accented particle $a w$ is a frequently used epistemic particle that mostly occurs in postpredicate position. It takes the entire proposition within its scope and expresses the addresser's evaluation of its truth, including assumption, incredulity, surprise, etc. It is not compatible with expressions of volition such as those expressed by imperative, voluntative, and optative mood markers. According to Zhang (2003: 209, 2004: 593), it is probable that the particle has developed from the interjection aw that is used in affirmative responses to a call. Example 237 illustrates the use of $a w$ as an interjection.

Example 237

Context: A calls to B. B confirms that $\mathrm{B}$ has heard the call.

A: Asen! Asen!

'Asen! Asen!'

$B: A w !$

'Yes!'

Observe that the call may only include the name of the person. No additional word such as 'Come here!' can occur in the utterance to which the answer is aw.

The interjection $a w$ can also be pronounced with an interrogative intonation to open for an explanation.

Example 238

A: Asen!

'Asen!'

$B: A w$ ?

'Yes! (What do you want?)' 
This interjection, with an interrogative intonation, can also be used when the addressee did not clearly hear what the addresser just said (Zhang 2004: 463).

Example 239

\begin{tabular}{|c|c|c|}
\hline $\begin{aligned} \text { A: } & \text { Pálte-m-di } \\
& \text { coat-POSS } 1 \mathrm{SG}-\mathrm{ACC}\end{aligned}$ & $\begin{array}{l}\text { àkel-e } \\
\text { bring-A.CONV }\end{array}$ & $\begin{array}{l}\text { sat } \\
\text { PUT.POSTV.IMP }\end{array}$ \\
\hline
\end{tabular}

$B: A w$ ?

'I beg your pardon.'

\section{Usages}

Emphasizing the truth of a statement

The particle can be used to confirm that the addresser regards a statement to be true. Example 240 expresses that the addresser is convinced of the truth of the statement, i.e. that what X said is appropriate. In Example 241, the particle is used to emphasize that the addresser agrees with a statement which is generally held true.

Example 240

Ayt-kan-dar-ï-n̈̈y

bärị jön $\quad \underline{a w}$.

tell-GAN.PTCP-PL-POSS3-GEN all appropriate AW.PART

'Everything X said is indeed appropriate.'

Example 241

Šołak-sïy aw $\quad{ }^{w} \ddot{o m i n}$.

short-COP2SG AW.PART life

'Life, you are indeed short.'

The confirmation marked by the particle in Example 242 can, depending on the context, be interpreted to the effect that the addresser regrets or is disappointed that the statement is true.

Example 242

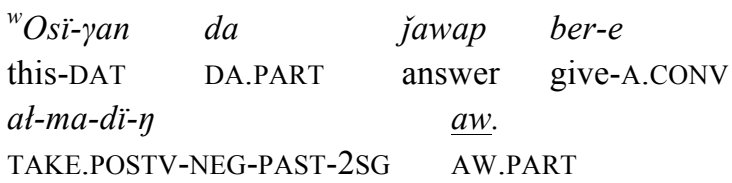

'It is indeed so that you could not even answer this question.'

Combination of $a w$ with the indirective particle ${ }^{y}$ eken

The particle aw may occur after the indirective particle ${ }^{y}$ eken in which case it expresses the addresser's surprise at the truth of the statement. 
Example 243

Jatyan-da ${ }^{w}$ osïn-day $\quad d a \quad$ teysịzdịk bot-a-di

false world-LOC this-EQUA DA.PART inequity BOL.COP-A.PRES-3

yeken aw.

E.COP.INDIR3 AW.PART

'There is apparently so much inequity in this false world, really!'

Example 244

${ }^{w}$ Osïn-day da sut wlik bot-a-dï ${ }^{y}$ eken

this-EQUA DA.PART beauty BOL.COP-A.PRES-3 E.COP.INDIR3

aw täbijat-ta.

AW.PART nature-LOC

'There is apparently so much beauty in nature, really.'

Combination of $a w$ with hypothetical forms

The particle may also be used to emphasize a wish expressed with the hypothetical mood form $\left\{-\mathrm{sA}^{2}\right\}$, as in Example 245.

Example 245

$\begin{array}{llll}{ }^{w} \mathrm{O} \quad & \text { kel-ip } & k a t-s a & a w ! \\ \mathrm{X} & \text { come-IP.CONV } & \text { STAY.POSTV-HYP3 } & \text { AW.PART } \\ \text { 'I indeed wish that X would come!' } & \end{array}$

Presumption

The particle can be used to mark that the addresser is, on the basis of probability, convinced of the correctness of a presumption (Zhang 2003: 210, 2004: 594).

Example 246

Context: The addresser observes that it has become warmer and draws the conclusion that spring is coming.

$\begin{array}{llll}\text { Köktem } & k e l-i p & k a t-\ddot{i p}-t i ̈ & \underline{a w} . \\ \text { spring } & \text { come-IP.CONV } & \text { STAY.POSTV-IP.POSTT-3 } & \text { AW.PART }\end{array}$

'Spring is definitely coming!'

Example 247

Context: The addresser gets the news that $\mathrm{X}$ missed the bus and draws the conclusion that $\mathrm{X}$ will be late.
Kešịg-ịp
kat-atïn
bot-di
aw.
be late-IP.CONV STAY.POSTV-ATIN.PTCP BOL.COP-PAST3 AW.PART

'X will definitely be late!' 


\section{Emphatic usage}

The particle $a w$ can be used when addressing a person in an emphatic way. It may introduce a discourse in which the addresser expresses emotions such as anger, sympathy, condemnation, love and fear. Zhang (2003: 210, 2004: 594) claims that in such expressions the particle particularly shows that the addresser is critical; see Example 248. As Example 249 illustrates, this is not always the case however. The particle can also express intimacy and friendliness with the interlocutor.

Example 248

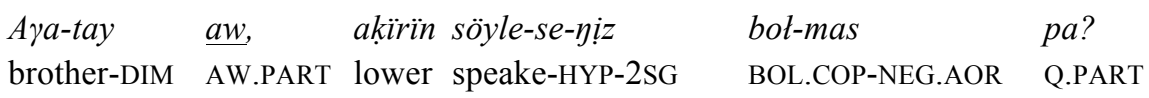

Minaw jiÿ̈n zat-ï roy.

this meeting hall-POSS3 ГOY.PART

'Hi, brother, couldn't you lower your voice? This is a meeting hall, you know.'

Example 249

$\begin{array}{llll}\text { Katka-m } & \text { aw, } & \text { turay-ïy } & \text { kayda? } \\ \text { dear-POSS1SG } & \text { AW.PART } & \text { house-POSS2SG } & \text { where }\end{array}$

'Hi, my dear, where is your house?'

Combination of $a w$ with deymin

According to Zhang (2003: 210, 2004: 594), the construction aw deymin can intensify an assumption of the addresser. It can be rendered as 'I would say', 'I would guess'.

Example 250

$\begin{array}{llll}\begin{array}{l}\text { Konak-tar } \\ \text { guest-PL }\end{array} & \text { jakïnda- } p & \text { kat-dï } & \underline{a w} \\ \begin{array}{l}\text { come } y \text {-minn. } \\ \text { coar-IP.CONV }\end{array} & \text { STAY.POSTV-PAST3 } & \text { AW.PART } \\ & & & \end{array}$

SAY-PRES-COP1SG

'I guess the guests have approached the house.'

Combination of $a w$ with ${ }^{i} y \dot{a} / \dot{a}$

The particle $a w$ is compatible with the particles ${ }^{i} y \dot{a}$ and $\dot{a}$ when used as a question tag. The combinations indicate that the addresser confirms a presumption $\mathrm{s} /$ he has made. It is not a request for confirmation from the interlocutor.

Example 251

Konak-tar jakïnda-p kat-dï aw $\quad$ iya $/ \dot{a}$ ?

guest-PL come near-IP.CONV STAY.POSTV-PAST3 AW.PART YẢ.PART/ Ȧ.PART

'The guests have indeed approached the house, haven't they?' 
Combination of $a w$ with modal adverbs

The particle $a w$ is compatible with modal adverbs expressing probability; see Example 255.

Example 252

\begin{tabular}{|c|c|c|c|c|}
\hline ak-tar & jakïnda-p & kat-dï & $\underline{a w}$ & sịrá. \\
\hline
\end{tabular}

The particle ${ }^{w} \ddot{o} z i$

Basic properties

The particle ${ }^{w} \ddot{o} z i\langle$ self-POSS3〉 has the same form as the reflexive pronoun of the third person 'himself / herself / itself' but it is grammaticalized as having another meaning. Zhang mentions that the reflexive pronoun of the first and second persons, 'özịm 'myself' and 'özị 'yourself', can also be used in this grammaticalized function (2004: 597). However this is not attested in our data. Uyghur does not have any similar particle based on the reflexive pronoun; see more below.

König (2001) points out that in many languages reflexive pronouns may function as intensifiers conveying different readings. We here provide some examples of the different usages of the particle in Kazakh.

When used as topicalizer, ${ }^{w} \ddot{o} z \underline{i}$ is not a modal particle. In such usages it follows a host constituent and is always accented.

The modal meaning conveyed by ${ }^{w} \ddot{o z} i$ in certain usages is to show the speaker's positive or negative attitude towards the statement. This is a type of deontic modal meaning. The evaluation is based on the speaker's judgment of whether the event is acceptable, allowable, permissible, unacceptable, forbidden, etc. In this usage, the particle is either in sentence initial or postpredicate position. In sentence initial position it is accentable but in postpredicate position it is not.

Usages

Non-modal usage: Topicalizer

The particle ${ }^{w} \ddot{o} z i$ can mark a topic constituent. In the following two examples the particle does not have any further interpretation.

Example 253

Son-da ${ }^{w} o$ kez-de besịk ${ }^{w} \ddot{z} \underline{z} \underline{i}$ kur tur-a-dï.

that-LOC X time-LOC cradle ÖZI.PART empty stand-A.PRES-3

'At that time, the cradle stands empty.' (T1/ 17) 
Example 254

Könsert ${ }^{w} \ddot{z} \underline{\underline{i}} \quad$ tartïmdi basta-t-dï $\ddot{\text { joy. }}$.

concert ÖZI.PART pleasant start-PASS-PAST3 ГOY.PART

'The concert started pleasantly indeed.'

The particle is often used as a topic marker in presentational copula sentences. In this usage it can be replaced by botsa. In Turkish, the hypothetical form of the copula ise is used as topicalizer.

Example 255

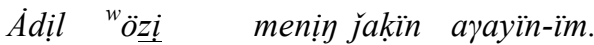

Ȧdil ÖZI.PART I.GEN close brother-POSS1SG

'Adil, he is my close friend.'

Example 256

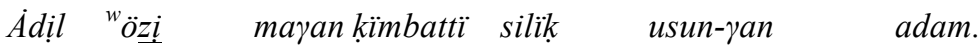

Ảdil ÖZI.PART I.DAT precious present give-GAN.PART person

'Adil is the man who gave me a precious present.'

In the next example, the topicalization of 'today' restricts the validity of the statement. The topicalizer botsa cannot be used in the same way.

Example 257

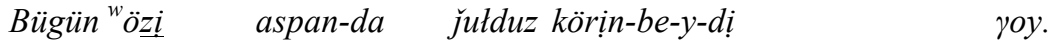
today ÖZI.PART sky-LOC star be visible-NEG-A.PRES-3 ГOY.PART

'Just today, no star is visible in the sky, you know.'

In Example 258, ${ }^{w} \ddot{o z} i$ adds the meaning of all people. Thus the sentence expresses the speaker's surprise over the fact that $\dot{A} d \dot{l} l$ of all people gave her a precious present, because this is not $\dot{A} d i l$ 's typical behavior.

Example 258

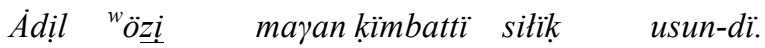

Ädil ÖZI.PART I.DAT precious present give-PAST3

'Ádil has given me a precious present.'

The particle ${ }^{w} \ddot{o} z i$ cannot be used as a focus particle in Kazakh.

Subjective attitude

The particle ${ }^{w} \ddot{o} z \underline{i}$ may attach to affirmative clauses, finite or non-finite, to express the speaker's positive or negative attitude. In Example 259, the speaker adds the particle ${ }^{w} \ddot{o} z i$ to the subordinate clause keške deyịn kömịr tasïtïp 'after (he) made me transport coal all the time' to express his negative attitude. 
Example 259

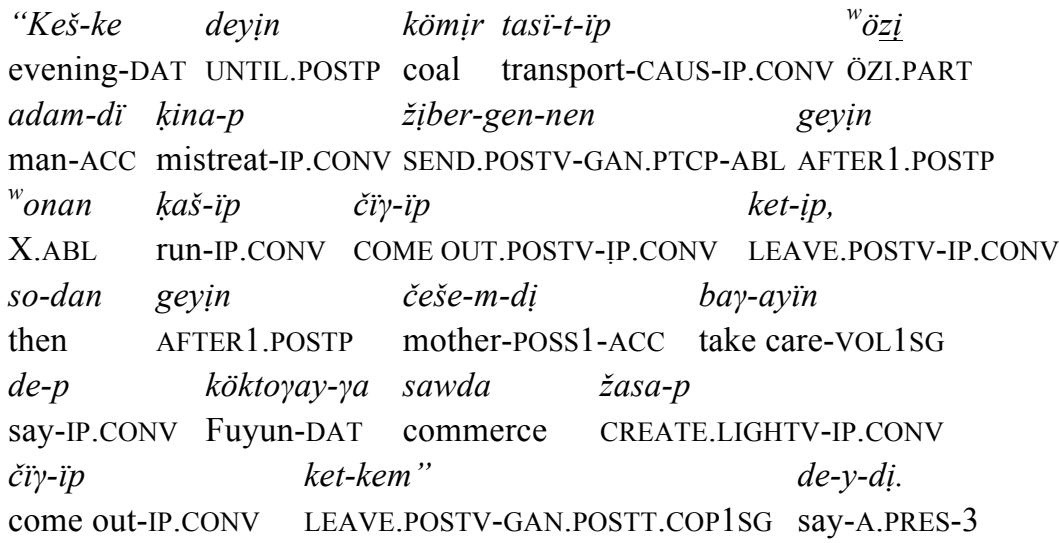

“"After (he) made me transport coal all the time, after he mistreated me so much (I) ran away from him. Then, in order to take care of my mother, I went to Fuyun to do business", he writes.' (T4/29)

In Example 260, the clause marked by ${ }^{w} \ddot{o} z \underline{i}$ is an exclamation conveying the speaker's positive attitude.

Example 260

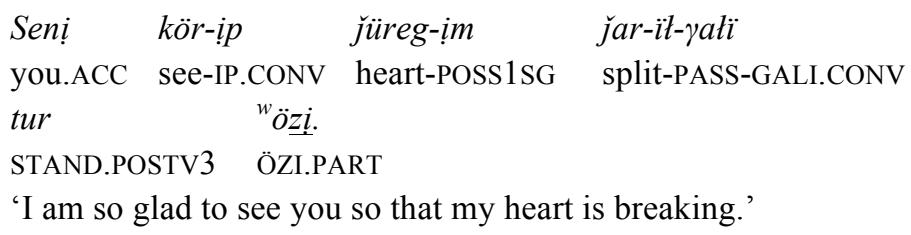

The particle ${ }^{w} \ddot{o} z i$ indicates 'simply', 'merely', 'just' in the following examples.

Example 261

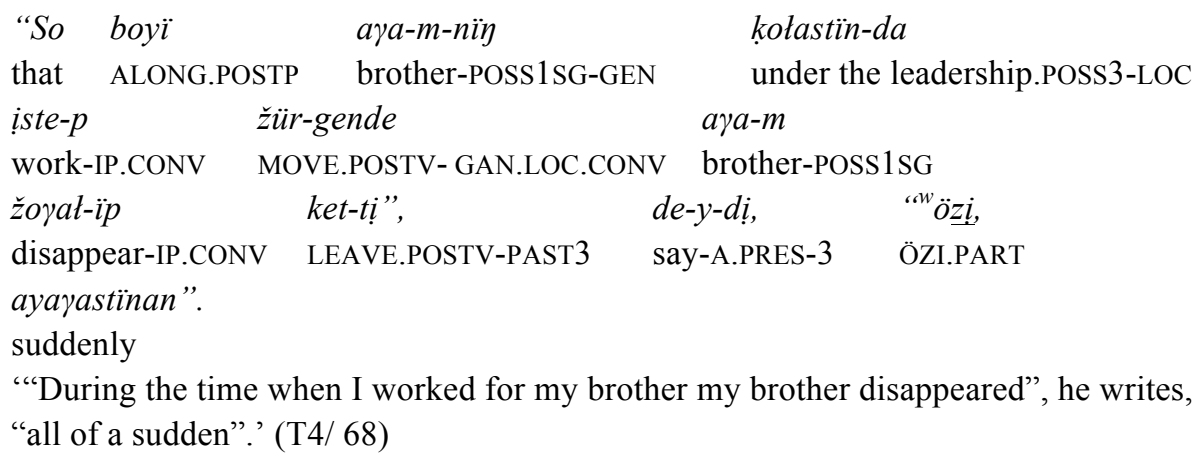


Example 262

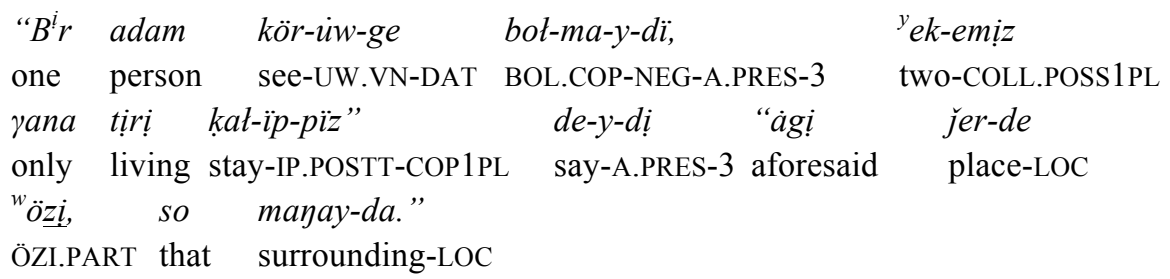

" "We couldn't see anyone, only the two of us have survived", he writes, "at that place, in those surroundings".' (T4/48)

Example 263

Tịl-ịy-di

kadịrle-se- $\eta \quad{ }^{w}$ on- $d a \quad{ }^{w} \ddot{o} z$

language-POSS2SG-ACC respect-HYP-2SG X-LOC self

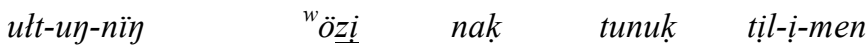

nation-POSS2SG-GEN ÖZI.PART exactly purely language-POSS3-WITH.POSTP

söyle-w-ge daydïan-uw kerek koy adam-dar.

speak-UW.VN-DAT get used to-UW.VN necessary ГOY.PART person-PL

'If you respect your language, then you must get used to speaking precisely and purely the language of your nation, mustn't you?' (T5/ 25)

The particle can be attached to a question and express-depending on the context - the speaker's positive or negative attitude. The negative attitude, according to Zhang (2003: 213, 2004: 597), can be the speaker's dissatisfaction or annoyance.

Example 264 negative attitude

Context: We have already been waiting a long time.

$\begin{array}{llllll}\text { Bịz } & \text { senị } & k a s ̌ a n-\gamma a & \text { deyinn } & \text { küt-e-mịz } & { }^{w} \ddot{z} z i ̣ ? \\ \text { we } & \text { you.ACC } & \text { when-DAT } & \text { UNTIL.POSTP } & \text { wait-A.PRES-COP1PL } & \text { ÖZI.PART }\end{array}$

'How long shall we wait for you?'

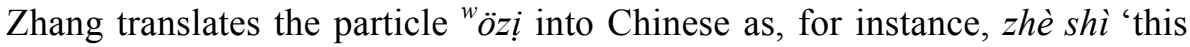
is' (2003: 213, 2004: 597). This Chinese form is also grammaticalized as a particle which is always in postpredicate position. The question is whether the use of the particle ${ }^{w} \ddot{o z} i$ in questions is influenced by Chinese. The meaning of the Chinese expression zhèshi 'this is' in Example 265 is rendered by the particle ${ }^{w} \ddot{o} z i$ in the corresponding Kazakh translation; see Example 266.

Example 265 Chinese

Context: My mother is not behaving as usual.

Wó mā zěnmé le, zhè shì?

I mother how PAST this is

'What is wrong with my mother?' 
Example 266

Čěse-m-e ne bol-yan "

mother-POSS1SG-DAT what BOL.COP-GAN.POSTT3 ÖZI.PART

'What is wrong with my mother?'

In certain cases, spoken Uyghur, like Chinese, uses the demonstrative pronoun $b u$ 'this' or mawu 'this one' in this sense.

Example 267 Uyghur

Bu nimä kil-yin-iy, bu?

this what do-GAN.PTCP-POSS2 SG this

'What have you done?'

Alternatively, this can be expressed also by:

Mawu nimä kil-yin-in, mawu?

this one what do-GAN.PTCP-POSS2SG this one

'What have you done?'

The same is also true in colloquial Kazakh, where the demonstrative pronoun bul 'this' or mïnaw 'this one' can be applied. The Uyghur example can be expressed in exactly the same way in Kazakh. This can also be expressed by using the other demonstrative pronoun; see Example 268.

Example 268

But/mïnaw kayt-ken-ịy, but/mïnaw?

this / this one how to do-GAN.PTCP-POSS2SG this / this one

'What have you done?'

Compare Example 268 with its Chinese equivalent.

Example 269 Chinese

$N \check{~ z h e ̀ ~ s h i ̀ ~ g a ̀ n ~ l e ~ s h e ́ n m e, ~ z h e ̀ ~ s h i ̀ ? ~}$

you this is do PAST what this is

'What have you done?'

The particle $D^{2} A^{2}$

Variants

The particle $D^{2} A^{2}$ is harmonic with four variants: $d a$, de, $t a$, te. After vowels and voiced consonants $d a$, de occur; see Examples 270 and 271. 
Example 270

Ayt-pa-y-di $\quad \underline{d a}$.

tell-NEG-A.PRES-3 DA.PART

'X clearly do(es) not tell.'

Example 271

Iste- $y-d i \quad$ de.

do-A.PRES-3 DA.PART

'X clearly work(s).'

The variants $t a$ and te occur after voiceless consonants.

Example 272

Kün ${ }^{i} s t i k$ ta.

day warm DA.PART

'The weather is unfortunately warm.'

Example 273

Bała köp te .

child many DA.PART

'The children are unfortunately numerous.'

In certain spoken varieties the variant $d \dot{a}$ occurs if the preceding syllable ends with a vowel or a voiced consonant, whereas $t \dot{a}$ occurs after voiceless consonants, e.g. Isteydi $\underline{d \dot{a}}\langle$ do-A.PRES-3 DA.PART〉 'X clearly work(s)',

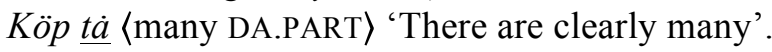

Uyghur has the variants $d \ddot{a}$ and $t \ddot{a}$; see the use of $d \ddot{a}$ in Example 274.

Example 274 Uyghur

$D \ddot{a}-y-d u \quad \underline{d \ddot{a}}$.

tell-A.PRES-3 DÄ.PART

'X clearly tells.'

The spoken Kazakh variants having $d \dot{a}$ and $t \dot{a}$ are probably influenced by Uyghur. This particle is different from the particle $D^{2} A^{2}$ meaning 'also' which etymologically comes from the word taki 'and, also' (Clauson 1972: 466)

Basic properties

The basic meaning of the particle $D^{2} A^{2}$ is to express epistemic evaluation. It occurs only in postpredicate position. Its function is to strengthen the validity of a statement, i.e. to express that it is obviously the case. The particle $D^{2} A^{2}$ is accented. Its usages in Kazakh are the same as those of the corresponding Uyghur particle. 


\section{Usages}

\section{Emphatic usage}

The particle $D^{2} A^{2}$ is used to express that the speaker emphasizes that the statement is understandable, unsurprising, expected, predictable, inevitable, reasonable, acceptable, logical, normal, natural and justifiable. Zhang (2003: 231, 2004: 612) states that the speaker employs this particle to emphasize that the statement is logical according to his/her understanding.

Example 275

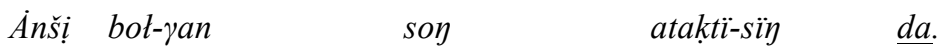
singer BOL.COP-GAN.PTCP AFTER2.POSTP famous-COP2SG DA.PART

'Since you are a singer, you are, of course, famous.'

Example 276

\begin{tabular}{|c|c|c|c|}
\hline tis-tan & kel-gen & sol & $b^{i}$ rneše \\
\hline 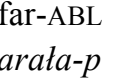 & $\begin{array}{r}\text { come-GAN.PTCP } \\
k \text { kayt- } a-d i\end{array}$ & AFTER2.POSTP & $\begin{array}{l}\text { several } \\
d a .\end{array}$ \\
\hline it- & RETURN.P & OSTV-A.PRES-3 & DA.PAR \\
\hline
\end{tabular}

'Since X came from far away, he will, of course, stay here for several days and then return.'

According to Zhang, the particle can also be used to express emotional nuances (qínggăn 'sentiment'; 2004: 613). In such cases, the particle carries emphatic accent, that is, it is pronounced as an exclamation.

Example 277

Bakït de-gen ${ }^{w}$ osï da!

happiness say-GAN.PTCP this DA.PART

'Clearly, this is happiness!'

Combinations with indirective forms

A statement marked by the copula ${ }^{y}$ eken or the verb form in $\left\{-\left(\mathrm{I}^{2}\right) \mathrm{ptI}^{2}\right\}$ conveys indirective meaning. The particle $D^{2} A^{2}$ can be combined with these markers and expresses that the speaker has just become aware of something. Here the accent falls on the last syllable of the preceding word. The combination can be interpreted as 'I see', 'it is obvious', 'it is clear'; see Example 278.

Example 278

Mïna mat-dar köršịles awut-diki ${ }^{y}$ eken

this cattle-PL neighborhood township-NIKI E.COP.INDIR3

de.

DA.PART

'It is obvious that these cattle belong to the neighborhood township.' 
In juxtaposed clauses

The particle $D^{2} A^{2}$ may be used in juxtaposed clauses to highlight the semantic relation between the two clauses. The nature of the relationship is not expressed by $D^{2} A^{2}$ particle. The reading is dependent on the content and can be paraphrased by using adverbial expressions like botmasa or aytpese. Zhang claims that in such expressions the particle conveys a regretful attitude (2003: 232, 2004: 613).

Example 279

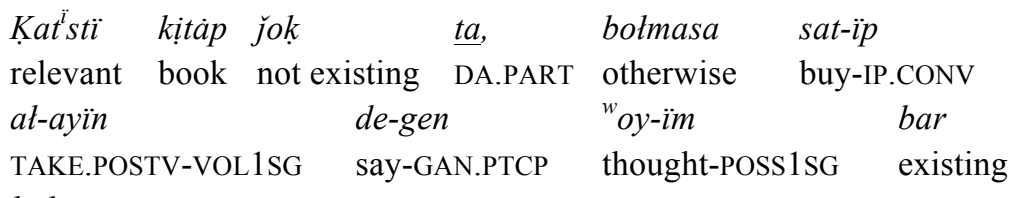

bot-atïn.

BOL.COP- ATIN.PAST.INTRAT3

'There is unfortunately not a relevant book, otherwise I would have bought a copy.'

Example 280

Kün jütïn-ba-y ak ket-ti, aytpese

weather warm-REF-NEG-A.CONV AK.PART LEAVE.POSTV-PAST3 otherwise

$s u^{w}-\gamma a \quad$ matta-p $p$ kel-er ${ }^{y}$-di $-k \quad$ te.

water-DAT Swim-IP.CONV COME.POSTV-AOR E.COP-PAST-1PL DA.PART

'The weather is still not warm. Otherwise we could have gone swimming.'

The particle $m I^{2} s$

Variants

The particle $m I^{2} s$ has two harmonic variants, one front, mis, and one back, $m \ddot{s}$, e.g. Kel-ipp-tị mịs 〈come-IP.POSTT-3 MIS.PART〉 'X has apparently come'. Ayt-ïp-tï mïs 〈tell-IP.POSTT-3 MIS.PART ' $\mathrm{X}$ has apparently said it'.

\section{Basic properties}

The unaccentable particle $m I^{2} s$, which occurs in postpredicate position, goes back to the indirective marker $\ddot{a} r-m i \check{s}$ derived from the verb $\ddot{a} r$ - 'to be'. Particles with similar forms occur in several other Turkic languages, e.g. Turkish imiš 〈I.COP.INDIR〉, and have an ambiguous temporal value allowing both non-past and past interpretations: 'is/was evidentially' (Johanson 2000: 67, 2003: 276). Uyghur possesses the reportive copula marker -(i)miš, e.g. Yaxš $i$ yazarimiš ' $\mathrm{X}$ is reportedly writes good' (Tömür $2011^{2}$ : 270).

Indirectivity does not express personal attitudes, and therefore not a modal category as defined in this study. Nonetheless, indirective markers "get various contextual interpretations and display various pragmatic extensions of their central meaning" (Johanson 2003: 282). This seems to be the case in Kazakh. Some scholars claim that the Kazakh particle $m I^{2} s$ has developed 
into a dubitative particle on the basis of its reportive meaning and that it thus expresses epistemic evaluation. The addresser is said to report a fact with an ironic and doubtful attitude (Geng et al. 1999: 230, KG 2002: 563, Zhang 2003: 212, 2004: 596).

\section{Usages}

In the following examples, functions of the particle $m I^{2} s$ will be illustrated. In Example 281, ${ }^{y}$ eken has indirective meaning, marking hearsay, inference or perception. When followed by $m I^{2} s$, as in Example 282, it is necessarily interpreted as conveying hearsay. The particle $m I^{2} s$ adds a dubitative meaning, expressing that something has been claimed to be the case although there is no proof for it. This meaning can be translated as 'allegedly'. Compare Examples 281 and 282.

Example 281

Kelin-i sutuw ${ }^{y}$ eken.

bride-POSS3 beautiful E.COP.INDIR3

'His bride is apparently beautiful.'

Example 282

Kelịn-i sułuw yeken mis.

bride-POSS3 beautiful E.COP.INDIR3 MIS.PART

'His bride is allegedly beautiful.'

In the following example, the particle $m I^{2} s$, without ${ }^{y} e k e n$, expresses an ironical comment implying that the statement is not true.

Example 283

Kelin-i suluw mïs.

bride-POSS3 beautiful MIS.PART

'His bride is reportedly beautiful (according to what is said, but not necessarily true).'

The particle $m I^{2} s$ conveys the dubitative meaning also when following an indirective verb form in $\left\{-\left(\mathrm{I}^{2}\right) \mathrm{ptI}^{2}\right\}$.

Example 284

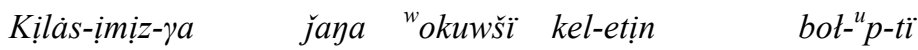

class-POSS1PL-DAT new student come-ATIN.PTCP BOL.COP-IP.POSTT-3

mïs.

MIS.PART

'A new student will allegedly, but not very probably, come to our class.' 
The Uyghur reportative copula marker -(i)miš conveys mostly reportive meanings. Depending on the context, it may imply a sarcastic, ironical meaning (Tömür 2003: 304, 20112: 271). Tömür states the differences between the reportive copula marker -(i)miš and the indirective copula $i k a ̈ n$. According to him, the reportive copula emphasizes that the source of the information is hearsay, while the copula ikän signals that the source of the statement is not identified (2003: 304, 2011'2 : 271).

Example 285 Uyghur

Yèz-iwat-kan-miš.

write-PRES-GAN.POSTT-MIŠ3

'X was reportedly writing' (Johanson 2003: 279).

In some contexts, this copula in Uyghur may get an ironical reading, expressing that the addresser does not think that the statement is true. Compare the Kazakh particle $m I^{2} s$, which always has an ironical meaning when it is not used in combination with ${ }^{y}$ eken.

The particle ${ }^{i} y \dot{a}$

Basic properties

The particle ${ }^{i} y \dot{a}$ conveys a subjective epistemic meaning confirming the truth of a proposition. It occurs in both sentence-initial and postpredicate positions and is always accented. In some expressions its meaning is similar to that of the Uyghur particle $h \ddot{a}$. Its most general function is to give an affirmative answer to a question, like English 'yes'.

Example 286

$\begin{array}{lll}A: \text { Xat- } t \ddot{ } & \check{j a z}-d \ddot{\imath}-\eta & b a ? \\ \text { letter-ACC } & \text { write-PAST-2SG } & \text { Q.PART }\end{array}$

'Did you write the letter?'

$B:{ }^{i} Y \dot{a}, \quad j a z-d \ddot{i}-m$.

YȦ.PART write -PAST-1SG

'Yes, I did.'

Usages

In rhetorical questions

The particle ${ }^{i} y \dot{a}$ can be added to interrogative sentences including the rhetorical particle ${ }^{y}$ eken. Such questions can be described as meditative-rhetorical questions. In this usage, ${ }^{i} y \dot{a}$ is interchangeable with the particle $\dot{a}$ (see below). Both particles may express the addresser's will to learn the truth. In Example 287, the question includes the rhetorical copula ${ }^{y}$ eken. Such ques- 
tions are rhetorical because the addresser, as a rule, does not expect an answer. The indirective copula can be interpreted in different ways depending on the context. In this example, it marks that the addresser is surprised to find that the weather is cold.

Example 287

$\begin{array}{lllll}\text { Kün } & \text { nege } & \text { suw-up } & \text { ket-ti } & \text { 'eken? } \\ \text { weather } & \text { why } & \text { cold-(BOL.COP-)IP.CONV } & \text { LEAVE.POSTV-PAST3 } & \text { RHET.PART }\end{array}$

'Why has it become so cold?'

In Example 288, the particle ${ }^{i} y \dot{a}$ or $\dot{a}$ is added to express a meditative reading that can be rendered in English with 'I wonder'. A corresponding Turkish expression is acaba 'I wonder if', 'oh, indeed!'

Example 288

Kün nege suw-up ${ }^{29} \quad$ ket-ti yeken

weather why cold-(BOL.COP-)IP.CONV LEAVE.POSTV-PAST3 RHET.PART

${ }^{i} \dot{a} \dot{a} / \dot{a}$ ?

YȦ.PART/Ȧ.PART

'I wonder why it has become so cold?'

The particle can also be added to yes-no questions containing the indirective particle. Depending on the context, the particle can express the addresser's anxiousness to learn the answer.

Example 289

Bata àke-sị-n

izde- $p \quad$ tap-tï $\quad m a$

child father-POSS3SG-ACC look for-IP.CONV find-PAST3 Q.PART

yeken $\quad$ 'yda $/ \dot{a}$ ?

RHET.PART YȦ.PART/Ȧ.PART

'I wonder if the child found his father?'

Interrogative sentences followed by the Kazakh indirective particle ${ }^{y}$ eken without an added ${ }^{i} y \dot{a}$ or $\dot{a}$ particle do not have the meditative-rhetorical meaning expressed by the corresponding Noghay indirective particle (Karakoç 2005: 26-27).

Example 290 Noghay

Tïs kïra-lar-da noyay-lar bar de-p

foreign country-PL-LOC DA.PART Noghay-PL existing say-IP.CONV

\footnotetext{
${ }^{28}$ Suwup is contracted from suwuk bolup 〈cold BOL.COP-IP.CONV〉 'became cold'. The stem suw in the example is a short form of suwuk.

${ }^{29}$ See the previous footnote.
} 


\begin{tabular}{|c|c|c|c|c|c|c|c|}
\hline \multicolumn{2}{|c|}{$\begin{array}{l}\text { esit-ken-miz. } \\
\text { hear-GAN.POSTT-1PL }\end{array}$} & \multicolumn{3}{|c|}{ 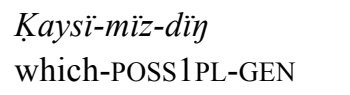 } & $\begin{array}{l}d a \\
\text { DA.PART }\end{array}$ & \multicolumn{2}{|c|}{$\begin{array}{l}\text { könil-imiz-de, } \\
\text { heart-POSS1PL-LOC }\end{array}$} \\
\hline on-da & noyay-lar & $k \ddot{p p}$ & pe & eken? & & O-lar-da & \\
\hline X-LOC & Noghay-PL & much & Q.PART & RHET. & PART & X-PL-LOC & \\
\hline noyay-š & $b a$ & & $m a$ & eken? & & O-lar-da & noyay \\
\hline Noghay & ER-DER & isting & Q.PART & RHET. & PART & X-PL-LOC & Noghay \\
\hline kul'tura & $\ddot{o s}-e$ & me & eken? & & Noyay & $t i l-i$ & \\
\hline culture & grow-A.PRES & Q.PART & RHET. & PART & Noghay & languag & -POSS3 \\
\hline yoy-ïl- $\gamma$ & & & $m a$ & eken? & & Eger no $\gamma_{c}$ & \\
\hline extingu & A-PASS-GAN.PT & & Q.PART & RHET. & PART & Nog & \\
\hline til-i & yaša-y & & bol-sa, & & biz-im & til-dey & \\
\hline languag & POss3 live-A & .PRES & BOL.COP- & HYP3 & we-GEN & languag & -EQUA \\
\hline me & eken? & de-gen & & sora & -lar & $t u w-a-d \ddot{i}$. & \\
\hline Q.PART & RHET.PART & say-GA & AN.PTCP & questi & on-PL & rise-A.PRES & $3 \mathrm{SG}$ \\
\hline
\end{tabular}

'We have heard that there are also Noghays abroad. In our heart, the questions are raised, "Are there many Noghay people there? Do they have any Noghay identity? Does the Noghay culture live among them? Is the Noghay language extinct? If the Noghay language is living, is it similar to our language?"' (Karakoç 2005: 26)

Introducing a new topic

In sentence-initial position, the particle ${ }^{i} y \dot{a}$ can precede a question that introduces a new topic. The function in this case is to draw the interlocutor's attention to the new topic and to mark that an answer is expected.

Example 291

${ }^{i} Y \dot{a}, \quad$ keše tün-de kayda bot-dï-n?

YȦ.PART yesterday evening-LOC where BOL.COP-PAST-2SG

'Well, where were you last night?'

There is a phonetically similar particle $\breve{j} \dot{a}$ which signals that a new topic will be introduced. This particle is probably a shortened version of $\breve{j} \dot{a} \dot{a} y d \dot{c}$ 'all right'. In my experience, the particle $\breve{j} \dot{a}$ is preferred by males, whereas females use ${ }^{i} y \dot{a}$ instead. In Example 292, the male addresser uses the particle and pronounces it as $\check{z} \dot{a}$.

Example 292

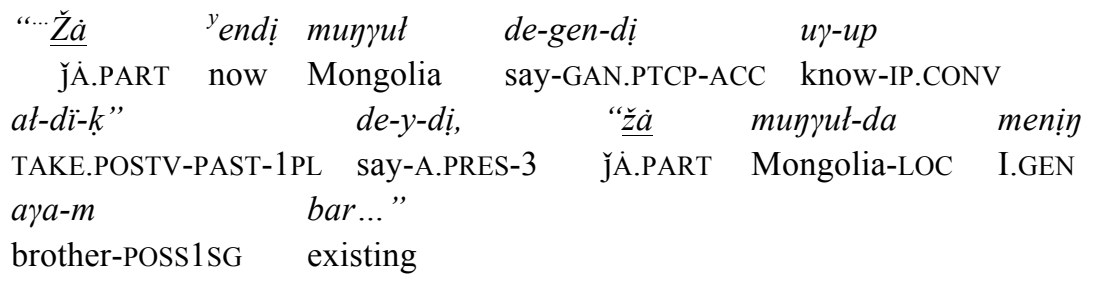

'..."Well, now we have got acquainted with Mongolia", he writes. "Well, I have a brother in Mongolia ..."” (T4/ 55) 
Sudden realization

In sentence-initial position, the particle ${ }^{i} y \dot{a}$ can denote that the addresser suddenly realizes something. In this case, the statement is not an answer to a question.

Example 293

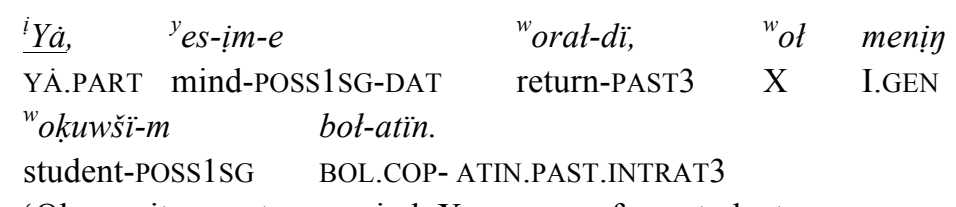

'Oh yes, it came to my mind, $\mathrm{X}$ was one of my students.

Example 294

Context: I am reading a newspaper. One piece of news reminds me of an event which I have already heard about.

${ }^{i} Y \dot{a}, \quad{ }^{y}$ esti -gen-min.

YȦ.PART hear-GAN.POSTT-COP1SG

'Oh yes, I have heard about it.'

Question tag

In postpredicate position, the particle ${ }^{i} y \dot{a}$ may be used when politely asking for a confirmation or consent. Zhang (2003: 199, 2004: 586) claims that in this usage the particle is always accented to signal that the interlocutor is earnestly requested to corroborate a statement based on the addresser's assumption. In our observation, it is used to ask for confirmation or consent, but the statement does not need to express the addresser's assumption. In this usage, ${ }^{i} y \dot{a}$ is interchangeable with the particle $\dot{a}$ (see below).

Example 295

Mïna üy aygerịm-der-dịki $\quad \stackrel{i}{y} \dot{a}$ ?

this house Aykerim-PL-DIKI YÄ.PART

'This house belongs to the Aykerims, does it not?

Example 296

Teledidar-dï söndị-ịp $\quad$ jat, $\quad \stackrel{i}{y} \dot{a}$ ?

television-ACC shut down-IP.CONV go to bed.IMP YȦ.PART

'Turn off the TV and then go to bed, is it OK?'

The particle $\dot{a}$

Basic properties

The particle $\dot{a}$ is always accented and occurs in both sentence-initial and postpredicate positions. It combines with verb forms of all moods and with different modal particles occurring in postpredicate position. Its basic meaning is also subjective epistemic evaluation. In some expressions, its function 
corresponds to that of the particle $i \dot{y} \dot{a}$. As an interjection, younger Kazakhs in China often use a copy of the Chinese particle $a$, which, when used as an interjection, is similar to the Kazakh particle both in function and form. An account of this phenomenon will be given below.

\section{Usages}

Meditative-rhetorical questions

The particle $\dot{a}$ can be added to interrogative sentences including the rhetorical particle ${ }^{y}$ eken to form meditative-rhetorical questions. In this usage, it is interchangeable with the particle ${ }^{i} y \dot{a}$.

Example 297

\begin{tabular}{|c|c|c|c|c|c|c|}
\hline $\begin{array}{l}\text { "Sodan } \\
\text { then } \\
\text { yeken }\end{array}$ & $\begin{array}{l}\text { jügüur-üp } \\
\text { run-IP.CONV } \\
\quad \dot{a} ?\end{array}$ & $\begin{array}{l}\dot{a g} \dot{ } \\
\text { aforesaid } \\
\text { awït }\end{array}$ & $\begin{array}{l}\begin{array}{l}s a y-\gamma a \\
\text { ravine-DAT } \\
\quad a d a m-d a\end{array}\end{array}$ & $\begin{array}{l}n e \\
\text { what } \\
-i\end{array}$ & $\begin{array}{l}b o t-d \ddot{i} \\
\text { BOL.COP-PA } \\
i \grave{s}-i ̣ n-d e-g i\end{array}$ & \\
\hline HET. & Ȧ.PART & household & person-P & SS3 & inside-PO & $-\mathrm{LO}$ \\
\hline y-ler & bot-di & & ${ }^{y}$ eken? & $d e-s e-k$ & ${ }^{w}$ ot & $s a y-d i$ \\
\hline yurt-PL & BOL. & 3 & RHET.PART & say-HY & YP-1PL X & $\mathrm{ACC}$ \\
\hline$\ddot{p} r-\dot{u} w-g$ & bot-m & $-d \ddot{\imath}$ & $\begin{aligned} & { }^{y} \text { eke } \\
\text { S-3 } & \text { E.CC }\end{aligned}$ & & $\begin{array}{l}d e-y-d i \\
\text { say-A.PR }\end{array}$ & \\
\hline
\end{tabular}

"'Then we ran to that ravine, to see what had happened to that ravine, what happened to the people living in the households inside the ravine. They disappeared", he writes.' (T4/45)

Interjection

Like the particle $a w$ (see above), the particle $\dot{a}$ is frequently used as an interjection in response to a call. It confirms that the addressee has heard the call.

Example 298

A: $\dot{A y} \quad k i \ddot{z}$ !

ȦY.INTERJEC girl

'Hey, girl!'

$B: \dot{A} !$

A.PART

'Yes!'

Instead of the Kazakh particle $\dot{a}$, many bilinguals today use a copy of the Chinese particle $a$ with rising tone, i.e. interrogative intonation. In example 299 , this particle is used as an echo question indicating that the respondent is ready to continue the dialogue. The particle may also be used to ask the addresser to repeat an utterance. 
Example 299

A: $\dot{A y} \quad$ kiż!

ÁY.INTERJEC girl

'Hey, girl!'

$B: A$ ?? (with rising intonation)

A.PART

'I beg your pardon?'

In Example 299, the particle can also be interpreted as a confirmation in the sense of "I am listening". Example 300 illustrates a similar use of $a$ in Chinese.

Example 300 Chinese

A: Xiăo huāhuā!

small.DIM Huahua

'Xiao Huahua!'

$B: A ! ?$

A.PART

'Yes?'

The particle $\dot{a}$ can express an immediate reaction confirming that the addressee has understood a given utterance; see the following two examples.

Example 301

Context: The addressee has listened to the addresser's instruction about how to download different apps.

A, solay ma?

A.PART like that Q.PART

'Yes, is it so? (I got it.)'

Example 302

Context: Two drivers have tried to catch up with each other, and finally one has overtaken the other.

A, bäle-m, $\quad{ }^{y}$ endi kat-ar-sïy.

À.PART unfortune-POSS1SG now stay-AOR-COP2SG

'Yes, my misfortune, now you will stay behind me.'

In the spoken language there are some set phrases expressing immediate reaction. 
Set phrase $\dot{a}$ degennen

$\dot{A}$ de-gen-nen $\langle\dot{A}$.PART say-GAN.PTCP-ABL〉 'while saying $\dot{a}$ ' expresses quickness and can be translated as 'in no time', 'in a very short time'.

Example 303

\begin{tabular}{|c|c|c|}
\hline $\begin{array}{l}\text { Bata- } m \\
\text { child-POSS1SG }\end{array}$ & $\begin{array}{l}\text { Uppsała- } \gamma a \\
\text { Uppsala-DAT }\end{array}$ & $\begin{array}{ll}{ }^{y} \text { endi } & \text { bar-dï- } \eta . \\
\text { now } & \text { go-PAST-2SG }\end{array}$ \\
\hline$d e-g$ & de-gen-nen & könịl-de-gị-dey \\
\hline Aं.PART & say-GAN.PTCP-ABL & will-LOC-GI-EQUA \\
\hline bot-a & koy-uw & $k a y-d a ?$ \\
\hline 3OL.COP-A.CON & PUT.POS & where-LOC \\
\hline
\end{tabular}

'My child, you just went to Uppsala. Where can you realize your wishes in such a short time?'

Set phrases $\dot{a}$ degeň̌e / à degenše botyan jok

The two phrases $\dot{a}$ de-genše $\langle\dot{A}$.PART say-GANŠA.CONV〉 'in as much time as it takes to say $\dot{a}$ ', and $\dot{a}$ de-genše bot-ran jok 〈Á.PART say-GANŠA.CONV BOL.COP-GAN.PTCP non-existing ' not even as much time as it takes to say $\dot{a}$ ' are interchangeable, both expressing quickness and immediacy.

Example 304

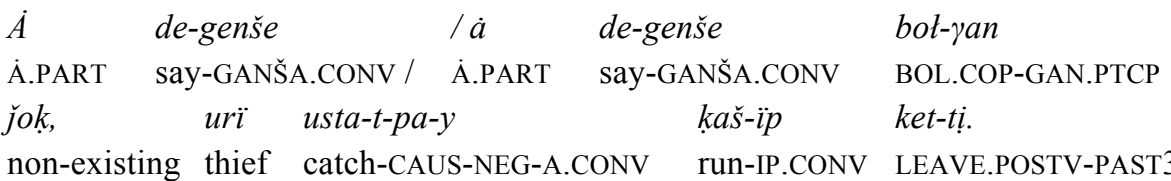

'The thief ran away immediately without being caught.'

Set phrase $\dot{a}$ dese $m \dot{a}$ de-

The phrase $\dot{a}$ dese $m \dot{a} d e$ - $\langle\dot{\mathrm{A}}$.PART say-HYP3 take.IMP say 'When one says $\dot{a}$ 'yes' the other one says $m \dot{a}$ 'take', expresses a retort, i.e. an answer to a remark in a sharp, angry, or witty manner.

Example 305

$\begin{array}{llcll}\text { But } & \text { bata } & \text { ülkey-e } & \text { gel-e, } & \\ \text { this } & \text { child } & \text { grow-A.CONV } & \text { COME.POSTV-A.CONV } \\ \dot{a} & \text { de-se } & m \dot{a} & \text { de-ytinn } & \text { bot-dï. } \\ \dot{a} & \text { de-HYP3 } & \text { take.IMP } & \text { de-ATIN.PTCP } & \text { BOL.COP-PAST3 }\end{array}$

'When growing up this child gives ill-mannered answers.'

Comment on a piece of information

The particle $\dot{a}$ can be used as an explanatory comment that can be interpreted as 'just to inform you', 'be aware that', and 'you should know that'. 
Example 306

$\begin{array}{lll}\text { Men } & \text { jür }-d i \dot{i}-m & \dot{a} ! \\ \text { I } \quad \text { move-PAST-1SG } & \dot{\text { A.PART }} \\ \text { 'I am going, you see.' } & \end{array}$

The past tense is used here to express that the action is about to take place, a kind of prospectivity. In a sense, the action has already occurred in the addresser's mind. The same is true for bold $i$ in Example 309; see below.

The use of the particle $\dot{a}$ in Example 306 is very similar to the corresponding Chinese expression with the particle $a$. Kazakhs living in China use this particle very frequently. See Example 307.

Example 307

$\begin{array}{llll}\text { Wó } & z o ̌ u & l e & a ! \\ \text { I } & \text { go } & \text { PAST } & \text { A.INTERJEC }\end{array}$

'I am going, you see!'

According to Zhang (2003: 198, 2004: 584), the function of such expressions is that the addresser wants to remind the interlocutor of the state of affairs presented in the sentence. In our view, the function is not to remind, but to add an explanatory comment.

The question tag

The particle $\dot{a}$ may be used by the addresser to remind the addressee of something that $\mathrm{s} /$ he knows about. The addresser expects a positive reaction from the addressee(s).

Example 308

Karsï jak ta sap ${ }^{y}$ etkị-ịp

opposite side DA.PART happen quickly-IP.CONV

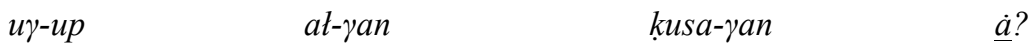

understand-IP.CONV TAKE.POSTV-GAN.PTCP resemble-GAN.POSTT3 A.PART

'The interlocutor seems to understand it at once, doesn't s/he?' (T5/ 34)

The usage of the particle $\dot{a}$ may correspond to the usage of ${ }^{i} y \dot{a}$ as a question tag (see above) to convey that the addresser expects the interlocutor to agree.

Example 309

J̌ejill-etin bot-di $\quad$ aw $\quad \underline{\dot{a} /{ }^{i} y \dot{a}}$ ?

be defeated-ATIN.PTCP BOL.COP-PAST3 AW.PART Aं.PART/YȦ.PART

'It has become clear that $\mathrm{X}$ will be defeated, right?' 
Combination with imperative and voluntative mood markers

According to Zhang (2003: 198, 2004: 584), when the particle $\dot{a}$ follows 'imperative' (in our terminology imperative and voluntative) forms, it can be used to ask the interlocutor to concern himself/herself with the requested affair or to wait for the consent of the interlocutor. In this usage the sentence in Example 310, Men istep köreyịn 'Let me try to do it', is pronounced with affirmative (falling) intonation and the following particle $\dot{a}$ with interrogative (rising) intonation. Observe that in this usage the intonation pattern is different from that in Example 311, which is pronounced as one intonational unit without a break before the particle. The accent/high tone is on the particle $\dot{a}$.

Example 310

$\begin{array}{llll}\text { Men } & \text { iste-p } & \text { kör-eyin, } & \dot{a} ? \\ \text { I } & \text { do-IP.CONV } & \text { SEE.POSTV-VOL1SG } & \dot{\text { À.PART }}\end{array}$

'Wǒ gàn gè shì shì, a?' (Zhang 2003: 198, 2004: 584)

['Let me try to do it, ok?']

Example 311

Tazalik-ti $\quad$ jaksï iste-y-der, $\quad \dot{\dot{a} /{ }^{i} y \dot{a}}$ ?

cleaning-ACC good do-IPM-PL Aं.PART/YÄ.PART

'Do the cleaning well, is this clear?'

There is a stylistic difference between the particles $\dot{a}$ and ${ }^{i} y \dot{a}$. According to Zhang (2003: 199, 2004: 585), ${ }^{i} y \dot{a}$ may make the utterance more polite.

\section{The particles de, dešị, and deseyši}

Basic properties

The particles de, deši position, are based on the verb de- 'to say' and reflect the stance of the interlocutor.

The particle $d e$, which has no variants, should not be confused with the variant $d e$ of the particle $D^{2} A^{2}$ (see above). It is always unaccented, with the preceding syllable carrying the accent. The particle de comes from the imperative form of the verb de- 'to say' (Zhang 2003: 216, 2004: 600). Though it also has an emphatic variant with a long vowel $e$; it cannot be proven that it goes back to a converb.

Different converb forms of the verb $d e$ - 'to say' have been grammaticalized as particles in Turkic languages. In Kazakh, the $\left\{-\left(I^{4}\right) p\right\}$ form $d e-p\langle$ de-IP.CONV $\rangle$ 'saying' is employed as a quotation particle in connection with a verb of speaking. 
Example 312

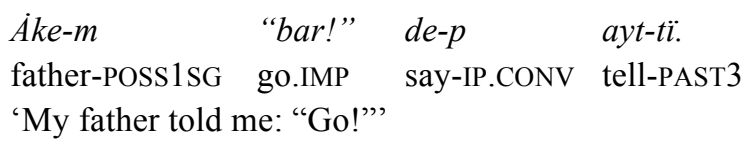

The quotation particle must normally be used to embed a direct quotation in a predicate based on a verb of speaking. The lexical verb de- 'to say' can, however, take a direct quotation without a quotation particle. When used together with a postverb, the converb form in $\left\{-\mathrm{A}^{2} / / \mathrm{y}\right\}$ of the verb $d e$ - is used, e.g. de-y kel-ip 〈say-A.CONV COME.POSTV-IP.CONV〉 'having said'.

Example 313

$\begin{array}{llll}\text { “Azattik-ka } & k \text { oljet-kiz-dị-k!”, } & d e-y & k e l-i p \\ \text { freedom-DAT } & \text { reach-CAUS-PAST-1PL } & \text { say-A.CONV } & \text { COME.POSTV-IP.CONV } \\ \text { köz-ịn-e } & \text { istïk jas } a t-d \ddot{i} . & & \\ \text { eye-POSS3-DAT } & \text { warm tear take-PAST3 } & \\ \text { 'Having said "We attained freedom!” X's eyes filled with warm tears.' }\end{array}$

The particles deši and deseyši are obviously complex, based on de-but also containing the particle $\check{s} I^{2}$. The form deš consists of the imperative of de-plus $\breve{s} I^{2}$. The form deseyši, is based on the hypothetical form of the second person desey 'imagine you say' plus $\breve{s} I^{2}$.

For the use of the participle degen as an emphatic particle, a topic particle, and a marker of contrast see Zhang (1999) and Muhamedowa (2011).

The usages of the particle de

The usages of the particle de are in some respects similar to those of the quotation particle dep 'saying' and its variant de-y kel-ip 'having said' mentioned above. The particle de, however, does not embed direct quotations, but is more of an emphatic particle expressing understanding or consent. It is often used when the addresser repeats information given by the interlocutor, thereby confirming that the message is understood. Uyghur has a corresponding particle $d \ddot{a}$ with the same function.

In the following example, B confirms having understood what A has said. The piece of information whose reception is confirmed can be repeated or paraphrased. Alternatively, the answer can be a simple confirmation without referring to the words of the interlocutor.

Example 314

\begin{tabular}{|c|c|c|}
\hline $\begin{array}{l}\text { A: Bu-łar fakułtet-ịmị-ge } \\
\text { this-PL department-POSS1PL-DAT } \\
\text { wokuwši-łar-ïmïz. } \\
\text { student-PL-POSS1PL }\end{array}$ & 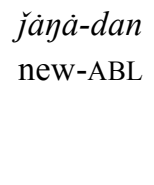 & 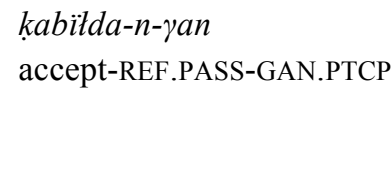 \\
\hline
\end{tabular}




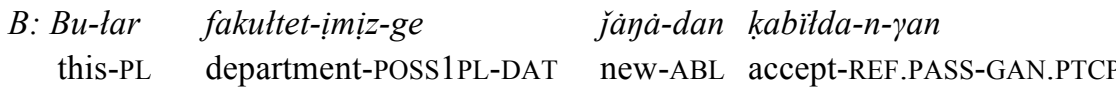

${ }^{w}$ okuwši-łar-ïmïz de.

student-PL-POSS1PL DE.PART

'I understand, these are the students who have recently been accepted at our department.'

or

B: Solay de.

so DE.PART

'I got it.'

The particle de can follow markers of indirectivity, the indirective copula ${ }^{y}$ eken, or the indirective verb form in $\left\{-\left(\mathrm{I}^{2}\right) \mathrm{ptI} \mathrm{I}^{2}\right\}$, when the information is based on a secondary source. Its function is still to confirm the receipt of the information given.

Example 315

${ }^{y}$ Ertey kün istik bot-a-dï ${ }^{y}$ eken de. tomorrow weather warm BOL.COP-A.PRES-3 E.COP.INDIR3 DE.PART 'I understand, it will apparently be warm tomorrow.'

The usages of the particle deš

The particle deši, in which the verbal stem carries the high pitch, ['defi], is an emphatic form that can be paraphrased as 'thus', 'that is to say', 'in other words', 'as claimed by you', 'according to you'. In Example 316, the fact that information received is based on a secondary source is expressed by an indirective form. Zhang (2003: 217, 2004: 600) claims that the particle in this usage expresses an epistemic evaluation; i.e. the addresser comes to realize the truth of a state of affairs just at the moment of speaking.

Example 316

${ }^{y}$ Ertey kün $\quad{ }^{i}$ stik bot-a-di $\quad{ }^{y}$ eken dešị.

tomorrow weather warm BOL.COP-A.PRES-3 E.COP.INDIR3 DEŠI.PART

'Thus it will apparently be warm tomorrow.'

In echo questions, when the addresser repeats all or part of what someone else has just said, the particle deši can express that the addresser regards the quoted statement to be doubtful, incredible or unconvincing. Such echo questions are pronounced with a special emphatic stress on the particle. 
Example 317

A: Men kör-me-dị-m.

I see-NEG-PAST-1SG

'I did not see (it).'

$\begin{array}{ccl}\text { B: “Kör-me-dị-m” } & \text { deši, } & \text { suwayt. } \\ \text { see-NEG-PAST-1SG } & \text { DEŠI.PART } & \text { liar } \\ \text { 'You say "I did not see (it)" you liar.' } & \end{array}$

The particle deši may occur at the end of a main clause to express that the addresser wants to remind the interlocutor that special attention should be given to the statement expressed by the clause. Zhang (2004: 601) observes that the addresser uses the particle ironically to remind the interlocutor of some shared memories.

\section{Example 318}

Context: The addresser does not believe that no lake in the world is brighter than Lake Sayram.

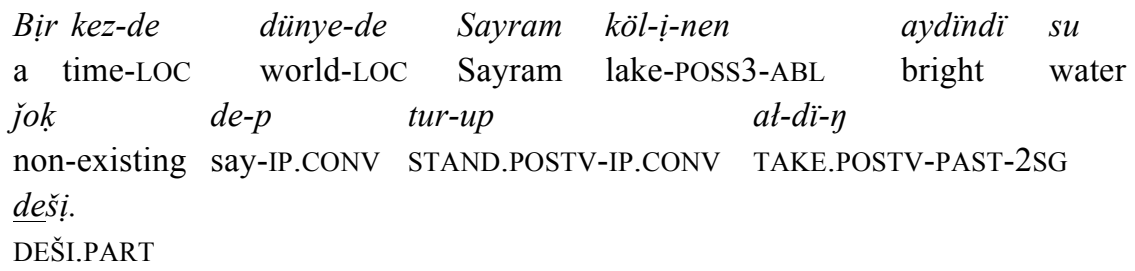

'Once you insisted that "no lake in the world is brighter than Lake Sayram".'

According to our observations, the particle need not always refer to a shared memory. It can also be used to introduce a new topic, such as Maržan in Example 319.

Example 319

\begin{tabular}{|c|c|c|c|c|c|}
\hline an & $\begin{array}{l}u z a k \\
\text { long }\end{array}$ & $\begin{array}{l}\text { wakï } \\
\text { time }\end{array}$ & $\begin{array}{l}\text { kezik-pe-gen } \\
\text { meet-NEG-GAN.PTCP }\end{array}$ & $\begin{array}{l}\text { sabaktas-ïm } \\
\text { classmate-POSS1SG }\end{array}$ & $\begin{array}{l}\text { deši } \bar{i}, \\
\text { DEŠI.PART }\end{array}$ \\
\hline & & & sälemdes-ip & $\begin{array}{l}\text { kayt-tï-m. } \\
\text { return-PAST-1SG }\end{array}$ & \\
\hline
\end{tabular}

'You see, Marjan is my classmate whom I had not met for a long time; I visited her at home.'

When the particle is attached to a question, as in Example 320, it may signal that the question is meant rhetorically, i.e. that no answer is required. The question is used to persuade the interlocutor to believe in the addresser's opinion. Zhang expresses the same view when writing that the particle signals that the addresser is eager to get the interlocutor's consent (2003: 218, 2004: 601-602). The particle deseyši can also be used in this function. 
Example 320

Context: The addresser is of the opinion that it is not possible for the local people to come to terms with the hot weather and expects the interlocutor to share this opinion.

Mïna ïstik-ka jergilliktị turyun-dar kałay töz-e-dị

this warm-DAT local inhabitant-PL how put up with-A.PRES-3

dešị?!

DEŠI.PART

'Tell me, how is it possible for the local inhabitants to endure this hot weather?'

The addresser can address the rhetorical question to himself/herself. In Example 321, the particle signals that there is no possible answer to the question.

Example 321

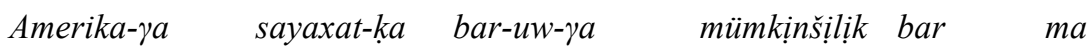

America-DAT travel-DAT go-UW.VN-DAT possibility existing Q.PART

yeken dešị?

RHET.PART DEŠI.PART

'Tell me, is there any chance for me to travel to America?'

The following example illustrates that the particle is used to add emphasis to an exclamation. The particle deseyš $i$ can also be used in this function.

Example 322

${ }^{y}$ Ertay tartuw-ï-n kör-se máz bot-a-dï dešị?

Ertay present-POSS3-ACC see-HYP3 satisfy-A.PRES-3 DEŠI.PART

'When Ertay sees the present he will be satisfied, won't he?'

The usages of the particle deseyš $i$

As mentioned, the particle deseyši 〈say-HYP-2SG-ŠI.PART〉 may occur in rhetorical questions and exclamations emphasizing the addresser's approval or disapproval. The syllable before the particle $\breve{s} I^{2}$ is accented.

Example 323

Kanday körkem jer desenšị?

how beautiful place DESEDŠI.PART

'It's such a beautiful place, isn't it?'

Example 324

Kanday jeksurun desenši?

how odious DESEDŠI.PART

'How odious, don't you think?' 
Zhang (2004: 602) points out that in the polite version of the hypothetical form of the second person deseyịzši can be used in formal style.

Example 325

Context: A schoolchild speaks to the teacher.

Ülkey-gende men de $b^{i} r$ muratïm bot-sa-m grow up-GAN.LOC.CONV I DA.PART a teacher BOL.COP-HYP-1SG

kanday jakssï desenizžši!

how good DESEDIZŠI.PART

'How good it would be if I also became a teacher when I grow up, don't you agree?'

The particle deseyṣ̌ may be used in the sense 'what if you say'.

Example 326

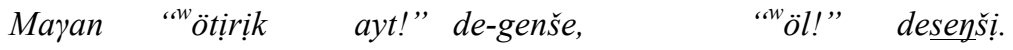

I-DAT lie tell say-GANŠA.CONV die DESEDŠI.PART

'Instead of saying to me "Tell a lie!", what if you say "Die!"

\section{The particle bilem}

\section{Basic properties}

The verbal form bilem 〈bil-A.PRES-COP1SG〉 'I know' from bịl- 'to know, to understand' is grammaticalized as a particle that conveys subjective modality based on epistemic evaluation. In initial or postpredicate position it emphasizes that the addresser is very sure of the statement and cannot be mistaken with respect to this (Zhang 2003: 235-234, 2004: 615). In initial position, the particle is accented and implies strong certainty.

Example 327.

Bilem, $\quad{ }^{w}$ ot keše kel-dị.

BILEM.PART $X$ yesterday come-PAST3

'I know, X came yesterday.'

When the particle stands in the postpredicate position, as in Example 328, the level of certainty may be reduced. The addresser just assumes that the state of affairs has taken place. In this case, it can be rendered as 'I think'.

Example 328

$\begin{array}{lll}{ }^{w} \mathrm{O} t \quad \text { keše } & \text { kel-dị, } & \text { billem. } \\ \mathrm{X} \quad \mathrm{y} e s t e r d a y & \text { come-PAST3 } & \text { BILEM.PART } \\ \text { 'X came yesterday, I think.' } & \end{array}$ 


\section{Lexical expressions}

In this chapter, lexical means of expressing modal notions, including adverbs and verbal and nominal constructions, will be dealt with. The list of items to be included here cannot be exhaustive. We will only describe some of the most frequently used lexical expressions of modality.

\section{Modal adverbs}

As described in the chapter Modal particles, the particles do not contribute to the description of events, but convey some kind of stance, a cognitive or affective attitude towards the events described. These can include meanings related to subjective reasoning and belief, personal involvement, emotions, evaluations, or judgments concerning the propositional content (Johanson 2012: 51). Similar concepts may be also expressed by some adverbs such as 'definitely', 'actually', 'really', 'indeed', 'apparently', 'perhaps', 'maybe', 'probably', 'possibly' etc. Because of this similarity, in some grammars the modal adverbs are dealt with as particles (Zhang 2003, 2004, Tömür 2011). In this study, we regard particles and adverbs as different categories. Unlike particles, adverbs possess a lexical meaning. Adverbs can modify predicates or sentences. When the adverbs modify a predicate, they have only the predicate in their semantic scope, and when they modify a sentence, they have the entire sentence in their scope. Our main concern here will be the modal adverbs that belong to the level of sentence adverbs. Modal adverbs are propositional operators that describe the speaker's own assessment of the propositional content or his/her personal commitment. Adverbs that modify, the predicate, for instance with respect to quantity or time, as in the following example, will not be discussed in this dissertation. 
Example 329

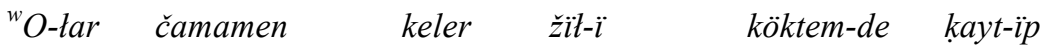

X-PL approximately coming year-POSS3 spring-LOC return-IP.CONV

kel-e-dị.

COME.POSTV-A.PRES-3

'Tāmen dàyuē zài míngnián chūntiān huílái.' (Zhang 2004: 626)

'They return approximately next year in the spring.'

In Kazakh, modal adverbs are relatively free to occur in postpredicate or sentence-initial positions depending on the context and the personal preferences of the speaker.

\section{Possibility}

Bälkịm 'maybe, perhaps', bàlki 'perhaps'

The adverbs bálkịm 'maybe, perhaps' and bàlki 'perhaps' express subjective evaluation of possibility in the sense of 'may be the case'. They are of Arabic/Persian origin. Similar lexical items with the same meaning are bälkim and bälki in Uyghur and belki in Turkish. They can be used as free variants, but according to Zhang, bälkịm is more frequently used (2004: 622).

The meanings of these adverbs have been described by Zhang (2004: 621-622). He observes that bálkịm 'maybe, perhaps' and bálki 'perhaps' can occur both in sentence-initial and sentence-final positions.

Example 330

Bälkim, ${ }^{w}$ ot ${ }^{y}$ ertey kel-se kerek.

perhaps $\mathrm{X}$ tomorrow come-HYP3 necessary

'Yěxǔ tā míngtiān lái.' (Zhang 2004: 622)

'X might perhaps come tomorrow.'

Actually, bälkim 'maybe, perhaps' can also be used to modify a non-first constituent and consequently occurs in other positions in the clause.

Example 331

${ }^{w}$ Ot bälkịm ${ }^{y}$ ertey kel-se kerek.

$\mathrm{X}$ perhaps tomorrow come-HYP3 necessary

'X might come, perhaps tomorrow.'

Mümkün 〈mümkịn〉 'possible'

The adjective mümkün 〈mümkịn〉 'possible' may function as an adverb and operate at the proposition level to express that the speaker evaluates the proposition as possibly true (see also Rentzsch 2012: 475). This adverb can also occur in sentence-final position. 
Example 332

Mümkün, keš kel-e-dị./ Keš kel-e-dị, mümkün.

possibly late come-A.PRES-3 late come-A.PRES-3 possibly

'It is possible that $\mathrm{X}$ will come late.'

\section{Probability}

Aytewịr / aytew 'anyway', 'anyhow'

Basic properties

The adverb aytewir / aytew can be translated into English by a number of expressions such as 'anyway' or 'anyhow', 'as a matter of fact', 'no matter what it is', 'after all', 'the point is', 'in any case', 'disregard the previous and then...'or 'the important thing is that'. The forms aytewir / aytew are interchangeable. We have not observed any differences in their usages. Aytew is most probably a contracted form of aytewị. According to Zhang (2003: 214, 2004: 598) aytewir is the standard version, whereas aytew is used in colloquial registers.

Zhang (2003: 214, 2004: 598) claims that aytewir/aytew can intensify a conclusion or a consequence, or express that a state of affairs cannot be changed. It always marks the message that the speaker wants to clarify and highlights what is most relevant in the given speech situation. Uyghur has a corresponding expression in iškilip, also used in the contracted form iškip 'anyway / anyhow'. Some Kazakhs in China use the Uyghur form of the particle (see $\mathrm{T} 8 / 7, \mathrm{~T} 8 / 8$ ).

\section{Usages}

Several examples below illustrate how this adverb is used in different positions in sentences. In Example 333, aytew introduces the clause which contains the important part of the statement.

Example 333

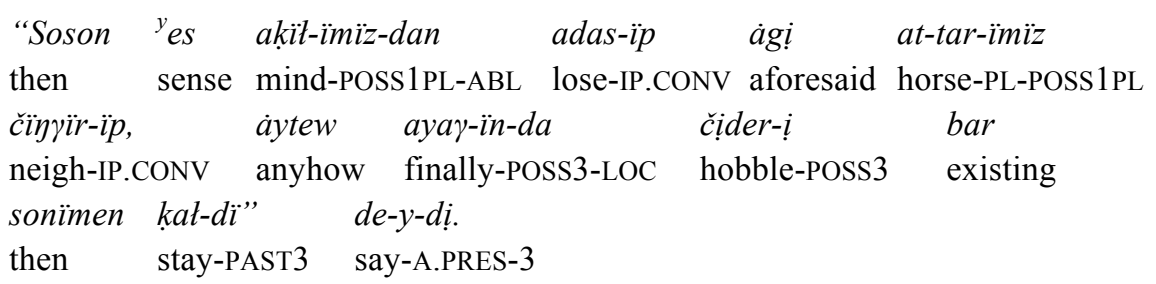

"'Then we did not know what to do, our horses neighed, anyway, finally thanks to the hobbles they did not run away", he says.' (T4/42)

The adverb can introduce a sentence as Example 334. 
Example 334

\begin{tabular}{|c|c|c|c|}
\hline $\begin{array}{l}\text { Bịl-me-y-mịn, } \\
\text { know-NEG-A. }\end{array}$ & PRES-COP1SG & $\begin{array}{l}\text { men-ịn } \\
\text { I.GEN }\end{array}$ & $\begin{array}{l}k u \nmid a \gamma-\ddot{i n}-a \\
\text { ear-POSS3-DAT }\end{array}$ \\
\hline$k i r-d i$ & $m e, \quad k i$ & $i r-m e-d i$ & me? $\quad$ Aytewir \\
\hline enter-PAST3 & Q.PART & enter-NEG-PAST3 & anyway \\
\hline$\ddot{u ̈ n}-\underline{i}$ & ${ }^{w} \ddot{o} \check{s}-\underline{i p p}$ & & kat-dï. \\
\hline ound-POSs3 & lapse int & to silence-IP.CONV & STAY.POSTV-PAST3 \\
\hline
\end{tabular}

In Example 335, aytew is in postpredicate position and indicates that the speaker believes there is nothing more to say about the issue.

Example 335

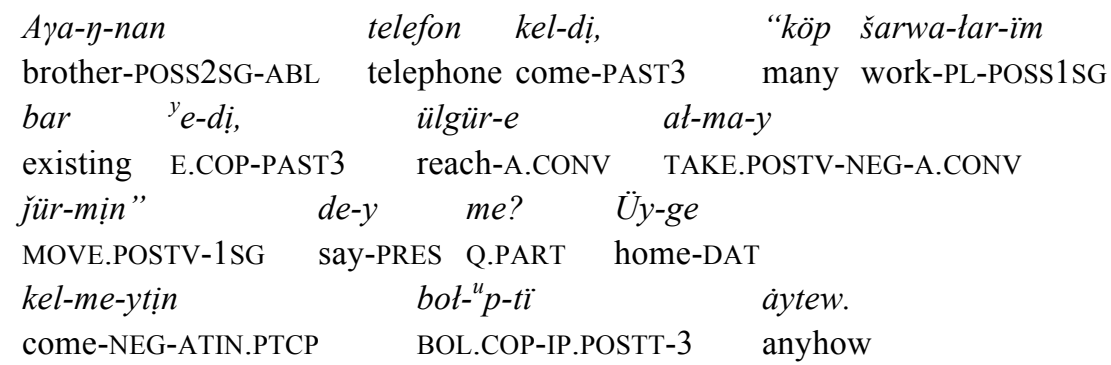

'There was a phone call from your brother, and he said "I have much work (to do), and (I) do not have any time" or something. Anyway he apparently will not come home.'

$B \dot{a} r i b^{i} r$ 'all the same, nevertheless'

Basic properties

The adverb $b \dot{a} r i b^{i} r$ can be used in the sense of 'all the same' or 'nevertheless'. In some cases, such as the first example below, the meaning can be interchangeable with aytewị / aytew 'anyway', 'anyhow'. Literally it comes from the pronoun $b \dot{a} r i$ ' all' and $b^{i} r$ 'one', or 'same'. Uyghur has a corresponding form bäribir with exactly the same function. This is a frequently used expression in other Turkic languages as well.

\section{Usages}

According to Zhang (2003: 215, 2004: 598), bärịb $b^{i}$ can indicate an unchangeable objective fact. We prefer to understand the function of $b \dot{a} r i b^{i} r$, for instance in Example 336, as expressing that the statement in the second clause is not conditioned by the statement made in the first clause. 
Example 336

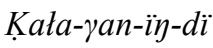

iste, $\quad$ bärị $b^{i} r$

want-GAN.PTCP-POSS2SG-ACC

do.IMP all the same

${ }^{y}$ ek-ken-ịy-di

at-a-sïy.

sow-GAN.PTCP-POSS2SG-ACC

take-A.PRES-COP2SG

'Do what you want, all the same, you reap what you have sown.'

In Example 337, $b \dot{a} r i b^{i} r$ is used in postpredicate position and expresses the attitude of the speaker.

Example 337

$\begin{array}{lllll}\text { Ket-se- } y & \text { ket-e } & \text { ber, } & \text { maran } & \text { bari } i b^{i} r . \\ \text { leave-HYP-2SG } & \text { leave-A.CONV } & \text { GIVE.POSTV.IMP } & \text { I.DAT } & \text { all the same }\end{array}$

'If you are leaving, then leave, it is all the same to me.'

The meaning conveyed by $b \dot{a} r i b^{i} r$ in Example 338 is the same as that of aytewir / aytew 'anyway'. The two adverbs are interchangeable in this example.

Example 338

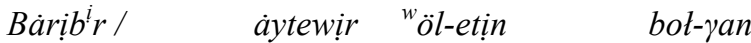

all the same anyway die-ATIN.PTCP BOL.COP-GAN.PTCP

soy, $\quad b^{i}$ rge ${ }^{w} \ddot{o l}$-eyik.

AFTER2.POSTP together die-VOL1PL

'We're dying anyway, so let us die together.'

Čamasï 'probably'

The adverb čamasï 'probably' indicates 'should be the case'. It goes back to the noun čama 'strength, power'.

Example 339

Aksakat ${ }^{30}$, čamasï, sịz poštašï-sïz yoy de-y-mịn.

sir probably you postman-COP2SG ГOY.PART say-A.PRES-COP1SG

'Sir, you should be a postman, I think.' (KD 10: 125)

Siyayï 'seemingly'

In Standard Kazakh, siyayi 'seemingly' $\leftarrow$ siyak 'appearance', siyki 'likely' $\leftarrow$ siyik 'physiognomy' may be found as sentence adverbs (KG 2002: 572) but this usage is not found in our data.

${ }^{30}$ Aksakat is a word used to address old persons politely. 
Example 340 Standard Kazakh

Siyayï, so-tar üy-de jok.

seemingly that-PL home-LOC not existing

'Seemingly, they are not at home.' (KG 2002: 572)

Example 341 Standard Kazakh

Siykï, so-łar ayt-pa-yan.

likely that-PL tell-NEG-GAN.POSTT3

'Seemingly, they did not tell.' (KG 2002: 572)

Asilli 'most probably', 'actually'

The adverb as illi 'actually, as a matter of fact' $\leftarrow$ asli 'fundamental, essential', is of Arabic/Persian origin. It expresses the speaker's assessment that the proposition is highly probable.

Example 342

Asilli $\quad{ }^{w}$ ot kel-me-y-dị.

most probably $\mathrm{X}$ come-NEG-A.PRES-3

'Actually, $\mathrm{X}$ is not coming.'

The other usage is when asili is used to express the meaning 'actually', 'as a matter of fact'. Zhang claims that $\dot{a}$ sil i 'actually' is used to correct a wrong estimation of a situation (2004: 616). Uyghur has the same adverb äsli 'actually' with similar function.

Example 343

But, assili, ${ }^{w}$ o-nïy katelig- $i \quad{ }^{y}$ emes $\quad{ }^{y} e$-dị.

this actually X.GEN mistake-POSS3 not E.COP-PAST3

'Zhè qíshí bìng bùshì tā de cuò.' (Zhang 2004: 616)

'This was not, actually, X's mistake.'

Sịra 'apparently, probably', zadï 'essentially', tegi 'obviously, apparently'

The adverbs sịra 'apparently, probably', zadï 'essentially', tegi 'obviously, apparently' are synonyms and express high probability. Uyghur employs the adverb zadi 'essentially' with similar functions. 
Example 344

${ }^{w}$ Osïnaw $\ddot{u} y$-de, ałayda, bar aw, sịá sïr

this house-LOC however existing AW.PART apparently secret

böten. J̌ayaÿ šat saray- $\gamma$ a teje-p, nege

strange aforesaid old man palace-DAT compare-IP.CONV why

kül-dị yeken?

laugh-PAST3 RHET.PART

'But there really is a secret in this house, probably. Why did that old man compare it to a palace and laugh?'

In the next example, the adverb occurs in a question. In this case, the speaker wants to elicit an exact answer (Zhang 2004: 627).

Example 345

Tegi kaysï- $y$-dịki durus čị-tï?

Precisely which-POSS2SG-NIKI right come out-PAST3

'Zuìhòu jiùjìng nǐmen shuí de duìle?' (Zhang 2004: 627)

'Precisely, which of your (answers) turned out to be right?'

Another adverb, synonymous to the above mentioned ones is, according to $\mathrm{KG}$, zayïri 'clearly, obviously' $\leftarrow$ zaxir 'prominent, obvious' of Arabic/Persian origin. According to this grammar, zayïrï can be added to a sentence ('kïstïrma müše') — sentence adverb in our terminology-to express the speaker's self assessment of the content. This lexical item may be used in some regions of Kazakhstan (2002: 574-575), but as mentioned above it does not occur in our data.

Example 346 Standard Kazakh

Zayïri, so-łar kel-e koy-mas.

clearly that-PL come-A.CONV PUT.POSTV-NEG.AOR3

'Obviously, they won't show up.' (KG 2002: 575).

\section{Certainty}

Arine / albette 'of course, certainly'

The adverbs arine / albette are used to indicate that the statement is established beyond doubt; i.e. it confirms the truth of the statement. It may be used in the sense of 'really', 'actually', 'certainly', 'indubitably' and 'of course'. Arine is of Iranian origin, from هر آيينه 'indeed, verily, certainly, undoubtedly' (APPED 2004: 3643), whereas àlbette is ultimately of Arabic origin with the form البته. They are interchangeable in meaning. The corresponding form in Uyghur is älwättä, and in Turkish elbet, elbette. The particles arine / albette may also be used in a meaning similar to Turkish tabii, a 
word of Arabic origin, written as طبيعي meaning 'naturally, of course' (Redhouse $\left.2000^{18}: 1075\right)$.

According to Zhang (2003: 234, 2004: 614), when these adverbs occur in sentence-initial position and carry the high tone, their function is to mark that in the speaker's opinion, the state of affairs referred to by the sentence is beyond doubt and obvious. When used alone as an utterance, these adverbs are normally stressed, i.e. the first syllable carries the high tone. In Example 347 , the whole sentence falls under the scope of the operator, and the stressed adverb affirms the whole statement.

Example 347

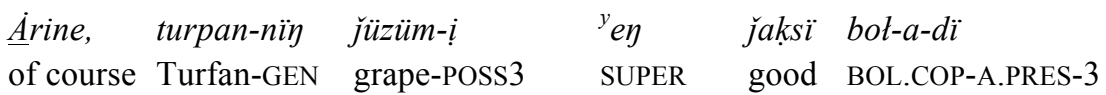
da.

DA.PART

'Dāngrán shì tǔlǔfān de pútáo zuì hăole ya.' (Zhang 2003: 234, 2004: 614)

['The best is, of course, the grape from Turfan.']

In Example 348, the operators arine / albette precede the predicate and only confirm the verb not the whole statement. As we can see from this example, the particle $D^{2} A^{2}$ (see Modal particles) can occur together with arine / albette.

Example 348

Bul pịkị-ge àke-m $\underline{a}$ rine/ $\underline{\text { allbette }}$

this opinion-DAT father-POSS1SG of course/ certainly

kelis-pe-y-dị de.

agree-NEG-A.PRES-3 DA.PART

'My father does not, of course, agree with this opinion.'

See a further example of the use of arine from our recordings.

Example 349

\begin{tabular}{|c|c|c|c|c|c|}
\hline Mübada & men & ${ }^{w} o d i$ & lünye-lịk & bot- ${ }^{u} p$ & ket-ip \\
\hline $\mathrm{nca}$ & I & $\mathrm{X} w$ & vorld-DER & BOL.COP-IP.CONV & LEAVE.POSTV-IP.CON \\
\hline$t-s a-m$ & & & menị & ${ }^{w}$ ot ̈̈r- $\gamma a n$ & $\ddot{u} y-\ddot{u} m$ \\
\hline & & & I.GEN & live-GAN.PTCF & house-POSS1SG \\
\hline asnang & & & $a d a$ & mat mülük-ter-ịm-nịn & $n g$ \\
\hline & & & DA.PART & property-PL-POSS1SG & SUPER \\
\hline
\end{tabular}




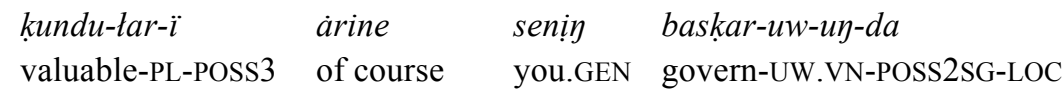

bot-a-dï.

BOL.COP-A.PRES-3

'In case I pass away, the house where I live, my home, and my most valuable other belongings, of course, will be in your hands.' (T7/2)

Zhang (2003: 234, 2004: 615) states that when arine / albette are not stressed they express objective evaluation in the sense of 'it is obvious that'.

Example 350

Arine/älbette munday köyịl güy-dị kazịr-gị kała of course / certainly this.EQUA mood state-ACC present-GI city turyun-dar- $\ddot{i}$ tüsün-e ber-me-y-dị. inhabitant-PL-POSS3 understand-A.CONV GIVE.POSTV-NEG-A.PRES-3 'It is obvious that people living in cities today often do not understand such feelings.'

The particles arine / albette are frequently used in poems, as the following examples illustrate.

Example 351

\begin{tabular}{|c|c|c|c|c|}
\hline $\begin{array}{l}\text { Kör-gen-c } \\
\text { see-GAN.P }\end{array}$ & $\begin{array}{l}\text { ler- } i-n \\
\text { TCP-PL-PO }\end{array}$ & SS3-ACC & $\begin{array}{l}\text { yasïr-łar } \\
\text { century-PL }\end{array}$ & $\begin{array}{l}s \ddot{u} y-u ̈ p-t i \\
\text { love-IP.POSTT-3 }\end{array}$ \\
\hline arine & ${ }^{w} o-t a r$ & top-ti & ${ }^{w} o z-\gamma a n$ & jüyrük-ter, \\
\hline of course & X-PL & a group-ACC & exceed -GAN.PTCP & runner-PL \\
\hline sàlem & saran & šïk-pa- & biyịk & ter! \\
\hline eeting & you.DAT & climb-1 & NEG-GAN.PTCP & \\
\hline
\end{tabular}
(What they saw), of course, were the forerunners who left the others behind. Greetings to you, we have not succeeded better.' (Aybergenov 2005)

Example 352

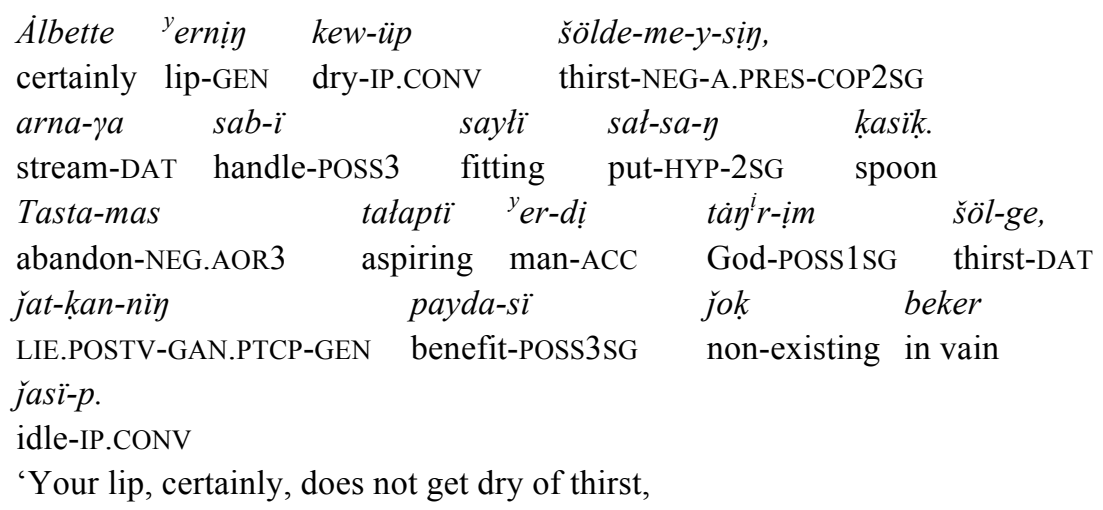


if you put a spoon with a fitting handle into the stream.

God will not let the aspiring man be thirsty,

there is no benefit in being uselessly idle.' (Šorayaḳov1984: 44)

Sözsịz, sözjok 'surely'

Sözsịz 'surely' is derived from söz 'word' with the private suffix $\left\{-\mathrm{sI}^{2} \mathrm{z}\right\}$ literally meaning 'without a word'. The complex adverb sözjok 'surely', from $s \ddot{z} z$ 'word' and jok 'non-existing', also expresses certainty. Both convey the meaning that the speaker does not have any doubt about the truth of the statement.

Example 353

J̌ẹịs sözsịz/sözjok bịz-dịkị.

victory surely we-NIKI

'The victory is definitely ours.'

\section{Constructions expressing volition}

\section{Order}

One of the lexical items expressing the notion of giving an order is the verb buyur- 〈buyïr-〉 'to order to be done'. The person who is getting the order functions as the object of the verb buyur-, and the action s/he is ordered to carry out is expressed by an infinitive phrase assigned the dative case.

Example 354

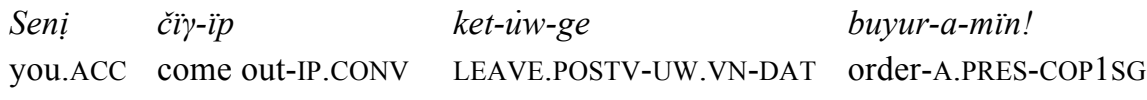

'I order you to go out!'

The same meaning can also be expressed with the participant who gets the order in the dative case and the action to be carried out being the object of the verb buyur- 'to order'. See the alternative version in Example 355.

Example 355

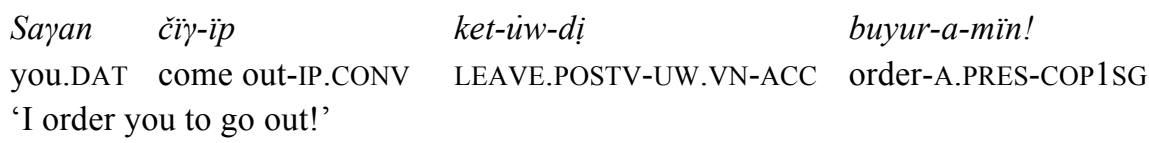

The following example illustrates the case when the verb takes both the participant and the action as objects. Both constituents are assigned the accusative case. Such a double accusative marking would be not accepted in Turkish. 
Example 356

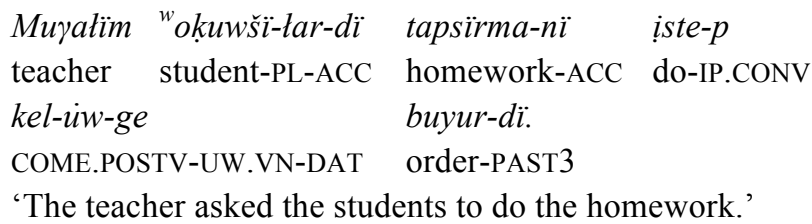

This use of buyur-, as in Examples 355 and 356, sounds solemn and ceremonious. Zhang (1990a: 90) observes that such expressions are used only on formal occasions when the addresser has a higher social position than the addressee. These expressions often occur in texts translated from Chinese, because in Chinese there is no imperative mood and orders are expressed by lexical means, e.g. by the verb mingling 'to order'. In Kazakh as spoken in China, the frequent use of the verb buyur- 'to order' is a frequential copy of the corresponding Chinese expression. See the Chinese translations of Example 355 .

Example 357

Wǒ mìnglìng ň̀ chūqù.

I order you go out

'I order you to go out.'

In Standard Kazakh, the expression buyur-a-mïn 〈order-A.PRES-COP1SG〉 'I order that, I command that' is used in the announcement of a constitutional judgment in the court, written in capital letters 〈БҰЙЫРАМЫН〉. See the following example.

Example 358 Standard Kazakh

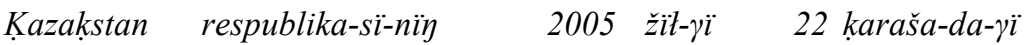

Kazakhstan republic-POSS3SG-GEN 2005 year-GI 22 November-LOC-GI

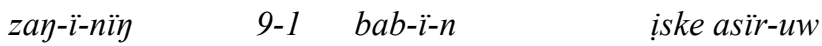

law-POSS3-GEN 9-1 chapter-POSS3-ACC put into practice-UW.VN

maksat-ïn-da BUYUR-A-MÏN:...

intention-POSS3-LOC order-A.PRES-COP1SG

'I proclaim the coming into force of the law of Nov. 22, 2005 paragraph 9/1 of the Republic of Kazakhstan.’

\section{Requesting, suggesting}

Requests in written applications can be expressed lexically by using the verbs 'ötin- 'to entreat, ask', sura- 'to beg' or tałap 'et- 'to request, ask'. Zhang observes (1999: 92) that because of their formal style, the polite form of the infinitive, i.e. $\left\{-\left(\mathrm{I}^{2}\right) \eta \mathrm{I}^{2} \mathrm{z}\right\}$, has to be used in the complement clause. The plural can optionally be added. 
Example 359

${ }^{w}$ Ötịnị̌s-ịm-di

kabïlda-w-(tar)-ïÿ̈z-dï

application-POSS1SG-ACC accept-UW.VN-(PL)-POSS2SG-ACC

wötịn-e-mịn / sura-y-mïn.

entreat-A.PRES-COP1SG inquire-A.PRES-COP1SG

'I entreat you to accept my application.'

The following example taken from our recordings illustrates the usage of the verb tałap ${ }^{y}$ et- 'to request, ask'.

Example 360

J̈̈yeden aya-łar-ïy-nïy

in particular brother-PL-POSS2SG-GEN and brother-PL-POSS2-GEN

da pikin-i-n at-ïp, tïnïs, ïntïmaktï

DA.PART opinion-POSS3-ACC take-IP.CONV peace collaboration

negịz-ịn-de menịy artkï mat mülk-üm-e iyelịk

basis-POSS3-LOC I.GEN last property-POSS1SG-DAT own

${ }^{y}$ et-iuw-üy-dị tałap ${ }^{y}$ et-e-min.

DO.LIGHTV-UW.VN-POSS2SG-ACC request DO.LIGNTV-A.PRES-COP1SG

'In particular, I ask you to listen to the advice of your elder brothers, as well as your younger brothers, and to possess my last properties on the basis of peace and collaboration.' (T7/ 3)

Suggestions can be expressed by the compound verb usunus ${ }^{y}$ et- 〈usïnïs et-〉 'to suggest'.

Example 361

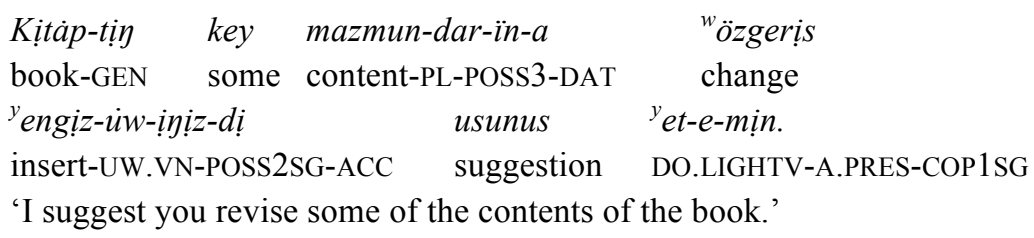

The addressee who is expected to carry out the speaker's proposal can be the subject of the complement clause. In this case, the subject of the complement clause is in the genitive. The following example illustrates the case when the subject siz-dị 〈you-GEN〉 'your' is included to the complement clause of the sentence given in Example 361.

Example 362

\begin{tabular}{|c|c|c|c|}
\hline $\begin{array}{l}S i ̣ z-d i ̣ \eta \\
\text { you-GEN }\end{array}$ & $\begin{array}{l}\text { kịtáp-tịn } \\
\text { book-GEN }\end{array}$ & $\begin{array}{l}\text { key } \\
\text { some }\end{array}$ & $\begin{array}{l}\text { mazmun-dar-ïn- } a \\
\text { content-PL-POSS3-DAT }\end{array}$ \\
\hline
\end{tabular}


${ }^{y}$ engị-uiw-ịniz-di

usunus $\quad{ }^{\text {eet-e-min. }}$

insert-UW.VN-POSS2SG-ACC suggestion DO.LIGHTV-A.PRES-COP1SG

'I suggest you revise some of the contents of the book.'

If the participant who is expected to carry out the proposal is a complement of the verb usunus ${ }^{y}$ et- then it is assigned the dative case; see for instance siz-ge 〈you-DAT) 'to you' in Example 363.

Example 363

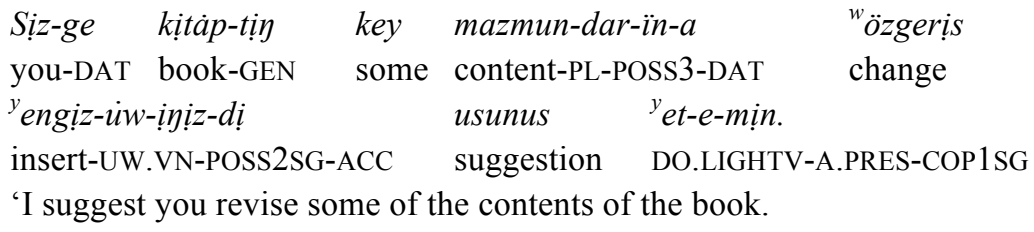

\section{Wishing}

A wish can be expressed lexically with the verb kata- 'to want, wish'. The non-main verb in the complement clauses occurs in the form of an infinitive and takes the accusative.

Example 364
But jer-ge
kel-iww-ị-n
kała-y-mïn.
this place-DAT come-UW.VN-POSS3-ACC
want-A.PRES-COP1SG

'I want $\mathrm{X}$ to come here.'

An overt subject of the infinitive takes the genitive: ${ }^{w}$ o-nïg kel-iw-i-n $\langle$ X.GEN come-UW.VN-POSS3SG-ACC .

Similar volitional predicates include tịle- 'to wish, desire', ümüt ${ }^{y} e t$ - <ümịt et-> 'to hope', armanda- 'to hope, aim at', kökse- 'to wish, desire'. Example 365 illustrates a case with the lexical verb tile- 'to wish, desire'.

Example 365

${ }^{y}$ Endi mïnaw negiz-i-nen ${ }^{y}$ endi sot àke NOW.FILL this is principle-POSS3-ABL NOW.FILL that father

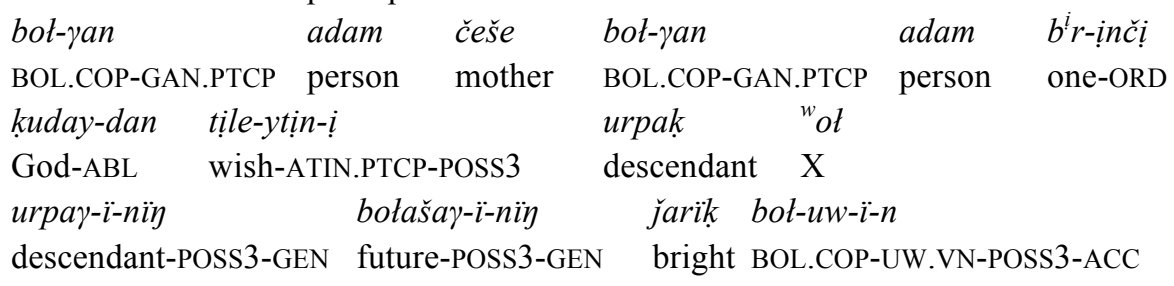


tịle-y-t.

wish-A.PRES-3

'It is in principle so that a father, a mother, wishes from God first of all that the children, the future of his/her children will be bright.' (T6/ 17)

\section{Constructions expressing necessity}

Necessity may be expressed by complex forms based on adjectival operators, such as kajet, kerek, tiyịs 'needed, necessary' together with a verbal noun. English interpretations can use such as modal verbs such as 'must', 'have to', 'should', or an adjective 'necessary'. Such expressions are impersonal and are often used to describe an expected or recommended behavior or expected circumstances. They can be used to give advice or to state social or ethical norms or behaviors, though without strong obligatory force. The negated expressions are built by adding 'emes 'is not' after the modal operators, or simply substituting kažetsịz 〈need-DER〉 'needless, unnecessary' for these modal operators. See Examples 366 and 367 for the use of these expressions of necessity.

Example 366

Ülken-der-dịn atdïn-da kelịn-der ibati bot-uw

elder-PL-GEN front.POSS3-LOC bride-PL courteous BOL.COP-UW.VN

kerek.

necessary

'Brides must be courteous towards old people.' (T8/2)

Example 367

But mịndet-ti way-ïn-da atkar-uw kajet/kerek/tiyis.

this task-ACC time-POSS3-LOC fulfill-UW.VN necessary

'One should complete this task in time. / It is necessary to complete this task in time.'

If the infinitive has an overt subject it is optionally assigned either the nominative or the genitive, as in Example 368. The different case assignments do not have any bearing on the meaning of the sentence.

Example 368

But mịndet-tị bịrew / bịrew-dịn way-ïn-da

this task-ACC somebody/somebody-GEN time-POSS3-LOC

atkar-uw-ï kajet/kerek/tiyis.

fulfill-UW.VN-POSS3 necessary

'Somebody has to do this in time.' 
According to KG (2002: 577), kerek construed with a verbal noun can also express the speaker's subjective assessment in some contexts.

Example 369

${ }^{y}$ Endị-gị šara katat sögis bot-uw kerek.

now-GI solution cruel reprimand BOL.COP-UW.VN necessary

'Now the solution must be a cruel reprimand.' (KG 2002: 577)

In old texts written in literary Kazakh, the construction is sometimes built with the verbal noun in $\left\{-\mathrm{M}^{3} \mathrm{~A}^{2} \mathrm{k}\right\}$ (see Non-modal expressions) in the nonmain clauses.

The word tazïm 'necessary, ought' can be construed with the participle in $\left\{-G^{4} A^{2} n\right\}$, as in Example 370, or with the verbal noun in $\left\{-\mathrm{w} / /-(\varnothing) \mathrm{U}^{2} \mathrm{w}\right\}$, as in Example 371, in order to express necessity.

Example 370

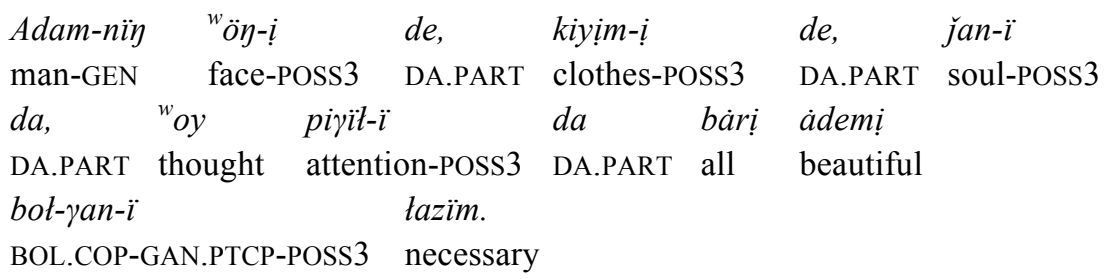

'One has to be beautiful both in face, clothes, soul, and thoughts.' (Kekilbayev 2013: 166)

Example 371

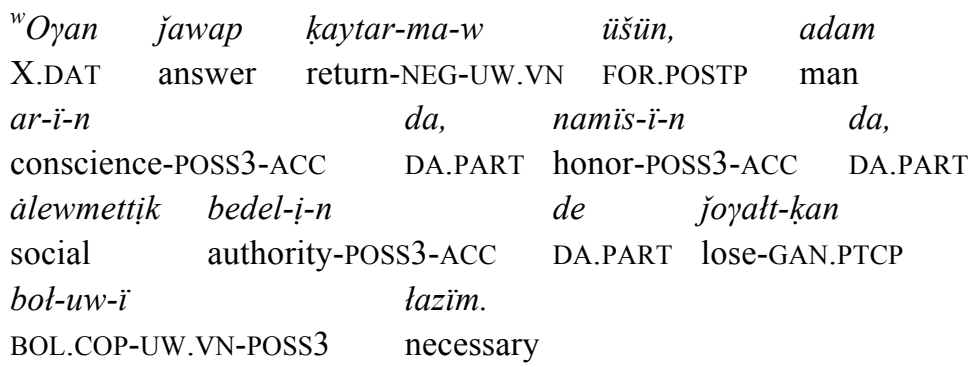

'For not giving an answer to $\mathrm{X}$, one should lose his/her conscience, honor, and social authority.' (DKLL $5: 654$ )

In order to express the meaning 'not necessary' the word kažet-siz 'needless, unnecessary' derived with the privative suffix $\left\{-\mathrm{sI}^{2} \mathrm{z}\right\}$ is used. In this case the verbal noun in $\left\{-\mathrm{w} / /-(\varnothing) \mathrm{U}^{2} \mathrm{w}\right\}$ has to be chosen. 
Example 372

$\begin{array}{ll}\text { Kel-iw-ịn } & \text { kajetsịz. } \\ \text { come-UW.VN-POSS2SG } & \text { needless } \\ \text { 'You do not need to come.' } & \end{array}$

Objective evaluations of necessity can be expressed with another impersonal

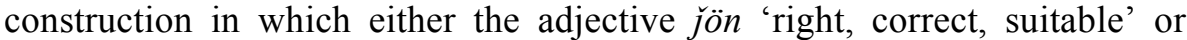
abzat 'right, correct, admissible' is used in combination with a participle in $\left\{-G^{4} A^{2} n\right\}$. In the corresponding English translations, modal verbs such as 'ought to' or 'had better' can be used. The constructions are mainly employed to express recommendations or expected behavior. Observe that $a b$ $z a t$ is less frequently used. The negated expression is more frequently expressed with kažetsiz 〈need-DER〉 'needless, unnecessary'.

Example 373

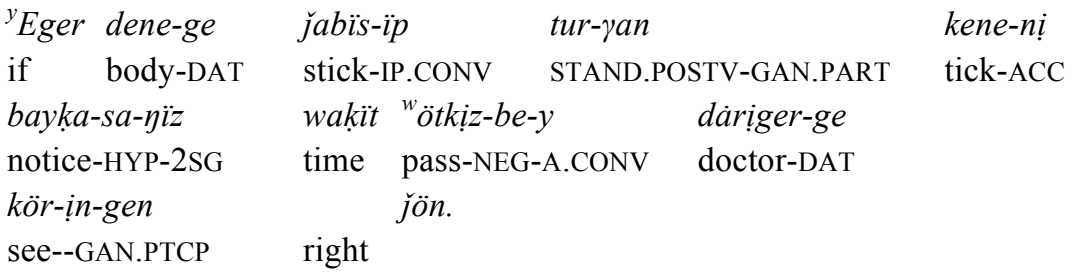

'When you notice a tick attaching itself to your body, you had better see a doctor before it is too late.'

Example 374

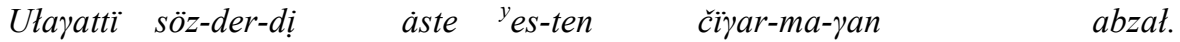
wise word-PL-ACC at all mind-ABL eliminate-NEG-GAN.PTCP correct 'One should never forget the wise words.'

An overt subject of the participle takes either the nominative or the genitive, as in Example 375. A possessive suffix attached to the participle marks agreement with the subject.

Example 375

$\begin{array}{llll}{ }^{y} \text { Ermek } /{ }^{y} \text { Ermek-tị } & { }^{w} \text { o- } \gamma a n & \text { bar-ïp } & \text { ayt-kan- } \ddot{l} \\ \text { Ermek / Ermek-GEN } & \text { X.DAT } & \text { go-IP.CONV } & \text { tell-GAN.PTCP-POSS3 }\end{array}$

jön / abzat.

right

'It would be better for Ermek to go and tell X.'

Some similar constructions are based on adjectives such as durus «durïs) 'right, true, correct', tayik 'suitable, appropriate'. The lexical verb can be either a verbal noun or a participle form in $\left\{-G^{4} A^{2} n\right\}$. 
Example 376

$\begin{array}{lllll}\text { Akïn-dar-dï } & \text { kategoriya-ya } & \text { böl-iw } & \text { durus/layik } & { }^{y} \text { emes. } \\ \text { poet-PL-ACC } & \text { category-DAT } & \text { divide-UW.VN } & \text { right/suitable } & \text { not }\end{array}$

'It would be better not to categorize the poet.'

Example 377

Kïz bata adepti bot-yan durus/tayï.

female child courteous BOL.COP-GAN.PTCP right/suitable

'The girl had better be courteous.'

The necessity marker šart 'essential' can occur with a verbal noun. The definition given to this term in DKLL $(15: 270)$ is necessary, “〈керек, қажет деген мағынада〉", however, the construction seems to indicate a stronger obligation than the other expressions of necessity, and can be translated into English as 'absolutely necessary', 'must', 'need to' or 'be required to'.

Example 378

Koy-dï 'örbịt-uw üsü̈n, $\quad{ }^{y}$ ey atd-ï-men

sheep-ACC fertilize-UW.VN FOR.POSTP SUPER front-POSS3-WITH.POST

tiyisti jayday bol-uw šart.

necessary condition BOL.COP-UW.VN essential

'For fertilizing sheep, it is first of all absolutely necessary to ensure suitable conditions.' (DKLL 15: 270)

There are also other expressions denoting strong obligation, for instance, the lexical item mindetti 'obligatory' construed with the dative form of the verbal noun. Example 379 can express both objective and subjective evaluation.

Example 379

Akel-uww-ge mịndetti-sịn.

bing-UW.VN-DAT obligatory-COP2SG

'You are obliged to bring (it).'

Another lexical item, mážbuir 'constrained, compelled', takes a complement clause based on the dative form of a verbal noun. Unlike other modal constructions this always expresses objective evaluation. A comparable English interpretation is 'be obliged to', 'have to'.

Example 380

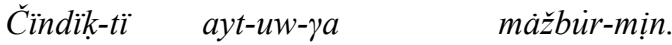

truth-ACC tell-UW.VN-DAT compelled-COP1SG

'I have to tell the truth.' 
When referring to necessity in the past, the copula bot-dï 〈BOL.COP-PAST3〉 must be added. See Examples 381 and 382.

Example 381

${ }^{w} O$-łar-dï üy-ge šakïr-uw-ïm kerek/kajet

X-pl-ACC home-DAT invite-UW.VN-POSS1sG necessary

bot-di.

BOL.COP-PAST3

'It was necessary for me to invite them home.'

Example 382

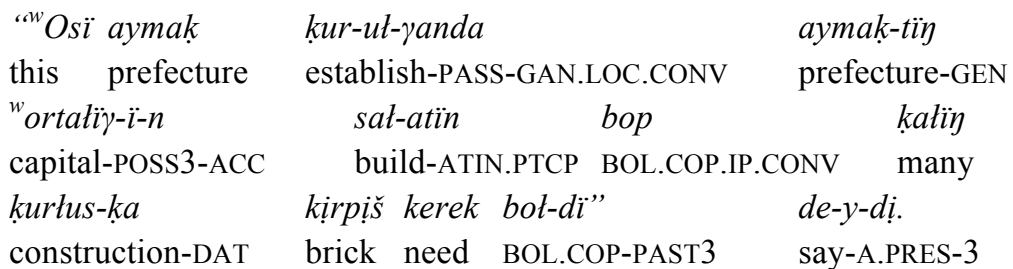

"'When the prefecture was founded, many bricks were needed to build the capital of this place", he writes.' (T4/74)

If the past copula ${ }^{\mathrm{y}} e-d i\langle$ E.COP-PAST 3$\rangle$ is attached, the meaning is counterfactual; see Example 386.

Example 383

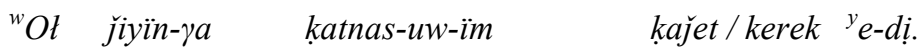

$\mathrm{X}$ meeting-DAT attend-UW.VN-POSS1SG necessary E.COP-PAST3

'I should have attended that meeting.'

\section{Comparison with Uyghur}

The Uyghur expressions of necessity are very similar to the Kazakh ones. According to Yakup (2009), the most significant difference between Kazakh and Uyghur in this respect is that Kazakh does not possess grammaticalized verbal suffixes that could be categorized as necessity markers. The other expressions are almost all the same, except for some lexical items that are different in the two languages. Constructions are built in Uyghur with the adjectives lazim, kerëk, zörür 'necessary' and šärt 'essential' construed with verbal nouns in $\left\{-\left(\mathrm{I}^{3}\right)\right.$ š $\}$ or in very few cases $\left\{-\mathrm{mA}^{2} \mathrm{~K}^{2}\right\}$. Observe that zörür 'necessary' is not used in Kazakh.

Example 384 Uyghur

Yol-da may-randa kattik dikkät kil-mak

road-LOC walk-GAN.LOC.CONV strong attention do-INF 
lazim/keräk/zörür/šärt.

necessary

'One should be very careful when walking on the road. / It is necessary to be very careful when walking on the road.'

Example 385 Uyghur

Wakit-ka ämäl kil-iš lazim/keräk/zörür/šärt.

time-DAT obey do-VN necessary

'One should respect the time. / It is necessary to respect the time.'

Yakup (2009: 490) mentions an expression based on the compound verb to rra käl- 'fit, suitable' construed with the dative case of a verbal noun. He considers the construction to be a less grammaticalized expression of necessity. In our opinion, however, the lexical item toyra käl-, from indicating the meaning of 'fit' and 'suitable' to the meaning of 'have to', has already gone through a slight process of grammaticalization. This expression also exists in Kazakh.

Example 386 Uyghur

\begin{tabular}{|c|c|c|c|c|}
\hline $\begin{array}{l}\text { Doktor-luk-ka } \\
\text { doctor-DER-DAT }\end{array}$ & $k i r-i \check{S}$ & üčün & čät'äl & til-i-din \\
\hline $\begin{array}{ll}\text { han } & b \dot{e} r-i s ̌-k \ddot{a} \\
\mathrm{n} & \text { give-VN-D }\end{array}$ & & $\begin{array}{l}k \dot{e} l-i-d u . \\
\text { o-PRES-3 }\end{array}$ & & \\
\hline
\end{tabular}

'In order to become a $\mathrm{Ph} . \mathrm{D}$. student one has to take an exam in a foreign language.' (Yakup 2009: 490)

The corresponding Kazakh expression would be as in the following example. Example 387

$\begin{array}{llll}\text { Doktorant-ka } & \text { kabïłda- } n \text { - } u w & \ddot{u} \text { šün } & \text { čet } \\ \text { doctor-DAT } & \text { accept-REF.PASS-UW.VN } & \text { FOR.POSTP } & \text { foreign }\end{array}$

tịl-ị-nen $\quad{ }^{y}$ emtikan ber-uw-ge $t^{u}$ wrakel-e-dị.

language-POSS3-ABL exam give-UW.VN-DAT have to-A.PRES-3

'In order to be accepted as a Ph.D. student one has to take an exam in a foreign language.'

\section{Constructions expressing possibility}

The notion of possibility comprises a scale of meanings ranging from permission to prohibition in a predominately deontic sense. Permission can be expressed in Kazakh by an impersonal expression based on the present tense

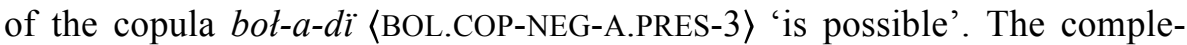
ment is a verbal noun in the dative or a clause based on a hypothetical verb form. 
Example 388

Kịr-üw-ge bot-a-dï.

enter-UW.VN-DAT BOL.COP-A.PRES-3

'It is possible to come in.'

Example 388 has an impersonal reading. In other cases, the personal reference is marked with a possessive marker attached to the verbal noun or to the hypothetical form $\left\{-\mathrm{sA}^{2}\right\}$; see Example 389 .

Example 389

$\begin{array}{lll}\text { Kị- } \dot{u} w \text { - } i \eta \eta-e / & k i r-s e-\eta & b o t-a-d \ddot{i} . \\ \text { enter-UW.VN-POSS2SG-DAT } & \text { enter-HYP-2SG } & \text { BOL.COP-A.PRES-3 }\end{array}$

'It is possible for you to enter.'

Note that according to Zhang (1990a: 93, 2004: 421), when the hypothetical form of the verb bears the sentence accent, this construction can indicate that the speaker is suggesting something to the interlocutor. In Example 390, the addresser speaks about his/her own judgment.

Example 390

Doxtïr-ya bir körịn-se-niz bot-a-dï.

doctor-DAT a be visible-HYP-2SG BOL.COP-A.PRES-3

'Nín yīnggāi zhăo yīshēng qù kàn yī kàn.' (Zhang 2004: 422)

['You should go and see a doctor.']

In Uyghur, the negated copula bol-ma-y-du〈BOL.COP-NEG-A.PRES-3〉 'it is not possible' with a complement clause based on a negated hypothetical form in $\left\{-\mathrm{mI}^{2}-\mathrm{sA}^{2}\right\}$ expresses strong necessity (Yakup 2009: 487). The same is also true for Kazakh. The necessity expressed by Example 391 is stronger than that expressed in Example 390.

Example 391

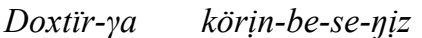
bot-ma-y-dï.

doctor-DAT be visible-Q.PART-HYP-2SG BOL.COP-NEG-A.PRES-3

'You absolutely must see a doctor.'

Permission can be expressed impersonally by the passive forms of the compound verbs jotber- 'to allow' or ruksat 'yet- 'permit to'. The complement of these verbs is a verbal noun in the dative, as in the following Examples 392 and 393. 
Example 392

Kịr-üw-ge jołber-ịl-e-dị.

enter-UW.VN-DAT allowed-PASS-A.PRES-3

'Entering is allowed. / One may enter.'

Example 393

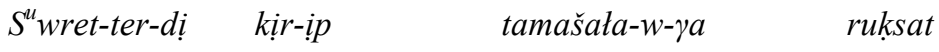

picture-PL-ACC enter-IP.CONV watch-UW.VN-DAT permit

${ }^{y}$ et-ịl-e-dị.

DO.LIGHTV-PASS-A.PRES-3

'It is permitted to enter and look at the pictures. / One may enter and look at the pictures.'

Observe that, in spoken registers, there is another impersonal expression built with the passive form of the compound verb jot koy- 'put on the way'. This construction seems to have been copied from Uyghur.

Example 394

Kir-iww-ge jotyoy-ït-a-dï.

enter-UW.VN-DAT allow-PASS-A.PRES-3

'Entering is allowed. / One may enter.'

Prohibition can be expressed with the negated form of the copula botadi ' is possible', i.e. bot-ma-y-dï 〈BOL.COP-NEG-A.PRES-3〉 'is not possible'; see Example 395. The complement of bot-ma-y-dï is a clause based on the dative form of a verbal noun.

Example 395

Temeki tart-uw- $\gamma a \quad$ bot-ma-y-dï.

tobacco smoke-UW.VN-DAT BOL.COP-NEG-A.PRES-3

'Smoking is not allowed.'

The subject of the complement clause can be represented by a possessive suffix on the verbal noun, e.g. ${ }^{w} \ddot{o t}-\dot{u} w$-ler-in-e 〈pass-VN-PL-POSS2SG-DAT〉 'your passing' in Example 396.

Example 396

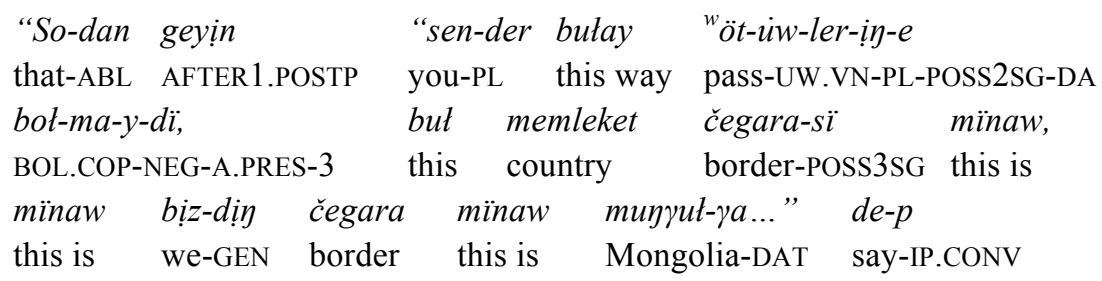




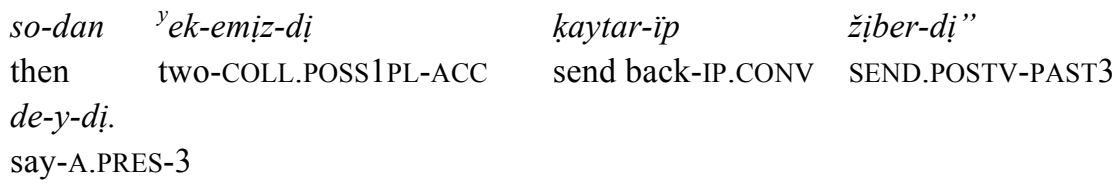

“"Then they said, 'You cannot pass like this, this is a country border, this is our border, this is the border of Mongolia...' Then, they sent us back", he writes.'

(T4/ 54)

The verbs tiyịm sat- 'to forbid, to prohibit', čekte- 'to forbid', teje- 'to restrict, to limit' or jot berme- 'not to give way', ruksat y etpe- 'not to permit' can also be used to express prohibition. Example 397 illustrates prohibition expressed with tiyim sat-.

Example 397

$\begin{array}{ll}\text { Temeki } \quad \text { tart- } u w & \text { tiyịm sat-ïn- } a \text {-dï. } \\ \text { tobacco } \quad \text { smoke-UW.VN } & \text { forbid-REF.PASS-A.PRES-3 } \\ \text { 'It is forbidden to smoke.' } & \end{array}$

\section{Constructions expressing probability}

A number of lexical items can render different meanings of probability and likelihood. Zhang describes them as particles (Zhang 2004). We treat them here as lexical items because they still have, to some degree, their original lexical meanings. Some of them can be inflected in person and number and take complements, namely complement clauses based on non-finite verb forms.

\section{Bołar, čĭ}

In some Turkic languages probability is expressed with a grammaticalized mood such as, the presumptive marker $\left\{-\mathrm{D}^{2} \mathrm{I}^{4} \mathrm{r}\right\}^{31}$ in Turkish, or $\{-\mathrm{Du}\}^{32}$ in Uyghur. A frequently used expression in Kazakh is the copula bot-ar 〈BOL.COP-AOR3〉 'it is probable' $\leftarrow$ bot- 'to become/be, to become/be possible', and čî-ar 〈COME OUT-AOR3〉 'can turn out to be' $\leftarrow$ čik- 'to turn out, result'. The difference between bołar and čijar can be described as their expressing different degrees of probability. Botar is used when the probability is not high. As for čijar, it is used to denote a higher degree of probability but not certainty. Bołar and čijar can be, in some cases, used interchangeably. Personal endings of the first and second persons can be added.

\footnotetext{
${ }^{31}$ For instance, Herhalde bir yer-ler-de karşılaş-mış-lz-dır (probably one place-PL-LOC meetPOSTT-1PL-DIR) 'We have probably met somewhere or other'. (Göksel and Kerslake 2005: 343, Example 81).

${ }^{32}$ For instance, Uyghur Äxmät öy-dä bar $d u\langle$ Ahmet home-LOC existing DU.COP3〉 'X might be at home'.
} 
See the two Examples 398 and 399, in which bołar and č̈jar takes nominal complement clauses.

Example 398

$\begin{array}{llllll}\text { Menịy } & \text { kökey-ịm-de } & \text { jür-gen } & b^{i} r & \text { bała } & \text { bar, } \\ \text { I.GEN } & \text { thought-POSS1SG-LOC } & \text { move-GAN.PTCP a } & \text { child } & \text { existing }\end{array}$

$b^{i} r$ 'opati sot bot-ar.

a faithful that is possible-AOR3

'One boy is on my mind, that is probably the faithful one.'

Example 399

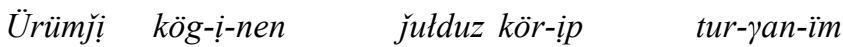

Ürümqi sky-POSS3-ABL star see-IP.CONV STAND.POSTV-GAN.PTCP-POSS1SG

${ }^{w}$ osï čĭ -ar.

this turn out-AOR3

'This is probably the first time I have seen a star in the sky of Ürümqi.'

The non-finite verb forms in the complement clauses can express different viewpoints. A $\left\{-G^{4} A^{2} n\right\}$ form renders a postterminal viewpoint; see Example 400.

Example 400

$\ddot{U} y$-ge kayt-ïp kel-gen bot-ar.

home-DAT return-IP.CONV COME.POSTV-GAN.PTCP be possible-AOR3

'X probably has returned home.'

Intraterminal or prospective meanings are expressed by $\left\{-\mathrm{A}^{2} \operatorname{tI}^{2} \mathrm{n} / /-\mathrm{yt} \mathrm{II}^{2} \mathrm{n}\right\}$.

Example 401

Bu-łar-dï sat-atïn čĭ -ar.

this-PL-ACC sell-ATIN.PTCP turn out-AOR3

'X will probably sell these.'

Focal intraterminal viewpoint can be expressed with the converb in $\left\{-\left(\mathrm{I}^{4}\right) \mathrm{p}\right\}$ of the lexical verb and the $\left\{-G^{4} A^{2} n\right\}$ form of a postverb. The postverb can be one of the following: 'oẗ̈r- 'to sit down, sit', / tur- 'to stand', / yür- 'to move, go on' / jatïr- 'to lie down, lie'. See Example 405.

Example 402

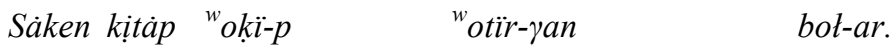

Säken book read-IP.CONV SIT.POSTV-GAN.PTCP be possible-AOR3

'Sảken is probably reading a book.' 
The four verbs 'otïr- 'to sit down, sit', / tur- 'to stand', / jür- 'to move, go on' / jatïr- 'to lie down, lie' can, of course, also be used as lexical verbs; see Example 406.

Example 403

Murat mektep-te jür-gen čĭ-ar.

Murat school-LOC move-GAN.PTCP turn out-AOR3

'Murat is probably at school now.'

If the lexical verb in the complement clause is a converb in $\left\{-\mathrm{A}^{2} / /-\mathrm{y}\right\}$ then only the postverb jat- 'to lie down, go to bed, be lying, be in bed' can be used; see Example 404.

Example 404

Murat mektep-ke bar-a jat-kan čĭ-ar.

Murat school-DAT go-A.CONV LIE.POSTV-GAN.PTCP turn out-AOR3

'Murat is probably going to the school now.'

Č̈jar can be pronounced with an interrogative intonation, as a tag question. In this case, it denotes a high degree of certainty.

Example 405

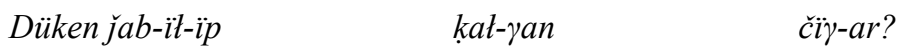

store close-PASS-IP.CONV STAY.POSTV-GAN.PTCP turn out-AOR3

'The store has certainly closed.'

Körịnedị and uksaydï

Likelihood is expressed by körịn-e-dị 'it seems' 〈be visible-A.PRES-3〉

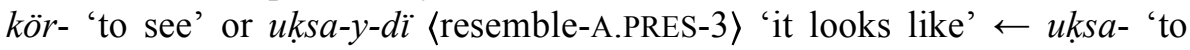
resemble'. These expressions are used either in impersonal constructions or as modal adverbs modifying predicates; see Examples 406 and 407, respectively.

Example 406

O-łar mayan kurt may ber-ịp jat-kan körịnedị.

X-PL I.DAT kurt fat give-IP.CONV LIE.POSTV-GAN.PTCP probably

'It seems that they give me kurt $^{33}$ and butter.'

Example 407

So gez-de àgi ${ }^{w} o$ kisi imam motda

that time-LOC AFORESAID.FILL $X$ person Imam Mullah

\footnotetext{
${ }^{33}$ A traditional Kazakh food made from solid yogurt. The solid yogurt is cut into small pieces and must be dried in the sun for some days (Kurał 2003: 178).
} 


\begin{tabular}{|c|c|c|c|c|}
\hline${ }^{w} o k \grave{s} s-y-t$ & so & \multicolumn{2}{|c|}{ mołta-łar-dï } & $k o t-\gamma a$ \\
\hline like-A.PRES-3 & THAT.FILL & Mulla & $\mathrm{L}-\mathrm{ACC}$ & hand-DAT \\
\hline 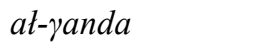 & apa & & $a t-\ddot{p} p$ & \\
\hline ake-GAN.LOC.CON & take & P.CONV & shoot & ONV \\
\hline tasta- $p-t i$ & & nespe. & & \\
\hline
\end{tabular}

THROW.POSTV-IP.POSTT-3 EMESPE.PART

'I guess that the person mentioned before (the brother) was an imam, a mullah. When the mullahs were arrested they took him and shot him.' (T4/70)

Siyaktï, sïkïldi, sekịldị, and $\dot{a} l p e t t i$

The postpredicate modal operators siyaktï 'like, similar' $\longleftarrow$ sïyak 'appearance, image', sïkïlï 'like, similar' $\leftarrow$ sïkï 'color', sekịldị 'like, similar' $\leftarrow$ sekịl 'form', àlpetti 'like, similar' $\leftarrow$ àlpet 'appearance' express likelihood. See Examples 408 and 409 for the use of siyaktï 'like, similar'. Example 409 illustrates a high-copying varity in which the copied Chinese elements are underlined.

Example 408

Kel-gen jot-ïmïz ${ }^{w}$ osï (but ${ }^{y}$ emes) siyaktï.

come-GAN.PTCP way-POSS1PL this (this not) seemingly

'Hǎoxiàng zánmen lái shí de lù (bù) shì zhè tiáo.' (Zhang 2004: 624)

['This seems (does not seem) to be the way we came.']

Example 409

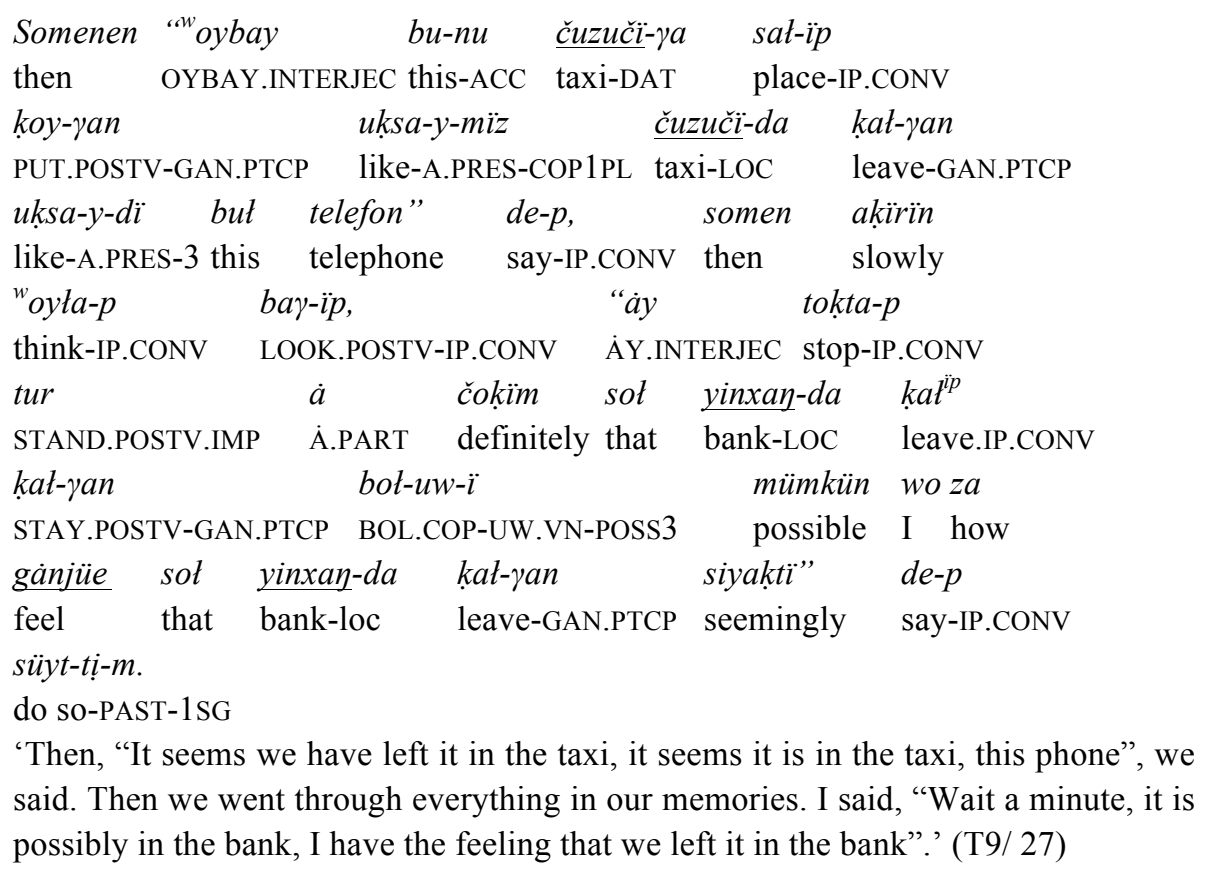




\section{Mümkün, ïktimat, kädịk}

Low probability is expressed by using the items mümkün 〈mümkịn〉 'possible', ïktimat 'probable', šübàli 'doubtful, suspicious', or kädịk 'improbable'. They take complement clauses based on a verbal noun. The subject of the complement clause is in the genitive as in Example 410. Observe that the same subject could also be in the nominative without changing the meaning. In this example, the adverb ábden 'completely' is used to express a higher degree of probability.

Example 410

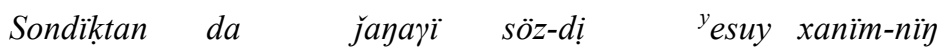
consequently DA.PART aforesaid word-ACC Yesui lady-GEN ayt-uw-ï ábden mümkün. tell-UW.VN-POSS3 completely possible 'Consequently, it is completely possible that lady Yesui said the aforesaid words.' (Jurtbayev 2005: 56)

In Example 411, the complement clause bes jas ilgerị ne keyin botuwi ' $\mathrm{X}$ 's being five years older or younger' follows the predicate mümkün 'possible'.

Example 411

Ketbuka kïrk-kïrik bes jas-ta, mümkün bes jas ịlgerị ne keyịn Ketbuka forty forty-five age-LOC possible five age ahead or behind bot-uw-ï.

BOL.COP-UW.VN-POSS3

'Ketbuka was forty or forty-five years old, plus or minus five years or so.' (Jurtbayev 2005: 39)

According to KG (2002: 579), the Kazakh variety spoken in Turkmenistan uses the lexical item šek 'doubt, suspicion' to express low probability. The word šek 'doubt, suspicion', a loanword of Arabic origin شاك ', is used in several Turkic languages. In Kazakh as spoken in China, šek 'doubt' is not frequently used.

Example 412 Kazakh in Turkmenistan

\begin{tabular}{|c|c|c|}
\hline $\begin{array}{l}\text { So- } \gamma a n \\
\text { that-DAT }\end{array}$ & 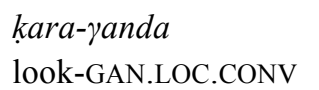 & $\begin{array}{ll}\text { tanïs } & d o s-\ddot{\imath} \\
\text { acquaintance } & \text { friend-POSs3 } 3\end{array}$ \\
\hline$o t-u w-\ddot{\imath}$ & šeh & \\
\hline BOL.COP-I & UW.VN-POSS3 & \\
\hline
\end{tabular}

'Accordingly, it is doubtful that $X$ is a friend of him/her.' (KG 2002: 579) 
Botmasïn 'it is hopefully not...'

The negated voluntative of the copula bot-ma-sin 〈BOL.COP-NEG-VOL3〉 $\leftarrow$ bot- 'to become, be' is used in the sense of 'it is hopefully not...'. According to Zhang (2002: 246, 2004: 625), botmasïn implies that the speaker is anxious that something should be the case. Zhang describes it as a particle, but in our opinion it is an idiomatically used lexical item. The complement clauses can be based on participles conveying different viewpoints. In Example 413 , the participle in $\left\{-G^{4} A^{2} n\right\}$ is used to express a postterminal meaning.

Example 413

Üstün-de četel jazuw-ï bar ${ }^{y}$ eken, četel-dịk

top.POSS3-LOC foreign letter-POSS3 existing E.COP.INDIR3 foreign-DER

konak joyat-t-ïp at-yan maÿ̈dï nárse botmasïn.

guest lose-CAUS-IP.CONV TAKE.POSTV-GAN.PTCP important thing could it be 'Zhè shàngbian yǒu wàiguó zì, bié shì wàiguó kèrén diūshī de zhòngyào dōngxi ba.' (Zhang 2002: 246, 2004: 626)

'There is a foreign letter there, hopefully it is not an important thing that a foreign guest has lost.' 


\section{Non-modal expressions}

For the sake of comparison, two categories expressing inherent properties will be briefly commented on in this chapter, although they do not correspond to the strict definition of modality used so far.

\section{Ability}

Forms expressing ability, that is an inherent property of a participant in a state of affairs, are based on a converb in $\left\{-\mathrm{A}^{2} / /-\mathrm{y}\right\}$ and the postverb at- 'to take' or bil- 'to know'. The negated forms expressing impossibility are $\left\{-\mathrm{A}^{2} / /-\mathrm{y}\right\}+a t-m a-\langle\mathrm{A} . \mathrm{CONV}$ take-NEG$\rangle /$ bil-me- $\langle\mathrm{A} . \mathrm{CONV}$ know-NEG〉, i.e. the negated forms of the postverbs. Observe that the lexical verb cannot be negated in such expressions. The postverb bil- is less frequently used today than at-. Ability forms indicate physical or mental ability to perform an action. They express an inherent property and not an attitude towards the content of the proposition, and will therefore not be treated here as modal expressions in the strict sense applied in this study.

The Turkish form expressing ability, $\{-(\mathrm{y}) \mathrm{Abil}-\}$, also expresses possibility. It is analogous to the Kazakh forms; i.e. it goes back to a converb in $\{$-yA\} and the postverb bil- 'to know', e.g. Yaz-abil-iyor-um (writeABIL-PRES-1SG) 'I am able to write / I can write / it is possible for me to write'. Negation is expressed with $\{-(\mathrm{y}) \mathrm{A}-\mathrm{mA}-\}$, e.g. Yaz-a-ma-m 'I am not able to write. / I cannot write / it is not possible for me to write'. In Turkish, the lexical verb can also be negated: Gel-me-ye-bil-ir (come-NEG-A.CONVABIL-AOR ' 'it is possible that $\mathrm{X}$ will not come'.

Examples 414 and 415 illustrate the use of the two Kazakh postverbs. The postverb at- can be used to express ability and possibility, whereas bil- expresses only ability. In spoken registers, the converb suffix $\left\{-\mathrm{A}^{2} / /-\mathrm{y}\right\}$ may disappear in contracted forms, e.g. $\breve{J} a z-a t-m a-y-d \ddot{~}$ (write-ABIL-NEGA.PRES- 3 ' ' $\mathrm{X}$ is not able to write / $\mathrm{X}$ cannot write / it is not possible for $\mathrm{X}$ to write'. The postverb al- does actually convey deontic and epistemic modality. Here we give only one example of the use of these postverbs $a l$ - and bil-; see Example 414. 
Example 414

$\check{J} a z-a \quad a t-a-m \ddot{n}$.

write-A.CONV TAKE.POSTV-A.PRES-COP1SG

'I am able to write / I can write / It is possible for me to write / I might write / I am allowed to write.'

Example 415

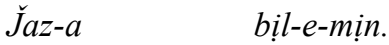

write-A.CONV KNOW.POSTV-A.PRES-COP1SG

'I am able to write / I can write.'

In Uyghur, form in $\left\{-(y) A^{2} 1 A^{2}-\right\}$ indicates ability and possibility as in Example 416.

Example 416 Uyghur

Kör-älä-y-män.

see-ABIL-A.PRES-COP1SG

'I am able to see / I can see / it is possible for me to see.'

The negation is signaled by adding the negation suffix $\left\{-\mathrm{M}^{2} \mathrm{~A}^{2}\right\}$ to the postverb; see Example 417.

Example 417 Uyghur

Kör-äl-mä-y-män

see-ABIL-NEG-A.PRES-COP1SG

'I am not able to see. / I cannot see / it is not possible for me to see.'

In colloquial Uyghur some morphophonological processes take place, e.g. regressive assimilation in the negation, Kör-ämmä-y-män 'I am not able to see. / I cannot see'.

\section{Intentionality}

The suffix $\left\{-\mathrm{M}^{3} \mathrm{~A}^{2} \mathrm{~K}^{2} \mathrm{s̆}^{2}\right\}$

The deverbal marker $\left\{-\mathrm{M}^{3} \mathrm{~A}^{2} \mathrm{~K}^{2} \breve{\mathrm{s}} \mathrm{I}^{2}\right\}$, which combines the suffixes $\left\{-\mathrm{M}^{3} \mathrm{~A}^{2} \mathrm{~K}^{2}\right\}$ and $\left\{-\breve{s}^{2}\right\}$, expresses the intention, willingness, or decision to perform an action or to have an action performed. ${ }^{34}$ Just like the previous forms of ability, the forms of intentionality denote inherent properties of participants in the state of affairs and do not express any attitude towards the

\footnotetext{
${ }^{34}$ In the following example the king does not intend to perform the action of building a bridge, but he intends to have this action performed: "The king said: 'I intend to build a bridge"."
} 
content of the proposition. Intentionality will therefore not be treated here as modality in the strict sense.

The agentive nominalizer $\left\{-\right.$ šI $\left.^{2}\right\}$ generates lexical items denoting persons occupied with what is denoted by the stem, e.g. mat-ši 'shepherd' $\leftarrow$ mat 'cattle'. The suffix $\left\{-\breve{s}^{2}\right\}$ is often used in combination with verbal nouns in $\left\{-\mathrm{w} / /-(\varnothing) \mathrm{U}^{2} \mathrm{w}\right\}^{35}$ to form agent nouns, e.g. küzet-uww-ši 'guardian' küzet-iww 'to guard'. Forms in $\left\{-\mathrm{wšs}^{2} / /-(\varnothing) \mathrm{U}^{2} \mathrm{wš} \mathrm{I}^{2}\right\}$ may, like other nominals, be used in attributive position.

Example 418

${ }^{y}$ Esịk küzet-üwši kart kịr-ịp kel-dị.

gate keep-UWŠI.PTCP old enter-IP.CONV COME.POSTV-PAST3

'The old man, who is a gatekeeper, suddenly came in.'

In contrast to the particle $\breve{s} I^{2}$ which is normally not accented (see the exceptions from this in Modal particles), the suffix $\left\{-\breve{s ̆}^{2}\right\}$ can carry the high tone. Observe that $\left\{-\mathrm{M}^{3} \mathrm{~A}^{2} \mathrm{~K}^{2} \mathrm{~s}^{2}\right\}$ can be accented on the second syllable. Thus we conclude that the second element is the suffix and not the particle.

\section{Usages of $\left\{-\mathrm{M}^{3} \mathrm{~A}^{2} \mathrm{~K}^{2} \breve{\mathrm{s}} \mathrm{I}^{2}\right\}$}

As predicate in main clauses

Copulas of the first and second persons attach to $\left\{-\mathrm{M}^{3} \mathrm{~A}^{2} \mathrm{~K}^{2} \breve{\mathrm{s}} \mathrm{I}^{2}\right\}$ when it is used as a predicate in main clauses. See Examples 419 and 420.

Example 419

\begin{tabular}{|c|c|c|c|}
\hline “Kị̌šị-nị & kurmet & "et-ịy-der!"' & $d e-p$ \\
\hline $\mathrm{g}-\mathrm{ACC}$ & respect & DO.LIGHTV-IMP-PL & say-IP.CONV \\
\hline $\begin{array}{l}{ }^{w} \text { ösiyet } \\
\text { will }\end{array}$ & $\begin{array}{l}\text { ayt-pakšs̆i-mi } \\
\text { tell-MAKŠI-C }\end{array}$ & $\begin{array}{ll}l & \text { men. } \\
\text { OP1SG } & \text { I }\end{array}$ & \\
\hline
\end{tabular}

'Respect young people! (These are) the wills I want to say.' (T6/ 7)

Example 420

$\begin{array}{ll}\text { Sen bügün kel-mekšil-sịn } & b e ? \\ \text { you today come-MAKŠI-COP2SG } & \text { Q.PART } \\ \text { 'Do you intend to come today?' } & \end{array}$

The corresponding negated expressions are formed with the copula ${ }^{y} e-m e s$ as in Example 421.

\footnotetext{
${ }^{35}$ The marker of verbal nouns has two variants. After stems ending in low vowels the marker is $\{-\mathrm{w}\}$, e.g. the verbal noun kara-w 'looking' formed from the verbal stem kara- 'to look'. Consonant stems and stems in high vowels take the marker $\left\{-(\varnothing) \mathrm{U}^{2} \mathrm{w}\right\}$, e.g. $\check{z} a z-u w$ 'writing' $\leftarrow \check{z} a z-$ 'to write', ${ }^{w} o k-u w$ 'reading' $\leftarrow{ }^{w}$ okii-'to read'. A bracketed initial zero sign (Ø) indicates that the final vowel of the stem is dropped when the marker is added. It is impossible to indicate alternants in one formula of this kind; double slashes can be used to separate them. Thus we use the notation $\left\{-\mathrm{w} / /-(\varnothing) \mathrm{U}^{2} \mathrm{w}\right\}$.
} 
Example 421

$\begin{array}{lll}\text { Men } & \text { kel-mekšs } & \text { 'emes-pịn. } \\ \text { I } \quad \text { come-MAKŠI.PTCP } & \text { not-COP1SG } \\ \text { 'I do not intend to come.' } & \end{array}$

The past meaning 'intended to' is expressed by adding the past tense copula ${ }^{y} e d i$ to $\left\{-\mathrm{M}^{3} \mathrm{~A}^{2} \mathrm{~K}^{2} \breve{\mathrm{s}} \mathrm{I}^{2}\right\}$. See the form kezdespekši ${ }^{y}$ edịm 'I intended to meet' in Example 422.

Example 422

\begin{tabular}{|c|c|c|c|}
\hline Ayžan-men & bügün kezdes-pekšs $\underline{i}$ & ${ }^{y} e-d i-m$ & \\
\hline Ayjan-WITH.POSTP & today meet-MAKŠI.PTCP & E.COP-PAST-1SG & \\
\hline $\begin{array}{l}\text { Čuүut jumus-um } \\
\text { urgent affair-POSs1sG }\end{array}$ & $\begin{array}{l}c \dddot{i} \gamma-\ddot{i p} \\
\text { come out-IP.CONV }\end{array}$ & $\begin{array}{l}\text { kat-ïp, } \\
\text { STAY.POSTV-IP.CONV }\end{array}$ & $\begin{array}{l}\text { bar- } a \\
\text { go-A.CONV }\end{array}$ \\
\hline
\end{tabular}

TAKE.POSTV-NEG-PAST-1SG

'I intended to meet Ayjan today. But an urgent affair arose and I could not go there.'

According to Zhang (2004: 380), the combination $\left\{-\mathrm{M}^{3} \mathrm{~A}^{2} \mathrm{~K}^{2} \mathrm{sI}^{2}\right\}$ plus ${ }^{y} e d i$ can also be used when the speaker intends to carry out the intended action later. The past tense copula ${ }^{y} e d i$ is used in such cases in order to make the expression more polite. See the form pịkirlespekši l edịm 'I would like to talk' in Example 426.

Example 423

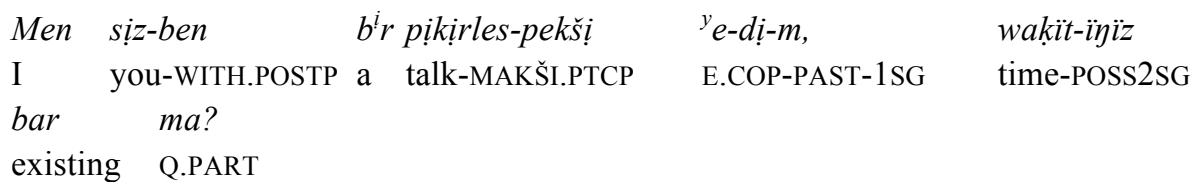

'Wǒ xiăng gēn nín jiāohuàn yīxià yìjiàn, nín yǒu kòng ma?' (Zhang 2004: 380)

'I would like to talk with you, do you have time?'

In our view, ${ }^{y}$ edi refers to the time of the intention, not to the fulfillment of the intended action. Instead of expressing the present intention, the speaker prefers to talk about the intention in the past tense which is more modest and polite. It leaves more freedom for negotiation. The speaker does not express the intention as a fact in the present situation, which makes it easier for the interlocutor to object. The same kind of situation is expressed in the following example. 
Example 424

Context: You want to meet me today but I prefer to meet Ayjan today. I propose that we meet tomorrow.

\begin{tabular}{|c|c|c|c|}
\hline Ayžan-men & bügün & kezdes-pekši & ${ }^{y} e-d i-m$. \\
\hline Ayjan-WITH.POSTP & today & meet-MAKŠI.PTCP & E.COP-PAST-1SG \\
\hline $\begin{array}{l}{ }^{y} \text { Ertey kel-se- } \eta \\
\text { tomorrow come-HY }\end{array}$ & & $\begin{array}{l}\text { kayt-e-di? } \\
\text { how to do-A.PRES- }\end{array}$ & \\
\hline
\end{tabular}

'I intended to meet Ayjan today. What if you come tomorrow?'

$\left\{-\mathrm{M}^{3} \mathrm{~A}^{2} \mathrm{~K}^{2} \mathrm{~S}^{2} \mathrm{I}^{2}\right\}$ with inanimate subjects

When the marker $\left\{-\mathrm{M}^{3} \mathrm{~A}^{2} \mathrm{~K}^{2} \breve{\mathrm{s}} \mathrm{I}^{2}\right\}$ attaches to a passive verb, the sentence does not include any person whose intention is rendered by the marker; i.e. the first actant is missing. Such a sentence is interpreted as conveying an impersonal intention, as illustrated in Example 425.

Example 425

Kešte $\quad b^{i} r$ juinatïs aš-ït-makšĭ.

evening a meeting open-PASS-MAKŠI

'A meeting is intended to be held in the evening.'

Intransitive verbs, as a rule, cannot take any passive suffix in Kazakh. However, certain intransitive verbs such as bot- 'to become, be' and čik- 'to come out' can be used with $\left\{-\mathrm{M}^{3} \mathrm{~A}^{2} \mathrm{~K}^{2} \mathrm{~s}^{2}\right\}$ to express impersonal intentions when the subject is inanimate and not capable of intending, such as jinatïs 'meeting' and kitap 'book' in the following examples. These are rendered here in Examples 426 and 427, which can be translated into English as passives.

Example 426

Kešte $\quad b^{i}$ r juinatïs bot-makšï.

evening a meeting BOL.COP-MAKŠI3

'A meeting is intended (to be held) in the evening.'

Example 427

Kịtàp čịk-paḳšï.

book come out-MAKŠI3

'A book is intended to be published.'

The following examples, 428 and 429, based on the intransitive verbs, $u \check{s}$ - 'to fly' and 'öt- 'to pass', in which the subject of the $\left\{-\mathrm{M}^{3} \mathrm{~A}^{2} \mathrm{~K}^{2} \breve{\mathrm{s}} \mathrm{I}^{2}\right\}$ is inanimate and is incapable of intending, can be understood as metonymical expressions. The inanimate subjects, ušak 'airplane' and mašina 'car', are used here to imply their controllers, the pilot and the driver. 
Example 428

Ušak uš-pakšĭ

airplane fly-MAKŠI3

'The airplane is going to take off.'

Example 429

Mašina ${ }^{w}$ öt-pekšịi.

car pass-MAKŠI3

'The car is going to pass.'

As a participle

The use of $\left\{-\mathrm{M}^{3} \mathrm{~A}^{2} \mathrm{~K}^{2} \breve{\mathrm{s}} \mathrm{I}^{2}\right\}$ in attributive position is mostly restricted to spoken registers, e.g. kel-mekši adam 〈come-MAKŠI.PTCP man〉 'the man who intends to come', ayt-pakšĭ söz-ịm 〈tell-MAKŠI.PTCP word〉 'the word I intend to say'. Corresponding expressions in the written language are expanded by

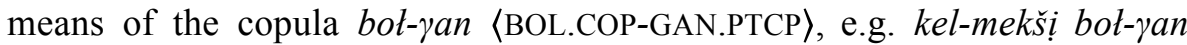
adam 〈come-MAKŠI.PTCP BOL.COP-GAN.PTCP man) 'the man who intends to come'.

When a word ending in $\left\{-\mathrm{M}^{3} \mathrm{~A}^{2} \mathrm{~K}^{2} \mathrm{~s}^{2}\right\}$ does not modify any head noun, then plural, possessive, and case suffixes cannot be attached to it, and the copula botyan has to be used to carry these suffixes. See the expression jazbakšï botyandarïmdï 'what I intend to write' in Example 433.

Example 430

\begin{tabular}{|c|c|c|}
\hline Jaz-bakšĭ & 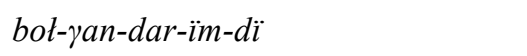 & $\dot{a} w e l i$ \\
\hline Al & BOL.COP-GAN.PTCP-PL-POSS1SG-ACC & at first \\
\hline$z-i ̣ y-m e n$ & $\begin{array}{l}\text { akïldas-bak-pün. } \\
\text { consult-MAKŠI-COP1SG }\end{array}$ & \\
\hline
\end{tabular}

'It is my strong intention first to consult with you concerning what I intend to write.'

In written registers, the marker $\left\{-\mathrm{M}^{3} \mathrm{~A}^{2} \mathrm{~K}^{2} \mathrm{~s}^{2}\right\}$ cannot take on any of these suffixes. In the spoken language, however, in some restricted cases, the possessive suffix can attach directly to $\left\{-\mathrm{M}^{3} \mathrm{~A}^{2} \mathrm{~K}^{2} \breve{\mathrm{s}} \mathrm{I}^{2}\right\}$, e.g. ayt-pakšï $m$ 〈tell-MAKŠI-POSS1SG〉 'what I want to say'. The same meaning can also be expressed periphrastically with ayt-pakši bot-yan-ïm 〈tell-MAKŠI.PTCP BOL.COP-GAN.PTCP-POSS1SG) 'what I intend to say'. Note a syntactically similar construction, consisting of the voluntative of the verb ayt- 'to say' and the participle of the verb de- 'to say': ayt-ayïn de-gen-im 〈tell-VOL1SG say-GAN.PTCP-POSS1SG) 'what I want to say'. The construction based on $\left\{-\mathrm{M}^{3} \mathrm{~A}^{2} \mathrm{~K}^{2} \breve{\mathrm{s}} \mathrm{I}^{2}\right\}$ plus bolyan expresses intention, whereas the one based on the voluntative plus degen expresses purpose. 
The sentential particle aytpakšsi

The $\left\{-\mathrm{M}^{3} \mathrm{~A}^{2} \mathrm{~K}^{2} \mathrm{SI}^{2}\right\}$ form derived from the verb ayt- 'to tell' has been grammaticalized as a sentential particle. In this function, aytpakši expresses an illocutionary speech act in the sense of 'I mean', 'what I want to say', etc. The particle cannot take any suffix to express person. Thus, in the following example, it is rendered in English as 'I mean', but the Kazakh particle does not specify the person.

Example 431

$\begin{array}{lcll}\text { Aytpakšï, } & \text { jab-ït-uw } & \text { saltanat-ïn- } a \\ \text { AYTPAǨSII.PART } & \text { close-PASS-UW.VN } & \text { celebration-POSS3-DAT } \\ \text { bar-aẗ̈n-dar } & \text { bar } \quad \text { ma? } & \\ \text { go-ATIN.PTCP-PL } & \text { existing } & \text { Q.PART } & \end{array}$

'What I mean is, is there anybody who will go to the farewell party?'

The suffix $\left\{-\mathrm{M}^{3} \mathrm{~A}^{2} \mathrm{~K}^{2}\right\}$

The suffix $\left\{-\mathrm{M}^{3} \mathrm{~A}^{2} \mathrm{~K}^{2}\right\}$, is a deverbal suffix which generates verbal nouns and participles and is mostly used in written language registers. Certain lexicalized forms may be found in spoken registers (see below). The suffix $\left\{-\mathrm{M}^{3} \mathrm{~A}^{2} \mathrm{~K}^{2}\right\}$, which presumably had a type of prospective meaning, has low frequency of use.

Usages of $\left\{-\mathrm{M}^{3} \mathrm{~A}^{2} \mathrm{~K}^{2}\right\}$

Verbal noun

The suffix $\left\{-\mathrm{M}^{3} \mathrm{~A}^{2} \mathrm{~K}^{2}\right\}$ derives verbal nouns. This was also the case in languages such as East Old Turkic and Chaghatay. In Kazakh, verbal nouns in $\left\{-\mathrm{M}^{3} \mathrm{~A}^{2} \mathrm{~K}^{2}\right\}$ are restricted to older literary texts and petrified expressions such as proverbs and sayings. The relatively frequent use of verbal nouns in $\left\{-\mathrm{M}^{3} \mathrm{~A}^{2} \mathrm{~K}^{2}\right\}$ in early Kazakh literary works is probably an influence of Chaghatay. See the postverb expression kamatïp kat-mak 'to be enclosed' in Example 432, and ari-mak 'to be exhausted', semir-mek 'to put on weight' in Example 433.

Example 432

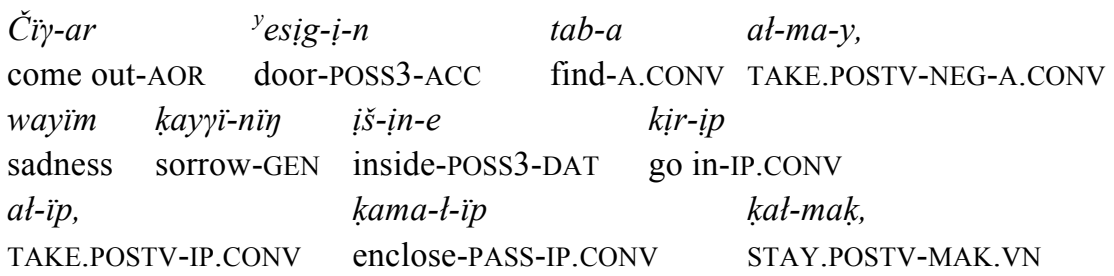


$\begin{array}{lllll}{ }^{w} \text { ot } & { }^{w} \ddot{o} z-\underline{i} & \text { de } & b^{i} r & \text { anturyandik ... } \\ \mathrm{X} & \text { self-POSS3 } & \text { DA.PART } & \text { a } & \text { weakness }\end{array}$

'To be enclosed in sadness and sorrow and not find a way out is itself a weakness.'

(Abai 2010: 14).

Example 433

Arï-mak, semị-mek $\quad{ }^{w}$ oy-dan.

be tired-MAK.VN put on weight-MAK.VN thought-ABL

'To be exhausted or put on weight depends on thoughts.' (KP 2009: 82)

In spoken language, instead of the verbal nouns kat-mak 'staying', arï-mak 'being tired', and semir-mek 'putting on weight', the infinitive forms in $\{-w$ $\left./ /-(\varnothing) \mathrm{U}^{2} \mathrm{w}\right\}$, kat-uw 'staying', ar-uw 'being tired', and semir-uw 'putting on weight', would be used in the above examples.

Predicate in main clauses

The form $\left\{-\mathrm{M}^{3} \mathrm{~A}^{2} \mathrm{~K}^{2}\right\}$ may occur as predicate in main clauses and indicates prospectivity in the sense of something foreseen or predicted. Personal copula endings can be added in the first and second persons. Negation is expressed by the copula ${ }^{y}$ emes 'is not'. In Examples 434 and 435, a form in $\left\{-\mathrm{M}^{3} \mathrm{~A}^{2} \mathrm{~K}^{2}\right\}$ functions as predicate.

Example 434 Literary Kazakh

But jüłjümalï telefon, Firefox OS jüye-sị-men

this mobile telephone Firefox OS system-POSS3SG-WITH.POSTP

jarïk kör-mek.

light see-MAK3

'This mobile phone is foreseen/predicted to be released with the Firefox OS system.'

Example 435

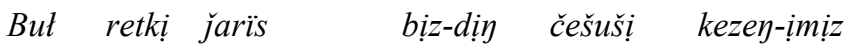

this time competition we-GEN decisive period-POSS1PL

bot-mak.

BOL.COP-MAK3

'This competition is foreseen to be a decisive period for us.'

The past tense copula ${ }^{y} e d i$ may be added to $\left\{-\mathrm{M}^{3} \mathrm{~A}^{2} \mathrm{~K}^{2}\right\}$, and indicates 'meant to'. See $\dot{a} k e l m e k^{y} e d i$ ' meant to bring' in Example 436.

Example 436

$\begin{array}{llllll}\text { Tay-day } & k \ddot{z} i ̈ t & k o y-d \ddot{l} & \text { ákel-mek } & { }^{y} e \text {-di, } & \text { Ułan } \\ \text { colt-EQUA } & \text { red } & \text { sheep-ACC } & \text { bring-MAK.PTCP } & \text { E.COP-PAST3 } & \text { Ulan }\end{array}$ 
kön-be-dị.

agree-NEG-PAST3

'X meant to bring a colt-like red sheep, but Ulan did not agree.'

According to Zhang (2004: 336), the form $\left\{-\mathrm{M}^{3} \mathrm{~A}^{2} \mathrm{~K}^{2}\right\}$ may be used with a particular function in interrogative sentences, namely to intensify the rhetorical meaning; see Examples 437 and 438 . The form $\left\{-\mathrm{M}^{3} \mathrm{~A}^{2} \mathrm{~K}^{2} \mathrm{s̆}^{2}\right\}$ cannot be used in this function.

Example 437

${ }^{y}$ El-dị närse-sị-n men kaytïp at-mak-pïn?

other-GEN thing-POSS3SG-ACC I how take-MAK-COP.1SG

'Biérén de dōngxi wǒ zěnme néng ná?!' (Zhang 2004: 336)

'How could I mean to take the belongings of other people?'

Example 438

${ }^{w}$ On-day bol-sa, bịz-dị kün-ịmịz ne bot-mak?

X-EQUA BOL.COP-HYP3 we-GEN life time-POSS1PL what BOL.COP-MAK3

'Yào nàyàng, wǒmen hái yǒu shé me huó tóu er?' (Zhang 2004: 336)

'If it is so, what will be the meaning of our life?

In set phrases

Forms in $\left\{-\mathrm{M}^{3} \mathrm{~A}^{2} \mathrm{~K}^{2}\right\}$ may be used adnominally to express that the following noun is appropriate for what the form $\left\{-\mathrm{M}^{3} \mathrm{~A}^{2} \mathrm{~K}^{2}\right\}$ denotes. Expressions of this type are set phrases, and it is not possible to expand them by adding a complement. Only a few expressions of this type are used today, e.g. ayt-pak $s \ddot{o z}\langle$ tell-MAK.PTCP word〉 'a word to say'. Observe that this expression has a passive meaning 'a word to be said'. The same meaning can also be expressed through a passive verb form, e.g. ayt-ït-mak söz 〈tell-PASS-MAK.PTCP word $\rangle$ 'a word to say (to be said)'. Another example would be $\ddot{u} y l e-n$-bek kïz 〈marry-REF.PASS-MAK.PTCP girl〉 'a girl to marry'.

In the following Example 439, the expression bermek jawabï 'the answer that X would give' is used.

Example 439

Tölegen ${ }^{w}$ o-n̈̈y ber-mek jawab-ï-n küt-üp

Tölegen X.GEN give-MAK.PTCP answer-POSS3SG-ACC wait-IP.CONV

jür-dị. B Birak àlị kün-ge deyịn sïbïs

MOVE.POSTV-PAST3 but now day-DAT UNTIL.POSTV sound

bot-yan jok.

BOL.COP-GAN.PTCP not existing

'Tölegen was waiting for the answer that $\mathrm{X}$ would give. But there was still no news.' 
Observe that in this example *bermek jawap cannot be used without a possessive suffix. Like $\left\{-\mathrm{M}^{3} \mathrm{~A}^{2} \mathrm{~K}^{2} \mathrm{~s} \mathrm{I}^{2}\right\}$, the suffix $\left\{-\mathrm{M}^{3} \mathrm{~A}^{2} \mathrm{~K}^{2}\right\}$ does not take on case, possessive, or plural suffixes. According to KG (2002: 533), this is because words with these suffixes cannot function as normal attributive modifiers. This is valid except for the very restricted cases mentioned above.

In attributive clauses

In attributive clauses with the predicate in $\left\{-\mathrm{M}^{3} \mathrm{~A}^{2} \mathrm{~K}^{2}\right\}$ the copula bot-yan 〈BOL.COP-GAN.PTCP〉 must be added; see, for instance, the expression kelmek botyan konaktar 'the guests who mean / are meant to come' in Example 440. For attributive clauses with a predicate in $\left\{-\mathrm{M}^{3} \mathrm{~A}^{2} \mathrm{~K}^{2} \mathrm{sI}^{2}\right\}$, (see above).

Example 440

\begin{tabular}{|c|c|c|c|}
\hline $\begin{array}{l}\text { Kel-mek } \\
\text { come-MAK.РТCP }\end{array}$ & 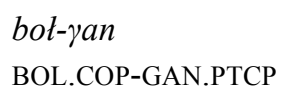 & $\begin{array}{l}\text { konak-tar-ïn-a } \\
\text { guest-PL-POSS3-DAT }\end{array}$ & $\begin{array}{l}\dot{a} z i \operatorname{rilik} \\
\text { preparation }\end{array}$ \\
\hline jasa-p & jürr. & & \\
\hline EATE.POSTV-IP & MOVE.PO & STV3 & \\
\hline
\end{tabular}

In the spoken language, the corresponding expressions can be formed with the aorist participle in $\left\{-\left(\mathrm{A}^{2}\right) \mathrm{r}\right\}$ or, in some cases, the participle in $\left\{-\mathrm{A}^{2} \mathrm{tI}^{2} \mathrm{n}\right.$ // -ytت̈ $\left.{ }^{2} \mathrm{n}\right\}$. For example, instead of kelmek botyan konak the expression keletin konak 'the guests who will be meant to come' can be used in Example 440.

Example 439 can be paraphrased as Example 441, where the aorist participle berer is used instead of bermek.

Example 441

\begin{tabular}{|c|c|c|c|c|}
\hline Tölegen ${ }^{w} o-n \ddot{y}$ & ber-er & jawab & $-\ddot{i}-n$ & \\
\hline Tölegen X.GEN & give-AOR.PTC & answe & r-POSS3SG-AC & \\
\hline jür $-d i ̣$ & $b^{i} r a k \quad \dot{a} l \underline{i}$ & kün-ge & deyin & sïbïs \\
\hline MOVE.POSTV-PAST3 & now & day-DAT & UNTIL.POSTV & sound \\
\hline 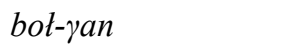 & jok. & & & \\
\hline OL.COP-GAN.PTCP & not existing & & & \\
\hline
\end{tabular}

'Tölegen has been waiting for the answer which $\mathrm{X}$ is expected to give, but there is still no news.'

In converb clauses

The $\left\{-\mathrm{M}^{3} \mathrm{~A}^{2} \mathrm{~K}^{2}\right\}$ form expanded with the copula bot- 'to become, be' may build converb clauses. In the adverbial clause in Example 442, the $\left\{-\mathrm{M}^{3} \mathrm{~A}^{2} \mathrm{~K}^{2}\right\}$ form in ázirle-mek is construed with the converb in $\left\{-\left(\mathrm{I}^{4}\right) \mathrm{p}\right\}$ of the copula bot-. 
Example 442

Sosïn Ayša tamak àzirle-mek

bot- ${ }^{u} p$,

as üy-ge

then Aysha food prepare-MAK.PTPC BOL.COP-IP.CONV

kitchen-DAT

karay jilji-dï.

TOWARD.POSTP move-PAST3

'Then Aysha moved towards the kitchen to prepare food.'

Small clause with nouns meaning intention

In Example 443, the $\left\{-\mathrm{M}^{3} \mathrm{~A}^{2} \mathrm{~K}^{2}\right\}$ form with its complement is construed with the noun niyet 'intention' to form an expression meaning 'to have the intention to', i.e. 'to intend to'.

Example 443

${ }^{y}$ Eger ${ }^{w}$ osïn-da jumus iste-y at-sa-m, $b^{i}$ raz

if this-LOC work do-A.CONV TAKE.POSTV-HYP-1SG some

äygịme-ler jaz-bak niyet-ịm bar.

story-PL write-MAK.PTCP intention-POSS1SG existing

'If I work here, I have the intention to write some stories.'

In Example 444, the complement based on $\left\{-\mathrm{M}^{3} \mathrm{~A}^{2} \mathrm{~K}^{2}\right\}$ is assigned the dative case, governed by the verb urun- 〈urïn-> 'to attempt'.

Example 444

Urï kapčik-tï baÿ̈p-pen bịldịr-t-pe-y

thief wallet-ACC care-WITH.POSTP let know-CAUS-NEG-A.CONV

kot-ïn-a tüs-ür-üp, $\quad$ kaš-pak-ka

hand-POSS3-DAT fall-CAUS-IP.CONV run away-MAK.PTCP-DAT

urun-up jat-kanda usta-t-di.

attempt-IP.CONV LIE.POSTV-GAN.LOC.CONV arrest-PASS-PAST3

'The thief was arrested when he attempted to run away, after he had carefully and stealthily stolen the wallet.'

Lexicalized as a noun

Lexicalizations such as jas ${ }^{i}$ r- ̈̈n-bak 〈hide-REF-MAK〉 'hide-and-seek', čak-pak 〈strike-MAK〉 'flint, lighter', or ị̌s-pek je-mek 〈drink-MAK eat-MAK〉 'foodstuff' express things that are suitable or otherwise relevant for the action in question.

The sentential particle demek

A lexicalized form demek 'that means', 'that is to say', thus', may be used as an illocutionary speech act, as in Example 445; see Illocutionary modality. 
Example 445

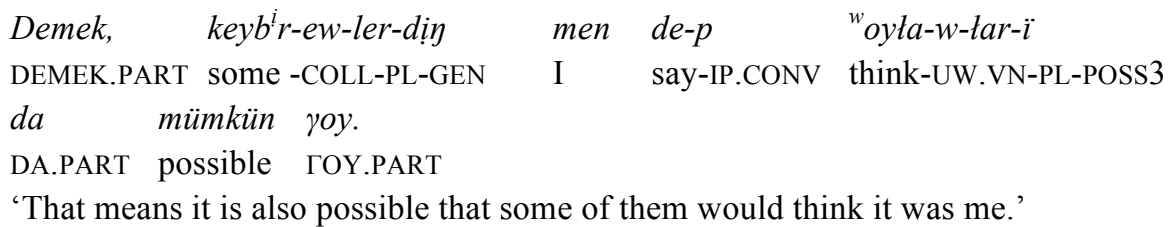

The conjunction turmak 'not to mention'

Zhang (2004: 568) describes the grammaticalized form turmak 'not to mention' as a conjunction indicating a contrast or an exception. See Example 446 for an illustration of this usage.

Example 446

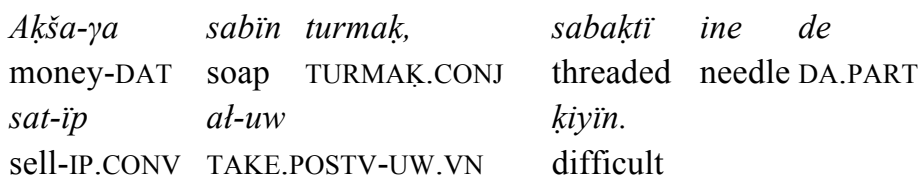

'With the money it is even difficult to buy a threaded needle, not to mention soap'.

Comparison of $\left\{-\mathrm{M}^{3} \mathrm{~A}^{2} \mathrm{~K}^{2} \mathrm{~S}^{2}\right\}$ and $\left\{-\mathrm{M}^{3} \mathrm{~A}^{2} \mathrm{~K}^{2}\right\}$

In grammars, the two suffixes $\left\{-\mathrm{M}^{3} \mathrm{~A}^{2} \mathrm{~K}^{2} \breve{\mathrm{s}} \mathrm{I}^{2}\right\}$ and $\left\{-\mathrm{M}^{3} \mathrm{~A}^{2} \mathrm{~K}^{2}\right\}$ are dealt with as variants. They are described as a single category labeled in some grammars as "maksattï keler šak" 'intentional/purposive future tense' (Geng et al. 1999: 228, MKL 2002: 466, KG 2002: 519) and as "niyet keler šak" 'intentional future tense' in Mamanov (2007: 116). In Chinese it is referred to as "mùdi jiānglái shi” 'purposive future tense' (Geng 1989: 129, Zhang 2004: 389).

This should not, however, blur the fact that there are significant semantic differences between their core meanings. For instance, Geng et al. (1999: 228-229) claim that $\left\{-\mathrm{M}^{3} \mathrm{~A}^{2} \mathrm{~K}^{2} \breve{\mathrm{S}} \mathrm{I}^{2}\right\}$ plus copula personal endings, e.g.

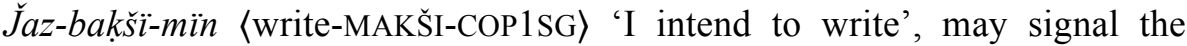
inevitability of the intended action. KG (2002: 534) describes how the element ("cубморф") $\left\{-\mathrm{s}^{2} \mathrm{I}^{2}\right\}$ is added to $\left\{-\mathrm{M}^{3} \mathrm{~A}^{2} \mathrm{~K}^{2}\right\}$ in order to specify its intentional meaning. Zhang (2004: 335-336) also states that $\left\{-\mathrm{M}^{3} \mathrm{~A}^{2} \mathrm{~K}^{2} \mathrm{~s}^{2}\right\}$ can be used to intensify the will of an agent. Moreover, he claims that $\left\{-M^{3} A^{2} K^{2}\right\}$ and $\left\{-\mathrm{M}^{3} \mathrm{~A}^{2} \mathrm{~K}^{2} \breve{\mathrm{s}} \mathrm{I}^{2}\right\}$ can be interchangeable, but that they express different attitudes on the part of the speaker. The form in $\left\{-\mathrm{M}^{3} \mathrm{~A}^{2} \mathrm{~K}^{2}\right\}$ implies indubitable certainty on the part of the speaker; thus it can be used to express a predetermined event. $\left\{-\mathrm{M}^{3} \mathrm{~A}^{2} \mathrm{~K}^{2} \breve{\mathrm{s}} \mathrm{I}^{2}\right\}$ on the other hand can signal less certainty about the occurrence of the event. In our observation, however, differences can be seen not only differences with respect to attitudes, but also with respect to other features. The two forms can be interpreted as similar when they occur as main-clause predicates, and in attributive function when 
the first argument is a controler, i.e. someone who can carry out the action consciously and willingly. However, when $\left\{-\mathrm{M}^{3} \mathrm{~A}^{2} \mathrm{~K}^{2}\right\}$ is used as an old infinitive it cannot be replaced by $\left\{-\mathrm{M}^{3} \mathrm{~A}^{2} \mathrm{~K}^{2} \mathrm{~s}^{2}\right\}$.

In Examples 447 and 448, the two suffixes are free variants in the predicate position of a main clause.

Example 447

Ake-m bügün kel-mek.

father-POSS1SG today come-MAK3

Example 448

Ake-m bügün kel-mekšị.

father-POSS1SG today come-MAKŠI3

Both examples can be translated in the same way:

'My father is expected / intends to come today.'

The copula bot-dï, past tense of bot- 'to become, be', can be added to $\left\{-\mathrm{M}^{3} \mathrm{~A}^{2} \mathrm{~K}^{2}\right\}$ and $\left\{-\mathrm{M}^{3} \mathrm{~A}^{2} \mathrm{~K}^{2} \mathrm{sI}^{2}\right\}$ to express a past intention to do something. Compare the following two examples where $\left\{-\mathrm{M}^{3} \mathrm{~A}^{2} \mathrm{~K}^{2}\right\}$ and $\left\{-\mathrm{M}^{3} \mathrm{~A}^{2} \mathrm{~K}^{2} \mathrm{sI}^{2}\right\}$ function as predicates expanded with bot-di and express a meaning of determination in the past. In Example 449, $\left\{-\mathrm{M}^{3} \mathrm{~A}^{2} \mathrm{~K}^{2}\right\}$ bot-di is used, whereas in Example $450\left\{-\mathrm{M}^{3} \mathrm{~A}^{2} \mathrm{~K}^{2} \mathrm{~s}^{2}\right\}$ bot-dï is used.

Example 449

Kasen dała-ya čik-pak bot-dï.

Kasen outside-DAT come out-MAK.PTCP BOL.COP-PAST3

Example 450

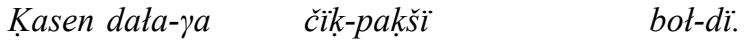

Kasen outside-DAT come out-MAKŠI.PTCP BOL.COP-PAST3

'Kasen decided to go out.'

In Examples 451 and 452, the forms are in attributive position and have the same readings.

Example 451

Ayt-pak $\quad{ }^{w}$ oy-ï-n tüsün-dü-m.

tell-MAK.PTCP idea-POSS3-ACC understand-PAST-1SG

Example 452

Ayt-pakši $\quad{ }^{w} o y-\ddot{i}-n \quad$ tüsün-dü-m.

tell-MAKŠI idea-POSS3-ACC understand-PAST-1SG

'I understood the idea that $\mathrm{X}$ intended / was expected to express.' 
However, in Example $453\left\{-\mathrm{M}^{3} \mathrm{~A}^{2} \mathrm{~K}^{2}\right\}$ cannot be replaced by $\left\{-\mathrm{M}^{3} \mathrm{~A}^{2} \mathrm{~K}^{2} \mathrm{s̆}^{2}\right\}$ because $\left\{-\mathrm{M}^{3} \mathrm{~A}^{2} \mathrm{~K}^{2} \mathrm{~s}^{2}\right\}$ expresses intention and not expectation. The intentional interpretation is not allowed by the context. Thus, Example 454 is not well formed.

Example 453

Jas kartay-mak, jok $\quad t^{u} w$-mak,

young grow old-MAK3 non-existing be born-MAK3

$t^{u} w$-yan $\quad{ }^{w} \ddot{l} l-m e k$.

be born-GAN.PTCP die-MAK3

'Young people are expected to grow old, non-existing people to be born, and born people to die.' (Axmetov 1976: 15)

Example 454

* J̌as kartaymakšĭi, jok tumakšii, tumak ${ }^{w}$ ölmekšịi.

From these examples, the conclusion can be drawn that intentional interpretation presupposes the involved entity's control-except for examples such as 447-452-whereas expectation is not dependent on control. Therefore $\left\{-\mathrm{M}^{3} \mathrm{~A}^{2} \mathrm{~K}^{2}\right\}$ and $\left\{-\mathrm{M}^{3} \mathrm{~A}^{2} \mathrm{~K}^{2} \mathrm{SI}^{2}\right\}$ are interchangeable when the interpretation can be intentional. In cases where the interpretation must be expectational $\left\{-\mathrm{M}^{3} \mathrm{~A}^{2} \mathrm{~K}^{2} \breve{\mathrm{s}} \mathrm{I}^{2}\right\}$ is excluded. The suffix $\left\{-\mathrm{M}^{3} \mathrm{~A}^{2} \mathrm{~K}^{2}\right\}$ may express what cannot be changed, what is predetermined, for instance in the sense of being scheduled. However $\left\{-\mathrm{M}^{3} \mathrm{~A}^{2} \mathrm{~K}^{2} \mathrm{sI}^{2}\right\}$ cannot have this meaning.

\section{Comparison with Uyghur}

Uyghur has the same markers $\left\{-\mathrm{mA}^{2} \mathrm{~K}^{2}\right\}$ and $\left\{-\mathrm{mA}^{2} \mathrm{~K}^{2} \mathrm{c} i\right\}$, but they are never used in the same meanings. There is a clear distinction between them. In main clause predicates, $\left\{-\mathrm{mA}^{2} \mathrm{~K}^{2}\right\}$ is only used as an old infinitive, while $\left\{-\mathrm{mA}^{2} \mathrm{~K}^{2} \mathrm{c} i\right\}$ is used to express intentionality, e.g. Kälmäkči ' $\mathrm{X}$ intends to come', not *Kälmäk. The Kazakh usage of $\left\{-\mathrm{mA}^{2} \mathrm{~K}^{2}\right\}$ in non-main clause predicates has no equivalent in Uyghur. ${ }^{36}$

The suffix $\left\{-\mathrm{mA}^{2} \mathrm{~K}^{2}\right\}$

The Uyghur infinitive marker $\left\{-\mathrm{mA}^{2} \mathrm{~K}^{2}\right\}$ is restricted to the old written style. It may also derive verbal nouns. Example 455 is a proverb.

Example 455 Uyghur

Al-mak-niך bär-mik-i bar.

take-MAK-GEN give-MAK.VN-POSS3 existing

'Taking entails giving.' (Tömür 2011: 240)

${ }^{36}$ For similar forms in Kirghiz, see Kirchner (2006b: 351). For Tatar and Bashkir, see Berta (2006: 294) 
The corresponding expression in Kazakh is illustrated in Example 456.

Example 456

$\begin{array}{lll}\text { At-mak-tïn } & \text { ber-meg- } i & \text { bar. } \\ \text { take-MAK-GEN } & \text { give-MAK-POSS3 } & \text { existing } \\ \text { 'Taking entails giving.' } & \end{array}$

The form $\left\{-m A^{2} K^{2} t A^{2}\right\}$, i.e. $\left\{-m A^{2} K^{2}\right\}$ plus locative, functions as an intraterminal (progressive) predicate in main clauses.

Example 457 Uyghur

$\begin{array}{lll}\text { Wätin-imiz } & \text { uč-kan-däk } & \text { ilgirili-mäktä. } \\ \text { country-POSS1PL } & \text { fly-GAN.PTCP-DEK.DER } & \text { progress-MAKTA }\end{array}$

'Our country is progressing very fast. (Tömür 2011: 240)

The corresponding expression in Kazakh, (see Example 458,) may be formed with the intraterminal in $\left\{-w d a / /-(\varnothing) \mathrm{U}^{2} \mathrm{wdA}^{2}\right\}$. This form is not very productive.

Example 458

$\begin{array}{llll}{ }^{w} \text { Otan-ïmïz } & \text { uškan } & k u s-t a y & a t^{d i ̈}-\gamma a \\ \text { country-POSS1PL } & \text { fly-GAN.PTCP } & \text { bird-EQUA } & \text { front-DAT } \\ \text { bas- } u w d a & & \\ \text { step -UWDA.INTRAT } & & \\ \text { 'Our country is progressing very fast.' } & \end{array}$

In Uyghur, the past tense copula $i-d i$ may be added to $\left\{-\mathrm{mA}^{2} \mathrm{~K}^{2} \mathrm{tA} \mathrm{A}^{2}\right\}$ to express a past intraterminal, as in Example 459. This usage is not very productive in Kazakh.

Example 459 Uyghur

Okưuči-lar dikkät bilän därs alii-makta i-di.

student-PL careful BILȦN.POSTP lesson listen-MAKTA E.COP-PAST3

'The students were listening attentively to the lesson.' (Tömür 2011²: 240)

The suffix $\left\{-\mathrm{mA}^{2} \mathrm{~K}^{2} \mathrm{c} \mathrm{c} i\right\}$

The Uyghur suffix $\left\{-\mathrm{mA}^{2} \mathrm{~K}^{2} \mathrm{c} \mathrm{i}\right\}$ may occur as a predicate in main clauses, just as in Kazakh. It expresses intention, willingness, and a decision to perform an action.

Copulas of the first and second persons attach to $\left\{-\mathrm{mA}^{2} \mathrm{~K}^{2} \mathrm{c} i\right\}$. In Example 460 , the copula of the first person is attached to $\left\{-m A^{2} K^{2} \check{c} i\right\}$. 
Example 460 Uyghur

Män käl-mäkči-män.

I come-MAKČI-COP1SG

'I intend to come today.'

The corresponding negation is formed with the copula $\ddot{a}$-mäs, as in Example 461.

Example 461 Uyghur

Män käl-mäkči ämäs-män.

I come-MAKČI not-COP1SG

'I do not intend to come'.

The suffix $\left\{-\mathrm{mA}^{2} \mathrm{~K}^{2} \mathrm{c} i\right\}$ may be expanded with the past tense form of the copula bot- 'to become, be'. Like the corresponding expression in Kazakh, the Uyghur form bol-di 〈BOL.COP-PAST3〉 adds the meaning of a decision in the past; see Example 462.

Example 462 Uyghur

Älkäm uxli-makči bol-di.

Alkam sleep-MAKČI BOL.COP-PAST3

'Alkam decided to sleep.' 


\section{Conclusions}

In this study, expressions of modality in Kazakh as spoken in China are described from a functional perspective. The modal notions volition, deontic evaluation, and epistemic evaluation express attitudes towards the propositional content and are conveyed in Kazakh by grammaticalized moods, particles, and lexical devices. All these categories are treated in detail, and ample examples of their different usages are provided.

The basic function of the four mood categories imperative, voluntative, optative, and hypothetical is the expression of volition. The markers are old suffixes also found in other Turkic languages. It has been demonstrated that these four mood categories can express a wide range of different volitional ideas depending on the context and their combinations with modifying elements.

The imperative mood has a number of specific features. For example, it only refers to second persons, normally does not have an overt subject, and cannot be combined with interrogative markers. Imperatives express orders, requests, permission, advice, suggestions, prohibitions, good wishes, and curses. Imperatives can be downtoned with the help of particles.

The voluntative mood primarily expresses subjective will. Its usages in all persons have been described. The first person expresses the addresser's willingness, readiness, intention, decision, or promise to perform a given action. The third person signals command, demand, instruction, appeal, invitation, or request that an action be brought about by some entity other than the addressee. The negated forms convey prohibitive meanings.

The optative mood denotes willing, wishing, desire, intention, hope, aspiration, incitement, requesting, promising, advice, expectation, necessity, obligation, or prediction with respect to a non-factual situation. It does not always express the speaker's subjective will. Its use has declined in Kazakh as in many other Turkic languages. Today it is mainly used in idiomatic expressions to express a polite request. In combination with the past copula ${ }^{y} e d i$, it expresses fear, worry, and warnings about the possible occurrence of an undesired situation.

The function of the hypothetical mood depends on whether it marks the predicate of a main clause or the predicate of the protasis in a conditional clause. In main clauses, it is an imaginative mood expressing supposed events, and as such it may convey desiderative meanings, i.e. desires, wishes, or hope in the sense of 'imagine it is the case', 'what if it were the case?' 
The hypothetical forms can combine with different forms of the copula and other items. The usages of these combinations have been studied in detail.

The modal nuances expressed by the non-productive imprecative in $\left\{-G^{4} I^{2} r\right\}$ and the aorist have been treated whenever suitable, also in comparison with corresponding forms in other Turkic languages.

The periphrastic expressions of modality dealt with in this study are $\left\{-G^{4} I^{2}\right\}+$ possessive personal markers + kel- as well as $\left\{-G^{4} \mathrm{I}^{2}\right\}+$ possessive personal markers + bar. Both devices convey inclination. The periphrastic constructions $\left\{-\mathrm{sA}^{2}\right\}+i y g \underline{i}+{ }^{y} e d i$ and $\left\{-\mathrm{sA}^{2}\right\}+$ deymin express wishes, whereas $\left\{-\mathrm{sA}^{2}\right\}+$ kerek expresses presumption.

Kazakh is characterized by the use of a large inventory of particles. Many express stance, i.e. some kind of cognitive or affective attitude towards the events described, and these play an especially significant role in spoken communication. A thorough description of the usages and the syntactic and phonetic properties of these particles has been provided.

One of the most frequently used particles, $\Gamma^{2} o y$, serves to convey epistemic evaluation, assessments of the propositional content. The basic semantic contribution of the particle $\breve{S} I^{2}$ is to express volition. Its function varies according to its combinations with different mood categories.

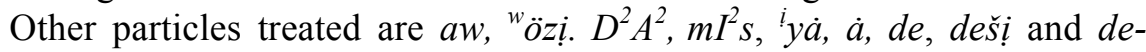
seyšị and bịlem.

Finally, attention has also been given to lexical categories such as adverbs, verbs, and set phrases expressing modal notions.

The definition of modality employed in this study excludes ability and intentionality, and these are accordingly not included among the modal categories dealt with. For the sake of comparison, however, descriptions of some non-modal categories are given in chapter Non-modal expressions.

The Appendix contains nine texts recorded by the author in the Kazakhspeaking regions of Xinjiang, China. These texts illustrate the use of many of the items treated in the study.

The following tables illustrate some important points in the description. Table 4 summarizes the forms and basic meanings of the synthetic devices. The various volitional and epistemic attitudes conveyed by modal particles are given in Table 5. Modal notions expressed by lexical categories are summarized in Table 6 . 
Table 4. Moods

\begin{tabular}{|c|c|c|c|c|}
\hline Moods & Person & Number & Forms & Modal nuances \\
\hline \multirow[t]{2}{*}{ Imperative } & 2 & SG & $\varnothing$ & orders, commands, re- \\
\hline & & PL & $\left\{-\left(I^{2}\right) n-d A^{2} r\right\}$ & $\begin{array}{l}\text { quests, permission, ad- } \\
\text { vice, suggestions, prohi- } \\
\text { bitions, good wishes, } \\
\text { curses }\end{array}$ \\
\hline \multirow[t]{3}{*}{ Voluntative } & 1 & SG & $\left\{-\left(\mathrm{A}^{2}\right) \mathrm{yI}^{2} \mathrm{n}\right\}$ & $\begin{array}{l}\text { wishing, willingness, } \\
\text { readiness, intention, deci- } \\
\text { sion, promise to perform } \\
\text { a given action, allow, } \\
\text { permit }\end{array}$ \\
\hline & & PL & $\left\{-\left(\mathrm{A}^{2}\right) \mathrm{yI}^{2} \mathrm{~K}^{2}\right\}$ & $\begin{array}{l}\text { wishes, intentions, de- } \\
\text { sires, proposals, cohorta- } \\
\text { tive use }\end{array}$ \\
\hline & 3 & $\mathrm{SG} / \mathrm{PL}$ & $\left\{-s I^{2} n\right\}$ & $\begin{array}{l}\text { commands, demands, } \\
\text { instructions, appeals, } \\
\text { invitations, requests, } \\
\text { permission, hope, wishes }\end{array}$ \\
\hline \multirow[t]{4}{*}{ Optative } & 1 & $\begin{array}{l}\mathrm{SG} \\
\mathrm{PL}\end{array}$ & $\begin{array}{l}\left\{-G^{4} A^{2} y-m I^{2} n\right\} \\
\left\{-G^{4} A^{2} y-m I^{2} z\right\}\end{array}$ & $\begin{array}{l}\text { wishes, desires, hope, } \\
\text { requests, fear, warning }\end{array}$ \\
\hline & 2 & SG & $\left\{-\mathrm{G}^{4} \mathrm{~A}^{2} \mathrm{y}-\mathrm{sI}^{2} \mathrm{y}\right\}$ & \\
\hline & & PL & $\left\{-G^{4} A^{2} y-s I^{2} \eta-d A^{2} r\right\}$ & \\
\hline & 3 & $\mathrm{SG} / \mathrm{PL}$ & $\left\{-G^{4} A^{2} y\right\}$ & \\
\hline \multirow[t]{5}{*}{ Hypothetical } & 1 & SG & $\left\{-\mathrm{sA}^{2} \mathrm{~m}\right\}$ & wishes, desires, requests, \\
\hline & & PL & $\left\{-\mathrm{sA}^{2} \mathrm{~K}^{2}\right\}$ & counterfactual wishes, \\
\hline & 2 & SG & $\left\{-\mathrm{sA}^{2} \mathrm{n}\right\}$ & regret \\
\hline & & PL & $\left\{-\mathrm{sA}^{2} \mathrm{ydA^{2 }} \mathrm{r}\right\}$ & \\
\hline & 3 & SG/PL & $\left\{-\mathrm{sA}^{2}\right\}$ & \\
\hline Imprecative & & & $\left\{-\mathrm{G}^{4} \mathrm{I}^{2} \mathrm{r}\right\}$ & curses, unrealistic wishes \\
\hline \multirow[t]{5}{*}{ Aorist } & 1 & SG & $\left\{-\left(A^{2}\right) r-m I^{2} n\right\}$ & epistemic possibility; \\
\hline & & PL & $\left\{-\left(A^{2}\right) r-m I^{2} z\right\}$ & commands, requests \\
\hline & 2 & SG & $\left\{-\left(\mathrm{A}^{2}\right) \mathrm{r}-\mathrm{sI} \mathrm{I}^{2} \mathrm{y}\right\}$ & \\
\hline & & PL & $\left\{-\left(\mathrm{A}^{2}\right) \mathrm{r}-\mathrm{sI}^{2} \mathrm{y}-\mathrm{dA} \mathrm{A}^{2} \mathrm{r}\right\}$ & \\
\hline & 3 & SG/PL & $\left\{-\left(\mathrm{A}^{2}\right) \mathrm{r}\right\}$ & \\
\hline
\end{tabular}


Table 5. Modal particles

\begin{tabular}{|c|c|}
\hline Modal particles & Modal nuances \\
\hline$\dot{a}$ & meditative-rhetorical use, comment \\
\hline$a w$ & $\begin{array}{l}\text { approval, regret, disappointment; comprehension, presumption, } \\
\text { assumption }\end{array}$ \\
\hline bịlem & certainty, assumption \\
\hline$D^{2} A^{2}$ & $\begin{array}{l}\text { statement is understandable, unsurprising, expected, predictable, } \\
\text { inevitable, reasonable, acceptable, and logical; regret; comprehen- } \\
\text { sion }\end{array}$ \\
\hline & comprehension \\
\hline ešị & comprehension; doubtful attitude \\
\hline eseyšị & approval, disapproval \\
\hline oy & $\begin{array}{l}\text { presumption, comprehension, plausibility of a possibility, surmise, } \\
\text { conjecture }\end{array}$ \\
\hline & meditative-rhetorical use, anxiousness \\
\hline & dubitative, ironical \\
\hline 2 & $\begin{array}{l}\text { reinforcement, entreaty, begging, appeal, emphasis of desire, } \\
\text { wishing, hope, disapproval, disappointment }\end{array}$ \\
\hline & sitive or negative attitude \\
\hline
\end{tabular}

Table 6. Lexical expressions

Modal notions

Modal words

Volition

buyur - 'to order to be done', wötin- 'to entreat, ask', sura- 'to beg', tałap ${ }^{y}$ et- 'to request, ask', usunus ${ }^{y}$ et- 'to suggest', kała- 'to want, wish', tịle- 'to wish, desire', ümüt 'y et- 'to hope', armanda- 'to hope, aim at', kökse- 'to wish, desire'

Necessity kajet, kerek, tiyịs 'needed, necessary', tazïm 'necessary, ought', jön 'right, correct, suitable' or abzat 'right, correct, admissible', durus 'right, true, correct', tayik 'suitable, appropriate', šart 'essential', mịndettị 'obligatory', mážbür 'constrained, compelled'

Possibility boładï 'to be possible', jotber- 'to allow', ruksat ${ }^{y}$ et- 'to permit', jolyoy- 'to allow', tiyim sat- 'to forbid, prohibit', čekte- 'to forbid', teje- 'to restrict, limit' or jołberme- 'not to allow', ruksat 'etpe- 'not to permit'

Epistemic evaluation bàlkịm 'maybe', bálki 'perhaps', mümkün 'possible', àytewịr / aytew 'anyway', 'anyhow', barrịbịr 'all the same', 'nevertheless', čamasï 'probably' siyayï 'seemingly', assili 'actually', sịra 'probably', zadï 'essentially', tegi 'apparently', bołar / 
čïar 'to be possible', körịnedị, uksaydï, siyaktï, sïkiłdï, sekịldị, alpetti 'it seems', mümkün 'possible', ïktimat 'probable', kädịk 'improbable' botmasïn 'it is hopefully not...', kerek 'necessity'; árine / àlbette 'of course, certainly', sözsịz, sözjok 'surely' 


\section{References}

Abay kara sözderị ['Prose works of Abai'] 2010. Almaty: Өнер Баспасы ['Öner Publisher'].

Abish, Aynur \& Csató, Éva Á. 2011. Recent developments in Kazakh as spoken in the People's Republic of China. Turkic Languages 15: 275-290.

Abish, Aynur \& Csató, Éva Á. forthcoming. Language attitudes and linguistic habits of young Kazakhs in Xinjiang. In: Kirchner, Mark \& Mukhamedova, Raikhangul (eds) Kazakh in post-soviet Kazakhstan. Proceeding of the internation Symposium on Kazakh, November 30-December 2, 2011.

Aibixi, Ayinu 2012. Modality in Kazakh spoken in China. In: Kincses-Nagy, Éva \& Biacsi, Mónika (eds) The Szeged Conference. Proceedings of the 15th International Conference on Turkish Linguistics held on August 20-22, 2010 in Szeged. (Studia uralo-altaica 49.) Szeged: Department of Altaic Studies. 39-46.

$A P P E D=$ The Aryanpur progressive Persian-English dictionary 4. 2004. Iran: Electronic Publishing and Information PC World.

Aybergenov, Tölegen 2005. Men sayan rašïk ${ }^{y}$ edịm ['I was in love with you']. Almaty: Раритет Баспа Компаниясы ['Raritet Publishing Company'].

Axmetov, A (ed.) 1976. Abay ${ }^{w}$ öleyderị ['The poems of Abay’]. Almaty: Жазущы Баспасы ['Writer Publisher'].

Baskakov, N. A. (ed.) 1958. Karakalpaksko-russkij slovar'. Moskva: Gosudarstvennoe izdatel'stvo inostrannyx i nacional'nyx slovarej.

Bektaev, Kałdïbay. B. 1995. Sözdịk. Kazakša-orïsša sözdịk jäne orïš̌a-kazaǩ̌sa sịlteme sözdịk ['Dictionary. Kazakh-Russian and Russian-Kazakh explanatory dictionary']. Šimkent: Türkistan.

Benson, Linda \& Svanberg, Ingvar 1988. The Kazakhs in Xinjiang. In: Benson, Linda \& Svanberg, Ingvar (eds) The Kazakhs of China: Essays on an ethnic minority (Studia Multiethnica Upsaliensia 5.) Uppsala: Uppsala University.

Benson, Linda \& Svanberg, Ingvar 1998. China's last nomads. The history and culture of China's Kazakhs. (Studies on Modern China.) Armonk \& London: M. E. Sharpe.

Berta, Árpád 2006. Tatar and Bashkir. In: Johanson \& Csató (eds) 2006²: 283-300.

Bradley, David 2005. Language policy and language endangerment in China. International Journal of the Sociology of Language 173: 1-21.

Clauson, Gerard Sir 1972. An etymological dictionary of pre-thirteenth-century Turkish. Oxford: Clarendon Press.

Csató, Éva Á. 1998. Should Karaim be 'purer' than other European languages? Studia Turcologica Cracoviensia 5: 81-89.

Csató, Éva Á. 2012a. Modal categories in Karaim. A case of complex contact morphology. In: Otsuka, Hitomi \& Stroh, Cornelia \& Urdze, Aina (eds) When morphologies collide... On what can happen morphologically in language contact. (Diversitas Linguarum 30.) Bochum: Brockmeyer. 121-130.

Csató, Éva Á. 2012b. On the sustainability of inflectional morphology. In: Johanson, Lars \& Robbeets, Martine (eds) Copies versus cognates in bound morphology. 
(Brill's Studies in Language, Cognition and Culture 2.) Leiden \& Boston: Brill. 371-380.

Dahl, Östen (ed.) 2000. Tense and aspect in the languages of Europe. Berlin \& London: Mouton de Gruyter.

De Jong, Frederick 2007. A grammar of Modern Uyghur. Utrecht: Houtsma.

DeLancey, Scott 1997. Mirativity: The grammatical marking of unexpected information. Linguistic Typology 1: 33-52.

Deny, Jean et al. (eds) 1959. Philologiae turcicae fundamenta 1. Wiesbaden: Steiner.

DEKLL $=$ Department of Kazakh Language and Literature, Minzu University of China. An introductory book. 2013. Beijing: Chinese Minzu University.

Dik, Simon C. 1989. The theory of functional grammar 1: The structure of the clause. Dordrecht: Foris.

Dik, Simon C. 1997. The theory of Functional Grammar 2: Complex and derived constructions. Dordrecht: Foris.

DKLL = Kazak adebi tịlinịn sözdigi 1-15 ['Dictionary of the Kazakh literary language 1-15'] 2011. Amatï: Kazaksstan respublikasï mảdeniyet ministịrlịgị tịl komitetị \& Kazaḳstan respublikasï bịlịm žảne yïlïm minịstịrlịgị yïlïm komitetị \& A. Baytursïn ułï atïndayï tịl bịlịmị institutï ['Almaty: Committe on language of the Ministry of Culture Republic of Kazakhstan \& Committe of Science committe of the Ministry of Education and Science of the Republic of Kazakhstan \& Ahmet Baytursunuli Language Institution'].

Doerfer, Gerhard 1959. Das Krimtatarische. In: Deny et. al. (eds) 1959: 369-390.

Encyclopaedia of Islam 1. Leiden: Brill. 1960.

Fang, Ruoyu 2009. Xīnjiāng hāsàkè zú rénkǒu guīmó biànqiān jí fēnbù ['The change and distribution of Xinjiang Kazakh population scale']. In: Zhang, Dingjing et al. (eds) Zhōngguó hāsàkè yǔyán wénhuà lùn jí ['Collective volume on Kazakh language and culture in China']. Beijing: The Ethnic Publishing House. 243261.

Fang, Xiaohua 2009. Xīnjiāng shăoshù mínzú shuāngyǔ jiàoxué: Xiànzhuàng, tèdiăn jí qí fănsī ['Minority bilingual education: current situation, characteristics and reflections']. Journal of Xinjiang Ili Normal University. Social Science Edition 2009, 4: 59-67.

Gabain, Annemarie von 1941. Alttürkische Grammatik. Leipzig: Harrassowitz.

Geng, Shimin 1989. Xiàndài hāsàkè yǔ yǔfă ['Modern Kazakh grammar']. Beijing: Chinese Minzu University Press.

Geng, Shimin \& Kảken, Mảken \& Orïnbay, Jumatay 1999. Kazịgị kazak tịli ['Modern Kazakh language']. Beijing: The Ethnic Publishing House.

Greenbaum, Sidney 1969. Studies in English adverbial usage. London: Longman.

Göksel, Aslı \& Kerslake, Celia 2005. Turkish: A comprehensive grammar. New York \& London: Routledge.

Hahn, Reinhard F. 2006. Uyghur. In: Johanson \& Csató (eds) 2006²: 379-396.

Hahn, Reinhard F. \& in collaboration with Ibrahim, Ablahat 2006. Spoken Uyghur. Seattle: University of Washington Press.

Hengeveld, Kees 1987. Clause structure and modality in Functional Grammar. In: van der Auwera, Johan \& Goossens, Louis (eds). Ins and outs of the predication. (Functional Grammar Series 6.) Dordrecht: Foris. 53-66.

Hengeveld, Kees 1988. Illocution, mood, and modality in a Functional Grammar of Spanish. Journal of Semantics 6: 227-269.

Huang, Xing 2000. Zhōngguó shào shù mínzú yǔyán huólì yánjiū ['Studies on minority language vitality in China']. Beijing: Chinese Minzu University Press. 
Hu, Zhenhua 1986. Ké'érkèzī yŭ jiăn zhi ['A brief introduction to Kirghiz']. Beijing: Chinese Minzu University Press.

Huang, Zhongxiang 1999. Hāsàkè yǔyán wénzì yánjiū gàikuàng ['A brief review of research on the Kazakh language and script']. Language and Translation (Ürümqi) 59: 10-15.

Johanson, Lars 1989. Aorist and present tense in West Oghuz Turkic. In: Tekin, Şinasi \& Tekin, Gönül Alpay (eds) Journal of Turkish studies 13. Gerhard Doerfer Festschrift. Harvard University: Office of the University Publisher. 99105.

Johanson, Lars 1999. Typological notes on aspect and actionality in Kipchak Turkic. In: Abraham, Werner \& Kulikov, Leonid (eds) Tense-aspect, transitivity, and causativity: Essays in honor of Vladimir Nedjalkov (Studies in Language Companion Series 50.) Amsterdam: John Benjamins. 171-184.

Johanson, Lars 2000a. Turkic indirectives. In: Johanson, Lars \& Utas, Bo (eds) Evidentials. Turkic, Iranian and neighbouring languages. Berlin \& New York: Mouton de Gruyter. 61-87.

Johanson, Lars 2000b. Viewpoint operators in European languages. In: Dahl (ed.) 2000: 27-187.

Johanson, Lars 2002a. Do languages die of 'structuritis'? The role of code-copying in language endangerment. Italian Journal of Linguistics 14: 249-270.

Johanson, Lars 2002b. Structural factors in Turkic language contacts. [With an introduction by Bernard Comrie.] London: Curzon.

Johanson, Lars 2003. Evidentiality in Turkic. In: Aikhenvald, Alexandra Y. \& Dixon, R[obert] M. W. (eds) Studies in evidentiality. (Typological Studies in Language 54.) Amsterdam \& Philadelphia: John Benjamins. 273-290.

Johanson, Lars 2006a. Indirective sentence types. Turkic Languages 10, 73-89.

Johanson, Lars 2006b. The structure of Turkic. In: Johanson \& Csató (eds) $2006^{2}$ : 30-66.

Johanson, Lars 2009. Modals in Turkic. In: Hansen, Björn \& de Haan, Ferdinand (eds) Modals in the languages of Europe. Berlin: Mouton de Gruyter. 487-510.

Johanson, Lars 2012a. Notes on Turkic stance particles. In: Erdal, Marcel \& Nevskaya, Irina \& Menz, Astrid (eds) Areal, historical and typological aspects of South Siberian Turkic. (Turcologica 94.) Wiesbaden: Harrassowitz. 51-58.

Johanson, Lars 2012b. Mood meets mood: Turkic versus Indo-European. In: Vanhove, Martine \& Stolz, Thomas \& Urdze, Aina \& Otsuka, Hitomi (eds) Morphologies in contact. Berlin: Akademie Verlag. 195-206.

Johanson, Lars 2013. On non-canonical modal clause junction in Turkic. In: Josephson, Folke \& Söhrman, Ingmar (eds) Diachronic and typological perspectives on verbs. Amsterdam: John Benjamins. 159-171.

Johanson, Lars (in print) Diskontinuität in der Entwicklung des Türkischen: Aufstieg und Niedergang des osmanischen Optativs. In: Akten der 6. Deutschen Turkologenkonferenz.

Johanson, Lars (forthcoming) A synopsis of Turkic volitional moods.

Johanson, Lars \& Csató, Éva Á. (eds) $2006^{2}$. The Turkic languages. New York \& London: Routledge.

J̌anbołatov, Sułtan 2008. Bịz ['We']. Beijing: The Ethnic Publishing House.

Jurtbayev, Tursïn 2005. Ketbuka ['Ketbuḳa']. Beijing: The Ethnic Publishing House.

Karakoç, Birsel 2005. Das finite Verbalsystem im Nogaischen. (Turcologica 58.) Wiesbaden: Harassowitz.

Kazak tịlịị̣ kïskaša etimołogyatik sözdigi ['Short Kazakh etymological dictionary’] 1966. Almaty: Ғïlïm Баспасы ['Science Publisher']. 
Kazakh Türkçesi Türkiye Türkçesi sözlüğü ['Kazakh-Turkish dictionary’] 2003. Ankara: Akçağ.

$\mathrm{KD}=$ Kazak tịlịị̣ tüsịndịrme sözdigi 1-10 ['The comprehensive Kazakh dictionary 1-10’] 1974-1986. Kazaḳ kenestịk sotsiałdik respublikasï yïłm ảkảdemiyasï tịl bịlịmị inistitutï ['The Institution of Academic Science of Kazakh Soviet Socialist Republic'] (eds). Almaty: Ғïlïm Баспасы ['Science Publisher'].

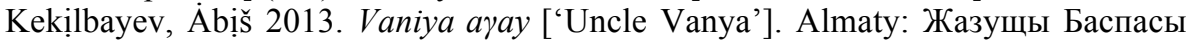
['Writer Publisher']

$\mathrm{KG}=$ Kazak grammatikasï ['Kazakh grammar'] 2002. Astana: Kazakstan respubłikasï bịlịm jàne yïłïm ministịrlịgị \& A. Baytursïn ułï atïndayï tịl bịlịmị institutī ['Ministry of Education and Science of the Republic of Kazakhstan \& Ahmet Baytursunuli Language Institution'].

Kirchner, Mark 2006a. Kazakh and Karakalpak. In: Johanson \& Csató (eds) $2006^{2}$ : 318-332.

Kirchner, Mark 2006b. Kirghiz. In: Johanson \& Csató (eds) 2006²: 344-356.

Korkina, E. I. \& Ubrjatova, E. I. \& Xaritonov, L. N. \& Petrov, N. E. (eds) 1982. Grammatika sovremennogo jakutskogo literaturnogo jazyka. Moskva: Nauka.

König, Ekkehard 2001. Intensifiers and reflexive pronouns. In: Haspelmath, Martin \& König, Ekkehard \& Oesterreicher, Wulf \& Raible, Wolfgang (eds) Language typology and language universals / Sprachtypologie und sprachliche Universalien/La typologie des langues et les universaux linguistiques: An international handbook / Ein internationales Handbuch / Manuel international 1. Berlin: de Gruyter. 747-760.

$\mathrm{KP}=$ Kazak makał mátelderịnị tüsịndịrme sözdigi ['An explanatory dictionary of Kazakh proverbs'] 2009. Ürümqi: Xinjiang Teenagers Press.

Krippes, Karl A. 1996. Uzbek-English dictionary. Kensington, Maryland, U.S.A.: Dunwoody Press.

Kurał, Ayubay (ed.) 2003. Kazak destürli medeniyetịnị entsikłopediyatïk sözdịgị ['An encyclopedic dictionary of the traditional Kazakh culture']. Beijing: The Ethnic Publishing House.

Lewis, Geoffery L. 1967. Turkish grammar. Oxford: Clarendon.

Li, Ruzhong 1994. Wǒguó hāsàkè mínzú jiàoyù de lìshǐ yǔ xiànzhuàng ['The history and present situation of the Kazakh national education in China']. Journal of Xinjiang University. Philosophy, Humanities \& Social Sciences (Xinjiang University) 1994, 3: 4-7.

Li, Zengxiang 2007. Hāsàkè yǔ ['The Kazakh language']. In: Sun, Hongkai et al. (eds) Zhōngguó de yǔyán ['The languages in China']. Beijing: Shāngwù yìn shūguăn ['The Commercial Press']. 1656-1675.

Light, Nathan 1993. Kazakhs of the Tarbaghatai: Ethno-history through the novel. The Turkish Studies Association Bulletin 17, 91-102.

Lyons, John 1977. Semantics 1-2. Cambridge: Cambridge University Press.

Mamanov, Ïbïrayïm 2007. Kazịrgị ḳazaḳ tịlị. Etịstịk ['Modern Kazakh language. Verbs']. In: Mamanov, Ïbïrayïm 2007. Kazak tịli bịlịịiṇ̣ máselelerị ['Problems in Kazakh linguistics']. Almaty: Арыс Баспасы ['Aris Publisher']. 16120.

Menges, Karl Heinrich 1959. Die Aralo-kaspische Gruppe. In: Deny et al. (eds) 1959: 434-488.

Menges, Karl Heinrich 1995. The Turkic languages and peoples. Wiesbaden: Harrassowitz.

MKL = Ramet, Mellat \& Ȧbịlyazï, Ałïmseyịt (eds) 2002. Kazịrgị kazak tịli ['The modern Kazakh language']. Ürümqi: Xinjiang Peoples Publishing House. 
Muhamedowa, Raihan 2011. From participle to topic particle: Kazakh degen in comparison with its functional equivalents in Turkish. Turkic Languages 15: 259-274.

Nurałyeva, N (ed.) 2008. Kazaǩša-ayitšinša sözdịk ['Kazakh-English dictionary’]. Almaty: Dayk Publication.

Quirk, Randolph \& Greenbaum, Sidney \& Leech, Geoffrey \& Svartvik, Jan 1985. A comprehensive grammar of the English language. London: Longman.

Ramat, Paolo \& Ricca, Davide 1998. Sentence adverbs in the languages of Europe. In: van der Auwera, Johan (ed.) Adverbial constructions in the languages of Europe. Berlin: Mouton de Gruyter. 187-275.

Redhouse Türkçe. Osmanlıca-İngilizce Sözlük $2000^{18}$. İstanbul: Redhouse.

Rentzsch, Julian 2012. Modality in Turkic between arbitrarity, grammaticality and lexicality. In: Kincses-Nagy, Éva \& Biacsi, Mónika (eds) The Szeged Conference. Proceedings of The 15th International Conference on Turkish Linguistics held on August 20-22, 2010 in Szeged. (Studia uralo-altaica 49.) Szeged: Department of Altaic Studies. 469-482.

Schreiber, Peter 1972. Style disjucts and the performative analysis. Linguistic Inquiry 3: 321-348

Schönig, Claus 2006. Turkmen. In: Johanson \& Csató (eds) 2006²: 261-372.

Shnitnikov, Boris N. 1966. Kazakh-English dictionary. Paris: Mouton.

Šorayaḳov, Omar 1984. Žarłï tảlịp ['Poor Talip'] In: Stanbekov, D. (ed.) Šàyị 〈Šayïr〉 ['Resin']. Almaty: Жазущы Баспасы ['Writer Publisher'].

Thomsen, Kaare 1959. Das Kasantatarische und die westsibirischen Dialekte. In: Deny et. al. (eds) 1959: 407-421.

Tömür, Hämit 2003. Modern Uyghur grammar. Morphology. İstanbul: Y1ldız.

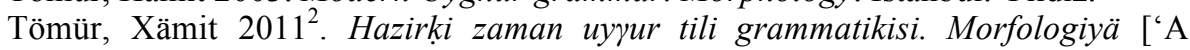
grammar of Modern Uyghur. Morphology']. Beijing: The Ethnic Publishing House.

UTIL = Uyzur tiliniy izahlik luyiti 1-6 ['Explanatory dictionary of the Uyghur language 1-6'] 1991-1998. Beijing: The Ethnic Publishing House.

van der Auwera, Johan \& Zamorano Aguilar, Alfonso (forthcoming) The history of mood and modality. In: Nuyts, Jan \& van der Auwera, Johan (eds) 2014. The Oxford handbook of mood and modality. Oxford: Oxford University Press.

Wurm, Stefan 1959. Das Özbekische. In: Deny et al. (eds) 1959: 489-524.

XJYB= Xīnjiāng niánjiàn ['Xinjiang yearbook'] 2011. Ürümqi: Xīnjiāng niánjiàn shè ['Xinjiang Yearbook Society Press'].

$\mathrm{XJUAR}=$ Xìnjiāng wéiwúér zìzhìū gàikuàng ['Overview of Xinjiang Uyghur Autonomous Region'] 2009. Beijing: The Ethnic Publishing House.

Yakup, Abdurishid 2009. Necessity operators in Turkish and Uyghur. In: Choi HanWoo (ed.) International Journal of Central Asian Studies 13. Festschrift to commemorate the 80th anniversary of Prof. Dr. Talat Tekin's Birth. 479-493.

Yang, Ling 1999 Wǒguó chūbăn de hāsàkè yŭ císhū lèi gōngjù shū mùlù ['Catalog of Kazakh dictionaries published in China']. Language and Translation 1999, 2: 78-80.

Zhang, Dingjing 1990a. Hāsàkè yǔ qíshǐjù ['Imperaives in Kazakh']. Journal of Xinjiang University. Philosophy, Humanities \& Social Science 1990, 2: 87-93.

Zhang, Dingjing 1993. Shuō -sa ['About -sa']. Language and Translation 1993, 2: 23-26.

Zhang, Dingjing 1999. Shuō de- ['About de-']. Journal of research on education: For Ethnic minorities. (Beijing: Chinese Minzu University Press.) 1999, 1: 146155. 
Zhang, Dingjing 2001. Hāsàkè yǔ zhīqíng yǔqì zhùcí ['Kazakh evidential particles']. Minority languages of China 2001, 6: 47-53.

Zhang, Dingjing 2002. Hāsàkè yǔ xūcí de chéngyuán jí qí yǔfă huà jìnchéng ['A survey of Kazakh function words: The markers and the process of their grammaticalization']. Journal of The Central University for Nationalities Humane and Social Sciences Edition 29. Beijing: Chinese Minzu University Press. 2002, 2: 21-29.

Zhang, Dingjing 2003. Xiàndài hāsàkè yǔ xūcí ['Function words of Modern Kazakh']. Beijing: The Ethnic Publishing House.

Zhang, Dingjing 2004. Xiàndài hāsàkè yǔ shřyòng yǔfă ['A practical grammar of Modern Kazakh']. Beijing: Chinese Minzu University Press.

Zhou, Minglang 2003. Multilingualism in China. The politics of writing reforms for minority languages 1949-2002. Berlin: Walter de Gruyter. 


\section{Appendix}

\section{Texts}

\section{T1. Bałanïy dünyege keluwịne bayłanïstï salttar 'Customs}

concerning the birth of a child'

Metadata

Gender: female

Age: 46

Date of birth: 23th April 1964

Place of birth: Ürümqi County, Xinjiang Uyghur Autonomous Region of China

\section{Education: High School}

Language competence: Kazakh (mother tongue), Chinese (understands and speaks), Uyghur (understands and speaks)

Date of recording: 17th July 2010

Place of recording: Burqin County (in a Kazakh village), Altay.

Running text

$\mathrm{T} 1 / 1-\mathrm{T} 1 / 10$

Bịzdịn ḳazak kałḳi ${ }^{\mathrm{y} e n d i ̣ ~ t o y ~ j a s a p ~ b a ł a ł i ̈ ~ b o ł \gamma a n n a n ~ b a s t a p . . . ~ T o y ~ j a s a \gamma a n n a n ~}$ keyịn, ${ }^{\mathrm{y}}$ endị bałałi boładi. Bałałi bołyannan keyịn to

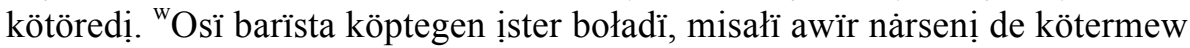
kerek, diḳat kịłatïn ịster boładï. Awïr närsenị kötermew kerek, wonan keyịn àgị ałbatï kałaymaḳan dảrị ịsspew kerek. Soł kezde ${ }^{\mathrm{y}}$ endị ịs̆tegị nảrestenịn

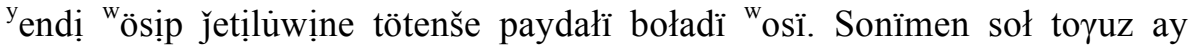

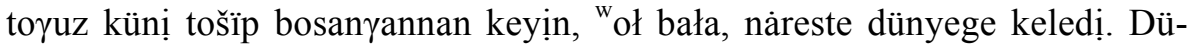
nyege kelgennen keyịn, bịzdịn kazak kałḳinda ${ }^{\mathrm{y}}$ endị čịldeḳana degen $\mathrm{b}^{\mathrm{i}} \mathrm{r}$ ${ }^{\mathrm{y}}$ endị nemene toy ${ }^{\mathrm{w}}$ ötkịzedị ${ }^{\mathrm{y}}$ endị kịsṣigịị̣m. ${ }^{\mathrm{w}} \mathrm{O}$ kezde ${ }^{\mathrm{y}}$ endị köršịlerdị, jaḳïn

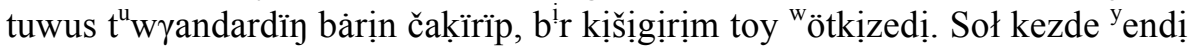
tay atḳanča ${ }^{y}$ endị wözịmịzdịn yendị ánderịmịzdị čïḳap, ḳara jor ya deytịn biyịmịz bar ${ }^{\mathrm{y}}$ endị ${ }^{\mathrm{w}}$ osïdardï aytïp, türlị türlị kïzïḳtï ảngịmeder čìrarïp, wosïnday köršị kołandar ${ }^{\mathrm{y}}$ endị buł bałanïn dünyege kelgendịgịnen sonday kuwanïšta boładï. 
$\mathrm{T} 1 / 11-\mathrm{T} 1 / 20$

Sonïmen süyte süyte soł bała... jetị künnen keyịn buł bałanï besịkke saładï.

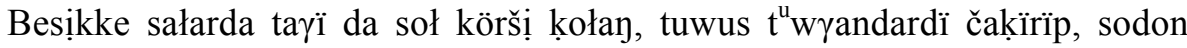

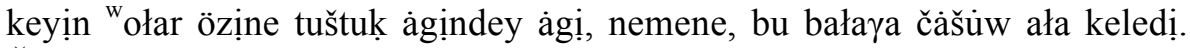
Čăšù ała kep sonïmen bunï besịkke saładï. Besịkke sałuw barïsïnda, buł

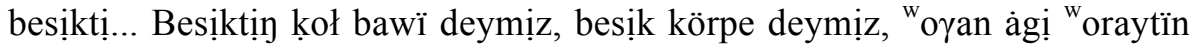
jörgek, ana mïnasïnïn bảịn, wözderịnịn kołdarïmen tịg̣̣p, türlị tüstegị

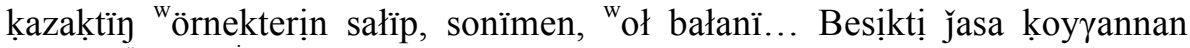

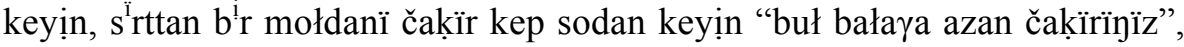

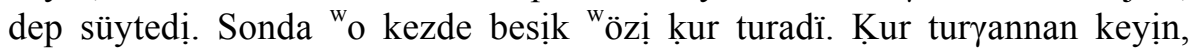

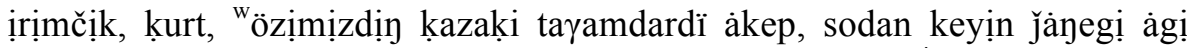

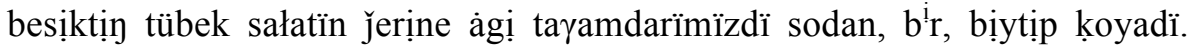

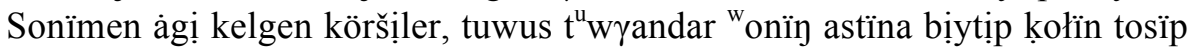

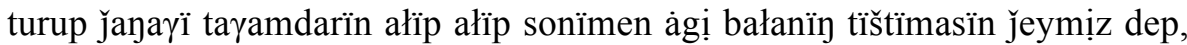
àgịnị jeydị. Jep, jep bołyannan keyịn, sodan keyịn janayï mołda azan čakïradï.

\section{$\mathrm{T} 1 / 21-\mathrm{T} 1 / 30$}

Azan čakïrïp, sodan keyịn, senịn atïn pảlembay dep bayayï, mảselen, ayguł yáki serịk dese: "serịk!” senịn atïn "serịk!” senịn atïn “serịk!” dep so sekịldị àgị üš ret čaḳïradï. Azan čaḳiradï, "osïnday at ḳoyadï bałaja. Azan čaḳïrïp at koyadï. ${ }^{\mathrm{w}}$ Onan keyịn, süyte süyte kep, bu bałanï... ${ }^{\mathrm{y}}$ Endị... kịrì k kün boładï.

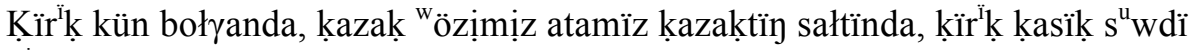
$b^{i}$ r tegenege quyup ałamïz da, buł bałanï $s^{u} w \gamma a$ čomïłdïramïz. $S^{u} w \gamma a$

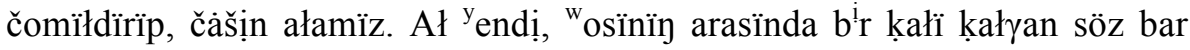
${ }^{\mathrm{y}}$ eken. Buł bała üš tört kün ${ }^{\mathrm{w}}$ ötkennen keyịn, àgịndey àgị, terịsị jaman bo ketpesịn dep, tuzdu... àgị, $\mathrm{s}^{\mathrm{u}}$ wdï biraz jiłłman kïp ałamïz da, woyan àgị, tuzdï aštïrak kïip sałïp ap, bałanï, neše ret, kïrḳi čịḳança, soł àgị, tuzduḳ s sưa

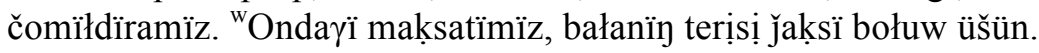

\section{$\mathrm{T} 1 / 31-\mathrm{T} 1 / 41$}

Keyịngị kezde, bayayï, keyb rewderdịn denesị kịsīnïp jatadï, ana mïna boł"p

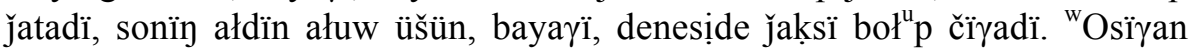
k̦aratiłyan söz buł. ${ }^{\mathrm{w}}$ Onan geyịn, ${ }^{\mathrm{w}}$ onïn ${ }^{\mathrm{w}}$ ortasïnda, àgịndey àgị, bałanïn

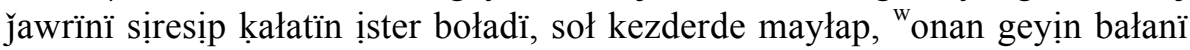
kerịp sozadï. Mȧselen, mïna ḳołdan ałïp ap, bịytịp köterịp, sozamïz. "Onan geyịn, b ${ }^{i}$ koł, bi ayaḳtan, bịytịp sozatïn kezder boładi. ${ }^{\mathrm{w}}$ Onan geyịn, jawïrïndarï àgị üyüsüp kaładï. Soł kezderde àgị bịzdịn ḳazaḳtïn tas čàyị dep koyamïz, tas čàị dep b’r kök čüperek boładï, kök čüperekke kaynatïp, àgị samasïn bịytịp ḳoyïp ałamïzdaүï, bałanïy mïna jawrïnïna bịytịp čaptap, bịytịp koyï koysa, àgịịn àgị, suwuk asïp turyan bała derew saḳaya ḳaładï. Sonda, wonan geyịn, ḳirḳïn ayttịk ḳoy à, "onan geyịn, ḳirḳï tošadï. Sodan ḳirḳi

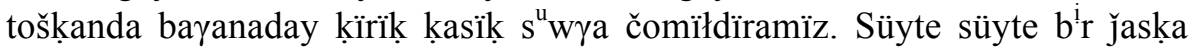
keledị, süyte süyte ülkeyedị. Mȧselen, ${ }^{y}$ endị, uł bałałar bołsa, bes jasḳa kel- 
gende bu bałanï sündetteymịz. Mołdanï čakïrïp, sündettep, wözịmịzdị̣ sałtïmïz boyïnča sündettep, jetị jasḳa kelgende bayayï sündet toyïn jasaymïz uł bała bosa. Ał, ḳizbała bosa, bunïn besịk toyïn jasaymïz dep. So, sonday brr, wözịmịz ḳuwanïp, ḳał̌a berịp, dos jaran, tuwus $t^{\mathrm{u}} w \gamma$ andarïmïzdï, körṣ̌ kołandarïmïzdï čakịirïp, sonday sałttarïmïz bar wötkịzịp jaatatïn.

Annotated text

$\mathrm{T} 1 / 1$

Bịz-dị kazak katk-ï yendi toy jasa-p

we-GEN Kazakh people-POSS3 NOW.FILL wedding create-IP.CONV

batati bot-yan-nan basta-p...

pregnant BOL.COP-GAN.PTCP-ABL start-IP.CONV

'Our Kazakh people get married, and then they start to get children...'

$\mathrm{T} 1 / 2$

Toy jasa-yan-nan keyị, ${ }^{y}$ endị bałati

wedding create-GAN.PTCP-ABL AFTER1.POSTP NOW.FILL pregnant

bot-a-dï.

BOL.COP-A.PRES-3

'After they have got married they get children.'

$\mathrm{T} 1 / 3$

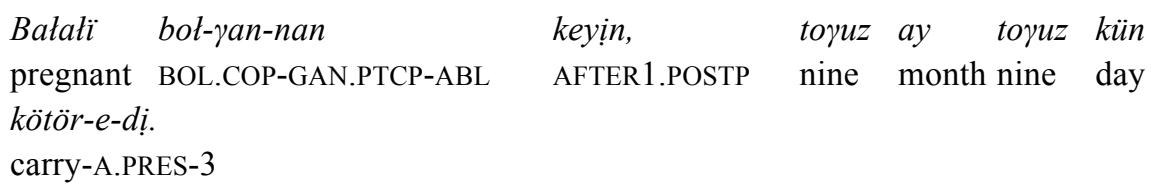

'After they have become pregnant, they bear (the baby) 9 months and 9 days.'

$\mathrm{T} 1 / 4$

${ }^{w}$ Osï barïs-ta, köp-tegen iss-ter bot-a-dï,

this course-LOC lot-APPROX thing-PL BOL.COP-A.PRES-3

misatï, awïr närse-ni de köter-me-w kerek,

for example heavy thing-ACC DA.PART carry-NEG-UW.VN necessary

dikat kï-atïn is-ter bot-a-di.

careful do-ATIN.PTCP thing-PL BOL.COP-A.PRES-3

'During this time, there are very many things, for example, one should not carry heavy things, and there are things which you have to pay attention to.'

$\mathrm{T} 1 / 5$

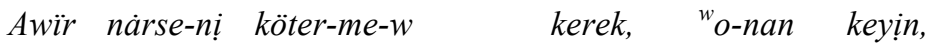
heavy thing-ACC carry-NEG-UW.VN necessary X-ABL AFTER1.POSTP

àgi atbatï kataymakan därị $i \grave{s}-p e-w \quad k e r e k$.

AFORESAID.FILL random arbitrary medicine drink-NEG-UW.VN necessary

'One should not carry heavy things, or take medicine without careful judgment.' 
$\mathrm{T} 1 / 6$

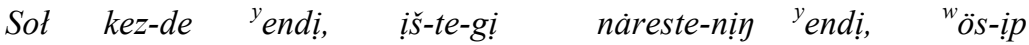

that time-LOC NOW.FILL inside-LOC-GI infant-GEN NOW.FILL grow-IP.CONV

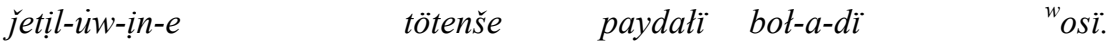

mature-UW.VN-POSS3-DAT extraordinary useful BOL.COP-A.PRES-3 this

'Then this will be very useful for the growth and development of the unborn baby.'

$\mathrm{T} 1 / 7$

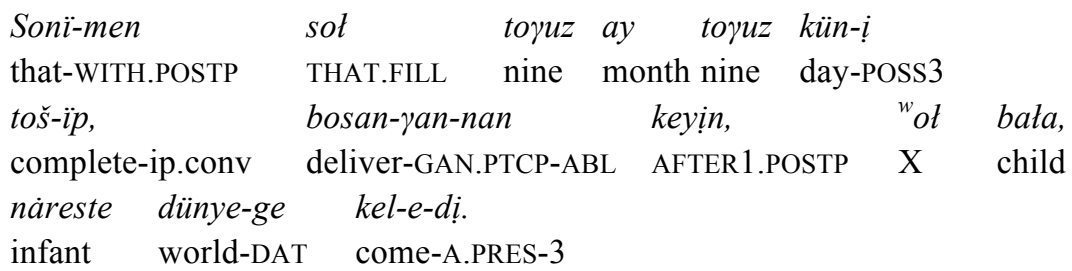

'Then, when the nine months and nine days have passed, that baby is born.'

$\mathrm{T} 1 / 8$

\begin{tabular}{|c|c|c|c|c|c|c|c|}
\hline $\begin{array}{l}\text { Dünye-ge } \\
\text { world-DAT }\end{array}$ & $\begin{array}{l}\text { kel-g } \\
\text { come }\end{array}$ & $\begin{array}{l}n \text {-nen } \\
\text { GAN.PTCP-ABL }\end{array}$ & $\begin{array}{l}\text { keyin } \\
\text { AFTE }\end{array}$ & 1.POSTP & $\begin{array}{l}b i z-c \\
\text { WE- }\end{array}$ & & $\begin{array}{l}\text { kazak } \\
\text { Kazakh }\end{array}$ \\
\hline katk-ïn-da & & ${ }^{y}$ endi, & $\operatorname{lna}^{37}$ & de-gen & & $b^{i} r$ & ${ }^{y}$ endi, \\
\hline $\mathrm{PO}$ & LOC & NOW.FILL čilde & rana & say-GAN.I & РTCP & $\mathrm{a}$ & NOW.FILL \\
\hline ene & toy & ${ }^{w} \ddot{o t} t k i ̣$ & & ${ }^{y}$ endị & $k i \grave{s} !$ & $i m$. & \\
\hline
\end{tabular}

WHAT.FILL celebration hold-A.PRES-3 NOW.FILL rather small

'When it has been born, our Kazakh people hold a celebration which is called childekana, which is, a relatively small one.'

$\mathrm{T} 1 / 9$

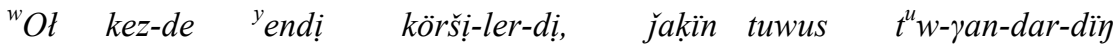

$\mathrm{X}$ time-LOC NOW.FILL neighbor-PL-ACC close relative kinsman-PL-GEN

bär-i-n čakïr-ïp, $\quad b^{i} r \quad$ kịsịiginim toy

all-POSS3-ACC invite-IP.CONV a rather small celebration

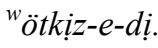

pass through-A.PRES-3

'At that time, they call the neighbors, all the close relatives and hold a relatively small celebration.'

$\mathrm{T} 1 / 10$

Sot kez-de ${ }^{y}$ endị tay at-kanča ${ }^{y}$ endị ${ }^{w} \ddot{o z}$-ịmịz-dị

that time-LOC NOW.FILL dawn-GANŠA.CONV NOW.FILL self-POSS1PL-GEN

${ }^{y}$ endị an-der-ịmịz-dị čirka- $p, \quad$ kara jorya

NOW.FILL song-PL-POSS1PL-ACC sing-IP.CONV black jogtrotting horse

37 A celebration for a newborn baby (Kurał 2003: 452). 


\begin{tabular}{|c|c|c|}
\hline $\begin{array}{l}\text { de-ytịn } \\
\text { say-ATIN.PTCP }\end{array}$ & $\begin{array}{ll}\text { biy-ịmiz } & \text { bar, } \\
\text { dance-POSS1PL } & \text { existing }\end{array}$ & $\begin{array}{lll}{ }^{y} \text { endi, } & { }^{w} \text { osï-dar-dï, } & \text { ayt- } \ddot{i p} \\
\text { NOW.FILL this-PL-ACC } & \text { sing-IP.CONV }\end{array}$ \\
\hline türlị türlị & àygịme-der & $\check{c} \ddot{i} \gamma a r-\ddot{i} p^{38}$ \\
\hline different sorts & interesting & tell-IP.CONV this-EQUA \\
\hline köršị kołay-dar & bała-n̈̈y & dünye-ge \\
\hline ighbor-PL & NOW.FILL this & world-DAT \\
\hline l-gendiginen & son-day & wanïš-ta \\
\hline me-GANDIKI & that-EQUA & BOL.COP-A.PRES-3 \\
\hline
\end{tabular}

'Until the break of day we sing our songs and we have a dance which is called "black jog-trotting horse", we sing all those, and people tell interesting stories and the neighbors become very happy because this child has been born.'

$\mathrm{T} 1 / 11$

\begin{tabular}{|c|c|c|c|c|c|}
\hline $\begin{array}{l}\text { Sonï-men } \\
\text { that-WITH.POSTP }\end{array}$ & & $\begin{array}{l}\text { üyt-e } \\
\text { do so-A.CON }\end{array}$ & $\begin{array}{l}\text { süyt-e } \\
\text { do so-A.CON }\end{array}$ & $\begin{array}{l}\text { bata } \\
\text { child }\end{array}$ & $\begin{array}{l}\text { jetị } \\
\text { seven }\end{array}$ \\
\hline keyịn & but & bała-nï & besịk-ke & sat-a-dï. & \\
\hline FTER 1.POSTP & this & child-ACC & cradle-DAT & put-A.PRES-3 & \\
\hline
\end{tabular}

$\mathrm{T} 1 / 12$

Besịk-ke sat-arda tayi da sot körši kołay

cradle-DAT put-AOR.LOC.CONV again DA.PART that neighbor

tuwus tuwran-dar-dï čakïr-ïp, so-dan keyịn

relative kinsman-PL-ACC invite-IP.CONV that-ABL AFTER1.POSTP

${ }^{w}$ o-łar ${ }^{w} \ddot{o z}$-ịn-e tuštuk ${ }^{39}$, àgindey a a gi,

X-PL self-POSS3-DAT suitable LIKE.AFORESAID.FILL AFORESAID.FILL

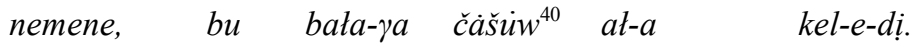

WHAT.FILL this child-DAT present take-A.CONV COME.POSTV-A.PRES-3

'Moreover, when they put the baby into the cradle they invite the neighbors and relatives, and they bring suitable presents and they put them into the cradle.'

$\mathrm{T} 1 / 13$

\begin{tabular}{|c|c|c|c|c|}
\hline$\check{C} \dot{a} \check{s} \dot{u} w$ & $a t-a$ & $k e^{l}-\underline{i} p$ & sonï-men & $b u-n \ddot{l}$ \\
\hline present & bring-A.CONV & COME.POSTV-IP.CONV & that-WITH.POSTP & this-ACC \\
\hline besịk-ke & $s a t-a-d i ̈$. & & & \\
\hline Idle-DA & $\mathrm{T}$ put-A.PRES-3 & & & \\
\hline
\end{tabular}

38 Normally ayt- is the verb for 'to tell, to say'. The use of čizar- 'to invent' in this context means to find something very interesting to tell.

39 This word, which is not found in Kazakh dictionaries, is most probably copied from Uyghur (Uyzur tilinin izahlik luyiti).

40 The word is derived from čášs- 'to throw'. A present consisting of kurt (see footnote 33), candies and silver coins is thrown to the bride in a respectful way when she moves into her new home (Kurał 2003: 451). Here the word refers to a present given to a child. 
$\mathrm{T} 1 / 14$

Besịk-ke sat-uw barïs-ïn-da, but besịk-tị...

cradle-DAT put-UW.VN course-POSS3-LOC this cradle-ACC

'When they put (the baby) into the cradle, this cradle...'

$\mathrm{T} 1 / 15$

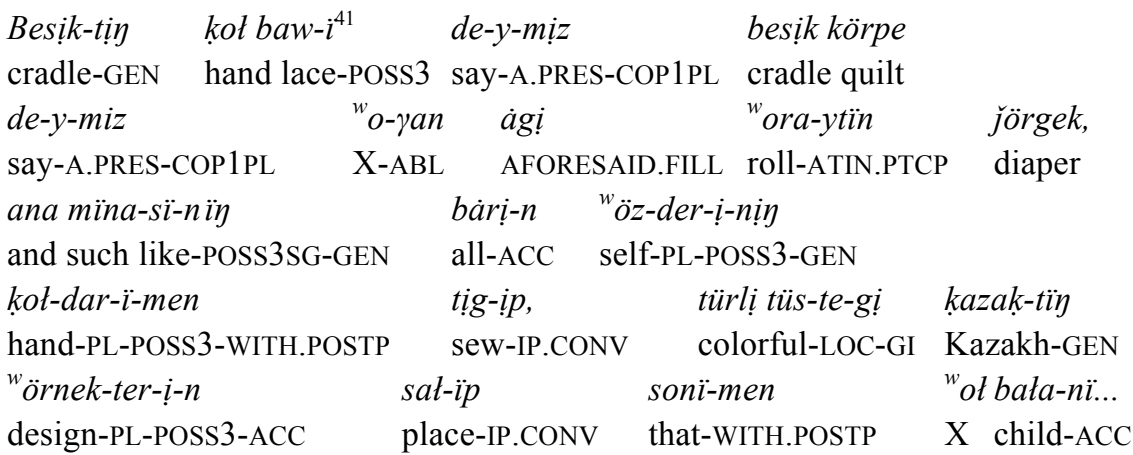

'What we call the cradle's hand lace, what we call cradle quilt, the diaper which is rolled around the baby, they have made all these things themselves, in colorful Kazakh design, and then that baby...'

$\mathrm{T} 1 / 16$

\begin{tabular}{|c|c|c|}
\hline $\begin{array}{l}\text { Besilk-ti } \\
\text { cradle-ACC }\end{array}$ & $\begin{array}{l}\check{j a s a}^{-p} \\
\mathrm{C} \quad \text { construct-IP.CONV }\end{array}$ & $\begin{array}{ll}\text { koy-yan-nan } & \text { keyịn, } \\
\text { PUT.POSTV-GAN.PTCP-ABL } & \text { AFTER1.POSTP }\end{array}$ \\
\hline$s^{i} r t-t a n$ & motda-nї & čakïrip $\quad k e^{l i-i p}$ \\
\hline outside-ABI & mullah-ACC & COME.POSTV-IP.CONV \\
\hline dan $\quad h$ & keyịn & 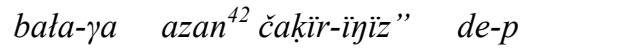 \\
\hline at-ABL & AFTER1.POSTP & child-DAT recite the azan-IMP say-IP.CONV \\
\hline
\end{tabular}

'After they have constructed the cradle, they invite a mullah from outside, then they say (to the mullah): please, recite the azan for this baby.'

$\mathrm{T} 1 / 17$

Son-da ${ }^{w} o$ kez-de besịk ${ }^{w} \ddot{o z}-i$ kur tur-a-dï. that-LOC X time-LOC cradle ÖZI.PART empty stand-A.PRES-3

'At that time, the cradle stands empty.'

41 A piece of lace in the cradle to which the baby's hands are tied (Kurał 2003: 57).

42 Azan (from Arabic adhān) consists of formulas pronounced into the right ear of a child shortly after its birth (Encyclopedia of Islam 1, p. 188). 
$\mathrm{T} 1 / 18$

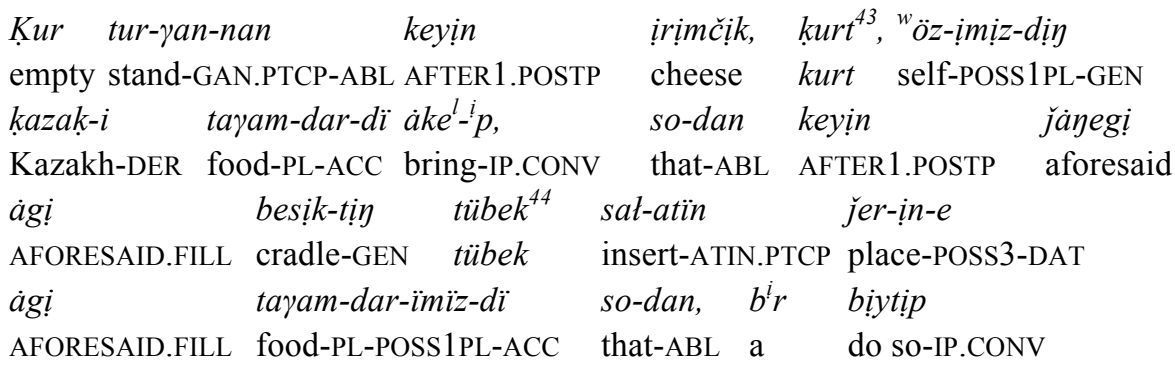

koy-a- $d i$.

PUT.POSTV-A.PRES-3

'So the cradle is empty, and then they bring our Kazakh food, such as cheese and kurt, put into that (aforesaid) cradle where the tübek is inserted, and they put the food into that place like this.'

$\mathrm{T} 1 / 19$

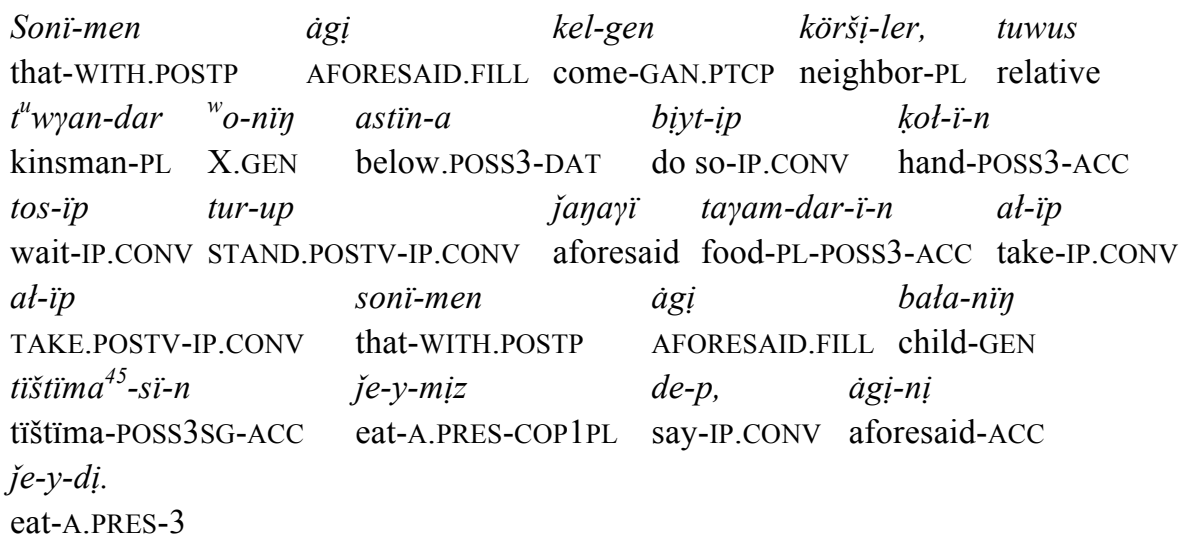

'Then, those neighbors and relatives who attend hold their hands, like this, under it ${ }^{46}$ and catch the things I have already mentioned, the food, and then they say "We eat the tïstima of this baby", and eat it.'

\footnotetext{
43 See footnote 33 .

44 Tübek is a device put on the genitals of the male baby when he is lying in the cradle. It serves to transport the urine into a pot underneath the cradle.

45 Tï̌tima is the name of a ritual performed when a baby is put into the cradle for the first time. Relatives and friends gather around the cradle, in which there is a hole. The baby's excrement is expected to fall down into a pot or a tübek. The guests throw the food they have brought as a present through the hole, asking: Tïs-tï ma?' 〈defecate-PAST3-Q〉 'Did X defecate?' This expression has been lexicalized as a noun and is used as the name of this ritual.

46 Where the tübek is inserted.
} 
$\mathrm{T} 1 / 20$

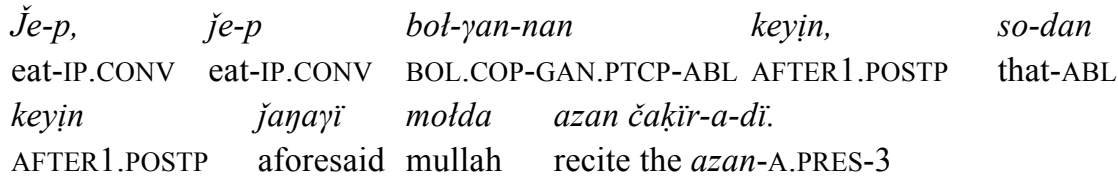

'(They) eat. After they have eaten, after that the mullah I have mentioned recites the azan.'

$\mathrm{T} 1 / 21$

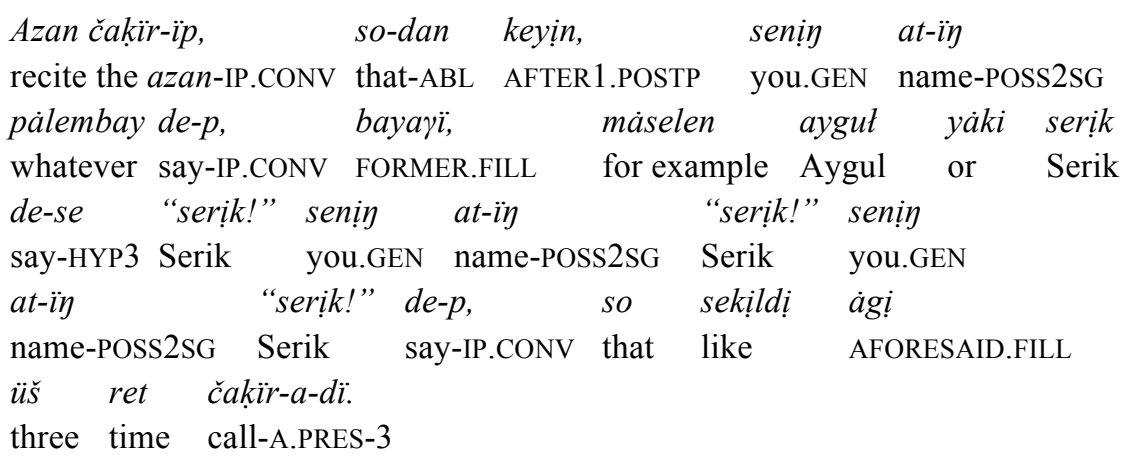

'Now he has recited the azan, and then he calls your name, whatever you are called, simply, for example, if the baby is called Aygul, or Serik, "Serik! Your name is Serik! Your name is Serik!" in this way, he calls out (the name) three times.'

$\mathrm{T} 1 / 22$

Azan čakïr-a-dï, $\quad{ }^{w}$ osïn-day at koy-a-dï bała- $\gamma a$. recite the azan-A.PRES-3 this-EQUA name put-A.PRES-3 child-DAT 'He recites the azan, in this way he gives a name to the baby.'

$\mathrm{T} 1 / 23$

Azan čakïr-ïp at koy-a-dï.

recite the azan-IP.CONV name put-A.PRES-3

'He recites the azan and gives a name to the baby.'

$\mathrm{T} 1 / 24$

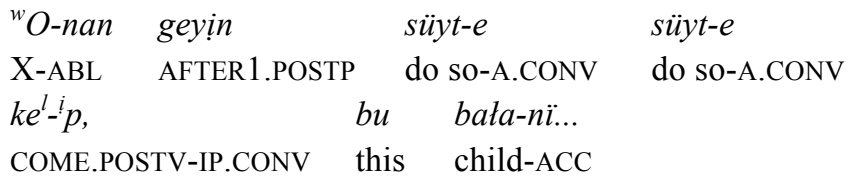

'Then, time goes by, and this child...'

$\mathrm{T} 1 / 25$

${ }^{y}$ Endi kïrïk kün bot-a-dï.

NOW.FILL forty day BOL.COP-A.PRES-3

'Forty days have passed.' 
$\mathrm{T} 1 / 26$

Kïrk kün bot-yanda, kazak, ${ }^{w} \ddot{o z}-$-imị ata-mïz

forty day BOL.COP-GAN.LOC.CONVKazakh self-POSS1PL father-POSS1PL

kazak-tïn satt-ïn-da kïrïk kasïk $s^{u} w$-dï $b^{i} r$ tegene-ge

Kazakh-GEN tradition-POSS3-LOC forty spoon water-ACC a basin-DAT

kuy-up at-a-mïz da, but bała-nï

pour-IP.CONV TAKE.POSTV-A.PRES-COP1PL DA.PART this child-ACC

$s^{u} w-\gamma a \quad$ comïldir-a-mïz.

water-DAT bathe-A.PRES-COP1PL

'When forty days have passed, we Kazakhs, according to the tradition of our Kazakh ancestors, we pour forty spoons of water into a basin and immerse the baby in that water.'

$\mathrm{T} 1 / 27$

$S^{u} w-\gamma a \quad \check{c o m i ̈ l d i r}-i \ddot{p}, \quad \check{c} \dot{a} s \grave{s}-i+n \quad a t-a-m \ddot{z}$.

water-DAT bathe-IP.CONV hair-POSS3-ACC take-A.PRES-COP1PL

'We bathe it in the water and cut its hair.'

$\mathrm{T} 1 / 28$

At ${ }^{y}$ endi, $\quad{ }^{w}$ osï-nïy ara-sïn-da $b^{i} r \quad k a t-i^{p}$

however NOW.FILL this-GEN among-POSS3SG-LOC a remain-IP.CONV

kat-yan söz bar yeken.

STAY.POSTV-GAN.PTCP word existing E.COP.INDIR3

'However, now, there is one thing among them (the traditions) that I have not mentioned.'

$\mathrm{T} 1 / 29$

But bała üš tört kün "öt-ken-nen keyịn,

this child three four day pass-GAN-ABL AFTER1.POSTP

àgindey $\quad \dot{a g} \dot{i}$ terị-si $i$ jaman

LIKE.AFORESAID.FILL AFORESAID.FILL skin-POSS3SG bad

$b o^{t-u p} \quad k e t-p e-s i n n t e-p, \quad t u z d u \ldots$

BOL.COP-IP.CONV LEAVE.POSTV-NEG-OPT3 say-IP.CONV salty

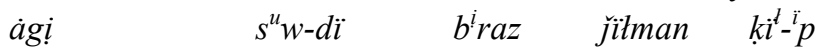

AFORESAID.FILL water-ACC a little bit warm do-IP.CONV

at-a-mï $\quad d a, \quad{ }^{w} o-\gamma a n \quad \dot{a} g i$

TAKE.POSTV-A.PRES-COP1PL DA.PART X-ABL AFORESAID.FILL

tuz-dï aštï-rak $\quad k i i^{\prime}-\ddot{p} \quad$ sat-ïp

salt-ACC strong-COMP do-IP.CONV PLACE.POSTV-IP.CONV

at- ${ }_{-i} p, \quad$ bata-nï neše ret kïrk-ï

TAKE.POSTV-IP.CONV child-ACC several time forty-POSS3 
$\begin{array}{lllll}\check{c} \dddot{c} k-k a n c ̌ a & \text { sot } & \dot{a} g \underline{i} & t u z d u k^{47} & s^{u} w-\gamma a \\ \text { come out-GANŠA.CONV } & \text { that } & \text { AFORESAID.FILL } & \text { salty } & \text { water-DAT }\end{array}$

čomïtdïr-a-mïz.

bathe-A.PRES-COP1PL

'Three or four days later, in order for the baby not to have bad skin, we warm up some salty water a little bit, put salt (into it), and add more salt to it; we immerse the child into such salty water several times until forty days have passed.'

$\mathrm{T} 1 / 30$

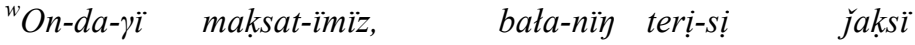

$\mathrm{X}$-LOC-GI intention-POSS1PL child-GEN skin-POSS3SG good

bot-uw üš̈̈n.

BOL.COP-UW.VN for

'Our intention in doing this for the skin of the child to be healthy.'

$\mathrm{T} 1 / 31$

Keyịngi kez-de bayayi $\quad k e y b{ }^{i}$ r-ew-der-dị dene-sị

later time-LOC FORMER.FILL some-COLL-PL-GEN body-POSS3SG

kǐsin-ïp jat-a-dï ana mïna bot- ${ }^{u} p$

itch-IP.CONV LIE.POSTV-A.PRES-3 and such like BOL.COP-IP.CONV

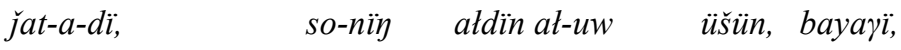

LIE.POSTV-A.PRES-3 that-GEN prevent-UW.VN for FORMER.FILL

dene-si de jaksï bot- ${ }^{u} p \quad \check{c} \ddot{\imath} \gamma-a-d \ddot{i}$

body-POSS3SG DA.PART good BOL.COP-IP.CONV COME OUT.POSTV-A.PRES-3

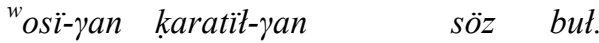

this-DAT consider-GAN.PTCP word this

'It is so that some persons later in their life get itchy skin or other things happen. And in order to prevent such problems, it is certainly good for the (whole) body. This is what I have wanted to tell you.'

$\mathrm{T} 1 / 32$

${ }^{w}$ O-nan geyị, $\quad{ }^{w}$ o-nïy $\quad{ }^{w}$ orta-sïn-da,

X-ABL AFTER1.POSTP X.GEN middle-POSS3SG-LOC

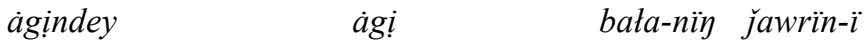

LIKE.AFORESAID.FILL AFORESAID.FILL child-GEN shoulder blade-POSS3

sịres-ịp kat-atïn iss-ter bot-a-di,

stiff-IP.CONV STAY.POSTV-ATIN.PTCP thing-PL BOL.COP-A.PRES-3 that

kez-der-de mayta- $p, \quad{ }^{w}$ o-nan geyin bała-nï

time-PL-LOC grease-IP.CONV X-ABL AFTER1.POSTP child-ACC

${ }^{47}$ Tuzduk 〈salt-DER〉 'salty' should in Kazakh normally be tuzdï, a word consisting of a noun and a denominal nominal suffix form in $\left\{-\mathrm{L}^{4} \mathrm{I}^{2}\right\}$. The ending used here is a copy of $\left\{-1 \mathrm{I}^{4} \mathrm{~K}^{2}\right\}$ in Uyghur. 
ker-ipp soz-a-di.

straighten-IP.CONV stretch-A.PRES-3

'Later, one of the things is that if the baby's shoulder blade gets stiff, in such a case they put grease on the baby and then straighten and stretch the baby.'

$\mathrm{T} 1 / 33$

Máselen, mïna kot-dan at-ïp $\quad a^{t}-\ddot{p}$,

for example this arm-ABL take-IP.CONV TAKE.POSTV-IP.CONV

bịtịp köter-ịp, soz-a-mïz, ${ }^{w}$ o-nan geyin,

do so-IP.CONV lift-IP.CONV stretch-A.PRES-COP1PL X-ABL AFTER1.POSTP

$b^{i} r \quad k o t, \quad b^{i} r \quad$ ayak-tan bịtip soz-atïn kez-der

an arm a leg-ABL do so-IP.CONV stretch-ATIN.PTCP time-PL

bot-a-di.

BOL.COP-A.PRES-3

'For example, they take (the baby) by this arm, and doing so they lift it and stretch it, and sometimes they lift the baby by holding one arm and one leg and stretch it (the baby).'

$\mathrm{T} 1 / 34$

${ }^{w}$ O-nan geyị, jawïrïn-dar-ï $\quad \dot{a} g i$

X-ABL AFTER1.POSTP shoulder blade-PL-POSS3 AFORESAID.FILL

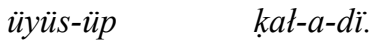

cramp-IP.CONV STAY.POSTV-A.PRES-3

'Then, it can happen that the baby, so to speak, suffers cramps in its shoulder blades.'

$\mathrm{T} 1 / 35$

Sot kez-der-de àgị bịz-dịn kazak-tïy tas čày-ị

that time-PL-LOC AFORESAID.FILL we-GEN Kazakh-GEN tea.brick-POSS3

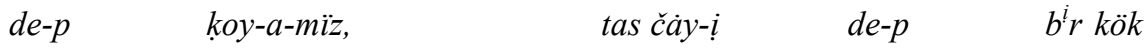

say-IP.CONV PUT.POSTV-A.PRES-COP1PL tea.brick-POSS3 say-IP.CONV a blue

čüperek bot-a-dï, kök čüperek-ke kaynat-ïp, agi

rag BOL.COP-A.PRES-3 blue rag-DAT boil-IP.CONV AFORESAID.FILL

sama-sï-n biytip koy-ïp at-a-mïz

tea-POSS3SG-ACC do so-IP.CONV place-IP.CONV TAKE.POSTV-A.PRES-COP1PL

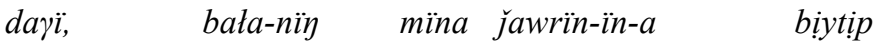

DAГÏ.PART child-GEN this scapula-POSS3-DAT do so-IP.CONV

čapta-p biytip koy-i $i^{p} \quad k o y-s a$,

paste-IP.CONV do So-IP.CONV place-IP.CONV PUT.POSTV-HYP3

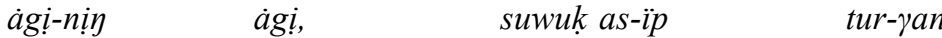

aforesaid-GEN AFORESAID.FILL cold exceed-IP.CONV STAND.POSTV-GAN.PTCP 
bała derew sakay-a kat-a-dï.

child immediately recover-A.CONV STAY.POSTV-A.PRES-3

'In such a case, then there is the thing we call our Kazakh tea brick, we say tas čay; there is a blue cloth, we boil the tea in this blue cloth, and we do so with the tea leaves, and then we put it on the baby's shoulder blade and paste it onto the shoulder blade of that baby. The baby, whose body has been full of coldness, immediately recovers.'

$\mathrm{T} 1 / 36$

Son-da, ${ }^{w}$ o-nan geyin $\quad k \ddot{r} k-\ddot{i}-n \quad$ ayt-tï-k koy

that-LOC X-ABL AFTER1.POSTP forty-POSS3-ACC tell-PAST-1PL ГOY.PART

$\dot{a}, \quad{ }^{w} o-n a n$ geyịn kïk-ï toš- $a$-dï so-dan

A.PART X-ABL AFTER1.POSTP forty-POSS3 complete-A.PRES-3 that-ABL

kïrk-ï toš-kanda barana-day kïrïk kasïk

forty-POSS3 complete-GAN.LOC.CONV previously-EQUA forty spoon

$s^{u} w-\gamma a \quad$ comïldïr-a-mïz.

water-DAT bathe-A.PRES-COP1PL

'Then, after that, we said forty (days), right? Then the forty (days) are completed, after forty (days), we wash the baby in forty spoons of water as previously.'

$\mathrm{T} 1 / 37$

$\begin{array}{lllll}\text { Süyt-e } & \text { süyt-e } & b^{i} r \check{j a s}-k a & k e l-e-d \underline{i} & \text { süyt-e } \\ \text { do so-A.CONV } & \text { do so-A.CONV } & \text { a year-DAT come-A.PRES-3 } & \text { do so-A.CONV } \\ \text { süyt-e } & \text { ülkey-e-dị. } & & & \\ \text { do so-A.CONV } & \text { grow-A.PRES-3 } & & & \end{array}$

'As time goes by, it turns one year old and gradually grows up.'

$\mathrm{T} 1 / 38$

Máselen ${ }^{y}$ endị ut bała-łar bot-sa, bes jas-ka

for example NOW.FILL male child-PL BOL.COP-HYP3 five year-DAT

kel-gende bu bała-nï sündette-y-miz.

come-GAN.LOC.CONV this child-ACC circumcise-A.PRES-COP1PL

'For example, if it is a boy, when he is five years old, we circumcise him.'

T1/ 39

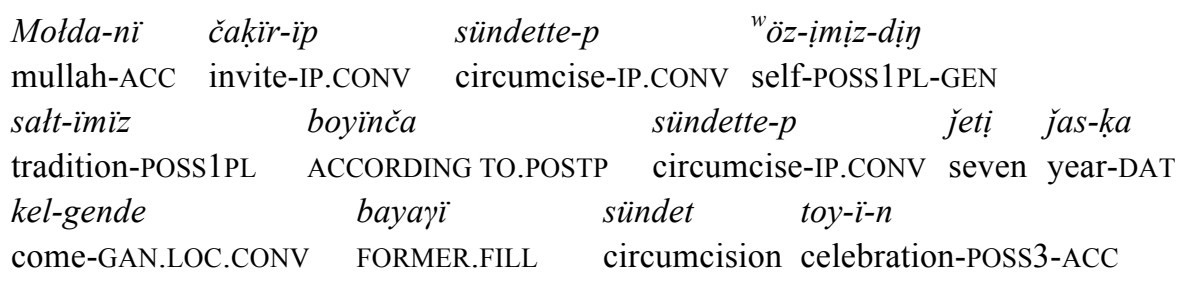


jasa-y-mïz ut bała bot-sa.

make-A.PRES-COP1PL male child BOL.COP-HYP3

'We invite a mullah, and he circumcises the boy. After he has circumcised him, according to our tradition, when he is seven years old, it is so that we arrange a Circumcision Feast for him, if it is a boy.'

$\mathrm{T} 1 / 40$

At kïz bała bot-sa bu-nïy besịk toy-ï-n

but female child BOL.COP-HYP3 this-GEN cradle celebration-POSS3-ACC

jasa-y-mïz dep.

make-A.PRES-COP1PL DEP.PART

'However, if it is a girl, we arrange a Cradle Feast for her, that is how it is.'

$\mathrm{T} 1 / 41$

So son-day $\quad b^{i} r \quad{ }^{w} \ddot{o z}-\underline{i m i t} \quad k$ kuwan- ̈̈p $\quad k a t j a^{48}$

THAT.FILL that-EQUA a self-POSS1PL rejoice-IP.CONV kalja

ber-ip, $\quad$ dos jaran, tuwus $\quad t^{u}$ wran-dar-ïmïz-dï,

give-IP.CONV friend relative kinsman-PL-POSS1PL-ACC

körši kołay-dar-ïmüz-dï čakür-ïp, son-day satt-tar-ïmïz

neighbour-PL-POSS1PL-ACC invite-IP.CONV that-EQUA tradition-PL-POSS1PL

bar wötkiz-ipp jat-atïn.

existing go through-IP.CONV LIE.POSTV-ATIN.PTCP

'We have such a tradition celebrating that we rejoice, giving kalja and inviting our friends, relatives and neighbors.'

T2. Aygilli adam: Musattar 'A famous person: Musattar'

Metadata

Gender: male

Age: 60

Date of birth: September 1941

Place of birth: Bortala Mongol Autonomous Prefecture, Xinjiang Uyghur Autonomous Region of China

Education: University

Language competence: Kazakh (mother tongue), Uyghur (understands, speaks, reads, and writes), Chinese (understands, speaks, reads, and writes), Mongol (understands)

Date of recording: 12th August 2010

Place of recording: Ürümqi

48 Meat of a sacrificial animal for a woman who has just given birth or for a person who has recovered from a disease (Kurał 2003: 435). 
Running text

$\mathrm{T} 2 / 1-\mathrm{T} 2 / 10$

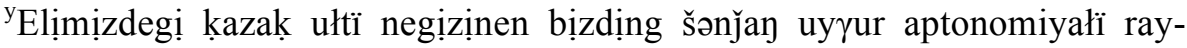
onïnïn ịle kazak aptonomiyałï wobłïsïna ḳarastï, ịle, ałtay, tarbayatay aymaḳtarïnïn àr kaysï awdandarïnda, ürümj̣̣ ḳałasïnda jảne ürümj̣i ḳałasïna karastï ürümj̣i awdanï, dabančïn rayonï, duysan rayondarïnda, sanǰi xuyzu aptonomiyałï wobłïsïna karastï mori kazaḳ aptonomiyałï awdanïnda, jảne šonǰi, jemsar, manas, ḳutïbi siyaḳtï awdandarda jảne ḳumïł aymayïnïy barköl kazaḳ aptonomiyałï awdanï, buratała muyjïł aptonomiyałï wobïłïsïna ḳarastï arasan, jīn awdandarïmen, buratała kałasïna ${ }^{\mathrm{w}}$ osï siyaḳtï ǰerlerge tarap ${ }^{\mathrm{w}}$ ornałasḳan. ${ }^{\mathrm{y}}$ Elịmịzde b ${ }^{\mathrm{i}} \mathrm{r}$ milliyon tört jüz mïnnïn üstünde ḳazaḳ jasaydï.

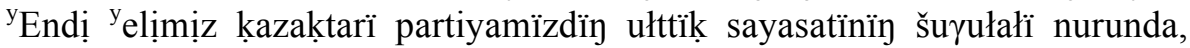
basḳa ułttarmen terezesị ten bol ${ }^{\mathrm{u}} \mathrm{p}$, b ${ }^{\mathrm{i}}$ rlịkte jasap kele jatïr. ${ }^{\mathrm{y}}$ Endị ${ }^{\mathrm{y}}$ elịmịz kazaḳtarïnïn ịṣ̣̌nde neb ${ }^{i} r$ yałïm, profesor, tảrix zerttewšisị, àdebiyetčị, aḳïn jazuwšiłar čịtị. ${ }^{\mathrm{y}}$ Endị bułar ${ }^{\mathrm{w}}$ osï b ${ }^{\mathrm{i}} \mathrm{r}$ top yałïmdar, mamandarïmïz bịzdị kazaḳ ułtumïzdïn mảdeniyetịnịn damuwïna, wörkendeưwịne wöte zor ülester

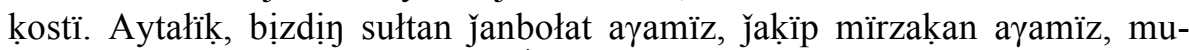

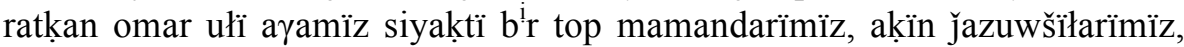
sïnšiłarïmïz, tảrixšiłarïmïz bar. ${ }^{\mathrm{y}}$ Endị ${ }^{\mathrm{w}}$ osïłardïn ịšịnde jàne men b ${ }^{\mathrm{i}} \mathrm{r}$ adamdï

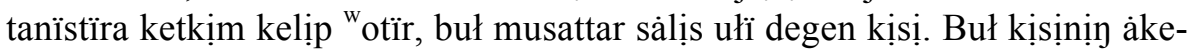

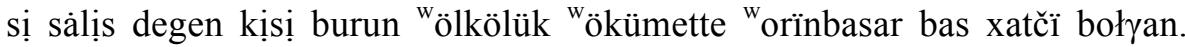

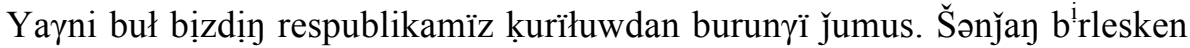
wökümetịnde, gomindan kezịnde bïłay aytḳanda, wölkölük wökümettị̣ bas katčïsï bołyan.

$\mathrm{T} 2 / 11-\mathrm{T} 2 / 20$

Bas ḳatčïnïn ${ }^{\mathrm{w}}$ orïnbasarï bołyan. ${ }^{\mathrm{y}}$ Endị musattar bu kịsịnị̣ àsịlị atï sảtảrḳan

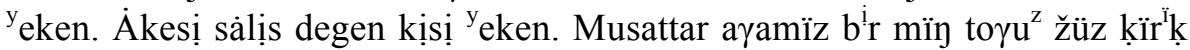
yekịnšị žiłï mawsïmda ürümj̣i kałasïnda dünyege kelgen. Karšadayïnan aya-

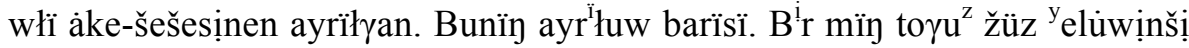
žỉiï musattardïn ảkesị sảlịs semiyasïmenen jảne baǰasï ảbdịkerịm degen kịsị semiyasïmenen "ölke azat bołyan gezde, buł kịsịler ${ }^{\mathrm{w}}$ osï ${ }^{\mathrm{y}}$ endị četelge ketưw rukssatïn ałïp, sonïmen ḳarayurum tawïnïn yetegịne baryan waḳtïnda, soł kezdegị gomindannïn garnizonï .səłinï jołbarïs degen jayïnan wöltịị̣lịp, sonïmen buł musattar sảlịs ułï jảne toḳtar ảbdịkerịm ułï bu ${ }^{\mathrm{y}}$ ekewị de jetịm kaładï. Soł kezde musattar segịz žasta, toḳtar ${ }^{\mathrm{w}}$ on jasta ${ }^{\mathrm{y}}$ eken. Sodan bułar basḳa köške ${ }^{\mathrm{y}}$ erịp, buł ${ }^{\mathrm{y}}$ ekị ǰetịm bała šizanya baryanda, jungo xałïk azattịk àrmiyàsị jayïnan bułar baүïp ałïnïp, soł kezdegị àskeri ḳołbaššï mučinjun degen kịsị genarał, bu kịsị musattardï bayïp aładï yeken. Sonïmen buł ana sattar degen sảttảrḳan degen attïn ałdïna mu degen wözịnịn pamiliyasïn ḳosïp sonïmen musattar boł ${ }^{\mathrm{u}} \mathrm{p}$ ketken jerị ${ }^{\mathrm{w}}$ osï ${ }^{\mathrm{y}}$ eken bu kịsịnị̂. 


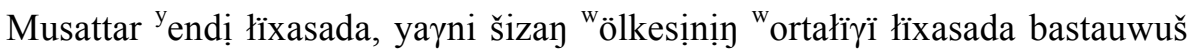

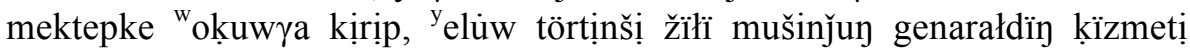
lảnjuguge žötkelgende, musattardï lảnjùdegị batïs sołtüstük ułttar instutïna

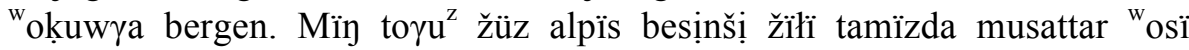

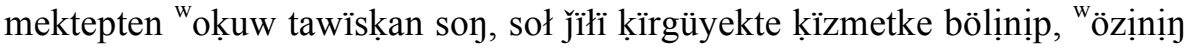

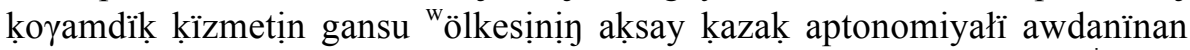

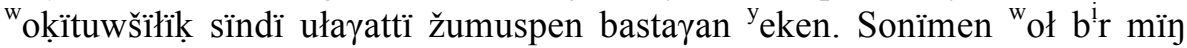

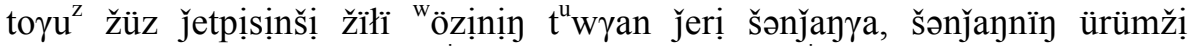

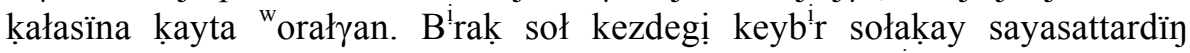

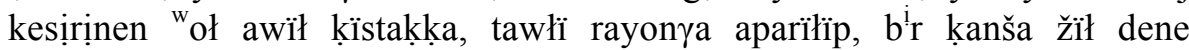

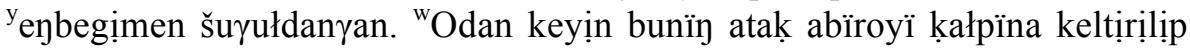

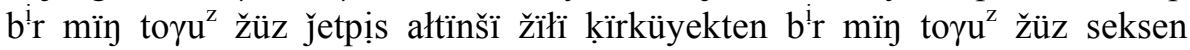
segịzịnšị žiłi ḳantarya deyịn ürümj̣̣ awdanï mádeniyet jurtïnda kïzmet

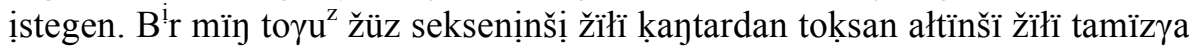
deyịn šənj̄an xałị̣ radiyo stansiyasïnïn àdebiyet körkömöner bölümünde kïzmet ịstegen. Sonïmen bu kịsị toḳsan ałtïnšï žïłi tamïzda kïzmet üstünde

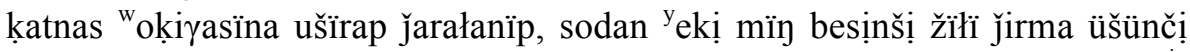
mamïrda ürümọịde kaytïs bołyan. ${ }^{\mathrm{y}}$ Endị musattar bu kịsịnịn ${ }^{\mathrm{y}} \mathrm{ey} \mathrm{ülken} b^{\mathrm{i}} \mathrm{r}$ tanïłmałi ${ }^{y}$ elge, barłik adamya tanïłmałï bołyan jerị bu kịsị mïḳtï awdarmašĭ, wonan keyịn tanïłmałï sazger, kompuzitor. Bu kịsịnịn wözị muzikanï wöte jakssï woynaydï, wonan keỵ̣n ản jazadï, jảne köptegen tärixi mäteriyałdardï, ảdeby mảteriyałdardï da awdaryan. Juumustï da wöte šögel jakssị ịstegen kịsị.

\section{$\mathrm{T} 2 / 31-\mathrm{T} 2 / 35$}

Seksen besịnšị žïlï mamïrda jungo kommunistịk partiyasïna kịrgen. Šənǰa xałịk radiyo stansiyasïnï̈ àdebiyet körkömönör bölümị ḳazak gruppasïnïn

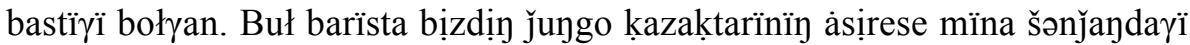
kazak ułtïnïn mảdeniyet ${ }^{\mathrm{w}}$ osï sałasïna wöte zor ülester ḳosḳan adam. ${ }^{\mathrm{y}}$ Endị wosï siyaḳtï bịzdịn šonjan kazaḳtarïnïn ịsṣinde tanïmałï adamdar, ${ }^{\text {wosïnday }}$ ${ }^{y}$ egeyler wöte köp kezịgedị. Bunïn bbị bịzdịn ułtïmïzdïn wözịnịn tegịne ḳatïstï, bayłanïstï bol ${ }^{\mathrm{u}} \mathrm{p}$ žatsa, ${ }^{\mathrm{y}}$ endị bị $\mathrm{r}$ jayïnan bịzdịn partiyamïzdïn ułttïk

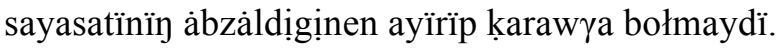

Annotated text

$\mathrm{T} 2 / 1$

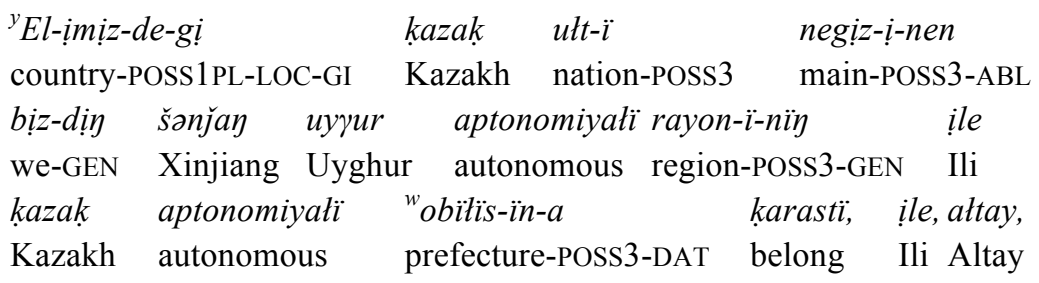




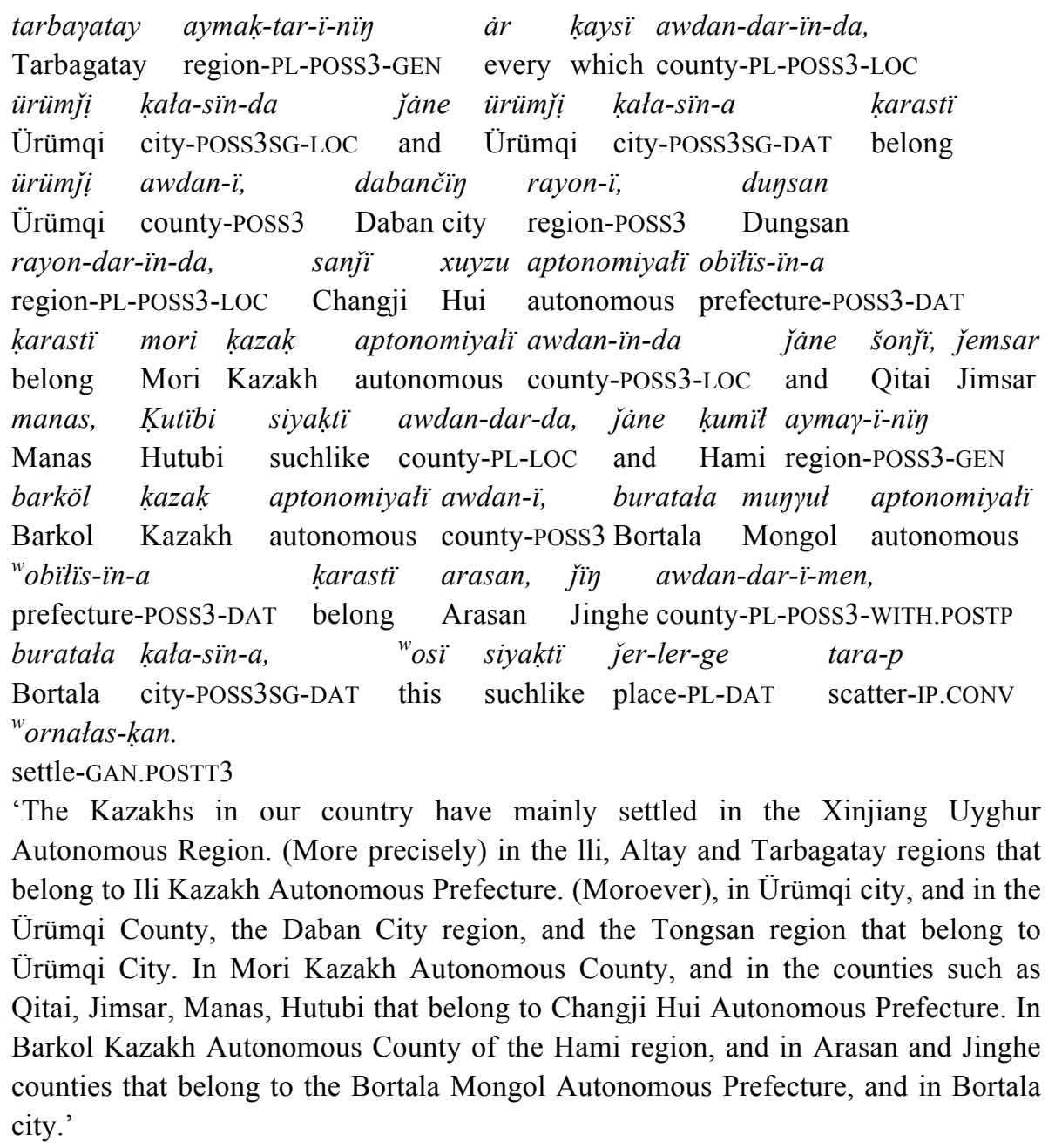

T2/ 2

\begin{tabular}{|c|c|c|c|c|}
\hline $\begin{array}{l}\text { El-ịmiz-de } \\
\text { ountry-POSS1 }\end{array}$ & $\begin{array}{l}b^{i} r \\
\text { one }\end{array}$ & $\begin{array}{ll}\text { milliyon } & \text { tört } \\
\text { million } & \text { four }\end{array}$ & $\begin{array}{l}\text { jüz } \\
\text { hundred }\end{array}$ & 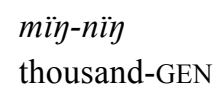 \\
\hline & kazak & jasa-y-dï. & & \\
\hline ver.POSS3-LOC & Kazakh & live-A.PRES-3 & & \\
\hline
\end{tabular}

'There are more than one million four hundred thousand Kazakhs living in our country.'

T2/ 3

\begin{tabular}{|c|c|c|c|}
\hline$n d i$ & ${ }^{y}$ el-ịmịz & kazak-tar-ï & partiya-müz-dïy \\
\hline & $\mathrm{c}$ & a-PL-POSS3 & I-POSS \\
\hline & $\begin{array}{l}-\ddot{-}-n \ddot{\eta} y \\
\text { POSS3-GEN }\end{array}$ & $\begin{array}{l}\text { nur-un-dc } \\
\text { light-POS }\end{array}$ & $\begin{array}{r}\text { baska } \\
\text {-LOC other }\end{array}$ \\
\hline
\end{tabular}




\begin{tabular}{|c|c|}
\hline ult-tar-men & tey $\quad b o t-{ }^{u} p,{ }^{49}$ \\
\hline nation-PL-WITH.POSTP & equal BOL.COP-IP.CONV \\
\hline$b^{i}$ rlịte $\quad$ jas $a-p$ & kel-e \\
\hline together live-IP.CONV & COME.POSTV-A.CONV LIE.POSTV.AOR3 \\
\hline
\end{tabular}

$\mathrm{T} 2 / 4$

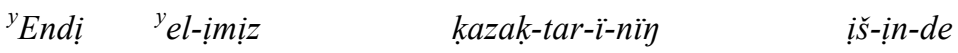

NOW.FILL country-POSS1PL Kazakh-PL-POSS3-GEN inside-POSS3-LOC

neb ${ }^{i} r \quad$ yatim, profesor, tärix zerttewši

all sorts of scientist professor history investigator-POSS3SG

adebiyetčị, akïn jazuwšï-łar čïk-tï.

literary scholar poet writer-PL appear-PAST3

'Well, there have been all sorts of scientists, professors, historians, literary scholars, poets, and writers among the Kazakhs in our country.'

$\mathrm{T} 2 / 5$

${ }^{y}$ Endi bu-łar ${ }^{w}$ osï $\quad b^{i}$ r top yatïm-dar, maman-dar-ïmüz NOW.FILL this-PL this a group scientist-PL researcher-PL-POSS1PL

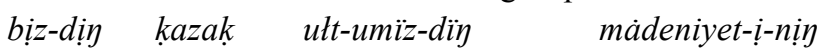

we-GEN Kazakh nation-POSS1PL-GEN culture-POSS3-GEN

dam-uw-ïn-a, "örkende-uw-ịn-e "öte zor

develop-UW.VN-POSS3-DAT prosper-UW.VN-POSS3-DAT very big

üles-ter kos-tï.

contribution-PL add-PAST3

'Well, this group of scientists and researchers has made a big contribution to the development and prosperity of the culture of the Kazakh people.'

$\mathrm{T} 2 / 6$

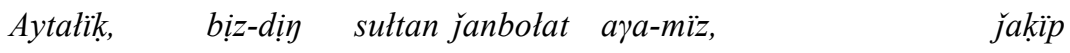

for example we-GEN Sultan Janbolat elder brother-POSS1PL Jakip

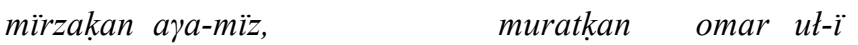

Mirzakan elder brother-POSS1PL Murankan Omar son-POSS3

ara-mïz siyaktï $b^{i}$ r top maman-dar-ïmï, akïn

elder brother-POSS1PL suchlike a group researcher-PL-POSS1PL poet

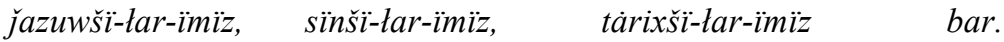

writer-PL-POSS1PL critic-PL-POSS1PL historian-PL-POSS1PL existing

'For example, we have a number of researchers, poets, writers, critics, and historians such as Mr. Soltan Janbol, Mr. Jakip Mirzakan, Mr. Muratkan Omar.'

${ }^{49}$ The expression terezesi tey, literally 'its window equal' is an idiom meaning 'with equal rights'. 
$\mathrm{T} 2 / 7$

${ }^{y}$ Endị ${ }^{w}$ osï-łar-dïy $i \check{s}-i ̣ n-d e \quad \breve{j a n e}$ men $b^{i} r$ adam-dï

NOW.FILL this-PL-GEN inside-POSS3-LOC and I a person-ACC

tanïstïr-a ket-ki-m kel-ip

introduce-A.CONV LEAVE.POSTV-GI.NESS-1SG COME.POSTV-IP.CONV

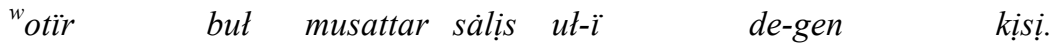

SIT.POSTV3 this Musattar Salis son-POSs3 say-GAN.PTCP person

'Now, I would like to introduce to you one of them: Musattar Salis.'

T2/ 8

But kịsị-nị àke-sị sàlis de-gen kisi

this person-GEN father-POSS3SG Salis say-GAN.PTCP person formerly

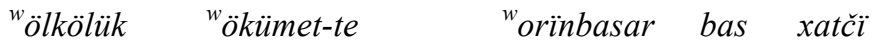

provincial government-LOC deputy chief secretary

bot-ran.

BOL.COP-GAN.POSTT3

'The father of this person, called Salis, was formerly the Deputy Chief Secretary in the provincial government.'

T2/ 9

Yayni but bịz-dị respublika-mïz kurït-uw-dan

actually this we-GEN republic-POSS1PL establish-UW.VN-ABL

burun- $\gamma \ddot{i}$ jumus.

BEFORE.POSTP-GI event

'Actually, this was before our republic (i.e. the Peoples' Republic of China) was established.'

$\mathrm{T} 2 / 10$

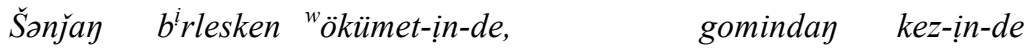

Xinjiang united government-POSs3-LOC Kuomintang time-POSs3-LOC

bïlay ayt-kanda, ${ }^{w}$ ölkölük ${ }^{w}$ ökümet-tịy bas

this way tell-GAN.LOC.CONV provincial government-GEN chief

katči-sï bot-yan.

secretary-POSS3SG BOL.COP-GAN.POSTT3

'In other words, he was the Chief Secretary of the provincial government in the Xinjiang United Government in Kuomintang times.'

$\mathrm{T} 2 / 11$

Bas katči-nïy $\quad{ }^{w}$ orïnbasar- $\ddot{i}$ bot-yan.

chief secretary-GEN deputy-POSS3 BOL.COP-GAN.POSTT3

'He was the deputy of the chief secretary.' 
T2/ 12

${ }^{y}$ Endị musattar bu kịsị-nịy àsịlị at-ï sätärkan NOW.FILL Musattar this person-GEN original name-POSS3 Satarkan yeken.

E.COP.INDIR3

'Well, Musattar's original name was, as I have learned, Satarkan.'

T2/ 13

Ake-sị sàlis de-gen kịi ${ }^{y}$ eken.

father-POSS3SG Salis say-GAN.PTCP person E.COP.INDIR3

'His father was a person called Salis.'

T2/ 14

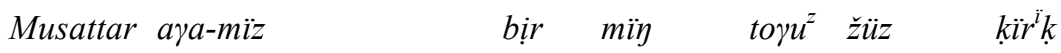

Musattar elder brother-POSS1PL one thousand nine hundred fourty

${ }^{y}$ eki-nši žit-ï mawsïm-da ürümy̆i kała-sïn-da dünye-ge

two-ORD year-POSS3 June-LOC Ürümqi city-POSS3SG-LOC world-DAT

kel-gen.

come-GAN.POSTT3

'Mr. Musattar was born in Ürümqi City in June 1942.'

T2/ 15

Karšaday-ï-nan ayawtï àke šeše-sị-nen ayrït-yan.

youth-POSS3-ABL dear father mother-POSS3SG-ABL lose-GAN.POSTT3 'He lost his beloved parents in his youth.'

T2/ 16

Bu-nïy ayrït-uw barïs-ï.

this-GEN lose-UW.VN process-POSS3

'The story of how he lost them.'

T2/ 17

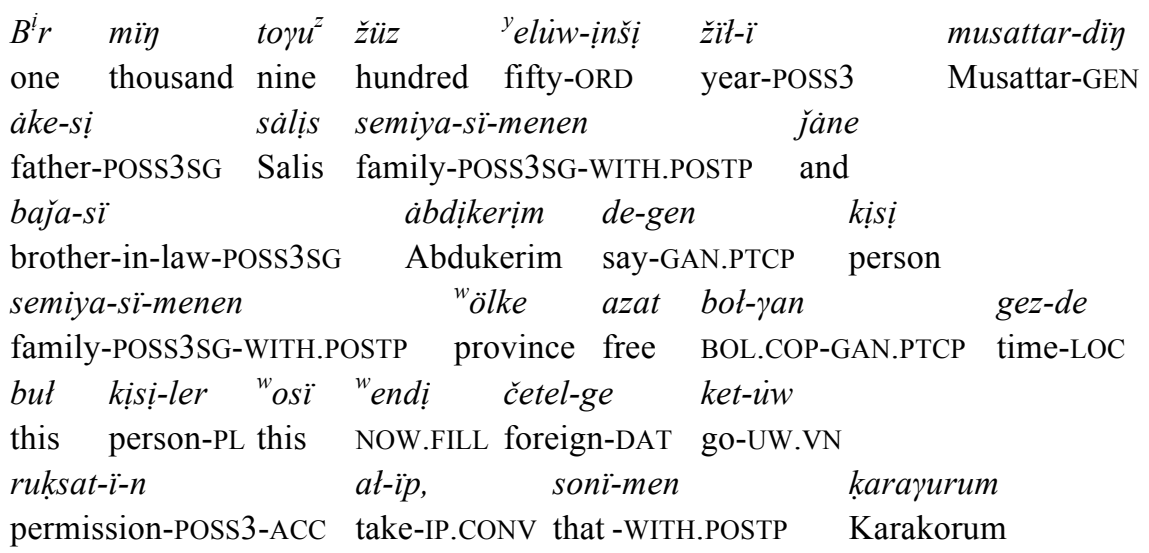




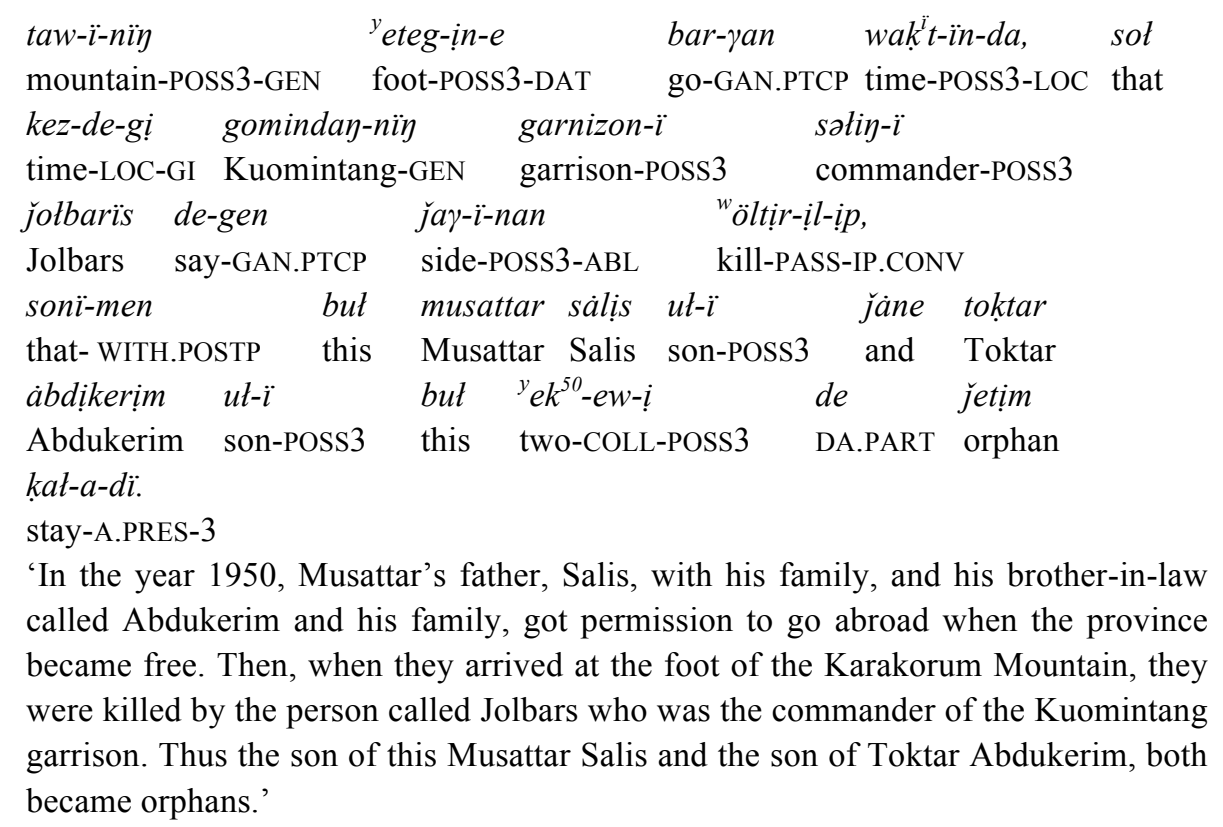

T2/ 18

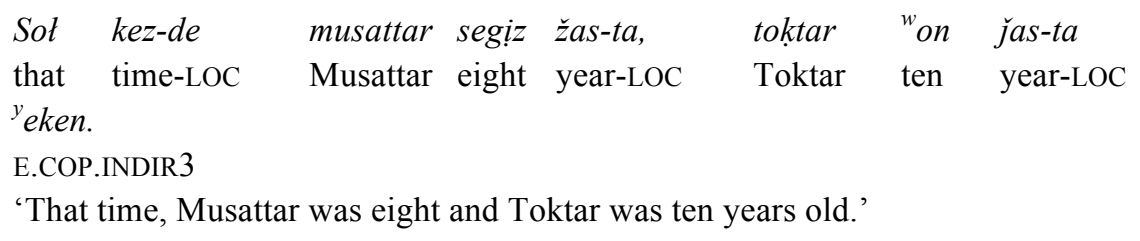

$\mathrm{T} 2 / 19$

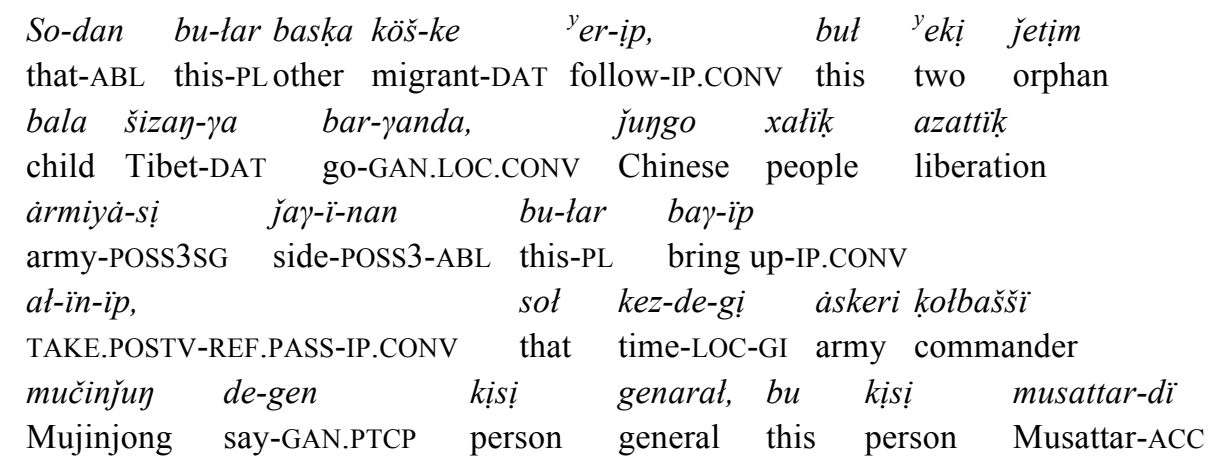

${ }^{50}$ When the collective suffix $\left\{-(\varnothing) \mathrm{A}^{2} \mathrm{~W}\right\}$ is added, certain stem-final vowels are dropped. 
bay-ïp at-a-dï $\quad$ eken.

raise-IP.CONV TAKE.POSTV-A.PRES-3 E.COP.INDIR3

'After that, they followed other migrants. When these two orphans arrived in Tibet, they were adopted by the Chinese People's Liberation Army. And General Mujinjong, who was at that time the army commander, adopted Musattar.'

$\mathrm{T} 2 / 20$

\begin{tabular}{|c|c|c|c|c|}
\hline Sonï-men & but & sättärkan & de-gen & $a t-t \ddot{y} y$ \\
\hline that- WITH.POSTP & this & Sattarkan & say-GAN.PTCP & name-GEN \\
\hline atdïn- $a$ & $m u$ & de-gen & ${ }^{w} \ddot{o z}-\underline{i}-n i ̣ \eta$ & pamiliya-sï-n \\
\hline front.POSS3-DAT & $\mathrm{Mu}$ & say-GAN.PTCP & self-POSS3-GEN & family-POSS3SG-ACC \\
\hline$k o s-\ddot{i} p$ & & musattar & $\operatorname{bot}_{-}^{u} p$ & \\
\hline dd-IP.CONV tha & UTT & Musattar & BOL.COP-IP.CONV & \\
\hline t-ken & & ${ }^{w}$ os $\ddot{~}$ & ${ }^{y}$ eken & kisi-nin. \\
\hline
\end{tabular}

LEAVE.POSTV-GAN.PTCP place-POSS3 this E.COP.INDIR3 this person-GEN

'As a result, he added the family name Mu before his name Sattarkan. That was how the name of this person became Musattar.'

$\mathrm{T} 2 / 21$

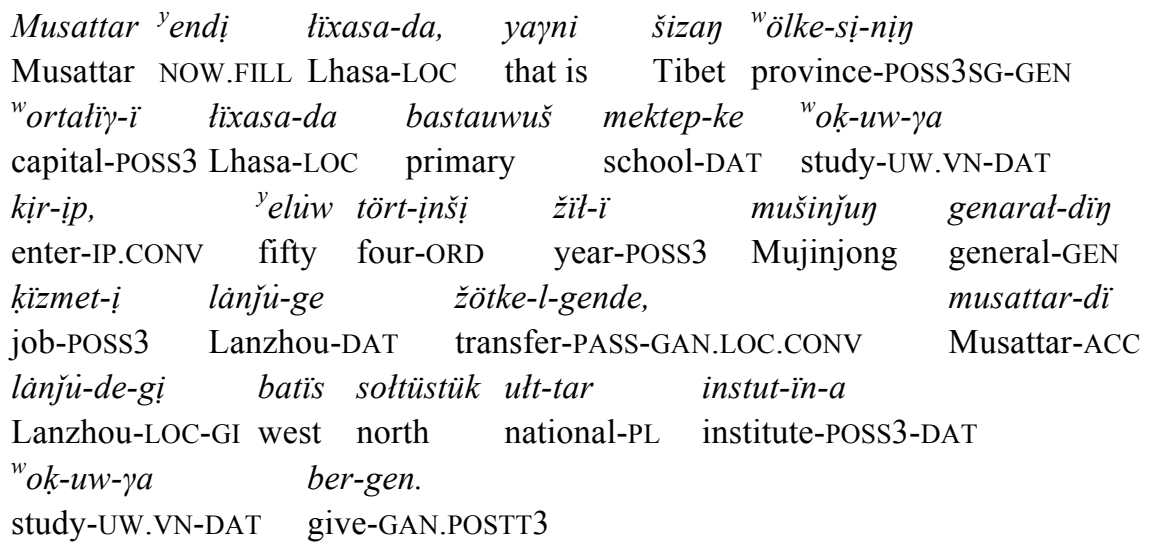

'Well, Musattar, started primary school in Lhasa, that is, in the capital of the province of Tibet, in Lhasa. When general Mujinjong was transferred to work in Lanzhou in 1954, he sent Musattar to study at the Northwest Institute for Nationalities in Lanzhou.'

$\mathrm{T} 2 / 22$

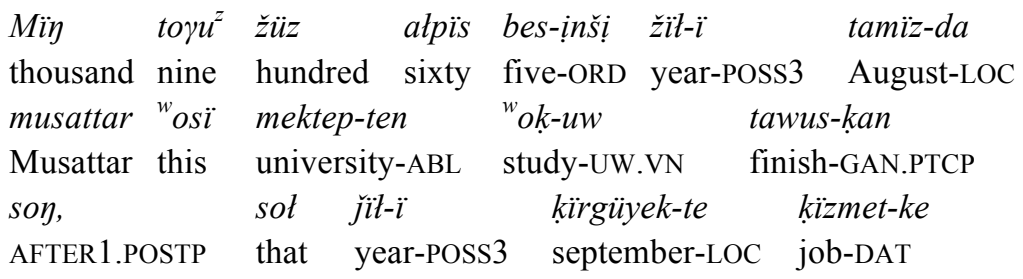




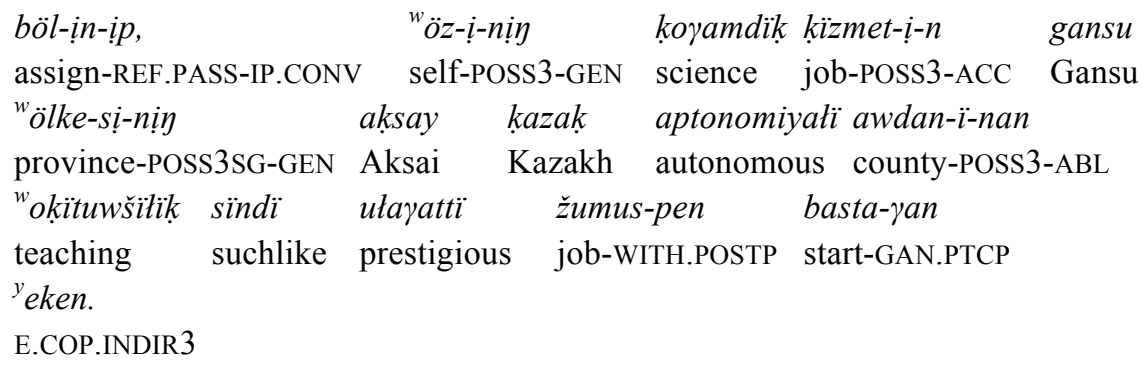

'After Musattar graduated from this university in August 1965, he was assigned to the prestigious job of a teacher and started teaching in the Aksai Kazakh Autonomous County of Gansu Province in September of the same year.'

$\mathrm{T} 2 / 23$

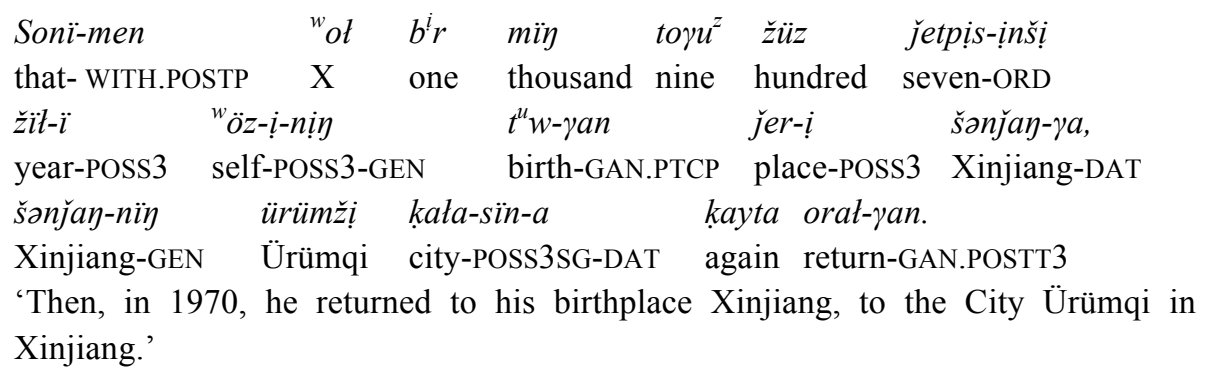

$\mathrm{T} 2 / 24$

$B^{i}$ rak sot kez-de-gi keyb ${ }^{i}$ r sołakay sayasat-tar-dï

but that time-LOC-GI some leftist policy-PL-GEN

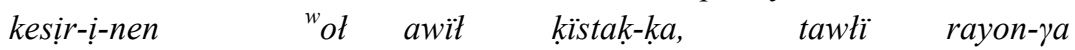

harm-POSS3-ABL $\mathrm{X}$ village countryside-DAT mountain region-DAT

apar-ït-їp, $\quad$ br k kanša žï dene ${ }^{y}$ eybeg-ị-men

take-PASS-IP.CONV a several year body labor-POSS3-WITH.POSTP

šu utdan- $\gamma$ an.

engage in-GAN.POSTT3

'But due to the harm of some leftist policies of that time, he was sent to the countryside and worked as a laborer for several years.'

$\mathrm{T} 2 / 25$

${ }^{w}$ O-dan keyịn bu-nïy atak abïroy-ï

X-ABL AFTER1.POSTP this-GEN reputation fame-POSS3

katpüna keltịr-ịl-p $\quad b^{i} r \quad$ mïy $\quad$ to $u^{z}$ žüz jetpis attï-nši

restore-PASS-IP.CONV one thousand nine hundred seven six-ORD

žit-ï kïrküyek-ten $b^{i} r \quad$ mïy to $u^{z}$ žüz seksen

year-POSS3 September-ABL one thousand nine hundred eighty

segịz-ịnši žĭtï kaytar- $\gamma a$ deyịn ürüm ǰ̣ awdan-ï

eight-ORD year-POSs3 January-DAT until Ürümqi county-POSs3 
mádeniyet jurt-ïn-da kïzmet ịste-gen.

culture home-POSS3-LOC job do-GAN.POSTT3

'After that his reputation was restored and from September 1976 until January 1988 he worked at the Culture Council of Ürümqi County.'

$\mathrm{T} 2 / 26$

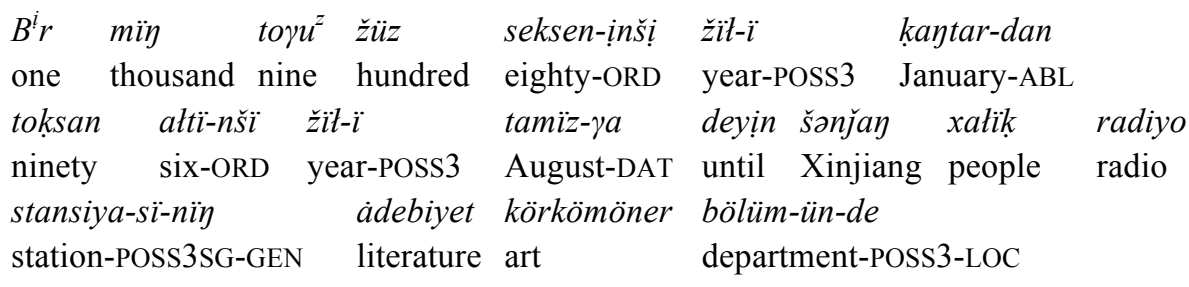

kïzmet iste-gen

job do-GAN.POSTT3

'From January 1980 until August 1996, he worked at the Department of Literature and Art of Xinjiang People's Radio Station.'

$\mathrm{T} 2 / 27$

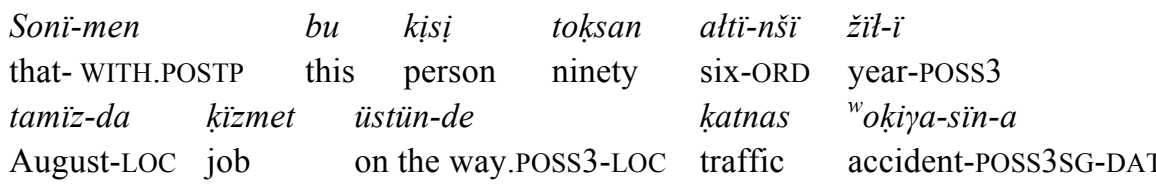

ušira- $p, \quad$ jarała-n-ïp, so-dan ${ }^{y}$ eki müy bes-ịnši

suffer-IP.CONV injury-REF.PASS-IP.CONV that-ABL two thousand five-ORD

žit-ï jirma üš-ünči mamïr-da ürümǰ̣-de kaytïs

year-POSS3 twenty three-ORD May-LOC Ürümqi-LOC die

bot-yan.

BOL.COP-GAN.POSTT3

'Then in August 1996, he was injured in a road accident on an assignment, after which, on 23 May of 2005 he died in Ürümqi.'

$\mathrm{T} 2 / 28$

${ }^{y}$ Endi musattar bu kisị-nịn ${ }^{y}$ ey ülken $b^{i} r \quad{ }^{y}$ el-ge, bartik now Musattar this person-GEN SUPER big a country-DAT all

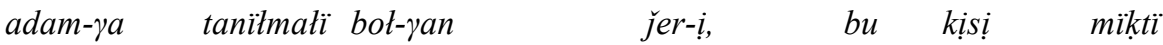
person-DAT known BOL.COP-GAN.PTCP place-POSS3 this person great

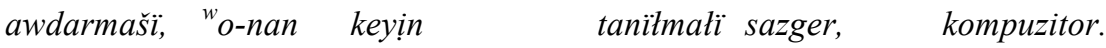
interpreter X-ABL AFTER1.POSTP known performer composer 'Now, Musattar, he is best known by the (Kazakh) people, all of them, for being a great interpreter and moreover a well-known performer and composer.'

$\mathrm{T} 2 / 29$

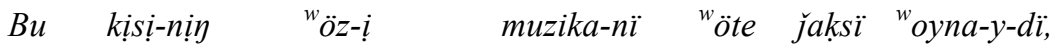

this person-GEN self-POSS3 music-ACC very good play-A.PRES-3 
${ }^{w}$ o-nan keyịn $\quad \dot{a} n \quad \check{j a z}-a$-dï, jäne köp-tegen

X-ABL AFTER1.POSTP song write-PRES-3 and much-APPROX

tárixi máteriyat-dar-dï, ádebi máteriyat-dar-dï $\quad d a$

historical material-PL-ACC literary material-PL-ACC DA.PART

awdar-yan.

translate-GAN.POSTT3

'He was good at performing music, and he composed songs. He also translated many historical and literary works.'

$\mathrm{T} 2 / 30$

J̌umus-tï da "öte šögel jaksï ịste-gen kịsị.

job-ACC DA.PART very serious good do-GAN.PTCP person

'He also was a person who did his job very seriously and well.'

$\mathrm{T} 2 / 31$

Seksen besịnšị žï-ï mamür-da jungo kommunistịk

eighty five-ORD year-POSs3 May-LOC China communist

partiya-sïn-a kịr-gen.

party-POSS3SG-DAT enter-GAN.POSTT3

'In May 1985, he became a member of Chinese Communist Party.'

$\mathrm{T} 2 / 32$

Šənjay xatïk radiyo stansiya-sï-nїy adebiyet körkömönör

Xinjiang people radio station-POSS3SG-GEN literature art

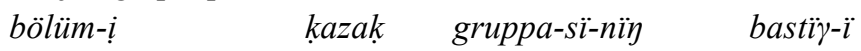

department-POSS3 Kazakh group-POSS3SG-GEN head-POSS3

bot-yan.

BOL.COP-GAN.POSTT3

'He became the head of the Kazakh Department at the Department of Literature and Art of Xinjiang People's Radio Station.'

$\mathrm{T} 2 / 33$

\begin{tabular}{|c|c|c|c|c|}
\hline $\begin{array}{l}\text { barïs-ta } \\
\text { course-LOC }\end{array}$ & $\begin{array}{l}\text { bịz-dịy } \\
\text { we-GEN }\end{array}$ & $\begin{array}{l}\text { juygo kazak-tar-ï-n } \\
\text { China Kazakh-PL-Po }\end{array}$ & 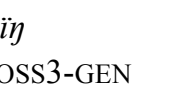 & $\begin{array}{l}\text { àsịrese mïna } \\
\text { especially this }\end{array}$ \\
\hline nјау-da-yї & kazak & $u t t-\ddot{\imath}-n \ddot{i} \eta$ & mádeniyet & ${ }^{w}$ osï \\
\hline & Kazakh & nation-POSS3-GEN & culture & this \\
\hline & & üles-ter & kos-kan & \\
\hline
\end{tabular}

'In this position, he was a man who made a great contribution to this field of the culture of the Chinese Kazakhs, especially of the Kazakhs in Xinjiang.'

T2/ 34

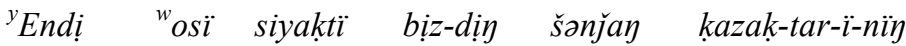

NOW.FILL this suchlike we-GEN Xinjiang Kazakh-PL-POSS3-GEN 


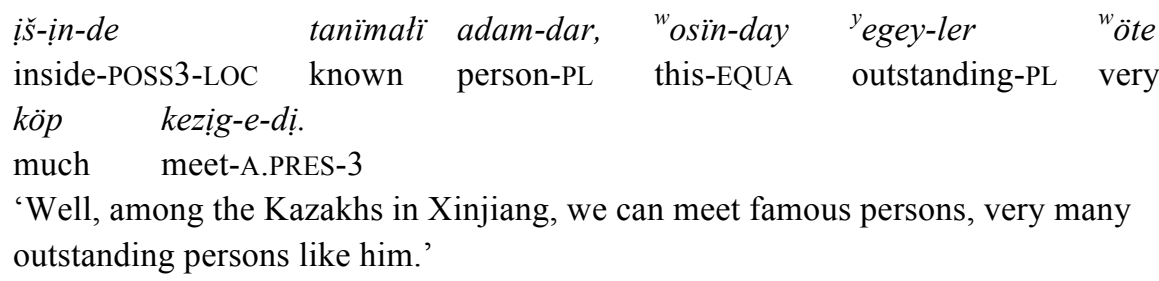

T2/ 35

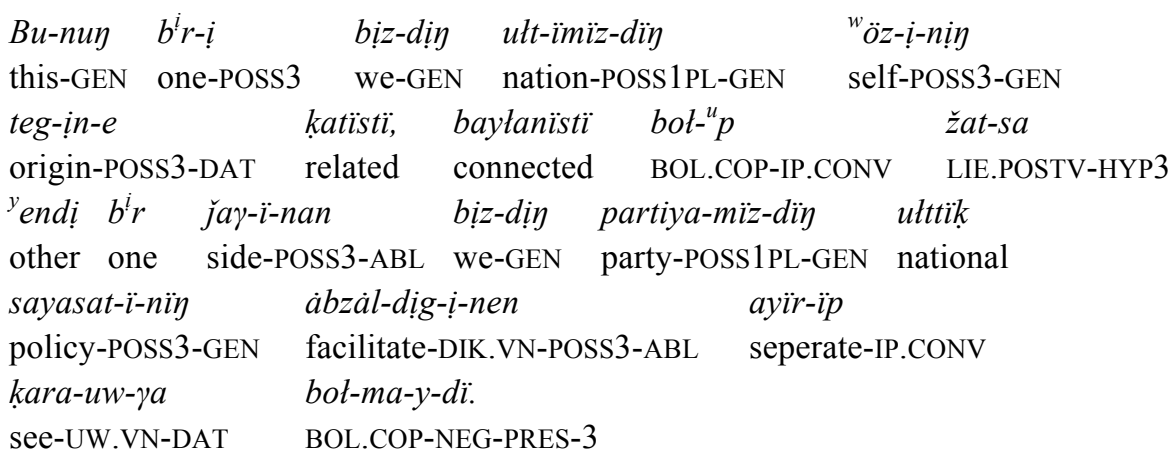

'One reason for this is related to the origin of our nation, and further more we cannot disregard the favorable national policy of our party.'

\section{T3. Buwuršindayï xatik ustazï 'A school teacher in Burqin'}

\section{Metadata}

Gender: male

Age: 70

Date of birth: September 1941

Place of birth: Burqin County, Altay Region, Xinjiang Uyghur Autonomous Region of China

Education: University

Language competence: Kazakh (mother tongue), Chinese (understands and speaks)

Date of recording: 10th July 2010

Place of recording: Burqin, Altay

Running text

T3/ 1-T3/ 10

Atïm šảymurat ḳurmanbay ułïmïn. Bïyïł jetpịs jasḳa šịtï̀m. B ${ }^{i} r$ mïn to $\gamma u^{z}$ žüz kïrị ḅ bịnšị žiłł küzde üštas tawïnda buwuršïn awdanïnïn jerị wosï tawda

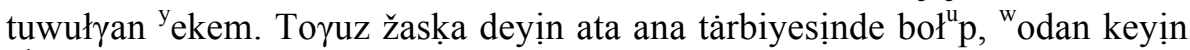
bị žỉła tayaw awïł mołłasï jumaš degen mołładan köneše ${ }^{\text {w}}$ oḳïdïm. ${ }^{\mathrm{y}}$ Elịmịz

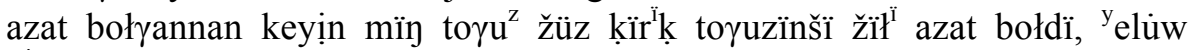
bịinšị žïłdan bastap bastawuš mektepte ${ }^{w}$ oḳïdïm. Kazïr ḳatay bastawuš mektebịnde. ${ }^{y}$ Elüw törtịnšị žïłï bastawuš mekteptị b tịị̣p buwuršïn awdandïk 


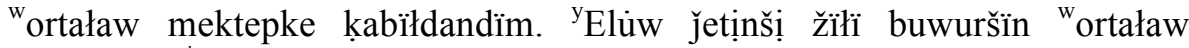

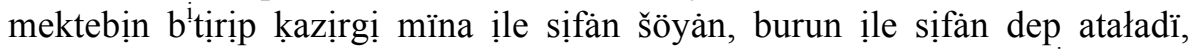

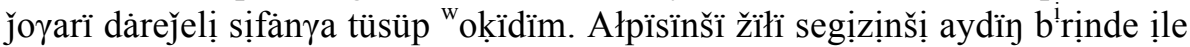

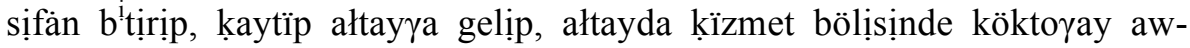

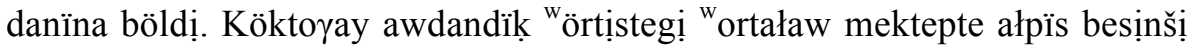

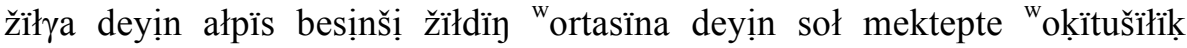
kïzmet ịstedịm.

\section{T3/ 11-T3/ 20}

Ałpïs ałtïnši žiłła ḳarsï semiyałịk ḳiyïnšiłị jạdayïmenen awdannïy

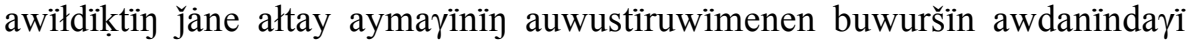
mekememe kayta keldịm. Kelgennen geyịn ${ }^{\mathrm{y}}$ egịstịk awïłïrïnïn jataktï wortaław mektebịnde ịstedịm. Buł barïsta buł ałyašïnda köšpendị mektep

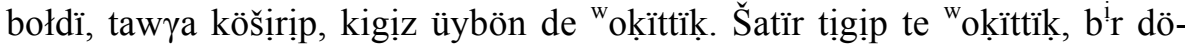
ybök üy salï terị sałyanday jerdede woḳittïk. Keyịn turaḳtï mektep sałïp

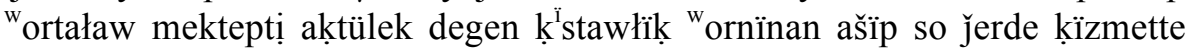
bołdïm. ${ }^{\mathrm{y}}$ Endị buł barïsta małši perzentter burun ${ }^{\mathrm{w}}$ osï b ${ }^{\mathrm{i}} \mathrm{r}^{\mathrm{y}}$ ekị mačiłị čar ${ }^{\mathrm{u}-}$

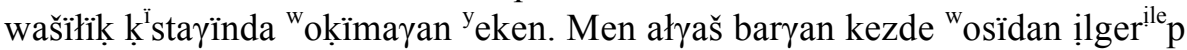
${ }^{w}$ oḳïyan üšte tört ${ }^{\text {w}}$ oḳušĭ yana bar ${ }^{\mathrm{y}}$ eken. Basḳa tịptị ï̌škanday tảrixta wokïmayan ${ }^{\mathrm{y}}$ eken. ${ }^{\mathrm{w}} \mathrm{o}$ jerden... bịz bastawuš mekteptị ịrgesịn bekemdewmen

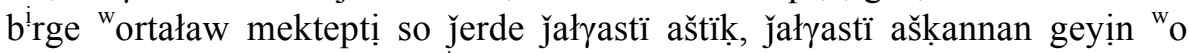

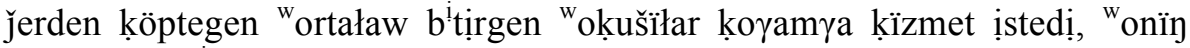

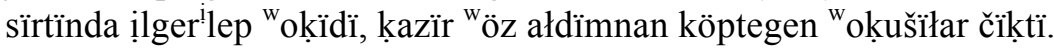

\section{T3/ 21-T3/ 30}

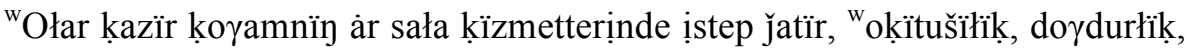

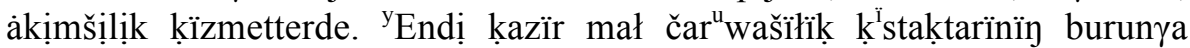

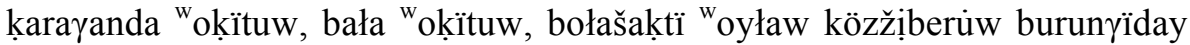

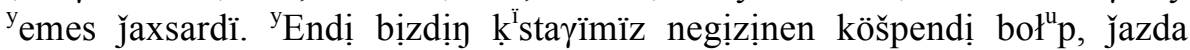

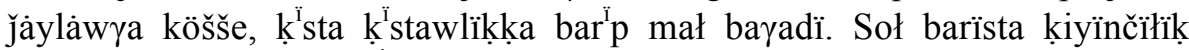
japałarda małšiłarmen b’ rge bołdïm. Mïna ${ }^{\mathrm{i}}$ emegeytị degen tör jảylàw bołdï, y emegeytị.... jetpịs ${ }^{y}$ ekịnšị žiłłi małčïłarmen b ${ }^{i}$ rge semiyammen köšüp jürüp,

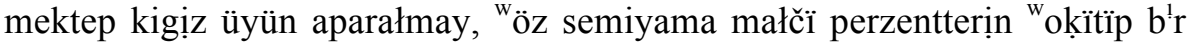

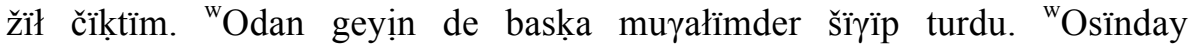
japałịkpenen bịz małči perzentterịn wokịtïp sawatïn ašïp ${ }^{\text {w }}$ ortaław bastawïš

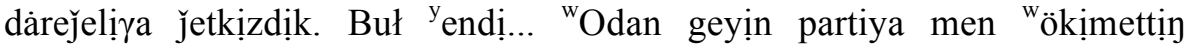
basšiłïjïmenen, könịl bölủwịmen bịzdịn ułttïk rayonda mektepter sałïp berdị, jataḳtï mektepter sałïndï.

\section{T3/ 31-T3/ 43}

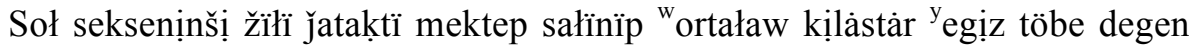

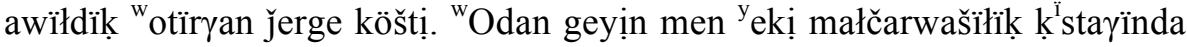
y ekị mektep bołdï ${ }^{w}$ osï mekteptịn jawapkeršịlịk ḳïzmetịn ịstedịm. Sonïmenen

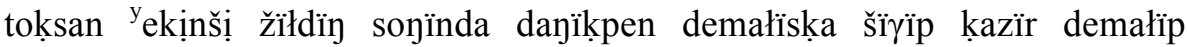




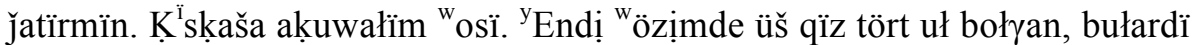
da ${ }^{w}$ oḳittïm. $\mathrm{B}^{\mathrm{i}} \mathrm{r}{ }^{\mathrm{y}}$ ekewị ${ }^{\mathrm{w}}$ oḳuw a arartuw sałasïnda jảne basḳa sałałarda, $\mathrm{b}^{\mathrm{i}} \mathrm{r}$ 'ekewị kịzmet ịsteydị, bịnešewị małčì bo(łii)p kazïr čarwašiłiłk kïzmet-

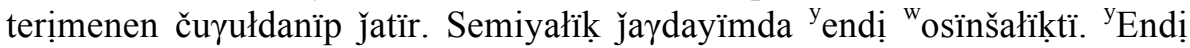
bịzdịn małčiłardïn mïna köṣ̌ k kon kiyïnčiłïyïmenen bała woḳita ałmaytïn ja mektep aštï, jataḳtï mekep aštï. ${ }^{\mathrm{w}}$ Osïnda ḳazïr bałałardï barïp ${ }^{\mathrm{w}}$ oḳitadï.

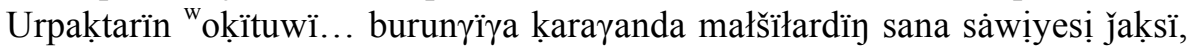

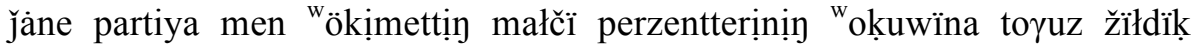

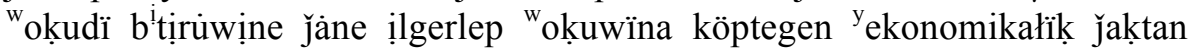
jardamdar berịp ḳazïr ${ }^{\mathrm{w}}$ oḳitïp jatïr. ${ }^{\mathrm{y}}$ Endị basḳa nemene aytamïz ${ }^{\mathrm{y}}$ endị.

Annotated text

$\mathrm{T} 3 / 1$

At-ïm š́amurat kurmanbay ut-ï-mïn.

name-POSS1SG Sheymurat Kurmanbay son-POSS3-COP1SG

'My name is Sheymurat, I am the son of Kurmanbay.'

$\mathrm{T} 3 / 2$

B̈̈yït jetpis jas-ka čịk-tï-m.

this year seventy age-DAT ascend-PAST-1SG

'This year I have entered my seventieth years.'

$\mathrm{T} 3 / 3$

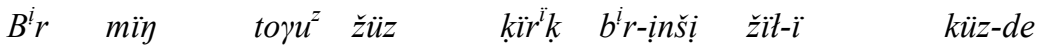

one thousand nine hundred forty one-ORD year-POSS3 autumn-loC

üštas taw-ïn-da buwuršïn awdan-ï-n̈̈y jer-ị

Üštas mountain-POSS3-LOC Burqin county-POSS3-GEN place-POSS3

${ }^{w}$ osi taw-da tuw-ut-ran ${ }^{y}$ ekem.

this mountain-LOC birth-PASS-GAN.PTCP E.COP.INDIR.COP1SG

'In the autumn of 1941, in the Üštas mountain of Burqin county, it was on this mountain that I was born.'

$\mathrm{T} 3 / 4$

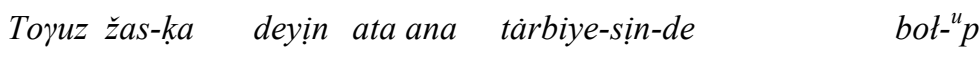

nine age-DAT until parents upbringing-POSS3SG-LOC BOL.COP-IP.CONV

${ }^{w}$-dan geyin $\quad b^{i} r$ žil-ya tayaw awï mołta-sï

that-ABL AFTER1.POSTP one year-DAT near township mullah-POSS3SG 
jumaš de-gen mołta-dan köneš $e^{51}{ }^{w}$ oḳi-dï-m.

Jumash say-GAN.PTCP mullah-ABL ancient study-PAST-1SG

'Until the age of nine, I was brought up by my parents, then I received religious education from a township mullah whose name was Jumash mullah.'

$\mathrm{T} 3 / 5$

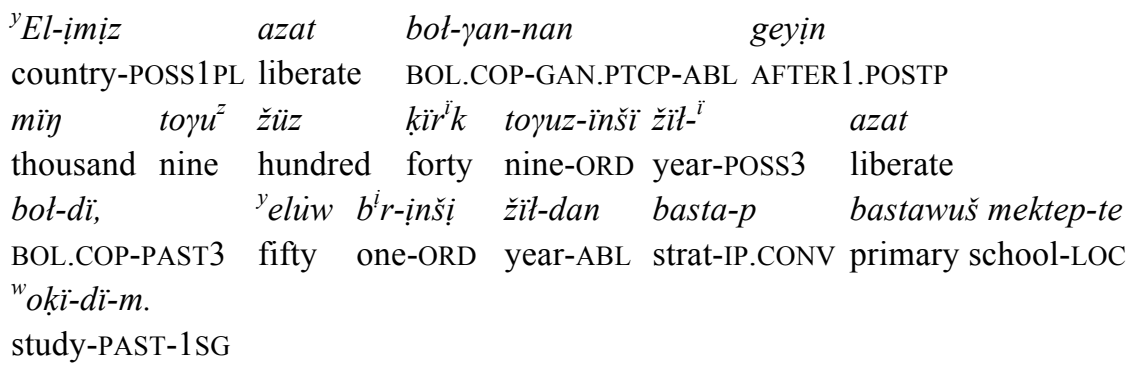

'After our country was liberated - it became free in 1949 - and from (19)51 on I studied at a primary school.'

$\mathrm{T} 3 / 6$

Kazïr-gị katay bastawuš mekteb-ịn-de.

present-GI Katay primary school-POss3-LOC

'In the present day Katay primary school.'

$\mathrm{T} 3 / 7$

${ }^{y}$ Eluw tört-ịnši žï-ï bastawuš mektep-tị b bị̂r-ịp buwuršïn

fifty four-ORD year-POSS3 primary school-ACC finish-IP.CONV Burqin

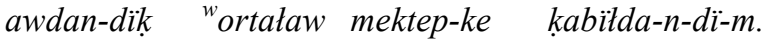

county-DER secondary school-DAT enroll-REF.PASS-PAST-1SG

'In (19)54, I completed the primary school and was enrolled in the secondary school in Burqin County.'

$\mathrm{T} 3 / 8$

${ }^{y}$ Eluw jetị-nši $\quad$ žit-ï buwuršïn $\quad{ }^{w}$ ortaław mekteb-ị-n

fifty seven-ORD year-POSS3 Burqin secondary school-POSS3-ACC

$b^{i}$ tịr-ịp kazịr-gị mïna ịle sifäan ${ }^{52}$ šöyàn ${ }^{53}$,

finish-IP.CONV present-GI this Ili pedagogical institute

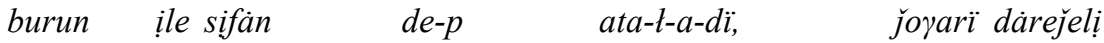

formerly Ili pedagogical say-IP.CONV call-PASS-A.PRES-3 high level

${ }^{51}$ Here köneše means religious education in Islam.

52 Sifän is a global copy of the Chinese word shïfàn 'pedagogical'.

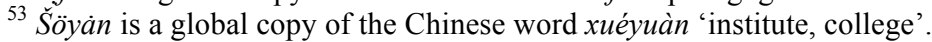




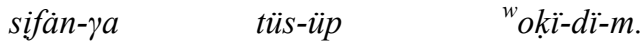

pedagogical-DAT enter-IP.CONV study-PAST-1SG

'In (19)57, I graduated from the secondary school in Burqin and I entered the present Ili Pedagogical Institute, it was formerly called Ili Pedagogical, a high level teacher-training (institute).'

$\mathrm{T} 3 / 9$

Atpïs-ïnši žit-ï segịz-ịnši $\quad$ ay-dïy $\quad b^{i} r$-ịn-de ịle

sixty-ORD year-POSS3 eight-ORD month-GEN one-POSS3-LOC Ili

sifän kitir-ip altay- $\quad$ kayt-ïp gel-ip

pedagogical finish-IP.CONV return-IP.CONV Altay-DAT come-IP.CONV

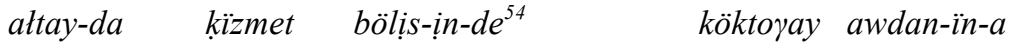

Altay-LOC job assignment-POSS3-LOC Fuyun county-POSS3-DAT

böl-dị.

assign-PAST3

'The first of August in (19)60, I graduated from Ili pedagogical and returned and came back to Altay, and in Altay I was assigned to work in Fuyun County.'

$\mathrm{T} 3 / 10$

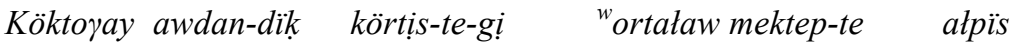

Fuyun county-DER Ku Ertix-LOC-GI secondary school-LOC sixty

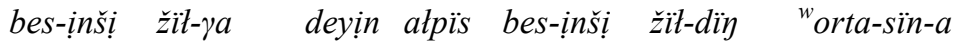

five-ORD year-DAT until sixty five-ORD year-GEN middle-POSS3SG-DAT

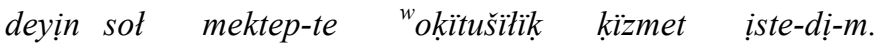

until that school-LOC teacher job do-PAST-1SG

'At the secondary school in Ku Ertix which is in Fuyun County, I worked as a teacher until (19)65, until the middle of (19)65.'

$\mathrm{T} 3 / 11$

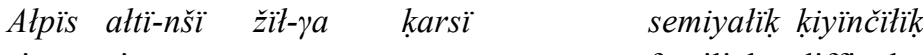

sixty six-ORD year-DAT AGAINST.POSTP familial difficult

jayday-ï-menen awdan-nïy awiłdïk-ẗ̈y jäne attay

situation-POSS3-WITH.POSTP county-GEN township-GEN and Altay

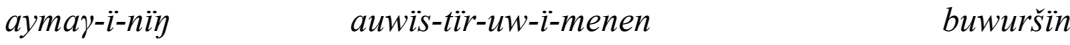

prefecture-POSS3-GEN transfer-CAUS-UW.VN-POSS3-WITH.POSTP Burqin

\footnotetext{
${ }^{54}$ Bölịs is a translational equivalent of Chinese fênpèi, '(job) assignment', the first element fên meaning 'divide'. The second element pèi means 'make arrangements for'. Kazakh selectively copied this Chinese expression on the verb böl- 'divide' + the deverbal nominal suffix -ịs. Thus bölis means '(job) assignment' in addition to an original meaning 'division'.
} 


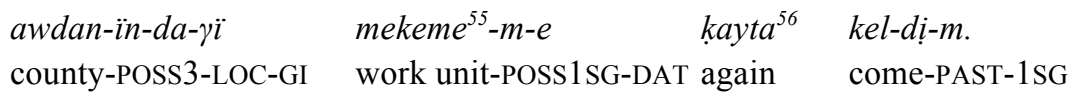

'Towards (19)66, because of my difficult family situation, I was transferred by the county and township and the Altay prefecture back to my work unit in Burqin county.'

$\mathrm{T} 3 / 12$

$\begin{array}{llll}\text { Kel-gen-nen } & \text { geyịn } & \text { yegistịk awïldïy-ï-nïy } \\ \text { come-GAN.PTCP-ABL } & \text { AFTER1.POSTP } & \text { Egistik township-POSS3-GEN } \\ \text { jataktï wortaław mekteb-ịn-de } & \text { iste-dị-m. } \\ \text { boarding secondary school-POSS3-LOC } & \text { work-PAST-1SG }\end{array}$

'After I arrived, I worked in the secondary boarding school in Egistik ('agricultural') township.'

$\mathrm{T} 3 / 13$

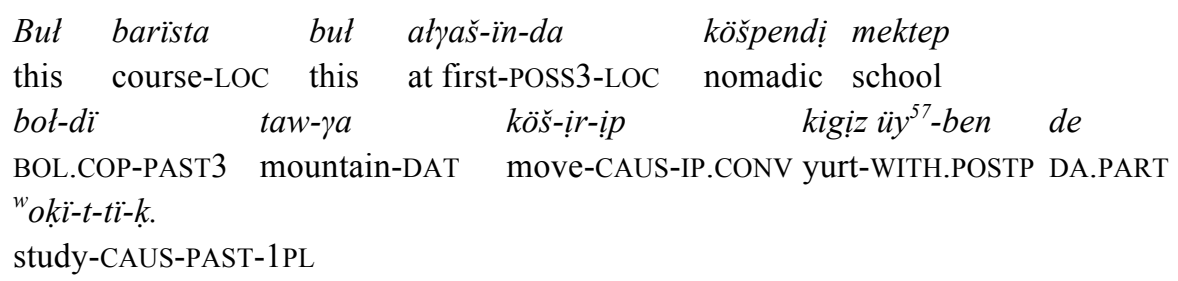

'During this time, this was at first a nomadic school (so) we moved to the mountains and taught (the students) in yurts.'

$\mathrm{T} 3 / 14$

\begin{tabular}{|c|c|c|c|c|}
\hline Šatïr $t$ & tig-ịp & te & ${ }^{w} o k \ddot{i}-t-t \ddot{i}-k$ & $b^{i} r$ döybök \\
\hline ent & set up-IP.CONV & DA.PART & study-CAUS-PAST-1PL & wooden \\
\hline$\ddot{u ̈ y}$ & $s a t-p$ & teri & sat-yan-day & jer-de 58 \\
\hline cottage & build-IP.CONV & skin & put-GAN.PTCP-EQUA & place-LOC \\
\hline & $\begin{array}{l}\text { wokï-t-tï-k. } \\
\text { study-CAUS-P }\end{array}$ & AST-1Pl & & \\
\hline
\end{tabular}

'We also set up tents and gave classes, we built a wooden cottage and also gave classes in a small room.'

$\mathrm{T} 3 / 15$

$\begin{array}{llllc}\text { Keỵin turaktï } & \text { mektep } & \text { sat-ïp } & \text { "ortaław mektep-tị } \\ \text { later permanent } & \text { school } & \text { build-IP.CONV } & \text { secondary school-ACC } \\ \text { aktülek } & \text { de-gen } & k^{i} \text { staw-tïk } & \text { worn- } \ddot{-} \text {-nan } \\ \text { Aktulek } & \text { say-GAN.PTCP } & \text { winter residence-DER } & \text { place-POSS3-ABL }\end{array}$

\footnotetext{
${ }^{55}$ Mekeme is a translational equivalent of the Chinese word dānwèi 'work unit'. Mekeme is of Arabic origin, and means 'court of law, office, cooperation'.

${ }^{56}$ Kayta is a lexicalized adverb based on the converb in $\left\{-\mathrm{A}^{2} / / \mathrm{y}\right\}$.

${ }_{58}^{57}$ The word kigị $\ddot{u ̈ y}$ 'yurt' is a compound, meaning literally 'felt house'.

${ }^{58}$ Teri satyanday jer- literally means 'a place where skin was laid'. The speaker probably means that the place where they gave classes was rather limited in size.
} 
aš-ïp so jer-de kïzmet-te bot-dï-m.

open-IP.CONV that place-LOC work-LOC BOL.COP-PAST-1SG

'Later, (we) built a permanent school so that (we) opened the secondary school at the winter residence called Aktulek and I worked at that place.'

T3/ 16

${ }^{y}$ Endi but barïs-ta matši perzent-ter burun ${ }^{w}$ osï

NOW.FILL this course-LOC herdsman child-PL formerly this

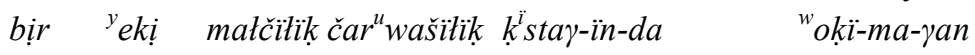

one two cattle-breeding village-POSS3-LOC study-NEG-GAN.PTCP

yeken.

E.COP. INDIR3

'And at that time, there were a few cattle-breeding villages in which the children of herdsmen had previously not studied.'

$\mathrm{T} 3 / 17$

Men atyaš bar-yan kez-de ${ }^{w}$ osï-dan illgerle-p

I at first go-GAN.PTCP time-LOC this-ABL go forward-IP.CONV

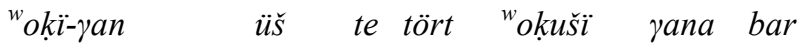

study-GAN.PTCP three or four student only existing

${ }^{y}$ eken.

E.COP.INDIR3

'When I went there for the first time, as I have heard, there were only three or four students who continued (their) studies after this (secondary school).'

T3/ 18

Baska tịpti ${ }^{i}$ škanday tärix-ta ${ }^{w}$ oḳi-ma-ran ${ }^{y}$ eken.

except even at all history-LOC study-NEG-GAN.PTCP E.COP.INDIR3

'Except (for them) nobody else has apparently studied in the past.'

T3/ 19

${ }^{w} \mathrm{O}$ jer-den bịz bastawuš mektep-tị ịrge-sị-n

$\mathrm{X}$ place-ABL we primary school-ACC foundation-POSS3SG-ACC

bekemde-w-men birge ${ }^{w}$ ortaław mektep-ti $i$ so jer-de

make solid-UW.VN-WITH.POSTP together secondary school-ACC that place-LOC

jalyastï ăs-tï-k, jatyastï aš-kan-nan geyịn

continuous open-PAST-1PL continuous open-GAN.PTCP-ABL AFTER1.POSTP

${ }^{w_{o}}$ jer-den köptegen ${ }^{w}$ ortaław bit-ịr-gen

$\mathrm{X}$ place-ABL quite a lot secondary finish-CAUS-GAN.PTCP

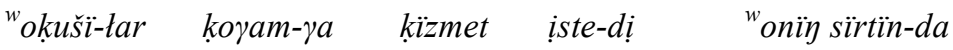

student-PL society-DAT work do-PAST3 besides.POSS3-LOC 
illgerle-p $\quad{ }^{\text {wokï-di. }}$

go forward-IP.CONV study-PAST3

'From then on, we further developed the primary school and at the same time we also continued to open secondary schools there, and after we had opened them, quite a lot of students who graduated from the secondary (school) worked for our society, others continued to study.'

$\mathrm{T} 3 / 20$

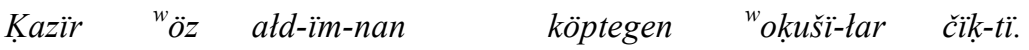
present self front-POSS1SG-ABL quite a lot student-PL come out-PAST3 'By now many of my students have graduated.'

$\mathrm{T} 3 / 21$

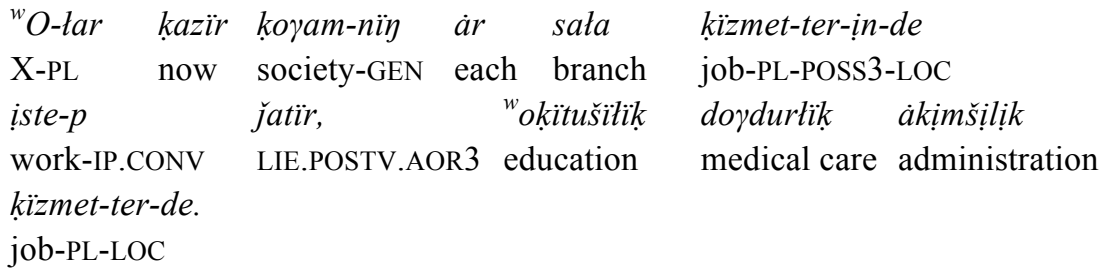

'Now they are working in all sorts of social services, (such as) education, medical care and administration.'

$\mathrm{T} 3 / 22$

${ }^{y}$ Endị kazïr matčar ${ }^{u}$ wašitik $\quad k^{\ddot{i}}$ stak-tar-ï-n̈̈y...

NOW.FILL present cattle-breeding village-PL-POSS3-GEN

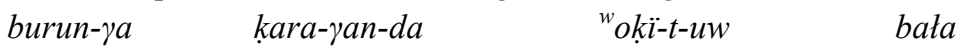

formerly-DAT look at-GAN.PTCP-LOC study-CAUS-UW.VN child

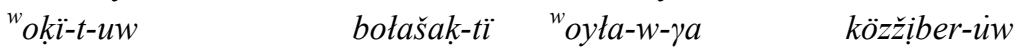

study-CAUS-UW.VN future-ACC think-UW.VN-DAT look-UW.VN

burun-yï-day $\quad{ }^{y}$ emes jaxsar-dï.

formerly-GI-EQUA not improve-PAST3

'And now in the present cattle-breeding villages... compared to the past, the education, the education of children, and how they think about the future, (these things) are not like previously, they have improved.'

$\mathrm{T} 3 / 23$

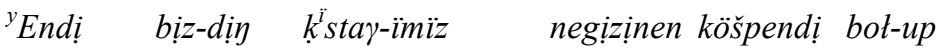

NOW.FILL we-GEN village-POSS1PL mainly nomadic BOL.COP-IP.CONV

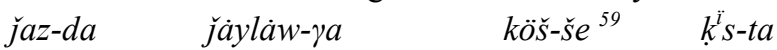

summer-LOC summer pasture-DAT move-HYP3 winter-LOC

${ }^{59}$ See footnote 22 . 
$k^{i}$ stawtik-ka $\quad$ bar- ${ }^{i} p \quad$ mat $\quad$ bay-a-dï.

winter residence -DAT go-IP.CONV livestock breed-A.PRES-3

'And our village is mainly nomadic, whereas (the people) in the summertime move to the summer pasture, in the winter (they) go to the winter residence and breed (their) livestock.'

$\mathrm{T} 3 / 24$

Sot barïs-ta kiyïnčitił japa-łar-da matši-łar-men

that course-LOC severe hardship-PL-LOC herdsman-PL-WITH.POSTP

$b^{i}$ rge bot-dï-m.

together BOL.COP-PAST-1SG

'At that time, I shared the severe hardship with the herdsmen.'

$\mathrm{T} 3 / 25$

Mïna ${ }^{y}$ emegeyti de-gen tör jäylàw $w^{60}$ bot-dï

this Yemegeyti say-GAN.PTCP prominent grassland BOL.COP-PAST3

yemegeyti....

Yemegeyti

'There was this prominent grassland called Yemegeyti. Yemegeyti...'

$\mathrm{T} 3 / 26$

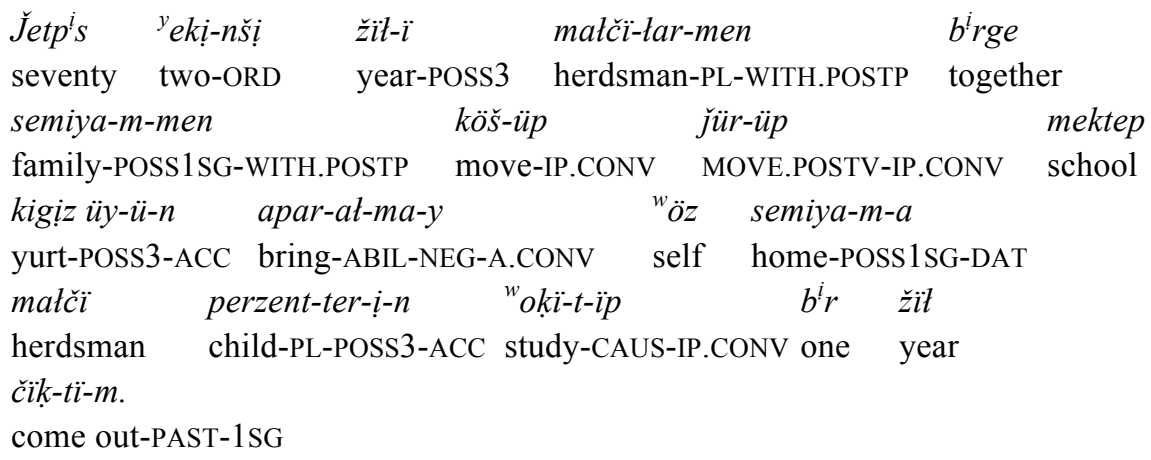

'In (19)72, I and my family migrated with the herdsmen, and (when) the school couldn't bring its yurt, I taught the children of the herdsmen in my home for one year.'

$\mathrm{T} 3 / 27$

$\begin{array}{lllll}{ }^{w} \text { O-dan } & \text { geyin } & \text { de } & \text { baska muratïm-der } & \text { šï- } \ddot{p} p \\ \text { X-ABL } & \text { AFTER1.POSTP } & \text { DA.PART } & \text { other teacher-PL } & \text { come out-IP.CONV }\end{array}$

${ }^{60}$ Tör jäyldaw is a grassland where the herdsmen breed their cattle. The Kazakhs divide large grasslands into three parts: 'etekti jäaläw 'a foothill grassland' where they live during the spring; 'orta jäylaw 'a middle grassland' to which they migrate to live during June and July; and tör jáylàw 'prominant grassland' where they live during August. Tör denotes the place of honor in a room or yurt (usually opposite the door), here it means that the time when they migrate to the upper part of the grassland is the best time for the grasses; it is the best place for the nomads. 
tur-dï.

STAND.POSTV-PAST3

'And also later other teachers kept doing so.'

$\mathrm{T} 3 / 28$

${ }^{w}$ Osïn-day japatïk-penen bịz matči perzent-ter-ị-n

this-EQUA difficułty-WITH.POSTP we herdsman child-PL-POSS3-ACC

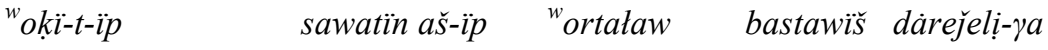

study-CAUS-IP.CONV educate-IP.CONV secondary primary level-DAT

jet-kịz-dị-k.

reach-CAUS-PAST-1PL

'With such difficulties, we taught and educated the children of the herdsmen and we made them complete the secondary and primary levels.'

$\mathrm{T} 3 / 29$

But ${ }^{y}$ endi...

this NOW.FILL....

'This is...'

$\mathrm{T} 3 / 30$

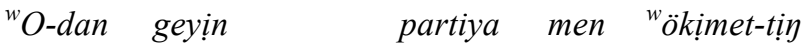

X-ABL AFTER1.POSTP party and government-GEN

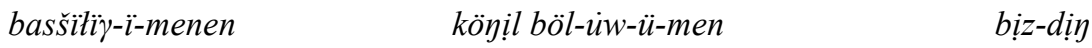

leadership-POSS3-WITH.POSTP solicitude-UW.VN-POSS3-WITH.POSTP we-GEN

ulttik rayon-da mektep-ter sat-ïp ber-di,

ethnic region-LOC school-PL build-IP.CONV GIVE.POSTV-PAST3

jataktï mektep-ter sat-ïn-dï.

boarding school-PL build-REF.PASS-PAST3

'Then with the solicitude of the leadership of the party (Communist Party of China) and government, they built schools in our minority region, boarding schools were built.'

$\mathrm{T} 3 / 31$

Sot seksen-ịnšị žï-ï jataktï mektep sat-ïn-ïp

that eighty-ORD year-POSS3 boarding school build-REF.PASS-IP.CONV

${ }^{w}$ ortaław kilàs-tàr ${ }^{y}$ egizztöbe de-gen awïldik ${ }^{w}$ otïr- $\gamma a n$

secondary class-PL Yegistöbe say-GAN.PTCP township sit-GAN.PTCP

jer-ge kös̆-tị.

place-DAT move-PAST3

'In that year of (19)80, a boarding school was built, and the secondary classes moved to the township settlement called Yegistöbe.'

$\mathrm{T} 3 / 32$

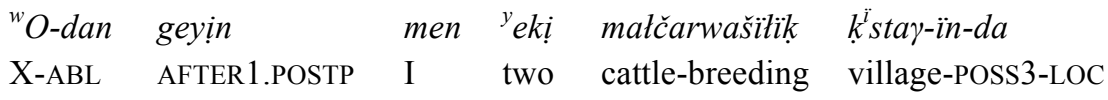


${ }^{y}$ eki mektep bot-dï ${ }^{w}$ osï mektep-tịy jawapkeršịlịk

two school BOL.COP-PAST3 this school-GEN director

kizmet-i-n iste-dị-m.

job-POSS3-ACC do-PAST-1SG

'Then, there were two schools in two cattle-breeding villages, and I worked as the director of the schools'

$\mathrm{T} 3 / 33$

$\begin{array}{lllll}\text { Sonï-menen } & \text { toksan } & { }^{y} \text { eki-nši } & \text {žit-dïy } & \text { soy- ̈̈n-da } \\ \text { that-WITH.POSTP ninety } & \text { two-ORD } & \text { year-GEN } & \text { end-POSS3-LOC }\end{array}$

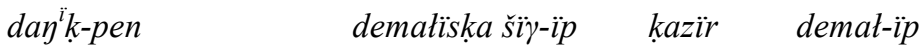

distinction-WITH.POSTP retire-IP.CONV present rest-IP.CONV

jatïr-mïn.

LIE.POSTV.AOR-COP1SG

'Then at the end of (19)92 I retired with distinction and now I am retired.'

$\mathrm{T} 3 / 34$

$K^{i ̈ s k a s ̌ a ~ a k u w a t-i ̈ m ~}{ }^{w}$ osï.

in brief situation-POSS1SG this.

'Briefly, this is my situation.'

$\mathrm{T} 3 / 35$

${ }^{y}$ Endi $\quad{ }^{w} \ddot{o} z-i ̣ m-d e \quad \ddot{u} s$ qüz tört ut

NOW.FILL self-POSS1SG-LOC three daughter four son

bot-yan, bu-tar-dï da woki-t-tï-m.

BOL.COP-GAN.POSTT3 this-PL-ACC DA.PART study-CAUS-PAST-1SG

'And I have three daughters and four sons, and I have also educated them.'

$\mathrm{T} 3 / 36$

$B^{i} r \quad{ }^{y}$ ek-ew-i $i \quad{ }^{w}$ oḳu arartu sała-sïn-da jäne baska

one two-COLL-POSS3 education sector-POSS3SG-LOC and other

sała-łar-da b ${ }^{i} r \quad{ }^{y}$ ek-ew- $i \quad$ kizmet iste-y-di,

field-PL-LOC one two-COLL-POSS3 work do-A.PRES-3

$b^{i}$ rneš-ew-i $i$ małči $\quad$ bot- $^{-} p \quad$ kazïr čarwašitik

some-COLL-POSS3 herdsman BOL.COP-IP.CONV present cattle-breeding

kïmet-ter-ị-menen čuүułdan-їp jatïr.

work-PL-POSS3-WITH.POSTP engage in-IP.CONV LIE.POSTV.AOR3

'Two of them are in the educational sector and other fields. Two of them are employees, and the others have become herdsmen, now (they) are engaged in cattlebreeding.'

$\mathrm{T} 3 / 37$

Semiyatï jayday-ïm da $\quad{ }^{y}$ endị ${ }^{w}$ osïnšatiktï.

family situation-POSS1SG DA.PART now so much

'So much for now about my family situation.' 
$\mathrm{T} 3 / 38$

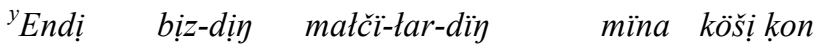

NOW.FILL we-GEN herdsman-PL-GEN this migration

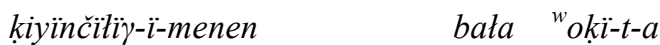

difficult-POSS3-WITH.POSTP child study-CAUS-A.CONV

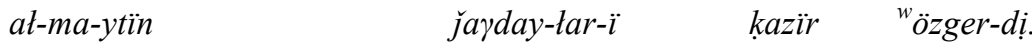

TAKE.POSTV-NEG-ATIN.PTCP situation-PL-POSS3 present change-PAST3

'The situation for our herdsmen, who (previously) could not educate their children because of the migration, has now changed.'

$\mathrm{T} 3 / 39$

${ }^{w} \ddot{O} z \quad{ }^{w}$ orta-mïz-da mïsat üš̈̈n awïldik-tan

self place-POSS1PL-LOC for example township-ABL

${ }^{w}$ ortaław mektep aš-tï, jataktï mekep aš-tï.

secondary school open-PAST3 boarding school open-PAST3

'At our place, for example, the township has opened a secondary school and a boarding school.'

$\mathrm{T} 3 / 40$

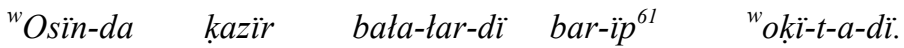

this-LOC present child-PL-ACC take-IP.CONV study-CAUS-A.PRES-3

'At present, the children go and get education there.'

$\mathrm{T} 3 / 41$

Urpak-tar-ï-n $\quad{ }^{w}$ okï-t-uw-ï... burun- $\gamma \ddot{i}-\gamma a$

generation-PL-POSS3-ACC study-CAUS-UW.VN-POSS3 formerly-GI-DAT

kara-yan-da matši-łar-dïy sana sáwiye-sị

look at-GAN.PTCP-LOC herdsman-PL-GEN intellect level-POSS3SG

jaksï.

good.

'The education of the generations...Compared to the past, the herdsmen's intellectual level is good.'

$\mathrm{T} 3 / 42$

Jäne partiya men ${ }^{\text {wökimet-tị } \ldots . . .}$

and party and government-GEN

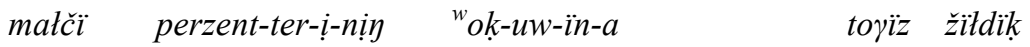

herdsman child-PL-POSS3-GEN study-UW.VN-POSS3-DAT nine year

${ }^{w}$ ok-uw-dï jütị-üw-ịn-e jäne ilgerle- $p$

study-UW.VN-ACC finish-UW.VN-POSS3-DAT and go forward-IP.CONV

${ }^{w}$ ok-uw-ïn-a köptegen ${ }^{y}$ ekonomikatik jak-tan järdäm-dàr

study-UW.VN-POSS3-DAT quite a lot financial side-ABL help-PL

${ }^{61}$ The expected form is apar-ïp 'took'. 
$\begin{array}{llll}\text { ber-ịp } & \text { kazïr } & { }^{w} \text { okï-t-ïp } & \text { jat ̈̈r. } \\ \text { give-IP.CONV } & \text { present } & \text { study-CAUS-IP.CONV LIE.POSTV.AOR3 }\end{array}$

'Moreover the party and the government... provide a large amount of financial help for the education of the herdsmen's children so that they finish nine years of schooling and continue to study. They educate them.'

$\mathrm{T} 3 / 43$

${ }^{y}$ Endi baska nemene ayt-a-mïz $\quad{ }^{y}$ endị?

NOW.FILL other what say-A.PRES-COP1PL now

'Well, what else is there to say now?'

\section{T4. Aytakïnï̈ àngịmesị 'The story of Aytakiin'}

Metadata

Gender: male

Age: 72

Date of birth: October 1939

Place of birth: Republic of Mongolia

Education: University

Language competence: Kazakh (mother tongue), Mongol (understands and speaks), Uyghur (understands, speaks, and reads), Chinese (understands, speaks, and reads), Russian (understands)

Date of recording: 3th August 2010

Place of recording: Ürümqi

Running text

T4/ 1-T4/ 10

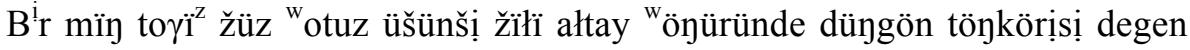

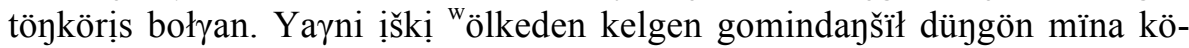
terịsšịlerị dep koyadï ${ }^{\mathrm{y}}$ endị ảdette ${ }^{\mathrm{y}}$ endị kerị küšter yoy. Sodan ana šinǰay kelịp, šinǰanda mïna čonǰidan...čonj̄i, turpan jaḳka kelịp so žerde kožaniyaz

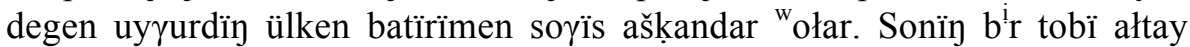
betịne "ötịp so žerdegị ${ }^{y}$ eldị tonap kïryïnčiłïk žasayan gezde žàyławda

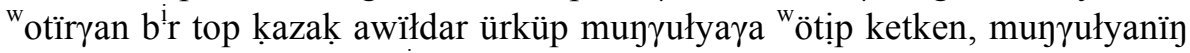
čegarasïna. Buł mölčerị b ${ }^{i}$ r mïn to $\ddot{\gamma i}^{\mathrm{z}}$ žüz ${ }^{\mathrm{w}}$ otuz ${ }^{\mathrm{y}}$ ekị, ${ }^{\mathrm{w}}$ otuz üš, ${ }^{\mathrm{w}}$ otus törtịnšị

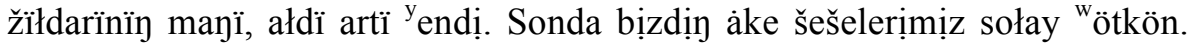

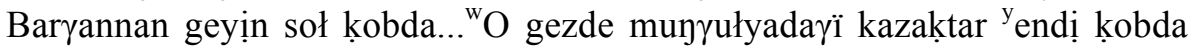
degen aymaḳka ḳaraydï ${ }^{\mathrm{y}}$ eken. ${ }^{\mathrm{w}}$ Onda mïna baynölgey aymayï degen ${ }^{\mathrm{w}} \mathrm{o}$ gezde žok. So ḳobda aymayïnïn aḳköl degen, sumïn dep ḳoyadï ${ }^{y}$ endị awdan, sonïsïna ḳonïstanïp ${ }^{\text {w}}$ otïradï.

T4/ 11-T4/ 20

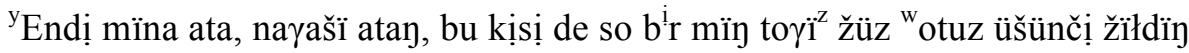

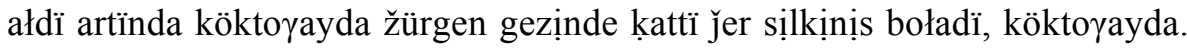




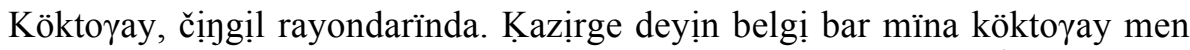
čịggịldin arałï үïnda. Soł kezde ana sịlkịnịsten jer jarïłïp ketken. Ȧzịrge deyịn soł jarïłïp ketken ǰerdịn sịlemị bar, àlị jer betịnde čunḳur bop žatïr. Sonda bu

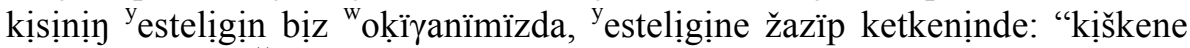

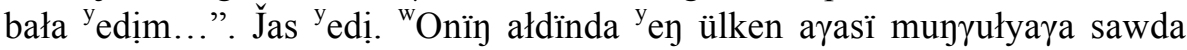

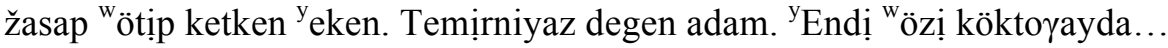

\section{$\mathrm{T} 4 / 21-\mathrm{T} 4 / 30$}

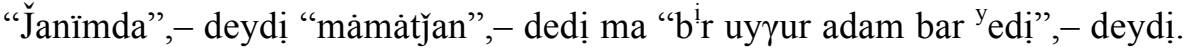
"Soł yekewịmịz sawda žasap žürdịk",- deydị. " "Endị men wözịm ảkemnen

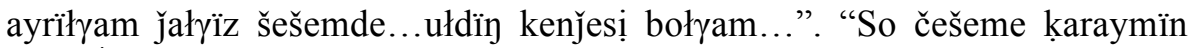
dep b'raz sawda žasap kelem dep...”. “wonïn ałdïnda men sawda žasaw

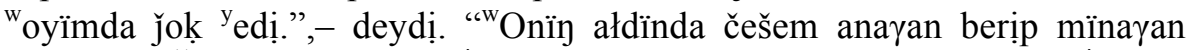
berịp..." "Čảịrttịkke berịp braz mołłałïk wokïdïm”. "wonan geyịn brewge

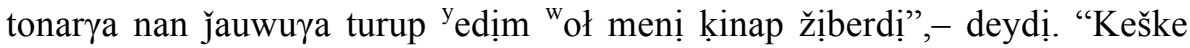

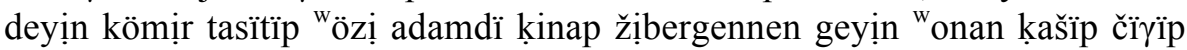

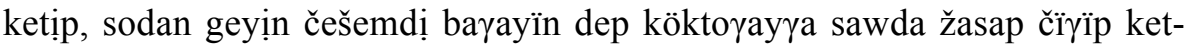
kem",- deydị. "Süytüp žürgende àdette kazaḳtardïn üyịnde ḳonïp žürüši "ek",- deydị.

\section{$\mathrm{T} 4 / 31-\mathrm{T} 4 / 40$}

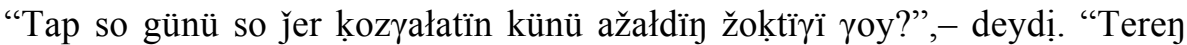
saydïn ịṣ̆ ḳałï adam kigịz üy ḳonyan ana b’r bułaḳ bar ${ }^{\mathrm{y}}$ endị, soł saydïn

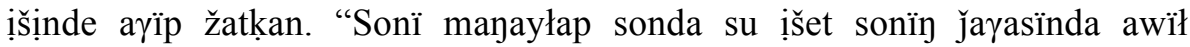
wotïrat",- deydị. "Mïnday teren uzun say",- deydị. "Soł günị tamayïmïzdï

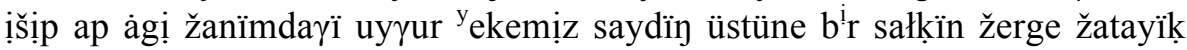
dep, žazdï günị bołatïn",- deydị. "Atïmïzdï čịderlep arḳandap ḳarayaydïn

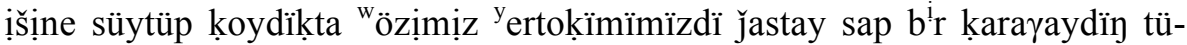
bịnde žattîk",- deydị “y ekemịz”. " $\mathrm{B}{ }^{i} r$ waḳta kałïn gürüldegen dawustan woyanïp kettịm”,- deydị. "woyanïp ketsem bükül ǰer dünye ałay düley jer

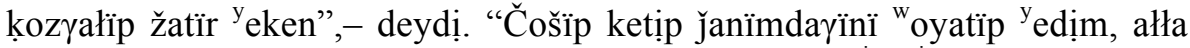
ałła ałła dep dey berdịk". "Sodan yekemịz woyanïp bị b bịmịzdị ḳušaḳtap imanïmïzdï aytïp "otïrdiḳ",-- deydị.

\section{$\mathrm{T} 4 / 41-\mathrm{T} 4 / 50$}

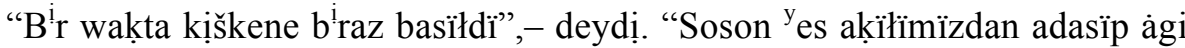
attarïmïz čïyүïrïp àytew ayayïnda čịderị bar sonïmen kałdï”,- deydị.

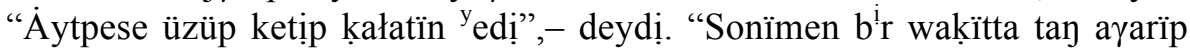

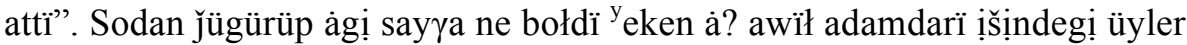
ne bołdï ${ }^{\mathrm{y}}$ eken? desek woł saydï körüwge bołmaydï yeken",- deydị. "Say

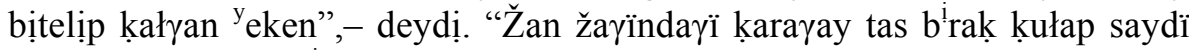
bịteptị",- deydị. "B'r adam körüwge bołmaydï, "ekemịz yana tịị kałïppïz",deydị "ảgị ǰerde, "özị, so manayda". "Čošïp kettịk. attï ákeldịk te ${ }^{\mathrm{e}}$ toḳimïmïzdï ${ }^{y}$ erttedịk te ${ }^{\mathrm{y} e k e m i ̣ z ~ s o ~ k ̣ a p i ̈ ~ k a s ̌ i ̈ p ~ b a r a m i ̈ z, ~ k ̣ a s ̌ i ̈ p ~ b a r a m i ̈ z ~}$ 


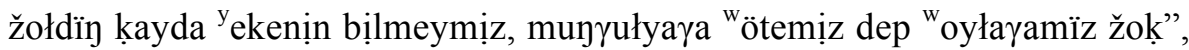
- deydị. "Kašïp baramïz ḳašïp baramïz ketịp baramïz".

\section{$\mathrm{T} 4 / 51-\mathrm{T} 4 / 60$}

"B ${ }^{i}$ r wakiitta bi ${ }^{i}$ àskerler ustap ałdï”,- deydị. "Süytsek buł mïna nemeneden

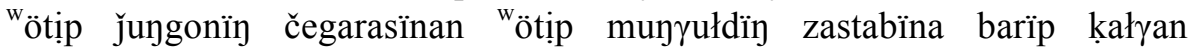
yekenbịz",- deydị. Soson "sender kaydan kele žatïrsïndar? "osïnday ǰer kozyałïp ałtay betịnen kele žatïrmïz". Sodan geyịn "sender bułay "ötüwlerịne bołmaydï, buł memleket čegarasï mïnaw, mïnaw bịzdị čegara mïnaw

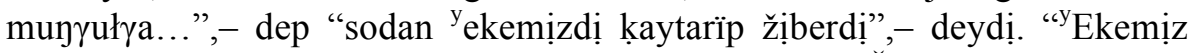

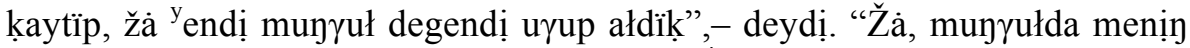
a a am bar, kaytpayïk, " endị "ekemịz urłanïp br žerden "ötüp keteyịk",- dep, ${ }^{y}$ ekewị astïnda àdemị atï bar àgị mịnịp žürgen sodan $b^{\mathrm{i}} \mathrm{r}$ žerden burułup

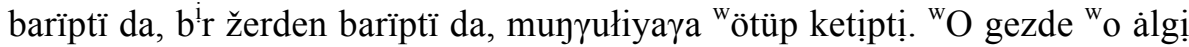
kalïn àsker turmaydi " eken, anda sanda br zastapta yana turadï ${ }^{\mathrm{y}}$ eken, kałyan jerị... "So sop boyï wötüp ketkem”,- deydị. Sodan “wötüp barïp, ịzdep žürüp

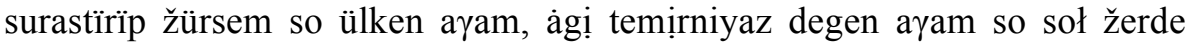
'eken",- deydị. " "W kịsị bayïp ałyan "eken”,- deydị. "Barïp, so kumdan "örtep, àley pảley bịrdenenị ịstep...

$\mathrm{T} 4 / 61-\mathrm{T} 4 / 70$

Koł astïnda adam ịstetedị ${ }^{y}$ eken. Men baryannan geyịn "àytaxun yaxši kảp ḳałdəク bałam, ảmdi sản minin išimni ḳəl” dep mayan berdị". "B 'raḳ ḳattï... jumusḳa kattï sałdī",- deydị. "Soson ayama renžịdịm",- deydị yoy. "Žumïsḳa ḳattï sałïp, süytüp kettị." "Sodan renj̣̣p süytüp keyde ketịp kałïp

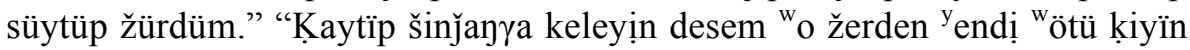

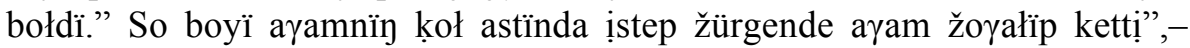
deydị. "wözị, ayak astïnan.” Keyịn mïna abdrasuł barïp... So gezde àgị "o

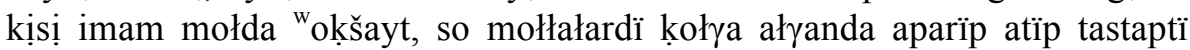
${ }^{\mathrm{e}}$ emespe.

\section{$\mathrm{T} 4 / 71 / \mathrm{T} 4 / 77$}

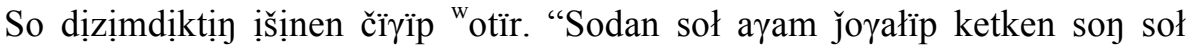

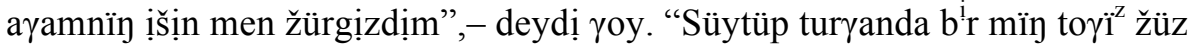
kïrḳinčï žïli bop ḳap ḳobdadan bölịnịp baynölgey aymayï degen aymaḳ

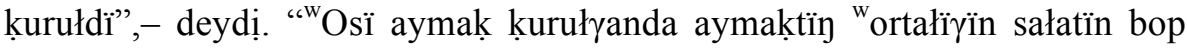
kałïn kurłusḳa kịrpịš kerek bołdï”,- deydị. Kịrpịštị ḳaydan čìraradii? kumdan wörtew kerek. "Sonïmen wonï men köterịp ałdïm",- deydị yoy. Köterịp ałïp soson wosïnï ịsteytịn negdịl dep koyadï yendị, br bịlestịk kurup, wo bịlestịn

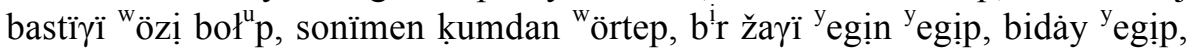
sảy ${ }^{{ }^{y}}$ egịp, kaposta, kartop, sảbịz ${ }^{y}$ egịpti, ałtïnsökse degen jerde. 
Annotated text

$\mathrm{T} 4 / 1$

$B^{i} r \quad$ mïy to $i^{z} \quad \check{z} \ddot{u} z \quad{ }^{w}$ otuz üš-ünši žï-ï attay one thousand nine hundred thirty three-ORD year-POSs3 Altay

"öyür-ün-de düygön töykörịs-ị de-gen

surrounding-POSS3-DAT Dungan revolution-POSS3 say-GAN.PTCP

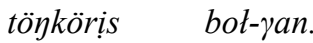

revolution BOL.COP-GAN.POSTT3

'In 1933, in the surroundings of the Altay (prefecture) there was a revolution called the Dungan Revolution.'

$\mathrm{T} 4 / 2$

\begin{tabular}{|c|c|c|c|c|}
\hline i & $\operatorname{den}^{62}$ & $\begin{array}{l}\text { kel-gen } \\
\text { come-GAN.PTCP } \\
\quad \text { de-p }\end{array}$ & $\begin{array}{l}d a \eta \text {-šit } \\
\text { intang-DER }\end{array}$ & \\
\hline
\end{tabular}

this revolutionary-PL-POSS3 say-IP.CONV PUT.POSTV-A.PRES-3 NOW.FILL

ádette $\quad{ }^{y}$ endi kerị küš-ter yoy.

usually NOW.FILL oppositional-PL TOY.PART

'In other words, the Dungans of the Kuomintang, who came from other parts of China, they are usually called the revolutionaries, oppositionals, you know.'

$\mathrm{T} 4 / 3$

So-dan ana šinjay-ya kel-ịp šinjay-da mïna

then THAT.FILL Xinjiang-DAT come-IP.CONV Xinjiang-LOC this

čonju-dan... čonji, turpan ǰak-ka kel-ịp so žer-de

Qitai-ABL Qitai Turfan side-DAT come-IP.CONV that place-LOC

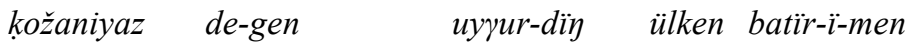

Kožaniyaz say-GAN.PTCP Uyghur-GEN big hero-POSS3-WITH.POSTP

soyïs aš-kan-dar $\quad{ }^{w} o$-łar.

fight open-GAN.PTCP-PL X-PL

'Then they came to Xinjiang, that is from Qitai in Xinjiang ...

They came to the land of Qitai and Turfan, and they were the ones who started the to fight there against the Uyghur's great hero called Kožaniyaz.'

$\mathrm{T} 4 / 4$

So-n̈̈y $\quad b^{i} r \quad$ tob- $\ddot{i} \quad$ attay bet-inn-e $\ddot{o} t-\ddot{u} p$

that-GEN a group-POSS3 Altay region-POSS3-DAT pass-IP.CONV

so žer-de-gi ${ }^{y} e l-d i \quad$ tona-p kiryïnčitik

that place-LOC-GI people-ACC rob-IP.CONV killing

${ }^{62} I \grave{s} k i{ }^{w}$ ölke is a translational equivalent of Chinese neidi, which literally means 'inland'. The people in Xinjiang, Xizang, and Hainan employ this word to refer to prefectures or places in China different from their own. 


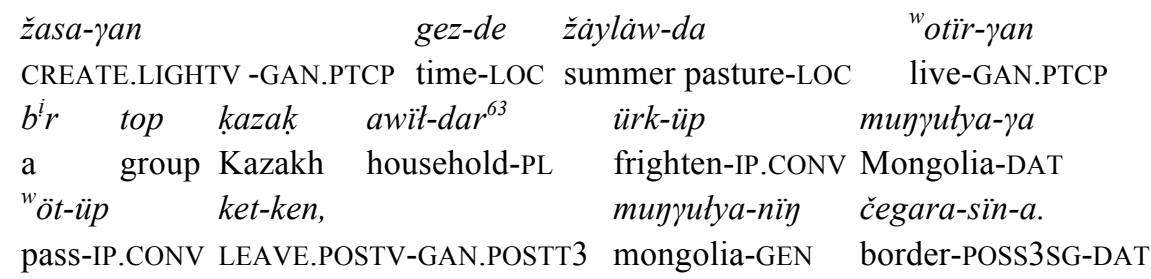

'Some of them went to the Altay region and when they robbed and killed the local people. Some Kazakh households living in the summer pasture got frightened and moved to Mongolia, to the Mongolian border areas.'

T4/ 5

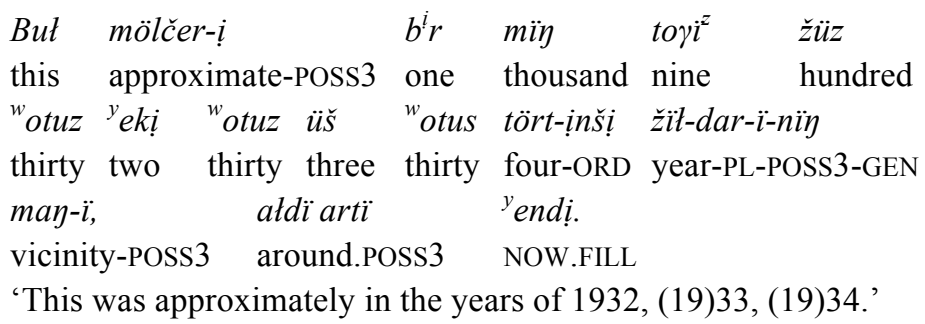

T4/ 6

Son-da bịz-dị̣ àke šeše-ler-ịmịz sołay ${ }^{w}$ öt-kön. that-LOC we-GEN parent-PL-POSS1PL that way pass-GAN.POSTT3

'At that time our parents had moved to the other side.'

T4/ 7

$\begin{array}{llll}\text { Bar-yan-nan } & \text { geyin } & \text { sot } & \text { kobda... } \\ \text { go-GAN.PTCP-ABL } & \text { AFTER1.POSTP } & \text { that } & \text { Kobda... }\end{array}$ 'After they went (to Mongolia), that Kobda...'

T4/ 8

\begin{tabular}{|c|c|c|c|}
\hline gez-de & 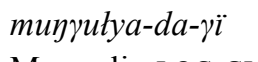 & kazak-tar ${ }^{y}$ endi & kobda \\
\hline time-LOC & Mongolia-LOC-GI & Kazak-PL NOW.FILL & Kobda \\
\hline & $-k a$ & $r a-y-d i$ & \\
\hline
\end{tabular}

'At that time, the Kazakhs in Mongolia belonged to a prefecture called Kobda (as I have heard).'

T4/ 9

${ }^{w}$ On-da mïna baynölgey aymay-ï de-gen

that-DAT this Bayan-Ölgii prefecture-POSS3 say-GAN.PTCP ${ }^{63}$ The word awït refers here to a group of yurts housing related families. It is translated here
as 'household'. In other contexts, the same word can mean 'village' and 'township'. 
${ }^{w} o \quad$ gez-de žok.

$\mathrm{X}$ time-DAt non-exisiting.

'At that time (the one) called Bayan-Ölgii prefecture did not exist.'

T4/ 10

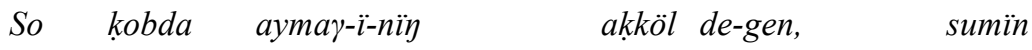

that Kobda prefecture-POSS3-GEN Akköl say-GAN.PTCP Sumïn

de-p koy-a-di $\quad{ }^{y}$ endi, awdan, soni-sïn-a

Say-IP.CONV PUT.POSTV-A.PRES-3 NOW.FILL county that-POSS3SG-DAT

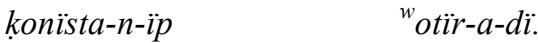

settle down-REF-IP.CONV live-A.PRES-3

'(The Kazakhs) settled down and lived in the county Akköl, usually called Sumïn, in the Kobda prefecture.'

T4/ 11

${ }^{y}$ Endi mïna ata, nayašĭata- $\eta^{64}, \quad$ bu kisi NOW.FILL this grandfather grandfather-POSS2SG this person DA.PART

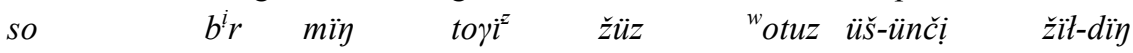

THAT.FILL one thousand nine hundred thirty three-ORD year-GEN

atdïartïn-da köktoyay-da žür-gen gez-ịn-de kattï

around.POSS3-LOC Fuyun-DAT move-GAN.PTCP time-POSS3-LOC strong

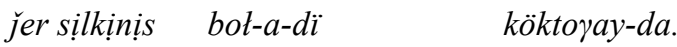

earthquake BOL.COP-A.PRES-3 Fuyun-LOC

'And now, this Grandfather, your grandfather, in about 1933, when he was in Fuyun there was a strong earthquake in Fuyun.'

T4/ 12

Köktoyay čịgịl rayon-dar-ïn-da.

Fuyun Qinggil region-PL-POSS3-LOC

'In the regions of Fuyun and Qinggil.'

T4/ 13

Kazịr-ge deyịn belgị bar mïna köktoyay men

present-DAT UNTIL.POSTP mark existing this Fuyun and

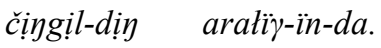

Qinggil-GEN between-POSS3-LOC

'A mark (of this) remians between Fuyun and Qinggil.'

T4/ 14

Sot kez-de ana sịlkịnịs-ten jer jar-ït-ïp

that time-LOC that shake-ABL earth split-PASS-IP.CONV

${ }^{64}$ Navašï ata means 'maternal grandfather'. 
ket-ken.

LEAVE.POSTV-GAN.POSTT3

'At that time the earth split because of that earthquake.'

$\mathrm{T} 4 / 15$

Azịr-ge deyịn sot jar-ït-ïp

now-DAT UNTIL.POSTP that crack-PASS-IP.CONV

ket-ken jer-dị sịlem-i $i$ bar à $i$

LEAVE.POSTV-GAN.PTCP earth-GEN remnant-POSS3 existing still

jer bet-ịn-de čujkur bop žatïr.

earth surface-POSS3-LOC hole BOL.COP.IP.CONV LIE.POSTV.AOR3

'A remnant remains in the earth that cracked, and there is still a hole on the surface of the earth.'

$\mathrm{T} 4 / 16$

Son-da bu kisi-nị ${ }^{y}$ estelig- $-i-n \quad b i z$

that-LOC this person-GEN diary-POSS3-ACC we

wokï-yan-ïmïz-da, $\quad{ }^{y}$ estelig-ịn-e žaz-ïp

read-GAN.PTCP-POSS1PL-LOC diary-POSS3-DAT write-IP.CONV

ket-ken-ịn-de "kịskene bała ${ }^{y} e$-dị-m..."

LEAVE.POSTV-GAN.PTCP-POSS3-LOC small child E.COP-PAST-1SG

'At that time, as we read in this person's diary, he writes "I was a child..."

$\mathrm{T} 4 / 17$

Jas $\quad{ }^{y} e-d i$.

young E.COP-PAST3

'He was young.'

$\mathrm{T} 4 / 18$

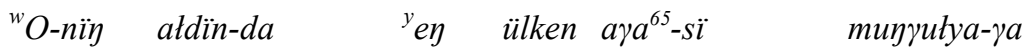

X.GEN front.POSS3-LOC SUPER big brother-POSS3SG Mongolia-DAT

sawda žasa-p, ${ }^{w}$ öt-üp ket-ken

commerce CREATE.LIGHTV-IP.CONV pass-IP.CONV LEAVE.POSTV-GAN.PTCP

yeken.

E.COP.INDIR3

'And before him his biggest brother moved over to Mongolia to do business.'

$\mathrm{T} 4 / 19$

Temịniyaz de-gen adam.

Temirniyaz say-GAN.PTCP person

'A man called Temirniyaz.'

${ }^{65}$ A $\gamma a$ means elder brother. 
$\mathrm{T} 4 / 20$

${ }^{y}$ Endị ${ }^{w} \ddot{o z}-i \quad$ köktoray-da...

but self-POSS3 Fuyun-LOC

'But he himself in Fuyun (county)...'

T4/ 21

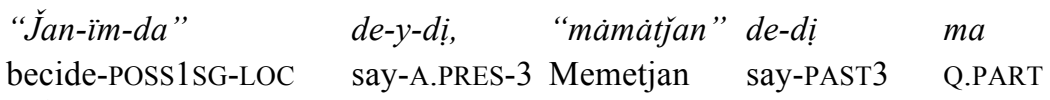

"brir uyjur adam bar ${ }^{y} e-d i ! "$ de-y-dị.

an Uyghur person existing E.COP-PAST3 say-A.PRES-3

" "Together with me"- he writes, "there was an Uyghur man"- he writes. I think he called him "Memetjan".'

T4/ 22

"Sol ${ }^{y} e k$-ew-ịmịz sawda žasa-p

that two-COLL-POSS1PL commerce CREATE.LIGHTV-IP.CONV

žür-dị-k" de-y-dị.

MOVE.POSTV-PAST-1PL say-A.PRES-3

"“He, the two of us were doing business"- - he writes.'

T4/ 23

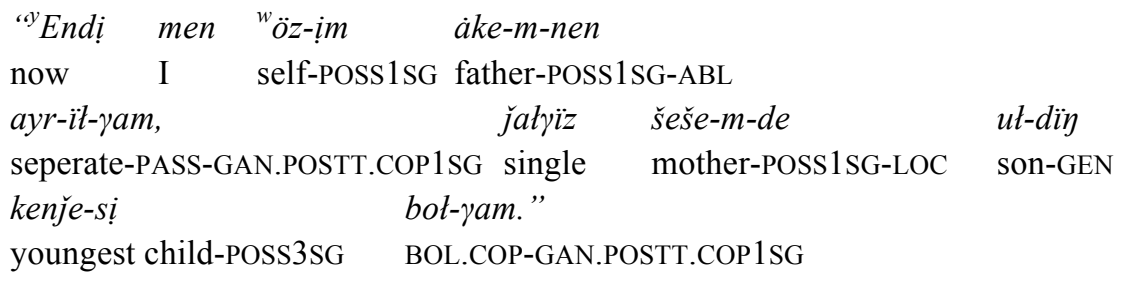

"'I myself had lost my father. I had been the youngest boy of my single mother".'

T4/ 24

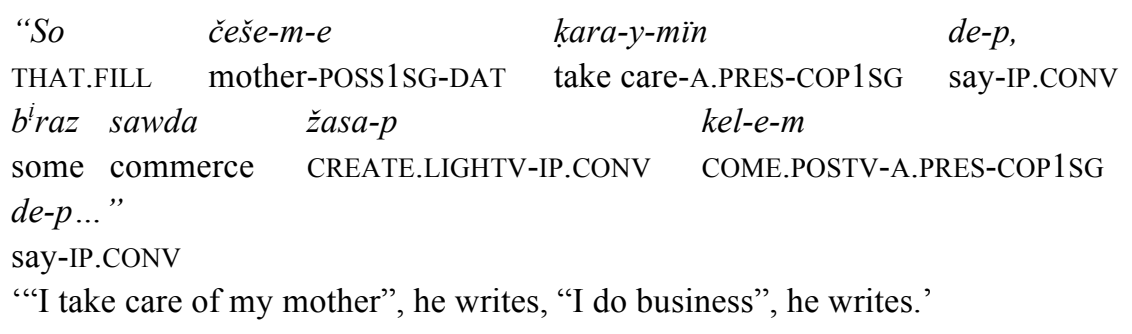

T4/ 25

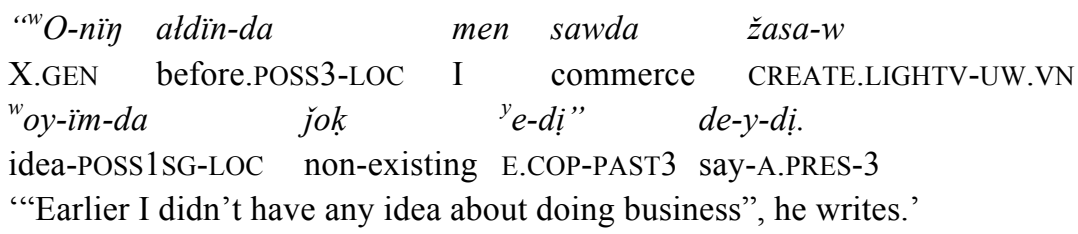


$\mathrm{T} 4 / 26$

\begin{tabular}{|c|c|c|}
\hline${ }^{\prime w} O-n \ddot{I} \eta$ & atdïn-da & anayan \\
\hline X.GEN & before.POSS3-LOC & that.DAT \\
\hline ber-ip & mïnayan ber-ip..."” & \\
\hline ve-IP.C & ONV this.DAT give-IP.CONV & \\
\hline
\end{tabular}

$\mathrm{T} 4 / 27$

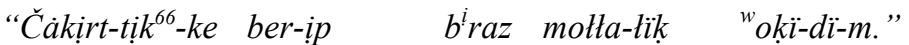
student-DER-DAT give-IP.CONV some Mullah-DER study-PAST-1SG "“(She) sent me to study and I studied a little religion".'

$\mathrm{T} 4 / 28$

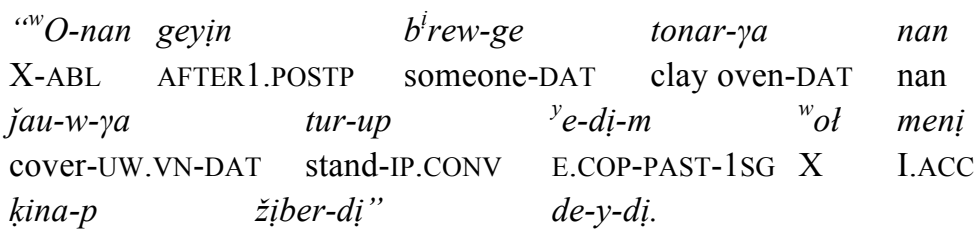

mistreat-IP.CONV SEND.POSTV-PAST3 say-A.PRES-3

"'Later I worked for someone as a baker, (but) he mistreated me (very much)", he writes.'

$\mathrm{T} 4 / 29$

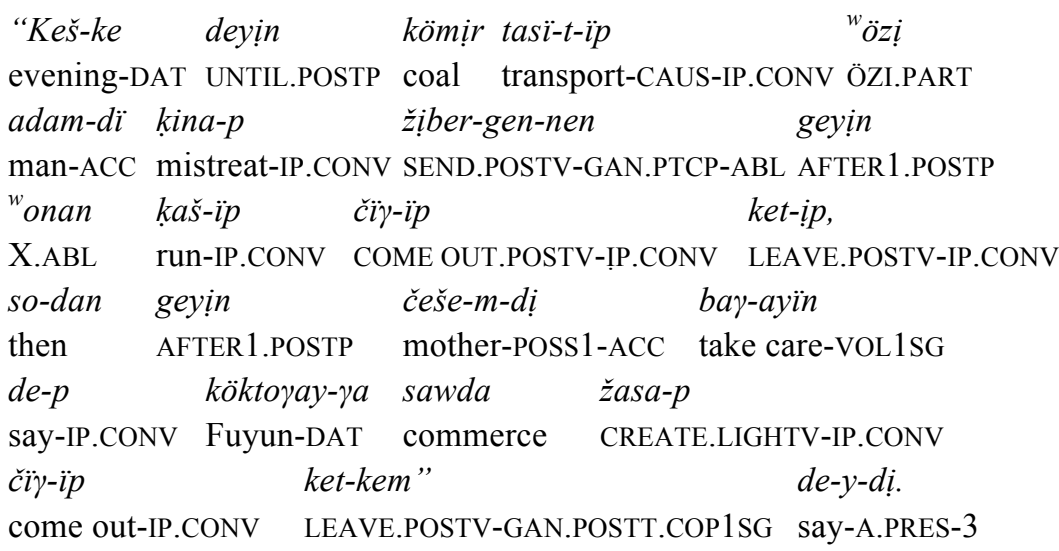

“"After (he) made me transport coal all the time, after he mistreated me so much (I) ran away from him. Then, in order to take care of my mother, I went to Fuyun to do business", he writes.'

$\mathrm{T} 4 / 30$

$\begin{array}{llll}\text { “Süyt-üp } & \check{z ̌ u ̈ r-g e n d e ~} & \dot{a} d e t t e & \text { kazak-tar-dïy } \\ \text { do So-IP.CONV } & \text { MOVE.POSTV-GAN.LOC.CONV } & \text { usually } & \text { Kazak-PL-GEN }\end{array}$

${ }^{66} \breve{C} \dot{a} k i ̣ t$ is a student of a Muslim religious school. 


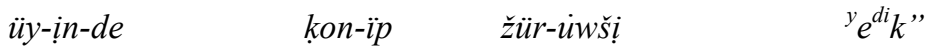

home-POSS3-LOC stay-IP.CONV MOVE.POSTV-UWŠI.PTCP COP.PAST.1PL

de- $y$-dị.

say-A.PRES-3

“"When I was there, we used to stay in Kazakh homes", he writes.'

$\mathrm{T} 4 / 31$

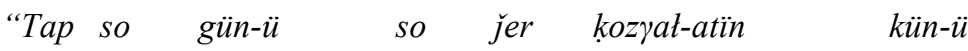

exact that day-POSS3 that earth- quake-ATIN.PTCP day-POSS3

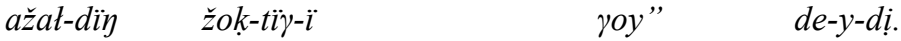

death-GEN non-existing-DER-POSS3 TOY.PART say-A.PRES-3

" "Just that day, the day of the earthquake, it was not the day for us to die, you know", he writes.'

$\mathrm{T} 4 / 32$

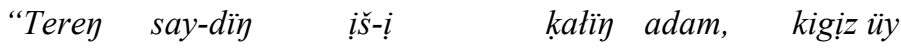
deep ravine-GEN inside-POSS3 many people yurt

kon-yan, ana b bir bułak bar ${ }^{y}$ endi $i$ sol

settle-GAN.POSTT3 that a spring existing NOW.FILL that

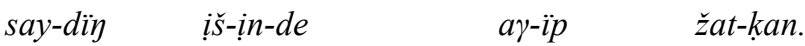

ravine-GEN inside-POSS3-LOC flow-IP.CONV LIE.POSTV-GAN.PTCP

" Deep inside the ravine there are many people, and there are yurts set up there, and a spring flows inside this ravine".'

$\mathrm{T} 4 / 33$

"Sonï mayayta-p son-da su ị̌s-e-t so-nïy

that.ACC come nearer-IP.CONV that-LOC water drink-A.PRES-3 that-GEN

jaya-sïn-da awï $\quad$ wotïr-a-t," ${ }^{67}$ de-y-dị.

shore-POSS-LOC household live-A.PRES-3 say-A.PRES-3

"“(People) move close to it and drink water there, and a household is settled on its shores", he writes.'

$\mathrm{T} 4 / 34$

"Mïnday terey uzun say”, de-y-dị.

such deep long ravine say-A.PRES-3

"'It is such a deep and long ravine", he writes.'

$\mathrm{T} 4 / 35$

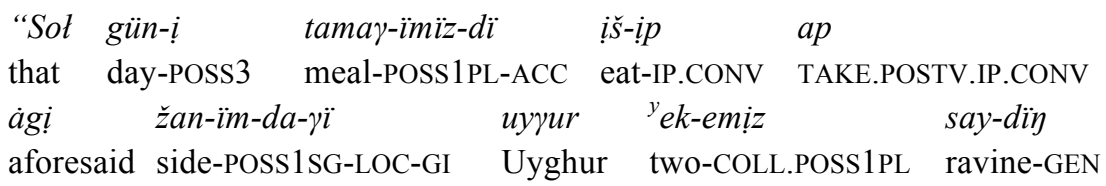

${ }^{67}$ The speaker means the place where people stay in the summer. 


$\begin{array}{lllll}\text { üstün-e } & b^{i} r & \text { sałkïn žer-ge } & \text { žat-ayïk } & d e-p, \\ \text { top.POSS3-DAT a } & \text { cool place-DAT } & \text { lie-VOL.1PL say-IP.CONV } \\ \check{z} a z d \ddot{l} \text { gün- } i & & \text { bot-atïn” } & & d e-y \text {-dị. } \\ \text { summery day-POSS3 } & \text { BOL.COP-ATIN.PAST.INTRAT3 } & \text { say-A.PRES-3 }\end{array}$

"'On that day, after we have eaten our meal, together with the aforementioned Uyghur, the two of us said 'let's sleep in a cool place up in the ravine'. It was one of the summer days", he writes.'

$\mathrm{T} 4 / 36$

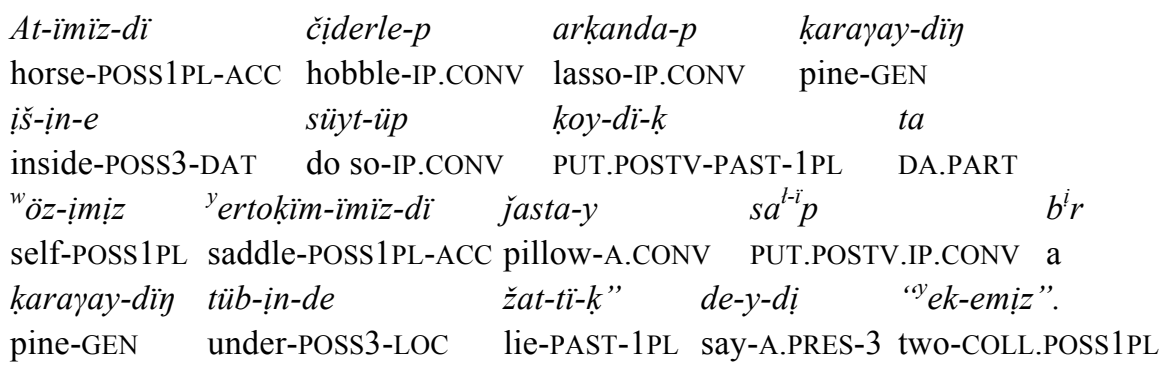

"'(We) hobbled and lassoed our horses among the pine trees, and then we pillowed our heads on our saddles, and slept under a pine tree", he writes, "both of us".'

$\mathrm{T} 4 / 37$

" ${ }^{i} r$ wak-ta katï gürülde-gen dawus-tan 'oyan-ïp

a time-LOC big rumble-GAN.PTCP sound-ABL wake up-IP.CONV

ket-ti-m” de-y-dị.

LEAVE.POSTV-PAST-1SG say-A.PRES-3

"“Suddenly, I was awakend by a big rumbling sound", he writes.'

$\mathrm{T} 4 / 38$

\begin{tabular}{|c|c|c|c|c|}
\hline 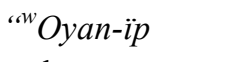 & ket-se-m & bükül ǰer & dünye & ałay düley \\
\hline wake up-IP.CONV & LEAVE.POSTV-HYP-1SG & whole earth & world & heavily \\
\hline$k o z \gamma a-t-\ddot{p} p$ & žatïr & "eken" & $d e-1$ & \\
\hline
\end{tabular}

earth- quake-PASS-IP.CONV LIE.POSTV.AOR3 E.COP.INDIR3 say-A.PRES-3

"'When I woke up, the whole earth was heavily shaking", he writes.'

T4/ 39

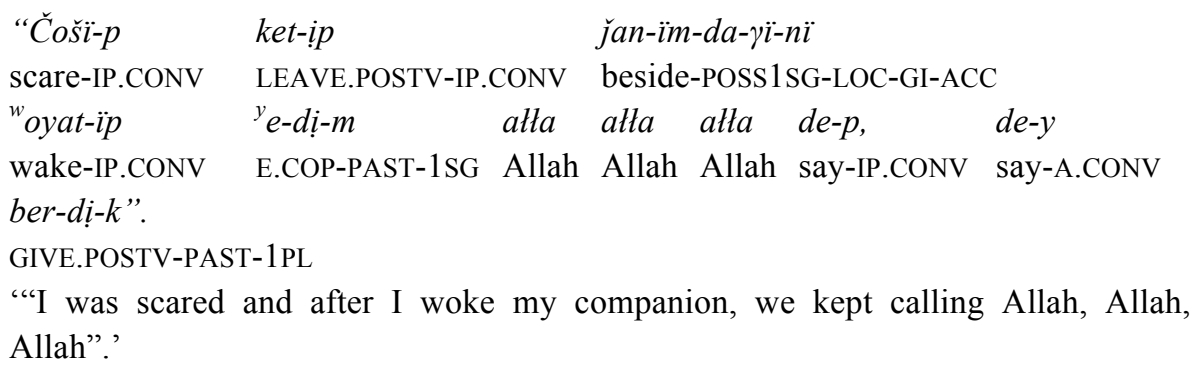


$\mathrm{T} 4 / 40$

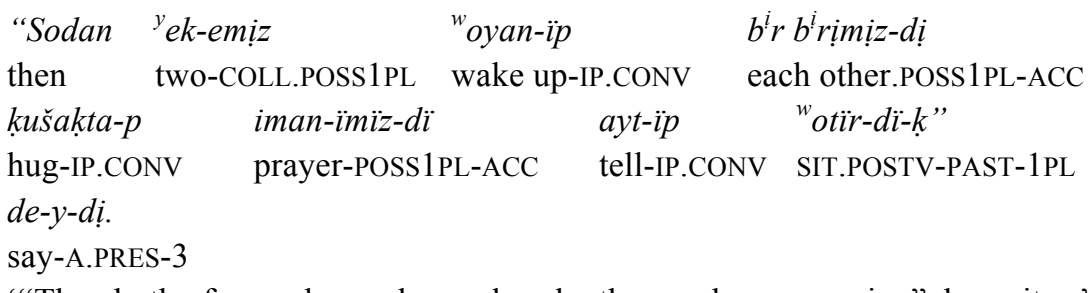

"“Then both of us woke up, hugged each other, and were praying", he writes.'

T4/ 41

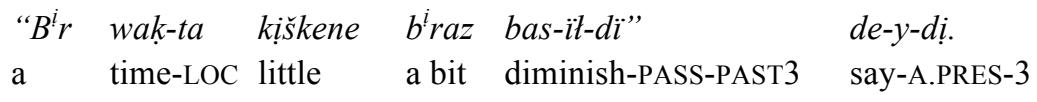

“"After some time, it diminished a bit", he writes.'

T4/ 42

"Soson ${ }^{y}$ es akï-ïmïz-dan adas-ïp ${ }^{68} \quad \dot{a g} \underline{\text { at-tar-ïmïz }}$ then sense mind-POSS1PL-ABL lose-IP.CONV aforesaid horse-PL-POSS1PL

č̈̈rïr-їp, aytew ayay-ïn-da čịder-ị bar neigh-IP.CONV anyhow finally-POSS3-LOC hobble-POSS3 existing sonïmen kat-dï” de-y-dị.

then stay-PAST3 say-A.PRES-3

"“Then we did not know what to do, our horses neighed, anyway, finally thanks to the hobbles they did not run away", he says.'

T4/ 43

\begin{tabular}{|c|c|c|}
\hline “Aytpese üz-üp & ket-ip & kat-atïn \\
\hline otherwise break-IP.CONV & LEAVE.POSTV-IP.CONV & STAY.POSTV-ATIN.PTCF \\
\hline$d e-y$ & & \\
\hline COP-PAST3 & & \\
\hline
\end{tabular}

"'Otherwise, they would have broken (the hobbles) and left", he writes.'

T4/ 44

\begin{tabular}{|c|c|c|c|c|}
\hline $\begin{array}{l}\text { "Sonï-men } \\
\text { that-WITH.POSTP }\end{array}$ & $\begin{array}{l}b^{i} r \\
\mathrm{a}\end{array}$ & 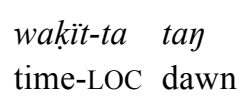 & $\begin{array}{l}\text { arar-ïp } \\
\text { grow light-IP.CONV }\end{array}$ & $\begin{array}{l}\text { at-tï. }{ }^{69,}, \\
\text { appear-PAST3 }\end{array}$ \\
\hline
\end{tabular}

T4/ 45

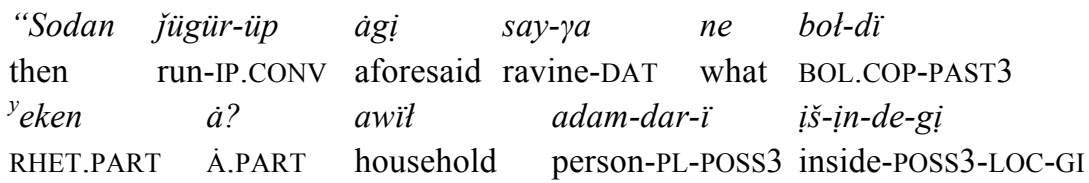

${ }^{68}{ }^{y}$ Es akïldan adasuw is a proverb meaning 'to go out of one's mind', 'to lose one's senses'.
${ }^{69}$ Tay a arïp at- is an expression meaning 'begin to grow light', 'dawn', 'daybreak'. 


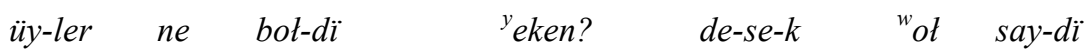

yurt-PL what BOL.COP-PAST3 RHET.PART SAy-HYP-1PL X ravine-ACC

kör-uw-ge bot-ma-y-dï "eken" de-y-dị.

see-UW.VN-DAT BOL.COP-NEG-A.PRES-3 E.COP.INDIR3 say-A.PRES-3

" Then we ran to that ravine, to see what had happened to that ravine, what happened to the people living in the households inside the ravine. They disappeared", he writes.'

$\mathrm{T} 4 / 46$

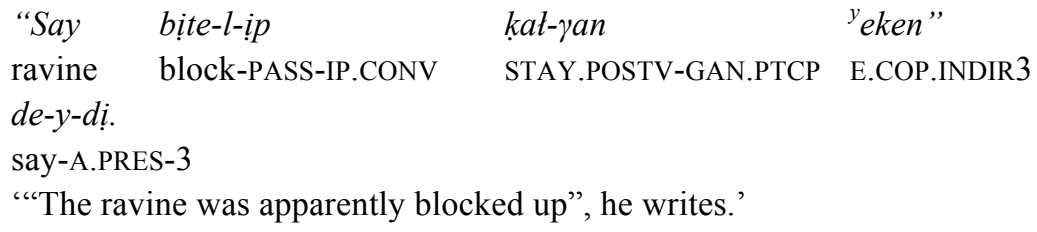

$\mathrm{T} 4 / 47$

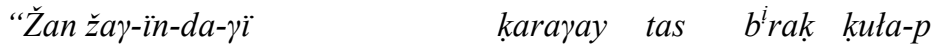
the one around-POSS3-LOC-GI pine stone all topple-IP.CONV
say-di bịte-p-tị" de-y-dị.
ravine-ACC block-IP.POSTT-3 say-A.PRES-3

"'The pines and stones around it toppled down and blocked the ravine", he writes.'

$\mathrm{T} 4 / 48$

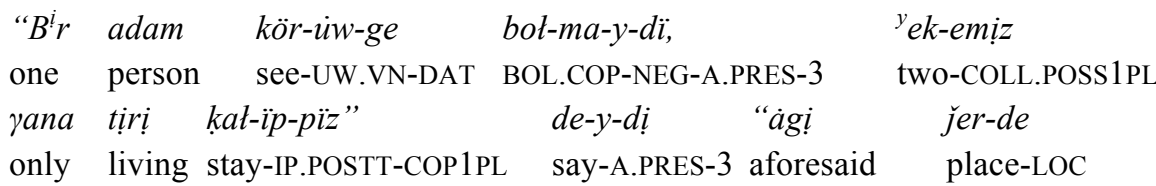

"özi, so mayay-da.",

ÖZI.PART that surrounding-LOC

"We couldn't see anyone, only the two of us have survived", he writes, "at that place, in those surroundings".'

T4/ 49

“Čoši-p ket-tị-k at-tï ákel-dị-k

frighten-IP.CONV LEAVE.POSTV-PAST-1PL horse-ACC bring-PAST-1PL

$\begin{array}{llll}\text { te } & { }^{y} \text { ertokïm-ïmïz-di } & { }^{y} \text { ertte-dị- } k & \text { te } \\ \text { DA.PART } & \text { saddle-POSS1PL-ACC } & \text { saddle-PAST-1PL } & \text { DA.PART }\end{array}$

${ }^{y} e k$-emiz $\quad$ so $\quad k a t p-\ddot{i} \quad k a s ̌-\ddot{p} \quad$ bar-a-müz

two-COLL.POSS1PL that mould-POSS3 run-IP.CONV GO.POSTV-A.PRES-COP1PL

kaš-їp bar-a-mïz žot-dï kay-da

run-IP.CONV GO.POSTV-A.PRES-COP1PL way-GEN which-LOC

$\begin{array}{lll}{ }^{y} e-k e n-\underline{i}-n & b i ̣ l-m e-y-m i \underline{z}, & \text { muy } r u t y a-\gamma a \\ \text { E.COP-GAN.PTCP-POSS3-ACC } & \text { know-NEG-A.PRES-COP1PL } & \text { Mongolia-DAT }\end{array}$ 
"öt-e-mịz de-p "oyta-ramïz žok"

pass-A.PRES-COP1PL say-IP.CONV think-GAN.PTCP.COP1PL non-existing

de-y-dị.

say-A.PRES-3

"We were frightened, and we brought the horses, and saddled them with our saddles, then the two of us kept riding and riding, we didn't know where to, we did not have the intention to go to Mongolia", he writes.'

$\mathrm{T} 4 / 50$

\begin{tabular}{|c|c|c|c|}
\hline Kaš- ̈̈p & 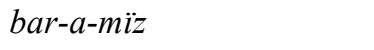 & $k a \check{s}-\ddot{\imath} p$ & 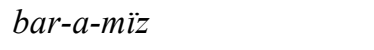 \\
\hline. $\mathrm{CONV}$ & GO.POSTV-A.PRES-COP1PL & run-IP.CONV & GO.POSTV-A.PRES-COP1PL \\
\hline & bar-a-mїz." & & \\
\hline & GO.POSTV-A.PRES-COP & & \\
\hline
\end{tabular}

“"We kept running away".'

$\mathrm{T} 4 / 51$

" $B^{i} r \quad$ wakït-ta $b^{i} r \quad$ asker-ler usta-p at-di"”

a time-LOC an soldier-PL stop-IP.CONV TAKE.POSTV-PAST3

$d e-y$-dị.

say-A.PRES-3

“"Then some soldiers stopped us", he writes.'

$\mathrm{T} 4 / 52$

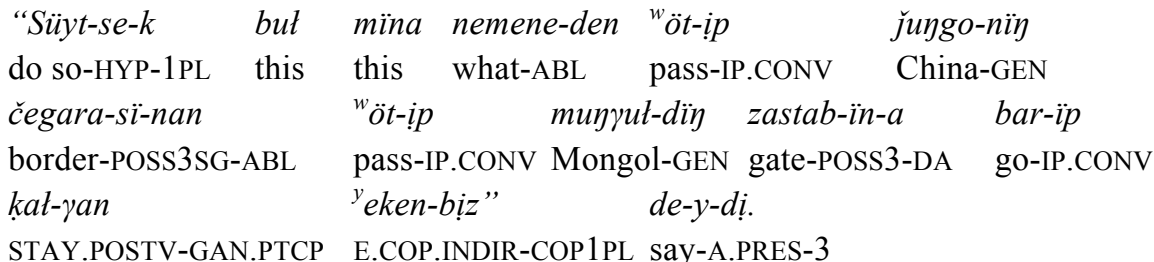

"'In fact, we passed the thing, we passed the Chinese border and apparently reached the entrance to Mongolia”, he writes.'

$\mathrm{T} 4 / 53$

Soson "sen-der kay-dan kel-e žatïr-s̈̈y-dar?"

then you-PL which-ABL come-A.CONV LIE.POSTV.AOR-COP2SG-PL

"wosïn-day jer kozra-t-ïp attay bet-ị-nen

this-EUQA earth shake-PASS-IP.CONV Altay region-POSS3-ABL

kel-e žatïr-mïz."

come-A.CONV LIE.POSTV.AOR-COP1PL

“"Then, (the soldiers asked), "Where are you coming from?" "We are coming from the Altay region, where there has been an earthquake".' 
$\mathrm{T} 4 / 54$

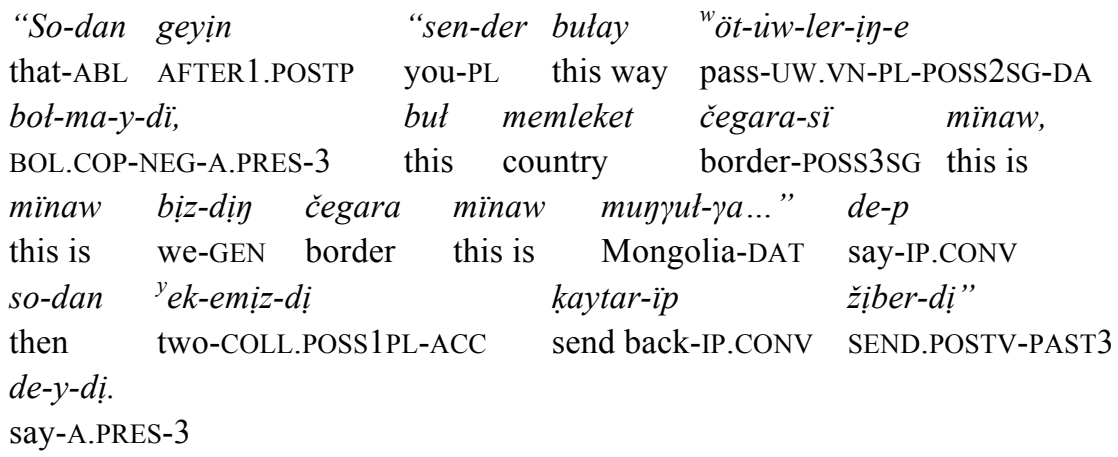

"“Then they said, 'You cannot pass like this, this is a country border, this is our border, this is the border of Mongolia...' Then, they sent us back”, he writes.'

$\mathrm{T} 4 / 55$

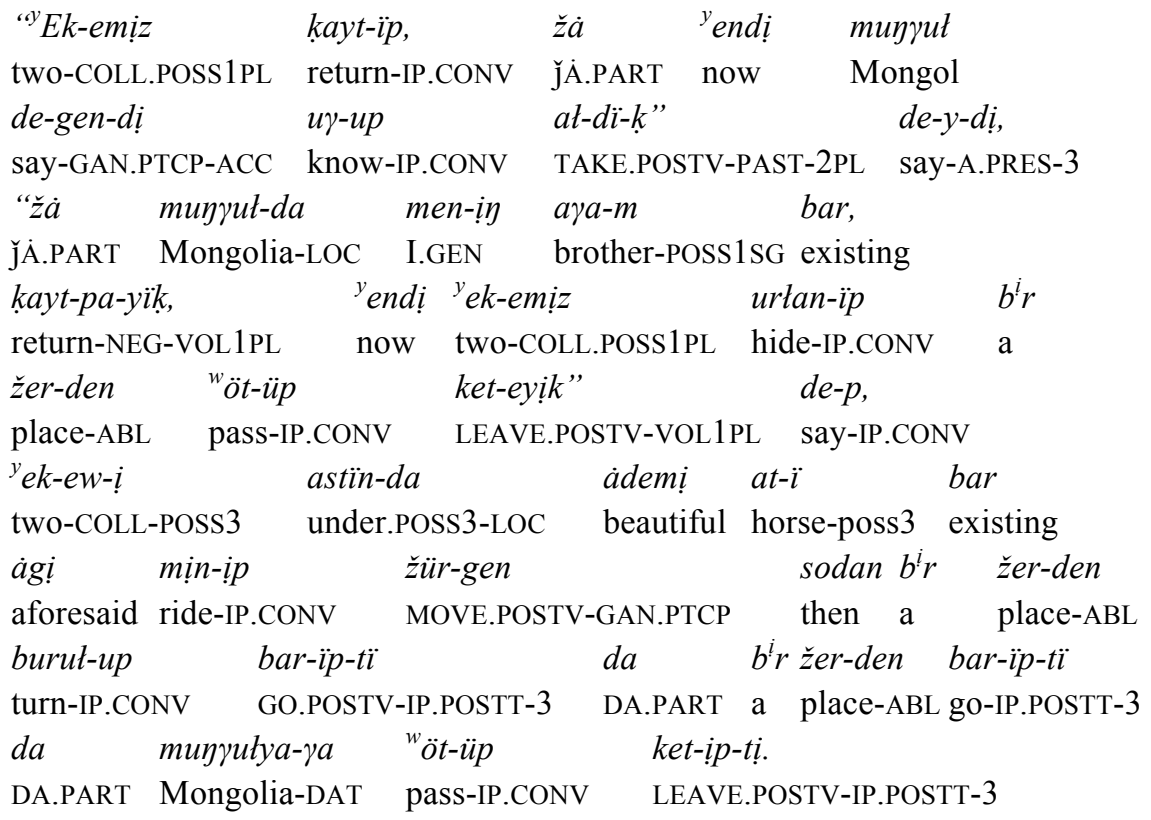

" "The two of us returned. Well, now we have got acquainted with Mongolia", he writes. "Well, I have a brother in Mongolia, let us not return, let us hide and cross somewhere." Thus the two of them, on the two beautiful horses, turned back at a place and passed quickly over to Mongolia.'

$\mathrm{T} 4 / 56$

${ }^{w} \mathrm{O}$ gez-de, $\quad{ }^{w} \mathrm{o}$ algi $\quad$ katïy àsker tur-ma-y-di

$\mathrm{X}$ time-loc X AFORESAID.FILL many soldierguard-NEG-A.PRES-3

yeken, anda sanda $b^{i}$ r zastap-ta yana tur-a-dï

E.COP.INDIR3 rarely a gate-LOC only guard-A.PRES-3 
yeken, $\quad$ katyan ǰer-i $\ldots$

E.COP.INDIR3 rest area-POSS3

'At that time, not many soldiers were stationed there, (they) were stationed only at one entrance but rarely, and the rest of the area was...'

$\mathrm{T} 4 / 57$

$\begin{array}{llc}\text { "So sop boyi } & \text { wöt- } \ddot{p} p \\ \text { THAT.FILL that } & \text { ALONG.POSTP } & \text { pass-IP.CONV } \\ \text { ket-kem" } & & d e-y-d i \\ \text { LEAVE.POSTV-GAN.POSTT.COP1SG } & \text { say-A.PRES-3 }\end{array}$

"'Since then I stayed in (Mongolia)", he writes.'

$\mathrm{T} 4 / 58$

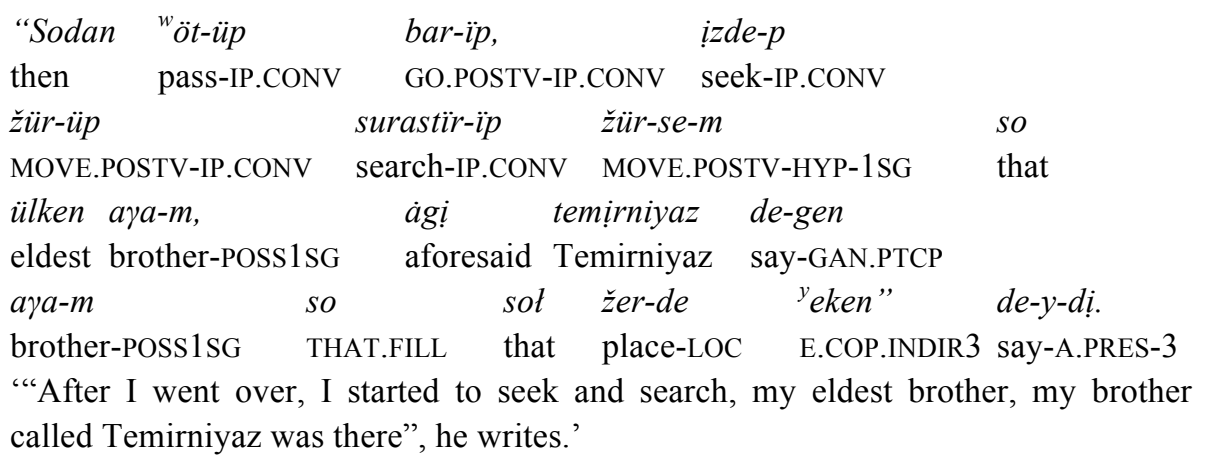

T4/ 59

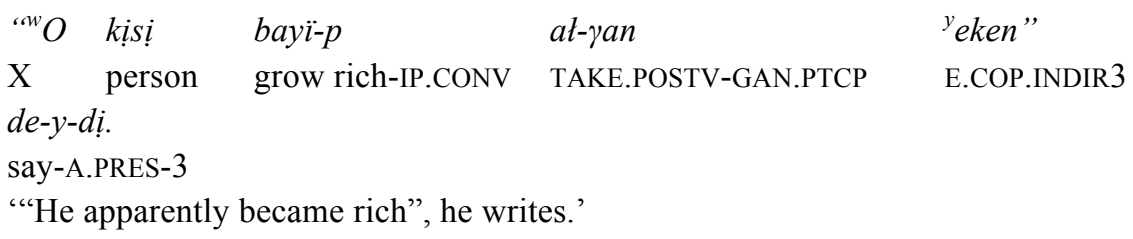

$\mathrm{T} 4 / 60$

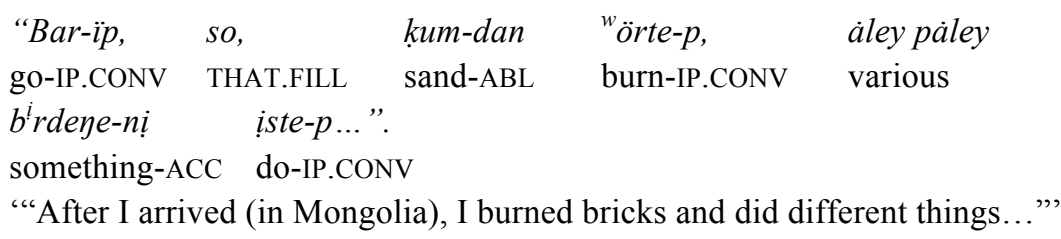

$\mathrm{T} 4 / 61$

$\begin{array}{lll}\text { Kołastïn-da } & \text { adam } \quad \text { iste-t-e-di } & \text { yeken. } \\ \text { under the leadership.POSS3-LOC people do-CAUS-A.PRES-3 } & \text { E.COP.INDIR3 } \\ \text { "“He apparently has people who work for him".' } & \end{array}$ 
T4/ 62

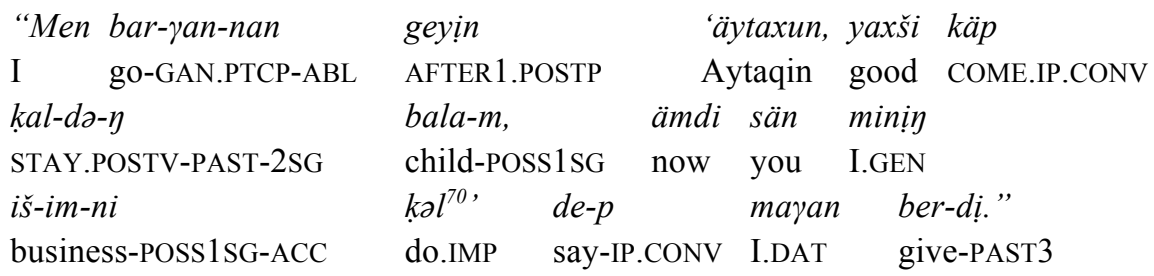

"'After I got there, 'Aytaqin, it is good that you came, my child, now you shall run my business' he said, and handed over (his business) to me".'

T4/ 63

B rak kattï...jumus-ka kattï sat-dï de-y-dị.

but hard work-DAT hard place-PAST3 say-A.PRES-3

" "But hard... (he) made me work very hard", he writes.'

T4/ 64

$\begin{array}{llll}\text { "Soson } & \text { a } a-m-a & \text { renžị-dị-m" } & d e-y-d i \underline{~} \\ \text { thus } & \text { brother-POSS1SG-DAT } & \text { offend-PAST-1SG } & \text { say-A.PRES-3 }\end{array}$

roy.

ГOY.PART

“"Thus, I am offended by my brother", he writes, you know.'

T4/ 65

$\begin{array}{lllll}\text { “Žumus-ka } & k a t t i ̈ & \text { sat-ïp } & \text { süyt-üp } & \text { ket-ti..” } \\ \text { work-DAT } & \text { hard } & \text { place-IP.CONV } & \text { do so-IP.CONV } & \text { LEAVE.POSTV-PAST3 } \\ \text { “"He made me work very hard”.' } & & \end{array}$

T4/ 66

$\begin{array}{lllll}\text { "Sodan } & \text { renǰ̣-p } & \text { süyt-üp } & \text { keyde } & \text { ket-ipp } \\ \text { then } & \text { offend-IP.CONV } & \text { do so-IP.CONV } & \text { sometimes } & \text { leave-IP.CONV }\end{array}$

kat-ïp süyt-üp žür-dü-m.”

STAY.POSTV-IP.CONV do SO-IP.CONV MOVE.POSTV-PAST-1SG

"“Then I was offended and sometimes left. (My life) was like that".'

T4/ 67

\begin{tabular}{|c|c|c|c|}
\hline $\begin{array}{l}\text { "Kayt-ïp } \\
\text { eturn-IP.CONV }\end{array}$ & $\begin{array}{l}\text { šinjay- } \gamma a \\
\text { Xinjiang-DAT }\end{array}$ & $\begin{array}{l}\text { kel-eyin } \\
\text { come-VOL1SG }\end{array}$ & $\begin{array}{l}d e-s e-m \\
\text { say-HYP-1SG }\end{array}$ \\
\hline & ${ }^{y}$ endi ${ }^{w} \ddot{o} t-\dot{u} w$ & kiyïn & bot-dï." \\
\hline
\end{tabular}

"When I have thought about going back to Xinjiang, but it has now become difficult to cross (the border)".'

${ }^{70}$ The sentence, yaxši käp ḳaldïy balam, ämdi sän minị̣ išimni kəal, is in Uyghur. 
$\mathrm{T} 4 / 68$

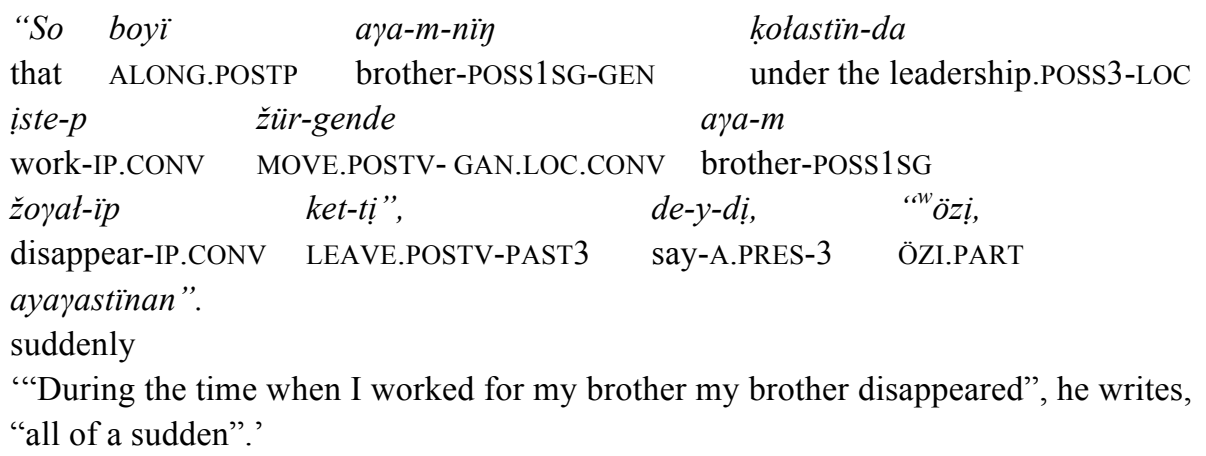

T4/ 69

Keyịn mïna abdrasut bar-ïp...

later this Abdurasul go-IP.CONV

'Later, Abdurasul went...'

$\mathrm{T} 4 / 70$

So gez-de a a $i \quad{ }^{w}$ o kisi imam mołda

that time-LOC AFORESAID.FILL $X$ person Imam Mullah

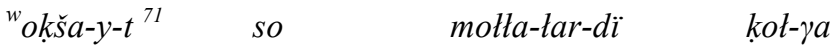

like-A.PRES-3 THAT.FILL Mullah-PL-ACC hand-DAT

at-randa apar-ïp at-ïp

take-GAN.LOC.CONV take-IP.CONV shoot-IP.CONV

tasta-p-ti $\quad{ }^{y}$ emespe.

THROW.POSTV-IP.POSTT-3 EMESPE.PART

'I guess that the person mentioned before (the brother) was an imam, a mullah. When the mullahs were arrested they took him and shot him.'

T4/ 71

So dịzịmdịk-tịy ị̌s-ị-nen čĭ-

that list-GEN inside-POSS3-ABL come out-IP.CONV SIT.POSTV3

'(His name) appeared on that list.'

$\mathrm{T} 4 / 72$

\begin{tabular}{|c|c|c|c|c|}
\hline $\begin{array}{l}\text { Sodan } \\
\text { len }\end{array}$ & $\begin{array}{l}\text { sot } \\
\text { that }\end{array}$ & $\begin{array}{l}a \gamma a-m \\
\text { brother-POSS1SG }\end{array}$ & $\begin{array}{l}\text { joyat-ïp } \\
\text { disappear-IP.CONV }\end{array}$ & $\begin{array}{l}\text { ket-ken } \\
\text { LEAVE.POSTV-GAN.PTCP }\end{array}$ \\
\hline & & 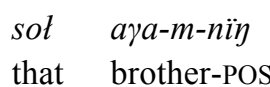 & $\begin{array}{l}i \check{S}^{72}- \\
\text { busin }\end{array}$ & S-POSS3-ACC \\
\hline
\end{tabular}

71 woǩšayt 'like, as' is uttered very close to Uyghur pronunciation. The Kazakh term should be $u k s a y t / u k s a y d i$ 'like, as'. One can find such pronunciation recently in Xinjiang due to the Uyghur influence.

${ }^{72} I \grave{s}$ 'work, business, job'. The consonant $\check{s}$ here is a material copy from Uyghur, whereas the Kazakh word is pronounced as is 'work, business, job'. 
$\begin{array}{llll}\text { men } & z \check{u ̈ r g} \underline{i} z-d i ̣-m ” & d e-y-d i & \gamma o y . \\ \text { I } & \text { run-PAST-1SG } & \text { say-A.PRES-3 } & \text { ГOY.PART }\end{array}$

“"Then after my brother disappeared, I ran my brother's business", he writes.'

$\mathrm{T} 4 / 73$

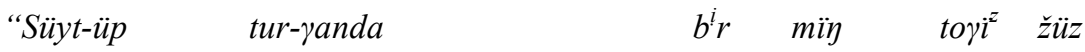

do So-IP.CONV STAND.POSTV-GAN.LOC.CONV one thousand nine hundred

kïk-ïnči žï-ï bop kap kobda-dan

fourty-ORD year-POSS3 BOL.COP.IP.CONV STAY.POSTV-IP.CONV Kobda-ABL

böl-ịn-ịp baynölgey aymay-ï de-gen

separate-REF.POSS-IP.CONV Bayan-Ölgii prefecture-POSS3 say-GAN.PTCP

aymak kur-ut-dï” de-y-dị.

prefecture establish-PASS-PAST3 say-A.PRES-3

"Then the year of 1940 arrived, and the prefecture called Bayan-Ölgii was established and separated from Kobda", he writes.'

$\mathrm{T} 4 / 74$

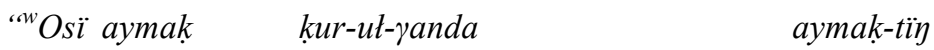

this prefecture establish-PASS-GAN.LOC.CONV prefecture-GEN

${ }^{w}$ ortatï- $-\ddot{-} n$ sat-atïn bop katïy

capital-POSS3-ACC build-ATIN.PTCP BOL.COP.IP.CONV many

kurtus-ka kịrpịs kerek bot-dï” de-y-dị.

construction-DAT brick need BOL.COP-PAST3 say-A.PRES-3

"'When the prefecture was founded, many bricks were needed to build the capital of this place", he writes.'

$\mathrm{T} 4 / 75$

Kịrpị̌s-tị kay-dan č̈̈rar-a-dï? kum-dan ${ }^{w} \ddot{o r t e}-w$

brick-ACC where-ABL produce-A.PRES-3 sand-ABL burn-UW.VN

kerek.

necessary

"Where is the brick produced? It has to be burnt from sand".'

$\mathrm{T} 4 / 76$

\begin{tabular}{|c|c|c|c|c|}
\hline "Sonï-men & ${ }^{w}$ onï & men & köter-ịp & at-dï-m" \\
\hline that-WITH.POSTP & X.ACC & I & undertake-IP.CONV & TAKE.POSTV-PAST-1SG \\
\hline$d e-y-d i$ & roy. & & & \\
\hline -A.PRES-3 & ГOY.PART & & & \\
\hline
\end{tabular}


$\mathrm{T} 4 / 77$

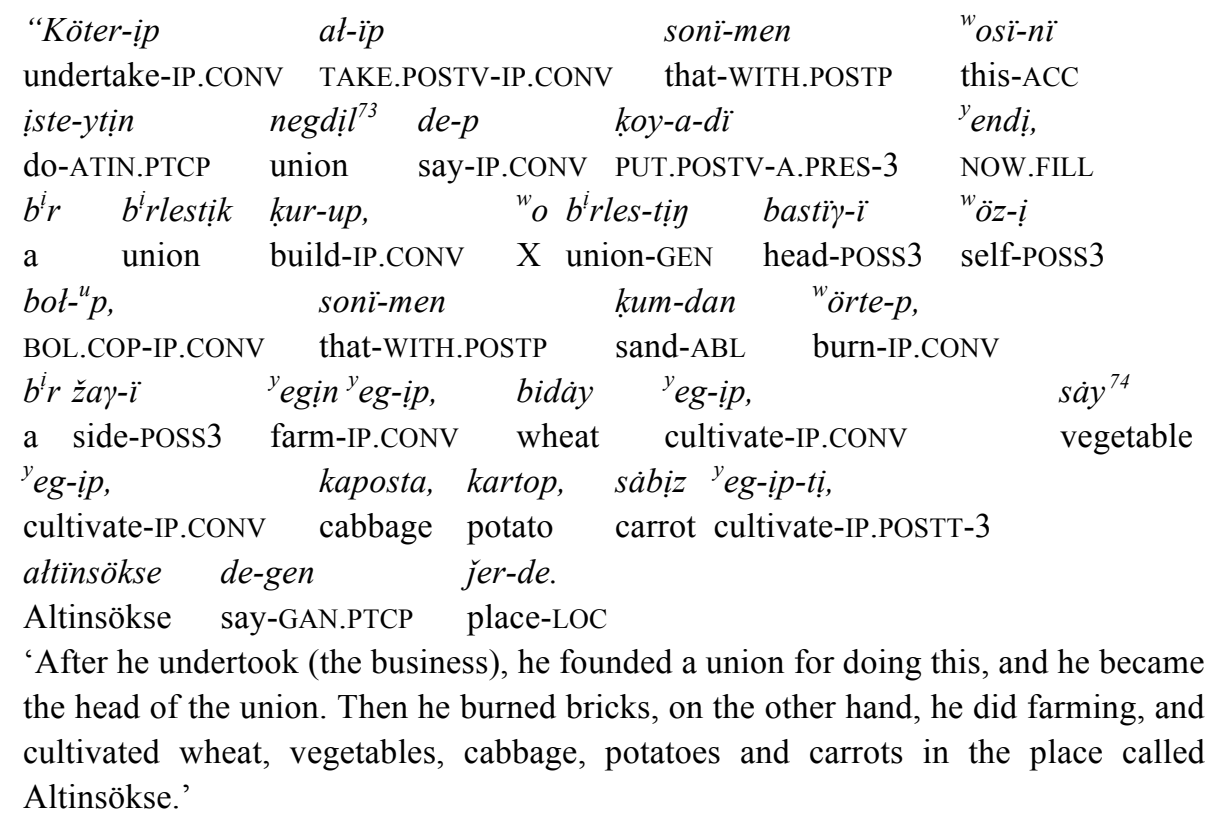

\section{T5. J̌uggodayi kazak tịli 'The Kazakh language in China'}

Metadata

Gender: male

Age: 58

Date of birth: 1952

Place of birth: Altay, China

Education: University

Language competence: Kazakh (mother tongue), Chinese (understands and speaks), Uyghur (understands).

Date of recording: 3th July 2011

Place of recording: Burqin, Altay

\section{Running text}

$\mathrm{T} 5 / 1-\mathrm{T} 5 / 10$

${ }^{\mathrm{y}}$ Endị tịl mảsảlȧsịndả soł jałpï wömịr sürüp kele jatḳan mảsele, kazïr ḳazaḳ tịlịnde mïnanday $b^{i}$ jajyịt bar. Buł ${ }^{y}$ endị keyịn tịlge tönetịn kawup, men

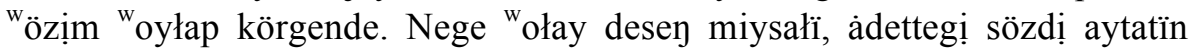

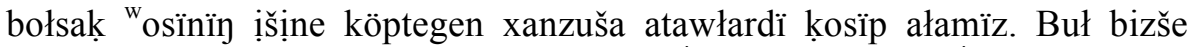

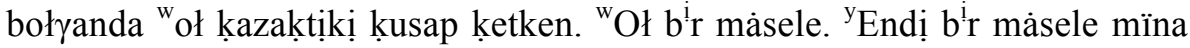

\footnotetext{
${ }^{73}$ Negdịl «нэгдэл〉 'union' is a Mongol term.

${ }^{74}$ Sày 'vegetables' is a global copy of the Chinese lexical item cài 'vegetables, dish, greens'. This term is currently often used among Kazakhs in China instead of köktat 'vegetables'.
} 
telepon nömịrdị aytayïk mïsałï karapayïm närsenị. ${ }^{\text {w}}$ Osï telepon nömịrịn

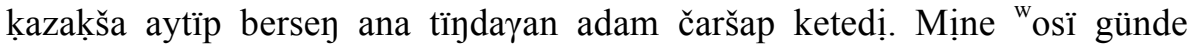

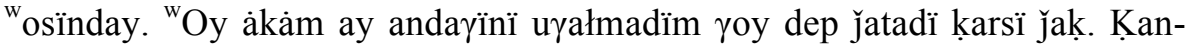
zušasïn łïp ${ }^{\mathrm{y} e t k i ̣ z i ̣ p ~ u \gamma u p ~ a ł a d i ̈ . ~}$

$\mathrm{T} 5 / 11-\mathrm{T} 5 / 20$

Mịne buł nemene? Buł tịldegị čïbarlïk. Kele jatḳan čǐbarliḳ, kele jatḳan

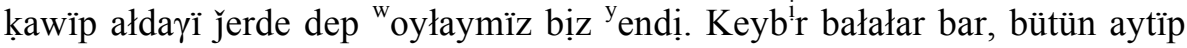
turyanï kanzuša ${ }^{y}$ ekenịn de bịlmeysịn, kazaḳša ${ }^{y}$ ekenịn de bịlmeysịn. Kaysï günị men joł jönekey bir mašinaya ${ }^{w}$ otïrïp keldịm. $B^{i}{ }^{y}{ }^{y}$ ekị bała ${ }^{w}$ otïrïpti ${ }^{y}$ eken,

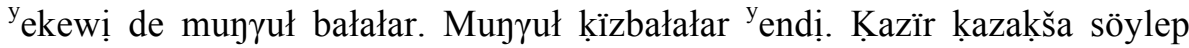

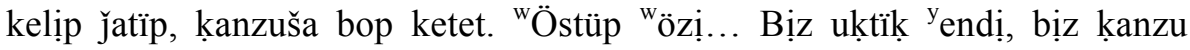
tịlịnen ḳabarïmïz bar bołyannan keyịn.

$\mathrm{T} 5 / 21-\mathrm{T} 5 / 30$

Sonda mịne ḳazịrgị jastarda buł ${ }^{\mathrm{y}}$ endị bị r ülken buł... Arïsïn kuwatïn bołsak buł ułttïn ruhï mȧselesị. "Özịnnị̣ ułtïndï sen kadịrlemesen... Ułtïndï kadịrlesen sen tịlịn kadïrlewün kerek. Tịlịndị kadịrlesen ${ }^{\text {wonda }}$ wöz ułtunnïn

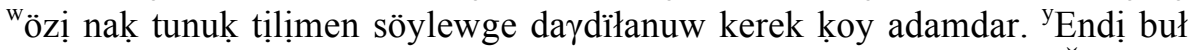

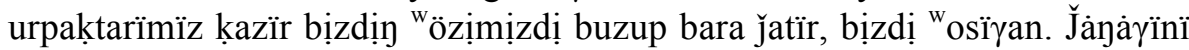
bịz xanzuša aytamïz, nömịrdị. ${ }^{\text {} O ̈ z i ̣ ~ s u ̈ y t e m i ̣ z . ~}{ }^{\mathrm{w}}$ Onay sekịldị à? $\mathrm{K}^{\mathrm{i}} \mathrm{ymiya}$ aiik tïnayïtḳištï ałïp kel dep ǰatḳan kịsịnị ${ }^{y}$ estịgem jok men. ${ }^{\text {w} O n i ̈ ~ a y t p a y d i ̈ . ~}$

$\mathrm{T} 5 / 31-\mathrm{T} 5 / 43$

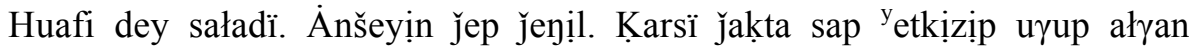

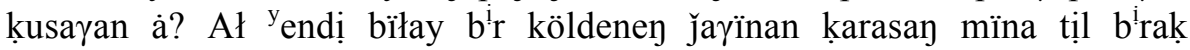
čibarłap... Babam, mamam deydị. Buł kazak tịlị yemes. Baba dey saładï. Mama dey saładï. Jep jenịl sekịldị. Sonda turmustuk daydïda wosï tịldịn azuw mȧselesị... ${ }^{\mathrm{y}}$ Endị sen ảdette tịldị zerttep jür ${ }^{\mathrm{y}}$ ekensịn... ${ }^{\mathrm{w}}$ Osï jakta ülkendew küš čìarsa boładï ${ }^{\mathrm{e} e n d i ̣ . ~}$

Annotated text

T5/ 1

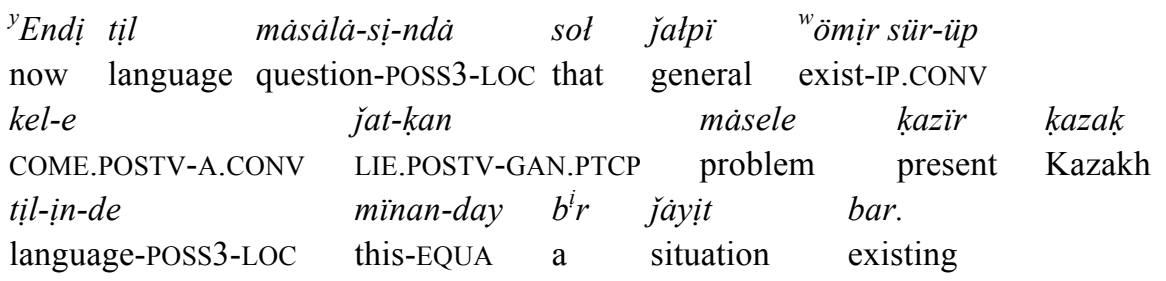

'Now, concerning the language, the general problem we are facing is that the present-day Kazakh language is in a special situation.' 
$\mathrm{T} 5 / 2$

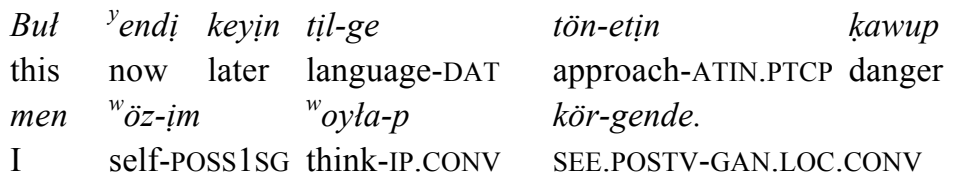

'I think that this is an imminent danger to the future of the language.'

$\mathrm{T} 5 / 3$

Nege ${ }^{w}$ ołay de-se- $\eta \quad$ mïsat-i $\quad \dot{a}$ dettegi söz-dị

why so say-HYP-2SG example-POSs3 usual word-ACC

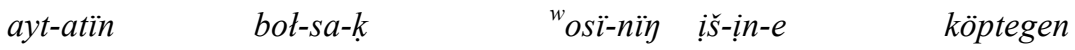

say-ATIN.PTCP BOL.COP-HYP-1PL this-GEN in between-DAT quite a lot

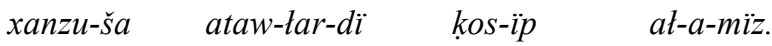

Chinese-der term-PL-ACC add-IP.CONV TAKE.POSTV-A.PRES-COP1PL

'If you ask why, for instance, if we say a usual sentence (in Kazakh), then we add quite a lot of Chinese terms to it.'

$\mathrm{T} 5 / 4$

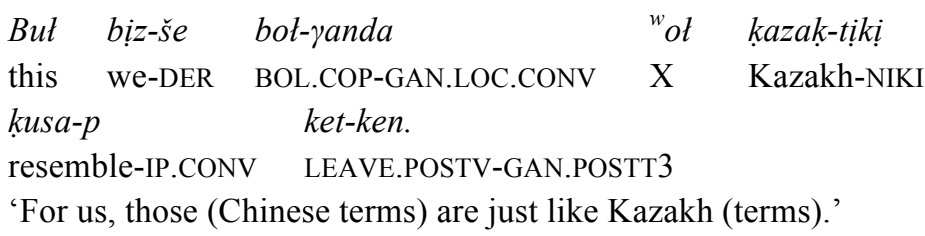

$\mathrm{T} 5 / 5$

${ }^{w}$ Ot $\quad b^{i} r$ másele.

$\mathrm{X}$ a problem

'That is a problem.'

$\mathrm{T} 5 / 6$

${ }^{y}$ Endị $b^{i} r \quad$ másele mïna telepon nömịr-dị ayt-ayïk

now an issue this telephone number-ACC say-VOL1PL

mïsatï karapayïm nàrse-nị.

example-POSS3 simple thing-ACC

'Now another issue, let us say phone numbers, for example, a simple thing.'

$\mathrm{T} 5 / 7$

${ }^{w}$ Osï telepon nömịr-ị-n kazak-ša ayt-ïp

this telephone number-POSS3-ACC Kazakh-DER tell-IP.CONV

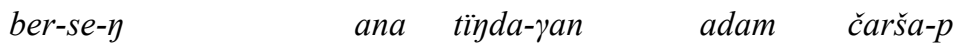

GIVE.POSTV-HYP-2SG that listen-GAN.PTCP person tire-IP.CONV

ket-e-di.

LEAVE.POSTV-A.PRES-3

'If you say a phone number in Kazakh, the listener gets tired.' 
$\mathrm{T} 5 / 8$

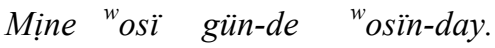

look this day-LOC this-EQUA

'Look, this is how it is today.'

$\mathrm{T} 5 / 9$

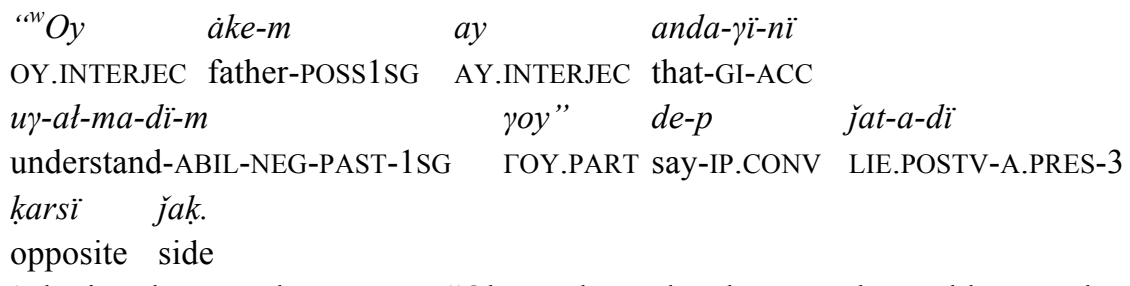

'The interlocutor always says, "Oh my dear, oh, I have not been able to understand it".'

$\mathrm{T} 5 / 10$
Kanzu-ša-sï-n
tïp ${ }^{y}$ etkị-ịp
$u \gamma-u p$
Chinese-DER-POSS3-ACC
happen quick-IP.CONV
understand-IP.CONV
at-a-di.

TAKE.POSTV-A.PRES-3

'In Chinese, they understand it at once.'

$\mathrm{T} 5 / 11$

Mịne but nemene?
look this what
'Look, what is this?'

$\mathrm{T} 5 / 12$

But tịl-de-gị čibartïk.

this language-LOC-GI contamination

'This is language contamination.'

$\mathrm{T} 5 / 13$

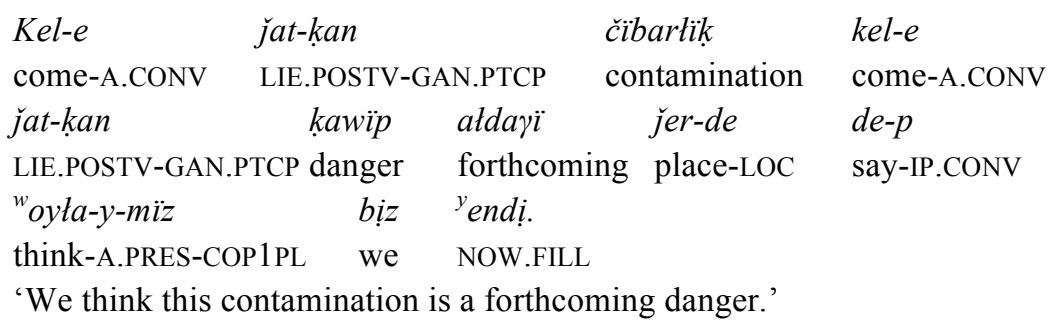


$\mathrm{T} 5 / 14$

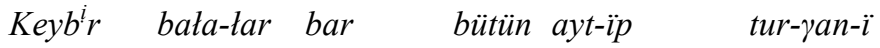

some child-PL existing whole tell-IP.CONV STAND.POSTV-GAN.PTCP-POSS3

kanzu-ša ${ }^{y} e-k e n-i-n$ de

Chinese-DER E.COP-GAN.PTCP-POSS3-ACC DA.PART

bill-me-y-sịn kazak-ša $\quad{ }^{y} e-k e n-i ̣-n \quad d e$

know-NEG-A.PRES-COP2SG Kazakh-DER E.COP-GAN.PTCP-POSS3-ACC DA.PART

bill-me-y-sị .

know-NEG-A.PRES-COP2SG

'There are some children who, whatever they say, you don't know whether it is

Chinese or Kazakh.'

$\mathrm{T} 5 / 15$

Kaysï gün- $-i \quad$ men jot jönekey $b^{i} r \quad$ mašina- $\gamma a$

which day-POss3 I way during a bus-DAT

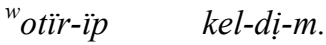

sit-IP.CONV COME.POSTV-PAST-1SG

'One day, during a trip, I took a bus.'

$\mathrm{T} 5 / 16$

$B^{i} r \quad{ }^{y}$ eki bała ${ }^{w}$ otïr-ïp-tï $\quad{ }^{y}$ eken, ${ }^{y}$ ek-ew- $i$

a two child sit-IP.POSTT-3 E.COP.INDIR3 two-COLL-POSS3

de muyrut bata-tar.

DA.PART Mongol child-PL

'There were two children sitting there, both of them were Mongols.'

$\mathrm{T} 5 / 17$

Muyrut kïzbała-łar ${ }^{y}$ endi.

Mongol young girl-PL NOW.FILL

'They were Mongol young girls.'

$\mathrm{T} 5 / 18$

Kaz̈̈r kazak-ša söyle-p kel-ịp

now Kazakh-DER speak-IP.CONV COME.POSTV-IP.CONV

jat-ïp kanzu-ša bot- ${ }^{u} p \quad$ ket-e-t.

LIE.POSTV-IP.CONV Chinese-DER BOL.COP-IP.CONV LEAVE.POSTV-A.PRES-3

'They spoke Kazakh first and then they switched to Chinese.'

$\mathrm{T} 5 / 19$

${ }^{w} \ddot{O} s t-\ddot{u ̈ p} \quad{ }^{w} \ddot{o z i} \ldots$

do so-IP.CONV ÖZI.PART

'Just like this...' 
$\mathrm{T} 5 / 20$

\begin{tabular}{llllll} 
Bị $\quad$ uk-tï-k & ${ }^{y}$ endi, & bị & kanzu & tịl-ị-nen \\
we understand-PAST-1PL & NOW.FILL & we & Chinese & language-POSS3-ABL \\
kabar-ïmïz & bar & bol-yan-nan & & \multicolumn{2}{c}{ keyịn. }
\end{tabular}

knowledge-POSS1PL existing BOL.COP-GAN.PTCP-ABL AFTER1.POSTP

'We understood it, because we know Chinese.'

$\mathrm{T} 5 / 21$

Son-da mịne kazịr-gị jas-tar-da but ${ }^{y}$ endị $b^{i} r$

that-LOC here present-GI young-PL-LOC this NOW.FILL a

ülken but...

big this

'Thus, here, in the present young generations, this is a big...'

$\mathrm{T} 5 / 22$

\begin{tabular}{|c|c|c|c|}
\hline $\begin{array}{l}\text { 1rï-sï-n } \\
\text { o the other }\end{array}$ & le-POSS3-ACC & $\begin{array}{l}k u w \text {-atïn } \\
\text { trace back-ATIN.PTCP }\end{array}$ & $\begin{array}{l}b o t-s a-k \\
\text { BOL.COP-HYP-1PL }\end{array}$ \\
\hline $\begin{array}{l}\text {-tïy } \\
\text { ion-GEN }\end{array}$ & $\begin{array}{l}\text { ruh-ï } \\
\text { spirit-POSs3 }\end{array}$ & $\begin{array}{l}\text { mäsele-sị. } \\
\text { issue-POSs3 }\end{array}$ & \\
\hline
\end{tabular}

'Looking at it more deeply, this is an issue concerning the spirit of the nation.'

$\mathrm{T} 5 / 23$

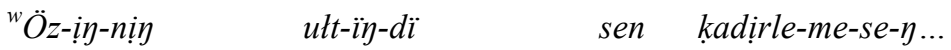

self-POSS2SG-GEN nation-POSS2SG-ACC you respect-NEG-HYP-2SG

'If you don't respect your own nation...'

$\mathrm{T} 5 / 24$

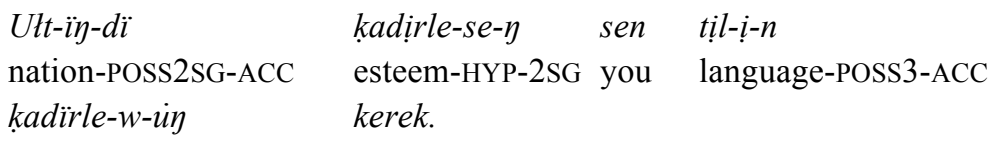

respect-UW.VN-POSS2SG necessary

'If you esteem your nation, you have to esteem its language.'

$\mathrm{T} 5 / 25$

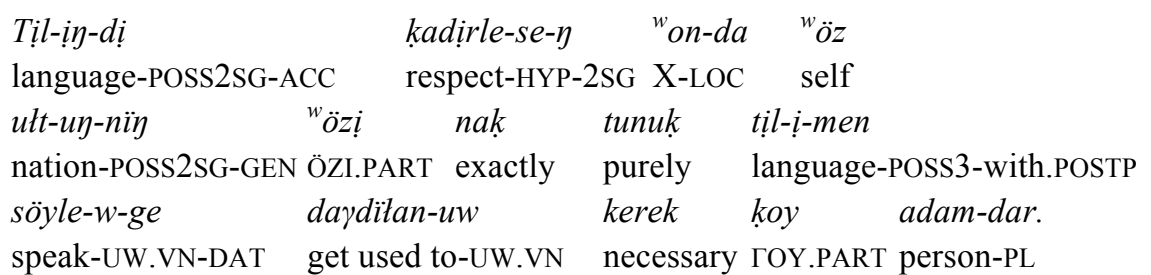

'If you respect your language, then you must get used to speaking precisely and purely the language of your nation, mustn't you?' 
$\mathrm{T} 5 / 26$

${ }^{y}$ Endị but, urpak-tar-ïmïz kazïr bị-dịy ${ }^{w} \ddot{o z}$-ịmịz-dị

NOW.FILL this generation-PL-POSS1PL present we-GEN self-POSS1PL-ACC

buz-up bar-a jatïr, bị-di ${ }^{w}$ osï- $\gamma a n$.

destroy-IP.CONV GO.POSTV-A.CONV LIE.POSTV.AOR3 we-ACC this-DAT

'Now, in this respect, this (young) generation has a bad effect upon us as well.'

$\mathrm{T} 5 / 27$

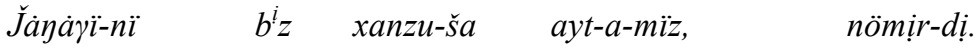

aforesaid-ACC we Chinese-DER say-A.PRES-COP1PL number-ACC

'As mentioned before, we say (phone) numbers in Chinese.'

$\mathrm{T} 5 / 28$

${ }^{w} \ddot{O} z i \quad$ süyt-e-mị.

ÖZI.PART do SO-A.PRES-COP1PL

'We simply do so.'

$\mathrm{T} 5 / 29$

$\begin{array}{lll}{ }^{w} \text { Oyay } & \text { sekild } i & \dot{a} ? \\ \text { convenient } & \text { like } & \text { À.PART }\end{array}$

'It is sort of easier, isn't it?'

$\mathrm{T} 5 / 30$

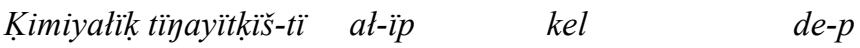

fertilizer-ACC take-IP.CONV COME.POSTV.IMP say-IP.CONV

jat-kan kịsị-nị jesti-ge ${ }^{n}-{ }^{i} m$ jok men.

LIE.POSTV-GAN.PTCP person-ACC hear-GAN.PTCP-COP1SG non-existing I

'I have never heard a person say "Bring the kimiyatik tïyayïtkišs!" ("fertilizer" in Kazakh).'

$\mathrm{T} 5 / 31$

${ }^{w} O-n \ddot{i} \quad$ ayt-pa-y-dï.

X-ACC Say-NEG-A.PRES-3

'They do not say it.'

$\mathrm{T} 5 / 32$

Huafi $^{75}$ de-y sat-a-di.

fertilizer say-A.CONV PLACE.POSTV-A.PRES-3

'They just say huafi ('fertilizer' in Chinese).'

${ }^{75}$ The lexical item huafi 'fertilizer' has been globally copied from Chinese huàféi. The Kazakh term for fertilizer is kimiyatik tïnayïtkiš. 
$\mathrm{T} 5 / 33$

Anšeyịn jep ǰẹịl.

just easy.RED

'It is just easier to say.'

$\mathrm{T} 5 / 34$

Karsï jak ta sap ${ }^{y}$ etkiz-ịp

opposite side DA.PART happen quickly-IP.CONV

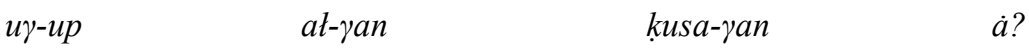

understand-IP.CONV TAKE.POSTV-GAN.PTCP resemble-GAN.POSTT3 Ȧ.PART

'The interlocutor seems to understand it at once, doesn't s/he?'

$\mathrm{T} 5 / 35$

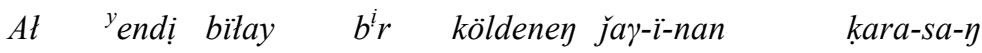

but now this way an opposite side-POSS3-ABL look-HYP-2SG

mïna tịl birak čibarła-p...

this language compeletely contaminate-IP.CONV

'However, if you look at it from the other side, the language has been completely contaminated...'

$\mathrm{T} 5 / 36$

Baba-m, mama-m de-y-dị.

father-POSS1SG mother-POSS1SG say-A.PRES-3

'They say babam (my father) and mamam (my mother).'

$\mathrm{T} 5 / 37$

But kazak til-i ${ }^{y}$ emes.

this Kazakh language-POss3 not

'This is not Kazakh.'

$\mathrm{T} 5 / 38$

Baba de-y sat-a-di.

father say-A.CONV PLACE.POSTV-A.PRES-3

'They just say baba (father).'

$\mathrm{T} 5 / 39$

Mama de-y sat-a-di.

mother Say-A.CONV PLACE.POSTV-A.PRES-3

'They just say mama (mother).'

$\mathrm{T} 5 / 40$

J̌p ǰẹịl sekịldị.

easy.RED like

'It is sort of easier.' 
$\mathrm{T} 5 / 41$

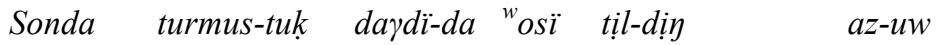

thus life-DER habit-LOC this language-GEN deteriorate-UW.VN

másele-si...

problem-POSS3

'Thus, in our daily habits, this is a problem of language deterioration...'

$\mathrm{T} 5 / 42$

${ }^{y}$ Endi sen adette tịl-di $i \quad$ zertte- $p$

NOW.FILL you usually language-ACC investigate-IP.CONV

jür $\quad$ 'eken-sịn...

MOVE.POSTV E.COP.INDIR-COP2SG

'Well, you are apparently a linguist...'

$\mathrm{T} 5 / 43$

${ }^{w}$ Osï jakk-ta ülken-dew küš čĭjar-sa bot-a-dï endị.

this side-LOC big-COMP make effort-HYP3 BOL.COP-A.PRES-3 NOW.FILL

'More effort should be made in this field.'

\section{T6. Urpakka akiliya 'Advice to the descendants'}

Metadata

Gender: male

Age: 71

Date of birth: 1941

Place of birth: Kaba county, Altay, China

Education: Primary school

Language competence: Kazakh (mother tongue), Chinese (understands and speaks).

Date of recording: 17th July 2012

Place of recording: Terekti, Altay

Running text

T6/ 1-T6/ 10

J̌asïm mịne jetpịstịy üstüne čịkti. ${ }^{\mathrm{y}}$ Endị mayan sen ${ }^{\mathrm{y}}$ endị mïna urpaḳ jönịnde ne jazasïn, ne aytasïn desen, menịn urpaḳ jönịnde aytarïm: bịinčị: "urpaḳ jaḳsïdan üyrenịnder!” "J̌amannan jirenịnder!” "Dosḳa meyrịmdị boł!" "Dušmanïna katā boł!" "Ülkendị siła!" "Kịṣ̌inị kurmet yetịnder!",-_ep wösiyet aytpaksšimïn men. Üytkenị, adam mïn jasamaydï urpaḳ mïn jasaydï

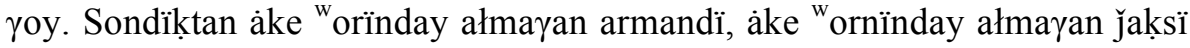
ịsterdị urpak ${ }^{\mathrm{w}}$ orïndayt. Sondïktan urpaḳka jaḳsï bołuw jönịnde, ülgịlị bołuw

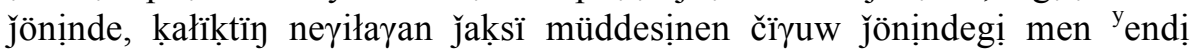
jazsamda arïzdansamda bałałarïma ${ }^{\mathrm{w}}$ osï... 
$\mathrm{T} 6 / 11-\mathrm{T} 6 / 20$

Üytkenị adam urpaḳpen körkeyedị, urpak bołašaḳtïn iyesị. Sondïktan ${ }^{\mathrm{w}}$ oł urpaḳpen körkeyịp urpaḳ bołašaḳtïn iyesị bołyandïүï sebeptị, soł bołašaḳtïk urpaḳtï ata ana jaḳsï ịske jetekteủw, jaḳsï ịstị üyretủw, jakssï ịske

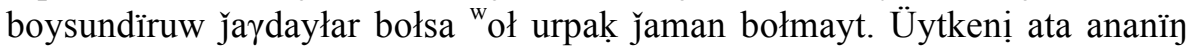
wösiyetịn tïndayan urpaḳta jaman bołmayt. Üytkenị àkeden nenị kördịn češeden nenị kördịn... Keyb rewler aytīp jatadï $\gamma$ oy, keyde bị urpaḳtarya renj̣igen kezde ayt $t^{\dddot{p}}$ j̆atadï: "ày mïnaw àke češenị̣ tärbiyesịn körmegen $\gamma$ oy mïnaw". "Mïnawïn nedegen körgensịz, nedegen nảšar 'edị”, dep süytüp

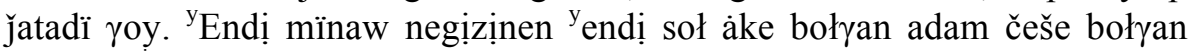

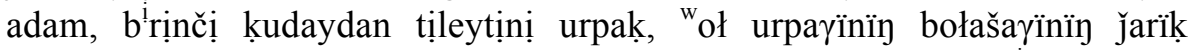

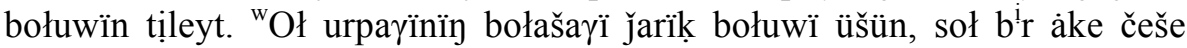
wözịndegị bar kasiyet, wözịndegị bar wönegelị ịsterị bołsa urpaḳka üyretịp

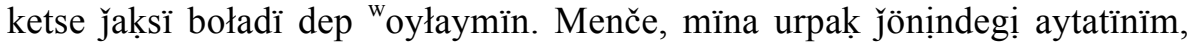
soł ${ }^{y}$ endị buł sekịldị ịstermenen čưułdanïp jakssï bołuwïn tịleyịm ${ }^{\mathrm{y} e n d i ̣ . ~}$

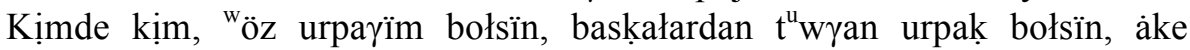
češenịn wösiyetịn, àke češenịn j̆aḳsï tảlịm tảrbiyesịn üyrense boładï ${ }^{\mathrm{y} e n d i ̣ . ~}$

$\mathrm{T} 6 / 21-\mathrm{T} 6 / 24$

${ }^{\mathrm{w}} \mathrm{O}$ àke češe degende, ${ }^{\mathrm{w}}$ oł àkenịnde bịzdịnde keyb ${ }^{\mathrm{i}} \mathrm{r}$ katelịk jerlerịmịz boładï. Ȧke men češenịn. ${ }^{\mathrm{w}} \mathrm{O}$ n nảša jerlerịn urpaḳ: "woy, menịı ảkem süyttị, àytịp

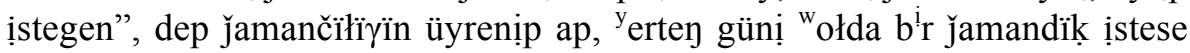
wonïn nemene beker... Bołašaḳtïk urpaḳ bołałmaydï demekšịmịn yoy ${ }^{\mathrm{y} e n d i ̣ . ~}$

Annotated text

T6/ 1

J̌as-ïm mịne jetpis-tị üstün-e čïk-tï.

age-POSS1SG here and now seventy-GEN over.POSS3-DAT ascend-PAST3

'I am now over seventy years old.'

$\mathrm{T} 6 / 2$

${ }^{y}$ Endị maransen ${ }^{y}$ endị mïna urpak jön-ịn-de now I.DAT you NOW.FILL THIS.FILL descendant direction-POSS3-LOC

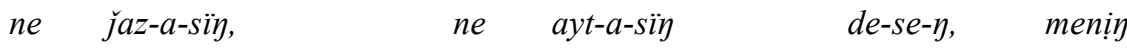
what write-A.PRES-COP2SG what tell-A.PRES-COP2SG say-HYP-2SG I.GEN urpak jön-ịn-de ayt-ar-ïm $b^{i} r$-ịnčị:

descendant direction-POSS3-LOC tell-AOR-POSS1SG one-ORD "Urpak jaksï-dan üyren-ịy-der!" descendant good-ABL learn-IMP-PL

'Now, If you ask me what I would write and what I would say concerning the descendants, what I would say concerning the descendants is first of all "Young ones, learn from what is good!".' 
T6/ 3

“J̆aman-nan jiren-ịy-der!”

bad-ABL loathe-IMP-PL

"'Loathe what is bad!"”

T6/ 4

"Dos-ka meyrịmdi boł!"

friend-DAT compassionate BOL.COP.IMP

" Be compassionate towards your friends!"”

T6/ 5

“Dušman-їy-a katay bot!"

enemy-POSS2SG-DAT hard BOL.COP.IMP

"“Be hard towards your enemies!",

T6/ 6

"Ülken-dị siła!"

old-ACC respect.IMP

“"Respect old people!",

T6/ 7

$\begin{array}{llll}\text { "Kišịi-ni } & \text { kurmet } & { }^{y} \text { et-ịy-der!” } & \text { de-p } \\ \text { young-ACC } & \text { respect } & \text { DO.LIGHTV-IMP-PL } & \text { say-IP.CONV } \\ \text { wösiyet } & \text { ayt-pakši-mïn } & \text { men. } \\ \text { will } & \text { tell-MAKŠI-COP1SG I } & \end{array}$

“"Respect young people!” This is my advice, which I want to tell (the descendants).'

T6/ 8

Üytkeni, adam mïy jasa-ma-y-dï urpak mïy because man thousand live-NEG-A.PRES-3 descendant thousand jasa-y-dï joy.

live-A.PRES-3 ГOY.PART

'Because a man does not live for thousand years but the descendants do, you know.'

T6/ 9

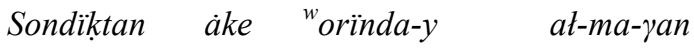

therefore father fulfil-A.CONV TAKE.POSTV-NEG-GAN.PTCP

arman-dï, ake ${ }^{w}$ ornïnda-y at-ma-yan

hope-ACC father fulfil-A.CONV TAKE.POSTV-NEG-GAN.PTCP

jaksï ịs-ter-dị urpak $\quad{ }^{w}$ orïnda-y-t.

good thing-PL-ACC descendant fulfil-A.PRES-3

'Therefore, the descendants fulfil the hope and good things that couldn't be realized by the father.' 
T6/ 10

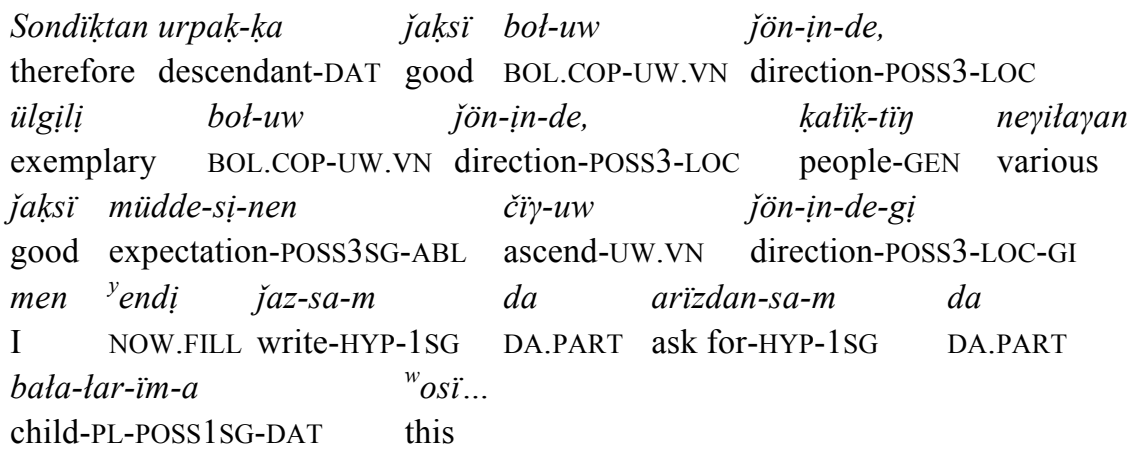

'Therefore, no matter what I would write to the descendants or ask of them, concerning to be good, to be exemplary, to fulfil people's various expectations, this is to my children...'

T6/ 11

Üytkenị adam urpak-pen

körkey-e-di, $\quad$ urpak

because man descendant-WITH.POSTP prosper-A.PRES-3 descendant

bołašak-tïy iye-sị.

future-GEN possessor-POSS3SG

'Because, a man prospers through his descendants and the descendants are the possessors of the future.'

T6/ 12

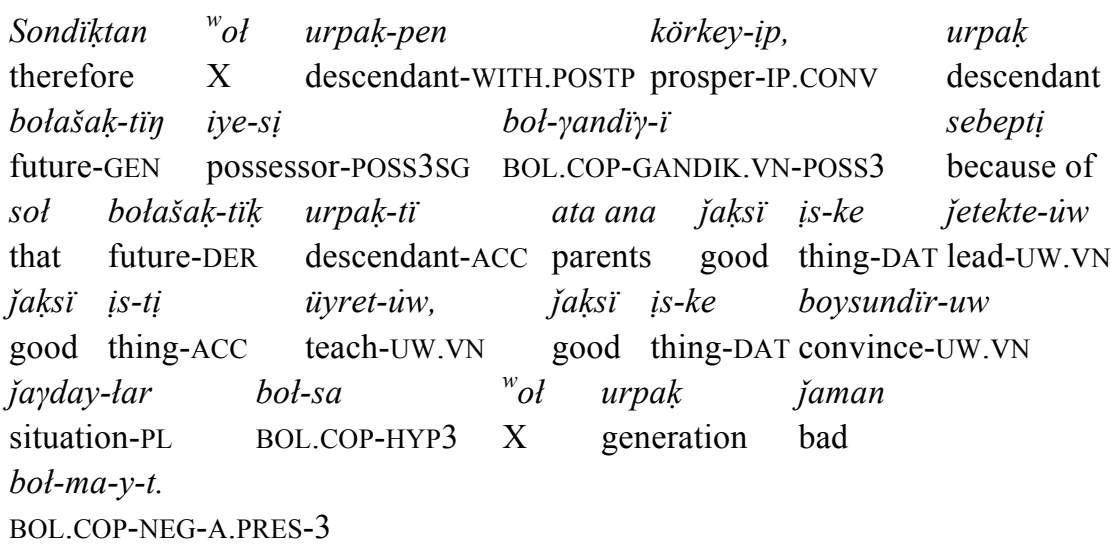

'Therefore, because a man prospers through his descendants and these are the possessors of the future, if the parents lead the descendants to the right way, if they teach (them) good things and convince them to do good things, the descendants will not be bad.' 
T6/ 13

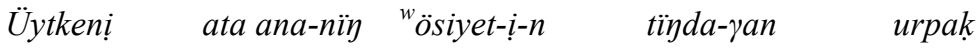

because parents-GEN will-POSS3-ACC listen-GAN.PTCP descendant

ta jaman bot-ma-y-t.

DA.PART bad BOL.COP-NEG-A.PRES-3

'Because a descendant who listens to her/his parents won't be bad.'

T6/ 14

Üytkenị àke-den ne-nị kör-dị-y češe-den ne-nị

because father-ABL what-ACC see-PAST-2SG mother-ABL what-ACC

$k \ddot{r}-d i-\eta \eta .$.

see-PAST-2SG

'Because what you have seen from your father, what you have seen from your mother...'

T6/ 15

Keyb $b^{i}$ rew-ler ayt- ${ }^{-i} p \quad$ jat-a-dï joy, keyde

some-PL tell-IP.CONV LIE.POSTV-A.PRES-3 ГOY.PART sometimes

$b^{i} r$ urpak-tar-ya kenjị-gen ayt- ${ }^{i} p$

once generation-PL-DAT infuriate-GEN.PTCP moment-LOC tell-IP.CONV

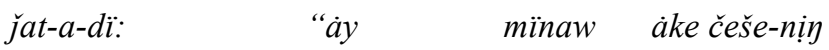

LIE.POSTV-A.PRES-3 AYY.INTERJEC this is parents-GEN

tárbiye-sị-n kör-me-gen roy mïnaw”.

good manners -POSS3SG-ACC see-NEG-GAN.POSTT3 ГOY.PART this

'As you know, some people often say, sometimes, when (they) get angry with the young ones, "Well, this (child) surely has not learned good manners from her/his parents".'

T6/ 16

"Mïnaw-ïy nedegen körgensịz, nedegen näšàr ${ }^{y} e$-dị”,

this-POSS2SG how ill-mannered how bad E.COP-PAST3

de-p süyt-üp jat-a-dï roy.

say-IP.CONV do So-IP.CONV LIE.POSTV-A.PRES-3 ГOY.PART

"What an ill-mannered, what a bad (child) this is", (they) often say so, as you know.'

T6/ 17

${ }^{y}$ Endi mïnaw negị-ị-nen ${ }^{y}$ endi sot àke

NOW.FILL this is principle-POSS3-ABL NOW.FILL that father

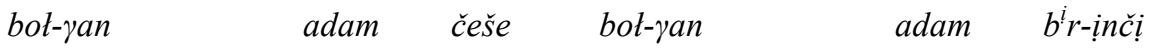

BOL.COP-GAN.PTCP person mother BOL.COP-GAN.PTCP person one-ORD

kuday-dan tịle-ytịn- $\underline{i}$ urpak, ${ }^{w}$ ot

God-ABL wish-ATIN.PTCP-POSS3 descendant X

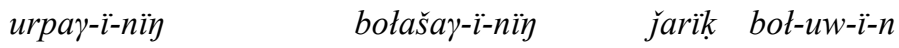

descendant-POSS3-GEN future-POSS3-GEN bright BOL.COP-UW.VN-POSS3-ACC 
tịle-y-t.

wish-A.PRES-3

'It is in principle so that a father, a mother, wishes from God first of all that the children, the future of his/her children will be bright.'

T6/ 18

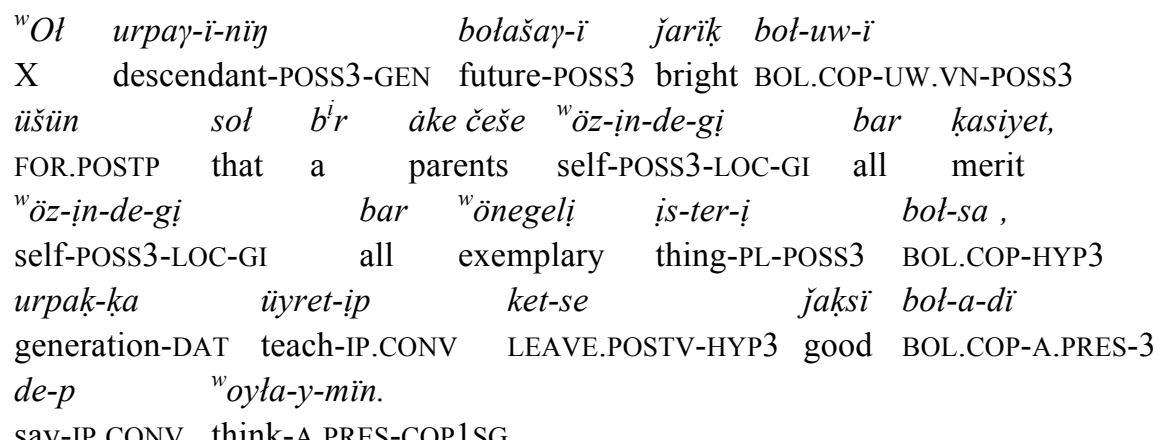

say-IP.CONV think-A.PRES-COP1SG

'In order to ensure that the future of the descendants is bright, I think, it is good that the parents teach their children all the good qualities and exemplary features themselves might have.'

T6/ 19

\begin{tabular}{|c|c|c|c|c|}
\hline $\begin{array}{l}\text { Men-če, } \\
\text { I-DER }\end{array}$ & $\begin{array}{l}\text { mïna } \\
\text { this }\end{array}$ & $\begin{array}{l}\text { urpak } \\
\text { descendant }\end{array}$ & $\begin{array}{l}\text { jön-ịn-de-gi } \\
\text { direction-POSS3-LOC-GI }\end{array}$ & $\begin{array}{l}\text { ayt-atïn-ïm, } \\
\text { tell-ATIN.PTCP-POSS1SG }\end{array}$ \\
\hline sot & ${ }^{y}$ endi & sekildị & is-ter-menen & $\check{c} u \gamma u \nmid d a n-\ddot{p} p$ \\
\hline & NOW.FILL & this & thing-PL-WITH.POSTP & engage in-IP.CONV \\
\hline & bot-uw-ï-n & & tịle-y-ïm & yendị. \\
\hline & $\mathrm{BC}$ & (1) & wish-A.PRES-COP & NOW.FILL \\
\hline
\end{tabular}

'As for me, what I will tell you about the descendants is that I wish they do such things and that they are good.'

T6/ 20

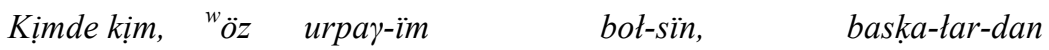
whoever self descendant-POSS1SG BOL.COP-VOL3 other-PL-ABL

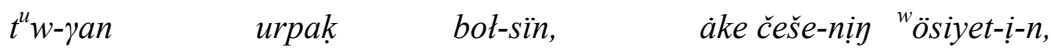
bear-GAN.PTCP descendant BOL.COP-VOL3 parents-GEN directive-POSS3-ACC àke češe-nị̣ jaksï̈ tálịm tärbiye-sị-n üyren-se parents-GEN good good manners-POSS3SG-ACC learn-HYP3 bot-a-dï $\quad{ }^{y}$ endị. BOL.COP-A.PRES-3 NOW.FILL

'Whoever, no matter if it is my own child or others', it would be good if he/she learns the directives and good manners from the parents.'

$\mathrm{T} 6 / 21$

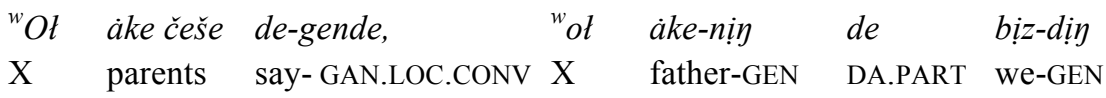


de keybịr katelik jer-ler-ịmịz bot-a-dï.

DA.PART some faulty place-PL-POSS1PL BOL.COP-A.PRES-3

'Speaking about parents, fathers, and we too have faults.'

T6/ 22

Ake men češe-nị .

father and mother-GEN

'Both fathers and mothers (have faults).'

T6/ 23

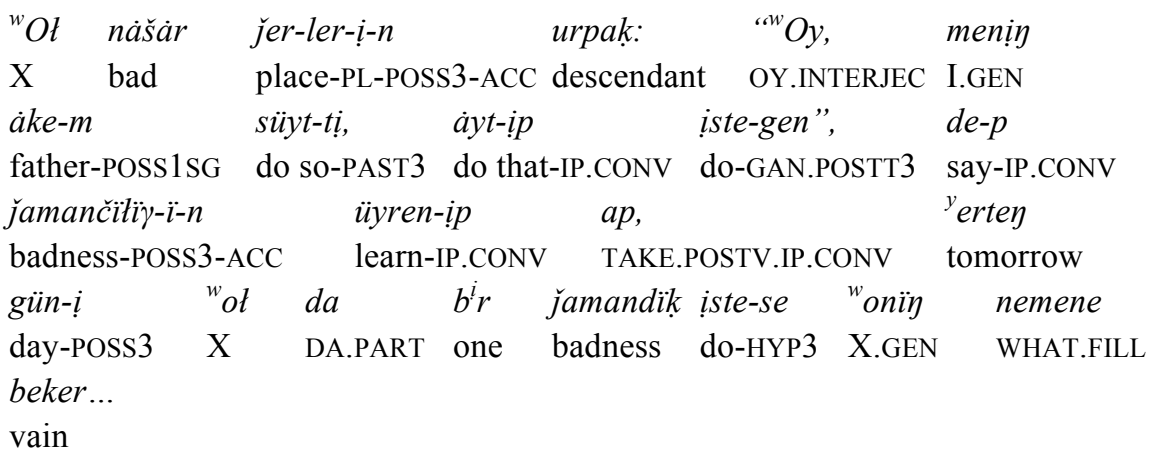

'The children speak about these faults: "Oh, my father has done so and so...", and they learn the bad thing and when they later also do bad things and then it is in vain...'

T6/ 24

Bołašak-tïk urpak bot-at-ma-y-dï

future-DER generation BOL.COP-ABIL-NEG-A.PRES-3

de-mekšị-mịn loy ${ }^{y}$ endị.

say-MAKŠI-1SG TOY.PART NOW.FILL

'I want to say that they cannot become the generation for the future, as you know.'

\section{T7. 'Ösiyetịm 'My testament'}

Metadata

Gender: male

Age: 71

Date of birth: May 1941

Place of birth: Jemeney county, Altay, China

Education: High school

Language competence: Kazakh (mother tongue), Chinese (understands)

Date of recording: 20th July 2012

Place of recording: Kaba, Altay 


\section{Running text}

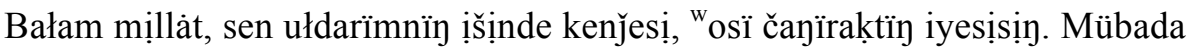
men ${ }^{\mathrm{w}} \mathrm{o}$ dünyelịk bol ${ }^{\mathrm{u}} \mathrm{p}$ ketịp jatsam, menịn ${ }^{\mathrm{w}}$ osï wotïryan üyüm-baspanam, basḳada małmülükterịmnịng ${ }^{\mathrm{y}}$ en ḳundułarï ärine senịn basḳaruwunda boładï. Jüyeden a yałarïnnïn jảne bawïrłarïnnïn da pịkịị̣n ałïp, tïnïšo ïntïmaḳtï negịzịnde menị̣ artḳï małmülküme iyelịk y etủwündị tałap ${ }^{y}$ etemịn. Ȧken tölegen.

\section{Annotated text}

T7/ 1

\begin{tabular}{|c|c|c|c|c|}
\hline$a ł a-m$ & $\begin{array}{l}\text { milllàt, } \\
\text { Millat }\end{array}$ & $\begin{array}{l}\text { sen } \\
\text { you }\end{array}$ & 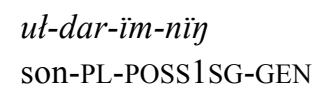 & $\begin{array}{l}i \stackrel{\text { š- }}{ } \text { n-de } \\
\text { inside-POSS3-LOC }\end{array}$ \\
\hline borr & & & $\begin{array}{l}\text { iye-si-sing. } \\
\text { owner-POS }\end{array}$ & $\mathrm{G}-\mathrm{COP} 2 \mathrm{SG}$ \\
\hline
\end{tabular}

'My son Millat, you are the youngest among my sons, and you are the owner of this house.'

$\mathrm{T} 7 / 2$

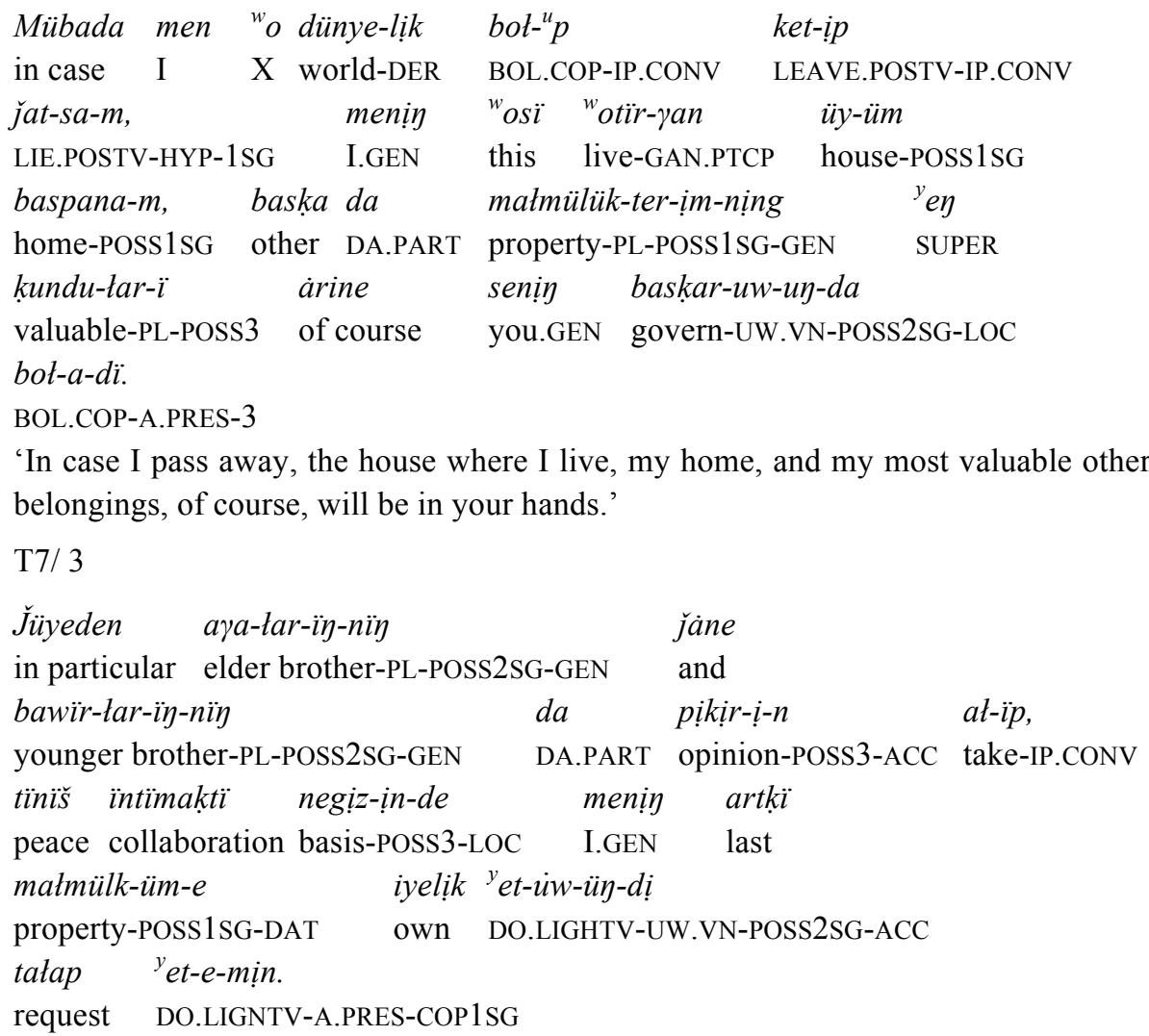


'In particular, I ask you to consult with your elder brothers, as well as your younger brothers, and become the owner of my last properties in a peaceful and collaborative way.'

$\mathrm{T} 7 / 4$

Ake- $\eta \quad$ tölegen.

father-POSS2SG Tölegen

'Your father, Tölegen.'

T8. Kelịn botuw 'To be a bride'

Metadata

Gender: female

Age: 71

Date of birth: May 1940

Place of birth: Kaba county, Altay, China

Education: University

Language competence: Kazakh (mother tongue), Uyghur (understands), Chinese (understands and reads).

Date of recording: 25th July 2012

Place of recording: Kaba, Altay

Running text

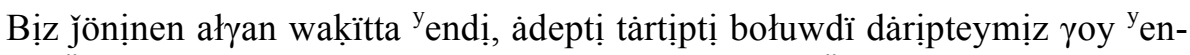
dị. Ülkenderdịn ałdïnda kelịnder ibałï bołuw kerek. Ülkenderdị siław kerek.

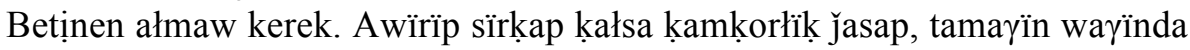
berịp, dảrị berịp degen siyaḳtï. Tịptị šamasï kelmeytịn adamdar bołsa, juwundïrïp, kiỵ̣mịn juwup, basï gözün juwup, wöstüp ḳoysa da boładï yoy. ${ }^{\mathrm{y}}$ Endị mïnday keyb $\mathrm{r}^{\mathrm{w}}$ oḳaš ịsterdị körgen wakịtïnda ülkender ${ }^{\mathrm{y}}$ endị ${ }^{\text {ĭ } ̌ ̣ i ̈ p ~}$

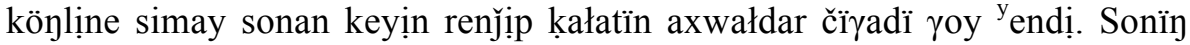
üšün ibałï bołuw kerektị dảrịpteymịz, àdeptị bołuw kerektị dảrịpteymịz. Söz

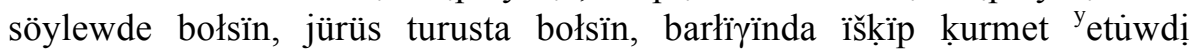

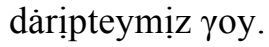

Annotated text

T8/ 1

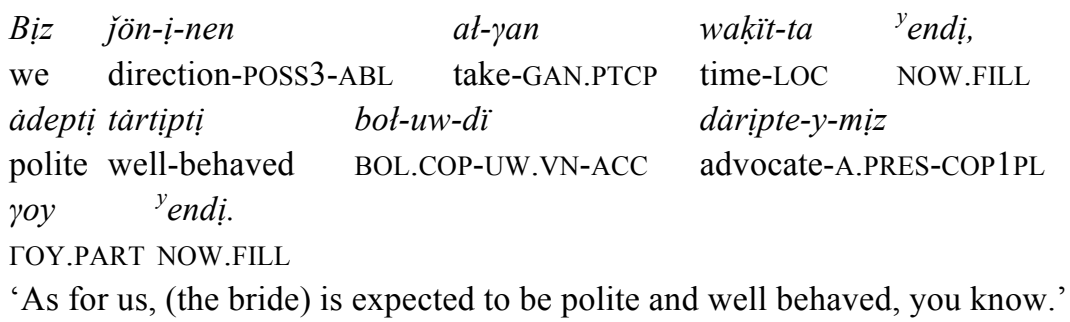


$\mathrm{T} 8 / 2$

$\begin{array}{llll}\begin{array}{l}\text { Ulken-der-dị } \\ \text { elder-PL-GEN }\end{array} & \begin{array}{l}\text { atdïn-da } \\ \text { front.POSS3-LOC }\end{array} & \begin{array}{l}\text { kelịn-der } \\ \text { bride-PL }\end{array} & \begin{array}{l}\text { courteous BOL.COP-UW.VN } \\ \text { kerek. }\end{array} \\ \text { necessary } & & \\ \text { 'Brides must be courteous towards old people.' }\end{array}$

T8/ 3

Ülken-der-dị siła-w kerek.

old-PL-ACC respect-UW.VN necessary

'(The bride) must respect the old people.'

$\mathrm{T} 8 / 4$

$\begin{array}{lll}\text { Bet-i-nen } & a t-m a-w & \text { kerek. } \\ \text { face-POSS3-ABL } & \text { take-NEG-UW.VN } & \text { necessary } \\ \text { '(The bride) must not be rude towards them.' }\end{array}$

$\mathrm{T} 8 / 5$

\begin{tabular}{|c|c|c|c|c|}
\hline $\begin{array}{l}\text { Awirr-̈̈p } \\
\text { fall sick-IP.CONV }\end{array}$ & $\begin{array}{l}\text { sïrka-p } \\
\text { get sic }\end{array}$ & k-IP.CONV & $\begin{array}{l}\text { at-sa } \\
\text { ГAY.POSTV-HYP3 }\end{array}$ & $\begin{array}{l}\text { kamkortik } \\
\text { help }\end{array}$ \\
\hline jasa-p, & & 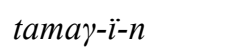 & $w a \gamma-\ddot{i n}-d a$ & \\
\hline CREATE.LIGHTV- & IP.CONV & food-POSS3-ACC & time-POSS3- & \\
\hline er-ip & därị & ber-ipp & de-gen & . \\
\hline give-IP.CONV & 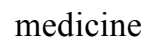 & give-IP.CONV & say-GAN.PTCP & like \\
\hline
\end{tabular}

'If they get sick, (the bride) should help by giving them food and medicine in time, and suchlike.'

T8/ 6

\begin{tabular}{|c|c|c|}
\hline $\begin{array}{ll}\text { Tịpti } & \text { sama-sï } \\
\text { even } & \text { strength-POSS }\end{array}$ & $\begin{array}{l}\text { kel-me-ytịn } \\
\text { come-NEG-ATIN.PTCP }\end{array}$ & $\begin{array}{l}\text { bot-sa, } \\
\text { BOL.COP-HYP3 }\end{array}$ \\
\hline $\begin{array}{l}\text { juwun-dïr-ïp, } \\
\text { wash-CAUS-IP.CONV }\end{array}$ & $\begin{array}{ll}\text { kiyịm- }-i-n & \check{j u w-u p,} \\
\text { clothes-POSs3-ACC } & \text { wash-IP.CONV }\end{array}$ & $\begin{array}{l}\text { bas- } \ddot{l} \\
\text { head-Poss3 }\end{array}$ \\
\hline$g \ddot{o} z-\ddot{u}-n$ & $\check{\jmath} u w-u p$, & $k o y-s a$ \\
\hline eye-POSS3-ACC & do it as this-IP.CONV & PUT.POSTV-HYP3 \\
\hline bot-a-dï & roy. & \\
\hline RT BOL.COP-A & ГOY.PART & \\
\hline
\end{tabular}

'When the (old) people are not able (to take care of themselves), then the bride should even be able to wash them, wash their clothes, and their hair and faces, shouldn't she?'

T8/ 7

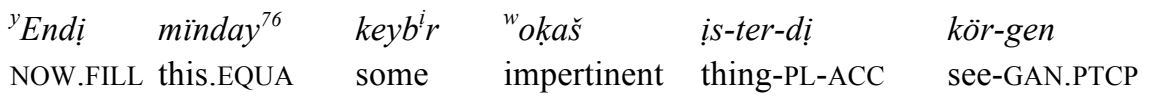

${ }^{76}$ Mïnday is a contracted form of mïna-day 〈this-EQUA) 'like this' or mïnan-day 〈this-EQUA〉 'like this' 


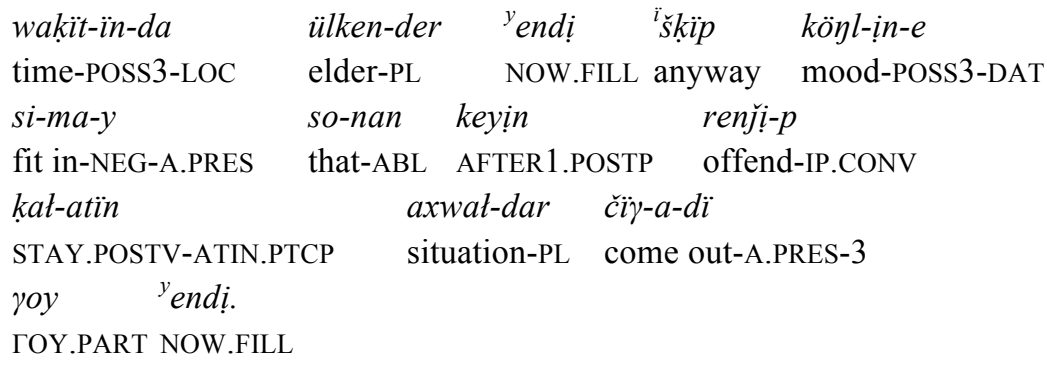

'When the old people have experienced some impertinences, they do not like it, and it can happen that they are offended, you know.'

$\mathrm{T} 8 / 8$

Sonïy üšün ibatï bot-uw kerek-ti

that.GEN FOR.POSTP courteous BOL.COP-UW.VN necessary-ACC

däripte-y-mị.

advocate-A.PRES-COP1PL

'That is why the bride is expected to be courteous.'

$\mathrm{T} 8 / 9$

Adeptị bol-uw kerek-ti darịte-y-mị.

polite BOL.COP-UW.VN necessary-ACC advocate-A.PRES-COP1PL

'We advise the bride to be polite.'

$\mathrm{T} 8 / 10$

Söz söyle-w-de bot-sïn, jürüs turus-ta

word speak-UW.VN-LOC BOL.COP-VOL3 behavior- LOC

bot-sïn, bartïy-ïn-da ïskïp kurmet ${ }^{y}$ et-uw-dị

BOL.COP-VOL3 all-POSS3-LOC anyway respect DO.LIGHTV-UW.VN-ACC

därịpte-y-mịz $\quad$ yoy.

advocate-A.PRES-COP1PL TOY.PART

'We expect the bride to respect (the old people) in speech, in behavior, and in all respects.'

\section{T9. Joyatyan kolfon 'The lost cell phone'}

\section{Metadata}

Gender: Female

Age: 30

Date of birth: August 1982

Place of birth: Ürümqi, Xinjiang Uyghur Autonomous Region of China.

Education: University

Language competence: Kirghiz (mother tongue), Kazakh (as second mother tongue), Uyghur (understands, speaks and reads), Chinese (understands, speaks, reads and writes). 
Date of recording: 20th October 2011

Place of recording: Ürümqi

Running text

T9/ 1-T9/ 10

Besịnši ayłarda yoy deymịn taza kịzïk bołdï. Gułi yekewịmịz kezdesetịn

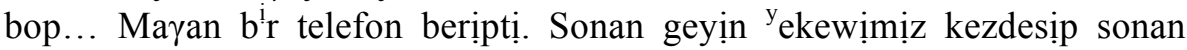
"ḳayda baramïz?” desem, "men kiyịm tịktịrưwšị yedịm, dašimịnya barïp" dep süyttị. Sonan geyịn "bopti”” dep, sonan geyịn "ekemịz fadwanšin ḳïłïsïp b ${ }^{i} r$ brịmịzge, so dašimịnda kezdesetịn bołdịk. Sodan geyịn tüste kezdestịk ḳoy deymịn taza kïzïk. Sonan geyịn dašimịn ya barïp, jumusumïzdï b tịrịp...

Ałdïnda b’ir yinxayya kịrdịk. Yinxayya kịrgen kezde gayxaw, kịm gułi

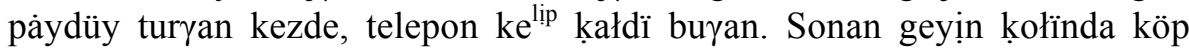
nerselerị bar bołatïn. Sonïmen ayttïm ${ }^{\mathrm{w}}$ o $\gamma$ an.

T9/ 11-T9/ 20

"Ȧy, nerselerịndị men köterịp turayïn, sen dyenxwada söylesịp bołyanša" dep süyttịm de. Soson "jok ị̌štenketpeydị” dep unamay ḳoydï. "E boptï dep

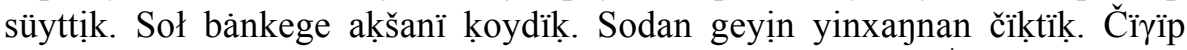
sodan geyịn, 'ekewịmịz jołdïn ${ }^{w}$ ortasïnda ketịp bara jatïp, b’ jererden tamak jeyịk pa dep... Sodan geyịn nảzảnya telefon berdịk. Nảzản ịstedị ma ịstemedị ma dep telefon bersek, nảzản dả dašimịnda mamasïmen bị rge guanjye $\mathrm{k}^{\mathrm{i} p}$ jürüptị. “"Woy, men mamamdï jołya sałïp tastayïn da sonïmen sendermen kezdeseyịn" dep süyttị. Sodan geyịn woł mamasïn jołya sałïp tastap, sonïmenen bịzge telefon berdị.

T9/ 21-T9/ 30

Sodan geyịn üšewümịz br jerde kezdesịp ${ }^{\text {w }}$ otïrïp... Nảzảnya telefon bereyịk desek ḳara, telefon joḳ, adaš. Gułidị epo šowjisï, pin go. Sonïmen telefon kane dep, sonïmen telefondï berdịk. Telefondï berịp jatïrmïz berịp jatïrmïz dyenxwa tojłï kara. Zay jïnzay tundïnï yij̄i zay tundïnï. Somenen oybay

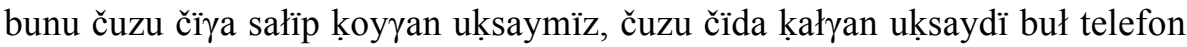
dep, somen aḳïrïn woyłap bayïp, ày, toḳtap tur à, čokïm soł yinxayda ḳałḳałan bołuwï mümkün, wo za gảnjüe soł yinxanda ḳałyan siyaḳtï dep süyttịm. Desem, somen "bar"ip köreyịkpa?” dep süyttị. Somen bar ${ }^{\mathrm{ip}}$ köreyịk dep bardịk yinxayła. Barïp, sodan geyịn suradïk.

T9/ 31-T9/ 40

Kịre ḳałyanda bawảnnan suradïk. Surap ayttïk: ày, womïn gạcay zayjui cün neygị sałi, cün čyenłï. Dạ ši womïndï dyenxwa jyu łazay juiłï dep ayttïk.

Desek sonïmen bawản... Mïna šîšyantïw bar šïyar bịz šịin köremịz dep süytsek, "woy, senderge körsetüwge bołmaydï, bịz wözịmịz köremịz ” dep unamaydï. Sonïmen güytàydịn ałdïna gep, sodan geyịn dảl so ḳïzbała hàymịy šyabản nï. So(men) so kïzdan suradịk. Surasaḳ basta türị wözgerịp turdï 
ana kïzbałanïy, b’r türlị fanjīn gảnüüe tin jinǰan dï. Sodan geyịn "šïnmï šowǰi?" dep süyttị. Sodan: "pingo šowǰi xisïdï pingo šowǰ”" desek, sodan geỵ̣n basïnda sözịnị bas ayayï ḳamłašpadï de, sodan geyịn, "a, gansảy igï wizu dama gịy nazow łï’ dep süyttị bịzge.

T9/ 41-T9/ 50

Sodan geyịn "a? šinmmï yandï dama?" dep süyttịk. Bugo dyenxwa hayzay ij̣̣ zay tundïnï. Womïn butindï zay da dyenxwa. Sodan geyịn ayttiḳ: "bukïnïn" dep süyttịk. "Bịz wosï jerge kelgen kezde telepon berdịk." "Dajšï wo pïnyow jyu ba dyenxwa łazáy jiłlï". "Dayšï wo jyu kandï činčin čuču dï”. "Ta ławgun šị jinčč" dep süttịk. "Zảy pảyčuso gunzo nï." "Dảyhur..."

T9/ 51-T9/ 61

"Womïn gịy ta da dyenxwa tï". "Womïn yaw bawản nï” dep süyttịk. Degen(de) łam, ana kïzbała, güytảydayị ịsteytịn kïzbała ündemey łam kịr ${ }^{\text {ip }}$ kettị. Kịrketịpłam, bị kezde łam, šowjidï ałïp čìïp jatïr. "A, šịbušị jüigï xisïdï

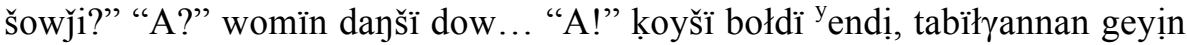
bołdï, bumen töbelespey koyayïk dep, somen č̣ kettịk àgị jerden. Süytüp àgị telefon jơałmadï. Üytkenị ana pingo šowjisïnïn kïnïn mịy yongwo dï rïn

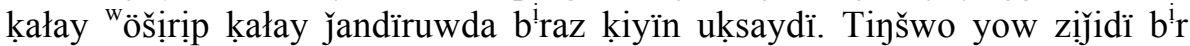
kịltị bar ${ }^{\mathrm{y}}$ eken deydị $\gamma$ oy ${ }^{\mathrm{w}}$ onïn, men de bịlmeydị ${ }^{\mathrm{y}}$ ekem. Sodan geyịn čịktiị, men gułi nảzản üšewümịz. Ảlgị ǰerden ałtïn tawup ałyan siyaḳtï bop.

Annotated text

Chinese lexical elements are underlied.

T9/ 1

Bes-ịnši $\quad$ ay-tar-da $a^{77} \quad$ yoy de-y-mịn $\quad$ taza $^{78}$ kizizik

five-ORD month-PL-LOC TOY.PART say-A.PRES-COP1SG very interesting

bot-di.

BOL.COP-PAST3

'In May, I think, something very interesting happened.'

$\mathrm{T} 9 / 2$

Guti ${ }^{y}$ ek-ew-ịmiz kezdes-etin bop ...

Guli two-COLL-POSS1PL meet- ATIN.PTCP BOL.COP.IP.CONV

'Guli and I, the two of us, decided to meet ...'

\footnotetext{
${ }^{77}$ The lexical item besinnšị ay 〈five-ORD month〉 'May' is a selective copy of Chinese wǔ yuè 'May'. The term in Kazakh is mamïr 'May'.

${ }^{78}$ The lexical item taza 'very' is a global copy of Uyghur taza 'very'.
} 
T9/ 3

Maran $\quad b^{i} r \quad$ telefon ber-ip-tị.

I.DAT a telephone give-IP.POSTT-3

'She called me.'

T9/ 4

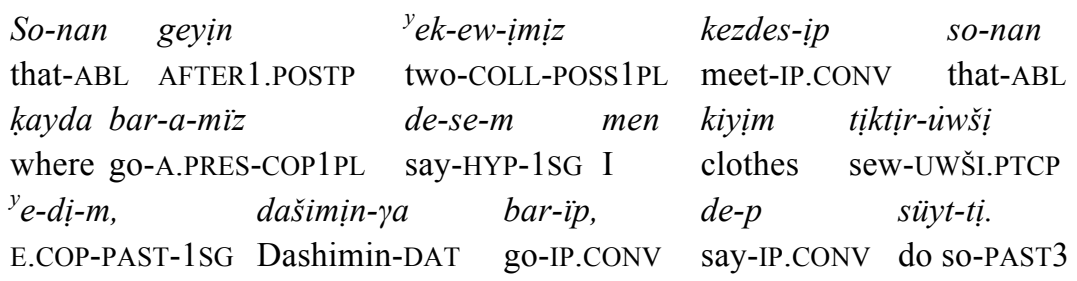

'Then, the two of us met, and then, when I asked, "Where shall we go?"- She said, "I was going to order a dress, go to Dashimin".'

T9/ 5

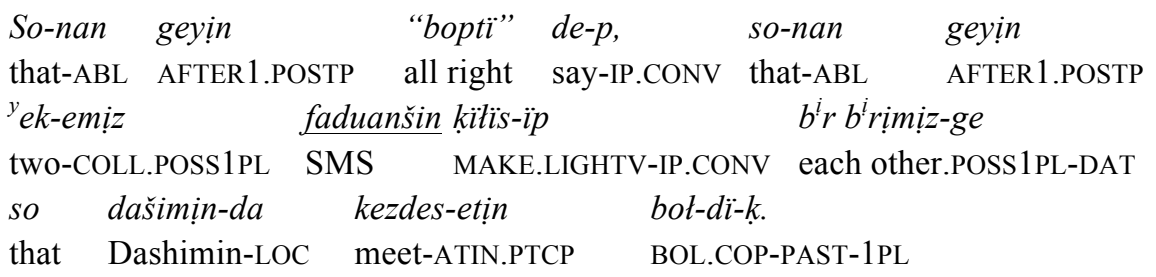

'Then, we said "all right". Then the two of us sent an SMS to each other, and we decided to meet in Dashimin.'

T9/ 6

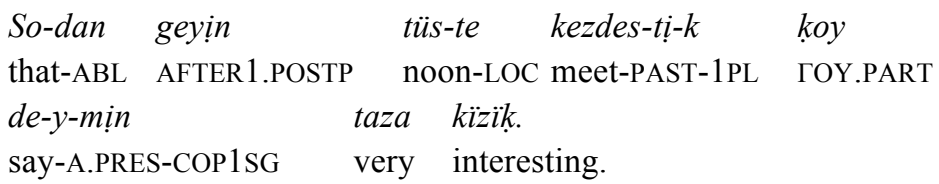

'Then we met at noon, I think. It was very interesting.'

T9/ 7

\begin{tabular}{|c|c|c|c|c|}
\hline$a n$ & geyịn & dašimịn- $\gamma a$ & bar- ̈̈p & јити \\
\hline & AFTER 1 & Dashimin-DAT & go-IP.CONV & \\
\hline & & $b^{i} r$ & yinxan- $\gamma a^{79}$ & $k i ̣ r-d i ̣-k$. \\
\hline & DNV & $3-\mathrm{LOC}$ & bank-DAT & ater-PAST-1PL \\
\hline
\end{tabular}

'Then we went to Dashimin, did our shopping and first we went to a bank.'

T9/ 8

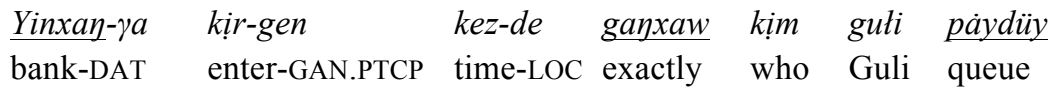

${ }^{79}$ Yinhay 'bank' is a lexical item globally copied from Chinese. The Kazakh term for bank is "bänke". 
tur-yan kez-de telepon $k e^{l-i p}$

stand-GAN.PTCP moment-LOC telephone come-IP.CONV

kat-dï buran.

STAY.POSTV-PAST3 this.DAT

'When we went into the bank, and while Guli was queueing up, she got a phone call.'

T9/ 9

So-nan geyịn kot-ïn-da köp nárse-ler-i

that-ABL AFTER1.POSTP hand-POSS3-LOC lots of thing-PL-POSS3

bar bot-atïn.

existing BOL.COP- ATIN.PAST.INTRAT

'Then she had lots of things in her hands.'

T9/ 10

Soni-men ayt-tï-m ${ }^{w} o-\gamma a n$.

that-WITH.POSTP tell-PAST-1SG X.DAT

'Then I said to her.'

T9/ 11

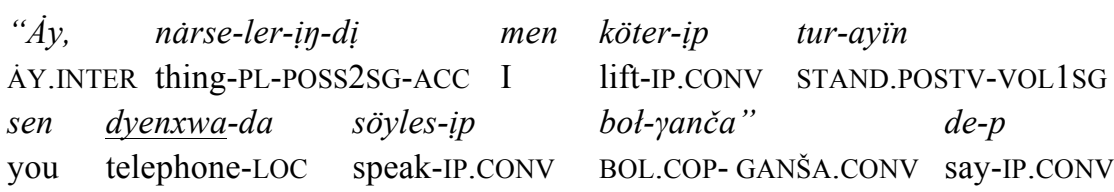

süyt-tị-m de.

do so-PAST-1SG DE.PART

'I said, "Look, I'll hold your things till you finish your conversation on the phone".'

T9/ 12

Soson "jok ǐstejk-et-pe-y-dị " de-p

then no nothing-DO.LIGHTV-NEG-A.PRES-3 say-IP.CONV

una-ma-y koy-dï.

agree-NEG-A.CONV PUT.POSTV-PAST3

'Then she said "No, no problem!"- and she did not agree.'

T9/ 13

${ }^{\text {" }} \mathrm{E} \quad$ boptï” de-p süyt-ti-k.

E.INTERJEC all right say-IP.CONV do so-PAST-1PL

“"All right”, we said and we did so.'

${ }^{80}$ The dropping of the last consonant of the verb kel- and the converb suffix $\left\{-\left(I^{4}\right) \mathrm{p}\right\}$ in the postverbal construction here, i.e. ke kat- 'arrive, come' is a phenomen copied from Uyghur. The correct Kazakh form is kelip kat-.

${ }^{81}$ Ištenketpeydi $<{ }^{y}$ ešteme ${ }^{y}$ etpeydi or ${ }^{y}$ eštene ${ }^{y}$ etpeydi 'no problem'. Literally it means 'it makes nothing'. 
T9/ 14

Sot bänke-ge akša-nï koy-dï-k.

that bank-DAT money-ACC deposite-PAST-1PL

'We deposited the money in the bank.'

T9/ 15

$\begin{array}{llll}\text { Sodan } & \text { geyịn } & \text { yinxay-nan } & \text { čik-tï-k. } \\ \text { that-ABL } & \text { AFTER1.POSTP } & \text { bank-ABL } & \text { come out-PAST-1PL }\end{array}$

'Then we left the bank.'

T9/ 16

\begin{tabular}{|c|c|c|c|}
\hline $\begin{array}{l}\check{C} \ddot{i \gamma} \text { - ̈̈p } \\
\text { come out-IP.CONV }\end{array}$ & $\begin{array}{ll}\text { sodan } & \text { geyin, } \\
\text { that-ABL } & \text { AFTER1.P }\end{array}$ & $\begin{array}{ll} & { }^{y} e k-e w-i m i \underline{z} \\
\text { OSTP } & \text { two-COLL-POSS1PL }\end{array}$ & $\begin{array}{l}\text { jot-dï } \\
\text { road-GEN }\end{array}$ \\
\hline${ }^{w}$ orta-sïn-da & ket-ip & bar-a & \\
\hline middle-POSS3SG-LOC & leave-IP.CONV & GO.POSTV-A.CONV & \\
\hline jat-ïp, & jer-den & tamak & \\
\hline IE.POSTV-IP.CONV & place-ABL & eat-VOL1PL & \\
\hline$d e-p \ldots$ & & & \\
\hline PART say-IP.CON & & & \\
\hline
\end{tabular}

'After we came out, when we were walking in the street, we said, "Shall we eat?"...'

T9/ 17

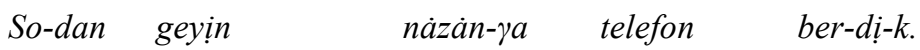

that-ABL AFTER1.POSTP Nazan-DAT telephone give-PAST-1PL

'Then we called Nazan.'

T9/ 18

Názán iste-di $\quad$ ma iste-me-di $i \quad m a$

Nazan work-PAST3 Q.PART work-NEG-PAST3 Q.PART

de-p telefon ber-se-k, näzán $d \dot{a}$

say-IP.CONV telephone give-HYP-1PL Nazan DA.PART

dašimịn-da mama-sï-men bírge

Dashimin-LOC mother-POSS3SG-WITH.POSTP together

gwanjye $k^{i l-i i} p^{82} \quad$ jür-üp-tị.

shopping MAKE.LIGHTV-IP.CONV MOVE.POSTV- IP.POSTT-3

'When we called Nazan to ask whether she was working or not, she was shopping in Dashimin with her mother.'

T9/ 19

\begin{tabular}{lllll} 
"wOy, & men & mama-m-dï & jot- $\gamma a$ & \multicolumn{1}{c}{ sat-ïp } \\
OY.INTERJEC I & mother-POSS1SG-ACC & road-DAT & place-IP.CONV \\
tasta-ÿ̈n & \multicolumn{2}{c}{$d a$} & sonï-men & sen-der-men \\
THROW.POSTV-VOL1SG & DA.PART & that-WITH.POSTP & you-PL-WITH.POSTP
\end{tabular}

${ }^{82}$ This kind of omission occurs only in Uyghur not in Kazakh. 
kezdes-eyịn" de-p süyt-ti.

meet-VOL1SG say-IP.CONV do so-PAST3

'She said, "As soon as I send my mother (home), I will meet you".'

$\mathrm{T} 9 / 20$

So-dan geyin ${ }^{w}$ ot mama-sï-n jot- $n a$

that-ABL AFTER1.POSTP X mother-POSS3SG-ACC road-DAT

sat-ïp tasta- $p$ sonï-menen

place-IP.CONV THROW.POSTV-IP.CONV that-WITH.POSTP

biz-ge telefon ber-dị.

we-DAT telephone give-PAST3

'Then she sent her mother and then she called us.'

T9/ 21

So-dan geyịn üš-ew-ümịz $\quad b^{i} r \quad$ jer-de

that-ABL AFTER1.POSTP three-COLL-POSS1PL a place-LOC

kezdes-ip $\quad{ }^{w}$ otïr-ïp...

meet-IP.CONV sit-IP.CONV

'Then we three met at a place and sat down at a place...'

T9/22

Näzän-ra telefon ber-eyịk de-se-k

Nazan-DAT telephone give-VOL.1PL say-HYP-1PL

kara, telefon jok, adaš.

look.IMP telephone non-existing friend

'When we wanted to call Nazan, look, there was no phone, (my) friend.'

T9/ 23

Guti-dị ápo šowji-sị pingo.

Guli-GEN iPhone-POSS3SG apple.

'Guli's iPhone, the Apple.'

$\mathrm{T} 9 / 24$

Sonï-men "telefon kane?" de-p, sonïmen telefon-dï that-WITH.POSTP telephone where say-IP.CONV then telephone-ACC

ber-di-k.

give-PAST-1PL

'Then, "Where is the phone?", we asked. Then we called (the phone).'

$\mathrm{T} 9 / 25$

Telefon-dï ber-ip jatïr-mïz

telephone-ACC give-IP.CONV LIE.POSTV.AOR-COP1PL 


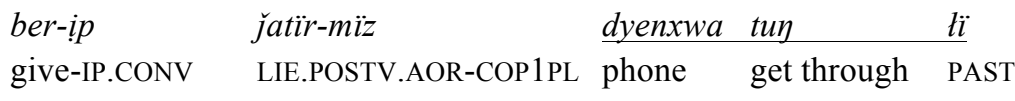

kara.

look.IMP

'We kept on calling the phone, look, the call got through.'

T9/26

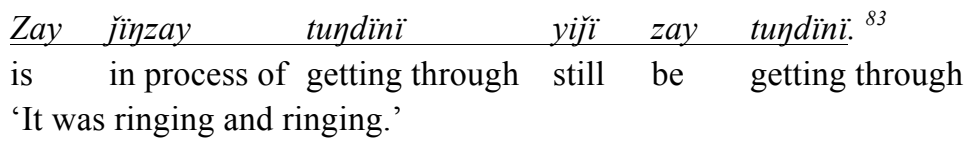

T9/ 27

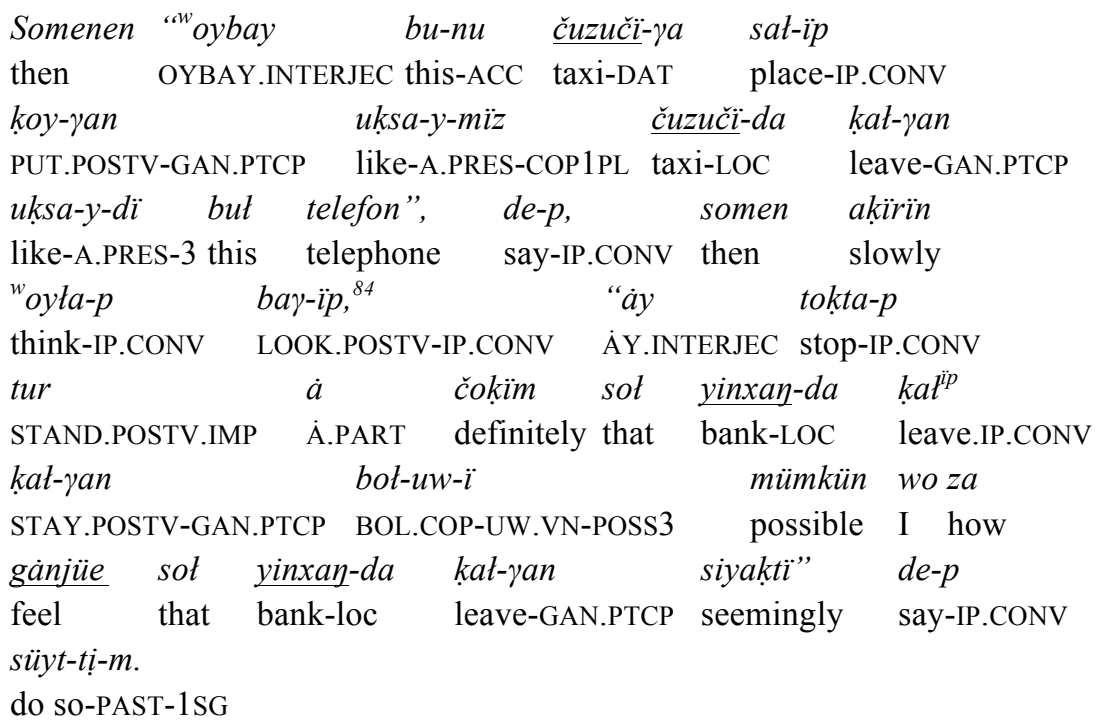

'Then, "It seems we have left it in the taxi, it seems it is in the taxi, this phone", we said. Then we went through everything in our memories. I said, "Wait a minute, it is possibly in the bank, I have the feeling that we left it in the bank".'

T9/ 28

\begin{tabular}{|c|c|c|c|c|}
\hline De-se-m, & somen & "bar & $k \ddot{r} r$-eyịk ${ }^{85}$ & pa?"” \\
\hline say-HYP-1SG & then & go.IP.CONV & SEE.POSTV-VOL1PL & Q.PART \\
\hline$d e-p$ & süyt-tị. & & & \\
\hline say-IP.CONV & do so-P & & & \\
\hline
\end{tabular}

'When I said that, then, she asked "Shall we try to go (back to the bank)?"”

\footnotetext{
${ }^{83}$ Here the speaker switches to Chinese.

${ }^{84}$ The usage of postverbal construction 'oyla-p bak- 'try to think, to think' is copied from Uyghur. The genuine Kazakh expression should be ${ }^{\text {w }}$ oyta- $p$ kör- 'to try to think, to think'.

${ }^{85}$ The dropping of the converb form here is also an Uyghur phenomenon.
} 
T9/ 29

Somen "bar kör-eyị" de-p bar-di-k

then go.IP.CONV SEE.POSTV-VOL1PL say-IP.CONV go-PAST-1PL

yinxay- $\gamma$ a.

bank-DAT

'Then, "Let us try!" we said and we went (back) to the bank.'

$\mathrm{T} 9 / 30$

Bar-ïp so-dan geyịn sura-dï-k.

go-IP.CONV that-ABL AFTER1.POSTP ask-PAST-1PL

'We went there and then asked.'

T9/ 31

Kịr-e kat-yanda bawàn-nan

go in-A.CONV STAY.POSTV-GAN.LOC.CONV security guard-ABL

sura-dï-k.

ask-PAST-1PL

'Having entered we asked the security guard.'

T9/ 32

Sura-p ayt-tï-k: "áy, womïn gaycay ask-IP.CONV tell-PAST-1PL ÁY.INTERJEC we just before $\begin{array}{llllllll}\text { zayji } & \text { cün } & \text { neygi } & \text { sa } & \text { ti, } & \text { cün } & \text { čyen } & \text { ti.." } \\ \text { in here } & \text { deposite } & \text { that } & \text { what } & \text { PAST } & \text { deposite } & \text { money } & \text { PAST }\end{array}$ 'We said, "Hi, we deposited, that thing, the money here just before".'

T9/ 33

\begin{tabular}{|c|c|c|c|c|c|}
\hline “Daクṣ̌ & womïndï & dyenxwa jyu & ta & zayji & $t i{ }^{\prime \prime}$ \\
\hline at that time & our & telephone precisely & forget & in here & $\overline{\text { PAST }}$ \\
\hline$d e-p$ & ayt-tï-k. & & & & \\
\hline Iy-IP.CONV & tell-PAST & 1PI & & & \\
\hline
\end{tabular}

T9/ 34

De-se-k, sonï-men $\quad$ bawän...

say-HYP-1PL that-WITH.POSTP securiy guard

'When we said (that) the security guard...'

T9/ 35

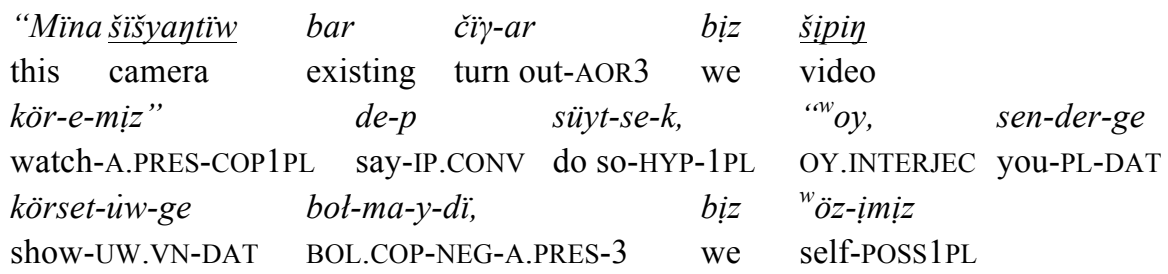


kör-e-mịz" de-p una-ma-y-di.

watch-A.PRES-COP1PL say-IP.CONV agree-NEG-A.PRES-3

'When we asked, "There must be a camera here. We will watch the video." The security guard did not agree and said, "It cannot be shown to you. We will watch it ourselves".'

T9/ 36

Sonï-men

that-WITH.POSTP

güytày-dị $\quad$ atdïn- $a$

kel-ip,

so-dan

geyin

counter-GEN front.POSS3-DAT

come-IP.CONV that-ABL

AFTER1.POSTP exactly that young girl has not off from work PART

'Then, we went to the counter, and that girl had not left the bank.'

T9/ 37

Somen so kïz-dan sura-dï-k.

then that girl-ABL ask-PAST-1PL

'Then we asked the girl.'

T9/ 38

Sura-sa-k basta tür-ị ${ }^{w}$ özger-ịp

ask-HYP-1PL in the beginning complexion-POSS3 change-IP.CONV

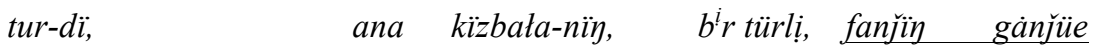

STAND.POSTV-PAST3 that young girl-GEN peculiar anyhow feeling

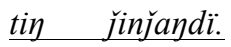

rather nervous

'When we asked the girl, her complexion first changed, somehow, I had the feeling that she was nervous.'

T9/ 39

So-dan geyịn “š̈nmï šowji” de-p süyt-ti.

that-ABL AFTER1.POSTP what cellphone say-IP.CONV do so-PAST3

'Then she asked, "What cellphone?",

T9/ 40

So-dan: "pingo šowji xisïdï pingo šowji" de-se-k,

that-ABL apple cellphone black apple cellphone say-HYP-1PL

sodan geyịn basinda söz-ị-nịy bas

that-ABL AFTER1.POSTP in the beginning word-POSS3-GEN beginning

ayay-i kamtaš-pa-dï de, so-dan geyị, "a?

end-POSS3 fit-NEG-PAST3 DE.PART that-ABL AFTER1.POSTP A.PART

gaysáy igï wizu dama giy nazow tï” de-p

just before an Uyghur aunt PART take PAST say-IP.CONV 
süyt-ti bịz-ge.

do so-PAST3 we-DAT

'Then, when we said, "iPhone, a black iPhone" she started to say things which did not make sense, then she said to us, "Oh, just before an Uyghur lady has taken it".'

T9/ 41

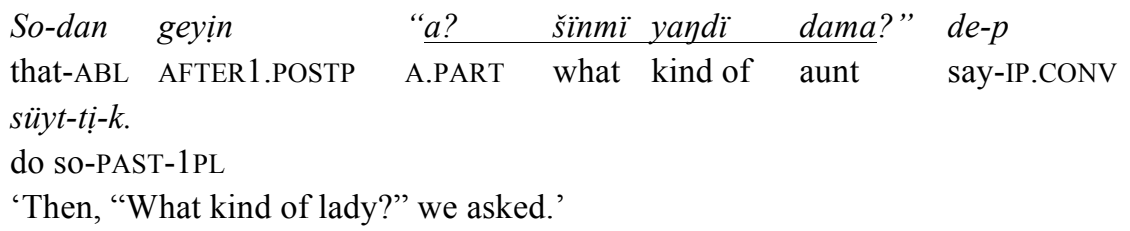

T9/ 42

\begin{tabular}{|c|c|c|c|c|}
\hline$g o$ & xwa hayzay & yiǰ̣ & zay & tuydïn̈. $^{86}$ \\
\hline & telephone still & maining & COP & \\
\hline
\end{tabular}

'But the phone was still getting through.'

T9/ 43

$\begin{array}{llll}\text { Womïn } & \text { butindi } & \text { zay } & \text { dadyenxwa. } \\ \text { we } & \text { incessant } \text { COP dial }\end{array}$

'We kept dialing.'

T9/ 44

So-dan geyin ayt-tï-k.: "bukïnïy" de-p that-ABL AFTER1.POSTP tell-PAST-1PL impossible say-IP.CONV süyt-tị-k. do so-PAST-1PL

'Then we replied, "It is impossible".'

T9/ 45

"Biz "osï jer-ge kel-gen kez-de telepon we this place-DAT come-GAN.PTCP time-LOC telephone

ber-di-k."

give-PAST-1PL

"“We made a call when we came here.",

T9/46

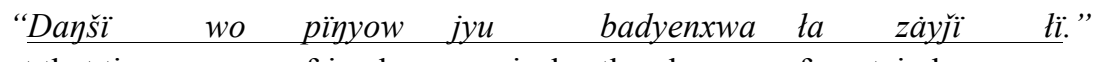
at that time my friend precisely the phone forget in here PAST "“At that time my friend left her phone here."'

\footnotetext{
${ }^{86}$ Here the speaker switches to Chinese.

${ }^{87}$ See the previous footnote.
} 
T9/ 47

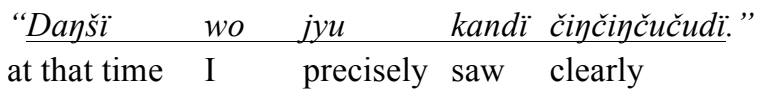

"I saw it very clearly that time.",

T9/ 48

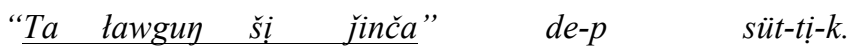

her husband COP policeman say-IP.CONV do so-PAST-1PL

"“Her husband is a policeman", we said.'

T9/ 49

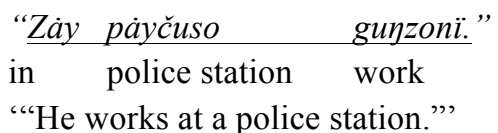

"“He works at a police station.",

T9/ 50

"Dáyhur..."

later

"Later...",

T9/ 51

$\begin{array}{llll}\text { "Womïn giyta } & \text { dadyenxwa } \\ \text { we } & \text { to he } & \text { dial }\end{array}$

"We called him.",

T9/ 52

$\begin{array}{llllll}\text { “Womïn } & \text { yaw } & \text { bawàn } & n \ddot{\imath} ” & d e-p & \text { süyt-ti-k. } \\ \text { we } & \text { will } & \text { report } & \text { PART } & \text { say-IP.CONV } & \text { do So-PAST-1PL }\end{array}$

"“We will report the case (to the police)", we said.'

T9/ 53

De-gende tam ${ }^{88}$, ana kizbała, güytày-da- $\gamma \ddot{i}$

Say-GAN.LOC.CONV PART that young girl counter-LOC-GI

iste-ytin kïzbała ünde-me-y tam kị $r^{i p}$

work-ATIN.PTCP young girl emit a sound-NEG-A.CONV PART go in.IP.CONV

ket-ti ${ }^{89}$.

LEAVE.POSTV-PAST3

'As soon as we said (that), that young girl, the young girl who worked at the counter went over to another room without saying anything.'

${ }^{88} \mathrm{Lam}$ is a particle copied from Uyghur.

${ }^{89}$ See footnote 85 . 
$\mathrm{T} 9 / 54$

\begin{tabular}{|c|c|c|c|c|c|}
\hline $\begin{array}{l}K i r^{i p} \\
\text { go in.IP.CONV }\end{array}$ & $\begin{array}{l}\text { ket-ip } \\
\text { LEAVE.POSTV-IP.CONV }\end{array}$ & $\begin{array}{l}\text { tam, } \\
\text { PART }\end{array}$ & $\begin{array}{l}b^{i} r \\
\mathrm{a}\end{array}$ & $\begin{array}{l}\text { kez-de } \\
\text { time-LOC }\end{array}$ & $\begin{array}{l}\text { tam, } \\
\text { PART }\end{array}$ \\
\hline$i$ & $\ddot{c} \ddot{i} \gamma-\ddot{i p} p$ & & & & \\
\hline ne-ACC & take-IP.CONV & OUT & CTI & ONV & V.AOR3 \\
\hline
\end{tabular}

'Very soon after she went over to the other room, she came out with the cellphone.'

$\mathrm{T} 9 / 55$

$\begin{array}{llll}\text { "A, } A \text { šibuši } & \text { jigi } & \text { xisïdï } & \text { šowji? } " \\ \text { A.INTERJEC if it is this black } & \text { cellphone } \\ \text { "WWell, is it this black cellphone?", } & \end{array}$

T9/ 56

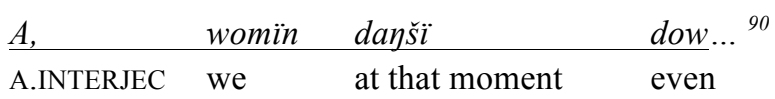

'Oh, at that moment we were even...'

T9/ 57

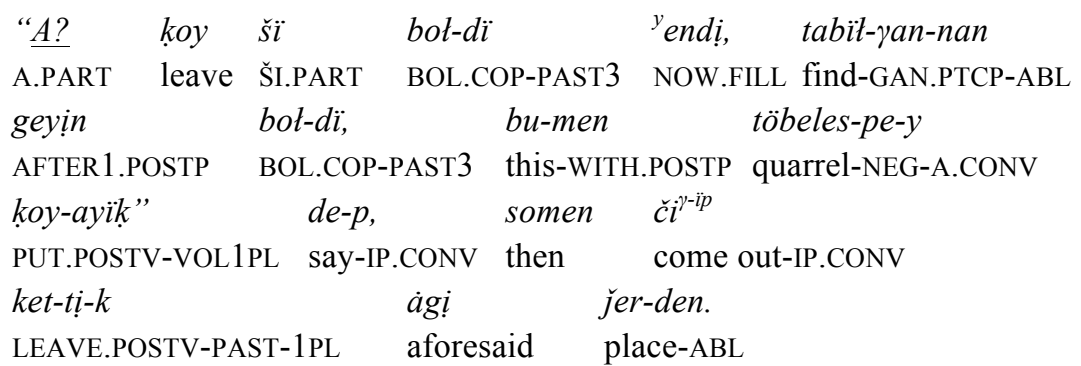

"'Well, never mind, after we have we found it, let us not quarrel with her", we said.

Then we left.'

T9/ 58

Süytüp àgi telefon joyat-ma-dï.

thus aforesaid telephone disappear-NEG-PAST3

'Thus the phone was not lost.'

T9/ 59

Üytkenị ana pingo šowji-sï-n̈̈y kïn̈̈ mìy yongwodï because that apple cellphone-POSS3SG-GEN probably NEG used rïn kałay ${ }^{w} \ddot{o ̈ s i ̣ r-i p p ~ k a ł a y ~ j a n d i ̈ r-u w ~-d a ~}$

person how switch off-IP.CONV how switch on-UW.VN-LOC

$b^{i}$ raz kiyn(al-atïn) uksa-y-di.

somehow have difficulty(-ATIN.PTCP) like-A.PRES-3

'Because, to a person who has never used an iPhone, probably, it seems to be difficult to switch on and to switch off (the phone).'

${ }^{90}$ Here the speaker switches to Chinese. 
T9/ 60

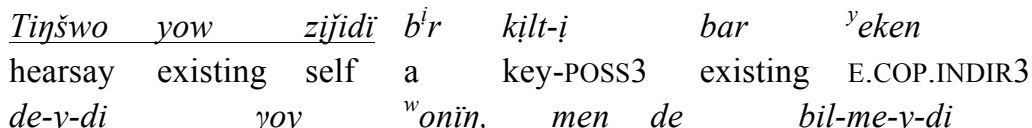

say-A.PRES-3 TOY.PART X.GEN I DA.PART know-NEG-A.PRES-3

${ }^{y}$ ekem.

E.COP.INDIR.COP1SG

'As I have heard, there is a code in it. I do not know it either.'

T9/ 61

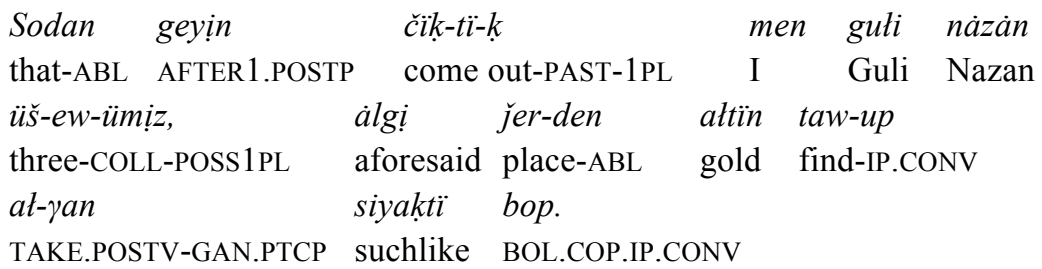

'Then we three, Guli, Nazan and I, left (the bank) as if we had found some treasure.' 
